\title{
Komunikacijski obrasci u svjetlu medijske etike u dokumentima katoličke crkve
}

\section{Zupčić, Šime}

Doctoral thesis / Disertacija

2020

Degree Grantor / Ustanova koja je dodijelila akademski / stručni stupanj: University of Zagreb, University of Zagreb, Faculty of Humanities and Social Sciences / Sveučilište u Zagrebu, Filozofski fakultet

https://doi.org/10.17234/diss.2020.7811

Permanent link / Trajna poveznica: https://urn.nsk.hr/urn:nbn:hr:131:882234

Rights / Prava: In copyright/Zaštićeno autorskim pravom.

Download date / Datum preuzimanja: 2023-04-26

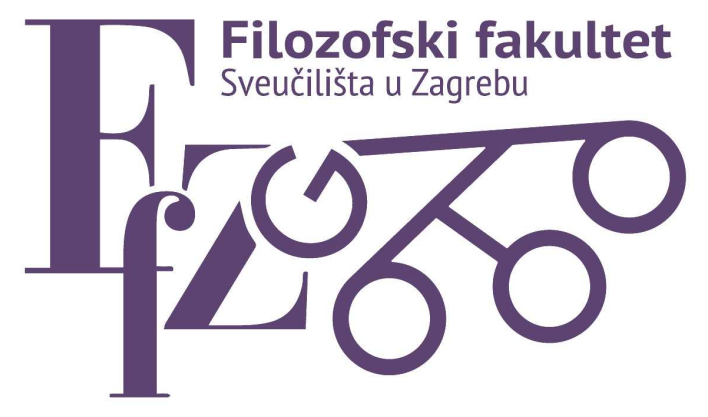

Repository / Repozitorij:

ODRAZ - open repository of the University of Zagreb

Faculty of Humanities and Social Sciences
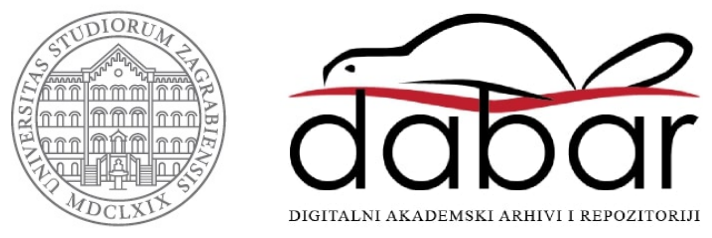


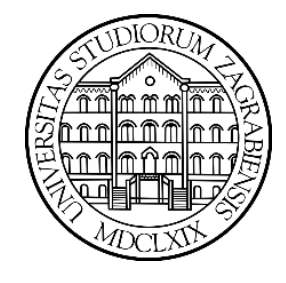

Sveučilište u Zagrebu

Filozofski fakultet

Šime Zupčić

\section{KOMUNIKACIJSKI OBRASCI U SVJETLU MEDIJSKE ETIKE U DOKUMENTIMA KATOLIČKE CRKVE}

DOKTORSKI RAD

Zagreb, 2020. 


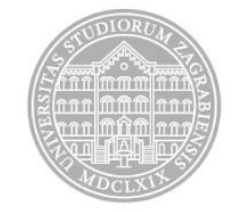

Sveučilište u Zagrebu

Filozofski fakultet

Šime Zupčić

\title{
KOMUNIKACIJSKI OBRASCI U SVJETLU MEDIJSKE ETIKE U DOKUMENTIMA KATOLIČKE CRKVE
}

DOKTORSKI RAD

\author{
Mentor: \\ dr. sc. Danijel Labaš, red. prof.
}

Zagreb, 2020. 


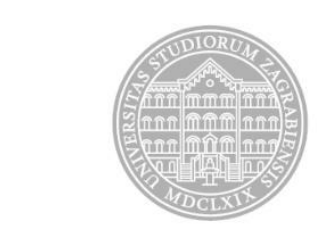

University of Zagreb

Faculty of Humanities and Social Sciences

Šime Zupčić

\title{
COMMUNICATION PATTERNS IN THE LIGHT OF MEDIA ETHICS IN THE DOCUMENTS OF THE CATHOLIC CHURCH
}

\author{
DOCTORAL THESIS \\ Supervisor: \\ Danijel Labaš, PhD, full professor
}

Zagreb, 2020. 


\section{INFORMACIJE O MENTORU}

Dr. sc. Danijel Labaš, red. prof., rođen je 1965. godine. Filozofiju i teologiju studirao je u Zagrebu i Rimu (Pontificia Università Gregoriana), iz komunikacijskih znanosti je doktorirao 1996. god. na Università Pontificia Salesiana u Rimu. Za disertaciju na temu "Funkcioniranje načela odgovornosti u etičkom utemeljenju informacije-komunikacije" nagrađen je Rektorovom nagradom. Po povratku u Hrvatsku bio je zaposlen kao zamjenik direktora Informativne katoličke agencije u Zagrebu, urednik informativnog programa Hrvatskoga katoličkog radija te kao novinar i urednik u Glasu Koncila.

Stručno se usavršavao na Radiotelevisione Italiana u Rimu i Westdeutscher Rundfunk u Kölnu. Na Hrvatskim studijima stalno zaposlen je od 2007., te je nositelj kolegija: Medijska pedagogija, Mediji u nastavi, Metodika područja društvenih znanosti (komunikologija), Osnove komunikologije, Novinarska etika, Semiotika u masovnom komuniciranju, Film i religija, Povijest i teorija filma, Veliki režiseri europske kinematografije, Mediji i djeca, Mediji i nasilje, Politička komunikacija, Sociološki aspekti masovne komunikacije, Mediji i bioetika, Introduction to Global Communication i Medienkommunikation und Öffentlichtkeitarbeit.

Od 2008. do 2012. bio je pročelnik je Odjela za komunikologiju na Hrvatskim studijima. Od 2010. do 2014. bio je prodekan, od 2010. do 2012. povjerenik za znanost, međunarodnu i međusveučilišnu suradnju, a od 2012. do 2014. obnašao dužnost povjerenika za nastavu i studente.

Sudjelovao je na brojnim znanstvenim skupovima u Hrvatskoj i inozemstvu, te je objavio više knjiga i zbornika, te znanstvenih i stručnih članaka u hrvatskim časopisima.

Područja njegova znanstvenoga zanimanja su deontologija medija i novinarska etika, semiotika i sociologija medija, medijska pedagogija, neverbalna komunikacija te odnos filma i religije. Predsjednik je Društva za komunikacijsku i medijsku kulturu i voditelj projekta Djeca medija. Član je više strukovnih udruga te Odjela za medije Matice hrvatske i Organizacijskog odbora Komunikološke škole. 


\section{SAŽETAK}

U suvremenom medijskom i novinarskom svijetu etička pitanja postaju sve aktualnija i relevantnija. Katolička se Crkva u svojim dokumentima izravno ili neizravno bavi pitanjima medija, kao i medijske i novinarske etike. Rad stoga istražuje odnos etičkog sadržaja i kriterija iznesenih u dokumentima Katoličke Crkve s jedne strane i suvremenih sadržaja i kodeksa medijske i novinarske etike s druge strane. U radu se analiziraju različiti etički pravci i istražuju zajedničke značajke te uspoređuju s etičkim prijedlozima iznesenima u dokumentima Katoličke Crkve. Uspoređujući teme i načine kako obje etike analiziraju bitne teme svog interesa, rad je ustanovio da se i medijska etika i teološka medijska etika dotiču uglavnom istih tema, te ih obrađuju na uglavnom isti način, uz određene razlike koje nisu značajne.

Rad zaključuje da teološka medijska etika može dati svoj doprinos medijskoj etici po svom stavljanju čovjeka u središte, svojim inzistiranjem na istini, uvođenjem pojmova savjesti, općeg dobra, solidarnosti, mira i ljubavi u etički diskurs, kao i snažnim inzistiranjem na odgovornosti, ali i govorom o utemeljenju normi i svrsi medijske etike.

Istraživanje je provedeno anketnim upitnikom među članovima Hrvatskog društva katoličkih novinara i djelatnicima svjetovnih medija koji se bave religijskim temama. Istražilo se u kojoj su mjeri upoznati s kriterijima za novinarsko djelovanje i s etičkim naukom o medijima. Načelno, može se zaključiti kako ispitanici za sebe smatraju da veoma dobro poznaju (i u skladu s njima djeluju) postulate i medijske etike i teološke medijske etike, dok za druge sudionike medijskog procesa (vlasnike, urednike, kolege novinare, publiku...) imaju mnogo niže mišljenje. Također, imaju veoma visoku razinu slaganja s tvrdnjama da su i medijska etika i teološka medijska etika potrebne suvremenom novinarstvu (s tim da smatraju kako medijska etika potrebnija nego teološka medijska etika).

Rezultati se mogu primijeniti u edukaciji i konkretnom radu medijskih djelatnika u cilju ostvarivanja pozitivnog pomaka u komunikacijskim obrascima suvremene društvene komunikacije.

Ključne riječi: mediji, etika, medijska etika, teološka medijska etika, crkveni dokumenti 


\section{DISSERTATION ABSTRACT}

The contemporary world of media and journalism discusses journalistic and media ethics more often nowadays, and questions regarding the (in) ability to set universal ethical standards in the field of traditional and new digital media have become more actual and relevant. The Catholic Church, in its documents, directly or indirectly, discloses the issues of the media, as well as the issue of media and journalistic ethics, and proposes and outlines ethical principles and postulates aimed not only for its own religious media but also for the secular media. The purpose of this dissertation is, accordingly, to explore the relationship between the ethical content and the criteria delineated in the documents of the Catholic Church on the one hand, and the contemporary content and codes of media and journalistic ethics on the other.

\section{Contemporary Philosophical Tendencies in Media Ethics}

The first chapter of the dissertation addresses contemporary philosophical tendencies in media ethics, through a detailed review of selected authors. Ethical issues in the context of the media have become more important, and not only have they also become more relevant to many scholars (philosophers, theologians, communication scientists ...), but also to media professionals - journalists or "media practitioners" - who, on a daily basis, make decisions which have significant ethical implications. Therefore, the first chapter of this dissertation presents, elaborates and analyzes contemporary secular media ethics, attempting to systematically introduce a representation of the contents related to ethics and morality in the field of media and journalism. The author aims to compare the findings with the current proposal of media ethics, which is based on the theological reflection of the documents created by the Catholic Church, to discover how these findings are different or similar, and whether both approaches to ethics offer commonalities and propose principles consistent with what in theory is called a minima of morality (minima moralia) for human actions, not only in the contemporary, today's world in general, but especially in the field of media, which is the main focus of this dissertation.

Due to the complexity of this field and a large community of scholars who have already addressed these topics, and still continue to address issues related to media ethics, this is not an easy task. Consequently, it was not possible to analyze the contributions of all the 
authors and present all the reflections upon the topic. The scientific methodology used in the dissertation therefore presents a selection of main reflections in the aforementioned area (combining the work of foreign and native authors), thus giving a (possible) illustration of contemporary media ethics and journalistic ethics. This chapter initially answers the question of what ethics is, elaborates further with a classification of ethics, presents and interprets some theories about journalism in relation to media ethics, addresses the truth as the foundation of media ethics, raises the question of why media ethics is relevant at all, and, finally, identifies as important the topic of ethical relativism. The chapter then presents and analyzes Jurgen Habermas's communication ethics as well as Karl Otto Apel's discourse ethics, delivers an analysis of Dal Jacquette's media ethics and his speech on moral responsibility in the media, offers an analysis of Louis Alvin Day on media ethics and Claude-Jean Bertrand on media deontology. Furthermore, the related work of other international and native authors is also covered in this chapter, especially through topics such as: media ethics and the inevitability of ethics in journalism, social and media reality, relationship between ethics, ownership and profit, crisis of values in the media, freedom of expression and the basis of journalistic activity, issues of manipulation and (auto)censorship in the media, credibility, sources of information and media literacy and responsibility of the recipient of the message.

\section{Analysis of Church Documents}

In the second chapter, the dissertation outlines the main highlights of media ethics present in church documents, both of those who speak directly about the media and of those who do not primarily address this topic, but also cover the topic from the standpoint of theological reflection. Some of these documents are contemporary, while the earliest document is issued in the first half of the 19th century. Consequently, the analysis of church documents begins with the document of Mirari vos (1832) by Pope Gregory XVI, and continues with the Vigilanti Cura (1936) by Pope Pius XI, with a special emphasis on the decree of the Council about the media Inter mirifica from 1963, which is considered to be the first document of the Second Ecumenical Council of the Vatican (1962-1965). Furthermore, other documents have also been analyzed and presented in the paper, but not in a chronological order, but rather by the importance of the topics and their relevance. The dissertation thus analyzes Communio et progressio (1971), the pastoral guideline of the Pontifical Council for the Media, published during the pontificate of Pope Paul VI, as well as 
a document by the same pope entitled Evangelii nuntiandi. The dissertation then presents documents such as Aetatis novae (1992), Redemptoris missio (1990), Pornography and Violence in the Media (1989), Rapid Development (2005), Ethics in Marketing (1997), Ethics in Information Media (2000), Church and the Internet (2002) and Ethics on the Internet (2002). In a separate chapter, the paper also analyzes and elaborates 50 Pope's messages, from the first message of 1967 published by Pope Paul VI., to the message published by Pope Francis in 2016. The 50 messages are published regularly by the Popes every year on World Media Day.

\section{The Comparison of Contemporary Tendencies in Ethics and Media Ethics in Church Documents}

The third chapter provides a comparative critical analysis of the prevailing ethical trends in the field of media ethics on the one hand and media ethics in church documents on the other hand, so that specific topics of media ethics are systematically addressed from both points of view, with a particular consideration of possible points of agreement and divergences.

\section{Establishing Norms and the Aim of Media Ethics}

Church documents put objective moral order at the forefront, using in this process the insights and suggestions of theological media ethics, while, on the other hand, in contemporary ethical theories, different attitudes and reflections can be noticed and one can use the term of reciprocal complementarity. The reflections of various authors on media ethics also contribute to the expansion of the theological approach to media ethics, which finds its foundation in the human dignity that comes from Biblical teaching that man is created "in the image and likeness of God" and is, therefore, at the center of all ethical reflection.

\section{Man as the Focus of Media Ethics}

Both, media ethics and church documents dedicated to media and media ethics, emphasize the need to put humans at the center, regardless of certain divergences and differences in their approaches. Nevertheless, it seems that church documents still show this need more often. They also approach this topic on the basis of theological thinking, as does media ethics in general, with a great deal of attention and openness to debate, considering it 
obvious that the relationship to humans is at the root of all ethics, and therefore putting human dignity and inviolable human rights and values at the center.

\section{Ethical Relativism as a Problem of Media Ethics}

Regarding the topic of ethical relativism, it should be stated that this topic is examined by authors who write about media ethics as well as in church documents (theological media ethics). It should be emphasized that church documents, as well as contemporary media ethics, often even when not discussing ethical relativism but writing about other topics and emphasizing universal values, actually indirectly reject ethical relativism associated with media ethics.

\section{Common Good}

Both, general media ethics and theological media ethics, have a high regard for the concept of the common good, and theological media ethics often connects this concept with the term "community". The common good is therefore manifested as the right of general population to truthful and objective, accurate and transparent information and access to information, so that even when media ethics does not explicitly use this term, it often underlines its meaning of the common good through other concepts (terminology).

\section{Freedom and Responsibility in the Media}

Both ethics are dedicated to addressing freedom and responsibility and both of them highly value these two concepts. Both ethics also significantly connect the two concepts in a harmonious relationship that reveals the fact that freedom cannot exist without responsibility, nor can responsibility exist without freedom. Although there is no significant difference, older church documents had expressed a certain negative attitude to the concept of freedom, and later on in this context, church documents have started to place a greater emphasis on responsibility, but the concept of freedom has, by no means, been excluded. Media ethics, on the other hand, emphasizes freedom and its connection with responsibility. 


\section{Truth as the Foundation of Media Ethics}

As far as the truth in the media is concerned, media ethics, as well as church documents based on theological ethics, place a great deal of emphasis on it, and it can be stated that both view it as the basis of media ethics without significant differences.

\section{Principles of Honesty and Objectivity in Media Ethics}

Both, general reflections on the principles of media ethics and church documents that convey a theological ethical point of view, speak of objectivity, but it appears that both concepts and principles - objectivity and honesty - seem to be a more common topic of general media ethics, which in a way introduces and insists more on the notion of honesty, and, in fact, considers that objectivity cannot be achieved in real circumstances. Therefore, contemporary media ethics focuses more on the concept of honesty, which seems to be more easily attainable. Church documents, on the other hand, do not emphasize so much the concept of honesty in the context of objectivity but they emphasize that it is impossible to achieve complete objectivity, and that it remains as such as an ideal to which one needs to aspire to.

\section{Media Ethics and Public Opinion}

Although contemporary media ethics and theological media ethics both discuss public opinion, it is, to some extent, differently evaluated by them. More specifically, contemporary media ethics often views public opinion with regards to published opinion (or, in relation with what is published by the media), and it considers as ethically correct the concurrence of these two opinions, and as ethically incorrect when this is not the case. Theological discussion on the topic accepts this to a certain extent, but it also assumes a different view of public opinion, which, according to church documents, does not necessarily rely on the correct judgment of ethical principles.

\section{Love as a Principle of Media Ethics}

The concept of love seen as a value that should exist in the media and which should guide the ethical actions of persons involved in the media, is an implicit and explicit topic of both, contemporary media ethics and theological ethics, and is frequently presented in church 
documents. It is clear that this is a concept and a principle that is not easy to define such as truth, objectivity, honesty and other similar concepts. Therefore, it becomes logical to imply that this concept should not be explicitly mentioned in the contemporary theories of media ethics, which does not exclude that it is not properly valued or promoted as such.

\section{Peace and Dialogue as Basic Principles of Media Ethics}

The topic of peace is not only present in church documents and media ethics, but peace and dialogue are viewed as values that the media should promote and put into practice in their work. This frequent highlighting of peace can help media ethics - in theory and practice - to understand better the importance of peace, as well as to encourage media professionals to be unambiguous (explicit) and courageous promoters of peace, that is so much needed by the modern world as a value upon which the coexistence of different people, societies and cultures is based upon.

\section{The Power of Media and Media Ethics}

Both, contemporary media ethics and theological media ethics which are presented in church media documents, strongly emphasize "the great power of the media", and there seems to be no significant difference between church documents and media ethics in this, apart from the fact that church documents together with the speech on the power of the media constantly emphasize that this power can be used for both good and bad, and that it all depends on how ethically or unethically those involved in the process will act.

\section{The Issue of Conscience and Media Ethics}

Theological media ethics, as well as the authors in the field of contemporary thinking about media ethics, especially the authors such as Luka Brajnović and Claude-Jean Bertrand, reflect on the issue of conscience, even though it may, in some ways, appear to be seen as an abstract concept, or, at least, as a concept that should have a religious meaning, which could not be defined otherwise in a scientific way. Both of the aforementioned authors - like many others, such as Robert Spaemann, Ivan Koprek and Ivan Devčić - define Kantian conscience as that inner voice in a (professional) man, which encourages him to act morally. As expected, the media ethics outlined in the documents of the Catholic Church further invoke the concept 
of conscience. With such a reasoning, even theological media ethics increases the knowledge about this and can thus better contribute to contemporary media ethics.

\section{Solidarity as the Basic Principle of Media Ethics}

At first glance, it could be concluded superficially and wrongly, that contemporary media-ethical trends do not use the notion of solidarity, while theological media ethics uses it relatively frequently. It is actually a somewhat "hidden" concept in the context of media ethics, which leads one to think that theological media ethics can contribute to media ethics by introducing this category into various international and national journalistic codes more openly and clearly.

\section{Media Credibility and Ethics}

The notion of credibility appears and is addressed in both ethics, without any significant difference. Assuredly enough, more frequent and straightforward talk about this can make the writing of the media become more ethical and, therefore, of better quality.

\section{Ethics and the Question of Media Ownership}

Both ethics identify as important the issue of the ownership of the media, or the association of the media, and the consequent problem of having only a few people as owners and managers of a large number of media, which leads to serious ethical issues and dilemmas. With sometimes slightly different points of view, both ethichs start from a realistic (and actual) picture of the contemporary media and try to find appropriate answers to the questions and challenges that the contemporary media face today.

\section{Censorship as a Problem of Media Ethics}

Contemporary media ethical thinking and church documents have given a great deal of attention to the topic of censorship, which is quite justified (legitimate), since throughout human history and the history of media constantly newer forms of willingness to control journalists and the media, most often through censorship and encouraging self-censorship, have appeared. Due to this, contemporary ethical thinking has identified many forms of pressure on journalists, which then often lead to self-censorship. On the other hand, church documents based on theological media ethics more often highlight the topic of censorship, 
and, at the same time, do not speak directly about self-censorship. The analysis of the data has shown that in moral theology, there has been a development of reflection about censorship: from the very beginning, when the Church was very indulgent to the phenomenon, to the present day, when the same phenomena is being viewed in negative terms. However, in relation to some topics, both contemporary media ethical approaches as well as theological ethics represent the obligation for censorship in certain situations, especially when it comes to hate speech, child pornography, spreading of violence or war advocacy.

\section{The Digital Devide as an Ethical Problem}

Theological and contemporary media ethics recognize the problem of the digital devide, which is not an entirely new phenomenon, but has been assuming new and different forms today. While attempting to recognize the problem, both media ethics wish to minimize this devide in their reflections as well as to reach a new world information order in which the free flow of information will be made available worldwide.

\section{The Issue of Privacy and Media Ethics}

Both contemporary and theological media ethics recognize the human right to privacy, emphasizing that this right should never be compromised. The research has shown that there is no significant difference in the approaches to these topics between contemporary and theological media ethics.

\section{Profit and Quality as the Focus of Media Ethics}

Contemporary media-ethical trends and ways of thinking, as well as theological ethics, speak about the relationship between profit and the quality of media content, and identify a negative phenomenon in which profit takes precedence over quality. They are conscious of the fact that the media require profit, and that the pure pursuit of this profit is not problematic or unethical in itself. The problem arises when profit becomes the sole criterion, quality an irrelevant factor, and information only a commodity. 


\section{Audience and Its Responsibility for Media Ethics}

Today, media research is remarkably dedicated to the media audience, and this topic can be examined considerably in contemporary media ethics as well as in theological ethics. Both ethics emphasize the responsibility of the audience for the media content. In some cases, even the boundary between media users and media creators is deleted, and a new concept, prosumer, generated from two words producer and consumer, has been introduced, based on the fact that this is exactly what the users of the media in reality are: the real creators of media content.

\section{Advertising and Ethics in Marketing}

Both contemporary thinking about media ethics and theological media ethics speak similarly about advertising or marketing. It is noticeable, however, in both standpoints, that advertising is viewed positively if it is used for the purpose of so-called positive advertising, and for the purpose of having better informed audiences. Nevertheless, the researchers do not fail to mention and thematize those negative aspects of advertising in cases where advertising is used in an unethical way, i.e. when is fraudulent and manipulative, and, therefore, any form of surreptitious advertising is rejected.

\section{Respect towards Women and Media Ethics}

Contemporary media ethics, as well as theological, pay considerable attention to the role of women in the media. Certain stereotypes have already been noticed and identified by the researchers, as well as a certain level of the exploitation of women that is currently present in the overall media. This research has shown that there is no significant difference between theological and contemporary media ethics in the analysis of this topic.

\section{Research of the Perception of Media Ethics}

The fourth chapter of the dissertation presents the results of a survey conducted among members of the Croatian Society of Catholic Journalists (Hrvatsko društvo katoličkih novinara) and secular media professionals who write about religious issues. The survey investigated the extent to which the members of the Croatian Society of Catholic Journalists were acquainted with the required criteria for journalistic activities and the theological ethics 
of the media. The purpose of the research was also to explore the perceptions of the interviewees in order to find out how they, in their role as active participants and as respondents in the media process, act (or do not act) in accordance with the basic postulates of media ethics. The control group consisted of journalists who write about religious topics for the public television, national commercial televisions, and national daily papers.

The survey examined the level of agreement of two groups of respondents with statements, in which the level of agreement no. 1 indicates "I disagree", and the level of agreement no. 5 stands for 'I fully agree'. The table below provides information on the average level of agreement with each claim, as well as the difference in the level of agreement between the two groups.

Table 1. Average Deviation in Attitudes between Two Groups of Respondents

\begin{tabular}{|l|l|l|l|}
\hline & Members of & $\begin{array}{l}\text { Journalists who } \\
\text { cover religious } \\
\text { Statement in the } \\
\text { topics } \\
\text { national media }\end{array}$ & Variation \\
\hline $\begin{array}{l}\text { Media ethics is necessary in } \\
\text { contemporary journalism. }\end{array}$ & 5.00 & 5.00 & 0.00 \\
\hline $\begin{array}{l}\text { Journalists know media ethics postulates. } \\
\text { pournalists respect media ethics } \\
\text { postulates. }\end{array}$ & 2.63 & 2.56 & 0.07 \\
\hline $\begin{array}{l}\text { Editors and media owners know secular } \\
\text { media ethics postulates. }\end{array}$ & 2.82 & 1.96 & 0.18 \\
\hline $\begin{array}{l}\text { Editors and media owners respect secular } \\
\text { media ethics postulates. }\end{array}$ & 1.90 & 2.81 & 0.01 \\
\hline Audience knows media ethics postulates. & 2.51 & 1.93 & 0.03 \\
\hline $\begin{array}{l}\text { Audience chooses the media content in } \\
\text { accordance with media ethics postulates. }\end{array}$ & 1.75 & 2.65 & 0.38 \\
\hline $\begin{array}{l}\text { I know media ethics postulates. } \\
\text { I respect media ethics postulates in my } \\
\text { work and professional life. }\end{array}$ & 4.43 & 1.75 & 0.35 \\
\hline
\end{tabular}

${ }^{1}$ HKDN - Hrvatsko društvo katoličkih novinara (Croatian Asssociation of Catholic Journalists) 


\begin{tabular}{|c|c|c|c|}
\hline $\begin{array}{l}\text { Theological media ethics is necessary in } \\
\text { contemporary journalism. }\end{array}$ & 4.53 & 4.19 & 0.34 \\
\hline $\begin{array}{l}\text { Journalists know theological media } \\
\text { postulates. }\end{array}$ & 2.31 & 1.84 & 0.47 \\
\hline $\begin{array}{l}\text { Journalists respect theological media } \\
\text { postulates. }\end{array}$ & 1.90 & 1.84 & 0.06 \\
\hline $\begin{array}{l}\text { Editors and media owners know } \\
\text { theological media postulates. }\end{array}$ & 2.34 & 1.71 & 0.63 \\
\hline $\begin{array}{l}\text { Editors and media owners respect } \\
\text { theological media postulates. }\end{array}$ & 1.80 & 1.40 & 0.40 \\
\hline $\begin{array}{l}\text { Audience knows theological media } \\
\text { postulates. }\end{array}$ & 2.09 & 1.96 & 0.13 \\
\hline $\begin{array}{l}\text { Audience chooses the media content in } \\
\text { accordance with the postulates of } \\
\text { theological media ethics. }\end{array}$ & 1.87 & 1.37 & 0.50 \\
\hline I know theological media postulates. & 4.46 & 4.50 & 0.04 \\
\hline $\begin{array}{l}\text { I respect theological media postulates in } \\
\text { my work and professional life. }\end{array}$ & 4.34 & 4.53 & 0.19 \\
\hline $\begin{array}{l}\text { Media ethics can help theological media } \\
\text { ethics. }\end{array}$ & 4.09 & 4.34 & 0.25 \\
\hline $\begin{array}{l}\text { Theological media ethics can help media } \\
\text { ethics. }\end{array}$ & 4.53 & 4.28 & 0.25 \\
\hline $\begin{array}{l}\text { Media ethics and theological media } \\
\text { ethics do not have significant differences. }\end{array}$ & 3.02 & 3.15 & 0.13 \\
\hline \multicolumn{3}{|l|}{ Average deviation } & 0.21 \\
\hline
\end{tabular}

Essentially, and based on the results obtained, it can be deduced that the respondents consider themselves to be very knowledgeable about the postulates of both media ethics and theological media ethics (and that they act in accordance with those postulates as well). On the other hand, it seems evident that the respondents have a different, much lower opinion about other participants in the media process (owners, editors, fellow journalists, audience...). There is a high level of agreement from all respondents in the survey that both media ethics 
and theological media ethics are required in contemporary journalism (nevertheless, media ethics is still perceived as more necessary than theological media ethics).

Respondents were also given three open-ended questions, and from their responses, it can be concluded that they considered truth, responsibility, objectivity and honesty as the basic postulates of media ethics. The same postulates are also considered as basic four principles in theological media ethics.

After a thorough analysis of the responses of the interviewees and the comparison of the results with what has been already accepted as the basic postulates by both, contemporary media ethics, as well as theological media ethics, it can be deduced that the respondents agree with and recognize the basic principles of both media ethics and theological media ethics.

Key words: media, ethics, media ethics, theological media ethics, church documents 


\section{SADRŽAJ}

INFORMACIJE O MENTORU

SAŽETAK

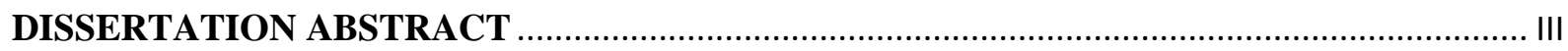

Contemporary Philosophical Tendencies in Media Ethics ..................................................... III

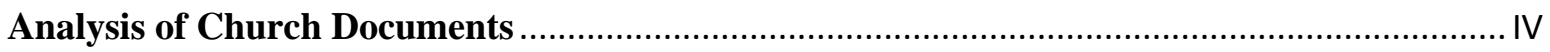

The Comparison of Contemporary Tendencies in Ethics and Media Ethics in Church

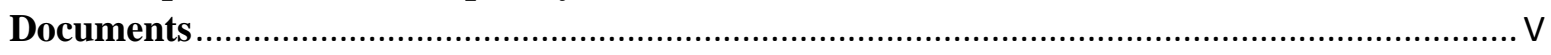

Establishing Norms and the Aim of Media Ethics ...................................................................

Man as the Focus of Media Ethics ........................................................................................

Ethical Relativism as a Problem of Media Ethics ................................................................... VI

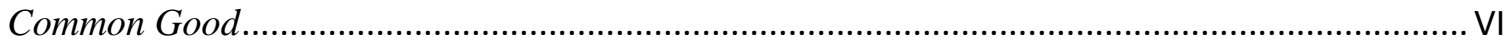

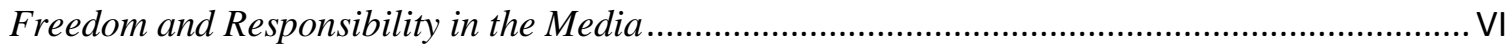

Truth as the Foundation of Media Ethics.................................................................................. VII

Principles of Honesty and Objectivity in Media Ethics.............................................................. VII

Media Ethics and Public Opinion ..................................................................................... VII

Love as a Principle of Media Ethics....................................................................................... VII

Peace and Dialogue as Basic Principles of Media Ethics ........................................................ VIII

The Power of Media and Media Ethics ............................................................................... VIII

The Issue of Conscience and Media Ethics ............................................................................. VIII

Solidarity as the Basic Principle of Media Ethics.................................................................... IX

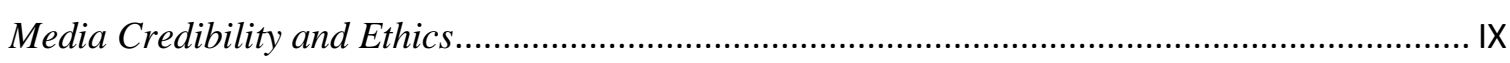

Ethics and the Question of Media Ownership ......................................................................... IX

Censorship as a Problem of Media Ethics ............................................................................. IX

The Digital Devide as an Ethical Problem............................................................................ $\mathrm{x}$

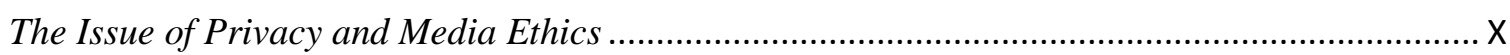

Profit and Quality as the Focus of Media Ethics ....................................................................

Audience and Its Responsibility for Media Ethics..................................................................

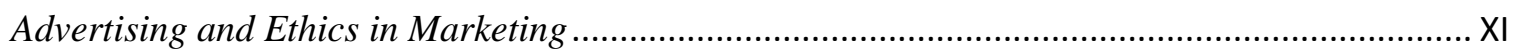

Respect towards Women and Media Ethics......................................................................

Research of the Perception of Media Ethics ……................................................................. XI

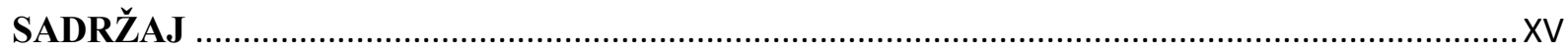

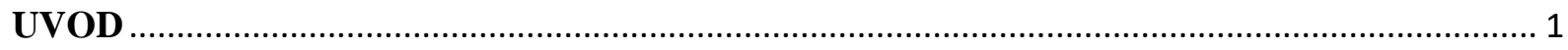


Struktura rada.

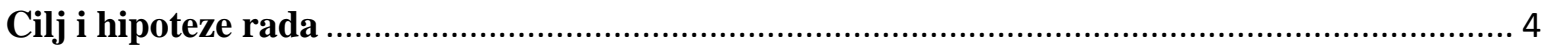

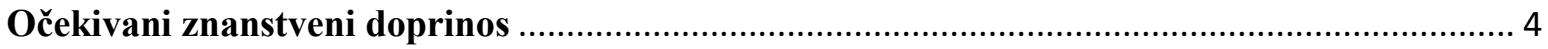

1. SUVREMENA TEORIJSKO-PRAKTIČNA RAZMIŠLJANJA O MEDIJSKOJ I

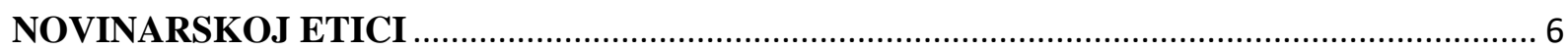

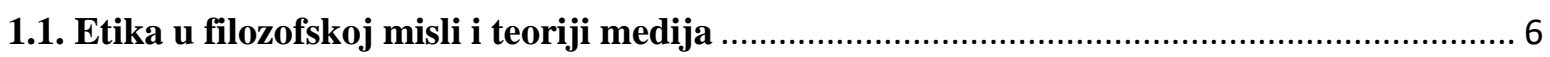

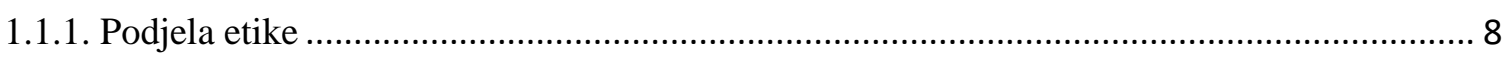

1.1.2. Teorije o novinarstvu i medijska etika .................................................................... 10

1.1.3. Istina kao temeljni pojam medijske etike .................................................................... 13

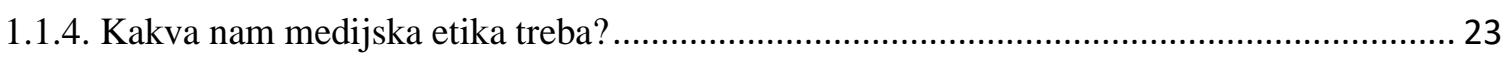

1.1.5. Čovjek kao središte medijske etike i etički relativizam................................................... 24

1.2. Suvremena medijska etika i njezine teme u razmišljanju odabranih autora ..................... 26

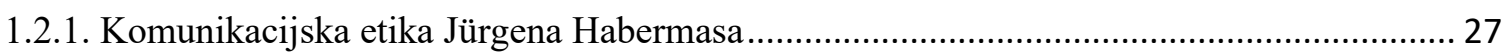

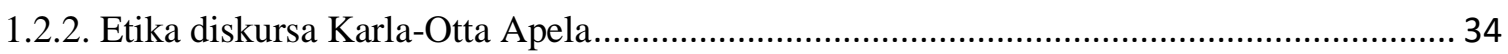

2.2.3. Dale Jacquette o moralnoj odgovornosti u medijima ....................................................... 44

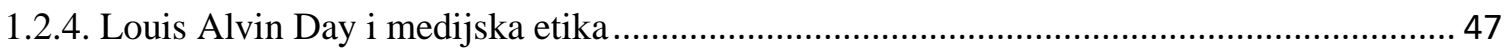

1.2.5. Claude-Jean Bertrand i deontologija medija ................................................................... 52

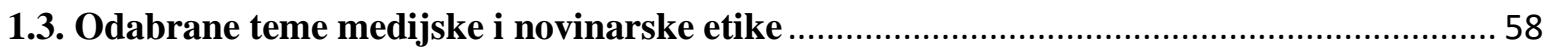

1.3.1. Medijska etika i nužnost etike u novinarstvu .................................................................. 59

1.3.2. Društvena i medijska stvarnost, odnos etike, vlasništva i profita......................................... 71

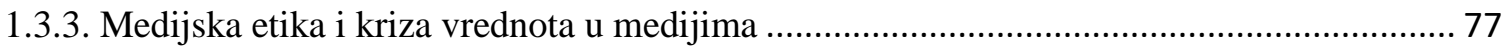

1.3.4. Sloboda izražavanja i temelji novinarskog djelovanja ........................................................ 81

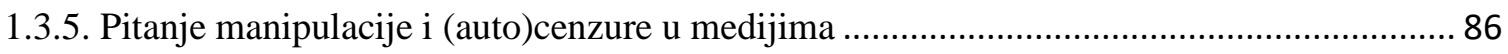

1.3.6. Vjerodostojnost, izvori informacija i medijska pismenost u kontekstu medijske etike....... 89

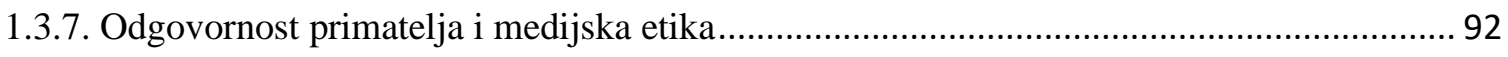

2. PRIKAZ I ANALIZA NAČELA U CRKVENIM DOKUMENTIMA O MEDIJIMA ............. 99

2.1. Negativan odnos Crkve prema medijima i nedostatak slobode izražavanja - Mirari vos

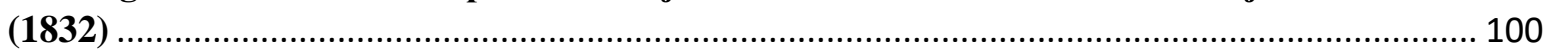

2.2. Naslućivanje promjene odnosa Crkve prema medijima - Vigilanti cura (1936) ............. 101

2.3. Mediji u svjetlu Drugog vatikanskog koncila, najznačajnijeg događaja 20. stoljeća u Crkvi

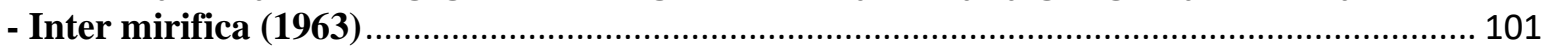

2.4. Postkoncilski smjer Katoličke Crkve i njezinog odnosa prema medijima ........................ 108

2.4.1. Magna carta nauka Crkve o medijima - Communio et progressio (1971) ........................ 108

2.4.2. Odgovornost za medijske sadržaje - Aetatis novae (1992) ........................................... 115

2.5. Dokumenti koji nisu primarno posvećeni tematici medija, ali tu tematiku značajnije

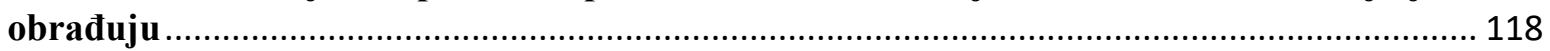


2.5.1. Mediji kao moćna sredstva u evangelizaciji - Evangelii nuntiandi (1975)

2.5.2. Mediji kao areopag suvremenog društva - Redemptoris missio (1990)

2.6. Općedruštvena pitanja u svjetlu medijske etike.............................................................. 120

2.6.1. Pornografija i nasilje u sredstvima društvenog priopćivanja (1989) ................................ 120

2.6.2. Moćna sredstva koja je nužno koristiti etički ispravno - Brzi razvoj (2005)...................... 122

2.7. Pravo društva na informaciju na temelju istine, slobode, pravde i solidarnosti - Etika u promidžbi (1997)

2.8. Temeljni dokument teološke medijske etike - Etika u obavijesnim sredstvima (2000)... 131

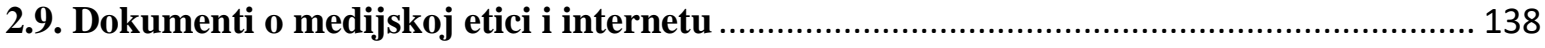

2.9.1. Pitanje interneta nadilazi samo tehničke mogućnosti - Crkva i internet (2002).............. 138

2.9.2. Nužnost etičkog djelovanja na internetu - Etika na internetu (2002) ........................... 140

2.10. Papine poruke za svjetski dan sredstava društvene komunikacije ........................... 147

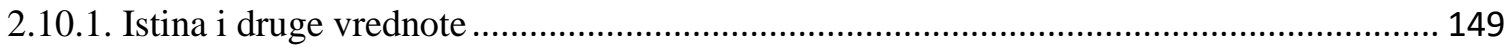

2.10.2. Odgovornost medijskih korisnika................................................................. 160

2.10.3. Čudesni Božji darovi i moćna sredstva ............................................................... 164

2.10.4. Obitelj i drugi međuljudski odnosi ................................................................ 167

2.10.5. Otvorenost prema drugim (narodima) ........................................................... 181

3. USPOREDBA SUVREMENIH MEDIJSKO-ETIČKIH PRAVACA I MEDIJSKE ETIKE U

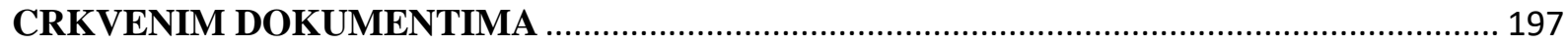

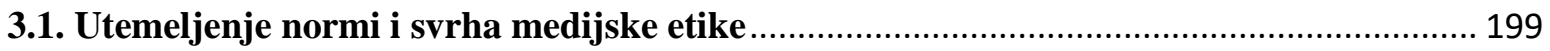

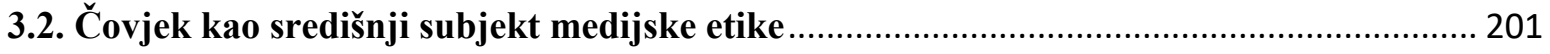

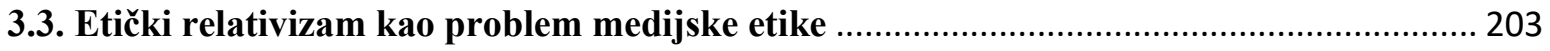

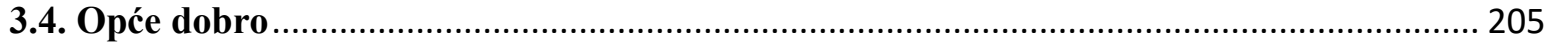

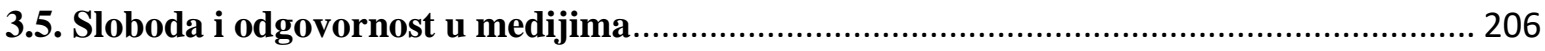

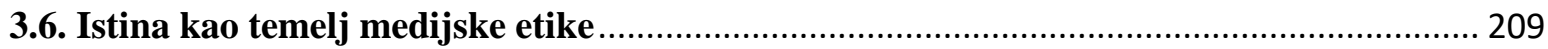

3.7. Načela poštenja i objektivnosti u medijskoj etici.......................................................... 211

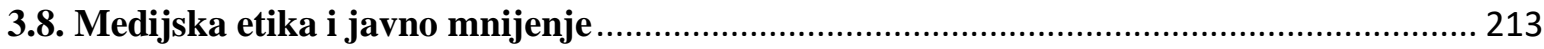

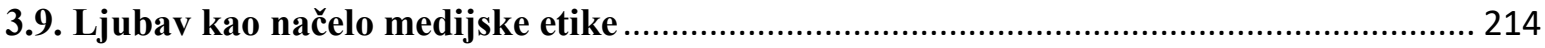

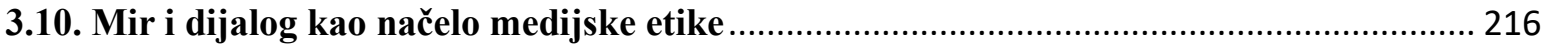

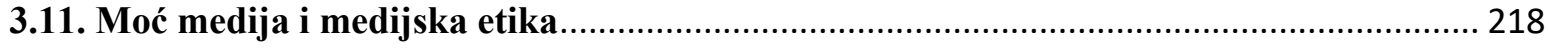

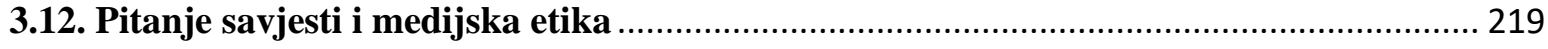

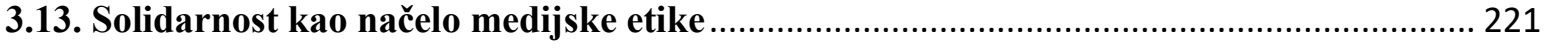

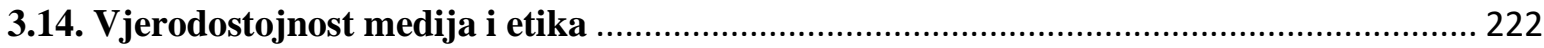

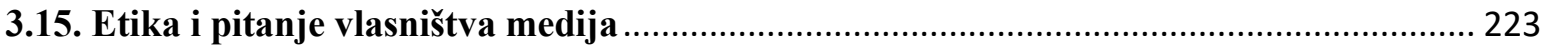

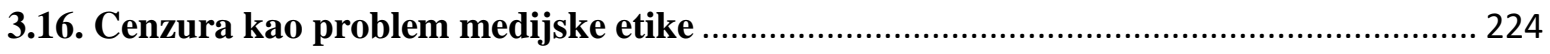


3.17. Digitalni jaz kao etički problem

3.18. Pitanje privatnosti i medijska etika ........................................................... 228

3.19. Profit i kvaliteta kao problem medijske etike ................................................ 229

3.20. Publika i njezina odgovornost za medijsku etiku ........................................... 230

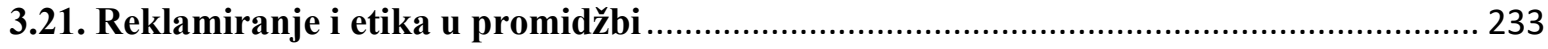

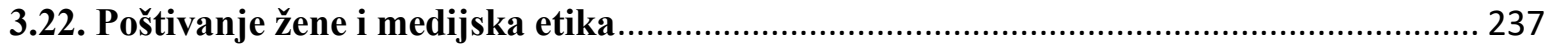

4. ISTRAŽIVANJE, ANALIZA I RASPRAVA POZNAVANJA MEDIJSKE ETIKE I

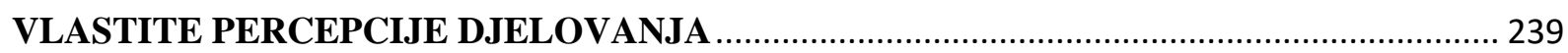

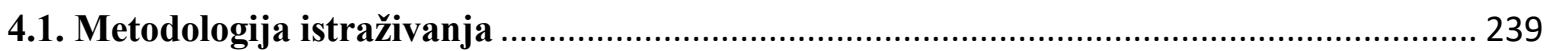

4.2. Analiza i rasprava rezultata istraživanja provedenog među članovima Hrvatskog društva

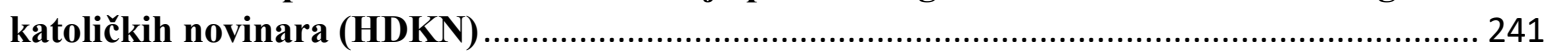

4.2.1. Prikaz i analiza rezultata na zatvorena pitanja...................................................... 241

4.2.2.Prikaz $\mathrm{i}$ analiza odgovora na otvorena pitanja ...................................................... 253

4.3. Istraživanje i rasprava rezultata dobivenih među religijskim novinarima ................... 258

4.3.1. Prikaz i analiza rezultata zatvorenih pitanja ......................................................... 258

4.3.2. Prikaz i analiza rezultata otvorenih pitanja....................................................... 270

4.4. Usporedbena analiza rezultata ankete po skupinama.......................................... 273

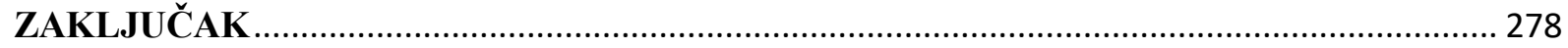

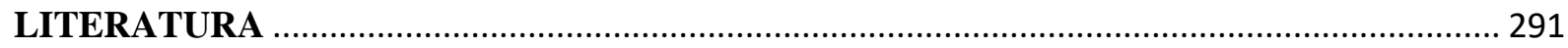

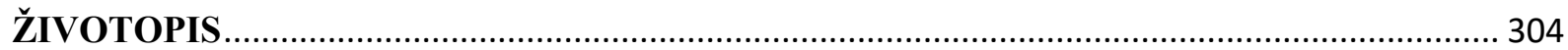




\section{UVOD}

U suvremenom društvu medijska i novinarska etika postaju sve potrebnije i važnije. S druge strane, Katolička Crkva u svojim dokumentima često se, izravno ili neizravno, dotiče pitanja medija, kao i medijske i novinarske etike. Stoga je jamačno znanstveno relevantno povezati i istražiti upravo navedeno: etički sadržaj i etičke kriterije iznesene u crkvenim dokumentima kao i suvremene pravce medijske i novinarske etike povezane s novinarskom strukom i njezinim etičkim kodeksima, te njihov međusobni odnos.

Moralna teologija se kao znanstvena disciplina bavi etikom na različitim područjima (medicinskom etikom, spolnom etikom, ekologijom etikom, itd), a jedno od područja kojima se bavi jest i medijska etika. Rad će otkriti u kojoj mjeri postoje razlike, a u kojoj podudarnosti i sličnosti u navođenju etičkih načela koja bi - prema teološkim postavkama i prema suvremenim etičkim pravcima - morala biti načela kojih se trebaju pridržavati novinari u obavljanju profesionalne djelatnosti.

Važno je istaknuti i da je teološki pristup medijskoj i novinarskoj etici jedan od relevantnih pristupa među različitim suvremenim etičkim pristupima, kao što su primjerice „Kommunikationsethik“ tj. „komunikacijska etika“ Karla Otta Apela i „Diskursethik“ tj. „etika diskursa“ Jürgena Habermasa, te da teološki pristup ima svoje osobitosti koje je vrijedno i potrebno istražiti, prezentirati, analizirati i kritički usporediti s drugim etičkim prijedlozima za djelovanje novinara i medija u cijelosti, jer je to područje - posebno u hrvatskom znanstvenom okruženju - nedovoljno istraženo.

Etika je kroz povijest, pa sve do danas, imala različite pravce i pristupe (Boss, 2004: 5), a njihovi su nazivi najčešće ovisili o vrhovnom načelu toga etičkoga pravca. No ona uvijek postavlja teška pitanja: „Etika ili moralna filozofija, kako se još naziva, postavlja ozbiljna i teška pitanja o načinu na koji bismo trebali živjeti svoje živote.“"(Sanders, 2004: 14). Upravo zbog težine i složenosti tih pitanja, često kao da je jednostavnije ne postavljati pitanja, ili pak u slučaju postavljanja pitanja, traže se jednostavni odgovori bez konačnih rješenja.

Crkva se od svoga osnutka uvijek koristila medijima koji su bili primjereni dobu u kojemu je živjela i djelovala, sve do današnjeg dana. Mediji su ,izazov s kojim se ona više ili manje drastično i uspješno susreće i suočava otkada postoji.“ (Devčić, 2006: 5). 
Kao što je nekada oblike i sredstva svoje komunikacije prilagođavala onima kojima se obraćala, tako i u suvremenom svijetu Crkva nastoji koristiti medije, ali preko svoga moralnoga nauka nudi i svoj doprinos pokušavajući utjecati na promjene u medijima u kojima vidi „Božje darove“ (Inter mirifica, 1963, br. 2.) U dokumentu Aetatis novae (1992) ističe se da Crkva ima „odgovornost koja zahtijeva da se razrade pastoralni programi posvema prilagođeni posebnim radnim uvjetima i etičkim izazovima pred kojima se nalaze komunikacijski profesionalci”, kao i da pastoralni programi trebaju jamčiti permanentni odgoj koji će moći pomoći u primjeni i prožetosti moralnim normama u profesionalnom i privatnom životu (br. 19).

Prvi crkveni dokument koji progovara o temi sredstava društvene komunikacije je enciklika Mirari vos (1832) pape Grgura XVI. u kojoj papa osuđuje slobodu tiska. No, uskoro Katolička Crkva kreće u drugom smjeru te već papa Pio XI. u Vigilanti cura (1936) „ne govori samo o opasnostima“, već medije „nastoji s pozitivne strane vrednovati“ (Balukčić, 2012: 131). Drugi vatikanski sabor je iznimno važan trenutak u otvaranju Crkve prema svijetu i suvremenim društvima, pa onda i prema medijima jer „u duhu otvorenosti i dijaloga sa svijetom te priznavanjem autonomije zemaljskih stvarnosti, Crkva na drugačiji način promatra svijet medija“ (Valković, 2012: 172). Nakon Drugog vatikanskog sabora nastavlja se u istom smjeru: „Slijedeći trag saborskih dokumenata, pošlo je i postkoncilsko Učiteljstvo: sredstva društvenog priopćavanja ušla su u gotovo sve dokumente pastoralnog značaja“ (Labaš, 1993: 93).

Etika je „filozofska teorijsko-praktična znanost koja istražuje moralnost ljudskih postupaka i proučava vrijednost, život i moralno ponašanje osobe i ljudske zajednice“ (Brajnović, 1997: 275), a isti autor etiku dijeli na opću koja proučava zakone, norme i činjenice moralnog ponašanja čovjeka i specijalnu etiku koja proučava to ponašanje $u$ različitim okolnostima u kojima se čovjek kao socijalno biće nalazi (Brajnović, 1997: 277). Počevši od toga, jasno je da će se ovaj rad baviti prvenstveno ovom drugom vrstom etike, $\mathrm{s}$ obzirom da medijska etika i deontologija novinarstva spadaju u područje specijalne etike. Važno je naglasiti da se u stručnim i znanstvenim krugovima deontologija novinarstva vrlo često poistovjećuje s etikom struke, tj. etikom novinarske struke u ovome slučaju, što će činiti i ovaj rad. Kvalitetno bavljenje medijskom etikom i deontologijom novinarstva, kao znanošću (a ne u kolokvijalnom značenju etike) nije moguće bez dobro postavljenih temelja opće etike, te stoga rad neće izostaviti niti načela opće etike. 
„Društvena obavijesna sredstva nisu ništa sama po sebi, ona su sredstva, oruđe, upotrijebljeni kako ljudi izaberu da ih upotrijebe. (...) Za ispravan odabir potrebno je dobro poznavati 'pravila moralnog reda' i 'vjerno ih provoditi u djelo'“ (Etika u obavijesnim sredstvima, 2000, br. 4). U istom dokumentu Crkva naglašava i sljedeće: „Društvena obavijesna sredstva mogu se koristiti za dobro ili loše, to je pitanje izbora.“ (br. 19). Iz navedenih, kao i mnogih drugih njezinih dokumenata, jasno se iščitava da Katolička Crkva naglašava etičku neutralnost samih medija kao sredstava, te istodobno pokušava predočiti etička načela, kriterije i smjernice za djelovanje.

\section{Struktura rada}

Rad se sastoji od četiri osnovne cjeline. U prvom dijelu rada se izlažu, obrađuju i kritički propituju suvremeni etički pravci na području medijske etike, s posebnim osvrtom na novinarsku etiku i deontologiju novinarstva.

U drugom se dijelu analiziraju i uspoređuju crkveni dokumenti koji izravno ili neizravno obrađuju medijsku etiku u širem, a novinarsku etiku u užem smislu.

Treći je dio središnji dio disertacije u kojemu se provodi usporedna kritička analiza prevladavajućih etičkih pravaca na području medijske etike s jedne strane i medijske etike u crkvenim dokumentima s druge strane. Usporedit će se etički kriteriji na jednom i drugom području, istaknuti podudarnosti i razlike kriterija i analizirati prijedlozi u crkvenima dokumentima koji se nude kao doprinos suvremenim etičkim pravcima medijske etike. Prikazani i analizirani kriteriji će kroz vlastite zaključke ukazati na moguće perspektive za daljnja propitivanja i istraživanja odnosa.

U četvrtom dijelu rada prikazat će se rezultati istraživanja. Istraživanje će se provesti među članovima Hrvatskog društva katoličkih novinara i djelatnicima svjetovnih medija koji se bave religijskim temama. Istražit će se u kojoj su mjeri upoznati s kriterijima za novinarsko djelovanje i s etičkim naukom o medijima. Kontrolnu skupinu čine novinari religijskih redakcija javne televizije, nacionalnih komercijalnih televizija, te nacionalnih dnevnih listova.

U izboru materijala rad će se ograničiti samo na dokumente papa ili papinskih komisija, dakle neće uključivati dokumente pojedinih biskupa i biskupskih konferencija ili pak drugih crkvenih struktura. U Crkvi se od 1967. svake godine, sedme nedjelje nakon 
Uskrsa, slavi Svjetski dan sredstava društvene komunikacije, a tom prigodom papa objavljuje posebnu poruku čiji sadržaj su upravo mediji, te se u tim porukama vrlo često dotiče i teme medijske i novinarske etike. Nadalje, postoji više crkvenih dokumenata koji direktno ili indirektno govore o medijima, te svi ti dokumenti i papine poruke uvijek u sebi imaju etičkih implikacija i izravno se pozivaju na moralno djelovanje. Analizirat će se i dokument u kojem se izravno govori o temi medijske etike (Etika u obavijesnim sredstvima, 2000).

\section{Cilj i hipoteze rada}

Cilj rada je istražiti etička načela medijske etike koja su sadržana u suvremenim etičkim pravcima te ih usporediti s načelima iznesenima u dokumentima Katoličke Crkve koji se bave medijima, te analizirati potencijalni međusobni doprinos.

Hipoteze rada su:

1. Unatoč razlikama među suvremenim etičkim pravcima na području medijske etike prisutan je značajan broj kriterija koji se podudaraju.

2. U crkvenim dokumentima koji se bave medijima postoje različita, ali temeljno slična etička promišljanja.

3. U crkvenim dokumentima i u svjetovnim etičkim pravcima i međunarodnim kodeksima časti postoji više od polovice zajedničkih kriterija, iako ih se različito tumači.

4. Članovi HDKN-a, prema samoprocjeni, poštuju etičke kodekse i nauk svoje vjerske zajednice o medijima.

5. Nema značajne razlike u samoprocjeni poštivanja kriterija etičkih kodeksa među članovima HDKN-a i djelatnicima svjetovnih medija koji se bave religijskim temama.

\section{Očekivani znanstveni doprinos}

U radu će se ostvariti dvostruki doprinos. U teorijskom dijelu će se detaljno analizirati i usporediti etička načela medijske etike sadržana u suvremenim etičkim pravcima i etička načela iznesena u dokumentima Katoličke Crkve. Tako će se steći uvid u njihova zajednička 
obilježja. U znanstveno-istraživačkom dijelu analizirat će se i verificirati kako poznavanje etičkih kriterija utječe na novinarsko djelovanje članova HDKN-a i novinara religijskih redakcija, što se može iskoristiti u cjeloživotnoj edukaciji. 


\section{SUVREMENA TEORIJSKO-PRAKTIČNA RAZMIŠLJANJA O MEDIJSKOJ I NOVINARSKOJ ETICI}

U suvremenom medijskom i novinarskom svijetu etička pitanja postaju sve aktualnija i relevantnija, jer riječ je o pitanjima kojima se ne bave samo mnogi znanstvenici (filozofi, teolozi, komunikolozi ...) nego se s njima u svom svakodnevnom radu susreću medijski djelatnici - novinari (,praktičari“) koji svakodnevno donose odluke koje imaju značajne etičke implikacije, posebno na one o kojima izvještavaju. Stoga rad u ovom poglavlju prikazuje, obrađuje i analizira suvremenu svjetovnu medijsku etiku, pokušavajući sustavno donijeti presjek onoga što suvremena svjetovna etika govori o pitanjima etike i morala u području medija i novinarstva, kako bi ju se kasnije moglo usporediti s prijedlogom medijske etike kojeg predlažu dokumenti Katoličke Crkve, te otkriti po čemu se razlikuju, u čemu su slični i nude li nam oba pristupa zajedničke značajke, pravila ili norme onoga što se naziva minima moralia za ljudsko djelovanje ne samo u suvremenom svijetu općenito, nego i na medijskom području. To nije nimalo jednostavna zadaća, te ju nije moguće obraditi predstavljajući i analizirajući sve autore i sva promišljanja, te smo stoga u ovom radu znanstvenom metodologijom donijeli presjek odabranih glavnih promišljanja u navedenom području, obrađujući strane i domaće autore, te time dajemo sliku suvremene medijske i novinarske etike u širem znanstvenom i praktičnom okruženju.

\subsection{Etika u filozofskoj misli i teoriji medija}

Gledajući etimološki, etika je znanost koja proučava ethos, tj. nešto karakteristično s područja ljudskih običaja, njegovih uobičajenih načina ponašanja $i$, konačno, same naravi i prirodne sposobnosti čovjeka da se ponaša na ovaj ili onaj način s nekim određenim ciljem. Ili, ako ćemo to kazati u nešto kraćem obliku, etika proučava ljudsko ponašanje, to jest ljudske čine (Brajnović, 1977: 274).

Dakako, nije moguće zaustaviti se samo na etimološkom tumačenju te je za ispravno razumijevanje pojma etike nužno naglasiti da ona ne proučava samo ljudske čine kao takve, već pod posebnim vidom ispravnosti ili neispravnosti tih čina pokušava dati odgovore jesu li neki čini u skladu s normama ispravnog ponašanja i djelovanja ili nisu. Valja napomenuti da se kod definiranja što bi to bilo ispravno ili neispravno dolazi do velikog broja pitanja na koja 
nije moguće jednostavno i jednoznačno dati odgovore. Kad bi se takve odgovore moglo dati jednostavno, vjerojatno bi i sama tema etike i medijske etike bila manje relevantna i aktualna, te bi se rješenja na mnoga etička pitanja mogla dati u samo nekoliko rečenica. No, mnoga znanstvena promišljanja, kako ona kroz povijest, tako i ona suvremena, pokazuju da to nije tako.

Kako navode Oliver A. Johnson i Andrews Reath (2007: 1) „etika je racionalan upit kako djelovati i kako živjeti život. Etika ili moralna filozofija - možemo koristiti oba pojma naizmjenično - jedno je od najstarijih područja kojim se filozofija bavila, i tijekom njezine povijesti obuhvaćala je više pitanja: Koja je istinska svrha života? Koja dobra je vrijedno imati i koja ponašanja je vrijedno ostvarivati? Koje karakterne osobine čine osobu dobrom i čine njezin život vrijednim življenja? Koji su principi koji daju distinkciju između dobra i zla? Koja načela trebaju voditi naš odnos s drugim ljudima?“ Isti autori pišu da je „etika ili moralna filozofija normativna kategorija, više nego deskriptivna. Nije zaokupljena pitanjima kako ljudi djeluju, nego kako bi trebali djelovati“ (Johnson, Reath, 2007: 1).

Etika je, prema Ivanu Čehoku i Ivanu Kopreku (2006: 7) ,temeljito, kontinuirano i argumentirano domišljanje o dobrom življenju i ispravnom djelovanju koje je započelo već u 5. stoljeću prije Krista i traje sve do danas. Budući da postoje različite moralne predstavke, etika traga za kriterijem, normom, mjerilom njihova utemeljenja. Načini su toga traganja, dakako, raznorodni, katkada nam se čak pričinjaju protuslovnima. No, suprotnosti su među onima koji razmišljaju o moralu drugačije od suprotnosti između neposredno življenih morala. One nisu neko slijepo nizanje, nego znanstvena rasprava koja je karakterizirana međusobnom željom shvaćanja i razumijevanja.“

Nicolai Hartmann (2003: 7) piše da ,tradicija novovjekovnog mišljenja uvijek iznova stavlja pred filozofiju tri aktualna pitanja: što možemo znati, što trebamo činiti, čemu se smijemo nadati? Drugo od njih važi kao temeljno etičko pitanje. Ono je onaj oblik ljudskog pitanja koji etici daje karakter 'praktične' filozofije, oblik pitanja koji hoće više od puko spoznajnog shvaćanja zbilje, a ipak manje od onoga za čim naposljetku teži čovjekova čežnja i nada. Neovisno od svakog jamstva da će to postići, neovisno od znanja o uvjetovanom i dohvatljivom kao i od vjerovanja u ono najdalje, krajnje, apsolutno, stoji ono u sredini između krute zbiljnosti života i lebdećih ideala vizionarskog gledanja. Samo nije okrenuto ničem zbiljskom kao takvom, pa ipak je blisko zbilji kao nijedna teorija i nijedna čežnja, uvijek 
započinjući od zbilje i pitajući iz njene datosti te uvijek imajući pred očima zbiljnost onoga što je u datome nezbiljno.“

Marko Sapunar (2004: 232) piše da je etika „teorija morala ili znanosti o moralu. Kao najopćenitija znanost o ispravnom ponašanju čovjeka uopće u smislu što točnije prosudbe što je dobro, a što zlo, etika daje čovjeku općenita iskustva u svezi s ispravnim ponašanjem.“

\subsubsection{Podjela etike}

Većina suvremenih autora govori o razlici između etike i morala. Dva su shvaćanja u tom razlikovanju. Kako navodi Čedomir Čupić (2010: 27) po jednima je moral univerzalna pojava koja se vezuje za pravila koja su u temelju ljudskih djelovanja, ponašanja i odnosa. Ta pravila pojedincu omogućuju da raspoznaje dobra i loša ponašanja, a čovjek ih prihvaća, pokorava im se i na taj način živi u društvu. Također, moral je i regulativna ideja jer snažno utječe na reguliranje pojedinačnog i društvenog života, $\mathrm{tj}$. na uspostavljanje reda, sigurnosti i stabilnosti. Kada većina ljudi prihvaća i živi po moralnim pravilima, cijelo društvo je uređenije, poredak stabilniji, a pojedinci sigurniji. Etika se pak kod tih autora shvaća u nešto užem značenju u odnosu na moral, tj. označava osobno primjenjivanje moralnih pravila $\mathrm{i}$ vrijednosti koje je pojedinac slobodno prihvatio, usvojio i prakticira ih u svakodnevnom životu. Dok sam moral, kao dominantan pojam daje opća pravila, etika na osnovu njih određuje pravila za određenu aktivnost. Iz toga onda proizlazi i etika određene grupe ili profesije (liječničke, odvjetničke, novinarske). Čupić podsjeća da se etika prema drugom shvaćanju određuje kao učenje ili nauk o moralu, a njen predmet su pravila moralnog ponašanja i donošenja suda o tome što je dobro a što loše ili zlo. Ovo shvaćanje posebno je došlo do izražaja kod anglosaksonskih teoretičara morala. U okviru ovog shvaćanja danas su se razvile tri etike: metaetika, normativna etika i praktična etika. (Čupić, 2010: 27) Metaetika se bavi proučavanjem karakteristika odnosno prirodom etike. No, različiti autori različito određuju područje njezina djelovanja. Po jednima ona obuhvaća proučavanje svih etičkih teorija, odnosno teorijsku etiku, a prema drugima ona se ograničava na proučavanje gnoseološko-logičkih pristupa moralu, odnosno moralnim sudovima i atributima morala i teorijama koje nastaju iz tog proučavanja. Tako metaetika istražuje značenje apstraktnih pojmova kao što su dobro, ispravno, pravda i poštenje. Također, ona ih vrijednosno ocjenjuje, ali i vrednuje načine njihovog opravdanja. Pri tome isključuje njihovo moralno ocjenjivanje. 
Zapravo, metaetika nudi precizna značenja pojmova koji su bitni za proces donošenja moralnih sudova. Preciznost je bitna za pojedince u društvu da bi mogli s ravnopravnih pozicija sudjelovati u moralnom prosuđivanju djelovanja i ponašanja i donošenju vlastitih odluka. Metaetika se ne bavi donošenjem moralnih sudova, već pokušava razdvojiti etičke vrijednosti od onih koje podrazumijevaju samo pitanje ukusa ili stava. $\mathrm{Na}$ primjer, posvećenost istini etičari prepoznaju kao nešto što je moralno dobro i ta vrijednost predstavlja jedan od temelja naših društvenih normi. Ona je također i temelj mnogih medijskih kodeksa i standarda ponašanja, s time što je na medijskim djelatnicima da ovaj prilično apstraktan koncept prilagode konkretnim moralnim dilemama. Metaetika nudi širok temelj za etičko donošenje odluka, ali ne daje smjernice kako da se dođe od točke A do točke B. Kada gledatelji ili čitatelji kažu da neki izvještaj nije pošten, je li njihova zabrinutost etičke prirode ili je to samo pitanje ukusa? Slično tome, medijski kritičar koji napiše da je TV serija „dobra drama“ nije iznio nikakav stav u pogledu moralne karakteristike emisije. (Čupić, 2010: 27-28) $\mathrm{S}$ druge pak strane, normativna etika bavi se normama, odnosno pravilima i principima moralnog života. Njena je zadaća definirati i obrazložiti norme ispravnog i dobrog postupanja. Ona daje upute za praktično moralno djelovanje i ponašanje. Norme, odnosno pravila i primjeri ponašanja omogućavaju pojedincima, grupama i društvu da izbjegnu kaos, odnosno nered. U svakodnevnom životu one pomažu da se ljudi orijentiraju i izbjegnu opasnosti koje stalno vrebaju. Na osnovu njih donesene su i zabrane onoga što je nepoželjno i nedopustivo: laž, prijevara, krađa. Dakle, normativna etika preporučuje što treba činiti ili kako postupiti da bi naše djelovanje i ponašanje bilo ocijenjeno kao dobro i ispravno (Čupić, 2010: 28-29). Primijenjena etika bavi se konkretnim slučajevima i problemima, te u rješavanju slučajeva i problema koristi ono što joj pruža metaetika, ali i osnovne principe i pravila koje daje normativna etika. Ona spaja teorijske i normativne elemente. U primijenjenoj etici se pokazuje moć teorijskih znanja i prosuđivanja i usvojenost osnovnih principa i pravila koje je donijela normativna etika. U konačnici, primijenjena etika omogućava da se analiziraju konkretna moralna ponašanja i odlučivanja. U različitim životnim situacijama provjerava se usvojena profesionalna etika, odnosno ona se demonstrira na praktičan način (Čupić, 2010: 30).

Dakako, u suvremenom svijetu gdje se sve (s pravom) propitkuje, postavlja se pitanje zašto je etika važna? Prvo, zbog razlikovanja dobra i zla, odnosno dobrog i lošeg ponašanja. Jer, bez tog razlikovanja život ljudi može biti i najčešće jest ugrožen, budući da se život ne može produžavati i razvijati oslanjajući se na zlo i loše. Upravo je zlo ono koje razara i 
destruktivno djeluje na život. S druge pak strane, univerzalne vrijednosti kao što su istina, pravda, ljubav, ljepota, sloboda, ljudsko dostojanstvo, solidarnost, dobro, one su koje potpomažu, razvijaju i slave život (Čupić, 2010: 30-31).

Etiku kao znanstvenu disciplinu najčešće dijelimo na opću i specijalnu etiku. Opća proučava zakone, norme i opće činjenice ljudskog moralnog ili nemoralnog ponašanja, dok specijalna proučava to ponašanje u različitim okolnostima u kojima se čovjek nalazi kao društveno biće (Brajnović, 1977: 277). Stoga medijska i novinarska etika svakako spadaju u specijalnu etiku, no i to se ne smije shvatiti kruto. Naime, svaka specijalna medijska etika svoje temelje pronalazi u općoj etici, te je bez nje nije moguće razumjeti. Isto se odnosi i na medijsku etiku koju nije moguće promatrati kao zasebnu cjelinu koju bi bilo moguće razumjeti bez opće etike.

Slično o ovoj podjeli pišu i Čehok i Koprek (2006: 113) koji ističu da sužavanje i sve veća različitost predmetnih područja pojedinih znanosti, specijalizacija i stručnost znanja onemogućuje cjelovito znanstveno promatranje, cjepkaju ljudska iskustva i, naposljetku, oslobađaju prostor za samostalne i nevezane znanstvene postupke istraživanja, kao i za stručno djelovanje pojedinih profesija. A to za sobom povlači i mnoštvo etičkih prijepora s kojima se često suočavamo u sklopu tzv. profesionalnih etika.

Claude-Jean Bertrand poput Luke Brajnovića i drugih autora govori o deontologiji medija, te u svom djelu istoimenog naziva jednostavno piše da se deontologija primjenjuje unutar određene profesije, a da je na određeni način riječ o nepisanoj tradiciji tj. prešutnom sporazumu što se smije raditi, a što ne smije (Bertrand, 2007: 27).

\subsubsection{Teorije o novinarstvu i medijska etika}

Govoreći o suvremenom novinarstvu, Brajnović (2011: 107-109) govori i o poznate četiri teorije o novinarstvu, ali u središte stavlja etičke implikacije novinarstva i medija. Prva je autoritarna teorija, koja pretpostavlja funkciju medija kao podršku politici i aktivnosti države i njenih tijela vlasti, a prema njoj novinarstvo treba podržati društvenu solidarnost i nacionalno jedinstvo. Prema ovoj teoriji, država ima pravo kontrolirati medije kao opće javno dobro, a to najčešće znači i uskraćivanje slobode medija. Iz svega što iznosi Brajnović, jasno je da je riječ o novinarstvu koje ne zadovoljava niti osnove medijske etike. Druga, tj. liberalna 
teorija funkciju medija vidi u zaštiti ljudskih prava i sloboda te u informiranju javnosti kako bi građani mogli sudjelovati u upravljanju u demokratskom društvu. Također, daje prednost privatnom vlasništvu u medijima, koje je neovisno i maksimalno slobodno u informiranju građana i kritici javne politike. Za razliku od prethodne teorije, pravo na publiciranje i izražavanje vlastitih stavova nije prerogativ države ili vlade, već temeljno pravo slobodnih pojedinaca. Treća teorija novinarstva, koju Brajnović naziva „društveno odgovorna“ stavlja novinarstvo u poziciju potrage za ravnotežom između liberalnog pritiska i bespogovorne slobode novinarstva, a to dokazuje potrebom da sloboda moćnih medija, koji imaju velik utjecaj na širu javnost, mora biti uravnotežena s njihovom društvenom odgovornošću. Novinarima pripisuje dužnost da javnosti podastru i iznesu različite poglede i vrijednosne sudove te da, zanemarujući zabavni okvir korisnika vijesti, osiguravaju dublje analize o najvažnijim ozbiljnim događajima. Društveno odgovorna teorija svakako opisuje novinarstvo koje bismo mogli okarakterizirati etički ispravnim, te nečim prema čemu bi etično novinarstvo trebalo i moralo težiti. Njegova suprotnost, s etičkog gledišta, jest četvrta teorija koju se naziva „totalitarna teorija“, a pripisuje se praksi u nekadašnjem Sovjetskom Savezu i nacističko-fašističkom poretku u Njemačkoj i Italiji, a mogli bismo, u blažem obliku, to reći i za novinarstvo u Hrvatskoj u vremenu totalitarnih režima 20. stoljeća. Prema ovoj teoriji mediji su obvezni pridonositi uspješnom i kontinuiranom razvoju (socijalističkog ili nacističko-fašističkog) sustava i neprikosnovenoj ulozi partije, te postulati novinarstva svakako nisu istinitost, objektivnost niti ostali postulati onoga što bismo nazvali etičnim novinarstvom, već je sve podređeno podržavanju i očuvanju političkog i društvenog sustava.

Brajnović (2011: 111) naglašava da se pitanja medijske i novinarske etike ne mogu svesti samo na pitanja etike, razboritosti, financijske koristi ili prava, jer novinarstvo obilježavaju načela koja medijima daju izuzetno važnu društvenu funkciju. Stoga on etičku dimenziju medija i novinara dijeli u nekoliko temeljnih zadaća. Prve su opće etičke zadaće: poput svake osobe i novinari bi trebali postupati u skladu s općim etičkim načelima kao što su istinitost, održavanje obećanja, izbjegavanje nepravde i služenje javnom dobru. Dakako, jasno je da ta načela dobivaju specifične interpretacije u izvještavanju i uređivanju, ali oni temelji tih načela ostaju univerzalni. No, da novinarstvo nadilazi te opće i univerzalne zadaće, potvrđuje društvena uloga novinarstva: poput svih drugih profesionalaca, novinari koriste svoje vještine da ispunjavaju svoju društvenu ulogu i opravdaju očekivanja javnosti. U mnogim demokratskim zemljama novinarima se ustavom jamči sloboda da potiču društvena dobra poput različitosti pogleda i sveobuhvatne analize pojedinih događaja. 
Prema Brajnoviću (2011: 111) etičan je novinar „neutralan komunikator važnih novosti i pogleda prema javnosti i nepristranih pogleda same javnosti, koristeći odgovorne i precizne metode pribavljanja vijesti za dobrobit stanovništva." Sljedeće su obveze svakog novinara, nastavlja isti autor: ,informirati javnosti o važnim događajima da im budu razumljivi, djelovati poput psa čuvara u pitanjima narušavanja prava, privatno ili javno; predstavljati otvoreni forum za izražavanje i kritičku raspravu o predmetima, pogledima i vrijednostima“ (Brajnović, 2011: 112). Iz svega toga predlaže i donosi etička načela koja se mogu podijeliti u više skupina. Prva skupina su proaktivna načela i standardi koji usmjeravaju novinare ili medije u smjeru aktivnog pronalaženja istine u nesputanom obliku. Standardi u tom slučaju uključuju točnost, ravnotežu i različitost u pristupu, proporcionalnost, korektnost i objektivnost s posebnim naglaskom na neovisnost u istraživanju. Standardi koji se vezuju uz ovakav novinarski pristup teže izbjegavanju sukoba interesa, neovisnosti od drugih institucija, odbijanje posebnih naklonjenosti i hrabrost da se kritizira one koji posjeduju neki oblik moći. Iduća skupina su tzv. „suspregnuta načela“, tj. standardi koji usmjeravaju novinare da koriste slobodu vlastite odgovornosti, u nastojanju da izbjegnu štetu i da pritom ostanu odgovorni prema javnosti. Također, novinari moraju biti spremni objasniti i obraniti svoje aktivnosti vezano za pojedine novinarske priče, posebno ako su one kontroverzne i nemaju važnost za pojedinca ili skupinu. Odgovornost u tom slučaju označava artikuliranost načela novinarstva, koje uključuju i mjere pomoću kojih javnost može postavljati pitanja i prigovoriti (Brajnović, 2011: 112), oslanjajući se pri tome na jasna načela komunikacijske etike u javnome prostoru.

A etiku komunikacije je teorijski razvio i njemački psihijatar i filozof Karl Jaspers u sklopu svojega egzistencijalizma. Polazeći od istraživanja ozbiljenja slobode pojedinačne egzistencije, Jaspers ističe činjenicu da se „sloboda ozbiljuje samo u zajednici“ i to na taj način da pojedinačna egzistencija uvijek i iznova djeluje (na djelatan, a ne na spoznajan način) te dolazi do ustanovljenja slobodne zajednice $s$ drugim egzistencijama. Načelo djelovanja pritom se ne razlikuje značajno od kategoričkog imperativa Immanuela Kanta, koji se može ,prereći“ i za medijsku etiku i novinarsku etiku, kako je to učinila Melita Poler Kovačič (2001: 26) koja postavlja tezu da je „kriza identiteta novinarstva kao kriza (novinarske) etike prije svega kriza subjekta - kriza novinara kao subjekta, kriza onog koji senzacionalističko zadiranje u privatnost proglašava svojim novinarskim zadatkom“. Dalje autorica nastavlja da se kriza medijske etike pokazuje u prevladavanju norme tržišne učinkovitosti nad profesionalnim novinarskim načelima, jer odluke o tome što postaje vijest, te kakva ta vijest treba biti oblikovana, ovisi o analizi troškova i koristi, a ne o mjerilima 
kvalitetnog novinarstva (Poler Kovačić, 2001: 29). Poler Kovačič (2001: 30) dalje nastavlja da novinarska neetičnost nažalost privlači publiku, te da je tržišno novinarstvo zapravo stvaranje neetičkih, ali profitabilnih slika. Ista autorica (Poler Kovačić, 2001: 31) piše da se kod razmatranja krize medijske etike ne smije zanemariti šira slika postmoderanog pristupa moralnosti, koji se često može nazvati i smrću etičnog. U tom kontekstu etika postaje iluzija bez koje bi postmoderan novinar trebao znati živjeti. Novinar stoga danas odbacuje čvrsto postavljene norme, te prihvaća antinomistički stav. Poler Kovačić (2001: 32) primjećuje i da danas u novinarstvu glavnu riječ vodi ekonomsko razmišljanje, a koje ocjenjuje čovjeka veoma redukcionistički.

Kako navode Danijel Labaš i Ivan Uldrijan (2010: 91) ako bismo u jednoj rečenici pokušali definirati novinarsku etiku mogli bismo reći kako je ona etika koja na temelju nekih općih, univerzalnih, etičkih načela tumači djelovanje u novinarskom pozivu.

Prijedlog sistematizacije medijske etike također je iznio Jürgen Wilke koji u svom razmatranju pitanja ove znanstvene discipline razlikuje teoretsku razinu, na kojoj se radi o strukturalnim, pravno-političkim i ekonomskim uvjetima etičnog djelovanja te o primjeni koncepcija, te empirijsku razinu na kojoj se istražuje činjenično etično ponašanje novinara te pragmatičnu razinu, koja se bavi, između ostalog, i ugradnjom, tj. uključivanjem etičkih normi u obrazovanje i njihovu primjenu u sklopu novinarske djelatnosti (Labaš, Uldrijan, 2010: 92).

Jedno od cjelovitih tumačenja ovog područja je ponudio i Mirko Juraj Mataušić (1996, prema Labaš, Uldrijan, 2010: 93) koji koristi termin „etika društvenog priopćavanja“ u kojemu se medijsko etičko vrednovanje odnosi na četiri područja: na društvenu i političku zajednicu koja zakonima i drugim sredstvima regulira i potpomaže (a nekada i odmaže) društvenu komunikaciju, na izdavače ili medijske sustave koji određuju idejni i politički smjer medija, ali i na njihove međusobne odnose koji su označeni ekonomskom konkurencijom, na medijske djelatnike kao osobe i skupine koje imaju svoje kodekse časti, te konačno na javnost koja je pozvana uključiti se u ovaj cjelokupni proces.

\subsubsection{Istina kao temeljni pojam medijske etike}

Već od samih početaka razmišljanja o medijskoj etici, istina se shvaća kao njezin temelj. Tako već 1801. godine Tunis Wortmann, u danas klasičnom djelu Rasprava o politici $i$ 
slobodi tiska kaže: „Svako odstupanje od istine je kobno. Nepristranost bi trebala biti postojana odlika tiska. Ni strah na jednoj strani, ni nada u nagradu na drugoj, ne smije zastrašiti tisak“" (Wortman, 1801, prema Knowlton, Parson, 1995: 64).

Komuniciranje istine je zasigurno najvažnija dužnost medija, te stoga nije moguće pisati o suvremenoj medijskoj etici, a ne pozabaviti se detaljno pitanjem istine u kontekstu medijske etike. To znači također i da svaki novinar mora potražiti istinu i iznijeti je javnosti na najbolji mogući način. Jedan od najvećih izazova današnjih novinara je kako spoznati i kako iznijeti istinu. Novinari danas moraju pokušati iznijeti istinu bez služenja vlasnicima medija i ekonomskim interesima. To nije lagana dužnost i zadaća, te zahtjeva veliku profesionalnu vještinu i poštovanje etičkih normi. Istina je nužan kriterij profesionalnog, a time i objektivnog novinarstva koje zahtjeva iskrenost i ozbiljnost. Osnovna uloga medija je iznošenje istine, a novinari se svakodnevno moraju suočavati s ovim izazovom (Labaš, 2006: 14).

Neosporno je da je prvotna zadaća novinara iznošenje istine i ona je temeljni princip medijske etike, kojemu ćemo se posvetiti u nastavku rada. Stjepan Malović (2005: 1) tako piše da je ,vijest istinita ili nije vijest“, čime još jednom potvrđuje ovaj temeljni postulat novinarske i medijske etike. Novinarstvo, baš kao i cijela komunikacija, temelji se na istini. Istinito informiranje temelj je pluralističkog, demokratskog odlučivanja. Teoretičari vrlo jasno ističu kako tu nema dvojbe: vijest se temelji na točnim podacima i ona predstavlja istinu. Ipak, Malović (2005: 21) primjećuje i da istina nije jednoznačna i da ju je teško odrediti.

\subsubsection{1. Što je istina i kako ju spoznajemo?}

Prema Rječniku filozofskih pojmova Ante Mišića (200: 128-129) ,istina“ (grč. $\dot{\alpha} \lambda \dot{\eta} \theta \varepsilon ı \alpha$; lat. veritas) znači određenu vezu s razumom, i to vezu jednakosti, poklapanje sadržaja nekog iskaza i stanja stvari koje taj izraz izražava. Dva su osnovna načina upotrebe pojma istina: supstantivistički $\mathrm{i}$ atributivni. U supstantivističkoj uporabi termina obično mislimo na neki određeni unutarnji sadržaj, kao neku supstanciju koju termin izriče. Tu se pojam koristi dosta široko koekstenzivno sa samim bitkom i tipičan je za filozofsku tradiciju Zapada, a temelji se na Aristotelu. Kod atributivne uporabe pojma istine taj se izraz javlja kao atribut, dakle kao pridjev 'istinit', te izriče neko svojstvo onoga o čemu se govori. Tu se onda 
radi o podudaranju (adaequatio) izraza ili sadržaja propozicije sa stanjem stvari koje ona izriče, o čemu piše i Alois Halder (2002: 160).

Govoreći o istini, potrebno je spomenuti i razne teorije istine. One nastoje što točnije odrediti što prihvatljivije značenje toga termina. Prva je teorija koherencije - pretpostavlja strogo logički oblikovan sustav propozicija ili stavova, kojem u stvarnosti odgovara strogi sustav odnosa. Te propozicije stoje u međusobnoj ovisnosti, jer se one moraju izvoditi jedna iz druge. Termin koherencija mogli bismo odrediti kao odnos između sklopa propozicija koji je takve naravi da nijedna od tih propozicija ne može biti neistinita ako je čitav sklop istinit. Sljedeća je pragmatička i neopozitivistička teorija, a prema toj teoriji neku propoziciju možemo smatrati istinitom ako su praktične konsekvence njezina prihvaćanja bolje od onih njezina neprihvaćanja ili odbijanja. Istina je ono što se pokaže kao najbolje, makar se ne može potpuno isključiti mogućnost pogreške, pa i to pokazuje da je pragmatička teorija samo kriterij, a ne definicija istine. Treća je teorija konsenzusa - prema toj teoriji, bit istine ili barem njezin glavni kriterij sastoji se u konsenzusu, tj. slaganju mišljenja oko neke tvrdnje ili iskaza, bilo da se uzima činjenično slaganje, bilo samo mogućnost da se mnogi ili svi u nečem slažu. Primjenjuje se osobito u povijesnim znanostima i pravu. Sljedeća je teorija interpersonalne verifikacije, a riječ je o lingvističkoj teoriji za određivanje značenja termina „,istinit“, „neistinit““ i njihovo uvođenje u jezik. Peta je teorija evidencije, koja zastupa tradicionalno mišljenje da se istina nalazi i dovršava u sudu, ali se ona ne može sastojati u podudaranju suda sa stvarnošću. Istinu se nastoji protumačiti na empirijski način. Doživljaj evidencije stoji u temelju pojma istine, a svi pojmovi proizlaze iz iskustva. Evidencija koju ne možemo dalje definirati garantira apsolutnost i objektivnost sudova. Konačno, valja spomenuti i teoriju korespondencije, koja se oslanja na Aristotela i Tomu Akvinskog, tj. na poznatu definiciju istine kao podudaranja uma i stvarnosti (Mišić, 2002: 262-263).

Nakon prikazivanja mogućih definicija istine, sljedeće pitanje koje nam se nameće odnosi se na mogućnost dolaska do istine, to jest: je li moguće spoznati istinu? Pri tome, držeći se teme disertacije, ponajprije možemo kazati kako je temeljna funkcija profesionalnog novinara da ljude izvještava o vijestima, dakle da ih istinito informira. U mnogim područjima donosimo odluke na temelju onoga o čemu su nas profesionalni novinari izvijestili, jer da nisu mi ne bismo imali mogućnosti doći do tih informacija, jer nitko nema fizičkih mogućnosti sve sam saznati. 
Dakle, iz navedenog možemo zaključiti kako je prvotni posao novinara da otkriva istinite činjenice svijetu i izvještava o njima, o čemu smo već pisali. Čini se jednostavno, no tu dolazimo do ne baš tako jednostavnih pitanja koja zahtijevaju odgovore koji su sve samo ne jednostavni. Naime, prema Kantu, „treba“ implicira „može“ (Kant, prema Jacquette, 2007: 19). Ovaj princip ukazuje na činjenicu da nekoga možemo smatrati moralno odgovornim samo za ono što je taj drugi sposoban uraditi.

Iz svega ovoga javlja se naizgled čisto filozofsko pitanje: „Je li moguće spoznati istinu?" To pak pitanje postaje veoma praktično pitanje za novinarstvo i medije općenito. Za odgovor na ovo pitanje možemo krenuti od skepticizma koji obilježava mnoge suvremene filozofske pravce u Europi nastale poslije Drugog svjetskog rata. I danas postoje mnoge pristalice ovog filozofskog promišljanja, što u filozofskom smislu predstavlja izazov novinarskom izvještavanju za koje znamo da kao glavnu odrednicu ima prenošenje istine. Prema tom obliku epistemološkog relativizma, činjenice kao takve ne postoje. Zapravo, postoje samo interpretacije, samo gomilanje razmišljanja i promišljanja koja samo interpretiraju prijašnja promišljanja, te se tako u interpretiranju natječu tko je u pravu, a zapravo je sve samo začarani krug u kojem nema spoznavanja istine. Ne možemo kazati da je ovo potpuno promašeno filozofsko promišljanje, no kao i u slučaju većine drugih ekstremnih stavova, i ovaj postmodernistički napad na objektivnost i istinu počiva na nekoj razumnoj tezi koja je onda sasvim zaoštrena u jednom smjeru, te time prestaje biti vjerodostojna. Polazište koje je točno jest činjenica da opažanje uključuje i osjet i sud, te da je konačno sud zapravo stvar interpretacije. No, nakon toga dolazi ono što je zaoštravanje u jednom smjeru. Naime, zašto bi se činio sljedeći korak koji je neopravdan, te se izveo zaključak da su sve interpretacije u epistemološkom smislu na istoj razini, da nema nikakve osnove da se neke interpretacije izdvoje kao istinite, a druge kao lažne, ili da postoje stupnjevi istinitosti i lažnosti interpretacija u opažanju, izražavanju i priopćavanju (Jacquette, 2007: 322-323). Uzmimo primjer novinskog izvještavanja o snažnoj buri koja je pogodila neko dalmatinsko mjesto, puhala dva sata, odgodila jednu trajektnu liniju, ali nije srušila niti jedno stablo, nanijela nikakvu materijalnu štetu, a još manje ugrozila živote stanovnika. Jedan novinar može na temelju svog opažanja, te svoje interpretacije stvarnosti, zaključiti kako je riječ o jednom od najvećih olujnih nevremena u povijesti ovih krajeva, kako su nesagledivi razmjeri šteta otkazivanja jedne trajekte linije, kako je nanesena nevjerojatna šteta lokalnom stanovništvu. Drugi pak novinar može, na temelju istih opažanja, tek usputno tijekom priloga spomenuti kako je dva sata puhala bura, te je zbog toga otkazana jedna trajektna linija, no 
kako nema nikakve značajnije štete za stanovnike. Teoretski gledano, riječ je o dvije interpretacije istog događaja ljudi koji su bili na istom mjestu. No, možemo li kazati kako su obje interpretacije jednako vrijedne? Može li stanovnik tog kraja ipak procijeniti obje interpretacije, te ipak kazati da je ona prva lažna, a druga istinita? Očit je odgovor da može, tj. da se određenom novinarskom izvještaju može prilijepiti etiketa „lažan“, a drugome „istinit“, ili pak barem jednome „,uglavnom istinit“, drugome „uglavnom lažan“. Dakako, stvaran život često ne nudi ovako „crno - bijele“ događaje, te je često veoma teško spoznati što je istina, a što laž. Daleko smo od tvrdnje da je lako spoznati istinu, jer time bi se otišlo u drugu krajnost, a upravo skepticizmu prigovaramo odlazak u krajnost. Dakle, istinu je teško spoznati, no to je ipak moguće, te stoga možemo tvrditi kako je moguće izvršiti temeljnu novinarsku zadaću, to jest primatelje ili recipijente izvještavati istinito. Vraćajući se na Kanta, te na njegov odnos između „moći“ i „trebati“, tvrdimo da novinari mogu spoznati istinu, pa stoga pred novinara istinu i trebamo staviti kao moralnu obvezu.

Dakako, to ne znači tvrditi da možemo doći do potpuno objektivnog shvaćanja i do cjelovite spoznaje istine. Tako i Carolyn Lee, bivša urednica fotografije u New York Timesu, kaže da nikada nećemo doći do čisto objektivnog shvaćanja bilo čega, jer stvarnost je uvijek u očima promatrača. Napominje da dva novinara mogu poći od istog skupa činjenica, a napisati dvije sasvim različite priče, kao što smo prikazali u prethodnom primjeru. No, to nipošto ne znači da novinar treba odustati od napora da otkrije objektivnu istinu (Knowlton, Parsons, 1997: 108). Naime, iako svjestan da nikada neće doći do potpuno objektivne istine, novinar to treba pokušavati, jer čineći to doći će veoma blizu željenog cilja, a to je zapravo jedino moguće, te stoga i dovoljno.

Naravno, u potrazi za istinom novinar je dužan provjeriti informacije na više načina. Nije dovoljno doći do neke informacije, odlučiti je li istina ili nije i zaključiti da je tu „kraj priče“. Novinar je dužan provjeravati točnost informacija, pouzdanost svjedoka i izvora, uspoređivati činjenice i tražiti eventualne kontradiktornosti, te na koncu uvijek brižljivo i oprezno formulirati ono do čega se došlo kako bi tekst bio jasan i precizan, jer i zbog obične nezgodne formulacije teksta nenamjerno može doći do neistinitog izvještavanja. 


\subsubsection{Specifičnost istine u novinarstvu}

Krenuvši od općenite definicije istine kao podudaranja između uma i stvarnosti, mogli bismo kazati da je istina $\mathrm{u}$ novinarstvu podudaranje napisanog/izrečenog/prikazanog $\mathrm{i}$ stvarnosti. No, netko bi se mogao zapitati zašto bi novinar uopće morao govoriti istinu, dok bi mu drugi na to odgovorili da je prva zadaća novinara prenositi recipijentima informacije o stvarnosti koja nas okružuje. Ako novinar prenosi lažnu ,informaciju“, to zapravo niti nije informacija, a samim time onda nema niti vijesti (Jacquette, 2007: 33).

Nadalje, može se postaviti pitanje zašto bi novinar imao posebnu obvezu govorenja istine, pri čemu je odgovor da on ima tu obvezu, kao što je ima i svaki drugi čovjek, pa bismo mogli kazati da novinar ima obvezu govoriti istinu, ali ne samo kao novinar, nego kao čovjek. No, ni to ne bi bilo posve točno zato što novinar osim osobne odgovornosti u ostvarivanju svoga poziva ima i društvenu odgovornost.

\subsubsection{Standardi novinarske istine i relevantna istina}

U promišljanju o novinarstvu, postoji mnoštvo stavova o tome što čini istinito izvještavanje. Prema Louisu Alvinu Dayu (2004: 106) postoje u najmanju ruku tri koncepta koji leže u osnovi pojma istine u izvještavaju. Prvi i najočigledniji koncept kaže da izvještavanje mora biti točno. Bez toga se ne može nastaviti dalje. Činjenice se moraju provjeriti, moraju se zasnivati na čvrstim dokazima, ne tek na nekim pretpostavkama. Ovo je minimalan zahtjev ispod kojeg se ne smije ići. Ono što također u novinarstvu nije opravdano i smatra se smrtnim novinarskim grijehom jest izmišljanje ili mijenjanje sadržaja izjava, čak i kada odražava bit onoga što je rečeno. Ovdje postoji dilema što s gramatičkim i stilskim pogreškama citirane osobe, tj. treba li ih ispraviti iz poštovanja prema njoj (da se ne bi označilo osobu kao onu koja ne poznaje zakonitosti vlastitog jezika). Nadalje, posebna slabost u ovom području točnog izvještavanja jesu izvještaji o raznim znanstvenim istraživanjima. To postaje sve aktualnije budući da našim medijskim i društvenim prostorom sve više dominiraju razna istraživanja, a posebno ankete s veoma upitnom znanstvenom vjerodostojnošću. Bez nužnog intelektualnog oruđa za ocjenu metodologije istraživanja i izvedenih zaključaka, novinari često ta istraživanja prihvaćaju nekritički. No, potreban je bar minimum poštenja, pa je potrebno naglasiti tko je naručitelj određenog istraživanja, te tko je istraživanje proveo, a 
onda se recipijentima medija može prepustiti da procijene vjerodostojnost određenog istraživanja (Day, 2004: 106-107).

Drugi zahtjev za novinarskom istinom nalaže da bi istinita priča, osim što mora biti točna, trebala davati i kontekst iznesenih informacija. Vremenska i prostorna ograničenja često sprječavaju davanje detaljnih objašnjenja, jer davanje svih obrazloženja i svake najmanje sitnice te njeno stavljanje u neki širi kontekst svaku vijest bi učinilo nevjerojatno dugačkom, a u konačnici i nekorisnom. No, cilj bi trebao biti davanje suštinski kompletnog izvještaja. Priča bi trebala sadržavati što više relevantnih informacija, a od ključne važnosti je da se prosječnom recipijentu ponudi bar obrazloženje važnih informacija, te njihovo stavljanje u kontekst cijele priče. Dakako, činjenica je da se cijela istina o nekom događaju nikada ne može saznati, ali etička pitanja nastaju kada se namjerno zadrže neke ili sve činjenice od značenja za javni interes. No, osim namjernog, postoji problem i nenamjernog nedavanja ispravne slike o nekom događaju, kada novinari nemaju dovoljno znanja o događaju, osobi ili pojavi o kojoj izvještavaju. Primjer je slučaj kojeg je u New York Timesu opisala Lorry Goldmann, suradnica New York Timesa za vjerska pitanja. Ona govori o novinaru koji je poslan izvijestiti o molitvi pentekostalne vjerske zajednice na stepenicama američkog Kongresa, koji je u svoj novinarski prilog uvrstio i uznemirujuće riječi jednog od predmolitelja koji je pozvao na molitvu da Bog pobije sve u Kongresu. Novinar je mislio da riječ ,pobiti“ (eng. slay) i u tom kontekstu znači baš to - pobiti. Međutim, pentekostalci kada govore o „pobijanju“ ne misle na doslovno značenje, nego ima značenje da se nekoga nadvlada duhom i da treba moliti da se taj čovjek promijeni na takav način da ga ispuni ljubav prema Bogu. Nažalost, novinar to nije znao i nije se potrudio provjeriti je li doista riječ o nevjerojatnom pozivu na ubojstvo čitavog američkog Kongresa (Day, 2004 : 106-107), ili o nečemu ipak bitno drugačijem što nema veze s pozivom na ubojstvo.

Treći kriterij istinitog članka jest da on mora biti pošten, objektivan i uravnotežen. To na prvome mjestu znači izbjegavanje svake, pa i najmanje, pristranosti (Day, 2004: 109). Naime, recipijent želi sam imati mogućnost prosudbe, želi imati pravo na donošenje vlastitih zaključaka na temelju iznesenih informacija, ne treba mu netko drugi tko će mu kazati što i kako treba misliti, te koje zaključke donositi.

Novinari, kao što smo već naglasili, kao prvotnu zadaću imaju istinito izvještavati. No, to izvještavanje ne treba biti samo istinito, nego i relevantno. Dakle, zadaća novinara je iznošenje relevantne istine. No, što je relevantno, a samim time i relevantna istina? Naime, 
sam pojam relevantnosti je relativan u odnosu na različite interese, kontekste i sud. Jer, ono što jednoj osobi izgleda relevantno, ne mora isto tako izgledati i drugoj, baš kao što i ono što jedna osoba vjeruje da je istinito, ne mora ni u kom slučaju biti u skladu s onim što druga osoba vjeruje da je istinito (Jacquette 2007: 55). No, kao što smo ustvrdili već na početku da za istinom treba težiti unatoč poteškoćama, isto je i s relevantnosti informacija i vijesti.

A što znači kada kažemo da od novinara očekujemo relevantnu istinu? Znači da od novinara ne možemo očekivati da prenosi i da opisuje svaku moguću pojedinost, jer tada bi svaki novinarski članak postao knjiga, a novinarski prilog na televiziji bi trajao dulje od filma. Naime, novinari moraju donositi odluke i birati. Urednički proces ne počinje onog trena kada novinar preda članak uredniku, nego je prvi urednik svog članka novinar koji određuje što će uvrstiti u članak, a što ne. Drugim riječima, novinar odlučuje i koje su istine relevantne, a koje nisu, te je zbog toga ključna njegova sposobnost odabira, to jest selekcije informacija koje će njegovom odlukom - i njegovom moralnom odgovornošću - postati vijesti (Jacquette, 2007: 56).

Možemo kazati da je sve što je potrebno za donošenje ispravnih sudova o relevantnosti istine zapravo zdrav razum. On nam govori koje informacije bi razumno mogle biti zanimljive i potrebne recipijentima. Jasno, izmišljeni ekstremni primjeri ne rješavaju teža pitanja koja se pojavljuju u stvarnosti. No, neki opći principi primjenjuju se u svakom slučaju, čak i kada je njihova primjena nešto složenija. Relevantne istine su uvijek relevantne u odnosu na neki pretpostavljeni cilj ili svrhu, a u novinarstvu je vrhovni cilj uvijek pisati istinu i istinito izvještavati publiku, pa stoga mnogi autori danas upozoravaju da, primjerice, povećanje naklade, čitanosti, slušanosti ili gledanosti, ne može biti ni cilj ni svrha novinarstva. U većini slučajeva, novinar s iskustvom može bez problema ustanoviti je li informacija do koje je došao istinita, a ako je istinita je li riječ o relevantnoj ili nerelevantnoj istini. (Jacquette, 2007: $61)$.

\subsubsection{Medijska etika u kontekstu istine}

Poput drugih autora, i Labaš (2006: 54) postavlja neka pitanja medijske etike: služe li novine i novinari danas doista samo svojim prijateljima i vlasnicima, oglašivačima, interesnim krugovima i istomišljenicima, ne mareći za istinu? Mogu li novinari u iznimno užurbanom novinarstvu današnjice, u kome je važnije stići prvi nego napisati provjerenu informaciju, 
spoznati, doznati i javnosti prenijeti istinu, objektivno i bez zadrške? Istodobno daje i vrlo jasan i nedvosmislen odgovor: „Jedini je prihvatljiv odgovor: mogu i moraju, a istina je zahtjev i kriterij prema kojemu se neki medij procjenjuje kao pošten, ozbiljan i dostojan svoje društvene uloge.“ Ipak, ističe i realnu situaciju: „Novinari svakodnevno rade pod pritiskom i svjesni su da u njihovom radu najčešće strada etika, a da je prava žrtva njihova nemara i nepoštenog rada gotovo uvijek istina. Zato je novinar u svakodnevnom poslu pozvan preispitivati svoja načela i truditi se djelovati u skladu s geslom: 'Činjenice su svete, komentari slobodni'“ (Labaš, 2006: 54).

Isti autor (Labaš, 2006: 55) donosi jednu poznatu, a zanimljivu usporedbu: „U medijima je istina poput slona kojeg ispipavaju slijepci. Neki ispipavaju uho pa kažu da je slon plosnat, oni koji dohvaćaju slonove noge kažu da liči na stup, oni koji rukama obuhvaćaju surlu kažu da slon liči na zmiju, međusobno se bijesno svađaju, svaki je siguran u svoju verziju istine. Onoga koji bi im rekao da je slon sve to zajedno, i još mnogo više od toga, njega bi razapeli.“

Da je istina ipak cijenjena, primjećuje (Labaš, 2006: 55), ističući da unatoč tvrdnjama koje se tako često čuju, a možda i usprkos dojmovima publike, mediji zapravo vole istinu, ili se barem takvima vole prikazati. O tome svjedoče i neke reklame, poput prijašnje reklame za novine „24 sata“ koje su se prodavale uz slogan: „24 sata - cijela istina. Pola cijene.“ Ma koliko to ironično zvučalo, nad tim oglasom tzv. ,jedinoga hrvatskog tabloida“ postavlja nam se pitanje: Što je istina? Kakvo je razumijevanje istine danas?

Labaš (2006: 58) primjećuje i određene poteškoće i ograničenosti koje nastaju u novinarskom traganju za istinom, jer u traganju za činjenicama koje odgovaraju istini prirodna ograničenost razuma, a u novinarstvu i velika ograničenost vremena, može zasjeniti ozbiljnost i temeljitost istraživanja. Također, i druge osobne koristi, koje mogu biti različitog opsega i različitih motiva, mogu potamniti istinu. Govoreći o dolaženju do istine, Labaš (2006: 60) piše da neki filozofski pravci ističu da do istine možemo, kao razumska bića - doći dijalogom i komunikacijom. Čini se da je takvo razmišljanje prihvaćeno i u novinarstvu, zaključuje Labaš, te nastavlja da uz sve zapreke slobodi komunikacije i dolasku do istine, u novinarstvu kao i u drugim segmentima ljudskih znanja, postoji jedna koja je gora od njih svih, a to je: ideologija, jer se ona protivi dijalogu, te ne želi zajednički tražiti i doći do prave istine. Ideologija je zapravo u biti nepoštivanje sugovornika, njegove vrijednosti i njegova mišljenja. Dok dijalog polazi od pretpostavke vjere u postojanje istine do koje se može doći i uz pomoć 
drugoga, te na poštivanje drugoga, ideologija polazi od dijametralno suprotnih postavki (Labaš: 2006: 62). Isti autor (Labaš, 2006: 64-65), polazeći od poznate misli još od doba grčke filozofije da je ,čovjeku (je) potrebno sedam godina da spozna istinu, još sedam da je prenese drugima“, naglašava da ako nakon ove rečenice zamislimo bilo koju novinarsku redakciju, bit će očito nešto drugo: nitko nema „sedam godina““ za razmišljanje i odvagivanje vijesti, jer novine izlaze svakodnevno, radijski ili televizijski dnevnik samo što nije počeo, a u današnje doba internetskog - digitalnog i konvergentnog - novinarstva vijesti se objavljuju iz sekunde u sekundu. U skladu s gore navedenom tvrdnjom, filozofu je lako, on ima „sve vrijeme ovog svijeta“, dok novinar za svoju jednako odgovornu zadaću dolaska do istine ima daleko manje vremena. Novinari istinu doznaju u hodu, dijaloški, u kontaktu s drugim ljudima, promatrajući, odvagujući, ocjenjujući. No, nemaju vremena sjesti i dulje razmisliti, ne mogu se služiti ,peripatetičkim školama“ u kojima će u dugim šetnjama i razmišljanjima otkrivati istinu. Ipak, po uzoru na filozofe koji su spoznavali istinu traganjem za njom, to su dužni i novinari, a razlika je samo u vremenu kojeg novinari imaju znatno manje.

Malović, Sherry Ricchiardi i Gordana Vilović (2007: 50) ističu da je poštovanje istine najvažnija profesionalna obveza novinara i ona je neizostavan članak u preambulama i člancima etičkih kodeksa. Isti autori naglašavaju i da je zanimljivo da se u većini pisanih načela ne koristi sintagma „objektivno informiranje“, već uvodi kategorija „pošteno“. Poštenje tako postaje ultimativna kategorija koja se zahtjeva od novinara. Samo pošten novinar ima potpuni integritet i stoga mu korisnici medija vjeruju, naročito kad izražava svoje mišljenje o različitim zbivanjima (Malović, Ricchiardi, Vilović, 2007: 51).

Isti autori (Malović, Ricchiardi, Vilović, 2007: 53) primjećuju da većina novinarskih etičkih kodeksa vrlo jasno razlikuje informaciju, mišljenje i oglas. Prvo, drugo i treće ne smiju se miješati i moraju biti strogo odijeljeni. Ipak, smatraju da je u praksi nešto drugačije, tj. navode da je boljka novinarstva u zemljama u tranziciji to da se vrlo često te tri kategorije miješaju, pa čitatelj ne zna gdje prestaje informacija, a počinje komentar, a sve je protkano propagandnim porukama kojima je mjesto među oglasima. Smatraju da novinarstvo brka komentar s propagandnim stavovima političkih stranaka ili nekih centara moći, što je izrazito neetično. Strani etički kodeksi, poput njemačkog, francuskog, finskog, američkog ili bilo kojeg drugog su dosta kritičniji prema ovoj pojavi, te vrlo jasno naglašavaju potrebu za posve odvojenim prezentiranjem vijesti od komentara, a pogotovo od oglasa. 


\subsubsection{Kakva nam medijska etika treba?}

Kao što navode Labaš i Uldrijan (2010: 86) više no ikada prije u suvremenom je društvu važno promišljati o medijskoj etici. Iako će teoretičari, ali i laici koji prate medije reći da se ona nalazi u dubokoj krizi i poteškoćama, ona je neophodna, osobito u današnje doba novih medija. Na tu krizu u medijima utječu mnoge poteškoće pred kojima se novinari i novinarstvo danas nalaze, kao što su suočavanje s monopolom i pritiscima vlasnika, ili pak oglašivača i borbe za opstankom na tržištu, preko pritisaka iz redova politike, ali i svih drugih interesnih skupina. Sve to, kao i pogrešno shvaćanje slobode medija, dovelo je do uočljive tabloidizacije medija i sužavanja i nestajanja granica između novinarstva i ,nenovinarstva“, između novinara i onih koji se nazivaju novinarima. A „novinarski poziv je osobit i razlikuje se od mnogih drugih jednostavno zato što se pogreške u njemu ne daju sakriti. One se vide odmah, i vidi ih veliki broj ljudi““(Vilović, prema Labaš, Uldrijan, 2010: 86).

Helmut Spinner (1992, prema Labaš, Uldrijan, 2010: 89) napisao je da novinarstvo danas ima kritiku kao zvanje, informaciju kao zadaću, zabavu kao posao ili trgovanje, pa bi trebalo imati i moral kao „legitimaciju“ ili iskaznicu, da mu život ne bude velika laž.

Labaš i Uldrijan (2010: 89) navode da bi se netko mogao i upitati zašto je potrebna etika u sredstvima društvene komunikacije, kao i etičnost u djelovanju samih novinara, kada su korisnici ionako oni koji odlučuju o sudbini medija $\mathrm{i}$ to njihovim korištenjem ili nekorištenjem, kupovanjem ili izbjegavanjem, pa prema tome oni mogu i nagraditi ili kazniti etičnost ili neetičnost pojedinih medija. Na to pitanje ne može se dati tako jednoznačan i jednostavan odgovor, jer niti pojedinci kao korisnici medijskih usluga niti javnost u cjelini nema stupanj zrelosti potrebne za donošenje racionalnog suda i racionalne odluke o korištenju medija, pa je o medijskoj pismenosti potrebno daleko više i češće raspravljati i u okviru odgovornosti primatelja medijskih poruka, te ih osposobljavati za donošenje ispravnih odluka, a istovremeno raditi na etičnosti medijskih sadržaja.

Dakako, to „osposobljavanje za donošenje ispravnih odluka“ o kojima pišu Labaš i Uldrijan, je nešto što treba započeti već u najranijoj dobi, a u tome može pomoći medijska pismenost. O toj temi piše sve više autora, osim već spomenutog Labaša, na hrvatskom govornom području potrebno je spomenuti Lanu Ciboci, koja je posljednje istraživanje objavila 2018. god, a u kojem je istraživala medijsku pismenost kod učenika osmih razreda. Na tom mjestu (Ciboci, 2018: 24) piše da je medijska pismenost rezultat medijskog 
obrazovanja, te da podrazumijeva pristup medijima kao i analizu, vrednovanje i stvaranje sadržaja, a da se medijska pismenost smatra i jednim od ključnih oblika pismenosti 21 . stoljeća.

U kontekstu novinarskog traganja za istinom korisno je na pameti imati misli o razumijevanju istine u filozofiji Emmanuela Levinasa. „Njegovo razumijevanje istine puno govori i o današnjim medijskim djelatnicima. Pitanje istine u njegovoj filozofiji polazi od pokušaja nadilaženja ontološkog poimanja istine, dovodeći do njezina etičkog razumijevanja. Istina za kojom težimo, i koja omogućuje radikalno otvaranje našeg subjekta, jest, Levinasovim rječnikom rečeno, dobro, koje je uvijek s 'one strane bitka'. A to nas dobro poziva na 'odgovornost u pasivnosti', pa čak i za smrt drugoga“ (Labaš, prema Labaš, Uldrijan, 2010: 101).

Unatoč svemu, „nikada se ne bi smjelo zaboraviti da se moralni kriterij dobrog novinarstva utemeljuje $u$ istini i slobodi. Ispravno djelovanje i dobar život - misli se ovdje na uspjelo novinarstvo - poklapaju se u djelatnoj, ispravnoj i u istini utemeljenoj slobodi. Etos je novinarstva, dakle praktično sloboda“ (Koprek, prema Labaš, Uldrijan, 2010: 102). Dodali bismo tome kao zaključak: „Čovjek je, dakle, biće slobode i upravo po slobodi čovjek je i moralno biće“" (Oslić, prema Labaš, Uldrijan, 2010: 102).

\subsection{5. Čovjek kao središte medijske etike i etički relativizam}

Suvremeni etički pravci često u središte medijske etike stavljaju upravo čovjeka, kao što navodi i Brajnović (2011: 114) koji ističe da se mediji i cijela društvena komunikacija vrednuju prema tome služe li čovjeku, njegovim pravima, odnosno koliko utječu na slobodu i koliko pridonose praksi samoodlučivanja. Isti autor smatra da su pristup i prihvat medijskih proizvoda važan element profesionalnog odnosa, pri čemu istinitost i mogućnost provjere činjenica uvijek trebaju biti ključni motivi, što znači da moraju davati prednost ljudskim pravima nasuprot komercijalizaciji i ekonomiji, sprječavati instrumentalizaciju korisnika informacija, zaštititi žrtve katastrofa, te u konačnici usmjeravati se na potrebu trajnog pridržavanja etičkih kodeksa i društvenih vrijednosti. Iste te vrednote i kriterije za ispravan pristup medijskoj etici ističu i drugi autori, među kojima i Bertrand (2007), koji jednako tako u središte svojih razmišljanja stavlja čovjeka, tj. primatelja koji medijskim profesionalcima mora biti na prvome mjestu. 
Kao što navode Labaš i Uldrijan (2010: 103) za obnovu i očuvanje etičnog novinarstva i društvene komunikacije kakvu poznajemo nije dovoljno samo sastaviti desetak načela i objediniti ih u kodeks, misleći da se time rješavaju etičke dileme i problemi pred kojima se nalaze medijski djelatnici. Nema svrhe niti samo dijeliti deklarativne ukore onima koji okrenu glavu od temeljnih etičkih vrijednosti. Mnogo je važnije, ali i jedino pravo rješenje, vratiti se na čovjeka, na njegovo nepovredivo dostojanstvo, jer je on subjekt novinarstva, a njegovo se djelovanje u medijskom kontekstu očituje prije svega $u$ istini i slobodi. No, u kontekstu suvremenih etičkih pravaca i kod definiranja obilježja našega društva - koje je postmoderno, potrošačko, informativno i društvo znanja - sve se češće govori o teretu slobode i odgovornosti (Bruckner, Baumann i drugi), ali i o etičkom relativizmu (Vattimo, Ratzinger i drugi).

O temi etičkog relativizma govori, između ostalih, i Hartmann (2003: 29-30) koji kaže da je etički relativizam pitanje koje predstavlja bit filozofske etike. Ako su ćudoredne zapovijedi nastale, onda su one ljudsko djelo; tada ljudska misao ima moć da ih uzdigne i ruši; tada bi i filozofska misao imala moć da daje zapovijedi, kao što politička misao ima moć da izdaje zakone. Pozitivno pravo i pozitivni moral stajali bi tada na istoj stepenici. Tada je etika „praktična filozofija“ u normativnom smislu i pravo da podučava što se treba dogoditi nije prazna preuzetost. Na istom mjestu Hartmann piše da iako može biti tako da norme nastaju izvan filozofskog osvješćenja i vremenski prije njega te tako počinju važiti, filozofskoj bi etici dopala sva odgovornost za njih. Jer, u njezinoj bi nadležnosti bilo da norme revidira, da ih procjeni i odvagne, te ih prihvati ili odbaci. Etička misao bi prema tome bila pozvani zakonodavac ljudskoga života, imala bi moć i dužnost da čovječanstvo poduči nečemu boljem. Da filozofska etika stvarno ne snosi tu golemu odgovornost, osjećajno se može doduše lako uvidjeti, međutim potreban je stroži dokaz iz strukture etičkog fenomena, ističe Hartmann, te nastavlja da tu odgovornost ne bi mogla snositi niti jedna filozofska etika. Jer ljudska je misao upravo isto tako relativna kao i norme čiju bi relativnost ona trebala prevladati. Zbog toga se i te etičke teorije isto tako razlikuju i razilaze kao i promjenljive norme pozitivnog morala koje podupiru. Filozofska etika bi morala, kad bi se ozbiljno prihvatila te nemoguće zadaće, na sebe navući isti teret krivnje za preuzetnost postojećih normi koju bi trebala raskrinkati, što bi je zapravo dovelo u svojevrsnu kontradiktornost. Konačno, mogli bismo reći da ona i od sebe same mora otkloniti pretenziju apsolutnosti, koju pobija kod njih. 
Čehok i Koprek također govore o etičkom relativizmu koji je itekako relevantno pitanje u medijskoj etici. Tako navedeni autori (2006: 10), iako ne pišu direktno o medijskoj etici, naglašavaju da je u vremenu koje s obzirom na duhovni kulturni trend općenito možemo s pravom nazvati pluralističkim, sablažnjiv i izazovni problem etičkog relativizma, to jest shvaćanja da na području moralnosti ništa ne vrijedi apsolutno, bezuvjetno i nužno, nego tek u odnosu prema nečem drugom. Nadodaju i da se sav problem relativizma u etici okuplja oko nemogućnosti racionalne argumentacije na području moralnosti (Čehok, Koprek, 2006: 11). $\mathrm{Na}$ istom mjestu daju i odgovor na pitanje zašto zagovornik etičkog relativizma ostaje u zabludi: zato što tvrdi da ne postoje apsolutna mjerila za biti-dobar i biti-loš. Time pak nije izbrisana i bezuvjetna činjenica moralnosti, tj. moralna obveza. Relativistička je teza neodrživa. Ili, relativist kaže da bi bilo dobro da se pojedinac orijentira prema svojim relativnim mjerilima $i$, prema tome, realizira svoja djelovanja. No, tako i on, na neki način zastupa trajno, bezuvjetno, apsolutno mjerilo. Ili pak ako tvrdi: ravnanje po vlastitome zadobro-držanju uopće ne posjeduje vrijednost, čak niti relativnu, onda on svojem relativnom vrijednosnom sudu poriče sam objekt. U tom se slučaju relativizam okreće u svoj krajnji rezultat: etički nihilizam i amoralizam.

Zlatko Miliša, Mirela Tolić i Nenad Vertovšek (2009: 129) govore izravno o moralnom relativizmu u medijima: „Središnja ideja relativističkog pristupa je da su moralne vrijednosti ljudski konstrukti, a ne rezultanta transcendentalne istine. Pozicija moralnog relativizma u filozofiji govori da moral i/ili etika ne odražavaju apsolutne ili univerzalne moralne istine. Univerzalne vrijednosti su nadindividualne - duhovne vrijednosti. Međutim, te iste nadvremenske vrijednosti se ne mogu iskustveno spoznati a priori.“

\subsection{Suvremena medijska etika i njezine teme u razmišljanju odabranih autora}

Suvremena misao o medijskoj etici nudi široku lepezu različitih pristupa i mnogobrojnih autora koji na različite načine promišljaju o medijima $\mathrm{i}$ općenito $\mathrm{o}$ komunikaciji, stavljajući ih u kontekst etičkih pitanja. Na ovome mjestu izdvajamo one za koje procjenjujemo da su se bavili temama relevantnim za našu disertaciju, a čija će nam razmišljanja pomoći u stjecanju dubljega uvida u misaona strujanja i pružiti nam sliku suvremene medijske etike. 


\subsubsection{Komunikacijska etika Jürgena Habermasa}

Habermas i njegovo etičko promišljanje su veoma značajni te mogu pomoći u razumijevanju medijske etike. Habermas u svom temeljnom djelu Teorija komunikativnog djelovanja piše da svojom argumentacijom želi ukazati na potrebu za teorijom komunikativnog djelovanja koja se javlja kada želimo da se jednom, opet i na odgovarajući način, promisli problematika društvene racionalizacije, koja je u velikoj mjeri isključena iz stručne sociološke rasprave nakon Webera (Habermas, 1984: 6).

Habermas (1984: 19) piše da je medij u kojem se negativna iskustva mogu produktivno asimilirani teorijski diskurs, odnosno oblik argumentacije u kojoj sporna istina traži raspravu. Situacija je slična u moralno-praktičnoj sferi. Smatramo osobe racionalna ako mogu opravdati svoje postupke na temelju postojećih normativnih okvira. To osobito vrijedi za one koji, u slučajevima sukoba različitih normi, djeluju razborito, odnosno, ne daju da na njih utječu njihovi osobni interesi, niti ih slijede, već prosuđuju situaciju s moralnog stajališta, a da bi je razriješili na konsenzualni način. Medij u kojem hipotetski možemo testirati može li norma djelovanja, bila ona priznata ili ne, biti nepristrano opravdana, praktični je diskurs; to je oblik argumentacije u kojoj tvrdimo da su normativne ispravnosti postale tematizirane. $U$ filozofskoj etici, to nipošto ne znači da su tvrdnje valjanosti povezane s normama djelovanja, na kojima se temelje odredbe rečenice, a analogno prema tvrdnjama istinitosti, mogu biti diskurzivno opravdane. U svakodnevnom životu, međutim, nitko neće ući u moralne argumentacije, ako ne polazi od snažne pretpostavke da se konsenzus može u načelu postići među onima koji su uključeni. Isti autor (Habermas, 1984: 36) piše da svi argumenti, bilo oni koji se odnose na pitanja iz zakona i morala ili bilo da je riječ o znanstvenim hipotezama ili književnim djelima, zahtijevaju isti osnovni oblik organizacije, a to je onaj po sili ili snagom boljeg argumenta.

Habermas (1984: 42) ističe da samo istinitost prijedloga, kao i ispravnost moralnih normi i razumljivost dobro oblikovanih simboličkih izraza jesu, po samom svom značenju, univerzalne tvrdnje valjanosti koje mogu proći test valjanosti u diskursu. Habermas (1984: 69) također piše da interakcija s drugim osobama otvara put konstruktivnom rastu društveno priznatog „sustava moralnih normi“. Isti autor (Habermas, 1984: 89) jednako tako ističe da možemo klasificirati normativno regulirano djelovanje kao koncept koji pretpostavlja dva svijeta, objektivni svijet i društveni svijet. Nadalje, smatra da postoje sudionici komunikacije koji traže konsenzus i idu protiv istine, ispravnosti i iskrenosti, tj. protiv podudaranja ili 
nepodudaranja između onog što je izgovoreno, s jedne strane, te tri svijeta u kojima sudionik komunikacije uspostavlja odnos sa svojim iskazom s druge strane (Habermas, 1984: 100). Takvi odnosi se nalaze između izgovorenog i:

1. objektivnog svijeta (kao ukupnost svih subjekata o kojima su moguće istinite tvrdnje);

2. društvenog svijeta (kao ukupnost svih legitimno reguliranih međuljudskih odnosa);

3. subjektivnog svijeta (kao ukupnost govornikovih iskustava do kojih ima povlašten pristup).

Habermas (1984: 104) piše da u normativno uređenim djelovanjima komunikator ulaskom u međuljudske odnose zauzima odnos prema nečemu u društvenom svijetu. Ponašanje komunikatora je subjektivno „ispravno“ u smislu normativne ispravnosti, ako on iskreno vjeruje da slijedi postojeću normu djelovanja, a njegovo ponašanje je objektivno „ispravno“ ako normu koja je u pitanju smatraju opravdanom oni na koje se odnosi. Habermas (1984: 162-163) dalje navodi da su iz perspektive formalne etike temeljene na općim načelima podcijenjene one pravne norme (kao i stvaranja i primjene zakona) koje se pozivaju na magične svete tradicije, objave i slično. Norme se danas shvaćaju kao puke konvencije koje se mogu smatrati hipotetički snažnima. Habermas (1984: 193) zaključuje da su religijska tumačenja svijeta i religijska etika intelektualaca koji žele biti racionalni nužno izloženi imperativu dosljednosti.

O Habermasovoj komunikativnoj teoriji piše Žarko Paić (2009: 197-199) koji smatra da je najznačajnija teorija komunikacije djelovanja upravo ona Habermasova. U opreci $\mathrm{s}$ postmodernom Jean-Françoisa Lyotarda, ali s gotovo istih ekonomskih teorijskih pozicija, analizira se mogućnost svojevrsne nove utopije demokratskoga javnoga (raz)uma u okviru socijalno-kulturne politike liberalne konstrukcije zajednice. Njemačka teorija novih medija - s Friedrichom Kittlerom kao teorijskim predvodnikom vlastite postavke o komunikaciji - u suprotstavljanju cjelokupnoj tradiciji iznijela je neomarksističke teorije medija. U tom kontekstu kao posve izdvojena figura pojavljuje se Habermas. Dvije faze njegova mišljenja nisu nipošto posve razdvojene. Postoje stanoviti pomaci, ali naklonost paradigmi moderne koja se kao nedovršeni projekt zbiva u svim sferama suvremenoga društva i kulture neupitnom je osnovom njegove teorije (Habermas, 1968, 1981, 1988). U spisu Tehnika $i$ znanost kao ideologija iz 1968. godine Habermas slijedi ideje filozofskog antropologa Arnolda Gehlena. Tehnika produžuje ljudske organe. Društvo je određeno radom, a tehnika je 
kvalitativno novo nadomještanje fizičkoga rada industrijskoga razdoblja. Habermas se kritički odnosi spram Herberta Marcusea, jednog od njegovih prethodnika u programu Frankfurtske kritičke teorije društva, zato što je tehniku apsolutizirao na račun rada. Tehnika za njega nije nikakva osloboditeljica čovjeka od prisile i nužde rada, nego društveni fenomen. Tehnika i znanost pojavljuju se u kapitalizmu kao ideologija. To znači da se kroz njihovo uspostavljanje glavnim moćima društvene interakcije ljudska sloboda svodi na nešto tehnički nadomjestivo. Područje interakcije čovjeka s čovjekom i prirodom jest područje autonomnoga djelovanja. Komunikacija se zato Habermasu nužno pojavljuje u elementu društvene znanosti o slobodi koja se suprotstavlja prisili i nuždi rada (tehnici i znanosti). Već je otuda vidljivo da Habermas pripada „humanističkoj“ struji teoretičara medija. Njegova je spoznajno-teorijska pozicija u prvoj fazi mišljenja svođenje bitka na društvenu sferu događanja nepokorive slobode. Taj metafizički dualizam nije bio odlikom komunikologije Viléma Flussera. Naprotiv, ljudska se sloboda komunikacije pretpostavlja, ali ne kao subjekt spram kojeg je tehnika i znanost objektom. U tome leži problem s Habermasovim pojmom komunikacijskoga djelovanja, kojega izlažemo u nastavku rada. Nije nipošto slučajno da je kritika takvoga koncepta uvjet mogućnosti oslobođenja teorije novih medija od „pogubnosti digitalnoga humanizma“. Habermas pravi razliku između rada i interakcije. Rad je djelovanje sa svrhom. Njime se ozbiljuju definirani ciljevi. Takvo je djelovanje instrumentalno, racionalni izbor ili spoj obojega. Instrumentalno djelovanje utemeljeno je na tehničkim pravilima. Empirijsko znanje omogućuje predviđanje budućih procesa. S druge pak strane, racionalni izbor koji se krajem XX. stoljeća razvio kao nova sociologijska teorija djelovanja posebno $u$ ekonomskome području interesa određenih posebnim kulturnim tradicijama, odvija se prema strategijama koje počivaju na analitičkome znanju. Takve strategije omogućuju izbor preferencija. Iz njih proizlazi uspostava sustava vrijednosti. Strategijsko djelovanje racionalnoga izbora ovisno je o ispravnom vrednovanju alternativa u ponašanju subjekata/aktera, dok je instrumentalno djelovanje stavljanje organiziranog sredstva u funkciju dosezanja cilja djelovanja. Habermas razlikuje, dakle, komunikacijske ciljeve i svrhe (Paić, 2009: 197-198).

Što je za Habermasa prve i druge faze komunikacijsko djelovanje? To je simbolički posredovana interakcija. Više subjekata koji međusobno djeluju nalaze se suprotstavljeni u nekoj društvenoj situaciji. Njihova interakcija je posredovanje njihovih ideja i stavova. Komunikacijska situacija u kojoj se nalaze, smatra Habermas, određena je time što se ravna prema važećim normama na osnovi kojih se osobe ponašaju i to očekuju od drugih. Idealna 
govorna situacija pretpostavlja idealnu interakciju sudionika javne rasprave. Kako to izgleda, nije lako zamisliti. U drugoj fazi Habermasova mišljenja, koja se otvara njegovim dvosveščanim opsežnim djelom Teorija komunikacijskoga djelovanja iz 1981. godine, uvode se pojmovi koji zamjenjuju rad i interakciju, a to su sustav i svijet života. Preuzeo ih je iz fenomenologijskih spisa Edmunda Husserla. Institucionalni okvir društva čini njegov sociokulturni svijet života. Utjecaj Maxa Webera na Habermasovu teoriju modernosti čini se odlučujućim, čak i više no što je to Karl Marx, Georg Wilhelm Friedrich Hegel i Friedrich Schelling kad je riječ o analizi rada i prirode u okviru filozofijskoga sustava. Također, sustavi počivaju na interakciji. No ta je interakcija djelovanje sa svrhom. Sustavno je uvijek ono djelovanje koje strategijski i instrumentalno nastoji „pokoriti“ primarnu nesvodivost slobode na tehničke strukture. I komunikacija se u svijetu novih medija može tehnicistički, smatra Habermas, oblikovati s obzirom na model tržišne privrede. Komunikacija kao razmjena informacija na taj način postaje robom. Sustav na kojem počivaju informacije društveno je ustrojen tako da međuljudske odnose prikazuje/predstavlja kao odnose između stvari. Marxova kritika fetišizma robe iz Kapitala i u Habermasovim analizama moderne komunikacije zauzima bitno mjesto. Tehnička logika prožima sve podsustave. Ništa se u tom pogledu ne može promatrati izvan sustava. U svijetu života događa se komunikacijska racionalnost tako što se vladajući oblik dijaloga zasniva na idealu komunikacijskoga djelovanja. Pravila su igre unaprijed postavljena. Ona nisu privremena, nego univerzalna. To je bitna razlika Habermasa i njegova koncepta komunikacijskoga djelovanja spram Lyotarda i postmoderne. Da bi se komunikacijski proces odvijao nesmetano normativni okvir interakcije mora biti jezično razumljiv svima. Ne određuje jezik normi ,pravila ponašanja“, nego norma (komunikacije) određuje pravila ponašanja jeziku. Tako bi se moglo kantovski interpretirati ono što Habermas ustvrđuje u obratu modeme filozofije subjekta spram kasnomodernoga okreta spram jezika. Habermasov pojam komunikacijskoga djelovanja izveden u knjizi Teorija komunikacijskoga djelovanja, umjesto oštroga reza između sustava i svijeta života kao tehniciziranja slobode djelovanja sada se zadobiva u novoj suprotnosti općih medija kasnomodernoga društva. To su novac i moć. Habermas pritom polazi od temeljne postavke moderne filozofije s vrhuncem u Hegelovu sustavu apsolutnoga duha. Što preostaje? Habermas je krajem 60-ih godina prošlog stoljeća marksizam i traganje za „novim društvom“ izvan liberalno-demokratskog ispunjenja modernih ideja slobode smatrao neprimjerenim teorijsko-praktičnim pozicijama za analizu suvremenog doba znanosti i tehnike. Njegov kritički socijalno-demokratski republikanizam, koji proizlazi iz njegove teorije 
komunikacijskog djelovanja, nije stoga oportuna politika konsenzusa u globalnome kapitalizmu s glavnim polugama moći kapitala, nego logični „racionalni“ izbor. Ali problem je što se takav izbor opravdava idealnom govornom situacijom javnog demokratskog razuma (Paić, 2009: 198-199).

Kako navode Krunoslav Nikodem i Jerko Valković (2012: 789-790) u stručnoj literaturi se često ističe rani Habermasov rad u kojem on pokazuje kako razvoj masovnih medija narušava područje javnosti, odnosno ostavlja tek svojevrstan „,privid javnosti“. S tim u vezi je i poznati pojam „refeudalizacije javnosti““, kojim se želi kazati da mediji umjesto pružanja primjerenih informacija služe privatnim interesima kapitala, a građanima se prije svega obraćaju kao običnim potrošačima. Otuda i naziv, jer osnovni cilj je feudalni, odnosno veličanje kapitalističkog stila života, pa se sadržaj informacija uglavnom odnosi na akcijske pustolovine, trivijalnosti i senzacionalizam, veličanje suvremenih životnih stilova i osobnih želja. Habermas navodi da preopterećenost informacijama može negativno utjecati na razvoj „javne sfere“ i same demokracije jer neprimjerene informacije onemogućavaju aktivno sudjelovanje građana i potiču njihovu pasivnost. Više informacija ne znači nužno i poboljšanje demokracije, odnosno više ne znači nužno i bolje.

Habermas (2001: 4-5) piše da nakon što vrijednosti postanu problematične, javlja se pitanje „Što bih trebao raditi?“ iznad horizonta svrsishodne racionalnosti. Habermas (1980: 10) navodi da je sve gušće istkana komunikacijska mreža elektroničkih masovnih medija danas tako organizirana da ona, iako tehnički predstavlja potencijal oslobođenja, prije kontrolira lojalnost depolitiziranog stanovništva nego što služi da sa svoje strane podčini državne i društvene kontrole decentraliziranom, uspješno kanaliziranom i ograničenom diskurzivnom formiranju volje.

Hotimir Burger (1988: 8) pišući svojevrstan predgovor hrvatskog izdanja dvanaest predavanja Habermasovog Filozofskog diskursa moderne, piše da su ta predavanja o moderni i filozofiji u najbližoj teorijskoj vezi s Habermasovom teorijom komunikativnog djelovanja. U dvotomnoj knjizi posvećenoj toj temi Habermas $u$ samom uvodu ističe da pojam komunikativnog djelovanja sadrži tri kompleksne teme: prvo, pojam komunikativne racionalnosti, drugo, dvoslojni koncept društva, koji povezuje kategorije sistem i svijet života i treće, teoriju moderne, jer teorija komunikativnog djelovanja treba omogućiti konceptualizaciju životnog sklopa društva razumljenog na paradoksima moderne. Otkad je objavio ta dva sveska Teorije komunikativnog djelovanja i dodao mu treći 1984., prema 
Burgeru Habermasa gotovo da treba smatrati ne toliko nastavljačem kritičke teorije koliko baš autorom te teorije, koja se može shvatiti i kao temelj jedne kritičke teorije društva. To je nema sumnje njegovo životno djelo, ne samo po ambicioznosti, kompleksnosti i voluminoznosti, nego i zbog njegove nedovršenosti.

Burger (1988: 9) dalje piše da je Habermas prve motive za ovu koncepciju komunikativnog djelovanja naznačio još u knjizi Zur Logik der Sozialwissenchaften (1970), a nagoviještena je u obrisima već dvije godine prije u spisu Rad i interakcija (1968). Analizom Hegelovske jenske filozofije Habermas ustanovljuje $u$ tom spisu razliku između instrumentalnog djelovanja i komunikativnoga djelovanja. Ako bismo analizom njegove dvotomne Teorije komunikativnog djelovanja htjeli ustanoviti što je to komunikativno djelovanje onda to ne bi bilo lako. Jer u tom spisu on razvija tu teoriju u kontekstu socijalne teorije filozofije od Marxa nadalje. Osim toga, tu je teorija djelovanja povezana sa sistemskom teorijom i tradicionalnom tipu racionalnosti ponuđena je alternativa u obliku komunikativnoga, intersubjektivnoga racionaliteta.

Habermas (1988: 22) smatra da su moralni pojmovi modernog vremena skrojeni prema mjeri priznavanja subjektivne slobode individua, te se kao takvi s jedne strane temelje na pravu pojedinca da ono što mu je činiti uvidi kao valjano, a s druge strane, na zahtjevu da svatko smije slijediti svrhe posebne dobrobiti samo u skladu s dobrobiti svih drugih.

Nadalje, Habermas (1988: 23) piše da se moderni religiozni život, država i društvo, kao i znanost, moral i umjetnost preobražavaju u isto toliko utjelovljenja principa subjektivnosti. Radi se o strukturi samoodnošenja spoznajućeg subjekta koji se nadvija nas sebe kao objekt, da bi se kao u odrazu u zrcalu spekulativno zahvatio. Kant ovo filozofsko-refleksijsko polazište stavlja u osnovu svojim trima kritikama. Um postavlja kao najviše sudište pred kojim se mora opravdati sve što uopće podiže zahtjev za valjanošću.

Habermas (1988: 282) istodobno ističe da je nužna teorijski konstituirana perspektiva kako bi se komunikativno djelovanje moglo promatrati kao medij preko kojega se reproducira svijet života u cjelini. Doduše, iz tog se gledišta mogu izvući samo formalno pragmatični iskazi koji se odnose na strukture svijeta života uopće, a ne na određene svjetove života u njihovom konkretnom povijesnom liku. Svijet života se reproducira u onoj mjeri u kojoj se ove tri funkcije koje prekoračuju perspektive sudionika ispunjavaju: nastavljanje kulturnih predaja, integracija grupa preko normi i vrijednosti i socijalizacija sljedećih generacija. Ono što se tako vidi svojstva su komunikativno strukturiranih svjetova života općenito. 
Na sebi svojstven način Habermas smatra da u teoriji komunikativnog djelovanja kružni proces koji međusobno ukrštava svijet života i komunikativnu praksu svakodnevlja zauzima mjesto posredovanja koje su Karl Marx i zapadni marksizam rezervirali za društvenu praksu: „U ovoj se društvenoj praksi povijesno situirani, tjelesno inkarnirani, s prirodom konfrontirani um trebao pomiriti sa svojim drugim. Treba li sada komunikativno djelovanje preuzeti te iste funkcije pomirenja, teorija komunikativnog djelovanja povlači na sebe slutnju da ona, ipak, predstavlja samo inačicu filozofije prakse. Obje doista trebaju riješiti istu zadaću: umsku praksu shvatiti kao um konkretiziran u povijesti, društvu, tijelu i jeziku“" (Habermas, 1988: 297).

U konačnici, Habermas (2013: 149) progovara i o političkoj komunikaciji, te ističe da suvremena zapadna društva pokazuju impresivno povećanje obima političke komunikacije, no političkom javnom sferom istovremeno dominira vrsta posredovane komunikacije kojoj nedostaju definirajuće osobine deliberacije. Primjećuje i očite nedostatke: nedostatak interakcije licem $\mathrm{u}$ lice između prisutnih sudionika $\mathrm{u}$ zajedničkoj praksi kolektivnog odlučivanja, kao i nedostatak recipročnosti između uloga govornika i adresata u egalitarnoj razmjeni tvrdnji i mnijenja. Još više, dinamikom komunikacije upravlja moć medija da odabiru poruke i oblikuju njihovo predstavljanje te da strategijskom uporabom političke i društvene moći utječu na teme rasprave, kao i na otpočinjanje i uokvirivanje javnih tema.

O internetu Habermas (2013: 149) govori kao o ,protuteži prividnim deficitima koji potječu iz impersonalnog i asimetričnog karaktera emitiranja putem ponovnog uvođenja deliberativnih elemenata $\mathrm{u}$ elektroničku komunikaciju. Internet je zasigurno reaktivirao zasade egalitarne javnosti pisaca i čitatelja. Međutim, komunikacija na webu posredovana kompjutorom može imati nesumnjive demokratske zasluge jedino u posebnom kontekstu: internet može potkopati cenzuru autoritarnih režima koji pokušavaju upravljati i suzbijati javno mnijenje. (...) Unutar uspostavljenih nacionalnih javnih sfera, rasprave on-line od strane korisnika weba samo promoviraju političku komunikaciju, dok se news grupe kristaliziraju oko fokalnih točki vrsnog tiska, na primjer nacionalnih novina i političkih magazina.“

Habermas (2013: 153-154) ističe da je moć medija građena na tehnologiji masovnih komunikacija. Oni koji rade u politički značajnim područjima medijskog sustava ne mogu nego prakticirati moć jer oni odabiru i prerađuju politički značajan sadržaj i tako interveniraju i u formiranje javnog mnijenja i u raspodjelu utjecajnih interesa. Upotreba medijske moći manifestira se u izboru i formatu informacija, u obliku i stilu programa, kao i u učincima 
njihove difuzije - u postavljanju agende ili u poretku značenja i uokvirivanju tema (Callaghan i Schnell, 2005, prema Habermas, 2013: 154). Sa stajališta demokratske legitimacije moć medija ipak ostaje „nevina“ utoliko što novinari djeluju u funkcionalno specifičnom i samoregulatornom medijskom sustavu. Relativna nezavisnost masovnih medija od političkih i ekonomskih sustava bila je nužan preduvjet za uspon onoga što se danas naziva „medijsko društvo". To je posve novo dostignuće čak i na Zapadu čija se društva, kao što smo već spomenuli, ne nazivaju samo medijskim, nego i informativnim, vizualnim, a danas sve češće i digitalnim društvima.

\subsubsection{Etika diskursa Karla-Otta Apela}

Apel svojom etikom diskursa daje značajan doprinos medijskoj etici. U svom djelu The response of discourse ethics Apel (2001: 1) piše da se ne voli baviti filozofijom i njezinim disciplinama, posebno etikom, kao nečim što se, zajedno s ostalim, pojavljuje u „redu predavanja“ na sveučilištima. On kaže da bi takav stav bio, sam u sebi, duboko nefilozofski. Umjesto toga, radije započinje od konstitutivnih dijelova i dostignuća ljudske kulture kao odgovora na izazov povijesne situacije, ili - ovo je slučaj s etikom - odgovora na izazov ljudske situacije kao takve, u suprotnosti sa situacijom npr. životinja. Apel se na istom mjestu prisjeća da je prije nekoliko desetljeća počeo sam postavljati temelje tog djela izvanjskih izazova našoj ljudskoj moralnoj odgovornosti. Počeo je govoriti o potrebi „makro etike“ sveopće odgovornosti, u suprotnosti s tradicionalnom formom „mikro etike“ lojalnosti u malom grupama. U konačnici je došao do zaključka da koncept individualne odgovornosti pretpostavlja da je specifična odgovornost dodana osobi bez institucionalnog okvira u sklopu makroetike koja je potrebna danas.

Istodobno Apel (1996: 1) također piše da je svatko tko se bavi odnosom znanosti i etike u modernom globalnom industrijaliziranom društvu suočen s paradoksalnom situacijom: s jedne strane se nalazi potreba za univerzalnom etikom, onom koja se vezuje uz ljudsko društvo u cjelini, koja nije nikad bila tako potrebna kao danas, a s druge strane filozofska se potreba racionalnog utemeljenja univerzalne etike nikad nije činila zahtjevnijom nego u znanstvenom dobu. To se događa zato jer je u našem vremenu pojam intersubjektivne valjanosti unaprijed otuđen od strane znanosti, tj. od znanstvenog pojma normativne neutralnosti i ,objektivnosti“ bez vrednota. 
Među ostalim brojnim temama kojima se bavi, Apel (1980: 299) govori o jeziku kao predstupnju logike i ontologije, što će dovesti i do etičkih pitanja: naime, već se u jeziku „u neposrednoj zbilji misli“ kako ga Marx određuje u suglasnosti s Hegelom ispunjava ne samo osvješćivanje praktičnog čovjekovog susreta sa svijetom; u jeziku se, također, provodi posredovanje svijesti zahvatom čovjeka u svijet. Doduše, točno je, kao što je pokazao Gehlen, da jezik znači ,rasterećenje“ od neposredno praktičnog kontakta sa svijetom. Samo se zbog toga sistematika duha može konstruktivno uobličiti u jeziku i u gramatici izobraziti predstupanj logike i ontologije.

Nadalje, Apel (1980: 330-331) piše da se u svakom razgovoru između ljudi događa da jedan više ne pokušava drugoga uzeti hermeneutički ozbiljno u njegovim intencijama, nego ga objektivno distancira kad više ne pokušava uspostaviti jedinstvo jezika u komunikaciji, nego naprotiv, ono što drugi kaže pokušava vrednovati kao simptom objektivnih stanja stvari, koja je on u stanju objasni jezikom $\mathrm{u}$ kojem drugi sudionik ne sudjeluje. Za to djelomično raskidanje hermeneutičke komunikacije $\mathrm{u}$ korist objektivnih spoznajnih metoda karakterističan je odnos liječnika prema njegovim pacijentima. Ovaj model djelomično dokinute komunikacije može se učiniti plodotvornim za utemeljenje teorije na isti način kao pozitivni osnovni model razgovora.

Apel (1980: 417) ističe da je apstraktno logičko razlikovanje između intersubjektivno obavezujućih sudova činjenica i subjektivnih sudova vrijednosti zahtjevom za smislom svakog argumenta kao dijaloškog izričaja ukinuto u korist intersubjektivno obavezujuće minimalne etike. Tu minimalnu etiku, koju implicitno priznaje svatko tko argumentira, a koja također implicira angažman u smislu povijesnog razlikovanja neograničene komunikacijske zajednice, pretpostavlja i vrijednosno slobodna, empirijsko analitička znanost kao uvjet mogućnosti konsenzusa i time nalaženja istine.

Apel (1980: 492-493) piše da se komplementarnost između vrijednosno slobodnog objektivizma znanosti s jedne strane, te egzistencijalnog subjektivizma religioznih čina vjere i etičkih odluka s druge strane pokazuje kao moderni izraz liberalnog razdvajanja između javnog i privatnog životnog područja, koje se izgradilo u povezanosti s razdvajanjem države i vjerskih institucija. U ime tog razdvajanja zapadni liberalizam je najprije obaveznost religioznog vjerovanja i obaveznost moralnih normi sve više i više ograničavao na sferu privatnih odluka savjesti. Taj se proces još uvijek nastavlja, npr. odbacivanjem moralnih argumenata i principa iz načela prava. Općenito se može tvrditi da se na svim područjima 
javnog života u zapadnom industrijskom društvu moralna utemeljenja prakse nadomještaju pragmatičkim argumentima kakve zastupaju i isporučuju „stručnjaci“ na osnovu znanstveno tehnoloških pravila koja se po njima mogu objektivizirati.

U tom se kontekstu Apel (1980: 497-498) pita je li moguće navesti i opravdati jednu etički utemeljenu normu, koja bi za svakog pojedinca postala dužnost i da se od njega traži da principijelno teži jednom obavezujućem sporazumu s drugim ljudima. On smatra da taj zahtjev nije nikako utemeljen ili čak ispunjen pukim ukazivanjem na stanje stvari nekog (mogućeg) dogovora. Dogovori kao takvi ne pretpostavljaju nikakvu intersubjektivno važeću moralno temeljnu normu, ali i kao takve mjere strateške razboritosti također nisu u stanju utemeljiti moralnu obaveznost konvencija. U tom smislu, npr. „pozitivno pravo“ kao takvo a bez prešutne pretpostavke jedne moguće etike - nije normativno obavezujuće, nego je u najboljem slučaju efektivno. No, vrlo je karakteristično da pravni sistem, koji u društvu gubi moralni kredit, obično na dugu stazu također gubi i svoju efikasnost. Ovaj argument usmjeren je protiv svih vrsta liberalističke ugovorne teorije prava i morala, koja bi željela utemeljiti intersubjektivno važenje normi u smislu metodskog individualizma ili solipsizma, to jest jedino na osnovi empirijskog sjedinjavanja posredovanja pojedinačnih interesa, odnosno samovoljnih odluka: ako ne postoji etički princip, koji je kako normativno obavezujući tako i intersubjektivan, onda etička odgovornost ne može načelno transcendirati privatnu sferu. To, međutim, govori ne samo o tome da - formaliter - za svaku demokraciju fundamentalne konvencije (kao što su državni ugovori, ustavi, zakoni itd.) nemaju moralnu obaveznost, nego osim toga govori da - materialiter - moralne odluke pojedinaca ( $\mathrm{u}$ svakodnevici i u egzistencijalnim graničnim situacijama) koje se ne reguliraju izričito sporazumom nisu obavezne položiti račun pred zahtjevom za solidarnom odgovornošću čovječanstva. U praksi moralne odluke pojedinaca mogu stvarno rijetko transcendirati horizont solidarnosti intimne, tj. manje i prisne grupe koja se „drži skupa“ u masovnom društvu koje se oslobodilo od arhaičkih i religioznih veza zajednice.

Stoga Apel (1980: 500-501) piše i upozorava da postoje neke osnovne pretpostavke moderne analitičke filozofije koje pridonose da utemeljenje normativne etike izgleda gotovo nemoguće, te predočuje najvažnije od tih pretpostavki:

1. Iz činjenica se ne mogu izvesti nikakve norme (ili: iz deskriptivnih stavova ne mogu se izvesti preskriptivni stavovi i time nikakvi „,vrijednosni sudovi"). Apel to naziva Humeov princip ili Humeova distinkcija. 
2. Znanost, ako daje sadržajnu spoznaju ima posla s ,činjenicama“, pa stoga nije moguće znanstveno utemeljenje normativne etike.

3. Samo znanost daje objektivno znanje; objektivitet je identičan s intersubjektivnim važenjem; stoga nije moguće intersubjektivno važeće utemeljenje etike. Treba li se pokazati mogućnost utemeljenja normativne etike onda se čini, prema onom što je rečeno da je sve $u$ tome da se, $u$ najmanju ruku, jedna od navedenih premisa dovede $u$ pitanje. Ovdje su prema Apelu dosta izgledne dvije strategije argumentiranja:

a. Može se pokušati osporiti Humeova distinkcija (i time prva premisa) za naš problem: ako logički nije moguće norme izvesti iz činjenica, onda je ipak vrlo upitno jesu li sve znanosti, koje imaju empirijski sadržaj zbog toga čiste, tj. moralno slobodne od vrednovanja u našem sklopu znanosti o činjenicama. Moglo bi biti da samo prirodne znanosti - dakle ne ni empirijske humanističke znanosti ni filozofska „metaetika“ - ne mogu uopće konstituirati svoj fenomenalni predmet bez izvjesnog moralnog vrednovanja.

b. Druga strategija argumentiranja odriče se toga da posumnja u vrijednosni neutralitet znanosti uključujući filozofsku metaetiku; ona utoliko također ne sumnja u Humeovu distinkciju, nego je pretpostavlja. Umjesto toga ona postavlja pitanje: može li se objektivitet vrijednosno neutralne znanosti sam razumjeti filozofski a da se pri tom ne pretpostavi intersubjektivno važenje moralnih normi?, Ta argumentacija bi, dakle, neposredno dovela u pitanje važenje treće premise.

Sam Apel smatra da su oba ishodišta argumentiranja opravdana i da mogu nadopuniti jedno drugo. Prva postavka ipak ne može, čak i kad postigne svoj cilj dokazati mogućnost racionalnog utemeljenja etike; suprotno tome, može se pokazati da njeni rezultati postaju relevantni tek kad se pretpostavi da druga postavka može dokazati mogućnost racionalnog utemeljenja etike.

Čehok i Koprek (2006: 172-173) pišu da je danas aktualan taj etički pristup koji zastupa Apel i uz male razlike Habermas, a koji se trudi oko prijelaza prema „postkonvencionalnoj“ etici i to u našem modernom vremenu koje je jednostavno zaboravilo metafiziku. Apel taj prijelaz nalazi u tvrdnji da svatko tko pretendira ozbiljno se baviti etikom, to jest tko ulazi u etički diskurs, pretpostavlja da je obvezatno prepoznati postulate 
bavljenja tim pitanjima. Prema Apelu to znači da je onaj tko ozbiljno argumentira i traži intersubjektivnu istinu već odlučio biti moralan i već je priznao osnovna načela moralnosti. Intersubjektivnu istinu može tražiti samo onaj tko je uvjeren u njezinu mogućnost. Apel smatra da ljudi koji ozbiljno diskutiraju o etici priznaju barem jedan normativno-etički princip, a to je da sva sporna pitanja, razlike u mišljenju, sukobe i slično, treba riješiti među komunikacijskim partnerima, samo putem argumenata prikladnih za usuglašavanje i u konačnici za suglasnost.

I Abdulah Šarčević (1980: 561-562) govoreći o Apelu kaže da je on mislilac kome je, prije svega, stalo do dijalektičkog posredovanja teorije i prakse. Po tome je u izvjesnom smislu srodnik kritičke teorije društva koje bi trebalo promijeniti. Nema sumnje da upravo odavde polazi postavka o zbiljskom funkcioniranju filozofije u suvremenom svijetu jedinstvene, planetarne znanstveno tehničke industrijske civilizacije, a da je zadaća mišljenja faktičko posredovanje teorije i prakse života s obzirom na neodlučenu i neizvjesnu povijest i budućnost, to jest na mogući novi stil ljudskoga života. Naime, nužno je da se spozna da filozofija u suvremenosti, u kojoj je čovječanstvo postavljeno i oslonjeno na sebe i svoje mogućnosti, prebivajući u njima djelovanjem i mišljenjem, nije više moguća kao teorija dovoljna sebi samoj, što znači da ona ne može više u bilo kojoj formi ostaviti svijet izvan sebe, tako da spoznaje bit stvari posredstvom čiste kontemplacije pa tek onda usmjerava praksu života prema teoriji ili tako kao da bi mogla a priori odrediti svagda otvoreni i nedovršeni svijet, njegove zakone i artikulaciju njegovog smisla, jer je jasno da bi ona tada prekrila i u refleksiji „dokinula“ povijest što je neizvjesna i otvorena prema budućnosti i budućnosnom u sadašnjosti, a koja sama nije više praktično angažirana.

Šarčević (1980: 591) nadalje smatra da se poanta Apelove „transformacije filozofije“ u razdoblju znanosti, transcendentalno-pragmatičnog utemeljenja etičkih normi, sastoji u tome da se svi interesi mogu racionalno legitimirati i opažati samo u diskursu. Jer samo diskurs, po Apelovom mišljenju, predstavlja institucionaliziranje racionalne samorefleksije transcendentalne jezičke igre neograničene komunikacijske zajednice. Na taj način smo kadri odgovoriti na pitanje o supstancijalnom sadržaju umstvenog principa kao temeljne etičke norme neograničene komunikacijske zajednice.

Šarčević (1980: 600) zaključuje da se, prema Apelovim postavkama, sve ljudske institucije trebaju tvoriti iz umnog intersubjektivnog razgovora, a to znači: iz argumentativnog legitimiranja i predstavljanja ljudskih interesa, potreba i sličnog. To, dakako, implicira smisao 
moralne argumentacije. Riječ je o normama svake, a time i filozofske i znanstvene jezične igre, pod kojima Apel ne podrazumijeva samo sintaktičko-semantička pravila nego i umne, refleksivno utemeljive etičke standarde ljudskog zajedničkog života. U tom smislu ovdje nagoviještena poanta transcendentalne jezične igre - načelne ,,isprepletenosti“ jezičnih igara $\mathrm{i}$ životnih formi označava i doseže etičku dimenziju koja predstavlja uvjet mogućnosti logike i s njom istodobno sve znanosti i tehnologije. (Šarčević, 1980: 600).

Nadalje, Apel (2001a: 142-143) piše da se etika s Aristotelom razumije kao teleologijska ukupna perspektiva za vrednovanja u smislu dobroga života (za mene, odnosno za nas), eudaimonia, a danas postoje samo dvije alternative: radikalno individualistička etika autentična samoizbora kakvu zastupa egzistencijalizam, npr. Jean-Paul Sartre ili pak etika pripadnosti jakoj tradiciji vrednovanja u smislu određene sociokulturne životne forme. Danas za pojedinu osobu, za koju su sve konvencije vrednovanja i tradicije postale upitnima, kvaziegzistencijalistička etika autentična samoizbora može predstavljati posljednju svjesnu orijentaciju; praktički to vrijedi ipak samo za ,granične situacije“, kako ih je nazvao Jaspers: situacije radikalna „upojedinjenja“ $u$ kojima čovjek strahom pripravljen na smrt privremeno uzimlje opstanak na sebe. Čak i takve odluke autentična samoizbora općenito su, ipak, nošene pripadnošću jednoj sociokulturnoj životnoj formi koja u svakidašnjici omogućuje očekivanje recipročnosti etički relevantnih vrednovanja i načina ponašanja ljudi. A ta orijentacija na ono što se čini ne mora čak ni poprimiti karakter nenavlastitosti (dakle neautentičnosti) koju Martin Heidegger u Bitku $i$ vremenu povezuje s ovime; jer i za moderna je čovjeka s postprosvjetiteljskim mentalitetom posve moguće potvrđivati pripadnost jednoj sociokulturnoj životnoj formi, a time i supstancijalnoj ćudorednosti u Hegelovu smislu, čak još i iz perspektive autentična samoizbora i time je takoreći iznova prisvojiti, pa i ako pritom ostaje egzistencijalna suzdržanost Ovu pripadnost jednoj kulturnoj formi života i etosa, neovisno o tomu je li ona sazdana više religijski ili etnički, danas potvrđuje ne samo hermeneutički orijentirana filozofija post-heideggerovske i post-wittgensteinovske škole, nego i empirijska znanost o društvu i kulturi u širokome konsenzusu mnijenja. Utoliko se, dakle, kao mogući odgovor na (Aristotelovo) pitanje o orijentaciji dobroga života nadaje uvjerljiva potvrda Hegelova uvida u prednost povijesno izrasle, supstancijalne ćudorednosti pred svakom formalno-apstraktnom moralnošću: ova posljednja ne može odgovoriti na pitanje o vrijednosnome sadržaju dobroga života. Kaže li se time ujedno i to da je „trebanje“ u Kantovu smislu, dakle „trebanje“ u smislu univerzalno važećega principa pravednosti, u smislu „kategoričkoga imperativa“ posve „nemoćno“, da mu, dapače, u modernoj, 
postmetafizičkoj etici više ne može biti pridana nikakva orijentirajuća funkcija? Tu bi, prema Apelu, bilo nužno uvesti niz karakteristika suvremene svjetske situacije koje nam, naizgled u protuslovlju spram uvida historicizma i relativizma, pred oči dovode čak i prijeku potrebu univerzalno važeće, za sve pojedince i za sve različite kulture obvezatne etike čovječanstva: na prvome bi mjestu ovdje, paradoksalno, valjalo navesti pluralnost i različitost postojećih kultura: dakle, upravo onu činjenicu koja nam pred oči dovodi različitost i povijesnosociokulturnu relativnost formi etosa. Ta činjenica postavlja danas, a kakve nikada ranije u ljudskoj povijesti nije bilo, pitanje o zajedničkim pravima i normama na osnovi kojih mirna koegzistencija ovih različitih kultura treba biti moguća. Ponad toga postoji i problem sposobnosti različitih kultura za odgovornu suradnju u odnosu na očite probleme čovječanstva koji ih zajednički pogađaju - npr. na ekološku krizu. Ne zbiva se ni u kojem slučaju ono što je prije nekog vremena Lyotard sugerirao kao postmodernu situaciju: da više nema povijesnog jedinstva čovječanstva, da više ne postoji „mi“ u smislu moguće solidarnosti. Dapače, jedinstvo ljudske povijesti, koju su u XVIII. stoljeću anticipirali tek neki filozofi danas je tehnička, ekonomska i politička realnost, a solidarnost je u stanovitoj mjeri izazvana izvana npr. ekološkom krizom. (Apel, 2001a: 142-143). Mnogo je prije upravo mogućnost da svi pojedinci i kulture ozbilje svoju formu dobroga života u smislu „souci de soi“ ovisna o tomu da svi imaju priznato jednako pravo na tu brigu i da je svima zadana jednaka moralna obveza uvažavanja prava onih drugih - dakle onih s različitim formama života i etosa. Usput rečeno, neposredno pred svoju smrt Foucault je u praksi potvrdio ovu međuovisnost moralnoga univerzalizma i pluralističke etike „souci de soi“ time što se osobno zauzeo za ljudska prava. Već se na ovomu mjestu primjećuje da je protuslovlje između univerzalističke etičke obveze kantovske provenijencije $\mathrm{i}$ individualističke kulturno - relativističke etike dobroga života možda tek prividno. Protimba koju Hegel pretpostavlja kao da se ne razrješuje pokušava li se jedna forma etike razumjeti iz one druge i ,dokinuti“ je u drugu, nego ako se razumiju kao komplementarni odgovori na različita temeljna pitanja. (Apel, 2001a:143)

Nastavljajući svoje razmišljanje, Apel (2001a: 146) piše da se prema njemu utemeljujuća teza nadaje iz transcendentalno-pragmatičkoga posljednjeg utemeljenja etike uopće, koju razumije kao diskursno-teorijsku i komunikacijsko-teorijsku transformaciju Kantove etike. On polazi od toga da smo u aktualnome filozofijskom diskursu već uvijek nužno priznali kako svatko ima jednako pravo u diskursu pribaviti važenje svojem interesu za kulturnim identitetom. Kaže da sudionici tog diskursa imaju pravo na to sve dok su pripravni respektirati temeljne norme argumentativnoga diskursa među ostalim. Time je već utemeljena 
formalna komplementarnost univerzalističke etike pravednosti i individualnih orijentacija na vrijednosti posebne tradicije zajednice, doduše pod pretpostavkom - koju zastupa Kant, kao i John Rawls - prvenstva univerzalizma pravednosti koje svim ostvarenjima posebnih interesa u svakome trenutku nameće ograničavajuće uvjete. No ni taj uvid u prvenstvo univerzalizma pravednosti ne omogućuje pojedincu da iz načela univerzalizacije moralnosti deducira takve obveze koje, primjerice, a priori postavljaju ograničenja komunitarnoj etici dobroga života. Mnogo prije, ovo normativno postavljanje kao posredovanje između formalnoga univerzalizma i etnoetike koju se slijedi individualno i samo od slučaja do slučaja, mora biti predmetom diskurzivnoga tvorenja konsenzusa. U jednome multikulturnom društvu ovaj se problem posredovanja u idealnome slučaju postavlja kao obvezanost na neprestano komunikativno razumijevanje.

$\mathrm{Na}$ istom mjestu Apel (2001a: 146) ističe da u svim praktičnim diskursima o utemeljenju normi od početka postoji razlika između dva tipa problema odlučivanja. S jedne strane postoje brojni problemi, o kojima gotovo svakoga dana treba iznova diskutirati, a koji zahtijevaju odgovarajuće, situaciji primjereno rješenje: ti se problemi danas posebice javljaju na području primijenjene etike, primjerice na području znanstvene, biologijske, ekologijske, medicinske, privredne etike, itd. Upravo se na tim područjima mora uvijek iznova u argumentatiranom diskursu nalaziti ravnoteža između zahtjeva suvremenosti, npr. zahtjeva za odgovornošću za posljedice znanosti, tehnike, privrede, te etičko religijskih vrijednosnih tradicija. Pri tome je dostatno samo pomisliti na moguće sukobe između tehničkih nužnosti i mogućnosti moderne medicine, s jedne strane, te zapovijedi i zabrana različitih religija, s druge strane. Nasuprot ovim problemima koji se odnose na određene situacije, nalaze se oni kod kojih se radi o normama, što se u konačnici odnose na ravnopravnost i jednaku suodgovornost svih ljudi kao mogućih partnera u diskursu, koje se uopće ne da odijeliti od a priori priznatih proceduralnih temeljnih normi argumentiranog diskursa.

U intervjuu, na pitanje o normativnim pretpostavkama argumentacije, Apel (1990: 127128) priznaje da je prije govorio samo o jednakosti prava, ali da je neophodno dopuniti jednakost prava jednakošću suodgovornosti te da je samom refleksijom o postavljanju filozofskih pitanja jasno da, počinjući argumentaciju, ne uzima odgovornost za rješenje problema samo na sebe, već unaprijed pretpostavlja suodgovornost svih za rješenje problema, a tu je osnova ideja suodgovornosti, koja je neophodna u vrijeme postkonvencionalne etike. Nastavlja da danas, kada smo suočeni s ekološkim krizama koje prijete cijelom svijetu, ne 
možemo, zajedno s Kantom, prakticirati odgovornost unutar pojedinih osoba niti je povezivati uz posebne grupe ljudi, profesije. To je konvencionalizam. Sve to nije dovoljno jer, znajući za događaje koji se tiču svih nas, svi postajemo suodgovorni za njihov tijek. Pročitavši u novinama za procese koji se odvijaju pred nama u Istočnoj Europi ili za probleme s prljavom industrijom neposredno postajemo suodgovorni za njih, istaknuo je tada Apel. Pri tome je jasno da svatko preuzima odgovornost u skladu sa svojim mogućnostima i snagom. Nadalje piše: „Pitanje suodgovornosti ljudi različitih razina jest problem makroetike i, svakako, etike diskursa. Čim uključite televizor, vidite izvještaje o dijalozima, bilo da su oni na nacionalnoj ili internacionalnoj razini. Posvuda se odvijaju neki razgovori, teme su različite - od ekonomskih, ekoloških do vojnih. Na brojnim je konferencijama prisutna vrsta diskursa u kojem se razmatraju problemi koji se tiču interesa svih ljudi. To izgleda simptomatično i vrlo je značajno za etiku diskursa. Naravno, u tim razgovorima mnogo je elemenata strateškog pristupa, pregovaranja i nadigravanja. Ali to ne daje za pravo onima koji misle da je realnu situaciju diskursa moguće analizirali realistično - samo prihvaćanjem gole realnosti, uzimanjem u obzir samo kontingentnih činjenica koje utječu na diskurs. Oni zaboravljaju da je interpretacija tih diskursa i realne situacije u kojima se odvijaju moguća tek primjenom idealnih mjerila. Prema tome, da bismo realistično analizirali situaciju diskursa, nužno je primijeniti idealna mjerila, jer bez njih se ne može procijeniti određena situacija. No za njih je također potrebna osnova, a ona je krajnje utemeljenje etike“ (Apel, 1990: 128).

U istom intervju, Apel (1990: 130) nastavlja: „Na neki način mi već uvijek poznajemo istinu; kad argumentiramo, podrazumijevamo određeni pojam istine - kako je to na ovom tečaju istaknuo Wolfgang Kuhlmann - i preko toga ili iza toga ne možemo. U stanovitom smislu moramo pretpostaviti da nam je istina već znana, te da postoji nešto kao 'knowhow' u 'knowhat'. I, sada se susrećemo s tradicionalnim teorijama istine, teorijama adekvacije, evidencije, koherencije, teorijama pragmatičke uspješnosti itd. Sa stajališta transcendentalne pragmatike branim teoriju istine kao određenu vrstu konsenzusa. Konsenzus se ne tiče međuljudske suglasnosti ili suglasnosti unutar posebnih grupa. Teorija konsenzusa povezana je, prije svega, s idejom krajnjeg mišljenja beskonačne, idealne zajednice. To je, naravno, regulativna ideja kojoj apsolutno ništa ne može korespondirati. Kao drugo, teorija konsenzusa uključuje proceduralne principe prema kojima uvijek moramo uzeti u obzir sve dostupne kriterije, te pokušati postići konsenzus o tim kriterijima. Krajnje mišljenje jest mišljenje za koje se pretpostavlja da se ne može dovesti u pitanje, ono je rezultat otkrića narednog kriterija.“ 
$\mathrm{Na}$ pitanje o odnosu filozofijskoga Habermasovog stajališta i njegove paradigme transcendentalne pragmatike, Apel (1990: 130-131) odgovara da on i Habermas imaju mnogo zajedničkoga. Tu je, kao primjer iznio fundamentalnu intuiciju o potrebi prevladavanja metodološkog solipsizma - o potrebi stvaranja filozofije komunikacije. Ali već tu ima i razlika, jer je taj put promjene oduvijek razumijevao kao transformaciju transcendentalne filozofije, transcendentalno-pragmatički pristup, kao transformaciju Kantove etike. Habermas se, međutim, nakon početnog usuglašavanja s Apelom i nakon povremene upotrebe termina transcendentalne pragmatike, okreće u pravcu američkog pragmatizma. Habermas shvaća pragmatizam empirijski i sociološki, te se često izjašnjava o pretpostavkama koje se ne mogu poricati bez proturječnosti, zbog čega su transcendentalne i nužne. One omogućuju krajnje utemeljenje. Zato Habermas, govoreći o tim pretpostavkama, govori kao o uvjetima komunikacije koji moraju biti provjereni, testirani, upravo kao što se moraju testirati empirijske hipoteze lingvistike. Apel to odbacuje kao besmisleno, te se pita što uopće znači nešto testirati i eventualno falsificirati u skladu s principom falibilizma, odgovarajući odmah da to znači da mora pretpostaviti ono što u ovom slučaju mora falsificirali. Takve su sve one pretpostavke, zahtjevi s pretenzijom na važenje, zahtjevi za razumljivošću, iskrenošću, za istinom i za ispravnošću, za pripadnošću zajednici, traganje za istinom i pretpostavljanje da se ona u principu može dostići kao konsenzus; sve je to tu da bi se razumjelo što to znači izvršiti empirijsko testiranje, baš kao u lingvistici. Apel strogo razlikuje s jedne strane filozofsku, transcendentalno - pragmatičku tezu o pretpostavkama argumentacije, te s druge strane hipoteze koje mogu biti testirane i falsificirane. Apel ističe da Habermas te dvije stvari miješa i da je u tome najveća razlika među njima, te da zbog toga ispada staromodnim transcendentalnim filozofom, pa čak i metafizičarem, što Apel osobno poriče, smatrajući da nije riječ o metafizici, već o transcendentalnoj pragmatici, o trećoj paradigmi. Habermas tvrdi da treća paradigma ne smije biti transcendentalna. I ne samo to, on tvrdi da se ni dedukcija transcendentalne refleksije ne uklapa u treću paradigmu. Prema Habermasu, to pripada drugoj paradigmi, filozofiji svijesti. Apel ističe da je transcendentalna filozofija moguća i na razini treće paradigme. Habermas stoji iza nešto drukčije shvaćene treće paradigme, pri čemu iz nje isključuje mnoge karakteristike. Jedna od njih je transcendentalna filozofija, dok se Apel s time ne slaže. ${ }^{2}$

\footnotetext{
2 Prvu paradigmu Apel određuje kao ontološko-metafizičku, te je vezuje uz Aristotelovu misao. Druga paradigma započinje s Descartesom, sabirući se u Kantovoj filozofiji kao paradigmi filozofije sibjekta i odnosa subjekt-objekt u filozofiji svijesti. Treću paradigmu Apel označuje kao postjezičnu i postsemiotičku (Apel, 1990: 126).
} 
2.2.3. Dale Jacquette o moralnoj odgovornosti u medijima

Razmatrajući medijsku i novinarsku etiku, Dale Jacquette (2007: 15-16) piše da profesionalni novinari imaju moralnu odgovornost prije svega prema svojim čitateljima, gledateljima i slušateljima, na čije životne interese svakako utječe kvaliteta svakodnevnog izvještavanja o događajima. Podsjeća da novinari imaju veliku moć, budući da se gotovo svugdje u svijetu smatraju izvorom točnih informacija do kojih se dolazi inteligentnim, agresivnim istraživačkim izvještavanjem. Za ono što kažu u društvu s relativno slobodnim medijima pretpostavlja se da može biti nešto na što se s pouzdanošću može osloniti od najnižih do najviših razina donošenja odluka $\mathrm{u}$ jednom ogromnom krugu korisnika informacija. Jacquette (2007: 17) podsjeća da je odgovornost novinara u zavisnom odnosu s pravima: kad novinari koriste svoja profesionalna prava oni zauzvrat imaju profesionalne odgovornosti. Potrebno se zapitati u kakvom odnosu stoje odgovornost i prava, te dvije različite strane profesionalnog rada novinara.

Jacquette (2007: 19) definira medijsku etiku kao obvezu novinara da u najvećoj mogućoj mjeri izvještavaju istinito o stvarima relevantnim za javni interes. Nastavlja (Jacquette, 2007: 21) da dobar moralni princip može pridonijeti progresivnoj promjeni u svijetu ako je smislen dovoljnom broju ljudi i ako ga oni slijede u praksi kao standard profesionalnog ponašanja. Možda ne može ostvariti moralnu utopiju, ali može barem pomoći da se krene u pozitivnom smjeru, da stvari postanju barem malo bolje. Jacquette (2007: 2223) piše da sadašnjim ili budućim novinarima jednostavno iznijeti popis onoga što trebaju i što ne trebaju činiti ipak nije dovoljno da bismo to „nešto“ nazvali „medijskom etikom“. Moralne upute u vidu npr. deset profesionalnih zapovijedi, ma kako važne mogle biti za novinara, ne objašnjavaju zašto je neki skup pravila dobar niti ga opravdavaju, te time niti nisu dovoljan poticaj za pridržavanje tih propisa. Jacquette smatra da je potrebno prvo razjasniti cilj i svrhu novinarstva i otkriti filozofsku osnovu moralnih prava i odgovornosti novinara. Jer, vrlo je logički smisleno da ne možemo novinarima uputiti moralni zahtjev da istinito izvještavaju ako ne postoji filozofski inteligibilan pojam znanja ili istine.

Potom Jacquette (2007: 24-25) obrazlaže da je znanje moć, kao što je još u XVII. stoljeću primijetio Francis Bacon, te su informacije koje pružaju novinari isto tako potencijalno opasne i po pojedince i po društvo, upravo zbog svoje moći. Prema tome javnost očekuje da, kao moralni cilj dostižan čovjeku, mediji izvještavaju o vijestima istinito i pravovremeno u javnom interesu. Jacquette (2007: 25) ističe da iako bi novinari, kao i svi 
ostali željeli znati što je u pojedinoj situaciji dobro ili loše, odgovori ipak najčešće nisu jednostavni, što je donekle frustrirajuće. Moralni problemi stvarnog života često se, na nesreću, teže rješavanju od onih koje možemo naći u knjigama. Pa ipak, apstraktna istraživanja ideja sa svim svojim ograničenjima mogu igrati značajnu ulogu u ocrtavanju moralnog progresa, navodeći nas na to da razmišljamo o hipotetičkim situacijama koje su dovoljno slične problemima za koje je vjerojatno da ćemo ih sresti u stvarnim okolnostima.

Isto tako, Jacquette (2007: 91-92) se retorički pita zašto bi ikome bilo stalo do nekog apstraktnog moralnog ideala kada mora živjeti u svijetu surove stvarnosti. Ponekad se u ovom pitanju vidi način da se ospori primjenjivost nekog etičkog principa, a ponekad ono izražava moralni skepticizam koji će nas navesti da popustimo pred svakim pritiskom na našu želju da učinimo ono za što vjerujemo da je moralno ispravno. No, jasno je da pokušaj da se u profesiji poput novinarstva djeluje bez etičkih principa jednostavno ne može i ne smije biti opcija. Baš kao što se nijedno društvo ne može nadati da će opstati bez neke društvene etike koja usmjerava postupke njegovih građana i ustanova, tako nijedna profesija ne može očekivati da će ispuniti svoju funkciju bez oslanjanja na profesionalnu etiku, a s obzirom na društvenu dimenziju novinarstva u toj profesiji to je posebno izraženo. Jacquette (2007: 93) priznaje da je stvarni svijet uvijek poprilično složeniji i da na teške kušnje stavlja moralnu čvrstinu pojedinca. No, ako bi to impliciralo da se moramo odreći etike, tada bismo kao društvo upali u ozbiljne poteškoće. Jacquette donosi i jednu sportsku analogiju s pojedincem koji trenira za sportsko natjecanje. Taj pojedinac zna da ga njegova tjelesna ograničenja sprječavaju da pretrči ili prepliva određenu stazu za određeno vrijeme, ali vjeruje da, ako postavi sebi cilj da postigne neko, realistično promatrano, njemu nedostižno vrijeme, može poboljšati svoju tehniku, izdržljivost i borbenost u znatno većoj mjeri nego da je jednostavno slegnuo ramenima i priznao poraz, kazavši sebi da nikada neće biti kao Mark Spitz, Carl Lewis, Crystal Cox, ili već netko tko je njegov sportski idol. Isto vrijedi i za moralni život, pa tako i za odnos prema postulatima medijske etike. Dakako da apstraktni moralni ideali nisu dovoljni, no Jacquette (2007: 95) ističe njihovu važnost jer oni pružaju kognitivne i vrijednosne osnove za donošenje moralnih odluka u pojedinačnim slučajevima, sistematiziraju naša razmišljanja o onome što vjerujemo da je moralno ispravno ili moralno loše, pružaju cilj kojemu treba težiti usavršavajući svoje ponašanje tako da se ono sve više približava vrijednostima kojima težimo. Kad su izloženi na prikladan način, apstraktni moralni ideali mogu biti dostižni koliko i bilo što drugo što pokušavamo postići u životu. 
Govoreći o financijskoj, to jest gospodarskoj dimenziji medija, Jacquette (2007: 102) ističe da je potrebno sjetiti se dvije očigledne, ali ne i očigledno povezane činjenice. Novinarstvo je plemenita profesija čiji je cilj otkrivanje i prenošenje informacija, ali je istovremeno i veliki biznis. Novac je neophodan da bi se istraživale činjenice i prikupljale informacije i da bi se proizveli medijski sadržaji u kojima su one zabilježene. U tržišnim ekonomijama znamo da većinu velikih pothavata pokreću poduzetnici koji ulažu kapital da bi na tržište iznijeli proizvod ili uslugu imajući na umu profit, to im je on zapravo konačan cilj. Zašto bi inače to činili, osim ako ih u potpunosti ne vodi filantropski duh i kako bi se inače bez toga jasnoga cilja ostvarivale tako komplicirane i skupe aktivnosti širom svijeta kao što je novinarsko izvještavanje?

Jacquette (2007: 144) u tom kontekstu stoga ističe da nema apsolutne slobode medija, baš kao što nema ni apsolutno slobodnog čovjekovog čina ni u jednom drugom području. Npr. čak i u društvima gdje postoji visok stupanj slobode medija, jasno je da ta sloboda ne obuhvaća i ne smije obuhvaćati dopuštenje da se objavljuju osjetljive vojne tajne ili dječja pornografija ili upute kako u kućnoj radinosti napraviti tempiranu bombu. To su samo neki posve očiti primjeri, no jasno je da ima mnogo kategorija informacija i sadržaja za koje ne očekujemo da ih novinari slobodno objavljuju. Filozofija teži tome da shvati granice koje s pravom vrijede za slobodu izražavanja u izvještavanju o događajima i možda, što je važnije, da objasni vrijednost koju sloboda medija ima unutar tih granica, ispitujući pri tom i pitanje gdje te granice treba postavljati. Gore spomenuti primjer s dječjom pornografijom nam je posve jasan i tu nema dvojbi, no postoje pitanja gdje to nije tako jednostavno, npr. pitanja granice prava na privatnost javnih osoba kao što su političari. Govoreći o cenzuri i uskraćivanju informacija radi višeg dobra, Jacquette (2007: 183-184) ističe da je slobodno novinarstvo nužno za slobodno društvo, ali i obrnuto: slobodno društvo je nužno za slobodno novinarstvo, budući da društvo ne može slobodno funkcionirati ako nema slobodan pristup informacijama zato što upravljanje samim sobom pretpostavlja obrazovane građane koji postupaju na osnovu činjenica. Postavljajući to u filozofske okvire Jacquette (2007: 189) piše da uvođenje prioriteta među sukobljene moralne obveze pruža koristan model i za razumijevanje etike cenzuriranja inače slobodnog novinarstva. No, dakako, nikada se ne smije izgubiti iz vida činjenica da je jedini istinski slobodan narod onaj koji je informiran, a jedini način da društvo bude informirano jest da njegovi mediji budu slobodni (Jacquette, 2007: 195). 
Govoreći o zaštiti povjerljivih informacija, Jacquette (2007: 238) ističe da povjerljive informacije i anonimne izvore treba koristiti veoma rijetko, te da oni ne trebaju biti glavni izvor informacija za novinarsko izvještavanje. Izuzetak je, a ne pravilo, da vijest bude iznesena na svjetlo dana uz pomoć nekog anonimnog povjerljivog izvora. Ako neki novinar višestruko koristi „misteriozne izvore“ i izjavljuje da su oni povjerljivi i tajni, to je znak upozorenja na moguću etičku zloupotrebu.

Svatko tko zaista želi pomoći da se svijet promijeni, navodi Jacquette (2007: 374-375), trebao bi razmisliti o novinarstvu kao o načinu na koji osobe $\mathrm{s}$ pravim talentima $\mathrm{i}$ obrazovanjem mogu pružiti pozitivan doprinos ovom svijetu. Istina, to je idealizam, ali ne smije se odustati od tako visoko postavljenih ideala. Ponekad nas uče da realnosti tržišta čine medijsku etiku zastarjelom i da su važni samo prodaja, naklada i, u konačnici financijska strana novinarskog biznisa. No, srećom to ipak nije (samo) tako. Onima koji imaju ciničan stav o vrlinama i vrijednosti dobrog novinarstva Jacquette kaže da je vrhunac nepraktičnosti upravo propuštanje da se prihvate ideali i uloži energija u bilo koji praktičan posao koji, kao što se novinarstvo neprekidno dokazuje, čini život ljudi boljim, pridonosi dobrobiti društva. Medijska etika je samo drugo ime za kvalitetno novinarsko izvještavanje, a u krajnjoj liniji, kvalitetno izvještavanje je ono što prodaje novine i pridonosi većoj gledanosti televizije i općenito praćenju medija. To je često težak i opasan, mada lijep posao, a bez etički obrazovanih novinara koji izvještavaju o činjenicama, koji kao profesionalni novinari postupaju svjesni svojih moralnih prava i odgovornosti, naše razumijevanje situacije u svijetu, kao i mnoge svakodnevne odluke bile bi predane na milost i nemilost glasinama i neobaviještenoj nadi ili strahu.

\subsubsection{Louis Alvin Day i medijska etika}

Kad god se u razgovoru spomene izraz „medijska etika“, piše još jedan od relevantnih suvremenih autora s područja našega istraživanja Day (2014: 13), mnogi će reći da je ta sintagma klasični oksimoron. Profesori koji izlažu sadržaje medijske etike su sasvim navikli na zbunjene poglede, pa čak i nevjericu kada priznaju da se bave nečim što djeluje kao Sizifov posao, tj. kao besmislen akademski trud. Osjećaj svrsishodnosti lako može zamijeniti osjećaj uzaludnosti, napominje Day, jer skeptičnost prema moralnom obrazovanju stvara skeptičnost 
u pogledu moralne odgovornosti, a to pak stvara lidere bez moralne vizije. Zapravo, nikada nije postojala veća potreba da se ponovno naglasi značenje i važnost etičkog obrazovanja.

Vraćajući se u povijest, Day (2014: 20) podsjeća da je proučavanje etike u zapadnom svijetu počelo prije gotovo 2500 godina kada je Sokrat prema tvrdnjama svog vjernog učenika Platona obilazio Grčku suprotstavljajući se idejama o apstraktnim konceptima, poput pravde i dobra. Sokratova metoda istraživanja, koja se sastojala od beskonačnih pitanja i odgovora o prirodi moralnog postupanja, opstala je i do današnjih dana i često pokreće burne rasprave o moralnosti. Konflikt je osnovni sastojak debate o etici, jer čak i u određenom društvu ili kulturi mišljenja mogu postojati razlike o standardima istinskog moralnog postupanja.

Međutim, Day (2014: 28-30) je svjestan da se moralno znanje, bez kojeg nema moralne kondicije, ne sastoji od pamćenja skupa etičkih principa već od sposobnosti razlikovanja dobrog i lošeg ponašanja i moralne volje da se to znanje primjeni na stvarne etičke dileme u stvarnim životnim situacijama. Dakako, ne treba biti nerealan, nego biti svjestan da etička sposobnost nikada ne može dovesti do ljudske savršenosti, koja je, naravno, nedostižna. Zato moramo prihvatiti umjereniju procjenu moralnih vrlina, a Day navodi tri: kredibilitet, integritet i civiliziranost. Govoreći o kredibilitetu ili vjerodostojnosti kaže da bez nje ni druge vrline ne znače ništa. Biti kredibilan, vjerodostojan, znači biti osoba kojoj se može vjerovati i u koju se može imati povjerenje. Od šezdesetih godina 20. stoljeća izraz procijep kredibiliteta (engl. credibility gap) postao je sinonim za nedovoljno povjerenje u priopćenja državnih službenika, korporacija i institucija. Dakako, ni mediji nisu imuni od upadanja u ovakve procijepe kredibiliteta, što je činjenica koja se ogleda i u ispitivanjima javnog mijenja. Govoreći o integritetu, Day na temelju podjele Stephena Cartera kaže da se integritet sastoji od: razlikovanja dobrog od lošeg; postupanja na osnovu uočene razlike, makar i na osobnu štetu; i otvorenog govora da postupate na temelju razlikovanja dobrog i lošeg (Carter, 1996, prema Day, 2007: 29). Ovom popisu Day dodaje spremnost da se preuzme odgovornost za svoje postupke. Drugim riječima, ljudi od integriteta moraju biti aktivni u određivanju pravog načina postupanja, moraju biti spremni tako i postupiti i moraju biti spremni živjeti s posljedicama svog ponašanja. Navodi i poštovanje i požrtvovnost koje su pokretačke snage moralnih vrlina koje Day naziva civiliziranošću. Moralnost podrazumijeva uzimanje u obzir interesa drugih; potpuno sebična osoba ne može donositi etički ispravne sudove. Javnost često medijske djelatnike doživljava kao egoiste i taj stav je doveo do krize povjerenja u medije. Sve je više negativnih stavova u vezi s medijima, nesumnjivo izazvanih 
poimanjem da će novinari sve prekopati, čak i ako to nije etički, da bi došli do vijesti ili da reklamne agente i menadžere za odnose s javnošću više zanima manipuliranje javnim mnijenjem i ukusima potrošača od javnog interesa.

Govoreći o određenoj razini očekivanja publike od medija, Day (2014: 45) piše da bez obzira na izvor informacija, društvo ima pravo očekivati određenu razinu etičkog ponašanja od svojih medijskih institucija i javnosti. Smatra da publika u najmanju ruku zahtjeva informacije neopterećene svjesnim iskrivljivanjem činjenica. Iza toga ranga, etička očekivanja mogu varirati, u ovisnosti od uloge medijskog djelatnika. Mi očekujemo, na primjer, da novinari u svoje izvještaje uključe sve relevantne informacije, osim ako ne postoje neki važni razlozi da se određene informacije izostave. Također, očekujemo da njihovi izvještaji budu objektivni - da ne zastupaju nijedan skup vrijednosti.

Ono što $\mathrm{u}$ zadnje vrijeme najviše zabrinjava jest trend postupnog mijenjanja $\mathrm{i}$ miješanja novinarskih vrijednosti, komercijalnih i vrijednosti zabave, smatra Day (2014: 47). Na primjer, javljaju se reklame koje veoma sliče na uredničke komentare (advertorials) i TV reklame koje sliče na prave emisije (informercials), a riječ je o etički kontroverznim temama. Taj trend brisanja granice između različitih medijskih funkcija izaziva etičke zabrinutosti $u$ rasponu od manipulacije publikom do direktnog varanja publike.

U tom kontekstu Day (2014: 48-49) ističe važnost slobode izbora. Naime, on smatra da se etički sustav mora temeljiti na određenoj slobodi izbora. Društvo koje ne dozvoljava takvu slobodu moralno je siromašno. Subjekti koji djeluju moralno moraju imati nekoliko alternativa na raspolaganju i moraju biti u stanju svoje ovlasti koristiti bez straha od pritisaka, jer u suprotnom etičke norme nemaju smisla. Prema Bibliji, prvi moralni izbor donijeli su Adam i Eva kada su pojeli zabranjeno voće zbog čega su protjerani iz raja. Naravno, većina etičkih sudova ne završava tako drastičnim posljedicama, ali svejedno bez slobodnog izbora nema ni moralnog rasuđivanja.

Zato Day (2014: 49) pojašnjava da je svaki pojedinac, kao autonomni pojedinac odgovoran za svoje moralne postupke, ispravne i pogrešne, a legitimnost bilo kojeg etičkog sustava ovisi o njegovoj sposobnosti da sudionike podvrgne nekakvom standardu odgovornosti. Odgovornost može ići od neformalnih kazni, kada se sudi pred sudom javnog mnijenja, do formalnih kaznenih mjera, kao što je zabrana posla odvjetnicima koji krše etičke kodekse ili otkaz novinarima koji krše kodekse svojih kuća. Etički sustav koji ne obuhvaća 
odgovornost potiče slobodu bez odgovornosti i samim time nema moralni autoritet za poticanje časnog ponašanja.

Day (2014: 49) ističe da etički sustav nije pladanj s kojeg se mogu birati moralne poslastice. Društvo nameće određene odgovornosti svojim članovima kao uvjet članstva. Te odgovornosti se nazivaju moralnim obvezama. Ideja obveze prema drugima je važna za moralno rasuđivanje zato što predstavlja način odavanja počasti trijumfu vrlina nad osobnim interesima. Konkretne obveze se određuju pripadnošću određenoj grupi, profesiji ili zanimanju. Iz toga onda proizlazi i medijska etika.

Vodeći računa o takvom razmišljanju, Day (2014: 75) „moralno rasuđivanje“ definira kao sustavni pristup donošenju etičkih odluka, te kaže da ono poput drugih oblika intelektualne aktivnosti poprima oblik argumenta i uvjeravanja. Budući da etički sudovi podrazumijevaju prava i interese drugih, odluke se moraju donositi pažljivo i moraju biti takve da se mogu racionalno braniti. Osoba koja nije obučena za proces moralnog rasuđivanja mogla bi pretpostaviti da pitanja moralnog rasuđivanja, kao i ona o osobnom ukusu, nisu ništa drugo do pitanja stava, što bi dakako bilo posve pogrešno.

Konačno, Day (2014: 79) govori i o etici sa židovskim i kršćanskim predznakom. Fundamentalni kredo judeo-kršćanske tradicije jest savjet: „Ljubi bližnjega kao sebe samoga“. Judeo-kršćansku etiku karakterizira ljubav prema Bogu i cijelom čovječanstvu. Prema tom shvaćanju, sve moralne odluke trebalo bi zasnivati na poštovanju dostojanstva osoba kao cilju, a ne kao sredstvu da se dođe do cilja. Svi pojedinci bi trebali uživati poštovanje kao ljudska bića, bez obzira na njihov društveni status. Iako judeo-kršćanska etika zvuči pomalo utopijski, ona nudi neke pragmatične savjete za moralno ponašanje, navodi Day dodajući da bez obzira na pristup koji koristimo u donošenju etičkih sudova, one ljude na koje se naše odluke donose trebalo bi tretirati dostojanstveno. Drugim riječima, filozofija poštovanja ljudi trebala bi biti u osnovi svakog etičkog odlučivanja. Taj savjet svakako se odnosi na novinare koji podvrgavaju kritici poslove drugih i podvrgavaju ih očima javnosti.

Govoreći o privatnosti i pravu na privatnost - kao o posebno osjetljivoj medijskoj temi - Day (2014: 157) kaže da je privatnost neodređen koncept koji nije lako definirati. Opći stav je da pravo na privatnost znači pravo pojedinca da bude ostavljen na miru ili pravo da se ima kontrola nad neželjenim publicitetom u svezi s osobnim stvarima. Naravno, medijima je posao da ljude ne ostavljaju na miru. Njihov rad ide u pravcu otkrivanja, a ne prikrivanja. Stoga je pronalaženje ravnoteže između interesa pojedinca za privatnošću naspram interesa 
javnosti za pristupom informacijama o drugima, jedno od najtežih etičkih pitanja našeg vremena. Javni interes (za razliku od čisto privatne radoznalosti ili osobnog interesa) možda je najuvjerljivije opravdanje (a ponekad i izlika) za objavljivanje informacija. Informacije predstavljaju krvotok demokracije i tamo gdje je određeno znanje ključno za racionalan izbor potrošača ili kolektiv, ili pak za donošenje političkih odluka, argumenti u prilog objavljivanju, nasuprot povjerljivosti, u konačnici prevladaju (Day, 2014: 212).

Day (2014: 247-249) govori i o novinarstvu čekovne knjižice. Plaćanje sugovornika i izvora, kažu neki, može ukaljati kvalitetu informacija uključivanjem ekonomskih motiva u tu ,jednadžbu“. Većina tradicionalnih novinara i dalje prezire novinarstvo čekovne knjižice kao samo još jednu bespotrebnu kapitulaciju novinarskih vrijednosti pred komercijalnim interesima. Ako financijski poticaji za prikupljanje informacija postanu pravilo, kažu oni, onda novinarske agencije nisu ništa više od glasnogovornika onih koji imaju zanimljivu priču.

Oglašavanje daje mediju financijsku nezavisnost od vlade i drugih političkih interesa, ali stvara i zavisnost od komercijalnog sektora. Ekonomski pritisci koje nameće oglašavanje vide se na najmanje tri područja. Prvo, kvaliteta komercijalnog materijala određuje količinu prostora ili vremena koji ostaju za nereklamni sadržaj - vijesti i zabavu. Urednici novina su obvezni svoj sadržaj organizirati na prostoru koji preostane kada promidžbeni sektor rasporedi sve reklame i oglase. Na televiziji, producent mora ubaciti svoje priloge između reklama, tako da postoji limitirano vrijeme za svaki prilog. Na zabavnoj strani TV programi se stvaraju tako da vode k dramatičnom vrhuncu nakon kojeg slijede reklame. Drugo, posredne posljedice osjećaju se kada oglašivači smanje svoje budžete kao što se to radi u razdobljima ekonomske recesije ili kada prijeđu s jednog medija na drugi. Drugim riječima, kada reklamna industrija „kašlje“, mediji dobivaju prehladu. Još jedan način na koji komercijalni interesi mogu utjecati na nereklamni sadržaj jest preko izravnog pritiska na medijske menadžere. Oglašivače, što je razumljivo, nervira kada se nađu u vijestima u nepovoljnom kontekstu i nekada reagiraju povlačenjem svojih reklama iz neposlušnog medija, ili se služe drugim pritiscima da im se ne stvara daljnji negativni publicitet (Day, 2014: 292-293).

U potrazi za etičkim standardima za borbu protiv moralnih šteta govora mržnje, trebamo se prisjetiti da je sloboda govora osnova slobodnog društva. Civilno društvo ne zavisi od državne ili društvene kontrole izražavanja, bez obzira na to koliko je ona uvredljiva. Pravi protuotrov za govor mržnje nije gušenje govora, već mnogo više govora. Ključ za civilno društvo leži, koliko u publici, toliko i u onima koji to prenose (Day, 2014: 240). 
Producenti i urednici informativnog programa u biti su teleološki u svom pristupu prema objavljivanju ili emitiranju uvredljivog govora ili slika. Za moralnog novinara reakcija publike i posljedice za obitelj i prijatelje ljudi prikazanih u prilogu trebaju biti glavna briga prilikom donošenja odluka. U odlučivanju uključiti ili ne moralno uvredljiv materijal u vijesti, treba imati na umu jednu smjernicu: takve slike ne trebaju se koristiti za šokiranje ili povećanja naklade ili gledanosti. Te slike trebaju biti opravdane po istim pravilima dobrog novinarstva kao i bilo koje drugo uredničko pitanje. One, prije svega, trebaju biti vrijedne objavljivanja. Kada se potvrdi vrijednost vijesti takvih fotografija, treba odlučiti jesu li one od bitnog značenja za vijest. Pruža li vizualni prikaz značajne informacije ili razumijevanje onog što bi inače nedostajalo u vijesti? Te čimbenike potom treba odmjeriti u odnosu na druge vrednote, kao što su dobar ukus i poštovanje pristojnosti, te potom odlučiti na temelju svega toga (Day, 2014: 373).

$\mathrm{S}$ jedne strane, zaključno ističe Day, etički sustav zasnovan na moralnoj čednosti doveo bi do asketskog sadržaja u medijima koji bi vjerojatno odbila većina publike. S druge strane, apsolutna sloboda vodi moralnom kaosu i destrukciji kulturnog kontinuiteta. Praktično govoreći, nijedan ekstrem nije izvediv ni moguć. Dakle, u kulturno različitom društvu, strategija treba biti iznalaženje nekog srednjeg rješenja, kompromis između prekomjerne moralne čednosti i moralnog kaosa, zaključuje Day ne dajući konačno rješenje za mnoga otvorena pitanja medijske etike (Day 2014: 374).

\subsubsection{Claude-Jean Bertrand i deontologija medija}

Bertrand kao sveučilišni profesor - predavač novinarske etike i praktičar, tj. dugogodišnji novinar koji je ponudio i svoj posebni nacrt za medijsku etiku, spada u značajne autore. Njegova „Deontologija medija“, u kojoj je iznio načine osiguranja društvene odgovornosti (medija) tzv. NODO, svakako spada u svjetske klasike medijske etike. Iz perspektive koja nadilazi okvire nastanka ovog klasika, ozbiljniji prigovor je samo što je riječ o djelu koje je primjerima i osvrtima često vezano prvenstveno uz stanje medija u Francuskoj, no ipak to nije prevladavajuće, tako da je svakako riječ o djelu koje svojim doprinosom nadilazi medijsko stanje jedne države, te može biti od pomoći u univerzalnom promišljanju o temama medijske i novinarske etike. 
Kao što sam Bertrand (2007: 81-82) navodi, on je NODO „formulirao u početku devedesetih i obuhvaća svaki nedržavni način ili sredstvo što se koristi kako bi se mediji učinili odgovornima prema javnosti. Koncept je općenit, i samim time pomalo neodređen, a podrazumijeva kako pojedince ili skupine tako i redovne sastanke, pisane dokumente, male medije ili pak kakav dugačak proces ili neki poseban pristup. U normalnim okolnostima, NODO djeluje samo moralnim pritiskom, no djelovanje se može pojačati autoritetom upravitelja medija ili postojećih zakonskih odredbi.“

Bertrand (2007: 82) piše da iako je moderno "govoriti" o etici, rijetko je riječ o tome da se nešto i "učini". Autor smatra da je žalosno što novinari koji pišu knjige o deontologiji $a$ priori odbacuju svaki način da se postigne njezino poštivanje, a mnogi koji odbacuju NODO tvrde da se radi o prijetnji slobodi medija, ljudskim pravima i demokraciji.

Pišući o implementaciji novinarskih kodeksa, Bertrand (2007: 82-83) smatra da direktori redakcija imaju najjednostavniji, najjeftiniji i najdjelotvorniji način da se postigne poštivanje kodeksa: „To je lako kada je kodeks dio ugovora o zaposlenju: tada je sankcija (ukor, ostavljanje po strani, suspenzija, otkaz) brza, štoviše trenutna, i neopoziva.“ Ističe ipak i drugu stranu medalje: voditelji redakcije u dvojakoj su poziciji: oni su s jedne strane novinari, ali s druge strane u velikoj su mjeri i izvršni agenti vlasnika. Budući da im je prva briga rentabilnost, oni se često ne opterećuju deontologijom. (Bertrand, 2007: 83).

Kao rješenje mnogih problema etike i kvalitete u medijima, Bertrand (2007: 84) vidi obrazovanje. Smatra također da je važna evaluacija, jer najstarija metoda za popravljanje medija, najlakša i najbanalnija, jest kritika, negativna i pozitivna. Bertrand (2007: 84) smatra da je sustavno promatranje (monitoring) ,danas nužno s obzirom na to da su medijski proizvodi nevjerojatno brojni i da su mnogi od njih prolazni. I s obzirom na to da greške medija često spadaju u domenu propusta, koji je teško otkriti. Samo se nezavisni, sveučilišni stručnjaci mogu upustiti u dugoročnije proučavanje medija, u produbljenu analizu sadržaja, u istraživanje njihovih učinaka“" (Bertrand, 2007: 84).

Bertrand (2007: 84-85) važnim smatra i povratnu vezu, tzv. feed back, pitajući se kako valjano služiti društvu ako se ne slušaju pritužbe različitih skupina korisnika i članova drugih društvenih institucija?

Neki među vlasnicima medija, smatra Bertrand (2007: 104), osjećaju određenu odgovornost prema javnosti, a drugi su shvatili da se kontrola kvalitete isplati. Bez obzira u 
koju skupinu spadali, za mnoge od njih je zakon savršeno dovoljan, a NODO smatraju napadom na svoje pravo na vlasništvo. Ako se korisniku kojim slučajem ne sviđa što mu se servira, dovoljno mu je promijeniti novine ili kanal, smatraju vlasnici.

Bertrand (2007: 105) je dosta realan kada piše da „deontologija ili kontrola kvalitete nije neko jednostavno i globalno rješenje za sve probleme medija; to je najmanje što se može reći.“ Isti autor (Bertrand, 2007: 105) daje i odgovore na kritike koji neki upućuju prema NODO-u, a jedan od njih je beskorisnost, jer prema tim kritikama „dobrim“ medijima ne treba nikakva kontrola kvalitete: njihovo ju je osoblje oduvijek provodilo, a „loši“ ih ionako neće prihvatiti. Bertrand smatra da je u time ima istine, ali većina medija i većina novinara nisu ni sasvim dobri, ni sasvim loši - i trebaju im karte, vodiči i ograde, a NODO je upravo to.

Kao jedan od uzroka neprihvaćanja NODO-a, Bertrand vidi u aroganciji medijskih djelatnika koji bili ili ne kompetentni, misle da jesu kompetentni, posebno ako su stekli dobar glas, pa ne prihvaćaju kritike, posebno kad dolaze od korisnika medija, za koje smatraju da ništa ne znaju ili barem da nisu upućeni kao što su to medijski djelatnici. Novinari svaku intervenciju smatraju nasiljem nad „svetištem u kojem se oni, kao veliki svećenici informiranja, posvećuju svojemu pozivu“ (Bertrand, 2007: 107-108).

Bertrand ističe ipak temeljnu manu NODO-a, a to je da nijedan nije savršen, ali ističe $\mathrm{i}$ nedostatke cijele deontologije. „Među ostalim, vijeće za medije je prekomplicirano, kodeks premlitav, medijator preskup, izobrazba prespora itd. No ti pojedinačni nedostaci postaju gotovo beznačajni kada ih usporedimo s jednom teškom manom deontologije: ona riskira da odvrati pozornost onih koji doista odlučuju o ponašanju medija. Naravno, važne se odluke donose na vrhu, a ne u bazi. Glavni je kriterij, prema tome, ekonomski, a ne moralni. Važne odgovornosti ne pripadaju novinarima. Dakako, nemoralno je od jednoga reportera da u zamjenu za mito baci neki članak u smeće. Ali što reći za radio-postaju kojoj je draže uvećati profit nego angažirati dodatnog reportera koji joj je potreban da bi valjano pokrivala aktualna lokalna zbivanja? Dakako, suprotno je deontologiji da novinari prihvaćaju poklone ili usluge. Ali što reći o medijima koji mame oglašivače obećavajući im da će njihove reklame popratiti autorskim člancima kako bi ih istaknuli?“" Bertrand (2007: 110).

Bertrand (2007: 112) primjećuje da mediji o deontologiji obično počinju brinuti u nekim kriznim trenucima, a tada to najčešće nije briga o deontologiji, već samo grana odnosa s javnošću. Ipak, autor smatra da ima značajnih pomaka, a da je prvi faktor te pozitivne promjene polagan porast razine obrazovanja i aktivizma javnosti, jer korisnici medija su 
shvatili da su dobre medijske uloge od ključne važnosti, da tradicionalni mediji nisu bili zadovoljavajući, da mediji sve svoje zadaće moraju izvršavati kako treba, te postaju sve uvjereniji da i oni sami moraju preuzeti neke dužnosti u toj promjeni na bolje. Kao drugi faktor te pozitivne promjene Bertrand vidi i veću osviještenost mladih profesionalaca $u$ pogledu vlastite profesije, kao i veću borbenost u pogledu zalaganja za slobodu i odgovornost medija.

S obzirom na to da deontologija i NODO-i imaju više ciljeva, Bertrand (2007: 114) ih nabraja: „poboljšati usluge medija korisnicima, podići ugled medija u očima javnosti, na različite načine štititi slobodu riječi i medija, te postići strukovnu autonomiju koja će novinarima omogućiti da igraju svoju ulogu u širenju demokracije, a time i unapređenju opće dobrobiti čovječanstva““.

Bertrand (2007: 115) smatra i da će uvijek postojati potreba za zakonima i pravilnicima u medijima, prije svega zato da bi se svim vrstama medija zajamčile jednake šanse, kao i da bi se zauzdala prirodna tendencija trgovačkih društava ka koncentraciji i maksimizaciji profita, zanemarivanju javne usluge. Kao konačni razlog navodi činjenicu da novinar nije jedini odgovoran za sve što u medijima valja ili ne valja, jer ne bi li bilo apsurdno misliti da bi mediji ozdravili od svojih mana kada bi se samo njihovi namještenici ponašali prema deontologiji? Autor zaključuje da je potrebna trijada: zakoni, tržište i kontrola kvaliteta, a udio svakog sastojka u smjesi teško je odrediti, jer on varira ovisno o kulturi i povijesnim slučajnostima.

Bertrand (2007: 119) smatra da ,deontologija nije nekakva moda, tobože rođena u SAD-u nakon oštrih prosvjeda u šezdesetima, a u Europi nakon Zaljevskog rata. Ona nije neka efemerna protuofenziva izazvana valom javnog nepovjerenja. Nije ni neki intelektualni fanatizam, ni reklamerska strategija. Deontologija je jedina metoda za poboljšanje medijske usluge koja je u isti mah učinkovita i bezazlena. Ali, ona je spora. Djeluje na duži rok, što je razlog više da je što prije počnemo primjenjivati.“

O sukobu dviju sloboda u medijima, slobode poduzetništva i slobode izražavanja, Bertrand (2007: 8-9) piše: „Za medijske poduzetnike (i oglašivače) informacije i zabava građa su pomoću koje eksploatiraju jedan prirodni izvor, potrošača, te nastoje održati stanoviti ustaljeni poredak koji im se pokazuje profitabilnim. Nasuprot tome, za građane su informacije i zabava sredstvo u borbi za sreću koju ne mogu doseći ako se ne promijeni poredak“. Smatra da je teško naći rješenje za taj antagonizam. Navodi primjer dva rješenja koja su se 
desetljećima prakticirala u više od pola nacija na zemaljskoj kugli, a to je eliminacija jednoga od dvaju antagonista: diktature fašističkog tipa dokidaju slobodu izražavanja, obično ne dirajući u vlasništvo medija, dok komunistički režimi dokidaju slobodu poduzetništva, tvrdeći da zadržavaju slobodu izražavanja. Oba rješenja nisu nikakva rješenja, jer zapravo ne rješavaju problem, već ga samo preoblikuju. Rezultat je u oba slučaja jednak: osakaćeno novinarstvo postaje sredstvo zaglupljivanja i indoktrinacije. No, ni pokušaji koji su uslijedili nakon toga nisu donijeli sretna rješenja. Jedna je mogućnost da se industriji medija dopusti posvemašnja (politička) sloboda. Doista, ukidanje državnog monopola i vladina nadzora medijima mnogo je značilo za demokraciju i razvoj medija, no nakon toga njihova se sve veća komercijalizacija i koncentracija vlasništva ne slažu baš najbolje s pluralizmom, jer "konglomeratizacija" se ne slaže s nužnom nezavisnošću medija. Autor zaključuje da „,ilj medija ne može biti isključivo zarađivanje novaca, kao ni to da su jednostavno slobodni: sloboda je nužan, ali ne i dovoljan uvjet. Cilj koji valja postići jest imati medije koji će valjano služiti svim građanima. Posvuda na industrijaliziranom Zapadu privatni mediji odavna uživaju političku slobodu, a usluge koje pružaju svejedno su vrlo često ispod svake kritike“ (Bertrand, 2007: 9).

Bertrand (2007: 15) piše i o zaprekama slobodi medija, te ističe pet glavnih. Kao najstariju navodi tehnološku, koja danas nije značajna. Druga je politička: razvoj medija od početka su kočili oni koji imaju vlast, kao što i dandanas, čak i u demokraciji, država pokušava cenzurirati ili namjestiti informaciju. Treća zapreka je ekonomska koja danas postaje sve aktualnija: upotreba medija s jedinim ciljem da se ostvari profit. Kao četvrtu zapreku autor navodi zastarjela shvaćanja i običaje profesionalaca, a posljednja je kultura koja nas okružuje, jer ujedno može ograničavati.

Društvena komunikacija je suviše ozbiljna stvar da bi se prepustila isključivo profesionalcima, te sloboda govora, a time i tiska, nije povlastica pojedine skupine, već ona pripada javnosti, smatra Bertrand (2007: 22), te javnost ima osjećaj da je mediji varaju i iskorištavaju. Taj je animozitet ponekad opravdan, ali nije uvijek, jer ljudi često nisu upoznati s materijalnim zahtjevima sredstava javnog priopćavanja i izriču nepravedne pritužbe. Autor se pita i reagira li javnost kako treba onda kad je reakcija potrebna (Bertrand, 2007: 22).

Pišući o utjecaju medija Bertrand (2007: 31) uočava da se često zaboravlja na činjenicu da su potrebne najmanje dvije strane, pošiljatelj i primatelj, da bi neka poruka postojala, dakle nije sve samo na pošiljatelju. Primatelj interpretira poruku prema svom 
iskustvu, svom okruženju, svojim potrebama i željama, on nije žrtva medija nego njihov korisnik.

Bertrand (2007: 32) ističe da su prava i dužnosti neodvojivi, što je posebno važno u deontologiji. Ljudsko je biće sklono zahtijevati prava, ne spominjući dužnosti koje ih prate, što je posebno vidljivo danas u suvremenom društvu. A deontologija se bavi upravo dužnostima, jer polazi od toga da sloboda i odgovornosti idu zajedno, te deontologija formulira pravila koja zacrtavaju granice slobode svakog pojedinca i utvrđuju njegove dužnosti, a ta pravila proizlaze iz skupa moralnih načela.

Piše i o slobodi tiska, te ističe da je najvažnija ,vokacija medijskog profesionalca, kakve god bile njegove druge funkcije, provoditi slobodu komuniciranja radi informiranja ljudi o vlastitim zapažanjima u svijetu koji ga okružuje. Ta je sloboda jedno od onih ljudskih prava koje zovemo bezuvjetnima budući da se odnose na životno važne potrebe. Bez komunikacije nema društva, dakle ni dužeg opstanka pojedinca. Uvođenje neke diktature, bila laička ili teokratska, monarhijska ili imperijalna, vojna ili kolonijalna, buržoaska ili diktatura proletarijata, uvijek prati ukidanje slobode riječi i tiska. Ona je tako postala kako znak, tako i čimbenik demokracije. Nije beskorisno ponoviti: ako je istina da nema stvarne slobode bez granica, isto je tako istina da bez slobode ne može biti ni odgovornosti. Profesionalac treba slobodu s obzirom na državu, ali i s obzirom na vlasnike. Jednako mu je tako potrebna i stanovita 'ekonomska' sloboda: bez dostojne plaće, teško će izbjeći korupciju“" (Bertrand, 2007: 8-34).

Bertrand (2007: 46) uočava i različite poglede na deontologiju medija u različitim državama, budući da se ne vrednuje svugdje sve jednako. Tu se postavljaju pitanja trebaju li mediji sve što dolazi od vlade stavljati u znak pitanja, kako je to npr. u Sjedinjenim Američkim Državama, ili se ne treba upuštati u "neopravdane" napade na zastupnike, visoke dužnosnike i institucije (kako je to u Koreji ili Turskoj)? Na ovo pitanje je odgovor jasan, no na neka druga nije, npr. jesu li glavni urednici odgovorni za djela novinara iz svoje ekipe (Velika Britanija, Švedska) ili novinar odgovornost za svoje tekstove nikad ne smije prebacivati na nadređene (Francuska, Egipat)? Zar novinar uistinu nikad ne smije iznijeti vlastito mišljenje (Japan) ili ima pravo i na to (Egipat)?

Autor koristi i jednu zanimljivu sintagmu „ostavljanje u mraku“, te ističe da je izostavljanje ,najteži grijeh medija, a razlog može biti narav određenog medija, nedostatak sredstava ili nevoljkost vlasnika da se upusti u neizbježan trošak. No, izostavljanje može imati 
i drugih razloga: o nekim se temama govori malo ili loše zbog drevnih predrasuda i tabua, što vlasnika medija, što oglašivača (koji baš i ne mare za zaštitu potrošača, primjerice), što obrazovanih mladih ljudi koji napučuju redakcije, što najbogatijeg sloja javnosti ili većine stanovništva“" (Bertrand, 2007: 65-66).

Bertrand (2007: 67) uočava i miješanje informacije i zabave u medijima, tj. zamagljivanje granica između informacije i zabave. Mediji pate od nedostatka hijerarhizacije, a trebali bi bolje razlikovati i vrednovati zabavne od važnih vijesti i prednost davati onima koje mogu imati utjecaja na život ljudi. Bertrand (2007: 69) spominje i pojam „uskogrudnog informiranja“, osvrćući se posebno na fokusiranost medija samo na politiku. Piše da nitko ne može zanijekati njezinu važnost, no mediji joj posvuda daju neumjereno pozornosti.

\subsection{Odabrane teme medijske i novinarske etike}

Kroz ovo potpoglavlje rad će obraditi suvremenu medijsku etiku kroz izabrane teme i autore, dajući presjek onoga što suvremena medijska etika nudi. A riječ je o različitim temama koje se nekada mogu činiti kao da su zasebne, što bi bilo pogrešno, jer one u cjelini daju širu sliku o medijskoj etici i njezinoj nužnosti, budući da bez svake od njih pojedinačno nije moguće imati cjelovitu medijsku etiku.

Suvremeni teoretičari medija naglašavaju da novinari imaju uistinu teške zadaće koje pred njih stavlja društvo u cjelini (Brajnović, 2011: 117). Istovremeno, taj jedan od najpoznatijih i u svijetu najpriznatijih hrvatskih autora Brajnović naglašava da brojne ozbiljne analize stanja u različitim medijima ukazuju na značajnu eroziju profesije i profesionalnosti te zapostavljanje ili čak potpuni gubitak etičke dimenzije (Brajnović, 2011: 117). Ističe i da sloboda medija nikada nije apsolutna, te da načelo slobode novinarstva ne smije biti nešto što će štetiti samoj medijskoj etici, te stvarati kontraefekt. Tako Brajnović (2011: 117-118) piše da se nažalost danas sloboda medija često pretvara u zloupotrebu medija, te da je otvorena Pandorina kutija iz koje su izašli zli duhovi - bez realne mogućnosti da se uspostavi normalna kontrola. Smatra da su se zli duhovi izrodili u opaki senzacionalizam i žutilo velikog dijela novinarstva (Brajnović, 2011: 118).

Jedan drugi autor, Bertrand, ističe važnost i potrebu deontologije, te kaže da kada je o medijima riječ, to je „skup načela i pravila što ih uspostavlja struka, po mogućnosti u suradnji 
s korisnicima, kako bi se što bolje odgovorilo na potrebe raznih skupina unutar populacije“ (Bertrand, 2007: 10). Isti autor nastavlja da se mediji među demokratskim institucijama odlikuju jednom posebnošću: njegova moć ne počiva na nekom društvenom ugovoru, nekoj ovlasti koju im je dao narod, stoga da bi sačuvali ugled i nezavisnost, mediji se moraju prožeti svojom prvom odgovornošću: valjano služiti narodu (Bertrand, 2007: 10).

Brajnović (2011: 119) primjećuje da se često čuju pitanja kako postaviti globalna etička „pravila igre“ odnosno kako se postaviti prema utvrđenim društvenim vrijednostima, te sintetizira odgovore onih koji se bave medijskom etikom u odgovoru da se vrijednosti i pravila nalaze već u tisućljetnim prenošenim velikim vjerskim i filozofskim tradicijama čovječanstva i da nije potrebno otkrivati ,toplu vodu““.

Suvremeni teoretičari medija govore i o pravu na pristup informacijama, kao i o objektivnosti u njihovom prenošenju. Tako Helmut Bauer (1997: 57) kaže da ako svakom građaninu pripada neotuđivo pravo na „neometano korištenje općepristupačnih izvora“, onda se masovni mediji moraju ponajprije pobrinuti za to da se svakom čitatelju, slušatelju ili gledatelju ponudi što je moguće opširnija, čak i kompletna ponuda informacija. Nastavlja dalje da to ima smisla samo ako se to radi s najvećom mogućom objektivnošću. No, istovremeno primjećuje da objektivnost u krajnjoj liniji može postojati samo u idealističkim zamislima iz snova. Ipak, zaključuje da iako subjektivnost, koja se nalazi u svakoj individui, ne može biti totalno potisnuta. Ona ne smije postati jeftina isprika za manipulacije.

\subsubsection{Medijska etika i nužnost etike u novinarstvu}

Nije moguće baviti se novinarstvom, ističe Poler Kovačić (1998: 30), a da se, na ovaj ili onaj način, ne suoči s etikom, iz čega zaključuje da je etički odnos u samoj biti novinarskog izvješćivanja. Nadalje Poler Kovačić (1998: 31) navodi da je medijska etika zapravo etika (osobne) odgovornosti. Naime, bitno pitanje za (medijsku) etiku jest: kome ili čemu smo u svome radu odgovorni, tko ili što nas obvezuje? To se pitanje može postaviti i drugačije: što je osnova medijske etike na kojoj medijski djelatnik utemeljuje svoju odgovornost, odnosno etičnost, te također svoju slobodu? Također, važno pitanje je što je u novinarstvu cilj i najviše dobro? U potrazi za tim odgovorima Poler Kovačić polazi od filozofije prosvjetiteljskog filozofa Kanta, koji etiku nije temeljio na pojmu dobroga, nego na apriornosti moralnoga zakona. Prema njemu, pojam dobroga možemo izvesti tek iz moralnoga zakona. Prvi uvjet 
najvišeg dobra jest ćudoređe, a drugi je sretnost, koja je moralno uvjetovana i nužna je posljedica prvog. To znači da se u traženju najvišeg dobra u novinarstvu ne može izbjeći uvjet etike, otkrivene pomoću Kantovog poznatog pojma kategoričkog imperativa koji glasi: „Djeluj tako da maksima tvoje volje može istodobno vrijediti kao načelo općeg zakonodavstva“ i „Radi tako kao da će maksima tvojeg djelovanja pomoću tvoje volje postati opći prirodni zakon“. Primjenjujući to na medije, novinar koji sluša moralni zakon u sebi shvaća da npr. maksima „budi istinoljubiv samo onda kada ti to odgovara“ ne može vrijediti kao opći zakon. Ne može željeti niti očekivati da maksima ,ponekad prekrši sporazum koji si sklopio s izvorom informacija“" pomoću njegove volje postane opći prirodni zakon.

Poler Kovačić (1998: 37) nastavlja da novinar ima dužnost prema sebi kao prirodnom sucu samoga sebe, i to upravo zbog savjesti. Prema Kantu savjest je svijest o unutarnjem sudu u čovjeku (pred kojim se njegove misli međusobno optužuju i opraštaju si). Savjest ima svaki čovjek, jer ona je njegov unutarnji sudac koji promatra, prijeti mu i potiče mu strahopoštovanje.

Pravo javnosti na obaviještenost ima važnu etičku dimenziju, ističe Poler Kovačić (1998: 38), jer to pravo za novinara predstavlja posebnu odgovornost budući da novinari djeluju kao predstavnici javnosti. To znači da je novinarova prvenstvena odgovornost „odgovornost prema javnosti“. Vjerodostojnost novinarskog izvješćivanja pokazuje se u sposobnosti novinarstva da poštuje primarnu lojalnost prema javnosti kojoj je na određeni način poslano.

Poler Kovačić (1998: 39) piše da konkretna situacija moralnog prosuđivanja pak zahtjeva još razinu promišljanja koja, nakon što u temelju ima prvu razinu (Kantovu zapovijed poštovanja čovjekove osobe), tu razinu smješta u život i na taj način moralnome sudioniku, koji je suočen s određenim problemom ili dilemom, omogućuje etičnu odluku, a ne puku teoretsku definiciju. Te dvije razine nisu suprotstavljene, jer druga razina ne pobija prvu, nego je - baš suprotno - čak dodatno potvrđuje. Poštovanje obiju razina ključno je za ispravno i cjelovito shvaćanje medijske etike.

Važno da novinar u svom radu nipošto ne napušta temeljna etička načela, piše Poler Kovačić (1998: 40-41), te da na osobnoj razini osjeća dužnost koja mu određuje da ta načela treba slijediti. Mora sačuvati jezgru dužnosti kojima je u osnovi predan, te ih poštivati kao smjernice svojeg profesionalnog odlučivanja i djelovanja. Privrženost pravilima osigurava mu koncepcija vjernosti pravilima koju za ozbiljnije poimanje etike treba većina ljudi. Temeljna 
pravila mora slijediti, no ne „slijepo ili nepromišljeno“. Ako s dužnošću zbog dužnosti Kantovom verzijom deontološke etike - pretjerujemo, može se dogoditi da se osoba ponaša u skladu s krutim pravilom, što nije uvijek ispravno.

Poler Kovačić (1998: 42) zaključuje da je novinarska etika zapravo „etika novinara kao središnjih osoba medijske realnosti, a koji se profesionalno bave novinarskim poslom, odnosno obavješćivanjem javnosti preko masovnih medija kao temeljnim ciljem svoje javnosti. Osigurava filozofsko promišljanje novinarovog moralnog izbora i legitimnosti tih normi u određenoj situaciji“. Nadalje, navodi da je novinarska etika zapravo etika odgovornosti, koja kao novinarovu primarnu odgovornost određuje odgovornost prema javnosti. No, osnovni uvjet i pretpostavka novinarske etike jest sloboda, koja je pak utemeljena na poštovanju dostojanstva čovjekove osobe. Novinarska je etika tako suprotnost makijavelizmu: osobu poštuje kao cilj po sebi, najviše dobro, vrednotu i dostojanstvo. Poštovanje dostojanstva čovjekove osobe temelj je novinarske etike i temelj novinarske profesije uopće.

Kao što navode Malović, Ricchiardi i Vilović (2007: 7) etika je goruće pitanje suvremenih medija. Senzacionalizam, skandali, manipulacije, govor mržnje, povreda dostojanstva čovjeka i svih mogućih ljudskih prava nanijele su novinarstvu neprocjenjive štete, te se zbog toga potrebno vratiti na etička promišljanja.

Ne postoje čarobne formule ili laka rješenja za etičke dileme s kojima se novinari svakodnevno susreću, ali postoje univerzalne smjernice: tragati za istinom i izvještavati o njoj, biti nezavisan i odgovoran prema čitateljima, slušateljima, gledateljima i samome sebi. Ova jaka povezanost između izvrsnog novinarstva i etičkog novinarstva može puno postići u zadobivanju i odražavanju povjerenja javnosti u slobodnim društvima širom svijeta (Malović, Ricchiardi, Vilović, 2007: 24).

Malović, Ricchiardi i Vilović (2007: 34-35) upozoravaju na dodatne poteškoće s kojima se novinari suočavaju: novinarstvo se nikada ne radi mirno, polagano, u idealnim radnim uvjetima, njega karakterizira stalna borba s rokovima; brzina je najčešći i najvažniji kriterij, vijest ne smije zakasniti, jer rotacija i termin udarnih vijesti ne čekaju, a danas u doba novih medija možemo još i dodati kako je „lov“ na nove vijesti postao neminovnost svih informativnih portala $\mathrm{i}$ onih koji na njima rade. Novinari stoga moraju biti veoma dobro obučeni i sposobni za rad u veoma teškim uvjetima. Odluke se moraju donositi na brzinu, mora se reagirati na događaj, donositi odluke koje imaju dalekosežne posljedice. Spomenuti 
autori navode i da novinari spadaju među profesionalce koji moraju donositi ne samo brze, nego i velik broj odluka u vrlo kratkom vremenu, što ih dovodi u posebno stresne situacije. Ujedno, novinari moraju biti svjesni da će već sutra pred sudom javnosti snositi konzekvence za svoje odluke, iako su bili u stisci s vremenom prilikom odlučivanja, ali se moraju nositi i sa svojim vlastitim etičkim dilemama i propitivanjima.

Malović, Ricchiardi i Vilović su na temelju nekoliko svjetskih medijskih etičkih kodeksa definirali temeljna kršenja standarda medijske etike:

- „Neistinito izvještavanje (Istina je temelji novinarske profesije. Neistinito izvještavanje je svjesno prešućivanje informacija, iskrivljivanje istine, izmišljanje činjenica i događaja).

- Neprovjerene informacije (Novinar je obvezan svaku informaciju prethodno provjeriti iz najmanje dva neovisna izvora. Iznošenjem neprovjerenih informacija dovodi $u$ pitanje ne samo integritet osobe $\mathrm{i}$ istinitost događaja o kojem piše nego i svoj novinarski kredibilitet).

- Prikazivanje samo jedne strane u sukobu (Novinar treba saslušati sve strane u sukobu o kojem izvještava te ih uravnoteženo prikazati. Za novinara izvjestitelja sve su strane podjednako važne, a događaj će predstaviti što je moguće objektivnije i pošteno).

- Narušavanje temeljnih sloboda i prava čovjeka (Temeljna su prava čovjeka neotuđiva i svako njihovo narušavanje u medijima gruba je povreda Opće deklaracije o pravima čovjeka. Mediji podjednako moraju brinuti i o poštivanju prava djeteta i manjinskih skupina).

- Zloporaba izvora informacija (Svako netočno, tendenciozno i iskrivljeno prenošenje podataka dobivenih od izvora informacija smatra se zloupotrebom. Izvor informacija ima pravo staviti embargo - vremensko ograničenje - na objavljivanje vijesti).

- Plagijat i nepoštovanje autorstva drugih novinara (Plagijat je krađa, prisvajanje tuđeg autorstva i tekstova. Plagirati znači pokrasti tuđu literarnu svojinu, što u medijima znači novinarsku svojinu. Kad novinar prenosi podatke iz drugih medija, dužan je korektno navesti izvor informacije). 
- Govor mržnje (Sve vrste govora kojima se širi, potiče ili opravdava nacionalna i rasna netrpeljivost, ksenofobija, antisemitizam, vjerski i drugi oblici mržnje temeljeni na nesnošljivosti).

- Politička angažiranost novinara u funkciji promidžbe određene ideologije (Uravnoteženo, objektivno i pošteno izvještavanje isključuje promicanje političkih ideja i stavova samo jedne stranke i jednostrano prikazivanje neke ideologije. Novinar kao i svaki drugi čovjek ima pravo na vlastito političko opredjeljenje i angažiranje, što se ne smije odraziti na objektivnost izražavanja. Novinar se treba pridržavati načela: Činjenice su svete, a komentar slobodan.)

- Propagandna djelatnost (Novinar se ne smije baviti poslovima koji ugrožavaju njegovu samostalnost prosuđivanja i smanjuju objektivnost $u$ objavljivanju istinitih činjenica i narušavaju njegov novinarski dignitet. Novinar ne smije objavljivati informacije radi stjecanja osobne materijale koristi /mito, korupcija i slično/. Novinar ne smije biti autor plaćenih reklamnih i drugih promidžbenih tekstova)“ (Malović, Ricchiardi, Vilović, 2007: 60-61)

Medijski stručnjaci s punom odgovornošću upozoravaju na ugroženost novinarstva kao profesije, tj. svojevrstan gubitak potrebe za kvalitetnim novinarima, jer novinarstvo temeljeno na skandalima i nesrećama ne treba dobre i neovisne novinare. Takvi mediji koji su daleko od etike i profesionalnosti ne trebaju novinare koji se strogo drže svog profesionalnog kodeksa, njima ne treba profesionalno i čestito novinarstvo koje svaku informaciju provjerava iz najmanje dva izvora, izbjegava pogrdne riječi i uvrede, koje izbjegava novinarske oblike koji bi mogli izraziti političku, kao i svaku drugu pristranost prema jednoj strani u informativnom postupku, izbjegava svaki čin bahatosti i predrasuda, daje priliku da se izraze i oni koji teško dolaze do riječi, izbjegava sve što bi moglo iskriviti i dramatizirati izvješće, ne koristi nečasne metode u pribavljanju vijesti, izvore informacija kritički prosuđuje, priznaje svoje pogreške i odmah ih ispravi, stalno hrabri javnost i svoje čitatelje na kritiku medija (Malović, Ricchiardi, Vilović, 2007: 11).

Malović (2005: 85) ističe da je medijska etika jedna od najčešćih tema kada se govori o svemu lošem u masovnim medijima. Kritičari medija tada izvlače primjere kojima dokazuju kako se novinarstvo posve srozalo. No, ni sami novinari ne zaostaju, pa još oštrije kritiziraju jedni druge. Rijetko koje zanimanje tako javno i otvoreno govori o svojim pogreškama i 
kršenju etičkih načela kao novinarstvo. Malović (2005: 85) nadalje ističe da je normiranje medijske etike dobro i široko razrađeno. Primjena je, međutim, nešto posve drugo.

Novinarstvo nema u svim zemljama ista iskustva poštovanja etičkih načela, te jednako vrednovanje pojedinih ,prekršaja“. U SAD-u se npr. najviše osuđuje plagijat, što ne čudi kada se zna kakva je konkurencija i kako svaka takva krađa ugrožava tržišni uspjeh medija. $\mathrm{Na}$ području jugoistočne Europe to se ne gleda kao strašan prekršaj, dapače čini se kao da je sasvim uobičajen. Bolna tj. najslabija točka na kojoj hrvatski mediji ne prolaze na ispitu su, kako tvrdi Malović, njihovi odnosi s vlasti i sa svim centrima moći. Novinari ne smatraju velikim grijehom propagirati ideje, stajališta i djela utjecajnih, a često su za to i dobro nagrađeni (Malović, 2005: 86).

Malović (2005: 88) piše da se moral ne normira, već je riječ o sustavu vrijednosti koje pojedinac prihvaća. Isto tako se pita ima li morala u novinarstvu, ističući da je problem morala tj. često nemorala, problem ne samo u medijima $u$ tranziciji, koji su proizašli iz socijalističkog modela, gdje je dvostruki moral bio stalno prisutan, nego i u najrazvijenijim zemljama. Malović (2005: 89) zaključuje da su pitanja medijske etike, morala, dobrog ukusa i pristojnosti temeljna pitanja cjelokupne medijske struke. Mladi će novinari neke stvari naučiti na najgori mogući način, u okrutnoj školi i praksi života, pa će to biti i vrlo skupo školovanje. Naglašava i da se neki kriteriji i standardi ipak ne mogu naučiti. Možda je najbolji način procjene vrlo star i jednostavan: ne čini drugome ono što ne želiš da se učini tebi.

U svojim razmišljanjima Malović (2005: 25) posebno ističe važnost poštenja. Kaže da se događaj može promotriti s različitih stajališta, s time da se jedno može naglasiti, a drugo zanemariti, te pri odabiru onoga što je potrebno naglasiti ili zanemariti treba biti pošten. Znači, događaj treba nastojati prikazati što dosljednije. No, to nije jednostavno i novinari često upadaju u zamke. Isti autor (Malović, 2005: 26) se pita kako izvještavati, te daje dva različita odgovora. Tako navodi da je taj odgovor početkom 20. stoljeća glasio „objektivno“, a stoljeće poslije - „pošteno“.

Malović (2005: 29) primjećuje i da zbog povezanosti s izvorima, novinar može iskrivljeno izvještavati. Strana literatura takvo postupanje naziva „insider friendship“, dok Malović u slobodnom prijevodu tumači da je to zapravo „povezanost sa strukturama“. Navodi i brojne primjere povezanosti novinara s izvorima, a koji se očituju u pristranosti, favoriziranju, nekritičkom izvještavanju i sličnom. Novinar svoje poštenje nagriza i povezanošću sa sponzorima koji često znaju biti i više nego velikodušni čašćenjem novinara ili njihovim 
pozivanjem na skupa putovanja i slično. Poštenje se u tom slučaju ugrožava tako da se narušavaju etika i moral profesije.

Međutim, Malović (2007: 10) upozorava da bez obzira na značajnu ulogu medija većina običnih konzumenata nipošto ih ne doživljava kao nešto u što se vjeruje bez ozbiljne sumnje. Jednostavno, prošlo je doba kada se govorilo da je nešto točno zato što smo to pročitali u novinama, čuli na radiju ili vidjeli na televiziji. Mediji sve više gube na vjerodostojnosti i povjerenje konzumenata nije više bezrezervno. Dapače, kada se ispituje povjerenje ljudi u društvene institucije, mediji su obično negdje na začelju. Isti autor (Malović, 2007: 10-11) se dalje pita zašto je to tako, te daje i odgovore kroz koje provlači i neka nova pitanja: „Odgovori su, naoko, jednostavni: površnost, senzacionalizam, neprofesionalizam, manipulacije, neznanje... Je li tome tako? Jesu li novinari slabi, pa im stoga javnost ne vjeruje, ili su mediji napustili neke stare, provjerene vrijednosti i u lovu za zaradom i održavanjem forsiraju infontainment i senzacionalizam.“

Govoreći o nepristranosti, Malović (2005: 42) ističe da je ona jedan od najvažnijih i osnovnih preduvjeta suvremenog novinarstva. Novinar se u svom izvještavanju ne smije svrstati ni na koju stranu. Izvještaj mora prikazati sve upravo i samo onako kako se dogodilo, isključujući sve osobne sklonosti novinara. Dakako, novinar smije svoja stajališta iskazati u komentaru, ali nikako u vijesti. Sve navedeno čini se kao sasvim jasno, razumljivo i prihvaćeno, te dvojbi kao da nema. No, prilikom otvaranja novina, slušanja radija, gledanja televizije i pretraživanja internetom otvaraju nam se mnoge nedoumice i jedno pitanje bez jasnog i konkretnog odgovora: jesu li novinari nepristrani i mogu li to uopće biti?

Malović (2005: 16-17) ističe da svi autoritarni sustavi deklarativno potiču novinare na objektivnost, ali samo dok je ta „objektivnost“ u njihovu korist. Onog trenutka kada novinar objektivno izvještava o njihovim lošim stranama, vlastodršci pokreću mehanizme kroćenja medija i uspostavljaju svoju „objektivnost“ koja s objektivnošću nema poveznice (osim što je njezina suprotnost). Nadalje, isti autor (Malović, 2005: 17) piše da se kriteriji objektivnosti teško mogu primijeniti i zato je vrlo teško utvrditi što se doista dogodilo. Čak su i prirodne znanosti koje se smatraju egzaktnima oprezne u procjeni je li nešto objektivno tako kako se čini. Stoga je suvremeno novinarstvo sve više sklono koristiti pojam poštenja (fairness) umjesto objektivnosti (objectivity). Lance Bennet to objašnjava ovako: „Čini se da je poštenje primjereniji cilj izvještavanja s obzirom na zapreke koje stoje pred objektivnošću: vrijednosti sadržane u političkim događajima, varke proizvođača vijesti, poteškoću postizanja posve 
neutralna stajališta, nemogućnost prikazivanja svih strana i prikupljanja svih činjenica, te žurba kako bi se ispunili nerazumno kratki rokovi. Zbog tih i drugih poteškoća tisak se optužuje da nije objektivan, bez obzira na to koliko se trudi izlagati 'činjenice'. I stoga se čini da je 'poštenje' cilj koji je razumniji i koji je lakše obraniti: izvjestitelji se trude prikupiti što više informacija i 'objema stranama' dati jednako vrijeme da ih komentiraju i interpretiraju“ (Bennett, prema Malović, 2005: 17).

U povijesnom kontekstu Malović (1997: 155) podsjeća i da se kroz protekla razdoblja ne mijenjaju previše teme i dvojbe, jer je Nelson Antrim Crawford napisao i 1924. godine objavio djelo „The Ethics of Journalism“ - prvu knjigu tiskanu u SAD o toj temi, a i danas se raspravlja o sličnim temama i javljaju iste dvojbe.

Malović (2007: 10) isto tako piše da se medije vrlo često naziva „sedmom silom“ zbog njihove društvene snage, ističući da ipak ne bi smjeli biti „sila“. Naime, mediji su izuzetno moćni i mogu utjecati kako na društvo, tako i na pojedinca, no nije dobro kada mediji počnu djelovati s pozicije sile. Isto tako, mediji ne bi smjeli biti niti sluge vlastodržaca. Svaka vlast želi podjarmiti medije kako bi ostvarila utjecaj na društvo i pojedince. Ako ih već ne mogu podjarmiti, a onda barem utjecati na medije, što mediji ne bi smjeli dopustiti. Neki pak medije nazivaju „četvrtom vlašću“. Postoji društvena podjela na zakonodavnu, izvršnu i sudsku vlast. U suvremenim demokracijama pridružuju im se mediji kao četvrta vlast. Govoreći o medijima u Hrvatskoj Malović se pita jesu li oni doista postali sedma sila ili četvrta vlast.

Istovremeno ističe i važnost drugih segmenata društva: „Znamo vrlo dobro kako napis u medijima ipak nije dovoljan da bi se nešto promijenilo, znamo da treba šira društvena klima i razumijevanje, pa je zato potrebno da se javnost javlja i budi. Kada se javnost ne bi budila i javljala ne bi mediji mogli ništa učiniti, mogli bi, kao što je to slučaj bio prije, pisati bez ikakvog odjeka. Znači, mnogo je važnije da novinari mogu djelovati profesionalno, samostalno i neovisno, a ostvarenje utjecaja takvog izvještavanja onda nije više na novinarima, nego i na drugim dijelovima javnosti i civilnog društva. Novinari nisu ni suci, ni tužitelji, niti policija, oni rade svoj novinarski posao u kojemu ukazuju na ono što se događa, a dalje je na ostalim društvenim instrumentima, uključujući i državne organe, ministarstva i tužilaštva, da reagiraju“ (Malović, 2007: 10).

Novinari, nastavlja Malović (2007: 32), imaju velika prava. Neka su stečena, ali većina se temelji na zakonskim rješenjima, a jedno od najvećih je pravo da znaju. Pravo na pristup informacijama je izuzetno važno i temeljno za nesmetano objavljivanje novinarske profesije. 
Isti autor (Malović 2007: 32-33) podsjeća da je osnovno određenje novinarske profesije nezavisnost od svake ideologije. Nema pravog novinarstva ako počiva na nekoj ideologiji. To nipošto nije vrijednosno određivanje ideologije, ona može biti najbolja na svijetu, ali novinarstvo se mora temeljiti na drugim načelima.

Poseban etički problem danas je i prikriveno oglašavanja, pri čemu Malović (2007: 107) ističe da oglas mora biti jasno i vidljivo označen, što često nažalost nije slučaj, a prikriveno oglašavanje postaje sve češća praksa. Prodajni timovi medijskih tvrtki sklapaju unosne ugovore sa strankama te ugovaraju paket u kojem se nalaze vidno označeni oglasi, ali i prikriveni, koji se objavljuju kao redovni, uobičajeni novinarski prilog. To je najefikasniji vid oglašavanja, jer konzumenti medija misle da se radi o novinarskom radu, a ne plaćenom oglasu. Takvi prikriveni oglasi su posve neetični i novinar ne smije surađivati pri izradi oglasa, ali nažalost, prikrivenih oglasa je sve više, zbog čega ih je sve teže prepoznati.

Valković (2008: 275) piše i o temi etike u promidžbi, ističući da kao što se istinitost i autentičnost komunikacije ne može svesti samo na ispitivanje istinitosti ili podudarnosti poruke sa stvarnošću, tako se i promišljanje o istini u promidžbi ne može zaustaviti samo na istinitosti promidžbene poruke. Naime, etičko promišljanje o istini u promidžbi usmjerava pozornost na cjelokupni komunikacijski proces, dakako uvažavajući pritom specifičnosti promidžbene komunikacije.

Valković (2008: 276) ističe da je promidžba vrlo specifično područje, te da malo koji oblik komunikacije pobuđuje tako brojna i raznolika pitanja kao što je to slučaj $\mathrm{s}$ promidžbom, te na istom mjestu pomalo ironično nastavlja: „U njoj je svaka želja ostvariva, put do zadovoljstva i uspjeha osiguran, a svatko može na jednostavan način riješiti svoje probleme i postati sretan, uz jedan jedini uvjet - nabavu (reklamiranog) automobila, šampona ili deterdženta. Za ostvarenje toga cilja potrebno se samo odazvati promidžbenom pozivu, uputiti se do najbližeg centra i kupiti reklamirani proizvod (i svakako požurite, jer 'količina je ograničena'!). Današnja reklama 'briše granicu između onoga što je u njoj predstavljeno i mogućnosti da se to ostvari. Za nju su i nemoguće stvari moguće.' (...) Jedan od temeljnih preduvjeta etički prihvatljive promidžbe i time autentične komunikacije jest njezina istinitost. Međutim, koliko god to pitanje, odnosno odgovor na njega izgledao jednostavan, već samo pitanje o načinima i kriterijima prosuđivanje istine otvara nova pitanja i ukazuje na složenost problematike. Je: je li dovoljno, kako se često običava, istinitost neke komunikacije određivati isključivo prema istinitosti (podudarnosti) njezina sadržaja (u svjetlu Tomina 'adaequatio rei 
et intellectum', tj. slaganja između stvarnosti i onoga što je u našem umu)?“(Valković, 2008: 276).

Valković (2008: 277) dodaje da se kriterij vrednovanja istine ne odnosi samo parcijalno na neke pojedince, već na sve subjekte koji su uključeni u komunikaciju, te navodi i konkretno kako i na koga se odnosi. Ističe da to prvenstveno znači da se komunikacija mora temeljiti na autentičnosti onoga tko govori (pošiljatelja), a koji je pozvan na poštivanje istine vlastitog identiteta. Također, svaki govor i svaka komunikacija uključuju i poštivanje onoga kome se obraćamo, njegova dostojanstva i njegova cjelokupnog ambijenta. Naglašava i da se istina ne predstavlja i ne susreće u „čistom“, „prirodnom“ stanju, već je njezino poznavanje posredovano vizijama, pogledima i shvaćanjima života, odnosno svijeta.

Isti autor (Valković: 2008: 278) piše da je nužno nadvladati svaki oblik manipulativnog i utilitarističkog djelovanja, što u današnjem sustavu funkcioniranja medija nije lako ostvariti. Taj se problem veoma snažno doživljava u promidžbenoj komunikaciji, budući da je ona već po svojoj naravi komunikacija koja promatra sugovornike kao cilj i predmet konzumiranja, a što nikako ne može biti etički prihvatljivo.

Sumirajući sve navedeno Valković (2008: 285) piše da je promidžba etički prihvatljiva kada je obazriva prema vrednotama i normama, kako onih koji je kreiraju tako i onih kojima je upućena. „Oglašivače to upućuje na imperativ, ponajprije poznavanja ethosa publike kojoj promidžba govori, poštivanja njihovih vrijednosti, načina življenja te izbjegavanja mogućih povreda ili nepoštivanja njihova dostojanstva. Stoga etičnost promidžbe u komunikaciji ne može zaobići pitanje poštivanja vrijednosti i temeljnih dimenzija ljudske egzistencije, te bi trebalo postaviti pitanje: jesu li te teme i vrijednosti unutar promidžbe obrađivane s dužnom obazrivošću? Misli li se konkretno na prikazivanje i odnos prema nekim vrijednostima života čovjeka i društva. Kako se govori o ljubavi, kako se prikazuju i 'koriste' vjerske teme i motivi, kako se doživljava odnos prema bolesti ili smrti, osobito u kontekstu pojedinih kultura? Treba imati u vidu da se promidžba više puta ponavlja, te da na taj način može sadržaje i vrijednosti izlagati banaliziranju. Osim toga $\mathrm{u}$ promidžbi se susrećemo i s opasnošću pribjegavanja raznim stereotipima koji često na neprimjeren i omalovažavajući način prikazuju različite uloge ili prikazuju s nedovoljnim poštovanjem neke kategorije ljudi““ (Valković, 2008: 285).

Odgovornost za istinitost promidžbe, na koju su posebno pozvani oni koji je oblikuju, ekonomski subjekti koji je naručuju te masovni mediji preko kojih se promidžba najvećim dijelom distribuira, danas se doživljava kao veoma snažan i konkretan poziv na veću osjetljivost za one kojima promidžba progovara, za njihovu situaciju i njihove mogućnosti, 
piše Valković (2008: 299). Naglašava da je pitanje istinitosti u promidžbi zapravo neodvojivo od pitanja poštivanja dostojanstva čovjeka.

Malović (2007:113) se pita imaju li masovni mediji uopće „snage, želje i mogućnosti da pređu Rubikon i da umjesto korektnih izvještača postanu kreatori humanitarne djelatnosti, nositelji velikih, masovnih pokreta koji će mobilizirati javno mišljenje, ukazati na moguća rješenja i potaknuti konkretnu akciju? Je li to uopće zadaća masovnih medija i kako je oni mogu realizirati?““

Snaga medija je strahovita, npr. objavljivanje slike i vijesti na naslovnoj stranici novina o uhićenju uglednog gospodarstvenika izaziva trenutačne reakcije u poslovnom svijetu, te takva osoba i tvrtka koju predstavlja gube ugled i povjerenje, što se odražava na poslovanje. Okolina se počinje distancirati od takve osobe, a članovi obitelji izvrgnuti su društvenoj osudi. Također, i žena i djeca plaćaju kaznu zbog javne osude. Kažu da novinska vijest živi vrlo kratko, svega jedan dan, što je djelomice točno, jer posljedice ostaju mnogo duže. Može se dogoditi da ta osoba nakon nekoliko godina bude oslobođena svih optužbi, a vijest o tome više se ne probije na naslovnicu, te u svakom slučaju nema snagu prve, negativne vijesti. Šteta je za tu osobu golema i teško nadoknadiva, čak i kada dobije sudsku zadovoljštinu. Postavlja se pitanje: što napraviti? Ne objavljivati do pravomoćne sudske presude? To ni u kom slučaju nije opcija, jer uloga medija je posve drukčija: mediji moraju reagirati. Ali, na koji način reagirati već je posve drugo pitanje, kaže Malović (2004: 133).

Gordana Vilović (2007: 168) govori o vjerodostojnosti medija: „Vjerodostojnost nije tek teorijsko ili filozofsko pitanje, odvojeno od našeg posla. To je samo srce naših profesionalnih života. Vjerodostojnost ne znači povećanje naklade. To je izgradnja kvalitete i integriteta naših vijesti. Vjerodostojnost nije pokušaj iznalaženja novih načina kako riješiti probleme. Ona jest potpuno razumijevanje najviših profesionalnih i etičkih standarda. Vjerodostojnost nije čak niti ono što imamo pravo učiniti; svakako, imamo pravo tiskati što god želimo. Ali ključno pitanje je činimo li prave stvari.“ Na istom mjestu (Vilović, 2007: 168) autorica piše da problem vjerodostojnosti medija i uopće medijske profesije, možda nikada kao danas, nije bio doveden u pitanje učestalom lošom novinarskom praksom u gotovo svim medijima svijeta, neovisno jesu li to mediji „u tranziciji“ poput primjera iz naše i okolnih zemalja, ili su pak dio razvijenih demokracija i višestoljetne uspješne prakse koja unatoč svemu (profitu, okrupnjavanju medija i oglašivačima) njeguje i ozbiljno novinarstvo. Ili barem pokušava (ni to nije jednostavno). I u jednima i u drugima, medijski teoretičari i 
pravi novinari, brinu o imidžu medija i neprestano upozoravaju kako pošteno novinarstvo dostojno povjerenja čitatelja/gledatelja/slušatelja još uvijek ima smisla.

Vilović (2007: 171) piše da javnost s jedne strane i novinari i urednici s druge strane različito doživljavaju i tumače što su to vjerodostojne novine. Dok javnost smatra da novine koriste neprimjerenu dramatizaciju i senzacionalističke priloge jer žele prodati koji primjerak više, a ne zato što je to važna vijest, novinari i urednici tvrde da oni rade samo ono što od njih očekuje znatiželjna javnost. Javnost smatra da vjerodostojnost mediji pokazuju kroz njihovu glavnu zadaću donošenja točnih podataka i informacija, a ne u pokušaju tumačenja događaja.

Za medijsku etiku vjerodostojnost je ključni element na kojem se izgrađuje imidž nekog medija, kaže Vilović (2007: 178). Kao primjer je donijela novine, tj. od jednu najboljih svjetskih novina više od 150 godina, New York Times, kojoj se najteži udarac dogodio kad je otkriveno da je jedan od omiljenih novinara prepisivao i izmišljao priče i tekstove. I više godina nakon toga događaja, medijski teoretičari spominju koliko je taj događaj uzdrmao najnagrađivaniju novinu koja se uvijek ponosila vjerodostojnošću. To je tolika prekretnica u povijesti te novine da se na neki način računa s ,prije i poslije“ izmišljanja i prepisivanja, kao što se opća povijest računa ,prije i poslije Krista“ ili „prije nove ere“ i „poslije nove ere“. Povjerenje koje se u New York Timesu stoljeće i pol izgrađivalo, preko noći se narušilo.

I tabloidizacija novina pridonijela je padu profesionalnih standarda novinarstva, a i etičnosti (Vilović, 2003: 961). Iako govori prvenstveno o Hrvatskoj, ističe da se to nije dogodilo samo u Hrvatskoj nego i u ostalim postsocijalističkim zemljama Istočne Europe koje su imale drukčije načine izlaska iz dirigiranih i diktatorskih državnih uređenja. Vilović (2003: 692) smatra da medijska etika nije problem samo tranzicijskog novinarstva, već se i mnoge zemlje razvijene demokracije sučeljavaju s problemima neprimjerena informiranja javnosti. Stoga su, više nego ikada ranije, apeli za promicanjem etike u medijima sastavni dio svih zaključnih dokumenata novinarskih konferencija ili skupova novinskih izdavača.

Eventualne etičke dvojbe rješavaju se od slučaja do slučaja, piše Vilović (2003: 963), a na pitanje tko je odgovoran za neetične postupke ne daje egzaktan odgovor, već donosi više mogućnosti i pitanja: sami novinari, vlasnici medija koji određuju osnovne tonove izvještavanja, opća neosjetljivost na etiku, temeljno neznanje o potrebi etičnosti u novinarstvu ili nešto drugo. Sve su to pitanja koja uvijek iznova postavljamo kad se u praksi suočimo s neetičnošću u novinarstvu. Pažljivi medijski analitičari koje prate hrvatske novine od 
devedesetih godina prošloga stoljeća do danas reći će da su svi spomenuti elementi sadržani u izrazito lošoj slici etičnosti u novinama.

\subsubsection{Društvena i medijska stvarnost, odnos etike, vlasništva i profita}

Etika nije izvanzemaljska kategorija, ističe Thomas Bauer (2007: 64), nego bitno dobro komunikacije, jer svaka komunikacija sama od sebe postavlja pitanja o istini, istinitosti, koherentnosti, pouzdanosti i vjerodostojnosti, a etičke vrijednosti same od sebe također provociraju pitanje o njihovu komuniciranju (mir, sloboda, tolerancija, prihvatljivost, empatija, i tako dalje). Isti autor (Bauer, 2007: 66-67) piše da pitanje etike postaje odlučujuće pitanje, ne u obliku nekog filozofskog ili moralnog luksuza, ne kao ono koje se može postaviti poslije, nego kao pitanje koje se samo od sebe prvo postavlja. To podrazumijeva da je etika zapravo sama po sebi društvena veličina i da je samo društvo treba shvatiti kao etičku vrijednost, kao predodžbu koju treba zamišljati i za kojom treba težiti samo u interesu što je moguće boljeg stanja. A ako se društvo shvati kao veličina etike, to još više vrijedi za komunikaciju, kao uvjet njezine konstrukcije. Stoga je komunikacija u tom smislu istodobno i objekt i subjekt etike. Ona je također podjela društvenosti, gdje se upravo kroz tu podjelu (društvenu, kulturnu) utemeljuju veze.

Bauer (2007: 179) ističe da etika nije prvenstveno teret individualnog života, nego je kulturni horizont samoostvarenja društva, kroz koje pojedinac može spoznati moralni smisao svoje egzistencije. To vrijedi također i s obzirom na zahtjeve za kompetentnu medijsku uporabu: gdje se izgubio društveni smisao medijske uporabe, gdje po mogućnosti nije postao jasan ili gdje je bio izigran kroz zloupotrebu, tamo se zahtijevanje za moralnim korištenjem medija treba procijeniti kao svojevrstan pedagoški cinizam. Ako je čovjek društveno zainteresiran za etičku sposobnost primatelja, onda mora biti zainteresiran za društvenu relevantnost primateljeva položaja. Sve dok ekonomski uvjeti takav ekonomski program podjele društvenosti kroz medije otežavaju ili sprječavaju, ne treba se čuditi ekonomiziranom moralu primatelja, naglašava Bauer. Isti autor (Bauer, 2007: 180-181) kaže da su mediji etike, estetike i pragmatike društva, te da se u njima ogledaju horizonti vrijednosti, modeli smisla $i$ uzorci djelovanja društva.

Nikodem i Valković (2012: 812) pišu da građani ne doživljavaju da su mediji sugovornici konkretnog društva, odnosno ne osjećaju da su mediji tu upravo zbog njih. Mediji 
se u ovakvoj situaciji ne doživljavaju kao ogledalo društva, već se više ističe njihova moć stvaranja medijske slike ili čak medijske „stvarnosti“ koja nema poveznice s pravom stvarnošću.

Isti autori (Nikodem i Valković, 2012: 785) ističu da su pluralističke teorije polazile od hipoteze da su mediji „zrcalo društva“, zapravo da medijski sadržaji samo odražavaju društvo i time ne mogu imati veći utjecaj na društvene promjene i procese. S druge pak strane, marksističke teorije suprotstavile su se tom pogledu, naglašavajući i kritizirajući važnu ulogu medija u održavanju i razvoju nepovoljnih i nepravednih društvenih odnosa kapitalističkog sustava.

Valković (2006: 36-37) piše da je bitan preduvjet svake komunikacije vjerodostojnost, povjerenje koje mora odlikovati pošiljatelja (bilo osobu ili pak medij), odnosno izvor informacije. Naime, primatelj medijske poruke mora „vjerovati“ mediju. Zato je u današnjim sustavima zadaća stvaranja vjerodostojnosti jedan od velikih izazova za medije. Stoga mediji nastoje stvoriti sliku onoga kome se može vjerovati. Da bi to ostvarili, mediji ističu neke elemente i posežu za određenim djelovanjima, kao što su integritet i neovisnost. Razni utjecaji koji ugrožavaju neovisnost medija ne dolaze samo od strane politike ili ekonomske moći, već su danas snažni pritisci i od strane mnogih interesnih skupina.

Malović (2007: 13) ističe i da se teror tržišne uspješnosti pretvara u apsolutni kriterij kvalitete. Tako počinje vrzino kolo: što je publika manje obrazovana to su uspješniji primitivni medijski sadržaji. Što je manje intelektualaca, to je manje kvalitetnih medijskih sadržaja. Primitivni medijski sadržaji ne mogu popraviti slabu obrazovnu strukturu medijske publike. Što su primitivni sadržaji uspješniji, to je niža razina publike. Vrlo teško je prekinuti to vrzino kolo, pa sofisticirani sadržaji nemaju šansu proći, to jest nema šanse da se publici ponudi nešto kvalitetnije, jer „ona to ne želi““.

Kada razmišlja o vlasnicima medija, Malović (2007: 40) navodi da oni posve jasno pokazuju kakve novinare žele: mlade i nedovoljno obrazovane, jer imati takve ljude u redakciji znači imati podatnu glinu koja se mijesi prema zamislima medijskih mogula. Mladi i nedovoljno obrazovani novinari ne poznaju dovoljno novinarske standarde, ne znaju razlikovati što je etično, a što neetično (npr. povreda dostojanstva ili privatnosti pojedinca). Takvi se mogu posve lagano nagovoriti da nekoga „razapnu“, da objave bez razmišljanja tekst iz samo jednog izvora, da ne provjeravaju informacije, da se ne bune kada im urednik dopiše rečenicu, itd. 
No, nisu odgovorni samo vlasnici, pa Malović (2007: 48) ističe i novinarsku odgovornost: novinar nema neograničenu slobodu, već ima i odgovornost za objavljenu riječ. Odgovornost je bitna činjenica u shvaćanju novinarstva kao profesije. No, odgovornost se ne potiče sudskim presudama temeljenima na dvojbenim shvaćanjima slobode medija, već stvaranjem javne klime u kojoj nezavisni novinar odgovorno obavlja svoj posao, što je poprilično zahtjevno. Malović (2007: 86-87) ističe da bi uloga novinara trebala biti jasna, no često nažalost nije: „Ako ne izvještavaju u skladu sa standardima medijske etike, onda manipuliraju pa vjerojatno i lažu. Dakle, ako novinar napiše tekst u kojem iznosi činjenice temeljene na dva anonimna izvora, onda je to nepoštivanje temeljnih načela profesije i ne može se smatrati novinarskim uratkom. Ma što o tome mislili u redakciji i ma kako dobro poznavali svoje anonimne izvore, dok su anonimni, nisu izvori. Oni samo mogu poslužiti novinaru da nešto sazna, ali da to potvrdi iz vjerodostojna dva, nezavisna izvora.“ Međutim, Malović (2007: 88) navodi da rezultati istraživanja pokazuju kako se i u nas, ali i u svijetu, većina informacija priprema u uredima odnosa s javnošću, čak više od 60 posto. To znači da do konzumenata masovnih medija uglavnom dolaze informacije iz jednog izvora, s namjerom da promoviraju djelatnost te organizacije, što zasigurno nije objektivno. Time se stvara sasvim drukčija slika svijeta, koja je daleko od onoga što javnost želi.

Nakon što je etiku definirao kao sustavno traženje izbora što je dobro ili loše u ljudskom ponašanju - što je ispravno, a što pogrešno - Conrad Fink (1995: 1) primjećuje da nije uvijek jednostavno pronaći način kako etiku primijeniti na medije, te analizirati kako oni djeluju i kako bi trebali djelovati. Promatrajući to s praktične strane, primjećuje da novinari suočeni s mnogim preprekama često pristupaju moralnom rasuđivanju i etičkim problemima tako da ih ne rješavaju sustavno, već to čine bez strukturirane okosnice, te odlučuju brzo, gotovo instinktivno, temeljeći odluke na neutemeljenim vlastitim stavovima koji proizlaze, vjerojatno, iz vjerskog odgoja ili iz utjecaja kolega, obitelji i prijatelja. Fink to uspoređuje s odlaskom na daleki put na nepoznatom teritoriju bez karte, riskirajući gubitak vremena zbog besciljnog lutanja sporednim cestama i nedolazak na svoje odredište.

Fink navodi i neke specifično novinarske vrednote: sloboda, objektivnost, društvena odgovornost, pravo ljudi da znaju, služenje javnosti, nadgledanje moćnika, objektivnost i poštenje, suosjećajnost (paziti da se ne povrijedi one o kojima se piše), neovisnost, hrabrost i preispitivanje lojalnosti (Fink, 1995: 14-19). 
Novinari su u svom odlučivanju često ograničeni nekim preprekama: strahom (npr. od gubitka posla), željom za nagradom (napredovanjem ili povećanjem plaće), instinktom zajedništva (tendencija da se bez razmišljanja slijedi vodstvo drugih novinara), pravilima zaposlenika i marketinškim konceptom, koji potiču neke novinare da vrednuju vijesti ne po njihovoj unutarnjoj važnosti nego radije po onome što bi publika mogla željeti (Fink, 1995: 27).

Govoreći o objektivnosti Fink (1995: 32), kao i mnogi drugi autori, naglašava da je istinsku objektivnost nemoguće postići, budući je svaki pojedinac prožet i oslonjen na svoju kulturnu pozadinu i iskustva koja nužno utječu na to kako kao novinar vidi stvari i događaje.

Fink smatra da svaki ambiciozan novinar mora stvoriti osobni etički sustav kao dio svog davanja poštenog i uravnoteženog izvještavanja o događajima čitateljima i gledateljima, te navodi i temeljna pravila za to. Prvo što ističe je da iako je objektivnost nemoguće postići, ipak kod novinara mora biti vidljiva težnja da bude što objektivniji u odlučivanju koje vijesti će pratiti, kao i pri izboru izvora, obrađivanju činjenica, pisanju i „tajmingu“ objavljivanja ili istraživanja priča. Drugo je da sukob interesa, stvaran ili ga takvim percipira publika, može uništiti odnos povjerenja koji svaki novinar mora uspostaviti s čitateljima i gledateljima. Stoga je potrebno izbjegavati svako izvanjsko uplitanje, kao i politiku, koji mogu kompromitirati neovisnost novinara, kao i neetična osobna ulaganja i darove koji bi mogli utjecati na prosuđivanje samog novinara. Treća je potreba uravnoteženosti između prava pojedinca na privatnost i javnog prava ljudi da znaju o stvarima važnim za javni interes. Nije teško procijeniti kad je riječ o javnim dužnosnicima, onima koji traže svjetla pozornice, jer većina njihovog života i treba biti javna, no mnogo je kompliciranije i teže kad je riječ o osobama koje nisu javne osobe. Četvrta je potreba da se dobar ukus i mjera unesu u vrijednosne prosudbe u vijestima koje uključuju npr. vulgarnost i razvratnost, tugu, seksualne zločine i druge zločine ili samoubojstva koji mogu izazvati oponašanje to jest imitiranje (Fink, 1995: 55-56).

Profesionalnost i etičnost idu ruku pod ruku, jer kako piše Fink (1995: 87), biti netočan izvjestitelj znači također biti i neetičan izvjestitelj. Nadalje, novinar se mora nositi jednako pažljivo s malim detaljima priče, kao i s velikima, i ne smatrati se idealnim nego prepoznavati svoje vlastite slabosti - npr. nedostatak pozadinskih informacija o vijesti i ispraviti ih. Potrebno je i razviti zdrav skepticizam dok se istražuju činjenice, a potrebno je i držati se dalje od izvora koji pokušavaju podastrijeti dezinformacije. Također, etika poštenog 
pisanja zahtjeva da se u vijest uključe sve relevantne činjenice i da se vlastito mišljenje u novinarskom prilogu ne navodi. Nadalje ističe i da je važno pošteno izabrati citate, jer se vijest može posve iskriviti ako se izaberu citati koji ne odgovaraju govornikovoj namjeri.

Izvori vijesti su izrazito važni i kompleksi, te u etičkom promišljanju raste zanimanje za odnos novinar - izvor. Važno je razumjeti motiv izvora i kao novinar se pitati zašto daje informacije. Neki to čine da bi zadovoljili vlastite interese, drugi da bi uništili neprijatelja. Da bi novinar bio pošten prema svojim čitateljima, mora otkriti izvor kad god je to moguće. Ako nije moguće navesti izvor, treba opisati njegovu mjerodavnost koliko god je moguće više, tako da čitatelji ili gledatelji mogu odlučiti o pouzdanosti ili pak nepouzdanosti informacije.

O etici tajnog izvještavanja se žestoko raspravlja. Čitatelji, gledatelji i urednici vole rezultate istraživačkog novinarstva, ali ne odobravaju tehnike kao što su tajno snimanje slike ili zvuka. Urednici također ne vole novinarsko skrivanje identiteta izvjestitelja ili pojavljivanje pod lažnim identitetom (Fink 1995: 87-88).

Vlasništvo medija je jedno od važnih otvorenih pitanja i tema medijske etike. Kao što ističe Ante Gavranović (2006: 156-157) upravo nejasnoće oko vlasničkih odnosa postaju kočnice u razvoju, dovodeći do etički prijepornih okolnosti. Mnogi su mediji privatizirani u nepovoljnim uvjetima, a njihovi vlasnici su zaštitili svoja ulaganja i izvlače profit, pa su zbog toga u prvi plan došli komercijalizacija i senzacionalizam, na koje upozorava i Bertrand. U takvim se okolnostima onda razvija i nešto sasvim očekivano: najprije gubitak svih kriterija, a potom zabrinjavajući pad kvalitete medija. Sve navedeno dalo bi se svesti pod sljedeće: isprazna ekskluzivnost i senzacija po svaku cijenu umjesto pune i objektivne informacije. Dobili smo, zapravo, medijsku pozornicu na kojoj su odgovornost i etičnost izgubili svoje temeljno značenje: caruju prenositelji skandala i poznavatelji podzemlja, a sve je manje istinskog novinarstva. Potrebno je potražiti izlaze iz tog stanja, a jedini istinski izlaz je u vraćanju profesionalizma i profesionalne etike, u jasnom profiliranju medija, u vraćanju odgovornosti za manipuliranje medijskim sadržajima. Mediji bi, prema Gavranoviću, po svojoj misiji u društvu, morali ustrajno i hrabro promovirati osnovne vrijednosti društva koje želimo izgraditi.

Gavranović (2009: 23) smatra da je upitno u kojoj su mjeri u medijima prisutni čvrsto ukorijenjeni termini kao istinitost, pridržavanje činjenica i javna relevantnost informacije i što oni predstavljaju u realnosti suvremene medijske scene. Važnost pridržavanja standarda ne proizlazi samo iz posebnog poziva i uloge novinarstva u demokratskom društvu, već standardi 
postaju važan dio sustava ponude $\mathrm{u}$ demokraciji, jer njihova primjena osigurava slobodu mišljenja i govora. Time se pojačava njihova društvena odgovornost. No, jasno je da paralelno s tim utjecajem raste i odgovornost novinara i etička dimenzija medija. Tek nam predstoji ozbiljna analiza ukupnoga stanja, uključujući i stvarne vlasničke odnose u svim medijima, a ne samo u tiskanim. No, najviše se moramo pozabaviti gospodarskim okvirima u kojima djeluju mediji, vezano uz pooštrenu konkurenciju, napose na području elektroničkih medija. Sva pitanja iz domene vlasničkih odnosa na dnevnom su redu i drugih zemalja i njihovih izdavača. Još uvijek su otvorena pitanja autorskih prava, elektroničkog poslovanja, medijske koncentracije, politike konkurencije, poslovnih komunikacija, konvergencije, pitanja zaštite okoliša, poreza na dodanu vrijednost i druga.

Temom odnosa profita i dobiti bavio se i Bauer (1997: 33) koji kaže da su naklada i profit često suprotni kakvoći medijskog njihova sadržaja. Popularni medijski proizvod, proizveden na najjeftiniji način, u pogledu brojnosti čitateljstva i gledateljstva vrlo lako za sobom ostavlja kvalitetne medije. Isti autor kao primjer navodi kraj odličnog časopisa „Die Gegenwart“ (Sadašnjost) koji je u pogledu kakvoće bio na samom vrhu piramide časopisa, ali se brojem pretplatnika nalazio tako nisko da mu izdavač u konačnici nije htio odobriti novčana sredstva, jer jednostavno nije bio isplativ. No, ne trebaju nam samo Bauer i primjeri iz Njemačke, već se dovoljno prisjetiti prestanka izlaska ozbiljnog analitičkog tiskanog dnevnika „Vjesnika“ u Hrvatskoj, koji je (ako izuzmemo ovisnost o vlasniku, a vlasnik je bila država) pretendirao biti ozbiljan dnevni list, te je u značajnijem dijelu u tome i uspijevao, ali kod publike nije bio dovoljno „popularan“, te je zakonom tržišta došlo do njegovog gašenja.

Bauer (1997: 75) naglašava i prenosi i tvrdnje da danas sloboda tiska zapravo postaje sloboda onih stotinu ili više bogataša koji upravljaju medijima. Iako i sam Bauer naglašava da je to pomalo „agresivna“ izjava, nije moguće posve ju odbaciti, već je dapače na temelju opservacije stanja u suvremenim medijima nemoguće negirati točnost navedene tvrdnje, dakako ako ju se uzme s rezervom i u kontekstu prihvaćanja činjenice da je vlasništvo medija u rukama manjeg broja ljudi, nego što bi se to na prvi pogled reklo ili zaključilo.

Većina medija u Hrvatskoj djeluje po istom obrascu kao i globalni svjetski mediji, kažu Miliša, Tolić, Vertovšek (2009: 16), a to znači da su im tržište, prihod, čitanost, gledanost i slušanost glavni kriteriji ne zato da bi dokazali kvalitetu, već da bi time opravdali prodaju oglasnog prostora. Zapravo oglašivači dirigiraju medijima. Također, u velikom broju 
slučajeva „teror tržišne uspješnosti pretvara se u apsolutni kriterij kvalitete“ (Malović, 2007: 13, prema Miliša, Tolić i Vertovšek, 2009: 16).

Miliša, Tolić i Vertovšek, (2009: 58) primjećuju da u „ralje“ i zamke upadaju i odrasli iskusniji čitatelji, pa je pitanje što onda očekivati od mladih koji kroz medije vide uzdizanje nečije karijere, jer će misliti da je taj i takav pjevač ili književnica zaista nešto posebno kad o njemu „pišu i govore svi“? I zaista se zaprepaste kada doznaju da sva ta potpora zapravo dolazi iz istog medijskog stožera (jer prije nisu upoznati s vlasničkom strukturom medija).

Kunczik i Zipfel (2006: 96) podsjećaju da su ekonomski čimbenici važan aspekt ovisnosti odnosno neovisnosti novinara, te donose citat Paula Sethea, njemačkog novinara i suizdavača novina Frankfurter Allgemeine Zeitung koji je u jednom je pismu čitateljima napisao: „Budući da proizvodnja novina i časopisa zahtjeva sve veći kapital, sve više se smanjuje krug osoba koje mogu izdavati novine. (...) Sloboda tiska sloboda je za dvije stotine bogatih ljudi da šire svoje nazore. Uvijek ćete naći novinare tih nazora (...) Ali, tko drukčije misli, zar i on nema pravo izraziti svoje mišljenje? Ustav mu daje to pravo, a ekonomska ga zbilja uništava. Slobodan je tko je bogat (...). A budući da novinari nisu bogati, nisu ni slobodni“' (Kunczik, Zipfel, 2006: 96).

\subsubsection{Medijska etika i kriza vrednota u medijima}

Poznati komunikolog i teolog Mataušić (2002: 361-362), piše o krizi vrednota u medijima, te navodi da uz već poznate i uobičajene oblike povrede ljudskog dostojanstva u medijima (npr. pretjerano prikazivanja nasilja, pornografija, itd) dolazi i to da se danas $u$ hrvatskim medijima može optužiti bilo koga za bilo što, a da mu ne treba dokazivati krivnju. Također, uhodala se praksa bezobzirnoga „kopanja“ po privatnom životu pojedinaca, te se redovito uništava dobar glas, često zdravlje, a ponekad i egzistencija pogođenih. To je utoliko problematičnije što su najvažniji mediji još uvijek pod kontrolom političara, a svaki od centara političke moći u Hrvatskoj želi imati svoje medije. I dok se u Hrvatskoj još nisu dovoljno razvili mehanizmi novinarskog otpora utjecaju političara na medije, već se učvršćuje nova ovisnost o ekonomskoj sferi, zahvaljujući komercijalizaciji medija. To su uzroci i daljnjih zastranjena, pa se u hrvatskim medijima (a nije bolje stanje ni drugdje) ne poštuju neke od temeljnih vrednota medijske etike, na prvom mjestu istinitost i provjerenost onoga što se objavljuje. Također, javlja se koncentracija medija u rukama sve manje skupine vlasnika. 
Činjenica da mediji zahvaljujući slobodi i moći lakše ukazuju na neke zloporabe i nepravilnosti u javnom djelovanju nije dovoljno opravdanje za negativnosti. Isto tako, to što veći dio novinara svoj posao radi dobro, a većina medijskih sadržaja je prihvatljiva, ne može biti razlogom da se ne ukaže na nepoštivanje novinarskog zvanja i medijske etike u drugim slučajevima. Za popravak stanja potrebno je mnogo toga, počevši od potrebe raščišćavanja vlasničkih odnosa u medijima, definiranja stručnih kriterija za novinare, boljeg istraživanja stanja u medijima, cjelokupnog razvoja civilnoga društva s većim utjecajem građana na medije, te razvoj sudstva.

Mataušić (2002: 364) nadalje primjećuje da su političari uvijek težili za utjecajem u medijima, no u zemljama s dugotrajnijom demokratskom tradicijom stvorili su se oblici otpora novinara u javnim medijima, dok se u Hrvatskoj novinari često prilagođavaju novim nositeljima vlasti. No, ipak se polako učvršćuju i oblici otpora i kritički stavovi. I tu se može postaviti pitanje koliko novinar koji kritizira aktualnu vlast ovisi o nekim drugim centrima moći, što također nije zanemarivo.

Mediji su kod nas trenutačno u položaju „ničim ograničene moći“, zaključuje ipak Mataušić (2002: 364-365). To ide dotle da je lakše izboriti pravdu protiv policije ili vojske, nego protiv medija. Mataušić ističe i da je najveći dio medija danas roba na tržištu. Oni prodaju svoj proizvod, dakle tiskovinu ili program, a prodaju i svoju publiku onima koji se preko njih reklamiraju. Kod tiskanih i kod javnih medija to je kombinirano, a komercijalni elektronički mediji prodaju isključivo publiku svojim komitentima (Mataušić, 2002: 366). K tome, dodaje Mataušić (2002: 366), obično se naglašava potreba neovisnosti medija od političke sfere, a preko ovisnosti o ekonomiji olako se prelazi, dok i ona nije ništa manje problematična.

Govoreći o krizi vrednota, Mataušić (2002: 367) je svojedobno upozorio i da je jedan od razloga krize svakako to što polovica hrvatskih novinara nema fakultetsku naobrazbu. Tu je onda i nerazvijenost područja odnosa s javnošću naših ključnih državnih institucija, jer su rijetke one kod kojih se može dobiti informacija kad ju novinar treba. Novinara koji traži informacije često se doživljava kao neprijatelja, te će trebati još mnogo vremena dok osobe zadužene za odnose $\mathrm{s}$ javnošću ne nauče djelovati prije novinarskog istraživanja, dajući informacije koje su u interesu vlasnika organizacije, poduzeća ili institucije. Tu još ima mnogo toga naučiti i Crkva. 
Michael Kunczik i Astrid Zipfel (2006: 84) također govore o krizi vrednota, te polaze od toga da predodžba o novinaru kao neutralnom prenositelju informacija pretpostavlja da postoje neutralne informacije odnosno vijesti. Novinar se smatra nestranačkim i distanciranim instrumentom transmisije. Kritičari takvom poimanju novinarstva prigovaraju da neupitno prihvaća postojeći poredak i tako izbjegava preuzimanje političke odgovornosti. Umjesto da postavljaju kritička pitanja o društvenoj stvarnosti novinari služe etabliranim interesima kao glasnogovornici i zapravo su navodno „objektivni“ dvorski izvjestitelji. Toj kritici se može zamjeriti previd da i takvo „obavijesno novinarstvo“ ima važne zadaće u demokraciji, jer bez neutralnih obavijesti o odlukama koje donose izvršna, zakonodavna i sudska vlast, ne može uslijediti demokratsko formiranje volje, upozoravaju navedeni autori.

Kunczik i Zipfel (2006: 85) primjećuju da koncepciju angažiranog novinarstva u posljednje vrijeme u SAD-u nastavlja novinarstvo usmjereno prema građanima - „civil journalism“ i „public journalism“ ili „,community journalism“. Prema toj ideji o ulozi novinarstva, tradicionalni kriteriji izbora vijesti i izvješćivanja kao i ideal objektivne distance prema predmetu, trebaju se nadomjestiti radom koji bi bio koncentriran na potrebe i probleme građana i poticao stanovništvo na aktivno sudjelovanje u javnom životu. Prema takvoj koncepciji, novinari ne bi trebali samo otkrivati i dugoročno intenzivno izvještavati o problemima (prije svega problemu svakodnevice na terenu) nego bi trebali i sami raditi na njihovu rješavanju.

Govoreći o medijskoj etici, Kunczik i Zipfel (2006: 104) ističu da u novinarstvu etika znači pitanje o novinarski ispravnom i dobrom, a pri tome su ključne funkcije koje se unutar nekog društva pripisuju masovnim medijima. Npr. u demokraciji novinarstvo ima javnu zadaću, te treba pribaviti i širiti informacije o stvarima od javnog interesa, o tome zauzeti stav i kritizirati kako bi se utjecalo na proces formiranja mišljenja. Novinari u demokraciji u pravilu podliježu relativno malim pravnim ograničenjima koja su samo osnovni okvir za njihovo djelovanje. U praksi je stoga potrebno koristiti okvir samoograničavanjem koje se pojavljuje u obliku izuzetno važne novinarske profesionalne etike koja je neophodna. Prema mišljenju Ulricha Saxera, kojega navode spomenuti autori, autonomija koju mediji imaju u demokraciji jamči se u očekivanju određenih usluga novinarstva, poput izvještavanja o aktualnom, obrazovnih priloga, dakako uz odricanje zloupotreba.

Kako navode Kunczik i Zipfel (2006: 105) područje istraživanja o etici i masovnim medijima je još uvijek loše strukturirano. Isti autori pišu da je prijedlog sistematizacije 
područja medijske etike izradio Wilke, koji u znanstvenom razmatranju tog područja razlikuje tri razine: 1. teoretsku razinu, na kojoj se radi o strukturalnim, pravno-političkim i ekonomskim uvjetima etičkog djelovanja, te o primjeni koncepcija; 2. empirijsku razinu na kojoj se istražuje činjenično etičko ponašanje novinara i 3. pragmatičnu razinu, koja se bavi posredovanjem etičkih normi $\mathrm{u}$ obrazovanju i njihovoj primjeni $\mathrm{u}$ sklopu novinarskog „zanata“. Kunczik i Zipfel (2006:108) govore da se rasprava o etici u zemljama trećeg svijeta u praksi vodi ad absurdum. Većina novinara iz trećeg svijeta, a isto vrijedi i u mnogim državama nekadašnjeg istočnog bloka, toliko su potplaćeni da ne mogu djelovati kao neovisna društvena snaga koja kontrolira politiku. Upravo loša financijska situacija potiče „envelopment journalism“ („,novinarstvo kuverte“), tj. novinari uzimaju novac kako bi preživjeli. Kako je pokazalo istraživanje provedeno u odabranim zemljama nekadašnjeg istočnog bloka, u Bugarskoj se npr. događalo da novinari ucjenjuju poduzeća ili privatne osobe prijeteći da će o njima negativno pisati.

Kunczik i Zipfel (2006: 122) pišu da u svom poslu novinar stalno mora odmjeravati između više faktora: kriterija važnosti nekog događaja, pretpostavljenog interesa recipijenata te mogućih pozitivnih i negativnih posljedica objavljivanja odnosno neobjavljivanja informacija. Pri tome je novinar suočen i s ozbiljnom poteškoćom koja se krije u činjenici da odluka i za i protiv objavljivanja može imati neželjene posljedice. Osim toga masovna komunikacija, kako ističe Arnold Gehlen (1959, 56, prema Kunczik i Zipfel, 2006: 122) zahtjeva „tele-etiku“ jer, za razliku od personalne komunikacije, u njoj se posljedice djelovanja najčešće ne mogu izravno promatrati.

Valentin Pozaić (1992: 564) piše da je neosporno da mnogi djelatnici imaju svoj osobni visoki etos i trude se raditi u skladu s njim, te znaju da u središtu njihove profesije stoji čovjek, kao i da su pozvani na poštivanje ljudskog dostojanstva i ljudskih prava na svim razinama. Istovremeno, ističe i drugu stranu, tj. da nažalost ima i onih koji u toj struci ne žele govoriti ni slušati o zahtjevima profesionalne etike.

Tako Pozaić (1992: 557) kaže da budući da je TV-program ljudsko djelo jasno je da je potrebno birati, te da postoje neke granice onoga što je dobro a što je loše, što se isplati a što se ne isplati gledati i slušati. Isti autor (Pozaić, 1992: 558), nastavljajući govoriti o televiziji, a što se opet može primijeniti i na ostale medije, ističe da je područje moralnoga-nemoralnoga na televiziji široko kao što je širok televizijski program, odnosno kao što je široko područje ljudske djelatnosti koja dolazi na ekran. Tako bismo mogli govoriti o pitanju objektivnosti u 
izvješćivanju, o odgovornosti za neprovjerene senzacionalističke i negativističke vijesti, o moralnosti određenih programa koji predstavljaju lagodan, površan stil života, bez napora i odgovornosti; prikazivanje kao normalnog standarda i stila života do kojega, posebno mladi čovjek, ne može stići ni lako, ni brzo, ni poštenim putem; buđenje novih želja i stvaranje umjetnih potreba u duhu potrošačkog mentaliteta i uživalačkog nazora na svijet.

Istodobno Pozaić (1992: 567) ističe pozitivna svojstva medija: „Sredstva društvenog priopćivanja, napose TV, izvanredna su blagodat, na dvije razine. Na osobnoj razini ona omogućuju slobodu izražavanja osjećaja, misli i spoznaja, daju priliku za cjelovito potvrđivanje osobne vrijednosti i dostojanstva pojedinca. Na društvenoj razini ta sredstva promiču zajedništvo i napredak među ljudima pojedincima i narodima: pospješuju međusobno razumijevanje, slogu, dobrohotnost, dobrotvornost - solidarnost. Na toj razini ta sredstva pospješuju međusobno darivanje u pravednosti i ljubavi, a čiji je plod mir. Sažeto rečeno, sredstva društvenog priopćivanja u prvom redu promiču ljudsko dostojanstvo, istinu i opći napredak pojedinca i zajednice, kada se rabe u pozitivnom smislu.“ Ipak, isti autor na istom mjestu ne isključuje negativna svojstva kad zaključuje: „No, postoji i negativna mogućnost služenja tim sredstvima.“

Ipak, govoreći i o tim negativnim svojstvima, navodi važnost pozitivnog pristupa, tj. da umjesto borbe i prigovora treba stvarati takva djela koja će biti umjetnički vrijedna i prihvatljiva za sredstva društvenog priopćivanja, a etički-moralno u skladu s dostojanstvom ljudske osobe (Pozaić, 1992: 568).

\subsubsection{Sloboda izražavanja i temelji novinarskog djelovanja}

Marko Sapunar (2002: 123), govoreći o slobodi izražavanja, ističe da je ona proizašla iz osnovnih sloboda, te predstavlja temeljnu civilizacijsku tekovinu i neupitnu vrijednost. Suvremena društva svojim ustavima i zakonima izrijekom štite slobodu izražavanja kao temeljno ljudsko i građansko pravo. Demokracija kao oblik vladavine i sustav samoregulacije moderne političke zajednice, nezamisliva je bez aktivnog i informiranog građanina kao svoje pretpostavke. Otuda je logično da se takvom građaninu u demokratskoj političkoj zajednici, koja takvom hoće i ostati, mora zajamčiti ne samo pravo na oblikovanje i javno izražavanje mišljenja, nego i pravo da bude informiran, to jest da prima raznovrsne informacije, ideje i mišljenja drugih. 
Kao što podsjeća Sapunar (2002: 130), Opća deklaracija Ujedinjenih naroda o pravima čovjeka predstavlja prvi međunarodno-pravni instrument koji definira slobodu izražavanja. To je izraženo u 19. članku deklaracije koji kaže: „Svatko ima pravo na slobodu mišljenja i izražavanja; ovo pravo uključuje zadržavanje mišljenja bez uznemiravanja, kao i pravo traženja, primanja i širenja informacija i ideja, bilo kojim sredstvima i bez obzira na granice“.

Sapunar (2004: 324-325) navodi sedam dvojbenih odnosno problemskih etičkih okolnosti koje svakodnevno mora rješavati svaki novinar:

1. plagijat

2. podmićivanje

3. sukob interesa

4. prikrivanje informacija

5. prijevara

6. napad na privatnost $\mathrm{i}$

7. pretjerana angažiranost

Plagijat je s pravom na prvom mjestu tog popisa, ističe Sapunar (2004: 324), jer se on još u starom vijeku smatrao nečim najnedostojnijim ne samo novinara već i svakog čovjeka koji piše, jer je zapravo riječ o krađi. U staroj Kini se plagijat kažnjavao teškim kaznama (u „blažim“ slučajevima „samo“ odsijecanjem ruke, a u težim glave). Stari Rimljani su također osuđivali plagijat kao veliki grijeh.

Isti autor (Sapunar, 2004: 324) napominje da je sukob interesa veoma čest problem s kojim se susreće novinar, a kao primjer navodi novinarovu naklonjenost nekoj političkoj opciji ili stranci: kada prikupljeni materijal nalaže da se kritički govori o „njegovoj“ stranci, novinar kao njezin zagovornik može tu vijest ne objaviti ili iskriviti, jer mu je interes stranke jači od objektivnog izvještavanja. Etika ovdje lako rješava ovu dvojbu, ali je ona u životu teže ostvariva, pa je dobro istaknuti samo najteži slučaj ove dvojbe. Naime, novinar nikada ne smije lagati ni tajiti vijest ako ga neki njegov drugi interes nuka da to učini. Koliko će on tu vijest uljepšati ili preinačiti, to je nažalost nemoguće normirati, ali to ne znači da se smije odustati od zahtjeva za poštenim novinarstvom. 
Za prijevaru Sapunar (2004: 324) navodi da je izravno kažnjivo djelo, koje je i zakonski sankcionirano, pa valja kazati da to nijedan novinar u svojoj profesiji ne smije činiti. Neki novinari u želji da budu zanimljivi izmišljaju i sadržaj i podatke. No to je prevara, pa makar imala i neko opravdanje, ako u kontekstu prevare uopće možemo govoriti o opravdanju. Što se doista nije dogodilo i za što nema dokaza, o tome ne treba ni pisati, jasno je pravilo. Također, Sapunar (2004: 325) ističe da su napad i agresija na privatnost čovjeka također nedopustivi, jer gotovo svi zakoni o javnom informiranju zato štite osobni život čovjeka.

Sapunar donosi i upute za etično djelovanje u medijima:

1. „Na etiketiranje i uvrede ne odgovaraj po načelu 'zub za zub', već kulturno i argumentirano; to nije nimalo slabiji odgovor od odgovora punih žestoke retorike.

2. Kad uvidiš da neko stajalište nije više moguće braniti, odreci ga se; napusti ga elegantno i dok je vrijeme, jer ga kasnije nećeš moći obraniti i pokazat ćeš svoje neznanje, što je mnogo teže nego kad na vrijeme prestaneš braniti loše teze.

3. Obrana laži i neistina uvijek zahtijevaju još više laži, sve dok svakome ne postane jasno da si proziran lažljivac, zato nikad ne brani laži i neistine.

4. Priznaj zabludu u javnoj komunikaciji; to je mnogo bolje nego zablude pošto-poto braniti nedopustivim sredstvima, jer te to nužno vodi u kompromitaciju.

5. Ne polazi u javnom komuniciranju od pretpostavke da moraš imati pravo; nauči slušati i argumente drugih i priznaj i njima pravo kad je to očito i dokazano.

6. Priznaj istinu, objektivnost i stvaralačka dostignuća i svom najvećem neprijatelju, jer je istinski cilj javne komunikacije stalno otkrivanje novih istina.

7. Na uskogrudnost odgovaraj širinom sve dok vidiš da sugovornik na to pozitivno reagira, a ako ni tada nije sklon istinoljublju, onda je najbolje prekinuti dijalog, jer se tvrdoglavce ne može uvjeriti ni najjačim argumentima. Ako ih i drugi izoliraju, štetne posljedice će imati samo oni.

8. Na pakost i manipulacije odgovaraj javno, dosljedno i argumentirano.

9. Budi uvijek spreman da je čovjek ograničen i podložan svojim strastima, a posebno zavisti, zlobi, ali isto tako znaj da postoje i ljudske veličine.“ (Sapunar, 2004: 325) 
Kako podsjećaju Malović, Ricchiardi i Vilović (2007: 37-38), sloboda medija izuzetno je važna za ostvarivanje etičkih načela. Ona je preduvjet bez kojeg se medijska etika teško može ostvariti, tj. zapravo se i ne može ostvariti. Novinar se i u uvjetima pune slobode medija susreće s velikim i nerješivim etičkim dvojbama, te ona nije jamstvo ostvarenja medijske etike, ali preduvjet svakako jest. Mediji koji ne žive slobodno ne mogu ni razviti etička načela profesije. Čim je novinaru sloboda izražavanja sputana i čim mora više paziti hoće li zadovoljiti specifične interese vlasnika, a ne opće, profesionalne kriterije, stradava i etika. Ističu i da u utrci s vremenom stradavaju kriteriji: nema više vremena za provjeru informacija. Prevladava logika: „Objavi, pa provjeri!““.

Govoreći o novinarskoj slobodi Čupić (2010: 14) ističe da su sloboda izražavanja i sloboda kritike preduvjeti za ostale novinarske profesionalne standarde. Kaže da sloboda izražavanja proizlazi iz jednog od osnovnih prava - prava na slobodu, a bez slobode nema ni slobodnih pojedinaca ni slobodnog društva. Iz tog osnovnog prava proistječu i druga posebna prava na slobodu kao što su sloboda duha i sloboda komuniciranja s drugim. Prema toj podjeli, u okvirima slobode duha su sloboda misli i savjesti te sloboda izražavanja, odnosno sloboda mišljenja i sloboda izražavanja mišljenja i ideja - sloboda informiranja. Sloboda izražavanja je ljudsko pravo koje je istovremeno i građansko i političko. Sloboda izražavanja omogućuje pojedincu, u ovom slučaju profesionalcu (novinaru), pravo da ga nitko ne može, tj. barem ne bi smio, spriječiti da se slobodno izražava.

Isti autor moralnost ističe kao važan element integriteta, $\mathrm{tj}$. piše da integritet iziskuje intelektualnu sposobnost, visoku stručnost i moralnu kulturu (Čupić, 2010: 17). Samo sposobni i stručni, uz moralno djelovanje i ponašanje, mogu steći integritet u novinarskoj profesiji. Kad je u pitanju treći element integriteta - moralna kultura - treba imati u vidu da ona presudno djeluje na ukupan profesionalni identitet. Čupić ističe i savjest, tj. navodi da je stručnjak bez savjesti zapravo velika opasnost za poziv i profesiju. Naglašava i da je za moralnu kulturu (najbitniji element integriteta) potrebno razlikovati dobro od zla, postupati prema tom razlikovanju čak i po cijenu osobne štete, stalno i otvoreno o tome govoriti i pisati i spremno preuzimati odgovornost za svoja djela i ponašanje (Čupić, 2010: 18). Ujedno, poput Malovića i drugih autora, ističe da je poštenje (objektivnost) svojstvo čestitosti koje se pokazuje otvorenošću i ispravnim ponašanjem u odnosu prema drugima i prema javnosti (Čupić, 2010: 21). Poštenje u novinarstvu pretpostavlja objektivnost i posebno isključuje osobnu pristranost. Poštenje u obavljanju novinske profesije podrazumijeva također 
neizostavljanje činjenica, cjelovit pristup obradi događaja, primjerenost (relevantnost), odnosno isticanje važnih u odnosu na nevažne činjenice a ne obrnuto, iskrenost prema javnosti (nikakvo zavođenje ili manipulacija) i jasnoću umjesto fraziranja. Također, poštenje novinara isključuje bilo kakvu osobnu korist ili privilegiju, posebno materijalnu. Poštenim odnosom novinara umiruju se svi koji pokušavaju raznim sponzorstvima, poklonima, putovanjima, čašćenjima izvući osobnu i posebnu korist u javnosti. Posebno sklizak teren je suradnja sa sponzorima, jer je ona izrazito opasna po profesionalne standarde, a posebno dakako za područje medijske etike.

Ističe da nepristranost ne znači da novinari nemaju uvjerenja, sklonosti i vlastita shvaćanja. Nepristrani novinari događaje ne prikazuju već se drže činjenica i istina, oslobođeni svojih subjektivnosti (Čupić, 2010: 21).

Čupić (2010: 25) ističe i da bez učenja, prihvaćanja i življenja profesionalnih standarda zapravo nema valjanog novinara ni novinarstva. Profesija se podržava i održava usvajanjem standarda i sviješću o značenju i bitnosti standarda. To je ono što se naziva dostojanstvom poziva, ali i života onoga tko se opredijelio za novinarsku profesiju.

Kao što naglašava Čupić (2010: 35) temelji moralnih djelovanja i ponašanja osobe grade se u obitelji. U obitelji dijete stječe svijest o osjećaju razlikovanja dobra i zla. To se usađuje kod djeteta uputama i disciplinom, ali i djetetovom percepcijom roditeljskog ponašanja.

Isti autor (Čupić, 2010: 37) naglašava da je moralno informiranje i sazrijevanje novinara ne samo dug, nego i uvijek nezavršen proces. Moralno ponašanje zahtijeva stalno samopotvrđivanje ali i potvrđivanje sredine $\mathrm{u}$ kojoj se prakticira. Da bi dobar novinar obavljao svoj posao on uvijek treba voditi računa o dvije moći koje se nadopunjuju: moći znanja i moći savjesti. Novinar uvijek mora imati na umu da nema te naredbe, zapovijedi ili prijetnje koja može dovesti u pitanje savjest i osobnu odluku. U ljudskoj duši savjest uvijek svijetli, ponekad kao iskra, a ponekad kao plamen, kao neko vječno svjetlo. Gdje savjesti nema, nema ni svjetlosti, nema ni osobnosti. Savjest je sveti zakon u pojedincu. Čovjek koji posjeduje moć znanja, ali ne i moć savjesti, stručnjak je bez savjesti. Njegovo djelovanje na javnoj sceni je pogubnije od zločina i od glupaka, jer on može učiniti zlo na stručan i inteligentan način. Takvo zlo u profesiji je organizirano zlo čije su posljedice nemjerljive. Zbog toga je bitno da novinari imaju na umu da nikada ne odvajaju ove dvije moći s kojima bi trebali raspolagati. 
Zvonko Letica (2003: 40) se pita što je zapravo sloboda medija, te daje i odgovor, naglašavajući da nema kratka i jednostavna odgovora: odgovor od samo nekoliko riječi bio bi nepotpun i prema tome pogrešan. Bez obzira na naše želje, oni koji prate i proučavaju poštivanje medijskih sloboda smiruju nestrpljive tvrdeći da napori u njihovu pravcu ne vode pobjedi preko noći. Samo godine, pa i deseci godina borbe i hrabrosti bezbrojnih pojedinca vode rezultatima. Bez obzira kako glasio odgovor na spomenuto pitanje, Letica smatra da otvoreno, građansko društvo ne može postojati bez slobodnih medija.

Isti autor (Letica, 2003: 40) podsjeća da Međunarodna federacija novinara (IFJ), a kojoj pripada i Hrvatsko novinarsko društvo, slobodu sredstava masovnog priopćavanja, to jest medija definira kao „onu slobodu od ograničavanja koja je bitna da novinarima, urednicima i izdavačima omogući da unapređuju javni interes izdavanjem, emitiranjem ili širenjem činjenica i mišljenja bez kojih demokratsko biračko tijelo ne može donositi odgovorne prosudbe“.

Letica (2003: 40) primjećuje pojavu da u vremenima velikih promjena i nacionalnih nedaća vlade ponekad žele ukrotiti medije i podvrći ih svojoj volji uvjeravajući kako se sloboda govora mora vagati prema drugim potrebama društva. Dakako, ima i jasan protuargument toj tvrdnji koji kaže da je sloboda govora u demokraciji primarno pravo, a da je vlast koja uništava svoje sugrađane i medije u sukobu s biti demokracije, budući da je narod kojeg se ušutkava i lišava točne informacije zapravo narod lišen svojih ovlasti, bez mogućnosti da izrazi svoje probleme.

\subsubsection{Pitanje manipulacije i (auto)cenzure u medijima}

Pitanje manipulacije i cenzure, a još češće autocenzure, danas je aktualno. Valković (2006: 39) ističe da se danas javlja specifičan oblik manipulacije u izloženosti ogromnom broju ,informacija“, tako da je teško razaznati što se stvarno dogodilo, a što nije. Govori se o vijesti koja je u isto vrijeme predstavljena i skrivena. Tako se provodi nov način cenzure koja ne ide za skrivanjem od očiju javnosti već, naprotiv, za iznošenjem pred javnost strahovito velikog broja informacija koje se stavljaju na istu razinu, a dakako da sve nemaju istu vrijednost, te se može dogoditi da se „od šume ne vidi stablo“, to jest da medijski nepismena publika ne prepozna koja je vijest važna, a koja nije. 
Govoreći o novinarskoj slobodi, a time na neki način i o cenzuri, Gavranović (2009: 26) ističe da su sloboda izražavanja i novinarske slobode, ukupno uzevši, pod ozbiljnim pritiskom iz raznih izvora. Korumpirani političari u Latinskoj Americi, autokratski režimi na Srednjem istoku, konflikti u Africi, egzekucije i premlaćivanja novinara u zemljama istočne i jugoistočne Europe, neprijateljski nastrojeni režimi u Aziji, pokušaji ušutkivanja novinara u SAD-u, samo su dio opasnosti koje se javljaju na medijskoj pozornici i koje se ne mogu i ne smiju zanemariti.

Govoreći o slobodi medija, Malović (2004: 59) piše da ona „ima visoku cijenu. Novinari je plaćaju smrću, boravkom u zatvoru, gubitkom posla ili pak bijegom, pognute glave, u samocenzuru i neprofesionalnost. Sloboda medija nije ugrožena samo u nekim dijelovima svijeta, već se poput AIDS-a proširila cijelim svijetom. Sloboda medija traži stalnu brigu. Nema bolje zaštite do stalnog upozoravanja na svako narušavanje medijskih sloboda, na bilo kakav pokušaj ugrožavanja sloboda govora, prijetnji novinarima ili pokušaj da se novinare spriječi u objavljivanju istine.“

Miliša, Tolić i Vertovšek, (2009: 13) ističu da teoretičari suvremenih medija ukazuju na činjenicu da mediji danas stvaraju i nude sve više zabavnog programa, na štetu informativnog, obrazovnog ili znanstvenog sadržaja. Primjećuje se i da se situacija pogoršava, jer mediji sve više manipuliraju potrebama svih populacijskih segmenata društva, a poglavito mladih.

Govoreći o medijima i mladima Miliša, Tolić i Vertovšek (2009: 13) ističu da mediji postaju glavni agens u socijalizaciji mladog naraštaja, stoga autori smatraju da je osobito važno istraživati koje to vrijednosti mediji promiču. S obzirom da su vrijednosti paradigma ponašanja, one su važne u analizama medijskih sadržaja s kojima se odašilju snažni simboli i poruke. Mediji s vrijednostima koje odašilju imaju veliku usmjeravajuću funkciju na aktivnosti suvremenih mladih.

Kupnja određenog proizvoda, upozoravaju Miliša, Tolić i Vertovšek (2009: 105), često je rezultat želje da postanemo dio skupine koju on predstavlja stvarajući osjećaj pripadnosti skupini. Na taj način reklame vladaju u prostoru koji odvaja njihovo gledanje i kupnju proizvoda. Manipulator ne očekuje da se odluka o kupnji donese u trgovini. To kod kupca stvara lažnu sigurnost u vlastiti izbor. Odluka je u reklami koja fascinira i prije kupnje. Iz tog je razloga tako važno da ,reklama prodre u vas te živi unutar, a ne izvan vaše predodžbe o sebi samima: zapravo, da stvori tu predodžbu o našim potrebama.“ (Williamson, 
2002, 436, prema Miliša, Tolić i Vertovšek, 2009: 105). Poistovjećivanje sa skupinom uključuje svladavanje nekoliko zapreka, a jedna se tiče svladavanja različitosti njezinih članova. Tako postajemo ,jednaki“ jer u svakoj skupini postajemo „drugačiji“ na isti način. Međutim, reklama pokušava zavarati da je kupnjom proizvoda zadobiven status posebnosti. „To je ambivalentnost: reklame nam se istodobno obraćaju kao različitim i sličnima drugim ljudima“ (Williamson, 2002: 437, prema Miliša, Tolić i Vertovšek, 2009: 105).

Miliša, Tolić i Vertovšek (2009: 106) pišu da nas oglasi oslovljavaju kao jedinstvene, iako je ta neponovljivost opća, tj. te jedinstvenosti zapravo nema, budući da se oglas obraća zamišljenom pojedincu koji zatim postajemo mi sami. Kupujući Pepsi sugerira se da sudjelujemo u razmjeni, ne samo novca nego i razmjeni sebe i Pepsi-osobe. Postajemo „posebni“, no zapravo tek kao jedan od pripadnika kluba obožavatelja.

Govoreći nadalje o reklamama Miliša, Tolić i Vertovšek (2010: 75) tvrde da se danas stvari personaliziraju, a čovjek depersonalizira, te nastavljaju: „Predmeti postaju nadomjestak za stvarnost i stvarne emocije. Osjećaji se povezuju s proizvodom. Proizvod izaziva ili kupuje određeni osjećaj. On nam također daje osjećaj pripadnosti, jer se kupnjom upravo tog proizvoda svrstavamo u određenu skupinu. Odluka o kupnji određenog proizvoda donosi se prije odlaska u kupnju. Da bi imala učinak, reklama nas mora podsjećati da smo posebni i odnositi se prema nama kao prema neponovljivu subjektu. I tu je vidljivo proturječje, jer nam se reklama istodobno obraća kao različitima, ali i sličnim drugim ljudima koji su nam isti po statusu. Status opet određuje stvari. Mi postajemo tek dio skupine koja konzumira određeni proizvod.“

Isti autori (Miliša, Tolić i Vertovšek, 2010: 76) podsjećaju da istraživači upozoravaju na magičnu snagu tzv. subliminalnih reklama, a riječ je zapravo o tehnici tajnog i neizravnog zavođenja. Uz vidnu i slušnu poruku, tu je prisutna još jedna nevidljiva i neizrečena poruka. Npr. novo vozilo u nedirnutoj prirodi sa sloganom „Ovo je čudesan svijet“ posreduje poruku da vozilo ne šteti okolišu, te sugerira ljudima da ga mirne savjesti kupe, iako svi znamo da se i zbog masovne uporabe vozila zaštitni atmosferski sloj svake godine smanjuje.

Govoreći o oglašivačima Malović, Ricchiardi i Vilović (2007: 10) ističu da profit kao jedini pokretački motiv u medijskoj industriji ukazuje na nove opasnosti za etiku, neovisnost i profesionalizam u novinarstvu. Također, uočljiv je gubitak autonomije profesionalnih novinara u odnosu na poslodavce, a poslodavaca u odnosu na marketinške kompanije, te taj lanac ovisnosti stvara poteškoće. Interesi i utjecaj oglašivača sve su bliži uredničkoj politici 
pojedinih medija. Sve je više komercijalista pretvorenih u urednike, a uplitanje marketinških kompanija u uređivačku politiku poprima zabrinjavajuće razmjere.

Govoreći o medijskim primjerima seksualne fiksacije Miliša, Tolić i Vertovšek (2010: 85) pišu da brojne serije i emisije upravo sugeriraju seksualnu fiksaciju, a kao primjer navode „Ally McBeal“, „Seks i grad“, te „Seks inspektora“. U njima se npr. favorizira samohrana majka koja funkcionira bolje nego kad je u vezi sa suprugom, ljubav je ostvariva kroz količinu pruženog zadovoljstva, a svako se seksualno ograničenje shvaća kao uskraćivanje slobode. Krajnja posljedica može biti „društvo bez obitelji“ (Buchmann, 2003: 38, prema Miliša, Tolić, Vertovšek, 2010: 85) ili porast permisivnog odgoja gdje je djeci sve dopušteno. U porastu su „fast food“ obitelji kao sintagma koja se nudi za brze, površne i nezdrave pa čak i ugovorno kompromisne odnose među članovima obitelji. Također, isti autori (Miliša, Tolić, Vertovšek, 2010: 86) pišu da suvremene bizarnosti u medijima sve više potvrđuju tezu da danas sve ima svoju cijenu, a gotovo ništa svoju vrijednost.

Ako iz današnje perspektive promatramo vremena obilježena snažnim totalitarističkim režimima i medijima koji su se koristili u političke svrhe, upozorava Valković (2006: 36), može se reći da se mnogo toga promijenilo, te živimo u ambijentu koji je u mnogočemu različit od onoga kad su nastala prva promišljanja o medijskoj manipulaciji. Štoviše, možda se danas ne bi moglo govoriti o manipulaciji kako se u ono vrijeme shvaćala jer ne postoji takva „političko-povijesna“ pozadina, odnosno ne postoji snažna, središnja moć koja je karakterizirala totalitarne sustave držeći sve pod kontrolom i usmjeravajući prema ostvarenju određenog cilja. Međutim, nasuprot takvim razmišljanjima, nailazimo na potpuno suprotne teze u kojima se govori da su se upravo danas razvili i rasprostranili snažni oblici manipulativnog djelovanja (drugačijeg, možda suptilnijeg, ali ne blažeg) tako da će ovo naše vrijeme čak nazivati dobom manipulacije ili vremenom propagande.

1.3.6. Vjerodostojnost, izvori informacija i medijska pismenost u kontekstu medijske etike

Najil Kurtić (2007: 40) navodi da ako prosječan čitatelj o nekom događaju ima različite, pa i kontradiktorne vijesti, da će izabrat one u kojima prepoznaje više komponenti vjerodostojnosti, one koje dolaze iz brendiranih izvora koji su se već dokazali kao izvori i prenositelji vjerodostojnih vijesti. S obzirom na činjenicu da ekonomska snaga medija uglavnom ovisi o broju gledatelja i čitatelja može se govoriti o egzistencijalnoj ovisnosti 
medija o vjerodostojnosti vijesti koje emitiraju. To ih primorava, ili bi ih barem trebalo primoravati, da postupku izvještavanja i vijestima koje emitiraju priskrbe stvarne istinitosne kvalitete kao i da sam postupak prezentiranja vijesti obogate komponentama koje pojačavaju utisak vjerodostojnosti. Isti autor (Kurtić. 2007: 40) nastavlja: „Vjerodostojnost je koncept koji istovremeno obuhvaća sve komponente i aspekte istinitosti (točnost, preciznost, potpunost, nepristranost, ažuriranost) vijesti, kao i sve komponente i aspekte doživljaja jedne simboličke strukture (vijesti) kao vjerodostojne oznake za istinu.“

Kurtić (2007: 42-43) navodi da je novinarstvo pod imperativom pretpostavljene istinitosti. Obični ljudi su svakodnevno prinuđeni koristiti vijesti da bi razriješili različite životne dileme. Od odluke ponijeti li ujutro kišobran i kamo otići na godišnji odmor do pružanja podrške nekoj društvenoj akciji, čovjek je upućen na pretpostavku istinitosti informiranja iz masovnih medija, te vjeruje kako određena tvrdnja samim time što je iskazana $\mathrm{u}$ formatu vijesti i priopćena $\mathrm{u}$ informativnom mediju korespondira činjeničnom stanju. Isti autor (Kurtić, 2007: 43) ističe da je istovremeno sve očiglednije da izvještaj o nekom događaju nije jednostavan odraz stvarnosti, već je tvorevina koju oblikuju društveni, politički, ekonomski, kulturni i medijski procesi. Oni društveni čimbenici koji najviše dobivaju (ili gube) nekom verzijom priče (vlada, stranke, ekonomske strukture, moćni pojedinci i sl.), angažiraju se oko nametanja svoje ,verzije istine“ (ako možemo govoriti o „verziji istine“). Za posljedicu imamo različitost stvarnog svijeta i svijeta kakvim ga prikazuju mediji.

Danas su vijesti nepovratno usmjerene prema servisiranju komercijalnog tržišta, koje se zasniva na spektaklu i senzaciji, piše Kurtić (2007: 44). Time se rađa mutacija klasičnog informativnog žanra u neobičnu mješavinu zabavne prezentacije i minimalne informacije. Oglašivači, na ovakav ili onakav način, kontroliraju urednički sadržaj medija. Koncept „totalnih novina“ kao shvaćanje da se naklada, prodaja oglasnog prostora i vijesti moraju integrirati u jednu cjelinu je samo denominacija za očigledno instrumentaliziranje vijesti da bi se zadovoljili komercijalni interesi vlasnika medija. Sam pojam vijesti ispunjen je novim sadržajem: to sve češće i sve više postaju „meke priče“ zasnovane na emocionalnim i moralnim apelima i priklanjanjima, a ne klasične informacije koji bi mogle podržati kritičko rezoniranje i racionalni izbor u neizvjesnim životnim situacijama.

Kurtić (2007: 44-45) primjećuje da je sve prilagođeno prevladavajućoj lijenosti uma i sklonosti ka uživanju. Dominiraju kratke, napadno ilustrirane vijesti, dok tradicionalne javne teme skoro pa nestaju iz sadržaja, a njihovo mjesto zauzimaju vijesti o životnom stilu i 
servisne informacije čiji utjecaj najčešće ne prekoračuje granice trivijalnih neizvjesnosti. Dugotrajno ispitivanje pozadine događaja, prije nego se prenese vijest, jednostavno nije isplativo ako se želi ostati na tržištu, već je potrebno zadovoljiti kriterij koji se zove „biti prvi“ u objavljivanju vijesti. Publika, u kako god teškom socijalnom položaju bila, ima želju i potrebu da povjeruje kako su upravo važne samo teme koje ispunjavaju sadržaje masovnih medija. Svjesna je doduše velike iluzije koja dolazi s ekrana i novinskih stupaca, u stanju je o tome čak i suditi, no ipak u konačnici kao da nema ništa protiv toga. Vijest (informacija) je oslobođena obveze da donese konačnu istinu, dakle informaciju koja korespondira stvarnom stanju, da bude točan dokument o stvarnom događaju. Dovoljno je da ispuni formalne uvjete objektivnog (nepristranog) pristupa, ilustrira spektar događaja i aktera (dramatiku različitosti), i svi sudionici su zadovoljni konačnim proizvodom.

Kurtić (2007: 45) piše da samo izvještavanje zapravo poprima oblik izvornog retoričkog modela u aristotelovskoj tradiciji koji se više brine za čimbenike uvjerljivosti (stil prezentacije vijesti) nego za mjeru u kojoj to u što se uvjerava korespondira sa stvarnošću, tj. koliko to jest ili nije istina. Dakako, kao rezultat svega toga javlja se erozija pretpostavljanog povjerenja u masovne medije kao društveno odgovorne donositelje relevantnih vijesti.

Imperativ novinarstva je stavove i tvrdnje zasnivati isključivo na činjenicama, navodi Kurtić (2007: 47-48) dodajući da sve činjenice treba provjeriti u više međusobno nezavisnih izvora, tragati za svim relevantnim činjenicama, uključujući i proturječne činjenice $\mathrm{i}$ mišljenja, ne skrivati činjenice koje mogu biti osnova drugačijih interpretacija, bez predrasuda prihvaćati iskustvenu očiglednost svake nove činjenice bez obzira u kakvom se odnosu nalazila s onim što se o događaju ili procesu ranije znalo ili čak što se očekivalo ili željelo od strane komunikatora ili recipijenata, ne primoravati činjenice da podržavaju subjektivno gledište (zadato značenje). Što se medij više pridržava ovih pravila pri izvještavanju, to postaje vjerodostojniji.

Isti autor (Kurtić, 2007: 48) piše da sve činjenice jednostavno nisu podjednako značajne i relevantne, te da uključivanje u vijest nerelevantnih činjenica može zamaskirati pravu istinu, ali i učiniti samu vijest neinteresantnom i nerazumljivom.

Ksenija Žlof (2007: 78) podsjeća na ono što je posve jasno: među medijima vlada nemilosrdna konkurencija. Upravo zbog toga i takvoga okruženja novinari su ,prisiljeni“ svoje proizvode što je više moguće prilagoditi apetitima, željama i prohtjevima čitatelja, slušatelja ili gledatelja. A to znači, između ostaloga, javnost neprekidno hraniti senzacijama, 
aferama i otkrićima. U suvremenim medijima proizvodnja takve „robe“ postaje imperativ i modus operandi, ali i gotovo jedini način opstanka na tržištu. No, postavljaju se i neka pitanja: kako dobro prodati priču i kako proizvoditi senzacije iz broja u broj, kako biti brži od konkurencije? Nažalost, zbog brzine objavljivanja najnovijih vijesti i bombastičnih događaja nerijetko se zanemaruju najvažnija pravila novinarske profesije - provjeravanje informacija i potvrda koja dolazi iz relevantnih izvora. Potvrdu imenovanih izvora u objavama nerijetko zamjenjuju sintagme poput: „,neki tvrde“, „mnogi misle“, „,svi se slažu“, „naš sugovornik koji je želio ostati anoniman napominje“, „,iz izvora bliskih (nekomu ili nečemu) saznajemo“. Tako nastaju medijske objave koje su publici možda zanimljive i plitke pa stoga dobro prodaju novine, ali pritom je njihova vjerodostojnost upitna.

Kao što navodi Philippe Perebinossoff (2008: 47), novinari, direktori, glumci, izdavači, svi oni moraju odlučiti koju će ulogu etika imati u njihovom poslu. Oni mogu odlučiti da će ignorirati, omalovažiti ili prijeći preko etičkih zahtjeva, ali oni ne mogu jednostavno negirati njihovo postojanje. Isti autor (Perebinossoff, 2008: 167) navodi i da danas kad se svatko može baviti novinarstvom u slobodnom društvu, postaje sve važnije da obrazovne institucije pružaju etičku obuku za medijske vlasnike i djelatnike, kako bi se pridržavali etičkih načela. Ako nema vanjskih tijela koja potiču etičke prosudbe, principi se u novinarstvu ne inkorporiraju u struci, te ne štite profesiju.

\subsubsection{Odgovornost primatelja i medijska etika}

O odgovornosti primatelja u svjetlu medijske etike na hrvatskom govornom području pišu Labaš i Ana Vizler (2006) koji primjećuju da su primatelji tu da bi se posve aktivno i odgovorno koristili mnogobrojnim mogućnostima medija, ali i kako bi kontrolirali rad novinara. Primatelji su također na određeni način „,produžena ruka“ etičkih kodeksa te su svojim primjedbama, prijedlozima i pohvalama putokaz novinarskim djelatnicima, napose ako će ih se ozbiljno shvaćati. Pitanje koje u tome kontekstu traži svoj odgovor glasi: koliko su primatelji u Hrvatskoj danas zapravo medijski osviješteni i odgovorni da bi se medijima mogli koristiti u pozitivne svrhe, tj. pomagati razvoj kvalitetnih i društveno korisnih sredstava javnog priopćavanja, a „odmagati“ onima koji to nisu? (Labaš, Vizler, 2006: 278-279). To je jako zanimljivo pitanje na koje nije jednostavno dati jednoznačan i konkretan odgovor. 
Isti autori ističu i da mediji, naravno, sami po sebi nisu loši, te ih takvima može učiniti samo nepravilna uporaba od strane korisnika. Pretjerano izlaganje medijima može dovesti do bijega od realnosti i do zatvaranja u izolaciju. Mogućnost „kućne zabave“ preko medija može biti popraćena ugrožavanjem društvenih odnosa, krizom tradicionalnih oblika blizine i zbunjujućim stanjem uzrokovanim medijskom zasićenošću. Promičući nove kulturne vrijednosti te način razmišljanja o društvenim odnosima, nove tehnologije prijete i gašenjem tradicionalnih kultura. U svakom slučaju, ono što bi svi trebali imati na umu jest sasvim konkretna snaga medija, kao i njihov potencijal koji iz dana u dan sve više raste. Usporedno s tom snagom medija, treba jačati oprez i sposobnost kritike kod primatelja. A da se ne bi dogodilo da mediji postanu čovjeku gospodari umjesto da on postane njihov „upravitelj“, pojavljuje se i potreba uvođenja strogih etičkih kriterija (Labaš, Vizler, 2006: 280).

Također, Labaš i Vizler (2006: 282) donose prikaz jednog zanimljivog obrata i zamjene uloga koji su se dogodili u suvremenom društvu. Naime, polaze od toga da je kritička javnost ta koja ima ulogu kontrole vlasti i koja izražava glas građana, a da bi to bilo moguće, potrebna je razvijena demokratska kultura, a samim time i kultura dijaloga koji se, posredovanjem masovnih medija, odvija u javnosti. No, kako primjećuju autori, masovni su mediji s vremenom jačali i razvijali se, te pomalo preuzimali primat nad kritičkom javnošću ne želeći više biti samo u ulozi posrednika. Tim je obratom javnost postala samo ,publika“, a glavni su akteri mediji, „koji više nisu samo posrednici nego sami postaju kreatori javnosti““. $\mathrm{Na}$ taj način mediji iznose teme koje postaju temom javne rasprave. Upravo zbog takvog razvoja samih medija pojavljuje se pitanje odgovornosti publike, tj. primatelja, kao i pitanje medijske etike samih komunikatora.

Nadalje, Labaš i Vizler (2006: 282-283) podsjećaju da na području etike društvenog komuniciranja dugo nitko nije razmišljao o etici primatelja kao nizozemski komunikolog Cees J. Hamelink, koji se osobito bavio pitanjem odgovornosti primatelja i od njih tražio da se i oni u komunikacijskome procesu ponašaju moralno i etično. A kada se govori o „etičnom ponašanju“ onda se najčešće spominju pojmovi sloboda i odgovornost, upravo stoga što su oni nužni preduvjet da bi se uopće moglo etički djelovati. Kod etike odgovornosti, ispravnost se djelovanja vrednuje prema predvidivim posljedicama, a ne prema njegovim motivima, dok se kod etike uvjeravanja ispravnost djelovanja ocjenjuje na temelju uvjerenja, a ne s obzirom na moguće posljedice. Prema Maxu Weberu, da bi se ispravno djelovalo, potrebno je slijediti etiku odgovornosti: „Ustvari, osjećanje ljudskog dostojanstva je nerazdvojivo povezano s 
osjećajem odgovornosti.“ I etika Emmanuela Levinasa temelji se na načelu odgovornosti, i to odgovornosti za Drugoga, bližnjega koji je „polazište, kriterij i svrha čovjekova djelovanja“.

Isti autori (Labaš, Vizler, 2006: 283-284) napominju da kada se govori o etici društvenoga komuniciranja, potrebno je znati na koga se ta etika konkretno odnosi. Često se misli da su novinari ti koji su jedini „krivci“ kada na površinu isplivaju neke neprovjerene ili neistinite informacije. Pri tom se zaboravlja na odgovornost cijele društveno-političke zajednice, izdavača ili medijskog sustava, urednika i javnosti koja je pozvana ne samo biti pasivni korisnik nego biti dio i akter tog procesa. Primatelji ni sami nisu svjesni koliko su im se mediji zapravo „uvukli“ u svakodnevne živote. Svakoga jutra izvlači ih iz postelje poznati glas radijskog voditelja, za doručkom listaju dnevne novine, a večer je rezervirana za gledanje televizije, a danas - dodajemo - za provjeru statusa i objava na društvenim mrežama i informativnim portalima. I kad izađu iz svojih domova, hodajući ulicom, sa svakoga promidžbenog plakata ili sa zgrada „bombardira“ ih mnoštvo poruka. Dugi niz godina primatelji su bili na margini medijskih istraživanja, kao da se prethodno navedene činjenice nisu uzimale u obzir. Bezbroj knjiga i članaka napisano je upravo o medijima, njihovoj moći i utjecaju, o novinarima, njihovu radu i odgovornosti. No što je s većinom, sa svima onima kojima su svi ti medijski sadržaji i namijenjeni, to jest s korisnicima medija?

Kao što ističu Labaš i Vizler (2006: 287) nije upitna velika uloga primatelja, te se primatelja ne smije doživljavati kao žrtvu, budući da na mnogo načina može djelovati aktivno i ravnopravno te „rame uz rame“ ući u interakciju s medijima koji pružaju obilje sadržaja. Koristeći analogiju korištenja medija s igrom, zaključuju da je za vješto igranje potrebno mnogo strpljenja i vježbanja te da se kvalitetan igrač ne postaje preko noći. Time žele reći da bi se svaki korisnik medija trebao pozabaviti pitanjem kakvim se informacijama i medijima svakog dana koristi. Ističu da nije dobro ići linijom manjeg otpora, te reći: „Ne čitam novine i ne gledam televiziju jer tamo uvijek lažu!“, nego je potrebno boriti se za medijsko okruženje u kojem se može opstati bez straha od laži i podmetanja.

Iako se mnogi žale na kvalitetu medijskih sadržaja, ističu autori (Labaš, Vizler, 2006: 289), ipak ih prešutno prihvaćaju jer im je lakše bezbrižno se smjestiti u naslonjač i pratiti predvidljive dijaloge junaka televizijskih sapunica nego učiniti nešto u vezi s poboljšanjem programa. Naime, ono što ne zatražimo uglavnom i ne dobijemo, a tako je i s medijskim sadržajima. 
Ne postoji jednoglasan odgovor svih uključenih i zainteresiranih na pitanje na kome leži najveća odgovornost u medijskim procesima. Ipak, može se kazati da većina primatelja smatra kako najveća odgovornost leži upravo na vlasnicima medijskih poduzeća, izdavačkih kuća, na urednicima i novinarima. Od svih navedenih, korisnicima su novinari najmanje dragi, na njih imaju najviše primjedbi, vjerojatno zato jer s njima dolaze u najbliži kontakt. No, ne misle svi tako, dakako. Ima $\mathrm{i}$ onih koji ističu da nositelj, tj. sredstvo medijske komunikacije jest samo društvo. U konačnici, odgovornost za uspjeh masovne komunikacije pada na društvo u cjelini (Labaš, Vizler, 2006: 290).

Labaš i Vizler (2006: 291) primjećuju da se na kraju, nakon svih analiza, dođe do spoznaje o više vrsta odgovornosti na području medijskih procesa: „Austrijski komunikolog Heinz Pürer razlikuje individualnu etiku, etiku medijskog sustava te etiku publike. Njegov američki kolega Clifford Christians svu pažnju usmjerava na kolektivnu etiku publike. Prema njemu, moralna je obveza javnosti imati nadzor nad društvenim kretanjima kao što je komunikacija u društvu te postavlja 'etički zahtjev publici da svoju sudbinu kao medijskog primatelja uzme u svoje ruke i da se brine za kulturu na području komunikacije.' Nizozemski pak komunikolog Cees J. Hamelink kao najbitniju značajku etike publike vidi udruživanje medijskih potrošača $u$ zajednice koje bi putem međunarodnih inicijativa branile prava i interese primatelja. Etika publike trebala bi, zapravo, odrediti oblike i 'forum' javne odgovornosti te odrediti konkretne puteve za suodgovornost u proizvodnji i organizaciji medija.“

U suvremenom pluralističkom društvu svakom je dopušteno izraziti svoje mišljenje, što je rezultiralo javnim mnijenjem, a javno je mnijenje omogućilo primateljima da i oni daju svoj obol novomu komunikacijskom društvu te im stavlja na leđa odgovornost za kvalitetu medijskih sadržaja, ili u najmanju ruku sudjelovanje u toj odgovornosti. Etika primatelja podrazumijeva odgovorno biranje medijskih sadržaja, dakako onih koji omogućuju stjecanje novih spoznaja i promiču pozitivne društvene vrijednosti. Ali nije potrebno tu se zaustaviti, jer primatelji mogu i mnogo više, npr. mogu osnovati različite udruge putem kojih bi možda upravo svojom brojnošću ispravili narušenu ravnotežu na vagi odnosa pošiljatelja (novinara) i primatelja (korisnika), te bi svojim prijedlozima i kritikama utjecali na sadržaj i kvalitetu koje su ponudili mediji (Labaš, Vizler, 2006: 294).

Kao što ističe Labaš (2009: 37) problematika novih medija i njihovoga korištenja, kao i računalno posredovane komunikacije slična je problematici i prijašnjih komunikacijskih 
sredstava. Jer, bila stara ili nova, tehnologija nije kriva za različite poteškoće koje se javljaju. Većina „komunikacijskih“ odluka rezultat je prethodnih komunikacijskih praksi pojedinaca te njihova razumijevanja i upotrebe novih medija i e-komunikacije za određene ciljeve, kao što je bio slučaj i s prijašnjim komunikacijskim sredstvima i kanalima. Pri tome slobodan i odgovoran čovjek ne postaje robom, već sustvarateljem novoga medijskog prostora. Zato je nužno govoriti o subjektu, o čovjeku koji se medijima koristi, te o njegovoj slobodi i odgovornosti kojima i sam određuje sudbinu novih tehnoloških i komunikacijskih dostignuća do kojih je došao svojom racionalnom kreativnošću.

Labaš (2009: 137) primjećuje da dok se s jedne strane o stanju u novinarstvu i medijima govori i piše vrlo pesimistično, s druge strane logično je i opravdano, kako ističu drugi autori, stati u obranu medija i novinara, ističući njihove pozitivne strane i njihov neprijeporni doprinos razvoju društva u cjelini bez kojih bi i društvo bilo manje otvoreno. Mogli bismo reći da živimo u svijetu paradoksa. Jer, nije li paradoksalno da se za sva zla optužuju mediji dok oni zapravo nikad nisu bili bolji? Da bismo se i sami u to uvjerili, dovoljno je ,,prelistati prošlostoljetne novine, pogledati nekoliko emisija iz pedesetih godina ili pročitati žestoke napade negdašnjih kritičara" (Bertrand, 2007: 8, prema Labaš, 2009: 137). Mediji su dakle bolji, ali ostaju mediokritetski, upozorava Bertrand: ako je nekada većina ljudi i mogla bez njih, „danas se čak i u ruralnim područjima osjeća potreba ne samo za medijima nego za kvalitetnim medijima" (Bertrand, 2007: 8, prema Labaš, 2009: 137). Može se slobodno reći da poboljšanje medija nije tek poželjna promjena, nego nešto što je posve neophodno. Jer, ako se mediji ne promijene i ne poboljšaju, u pitanju je i opstanak same demokracije, zato što ona ne može funkcionirati bez dobro informiranih građana, a takvih građana ne može biti bez dobrih i kvalitetnih medija. „Mediji su u demokraciji jedan od temeljnih čimbenika zbog njihove uloge koja se sastoji u tome da informiraju i da pomažu građanima u oblikovanju mišljenja i kritike. Bez takvih medija, demokratski sustav nije sposoban vršiti svoju ulogu" (Lovrić, 2009: 101, prema Labaš, 2009: 137).

Ako žele vratiti izgubljeni ugled, čast i vjerodostojnost, novinari ne smiju biti „potpune neznalice“, nego moraju biti kompetentni (Labaš, 2009: 179). Tako ih je naime prije više od jednog stoljeća nazivala francuska intelektualna elita zbog njihova slabog kulturnog obrazovanja, a danas često kao da se to ponavlja. Novinar ne smije biti ni prosječan pisac koji od svega zna pomalo, koji možda i piše dobro, ali koji ništa ne poznaje temeljito. Jednostavno, danas je potrebna specijalizacija, potrebno je da novinar određene teme i 
određena područja poznaje izvrsno, kako bi se mogao na kompetentan način njima baviti. Mora se afirmirati kao dobar poznavatelj problema i tema koje obrađuje, a ujedno i sposoban izvještavati zanimljivo, istinito i uvjerljivo.

Osim intelektualne izobrazbe (koja svakako jest neophodna) suvremenim je novinarima potrebna i ona humana i humanistička, jer samo uz nju će se držati osnovnoga cilja informiranja: spoznati, objaviti, priznati i braniti istinu (Labaš, 2009: 180). Isti autor koristi i jednu zanimljivu usporedbu: „Razdvajati istinu od informiranja ili informiranje od istine - što danas srozava ugled i vjerodostojnost novinarske profesije - bilo bi slično pokušaju razdvajanja slane od slatke vode na ušću rijeke u more. Istina novinarima može pomoći da samokritično pogledaju tko su i što su danas, da se unatoč kritikama i gubitku vjerodostojnosti i danas ponašaju mudro i samokritično razmisle o onome što i kako svakodnevno čine“" (Labaš, 2009: 180).

O odgovornosti primatelja piše i već spomenuti Hamelink (1998: 49-50), koji, pozivajući se na Morta Rosenbluma, povlači jednu zanimljivu usporedbu, tvrdeći da ako proizvođači nisu bili bolji, to je zato što to nisu tražili potrošači, te tvrdi da ako pogriješi kirurg ili limar, korisnik će ga tužiti, a pita se zašto se ljudi koji se bave vijestima tako lako izvlače. Polazeći od interaktivnog odnosa profesionalac - klijent, zaključuje da se medijska etika ne može ograničiti na proizvođača i da treba postojati i etika korisnika medija. Argument utemeljenja i postojanja etike korisnika može se braniti tako da se pokaže kako ne samo proizvođači, nego i korisnici donose moralne odluke u pogledu slobode, kvalitete i odgovornosti medija. Do tih odluka dolazi se kada se korisnici nađu u situacijama da mogu odabirati među alternativama djelovanja koje predstavljaju različite vrednote. Isti autor donosi i „,eset zapovijedi za korisnike medija“ koje glase:

1. „Budi oprezan i kritičan korisnik medija.

2. Aktivno se bori protiv svih oblika cenzure.

3. Nemoj se neopravdano upletati u uređivačku neovisnost.

4. Čuvaj se rasističkih i seksističkih stereotipa u medijima.

5. Traži alternativne izvore informacija.

6. Traži pluralističke izvore informacija.

7. Štiti svoju privatnost. 
8. Budi pouzdan izvor informacija.

9. Ne sudjeluj u novinarstvu 'čekovne knjižice'.

10. Zahtijevaj odgovornost od medijskih proizvođača“" (Hamelink, 1998: 53).

O ovoj temi piše i Fink (1995: 12) koji ističe da je za korisnike medija učenje etike ključno za učinkovito služenje medijima, stavljajući pred korisnike konkretne zadaće: morate naučiti izabrati odgovorne, vjerodostojne novine i časopise, kao i kritički prosuditi njihovo prenošenje vijesti, informacija i zabave. Naglašava i da je vrijeme u kojem su primatelji pasivno primali što su mediji servirali postalo prošlost. Čitatelji, gledatelji i slušatelji mogu -i trebaju - medijima stvoriti pritisak kako bi osigurali da ne zalutaju od etike i ne iznevjere svoju novinarsku misiju, ističe isti autor.

Malović, Ricchiardi, Vilović (2007: 12) ističu da korisnik medija ne treba dobiti samo informacije koje zadovoljavaju njegovu prirodnu radoznalost, već i one koje bi trebao znati, a omogućuju mu da sudjeluje u slobodnoj političkoj i svakoj drugoj debati koja se nalazi u središtu demokratskog društva. Takav proaktivni pristup informacijama omogućuje pojedincu da se bori protiv samovolje svih onih koji drže moć, a koji egzistiraju na slabo informiranim ili posve neinformiranim građanima. 


\section{PRIKAZ I ANALIZA NAČELA U CRKVENIM DOKUMENTIMA O MEDIJIMA}

U ovom poglavlju rad prikazuje i analizira crkvene dokumente, s posebnim naglaskom na glavne teme medijske etike prisutne u crkvenim dokumentima i na crkvene stavove o pojedinim medijima u njima, kako u onima koji izravno govore o medijima, tako i u onima kojima to nije glavna tema, ali se ipak dotiču medija. Neki od tih dokumenata su iz novijega doba, dok je najstariji iz prve polovice XIX. stoljeća. Rad obrađuje i 50 papinih poruka - od prve poruke iz 1967. godine do poruke iz 2016. godine - koje poglavari Katoličke Crkve pape - redovito objavljuju svake godine u povodu Svjetskog dana sredstava društvenog priopćavanja, tj. Svjetskoga dana medija i koje imaju svoju osobitu važnost i izvan crkvenih okvira.

Prvi crkveni dokument koji progovara o temi sredstava društvene komunikacije je enciklika Mirari vos (1832) pape Grgura XVI. u kojoj papa osuđuje slobodu tiska. No, uskoro Katolička Crkva kreće u drugom smjeru te već papa Pio XI. u Vigilanti cura (1936) „ne govori samo o opasnostima“, već medije „,nastoji s pozitivne strane vrednovati.“ (Balukčić, 2012: 131). Drugi vatikanski sabor je iznimno važan trenutak u otvaranju Crkve prema svijetu i suvremenim društvima, pa onda i prema medijima jer „u duhu otvorenosti i dijaloga sa svijetom te priznavanjem autonomije zemaljskih stvarnosti, Crkva na drugačiji način promatra svijet medija.“ (Valković, 2012: 172). Nakon Drugog vatikanskog sabora nastavlja se u istom smjeru: „Slijedeći trag saborskih dokumenata, pošlo je i postkoncilsko Učiteljstvo: sredstva društvenog priopćavanja ušla su u gotovo sve dokumente pastoralnog značaja.“ (Labaš, 1993: 93).

Dio dokumenata koje se analizira u ovom radu već je bio preveden na hrvatski jezik, no značajan dio dokumenata i papinih poruka nije bio preveden. Tako je npr. od 50 papinih poruka za Svjetski dan sredstava društvenog priopćavanja gotovo 40 poruka za potrebe ovog rada prvo prevedeno, a tek nakon toga se moglo pristupiti analizi. Kad se u tekstu rada navodi pojedini dokument, u bilješci je naznačeno je li riječ o službenom prijevodu na hrvatski jezik koji je preuzet ili je pak riječ o osobnom prijevodu za potrebe ovoga rada. 


\subsection{Negativan odnos Crkve prema medijima i nedostatak slobode izražavanja - Mirari $\operatorname{vos}(\mathbf{1 8 3 2})$}

Dokument Mirrari vos (MV) objavljen je 1832. godine, a riječ je o prvoj enciklici pape Grgura XVI. U njoj papa osuđuje religijski pluralizam smatrajući ga opasnim za duše vjernika, uz što osuđuje i pluralizam mišljenja, a samim time i slobodu govora, ili šire shvaćeno i slobodu medija.

U dokumentu se jasno i izravno osuđuje sloboda mišljenja (a jasno je da bez nje nema ni slobode medija), te želja za novostima: „Iskustvo pokazuje, još od najranijih vremena, da su gradovi poznati po bogatstvu, vlasti i slavi nestali zbog ovog jedinstvenog zla, odnosno neumjerene slobode mišljenja, dopuštanja slobode govora i želje za novostima““ (MV, br. 14). ${ }^{3}$

U idućem broju 15 već se jasno osuđuje i sloboda objavljivanja: „Ovdje moramo uključiti tu štetnu i nikad dovoljno osuđenu slobodu objavljivanja bilo kakvih spisa i njihovog distribuiranja ljudima, a koje se neki usuđuju tražiti i promicati tolikom snagom. Užasnuti smo vidjeti neprihvatljive doktrine i velike pogreške rasprostranjene nadaleko i naširoko $u$ bezbrojnim knjigama, letcima i drugim spisima koji, iako nisu vrijedni, čine veliko zlo. Mi smo u suzama zbog zlostavljanja koje dolazi od njih na lice zemlje. Neki su toliko zavodljivi da svadljivo tvrde kako mnoštvo pogrešaka koje proizlaze iz njih mogu biti nadomještene nekom knjigom koja brani religiju i istinu. Svaki zakon osuđuje namjerno činiti zlo jednostavno zato što vjeruje da postoji dobro. Ima li itko razuman tko će reći da otrov treba širiti, javno prodavati i konzumirati, jer je dostupan lijek i oni koji ga koriste mogu biti otrgnuti od smrti uvijek iznova“ (MV, br. 15)?

Također, dokument ističe i ,zaslugu“ Crkve u cenzuri: „Crkva je uvijek poduzimala mjere kako bi uništila kugu loših knjiga“ (MV, br. 16).

Iz navedene kratke analize, kao i iz cijelog dokumenta, jasno je da je dokument nažalost u cijelosti negativno intoniran u odnosu na slobodu medija, te da cenzuru promatra kao nešto pozitivno, dapače kao vrijedno i potpuno neophodno.

\footnotetext{
${ }^{3}$ Dokument „Mirari vos“ nije preveden na hrvatski jezik, ta ga za potrebe ovog rada prevodim s poveznice: http://www.papalencyclicals.net/Greg16/g16mirar.htm
} 


\subsection{Naslućivanje promjene odnosa Crkve prema medijima - Vigilanti cura (1936)}

Vigilanti cura (VC) ${ }^{4}$ enciklika je pape Pija XI. iz lipnja 1936. godine, a posvećena je sredstvima društvene komunikacije, osobito kinematografiji.

Obraćajući se delegatima Međunarodnog udruženja filmske industrije na audijenciji na kojoj ih je primio poručuje da im je tom prilikom ,skrenuo pozornost na ozbiljnost problema $\mathrm{i}$ toplo pozvao sve ljude dobre volje, ne samo u ime vjere, nego i prave moralne i građanske dobrobiti ljudi, da koriste svaki način koji je u njihovoj moći, kao što je i tisak, kako bi kinematografija postala vrijedna pomoć u poduci i obrazovanju, a ne uništenju i propasti duša“" (VC, br. 1). Dakle, u ovome se dokumentu na kinematografiju gleda kao na nešto što može biti i dobro (pomoć u poduci i obrazovanju) i loše (propast duša), ovisno kako se pristupi.

Nadalje, govoreći o dužnosti Crkve da pomogne majkama i očevima u procjeni moralnosti filma za njihovu djecu, spominje se medije kao one koji mogu pomoći u tome: „Biskupi će također iskoristiti mogućnost katoličkog tiska u svrhu dovođenja u domove moralne ljepote i djelotvornosti tog sredstva“ (VC, br. 3).

„Posebna glasila ili druge pravovremene publikacije, kao što su dnevni katolički tisak, mogu se koristiti u ovu svrhu“ (VC, br. 3), ističe Pio XI. misleći na svrhu da se vjernicima preporuči što je dobro za gledanje.

U ovom dokumentu začetak je stava koji će Crkva kasnije još jasnije definirati, a to je da mediji sami po sebi nisu dobri ili loši, već da njihova etička prosudba ovisi o tome kako ih se koristi. S pozicije etičkog vrednovanja, važno postaje kako se s određenim medijem postupa i kako mu se pristupa, a ne o njemu samome na način da ga se može etiketirati dobrim ili lošim po samome sebi.

\subsection{Mediji u svjetlu Drugog vatikanskog koncila, najznačajnijeg događaja 20. stoljeća u Crkvi - Inter mirifica (1963)}

Drugi vatikanski koncil (1962.-1965.) jedan je od značajnijih događaja u povijesti Crkve, a zasigurno najvažniji crkveni događaj XX. stoljeća. Označio je prekretnicu u

\footnotetext{
${ }^{4}$ Dokument „Vigilanti cura“ nije preveden na hrvatski jezik, ta ga za potrebe ovog rada prevodim s poveznice: http://w2.vatican.va/content/pius-xi/en/encyclicals/documents/hf_p-xi_enc_29061936_vigilanti-cura.html
} 
teološkoj i svakoj drugoj misli Katoličke Crkve, a posebno je zanimljivo i važno da je od 16 dokumenata koji su plod tog Koncila prvi dokument upravo dekret o sredstvima društvenog priopćavanja Inter mirifica (IM). ${ }^{5}$

„, Inter mirifica je, naime, izazvala polemike i suzdržanost od kojih su neke optuživale da dekret ima još uvijek 'pretkoncilski karakter' i da ne posjeduje teološke vrijednosti nego da ima 'teološku prazninu', shvaćenu kao nedostatak teološko-dogmatskog sadržaja. Usprkos svemu možemo kazati da ta kritika nije bila na mjestu jer je sadržaj nacrta i dekreta samog, kasnije odobrenog i promulgiranog, bio teološki, barem u moralnom i pastoralnom smislu; i ako doktrinarno dogmatski nije bio razvijen za to postoje dva razloga. Prvi je bio taj što baš nitko, niti pred Koncil, niti za vrijeme Koncila nije tražio niti očekivao doktrinarno-dogmatski dokument o mass-medijima; drugi je bio da, da je to i želio, Koncil ne bi mogao izraziti istinsku i pravu dogmatsku teologiju o mass-medijima, jer u to vrijeme glede tog pitanja $\mathrm{u}$ Crkvi nije postojala zajednička nauka, niti je bila zadaća Koncila da je obradi i nametne“ (Labaš, 1993: 85).

Donošenje ovog dokumenta nije išlo lagano i glatko. Nakon što je predstavljen radni nacrt dokumenta, javljaju se pojedina mišljenja koja ističu jasne nedostatke predloženog teksta. Tako Valković (2013: 35) navodi: „Ubrzo nakon toga u javnosti se pojavljuju reakcije. Američki novinari traže tumačenje onog dijela u kojem se govori da se građanske vlasti trebaju brinuti kako se putem tih sredstava ne bi nanosila moralna šteta. (...) Tri američka novinara, Cogley, Kaiser i Novak, objavljuju deklaraciju u kojoj kažu da predloženi tekst ne može biti adekvatan izričaj aggiornamenta kako ga shvaća i kako o njemu govori papa Ivan XXIII. Tekst predstavlja korak unatrag, jer je previše apstraktan i suviše 'teološki'“،. Nadalje Valković (2013: 36) piše: „Deklaraciju su potpisali i neki istaknuti koncilski teolozi (B. Häring, J. Murray, J. Danielou). I druga kritika, koju je potpisalo 97 koncilskih otaca, dospijeva tih dana pred Komisiju. Traži se revizija teksta. Komunikacijska sredstva nisu samo sredstva kojima se obraća publici, već se putem njih treba ostvariti autentična komunikacija. Prigovor je da se u dovoljnoj mjeri ne naglašava važnost laika niti posvećuje dostatna pozornost problemima pojedinih biskupskih konferencija. Neslaganja i protesti protiv predloženog teksta nastavili su se i 25. studenog. Na ulazu u aulu u kojoj se toga dana trebalo glasati dijelili su se letci koje je potpisalo 25 koncilskih otaca. Oni su zahtijevali da se glasuje protiv predložene sheme. (...) Rezultat glasovanja je: 1598 glasova placet (prihvaća), 503 non

\footnotetext{
${ }^{5}$ Preuzet je službeni prijevod dokumenata Drugog vatikanskog koncila na hrvatski jezik, u izdanju Kršćanske sadašnjosti.
} 
placet (ne prihvaća) i 11 nevažećih listića. Iako je tekst prihvaćen s velikom većinom, broj onih koji su se protivili (u odnosu na prethodno glasovanje) je porastao. To je jedini koncilski dokument koji je prihvaćen s tako velikim brojem protivnih glasova.“

Ovaj dokument uvodi također i pojam koji je danas uobičajen u crkvenim dokumentima o medijima, a već spomenuti autor o tome piše: „Jedna od važnijih novosti dekreta je uvođenje nove terminologije 'sredstva društvenih komunikacija' (instrumenta communicationis socialis) (...) Koncil odabire između različitih naziva: audiovizualna sredstva (izraz nije prihvaćen jer ne obuhvaća sva sredstva o kojima je dekret htio govoriti), tehnička difuzivna sredstva (tecniques de diffusion) nije prihvaćen jer u prvi plan dolazi tehnički aspekt, a Crkvu više zanima pastoralni, odnosno moralni vid; mass media i mass communications (ti su se izrazi doživljavali diskutabilnima jer usmjeravaju pozornost prema mišljenjima mase)“ (Valković, 2013: 39). Iako ima svojih nedostataka, Valković (2013: 40), slično kao i Labaš, opravdava dokument: „Mora se imati u vidu da je Inter mirifica jedan od dva prva koncilska dokumenta. Zato je razumljivo da nije mogao sadržavati sve one naglaske koji će biti prepoznatljivi u kasnijim koncilskim dokumentima. Kako Mills kaže, taj se dokument pripravljao prije negoli je Koncil otkrio svoj 'specifični identitet, što će biti vidljivo za posljednjih zasjedanja'. Iako se za vrijeme oblikovanja tog teksta uočava svojevrsna evolucija, konačna je verzija u mnogim elementima slična shemi koju je na početku izradilo Tajništvo. Mills kaže da nijedan drugi koncilski tekst nije toliko obilježen pretkoncilskom slikom Crkve kao taj, a Sander kaže da se u njemu pokazuje u kojoj je mjeri pretkoncilsko vrijeme bilo u stanju shvatiti i integrirati moderni život i medijski posredovanu javnost.“

Govoreći o sredstvima društvenog priopćavanja, dokument kaže: „Majci je Crkvi poznato da ta sredstva, ako se ispravno rabe, pružaju efikasnu pomoć ljudskom rodu jer mnogo doprinose odmoru i naobrazbi duha te širenju i učvršćivanju Božjega kraljevstva; ona također zna da ih ljudi mogu upotrijebiti protiv nauma božanskog Stvoritelja i zlorabiti ih na svoju vlastitu štetu; ona, dapače, osjeća materinsku tjeskobu i bol zbog štete koja je njihova zloporaba prečesto nanijela ljudskom društvu. Stoga ovaj Sveti sabor, slijedeći budnu brigu papa i biskupa u tako važnoj stvari, smatra da mu je dužnost baviti se glavnim pitanjima koja su povezana sa sredstvima društvenog priopćavanja. Uz to se nada da će njegov tako iznesen nauk i upute koristiti ne samo spasenju Kristovih vjernika nego i napretku svega ljudskog društva“" (IM, br. 2). 
Dokument ističe da mediji zapravo pružaju „efikasnu pomoć ljudskom rodu“, ali ne tvrdi to čine bezuvjetno i u svakom slučaju, već jasno navodi uvjet - „ako se ispravno rabe“. Iz konteksta je jasno da se ovdje ne misli na tehničke aspekte upotrebe medija, već prvenstveno, tj. mogli bismo reći i isključivo, na etičke aspekte. Kad dokument navodi da ih čovjek može „upotrijebiti protiv nauma božanskog Stvoritelja i zlorabiti ih na svoju vlastitu štetu“, onda je jasno da se govori o neetičnoj upotrebi medija, što onda dovodi i do korištenja medija na vlastitu štetu, tj. na štetu samoga čovjeka, ne prvenstveno i samo kao pojedinca, već cjelokupne društvene zajednice.

Isti dokument $\mathrm{u}$ tom kontekstu govori i o nužnosti moralnog reda kod onih koji se medijima služe: „Da bi se ta sredstva ispravno rabila, prijeko je potrebno da svi oni koji se njima služe poznaju norme ćudorednoga poretka $\mathrm{i}$ da ih na tom području vjerno provode $u$ djelo. Neka se, dakle, promotriti sadržaj stvari koja se priopćuje, već prema posebnoj naravi svakoga sredstva; u isti mah potrebno je imati pred očima sve prilike ili okolnosti, to jest svrhu, osobe, mjesto, vrijeme i ostalo što dopunjuje samo priopćenje i što njegovu ćudorednu vrijednost može promijeniti ili posve izvrnuti; tu se ubraja način djelovanja koji je vlastit svakom pojedinom sredstvu, tj. snaga njegova utjecaja, koja može biti tolika da je ljudima, pogotovo ako su neiskusni, teško mogu zamijetiti, kritički sagledati i, ako je potrebno, odbaciti“" (IM, br. 4).

Dokument govori da je za ispravnu upotrebu medija (mogli bismo kazati: za etički ispravnu upotrebu) kod korisnika medija (kako dokument navodi: „svi oni koji se medijima služe") potrebno zapravo i poznavanje normi moralnog reda. Dakle, dokument jasno ističe da je potrebno i poznavanje određenih moralnih načela, tj. da nije dovoljno samo imati volju etički ispravno djelovati i služiti se medijima, već je potrebno i upoznati se s osnovnim etičkim načelima.

Ono što je tu naznačio za korisnike medija, kratko nakon toga dokument kao zadaću stavlja i pred one koji se profesionalno bave medijima: „No prije svega je nužno da si svi oni kojima je do toga stalo oblikuju ispravnu savjest o upotrebi tih sredstava, pogotovo u vezi s nekim pitanjima o kojima se u naše vrijeme žestoko raspravlja“ (IM, br. 5).

Za medijsko izvješćivanje naglašava se da mora biti istinito, ali dodaje i neke druge nužne karakteristike: „U ljudskom društvu, dakle, postoji pravo na informaciju o onome što ljudi bilo pojedinačno bilo kao društvo, svaki po svome položaju, trebaju znati. No pravilno služenje tim pravom traži da priopćenje, s obzirom na svoj predmet, uvijek istinito i, uz 
očuvanje pravednosti i ljubavi, cjelovito; osim toga neka je s obzirom na način pošteno i prikladno, tj. da sveto poštuje ćudoredne zakone i zakonita prava i dostojanstvo čovjeka, kako u traženju vijesti tako i u njihovu objavljivanju; ne koristi, naime svako znanje, a ljubav izgrađuje“ (IM, br. 5). Ovdje dokument odmah na početku ističe jedno od temeljnih etičkih načela u medijskom djelovanju, koje se vrlo često ponavlja u različitim dokumentima, a to je potreba da svako medijsko izvještavanje prije svega bude istinito. No, veoma sažeto i kratko ovaj dio Inter mirifice donosi i još neka nužna načela, a to je da se ne naruši pravda i ljubav, te da izvještavanje bude cjelovito (jer, izvještavanje može biti istinito, ali necjelovito, te utoliko zasigurno nije etično, makar je istinito). Također, jasno ističe da je potrebno da se „Sveto poštuje ćudoredne zakone i zakonita prava i dostojanstvo čovjeka“, pri čemu se još jednom naglašava nužnost poštovanja ćudorednih načela, ali ne načela samo radi načela, već se spominjanjem čovjekovog dostojanstva zapravo želi istaknuti da u tome leži i razlog potrebe poštovanja tih zakona. Također, kratkim dijelom rečenice u kojem kaže da „,ne koristi, naime svako znanje“, želi se istaknuti da i nije svako saznanje etički vrijedno objaviti, jer nije svako znanje korisno.

Govoreći o umjetnosti u medijima Drugi vatikanski koncil u ovom dokumentu koristi i pojam objektivnoga ćudorednog poretka: „Drugo se pitanje tiče odnosa između prava umjetnosti, kako kažu, i normi ćudorednoga zakona. Budući da se oko tog predmeta gomilaju rasprave koje često proizlaze iz krivih učenja u etici i estetici, Koncil izjavljuje da se svi trebaju apsolutno držati primata objektivnoga ćudorednog poretka, jer on jedini nadilazi i stavlja u pravilan suodnos sve druge ljudske redove, ne izuzevši ni red umjetnosti, bez obzira koliko oni bili vrijedni. Samo ćudoredni poredak zahvaća čovjeka - razumno stvorenje Božje pozvano na višnje stvari - u čitavoj njegovoj naravi i dovodi ga, ako se cjelovito i vjerno obdržava, do potpunoga postizanja savršenstva i blaženstva“ (IM, br. 6). Ovaj dio veoma je važan ne samo u kontekstu umjetnosti u medijima, već upravo da bi se lakše shvatilo kako ovaj dokument, a vrlo često i cjelokupno crkveno naučavanje, razumijeva etička načela: postoji objektivan ćudoredni poredak, te se prema tome učenju sve i svatko mora pokoriti tome redu, a to se načelo onda često primjenjuje i u etičkom promišljanju medija. Dakako, ovo se stajalište ne može promatrati samo na negativan način i kao svojevrsno ograničenje, jer suprotnost ovom gledanju bio bi etički relativizam koji u potpunosti odbacuje bilo kakav objektivan ćudoredni poredak, te je mnogo pogubniji za etičko promišljanje medija. No, nužno je ujedno razmisliti i o mogućim nedostacima navedenog crkvenog shvaćanja 
objektivnog ćudorednog poretka s jedne strane, a svakako da je još važnije shvatiti i očite nedostatke etičkog relativizma s druge strane.

Inter mirifica nastavlja: „Napokon, izvještavanje o ćudorednom zlu i njegovo opisivanje ili prikazivanje mogu, istina, i pomoću sredstava društvenog priopćavanja poslužiti da čovjek sebe dublje upozna i istraži, da se na svjetlo iznese i uzvisi veličina istine i dobrote, pri čemu se postižu prikladniji dramatski učinci; no ipak svime time moraju vladati ćudoredni zakoni kako se dušama ne bi nanijelo više štete nego koristi, pogotovo ako je riječ o stvarima koje zahtijevaju dužno poštovanje ili koje čovjeka ranjena istočnim grijehom lakše podražuju na opake strasti“ (IM, br. 7). Ovdje dokument ističe da kada se i govori o moralnom zlu u medijima, mora se paziti na koji se način to radi, kako od toga ne bi bilo više etičke štete, nego koristi za čovjeka pojedinca.

U dokumentu se upozorava i na moralnu odgovornost svih korisnika medija: „Posebne dužnosti obvezuju sve one koji po osobnom i slobodnom izboru primaju priopćenja koja se prenose tim sredstvima, tj. čitatelje, gledatelje i slušatelje. Ispravan izbor, naime, zahtijeva da daju prednost svemu što se odlikuje krjepošću, znanošću i umjetnošću; neka izbjegavaju ono što im prouzročuje duhovnu štetu ili je prilika za nju, što druge može lošim primjerom dovesti u opasnost ili se protivi dobrim oblicima priopćavanja, a pogoduje lošima; to se većinom događa kad je u pitanju plaćanje usluga priređivačima emisija koji ta sredstva rabe samo radi gospodarskih razloga“ (IM, br. 9). Ovo je tema koja se na različite načine obrađuje u različitim crkvenim dokumentima o medijima, no svima je zajedničko snažno isticanje odgovornosti samih korisnika medija, te se od njih zahtjeva etički ispravan izbor.

Dakako, naglašava se odgovornost i onih koji stvaraju (u najširem smislu shvaćeno) medijske sadržaje: „Posebnu ćudorednu obvezu s obzirom na ispravnu upotrebu sredstava društvenog priopćavanja imaju novinari, pisci, glumci, redatelji, producenti, oni koji ulažu novac, distributeri, vlasnici dvorana i prodajni agenti, kritičari i ostali koji na bilo koji način sudjeluju u proizvodnji i prijenosu onoga što se priopćuje; naime, sasvim je jasno koje i kolike odgovornosti svi oni snose u prilikama u kojima se danas ljudi nalaze, jer oni mogu informirajući i utječući povesti ljudski rod na pravi put ili u propast. Stoga će njihova dužnost biti da gospodarske ili političke, ili umjetničke interese tako usklade da se nikada ne protive zajedničkom dobru; da bi to lakše postigli, pohvalno je da pristupe svojim profesionalnim udruženjima koja će svoje članove - ako je potrebno učinivši ugovor o držanju moralnoga kodeksa - obvezati da poštuju ćudoredne zakone u poslovima i dužnostima svoga umijeća. 
Neka im uvijek bude na pameti da se velik dio čitatelja i gledatelja sastoji od mladih, kojima su potrebni tisak i predstave što pružaju moralno ispravnu zabavu te privlače duhove $\mathrm{k}$ uzvišenijim idealima. Neka se, osim toga, pobrinu da priopćivanja koja se tiču religije povjere na obradu čestitim i stručnim osobama i da se izvedu s dužnim poštovanjem“ (IM, br. 11). Ovdje dokument izrazito snažno ističe odgovornost onih koji stvaraju medijske sadržaje, te to možda čini snažnije nego u ijednom drugom dokumentu, jer navodi da „oni mogu informirajući i utječući povesti ljudski rod na pravi put ili u propast“, a ako je netko svojim djelovanjem sposoban ljudski rod povesti na pravi put ili u propast, njegova odgovornost je očigledno izrazito velika. Ističe se važnost i udruženja novinara, kao i njihovih etičkih kodeksa, no u ovom ulomku dokumenta sve ostalo ostaje u sjeni one snažno naglašene odgovornosti medijskih djelatnika.

U tom se kontekstu ističe i važnost državne (civilne) vlasti: „Građanka je vlast u toj stvari obvezana posebnim dužnostima radi zajedničkog dobra kojemu su ta sredstva namijenjena. Ta vlast mora u skladu sa svojom zadaćom braniti i osigurati istinsku i pravednu slobodu informiranja, koje je današnjem društvu bezuvjetno potrebno za njegov napredak, osobito što se tiče tiska; treba gajiti religiju, kulturu i lijepe umjetnosti; primatelje onoga što se priopćuje treba zaštititi da se mogu slobodno služiti svojim legitimnim pravima. Osim toga dužnost je civilne vlasti podupirati sve one inicijative koje se - premda su od najveće koristi, osobito za mladež - inače ne bi mogle ostvariti. Napokon, ta ista javna vlast, koja se legitimno skrbi za dobro građana, donošenjem i marnom provedbom zakona dužna je pravedno se i budno skrbiti da zbog loše upotrebe tih sredstava ne dođe do velikih opasnosti za javno ćudoređe i napredak društva. Takvom budnom skrbi neće biti povrijeđena sloboda pojedinca i udruga, pogotovo kada bi nedostajalo sigurno jamstvo od strane onih koji su preuzeli zadaću da se služe tim sredstvima. Posebno neka se pazi da se mladež zaštiti od tiska i predstava koje su štetne njihovoj dobi“ (IM, br. 12). Očito je da dokument ističe važnost državne, to jest javne vlasti, te nužnost zakonske i svake druge regulative kako bi se osiguralo (etički) ispravno djelovanje medija u društvu. Jasno je da onda iz toga proizlazi i velika odgovornost državne vlasti. No, postaje upitno je li ta uloga nepotrebno suviše naglašena, te može li prerasti u kontrolu medija od strane civilne vlasti? Crkveni oci koji su na Koncilu izrazili svoje neslaganje s ovim dokumentom, kao što je već navedeno, prigovarali su, između ostalog, i na ovaj dio dokumenta, a ne može se kazati da je njihov prigovor potpuno neopravdan. 
Govoreći o autorima medijskih sadržaja, dokument još jednom ističe: „Neka se pouče i potiču da donose takve sudove u kojima će uvijek biti osvijetljen i ćudoredan vidik stvari““ (IM, br. 15). Ovdje se zapravo naglašava i važnost obrazovanja za etiku, jer se zahtijeva da se medijske djelatnike „pouči“, što još jednom naglašava da je potrebno „učiti“ kako etički ispravno djelovati.

\subsection{Postkoncilski smjer Katoličke Crkve i njezinog odnosa prema medijima}

\subsubsection{Magna carta nauka Crkve o medijima - Communio et progressio (1971)}

Communio et progressio $(\mathrm{CP})^{6}$ je pastoralni naputak Papinskog vijeća za sredstva društvenog priopćavanja izdan 1971. godine u vrijeme pontifikata pape Pavla VI. Kako navodi Valković (2013: 48) za taj dokument „se može reći da je 'nastavak' koncilskog dekreta Inter mirifica, budući da je već u njemu bilo naloženo da se izda pastoralna instrukcija“. I sam pastoralni naputak se poziva na duh cjelokupnog Drugog vatikanskog koncila, ne fokusirajući se samo na Inter mirificu: „O punijem pak shvaćanju i oštroumnijem razabiranju društvenog priopćivanja, a prema tome i o ulozi njegovih sredstava za boljitak današnjeg društva, govori nekoliko dokumenata II. vatikanskog koncila, prvenstveno Konstitucija o Crkvi u suvremenom svijetu, zatim Dekret o ekumenizmu, Deklaracija o vjerskoj slobodi, Dekret o misijskoj djelatnosti Crkve, Dekret o pastirskoj službi biskupa u Crkvi, a navlastito dekret koji se sav bavi pitanjem sredstava društvenog priopćavanja“ (CP, br. 2). Enrico Baragli (1971: 47-48, prema Valković, 2013: 59) smatra da je taj tekst zapravo magna carta kada je riječ o nauku Crkve o medijima. Kao i većina drugih crkvenih dokumenata o medijima, i Communio et progressio ostaje dosta apstraktan, što se priznaje na početku dokumenta: „Ova pastirska uputa, koja se izdaje po nalogu Koncila, općenito izlaže doktrinarna načela i pastoralne savjete; ona ispušta što je pojedinačno i podrobno, jer neprekidna mijena i napredak ne daju da se to pobliže odredi osim prema posebnim okolnostima mjesta i vremena" (CP, br. 3). Iz toga, nažalost, proizlazi da i govor o etičkim pitanjima na neki način i u određenom dijelu ostaje upravo u sferi apstraktnog, tj. nedovoljno konkretnog.

Ipak, Communio et progressio ima veliku vrijednost. Ovaj dokument izravno ili neizravno progovara o mnogim temama medijske etike. Već u br. 6. navodi da načela koja prema kršćanskom moralu vrijede za ljudski suživot, vrijede i na području medija: „Sredstva

\footnotetext{
${ }^{6}$ Korišten je službeni prijevod na hrvatski jezik: Communio et progressio (2002), Zagreb, Kršćanska sadašnjost
} 
društvenog priopćavanja, mada se priopćivatelji njima obraćaju pojedincima, ipak dohvaćaju i pokreću svekoliko ljudsko društvo; te golemu broju ljudi hitro donose saznanja o životu u današnjem svijetu, ona iznose na vidjelo ono što naše vrijeme osjeća i misli. Svakako ih dakle valja smatrati prijeko potrebnima za duboke i sve zamršenije odnose i pothvate našeg društva. Stoga se i na njih protežu načela koja prema kršćanskom gledanju vrijede za ljudsko suživljenje.“ Dakako, kao i svaka primijenjena etika, teološka medijske etika ima određene specifičnosti u odnosu na područje kojim se bavi, no u biti to ostaju ona etička načela koja Crkva primjenjuje i u drugim područjima.

Mediji po svojoj biti, a posebno suvremeni mediji, trebali bi pridonositi što većem zbližavanju i povezivanju ljudi. No, istodobno zna se dogoditi i suprotno, o čemu govori i ovaj dokument: „Sredstva društvenog priopćivanja doista mogu silno pridonijeti međuljudskoj povezanosti; pa ipak, ako duhove i srca sputava neznanje ili ako ponestane dobronamjernosti, ona su kadra proizvesti upravo suprotno: to da se ljudi među sobom manje razumiju, i da poraste njihova nesloga; a u tome se korijeni nebrojeno zala. Ta i suviše često doživljavamo gdje ta sredstva poriču ili izopačuju najprječe vrednote ljudskog života, a po tim izopakama kršćaninov razum zaključuje da je zaista prije potrebno izbaviti i istrgnuti čovjeka iz grijeha što je u povijest ljudskog roda nadro uslijed najprvog pada“ (CP, br. 9). Iako koristi i neke teološke elemente i razmišljanje, ovdje je moguće izvući i etičko načelo koje izlazi iz okvira teološkog promišljanja, a to je da mediji postupajući etički ispravno ne bi trebali pridonositi razjedinjavanju ljudi, već upravo zbližavanju.

Dokument progovara i o ćudorednim, to jest moralnim i etičkim načelima prilikom upotrebne medija: „Čovjek je sam utvrdio način uporabe izuma za priopćivanje, pa će se $\mathrm{i}$ ćudoredna načela za tu uporabu također graditi na poštivanju dostojanstva čovjeka koji zazbilja mora postati dionik zajedništva Božjih posinaka“ (CP, br. 14). Nadalje, naglašava se i da u tome treba promatrati cjelovitog čovjeka: „Tko god dakle htjedne sredstva priopćivanja i njihovu uporabu ispravno smjestiti u povijest stvaranja i otkupiteljskog utjelovljenja i prosuditi njihovu ćudorednu vrijednost, nužno mora uzeti u obzir čitava čovjeka, prethodno stubokom proniknuvši društvenu narav priopćivanja i njegovih sredstava“ (CP, br. 15). Ono što dokument ovdje naglašava činjenica je da $u$ primjeni etičkih načela treba promatrati čovjekovo dostojanstvo i čovjeka u njegovoj cjelini. Riječ je ovdje o obuhvatnoj i antropološki fundiranoj primjeni etičkih načela koja je itekako potrebna u suvremenoj medijskoj etici. 
Kao i u mnogim drugim dokumentima o medijima, izričito se naglašava važnost istinitosti, no ovdje ju se još dodatno stavlja u odnos s nepatvorenošću i poštenjem: „Svaki priopćaj nužno mora biti prije svega nepatvoren, pošten i istinit. Nije dakle dovoljna dobronamjernost $\mathrm{i}$ ispravna nakana, pa da priopćaj bude odmah čestit; potrebno je osim toga da priopćaj po istini iznosi samu stvarnost; to jest da donosi pravu sliku o stanju stvari i da se odlikuje vlastitom, nutarnjom istinitošću. Zasluženost i ćudoredna odlika nekog priopćenja ne proizlazi samo iz njegova sadržaja niti iz same načelne poruke koja je u nj stavljena, nego i iz načina priopćivanja, iz načina i sredstva govora i uvjeravanja, iz popratnih okolnosti, iz same one množine ljudi kojima se priopćaj upravlja“ (CP, br. 17). Ovdje možemo vidjeti da ono što se u kršćanskoj moralnoj teologiji naglašava, a riječ je o ispravnoj nakani, u odnosu na medije koje dolaze do širokog kruga ljudi, nije dovoljno. Naime, bez obzira na možda i dobronamjernost i ispravnu nakanu, ako istovremeno ne prenosi istinu, u svijetu medija riječ je o nečemu etičkom potpuno neprihvatljivom. Iako je to na određen način prisutno i u interpersonalnoj komunikaciji, očito je da ovaj pastoralni naputak u sredstvima društvenog priopćavanja na to stavlja veći naglasak, što je i logično s obzirom na izraženu društvenu odgovornost medija.

Dokument, iako pokušava dati i određene odgovore, istovremeno i postavlja neka etička pitanja na koja ne daje odgovore, barem ne izravno, već prepušta samom čitatelju da on pokuša doći do odgovora: „Poznato je da su sredstva društvenog priopćivanja po svojoj naravi namijenjena širokom neodređenom sloju ljudi i, kako bi izbjegla da naškode interesima mnogih primalaca, često zauzimaju neodređen stav, pa je pitanje kako će se u tom slučaju moći u pluralističkom društvu razlikovati istinito od lažnoga, pošteno od nepoštenog? Kako izbjeći u sustavu slobodne konkurencije da javnost prisili ili spriječi ta sredstva da izazivaju ili raspaljuju ne tako plemenite i poštene težnje ljudske naravi? Kako spriječiti da tek mali broj ljudi ne zagospodari tim sredstvima, da se tako u društvu uguši istinski dijalog $\mathrm{i}$ zajedništvo? Kakva pomagala primijeniti da se u priopćivanju pomoću ovih tehničkih sredstava, a osobito preko televizije, ne povrijede ljudski odnosi? Budući da ona često pozivaju čovjeka da kao u nekom snu izađe iz granica realnosti, što se dade učiniti da on u svakom svagdašnjem djelovanju ne zanemari svoje životne zadatke? Kako će se moći spriječiti da ljudi ne upadnu u dokolicu i ne zahvati ih lijenost duha? Naposljetku, što poduzeti da pretjerano i trajno draškanje osjećaja ne spriječi djelovanje razuma?“ (CP, br. 21). Riječ je o pitanjima koja su aktualna pitanja i svjetovne medijske etike, te ni ona ne pronalazi jednostavno odgovore na njih. No, veoma je vrijedno u crkvenim dokumentima ponekad 
primijetiti i pitanja bez odgovora, jer upravo to pokazuje i otvorenost, pokazuje stav koji govori da Crkva ne zna i ne može ponuditi odgovore na sva pitanja, već da se odgovori traže u međusobnoj komunikaciji, jer takvi odgovori su vjerodostojniji od odgovora koji dolaze samo iz jednog izvora. Može se kazati da bi bilo dobro kad bi u crkvenim dokumentima o medijima bilo i više neodgovorenih pitanja, jer ponekad je i postavljanje dobrog pitanja velik korak prema rješenju.

Promjene koje su vidljive u društvu jasno se ocrtavaju i u svijetu medija, što potvrđuje i ovaj dokument: „Opadanje moralnih normi, što se zapaža na mnogim područjima suvremenog života, zabrinjava i na srcu je svim ljudima dobre volje; znakovi te promjene opažaju se u svim sredstvima društvenoga priopćivanja. Možemo dakako raspravljati koja je u tome krivnja tih sredstava“ (CP, br. 22). Također, mora se istaknuti da dokument ni ovdje ne daje konačan odgovor, ne tvrdi kategorički da krivnja za te negativne promjene u većoj ili manjoj mjeri leži na medijima, već to pitanje ostavlja otvorenim za raspravu.

Dokument progovara i o pravu na slobodu misli, kao i o pravu na primanje i davanje informacija za koja naglašava da su nerazdvojna, nakon čega nastavlja: „Ivan XXIII., Pavao VI. i Drugi vatikanski koncil jasno i izričito su potvrdili to pravo na informacije koje je nužno za život i razvoj pojedinca i suvremenog društva“ (CP, br. 33). Ističe se i kako je potrebno da „suvremeni čovjek bude ispravno, prikladno, potpuno i vjerno obaviješten kako bi ponajprije shvatio svijet koji se neprestano razvija“ (CP, br. 34). Kako to pravo ne bi ostalo samo načelno, dokument nastavlja: „Stoga na raspolaganju trebaju biti raznovrsna sredstva kako bi [suvremeni čovjek] mogao izabrati ona, koja više odgovaraju njegovim osobnim i društvenim zahtjevima. Ako nema te mogućnosti izbora različitih sredstava priopćivanja, to pravo ostaje samo na papiru“ (CP, br. 34). Ističe se i kako pitanje informiranja nije stvar pojedinaca: „Stoga se pravo na informacije ne može danas ograničiti na individualno područje već je zahtjev općeg dobra“(CP, br. 35).

Communio et progressio progovara i o jednom veoma aktualnom pitanju, a riječ je o sigurnosti novinara, te nasilju prema njima. Nakon što navodi da mnogi novinari prilikom izvještavanja čak i pogibaju, dokument kaže: „Crkva osuđuje i zabacuje svako nasilje protiv takvih osoba i protiv onih koji djeluju na području društvenog priopćavanja. Oni, naime, tragajući za vijestima i vjerno ih drugima prenoseći, brane i pomiču temeljno čovjekovo pravo na informaciju“ (CP, br. 36). Istovremeno, dok ih hvali, ističe da postoje i novinari koji nisu stručni: „Budući da sredstva priopćivanja po svojoj naravi često zahtijevaju neposredno vijesti 
i tumačenja, često se događa da ih iznose nedovoljno pripravljeni i nestručni izvjestitelji koji se toga posla olako prihvaćaju“ (CP, br. 38). Ističe još jednu poteškoću: „Druga teškoća proizlazi iz činjenice što vijesti, žele li biti svježe i privući pozornost naroda, moraju se što je moguće brže donijeti. To ujedno traži da se njihovo dobivanje plati. Tako se događa da ta neophodna brzina u prenošenju vijesti znade biti zapreka same točnosti. (...) U takvim prilikama izvjestitelji donoseći vijesti moraju paziti da naročito poštuju istinu“ (CP, br. 39). Ovaj dokument, kao i ostali crkveni dokumenti, pokušava donijeti uvijek dvije strane medalje, te valja istaknuti da ne donosi samo pohvalu ili samo kritiku u odnosu na novinare, već pokušava što objektivnije promotriti medijsku zbilju.

Dokument progovara i o pravima korisnika medija koji su pozvani na aktivnu ulogu u cijelom tom procesu: „Nadalje primatelji vijesti trebaju shvatiti položaj ljudi koji po svojoj dužnosti i po svom zvanju izvješćuju te ne smiju od njih očekivati neko savršenstvo koje nadilazi ljudske sile, ipak imaju pravo i dužnost tražiti da se lažne i zlonamjerne vijesti što prije javno opovrgnu, zahtijevati da se upotpune pojedinosti koje su izostavljene, žaliti se svaki put kad sredstva društvenog priopćivanja iskrivljuju činjenice stavljajući ih izvan njihova konteksta te protestirati kad se one pretjeraju ili im se ne daje važnost koju imaju“ (CP, br. 41).

Iako više puta i na više načina dokument ističe pravo pojedinca i društva u cjelini na informacije, ipak pod etičkim vidikom ne smatra to pravo apsolutnim, već postavlja i neke granice: „Pravo na informaciju ima svoje određene granice i ne smije doći u sukob s drugim pravima kao što su pravo na istinu koje štiti dobar glas pojedinca i društva, pravo na privatan život koje štiti intimnost obitelji i pojedinih ljudi; pravo na tajnu kad to zahtijeva potreba, profesionalna služba ili samo javno dobro. Kad je u pitanju opće dobro valja veoma razborito i trijezno prenositi vijesti“ (CP, br. 42). Također, dokument ističe još neka ograničenja: „Kad se okrutni i nasilni događaji opisuju i iznose, valja postupiti krajnje razborito i obazrivo. (...) Ako se pak ti okrutni događaji opisuju češće nego je potrebno te se popraćuju odveć realističkim slikama, nastaje opasnost da se iskrivi prava slika i stvarni uvjeti ljudskog života“ (CP, br. 43).

Dokument nije zaobišao ni temu odnosa reklama, tj. oglašavanja, promidžbe i medija koju promatra s više vidika i obrađuje na više načina: „Ako se pak reklamiraju štetni i nekorisni proizvodi, ako se o prodajnim predmetima iznose krive tvrdnje, ako se zloupotrebljavaju niži čovjekovi porivi, tada oni koji su odgovorni za reklamu nanose štetu 
društvu te gube povjerenje i reputaciju. Nadalje, pojedincima i obiteljima nanosi se šteta kad se stvaraju lažne potrebe, kad se stalno nastoji progurati u prodaju preraskošne stvari te tako dovodi u opasnost da kupac sebi ne nabavi nužno potrebno. Naročito valja izbjegavati reklamu koja bestidno zloupotrebljava seks za stjecanje novca ili prodire u podsvijest čovjekova duha te u opasnost dovodi i samu slobodu kupaca. Zbog toga oni koji prave reklame moraju sebi odrediti nužne granice da ne bi sama komercijalnost povrijedila ljudsko dostojanstvo i nepravdu nanijela društvu“ (CP, br. 60).

Iako ne koristi taj termin, Communio et progressio progovara i o potrebi „odgoja za medije“, što je također na određen način etičko pitanje: „Neophodno je da svi ljudi poprime izobrazbu kako bi shvatili osnovna načela o korištenju sredstava društvenog priopćivanja u društvu. (...) Sredstva društvenog priopćivanja intelektualno i moralno obogaćuju čovjeka jedino ako oni valjano shvaćaju njihovu narav i djelovanje. (...) Ta izobrazba treba dakle sadržavati jasan i točan opis osnovnih značajki pojedinih sredstava priopćivanja, zatim opis njihove uloge i raširenosti u pojedinim krajevima te konačno upute o njihovoj ispravnoj primjeni“ (CP, br. 64). Pod „ispravnom primjenom“ neprijeporno se misli na etičku dimenziju. Dakako, posebno se osvrće na djecu i mlade u pogledu tog odgoja: „Nikad nije prerano kod mladeži odgajati i stvarati smisao za umjetnost, kritički sud, svijest moralne dužnosti o izboru štiva, kinopredstava i radiotelevizijskih programa, jer su dječaci i mladež po sebi na tom području ranjiviji, a ujedno će im navika na samokontrolu što je steknu u mladosti biti od koristi čitava njihova života. (...) Neka stoga roditelji i odgojitelji potiču i usmjeruju mladež da sami ocjenjuju i izabiru sredstva priopćivanja, premda će koji put biti neophodno da sebi pridrže konačni sud pri tom izboru. Ako koji put budu smatrali neophodnim da donesu protivan sud i suprotstave se izboru sredstava priopćivanja svoje djece, neka uvijek nastoje jasno iznijeti svoje razloge. Više naime postižemo uvjeravanjem nego zabranom, naročito $u$ odgoju“ (CP, br. 67).

Naglašava se da medijski djelatnici sve svoje snage trebaju uložiti u službu čovjeka: „Priopćavatelji moraju biti pripravljeni ne samo tehnički, već i kulturno. Budući da su sredstva priopćavanja u službi ljudskog roda, priopćavatelji moraju sve svoje sile uložiti u službu čovjeka. Tu službu će pak moći valjano vršiti samo oni koji nastoje shvatiti i istinski ljubiti čovjeka“ (CP, br. 72). Nadalje, ističe se da se ne smije tražiti samo komercijalni i ekonomski uspjeh, ne samo iz etičkih razloga, već i čisto praktičnih: „Priopćavatelji koji svoje programe osiromašuju tražeći komercijalni i ekonomski uspjeh te površnu i kratkotrajnu 
popularnost, ne samo da čine lošu uslugu svojim klijentima već će prije ili kasnije samo izgubiti na svome ugledu i profesionalnom dostojanstvu“ (CP, br. 77).

Potiče se medijske djelatnike i na udruživanje, kako bi u zajedništvu došli do odgovora u susretu s teškoćama povezanih s njihovim pozivom, a iz čega bi se mogli roditi i moralni kodeksi: „Da bi priopćavatelji što bolje prevladali teškoće povezane sa svojim pozivom, neka se udružuju kako bi što bolje produbili svoju kulturu, međusobno izmjenjivali misli i zajednički surađivali. Tako udruženi moći će korisno raditi na sastavljanju moralnog kodeksa zasnovanog na čvrstim doktrinarnim temeljima i na poznavanju stvari. U tom kodeksu neka budu iznesena etička načela o profesionalnim dužnostima priopćavatelja usklađena s općim zahtjevima društvenog priopćivanja. Ta pak načela i pravila neka se više nadahnjuju pozitivnim negoli negativnim stajalištima te neka ne iznose jedino negativnosti koje valja izbjegavati već donose i konkretne smjernice za što uspješniju službu ljudskom društvu“ (CP, br. 79). Također, uz slobodu medija, naglašava se i potreba svijesti o odgovornosti: „Na opću je korist obrana slobode priopćivanja i osiguranja potrebnih uvjeta da svi oni koji rade u društvenom priopćivanju budu svjesni svojih odgovornosti, poštuju ljudsku osobnost i traže dobro svoje zemlje i svih naroda" (CP, br. 84).

Dokument se dotiče i pitanja utjecaja građanskih vlasti i njihovog donošenja zakonskih odredbi: „Građanske bi vlasti na tom području trebale donijeti više pozitivne negoli negativne smjernice. Nije naime njihova zadaća da koče i potiskuju, premda će katkada biti neophodno upotrijebiti i prisilne mjere. II. vatikanski koncil ističe da ljudsku slobodu treba svim silama poštivati i braniti i da je treba ograničiti jedino kad to traži opće dobro. Stoga se cenzura smije primijeniti jedino u krajnjim slučajevima“ (CP, br. 86). Ovdje je vidljiva jasna evolucija stavova u odnosu na prve crkvene dokumente o medijima, u kojima je prevladavao stav o cenzuri kao nečem potrebnom i vrijednom, dok se ovdje o cenzuri govori kao negativnoj, a prihvatljivoj samo u krajnjim slučajevima. Nekoliko poglavlja nakon ovoga, također se govori o zakonskim propisima, no sada posebno u odnosu na mlade: „Zakonski propisi trebaju, koliko je to u njihovoj moći, obraniti mladež od teških posljedica psihološke i moralne naravi koje im mogu nanijeti određeni programi a koji mogu imati trajan koban utjecaj“" (CP, br. 89).

Pozivajući se na papu Pavla VI. i njegovo inzistiranje na potrebu pomaganja razvijenijih naroda onima manje razvijenim, dokument to proteže i na područje medija, no istovremeno naglašava potrebu poštivanja etičkih predaja tih naroda: „Ta pomoć drugim 
narodima mora pridonijeti da se kod njih sačuvaju i učvrste njihove etičke predaje, njihova kultura, jezično i umjetničko blago što je od velikog značenja za njih. Ta se dakle suradnja ne smije shvatiti samo kao neka milostinja već kao izmjena vrednota za obostrano obogaćenje“ (CP, br. 94).

Ono što kroz čitav dokument čini, Papinsko vijeće u jednoj rečenici jasno i ističe: „Crkva, promatrajući svoju zadaću na tom području, nastoji spojiti katoličku nauku s nutarnjim zakonima društvenog priopćivanja“"(CP, br. 101).

Jasno se naglašava, kao i u mnogim drugim prilikama, važnost poštivanja dostojanstva osobe: „Crkva svojom duhovnom službom ponajpače nastoji da se jasno ispitaju i brižno poštuju temeljni zakoni priopćivanja a ujedno želi da se dostojanstvo osobe, bilo priopćavatelja bilo primatelja, priznaje u svim njezinim oblicima i da se s njome postupa sa svim poštovanjem kako bi priopćivanje kojim ljudi jedni drugima postaju bližnji preraslo uistinu u pravo zajedništvo“ (CP, br. 102).

Papinsko vijeće kao da sebi, ali i cijeloj Crkvi, daje i određenu zadaću za budućnost: „Teoretska i praktična rasprava o društvenom priopćivanju treba biti predmet i teoloških disciplina, naročito moralke i pastorala, a u bitnim značajkama o njemu valja nešto reći i u samoj katehizaciji“ (CP, br. 108).

Dokument daje poticaj pojedinim crkvenim strukturama i za konkretnije kritičke osvrte na medijske programe: „Kritički osvrti na radiotelevizijske programe, filmove, mogu biti od velike pomoći za kulturno i religiozno obrazovanje a osobito za odgoj kritičkog osjećaja u obitelji pri izboru i upotrebi sredstava priopćivanja. Na tom području valja posebno poštivati i slijediti autoritativne sudove koje u pojedinim krajevima nalogom biskupa daju posebna tijela ili ustanove u vezi s važnošću, korišću, moralnošću i kršćanskim vrednovanjem filma, radiotelevizijskih emisija i časopisima“ (CP, br. 112).

\subsubsection{Odgovornost za medijske sadržaje - Aetatis novae (1992)}

Papinsko vijeće za sredstva društvenih komunikacija objavilo je 1992. godine dokument Aetatis novae $(\mathrm{AN})^{7}$, a povod je bila 20. obljetnica naputka Communio et progressio što je vidljivo i u samom podnaslovu: „O društvenoj komunikaciji dvadeset godina

\footnotetext{
${ }^{7}$ Korišten je službeni prijevod na hrvatski jezik: Nadolaskom novog doba. Aetatis Novae (1998), Zagreb, Kršćanska sadašnjost
} 
nakon Communio et progressio“. No, Valković (2013: 65), kao i mnogi drugi autori, smatra da ovaj dokument nije dosegnuo značenje i snagu Communio et progressio o čijoj je dvadesetoj obljetnici objavljen. Cijeli dokument posvećen je tematici medija, te se bavi i područjem medijske etike.

Na samom početku dokumenta progovara se o odgovornosti za sadržaje plasirane kroz medije, usmjerenosti prema profitu i neetičnoj propagandi, pri čemu se u prvome redu misli na oglašavanje, to jest reklame: „U praksi se, često posve službeno, omalovažava javna odgovornost za upotrebu eterskih valova. Postoji sklonost da se uspjeh ocjenjuje prema dohotku, a ne prema usluzi. Profiterstvo i interesi propagandnih stručnjaka nedopustivo utječu na sadržaj sredstava priopćavanja: više se cijeni popularnost nego kakvoća, te se nameće najmanji zajednički nazivnik. Stručnjaci za reklame protupravno prelaze granice svoje uloge, koja se sastoji u tom da uoče stvarne potrebe i da im odgovore, te se trude, tjerani pohlepom za dobitkom, da proizvedu umjetne potrebe i uzore za potrošača“ (AN, br. 5). Čini se da je dokument odmah na početku „oštar“ prema određenim pojavama u svijetu suvremene masovne komunikacije, te ih dokument nedvosmisleno i s velikim pravom osuđuje. Na prvom mjestu naglašava upravo nedostatak odgovornosti za medijske sadržaje, a iz čega onda proizlaze i ostale neetične situacije. Čini se da se na određen način čak i preoštro osuđuje težnja za popularnošću i profitom, koji su zapravo legitimni čimbenici novinarstva, samo problem nastaje u trenutku kada postaju glavni i gotovo jedini čimbenik, a dokument nedovoljno jasno razlikuje te dvije stvarnosti koje nisu identične.

$\mathrm{U}$ istom broju, kao i kad je riječ o prethodnim temama, dokument progovara i o državnim zakonima koji iako su nužni, mogu postati sredstva pritiska i isključivanja: „Mora se upozoriti da usprkos tomu što se sada uočljivo poboljšava pravno politički okvir u kojem djeluju sredstva priopćavanja nekih zemalja, ipak ima drugih krajeva gdje su zahvati vlade još uvijek sredstvo tlačenja i isključivanja“ (AN, br. 5). Naime, dokument pohvaljuje uplitanje države na način donošenja određenih normi koje pridonose većoj odgovornosti, no istovremeno kritizira kada to uplitanje države postaje „sredstvo pritiska ${ }^{8}$ i isključivanja“, što je posve opravdana kritika, te se može ustvrditi da dokument ispravno postupa kada traži srednji put između potpunog nadzora od strane države kao jedne krajnosti, i prepuštanja stihiji i nereguliranju osnovnih zakonskih odredbi o medijima kao druge krajnosti.

\footnotetext{
${ }^{8}$ U službenom prijevodu je ,tlačenja“, no prikladnije i točnije je prevesti riječju ,,pritiska“.
} 
Dokument ističe i dvije strane medija - i ono što je dobro i ono što je loše: „Uza sve dobro što ga čine i za što su sposobna, sredstva javnog priopćavanja, koja su kadra biti toliko djelotvornim oruđem jedinstva i razumijevanja, mogu katkad postati i oruđem iskrivljenog pogleda na život, na obitelj, na religiju i na moral - pogleda koji ne poštuje istinsko dostojanstvo i određenje ljudske osobe. Hitno je potrebno da mediji poštuju cjelovit razvoj ljudske osobe, koji obuhvaća kulturnu, transcendentnu i religioznu dimenziju čovjeka i društva, i da mu pridonose“ (AN, br. 7).

U ovome kontekstu želimo istaknuti da Crkva u svojim dokumentima kod donošenja nekih etičkih smjernica, može ostaviti dojam da se postavlja ,iznad“ drugih etičkih pravaca i prijedloga., kao ona koja ima pravo određivati što i kako treba biti. U ovom dokumentu Crkva uspješno izmiče toj mogućnosti naglašavajući da nema pravo sebi svojatati pravo nametanja odluka i izbora, već samo pomoći, donoseći etičke moralne kriterije: „Kako je već bilo rečeno, tehnologija komunikacija predstavlja čudesan izraz ljudskog duha, a sredstva priopćavanja od znatne su koristi za društvo. No isto tako smo naglasili da je primjena komunikacijske tehnike samo dijelom bila blagotvorna, te njena svjesna upotreba zahtijeva zdrave vrijednosti i mudre odluke od pojedinaca, od privatnog sektora, od vlada i svekolikog društva. Crkva sebi ne svojata pravo da nameće te odluke i te izbore, nego nastoji pružiti stvarnu pomoć iznoseći etičke i moralne kriterije koji vrijede za to područje, kriterije koje nalazimo i u ljudskim i u kršćanskim vrijednostima“ (AN, br. 12).

Ovaj dokument se pokušava uhvatiti u koštac i s nekim sasvim konkretnim pitanjima medijske etike, te kaže: „Jasno je da su mnogi dotični problemi posljedice politike i posebne strukture sredstava javnog priopćavanja: da nabrajamo ovdje kao primjere isključivanje nekih skupina ili klasa od pristupa ${ }^{9}$ sredstvima komunikacije, sustavno ograničavanje temeljnog prava na informaciju koje se tu i tamo prakticira, sve češći slučaj da elite gospodarstva, politike i društva naširoko vladaju sredstvima komuniciranja. Sve je to suprotno temeljnim ciljevima i samoj naravi društvenih sredstava komuniciranja“" (AN, br. 14). I u idućem poglavlju dokument također ističe: „Neprihvatljivo je da ostvarivanje slobode komunikacije ovisi od bogatstva, od odgoja ili od političke moći. Pravo na komunikaciju pravo je svih“ (AN, br. 15).

Ovim dokumentom Crkva je sebi ujedno zadala i određene zadaće: „Rad na sredstvima priopćavanja donosi posebne društvene pritiske i etička pitanja. (...) To nameće

\footnotetext{
${ }^{9}$ U službenom prijevodu je ,prilaza“, no prikladnije i točnije je prevesti riječju „pristupa“.
} 
Crkvi posebnu odgovornost koja zahtijeva da se razrade pastoralni programi posvema prilagođeni posebnim radnim uvjetima i etičkim izazovima pred kojima se nalaze komunikacijski profesionalci; pastoralni programi kadri da zajamče permanentni odgoj koji će moći pomoći tim muževima i ženama - od kojih mnogi iskreno žele znati i činiti što je pravo na etičkom i moralnom polju - da budu sve više prožeti moralnim normama u svom profesionalnom i privatnom životu“ (AN, br. 19). Čini se bitnim ovdje primijetiti da iako želi dati određene smjernice, one nipošto nisu nametanje, već se jasno naglašava da se njima samo želi pomoći, dakle u potpunosti ostavljajući pojedincu autonomiju u njegovim dvojbama i etičkim nedoumicama uz pitanja o kojima se govori i uz mogućnost da se prikloni nekim drugim etičkim prijedlozima koji su mu na raspolaganju na društvenoj, znanstvenoj i profesionalnoj razini.

\subsection{Dokumenti koji nisu primarno posvećeni tematici medija, ali tu tematiku značajnije obrađuju}

2.5.1. Mediji kao moćna sredstva u evangelizaciji - Evangelii nuntiandi (1975)

Papa Pavao VI. 1975. godine objavio je dokument Evangelii nuntiandi $(\mathrm{EN})^{10} \mathrm{~s}$ podnaslovom: „Apostolski nagovor o evangelizaciji u suvremenom svijetu“. Premda taj dokument nije izravno posvećen tematici medija već evangelizacije, o njemu brojni inozemni i domaći autori navode da je vrlo važan za razumijevanje crkvenoga shvaćanja medija, pa i medijske etike (Mataušić, Valković, Strujić, Balukčić, White, Soukup, itd).

Ponajprije, dokument navodi da bi se Crkva „osjećala krivom pred Gospodinom kad ne bi upotrijebila ta moćna sredstva koja ljudski um svednevice čini još savršenijim. Pomoću njih ona poruku koju čuva 'propovijeda na krovovima'. U tim sredstvima ona nalazi uspješni oblik suvremene propovjedaonice. Zahvaljujući njima ona je u stanju govoriti masama. Upotreba sredstava društvenog priopćavanja uza sve to za evangelizaciju predstavlja trajni izazov: evanđeoska poruka bi preko tih sredstava morala doprijeti do ljudskih mnoštava, ali opet tako da bude kadra taknuti savjest svakog pojedinca, ući u srce svakako kao da je on jedini, sa svime što kao pojedinac ima najosobnije te polučiti pristanak i posve osobno zalaganje“ (EN, 46). Dok tekst o medijima govori da su „moćna sredstva“, te da ih „ljudski

\footnotetext{
${ }^{10}$ Korišten je službeni prijevod na hrvatski jezik: Evangelii Nuntiandi (2000), Zagreb, Kršćanska sadašnjost
} 
um čini još savršenijim“ ponajprije bi se moglo pomisliti na njihovu tehničku dimenziju, no u tom je izričaju implicitno prisutna i etička dimenzija, jer govor o moćnim medijima podrazumijeva i odgovornost za tu moć, a tu se već zalazi u područje etike, budući je govor o medijskoj odgovornosti imanentno etička kategorija. Također, kada se kaže da ti mediji omogućuju govor masama, onda je nužno upozoriti da bi se kod toga obraćanja mogle dogoditi i razne vrste manipulacija masama, što je eminentno etički problem.

\subsubsection{Mediji kao areopag suvremenog društva - Redemptoris missio (1990)}

Encikliku Redemptoris missio $(\mathrm{RM})^{11}$ objavio je 1990. godine papa Ivan Pavao II. Riječ je enciklici koja ne obrađuje pitanje medija, već trajnu vrijednost misijskoga djelovanja i zadaće Crkve u svijetu. U enciklici je riječ o temama prenošenja poruke kršćanstva, te se u sklopu toga između ostalog, obrađuje i pitanje uloge medija u toj vrsti djelovanja. Moglo bi se zaključiti da je u jednom takvom dokumentu teško pronaći i crkveno stajalište o medijima i viđenje medijske etike, no nije nemoguće, što su dokazali i mnogi autori poput Labaša, Vine Mihaljevića, Avery Dullesa, itd.

Najizravnije i najjasnije o medijima dokument progovara u br. 37. gdje navodi: „Prvi areopag današnjeg vremena jest svijet komunikacije, koji ujedinjuje čovječanstvo čineći od njega - kako se često kaže - 'globalno selo'. Društvena priopćajna sredstva postala su tako važna da su za mnoge glavno obavijesno i odgojno sredstvo, vodič i nadahnuće za pojedinačno, obiteljsko i društveno ponašanje. Osobito novi naraštaji žive pod utjecajem sredstava priopćavanja. Taj je areopag možda pomalo zanemaren; općenito se daje prednost drugim sredstvima naviještanja evanđelja i obrazovanju, dok se priopćajna sredstva, massmediji, prepuštaju slobodnom nahođenju pojedinaca ili malih skupina te $\mathrm{u}$ pastoralnom planiranju i zadobivaju drugotno mjesto. Uporabom priopćajnih sredstava ne želi se ipak navještaj samo proširiti: riječ je o dubljoj činjenici da o njihovu utjecaju ovisi većim dijelom sama evangelizacija. Nije dakle dovoljno upotrebljavati ih za širenje kršćanske poruke i crkvenog Učiteljstva, nego samu poruku treba ugraditi u tu 'novu kulturu' koju stvara suvremeno komuniciranje. To je složeno pitanje jer se ta 'nova kultura' rađa, prije negoli iz sadržaja, iz same činjenice da postoje novi načini priopćavanja s novim jezicima, novim tehnikama i novim psihološkim ponašanjima. Moj prethodnik Pavao VI. govorio je 'da je

\footnotetext{
${ }^{11}$ Korišten je službeni prijevod na hrvatski jezik: Redemptoris Missio (1991), Zagreb, Kršćanska sadašnjost
} 
rascjep između evanđelja i kulture drama našeg vremena', a taj se sud u području današnjeg komuniciranja u potpunosti potvrđuje.“

Ovo poglavlje enciklike izravno govori o medijima općenito, a neizravno upućuje i na problematiku medijske etike. Na prvome mjestu mora se spomenuti da dokument medijima pripisuje veliko značenje i važnost posebno kada ih papa naziva ,areopagom današnjeg vremena“, što potvrđuje i izričaj da su mediji zapravo danas postali „trg“, to jest prostor za široku javnu raspravu i dijalog. Upravo je u tom kontekstu implicitno prisutna i etička dimenzija jer mediji predstavljaju i šire prostor javne rasprave ujedinjujući čovječanstvo i potičući dijalog, što se može svrstati u etički pozitivne implikacije medija. Također, za medije se kaže da su „odgojno sredstvo“, a ako je riječ o odgojnom sredstvu onda je nužno promicati i etički ispravne i prihvatljive stavove. Papa nadalje upućuje i određenu samokritiku Crkvi kada kaže da je to područje medija na određen način zanemareno, potičući je samim time da se to stanje promijeni.

Enciklika na još dva mjesta (br. 83 i br. 90) izravno progovara o medijima, no riječ je o temama koje se ne dotiču područja medijske etike.

\subsection{Općedruštvena pitanja u svjetlu medijske etike}

2.6.1. Pornografija i nasilje u sredstvima društvenog priopćivanja (1989)

Papinsko vijeće za sredstva društvenog priopćavanja 1989. godine objelodanilo je dokument pod naslovom Pornografija $i$ nasilje $u$ sredstvima društvenog priopćivanja: pastoralni odgovor $(\mathrm{PN})^{12}$. Kako ističe Ivan Fučak (1989: 472) „tekst se ne bavi ni filozofskim razmišljanjima, ni negativnim etičkim normiranjem, osim bitnog; naprotiv, želi biti pozitivno usmjeren, lagan i svima pristupačan“.

Na samom se početku dokumenta naglašava da je došlo do ,revolucije u percepciji moralnih vrijednosti u posljednjih nekoliko godina, uključujući duboke promjene u načinu na koji ljudi razmišljaju i djeluju“ (PN, br. 1), a veliku odgovornost za to dokument pripisuje upravo medijima govoreći da „su mediji igrali i dalje igraju važnu ulogu u ovom procesu

\footnotetext{
${ }^{12}$ Dokument „Pornografija i nasilje u sredstvima društvenog priopćivanja: pastoralni odgovor“ nije preveden na hrvatski jezik, ta ga za potrebe ovog rada prevodim s poveznice: http://www.vatican.va/roman_curia/pontifical_councils/pccs/documents/rc_pc_pccs_doc_07051989_pornograph y_en.html
} 
individualne i društvene promjene“ (PN, br. 1). Pozivajući se na Drugi vatikanski koncil, dokument naglašava pozitivne vrijednosti medija, ali istovremeno govori i da ,pojedinci mogu ta sredstva komunikacije koristiti na način protivan zapovijedi Stvoritelja i kao instrumente zla“ (PN, br. 4). I ovdje se, kao i na mnogim drugim mjestima u raznim crkvenim dokumentima, ističe da mediji nemaju etičku vrijednost sami po sebi, već im tu vrijednost daje pojedinac u odnosu na način kako ih koristi.

Dokument progovara i o moralnim normama, te moralnim poteškoćama koje „Zahvaljujući“ medijima više nisu poteškoća samo bogatih zemalja, već i zemalja u razvoju: „U vremenu opće i nesretne zbunjenosti o moralnim normama, mediji su pornografiju i nasilje učinili dostupnima znatno proširenoj publici, uključujući mlade ljude, pa čak i djecu, te problem koji je u jednom trenutku bio ograničen uglavnom samo na bogate zemlje danas je počeo, putem medija, biti problem i zemalja u razvoju“" (PN, br. 6). Dokument i u br. 7 iznova naglašava dvostruku ulogu medija, tj. da oni „mogu biti učinkoviti instrumenti jedinstva $i$ razumijevanja“, ali da mogu biti i ,sredstva iskrivljenog pogleda na život, na obitelj, na religiju i moral.“

Govoreći o nasilju, dokument se prvenstveno fokusira na djecu: „Česta izloženost nasilju u medijima može biti zbunjujuća za djecu, jer oni ne mogu biti u stanju razlikovati maštu i stvarnost. U kasnijoj fazi, nasilje u medijima može stvoriti osobe podložne utjecajima, pogotovo kad je riječ o mladima, te mogu nasilje promatrati kao normalno i poželjno ponašanje, čak pogodno za oponašanje“ (PN, br. 12).

Na ovome području, dokument govori o sedam različitih aktera koji imaju svoju odgovornost, a na pravom mjestu navodi upravo medijske djelatnike. Za njih kaže: „Mnogi komunikatori su zadržali visoke osobne i profesionalne standarde i nastoje ispuniti svoje obveze uz snažnu predanost moralnim normama i općem dobru. Njihovi napori - osobito napori onih koji nastoje osigurati zdravu obiteljsku zabavu - zaslužuju priznanje i ohrabrenje. Pozivamo ove komunikatore da se pridruže u oblikovanju i primjeni etičkih kodeksa u medijima i oglašavanju, koji poštuju zajedničko dobro i promiču ljudski razvoj. Takvi kodeksi su osobito nužni za televiziju, jer televizija slikom može ući izravno u dom gdje djeca često mogu biti sama i bez nadzora. Učinkovita samokontrola je uvijek najbolji upravljač, i samoregulacija od strane medija može biti prva i najbolja linija obrane protiv onih koji bi korumpirali medije i samo društvo tražeći dobit iz pornografije i nasilja. Mi također pozivamo komunikatore da nam pomognu kroz medije učiniti dostupnijima korake koji se mogu 
poduzeti kako bi se zaustavio val pornografije i veličanje nasilja u društvu“ (PN, br. 23). Ovdje autori pozivaju medije na suradnju, a kao jedan od glavnih instrumenata predlažu upravo etičke kodekse koji medijskim djelatnicima mogu biti od velike pomoći.

Osim medijskih djelatnika, veliku odgovornost imaju i odgojitelji: „Škole i druge obrazovne institucije trebaju podržati i uliti socijalne i etičke vrijednosti koje promiču jedinstvo i zdravlje obitelji i samog društva. Posebno su vrijedni programi u medijskom obrazovanju koji kod mladih omogućuju kritički stav i pravilno oblikovane sposobnosti razlikovanja u korištenju televizije, radija i drugih medija, kako bi oni mogli znati kako se oduprijeti manipulaciji i navici pasivnog slušanja i gledanja“ (PN, br. 25).

U 30. poglavlju dokumenta nalazi se zanimljivo i etički vrijedno stajalište koje može biti korisno ne samo za pitanja kojima se bavi ovaj dokument, nego za cjelokupni doprinos Crkve nekim pitanjima iz područja medijske etike. Naime, u tom poglavlju piše da nije dovoljan, a niti primjeren, samo kritički stav Crkve prema medijima, te nastavlja: „Umjesto toga, Crkva bi trebala biti angažirana u nastavku razgovora s odgovornim komunikatorima kako bi se potaknulo njihovo djelovanje i pružila im se pomoć tamo gdje im je potrebna i gdje je traže. Katolički komunikatori i njihove profesionalne organizacije - sa svojim posebnim iskustvom - mogu odigrati ključnu ulogu u nastavku tog dijaloga“.

Na kraju, dokument zaključuje da želi dati „opću refleksiju na etičku i praktičnu prirodu problema pornografije i nasilja u obavijesnim sredstvima“" (PN, br. 32).

2.6.2. Moćna sredstva koja je nužno koristiti etički ispravno - Brzi razvoj (2005)

Papa Ivan Pavao II. je u posljednjoj godini svog života i pontifikata - 2005. godine objavio apostolsko pismo Brzi razvoj (BR ${ }^{13}$ s punim naslovom: „Apostolsko pismo Brzi razvoj Svetog Oca Ivana Pavla II. odgovornima za društvenu komunikaciju“. Zanimljivo je da Ivan Pavao II. koji je tijekom svog javnog djelovanja veliku pozornost pridavao medijima, u i posljednjoj godini svog života nešto o njima poručuje, te se obraća odgovornima za društvenu komunikaciju vrlo aktualnom temom u skladu s vremenom.

Već u trećoj točci Ivan Pavao II. progovara o etičkim dimenzijama medija, pozivajući se između ostalog i na istinitost koja je česta tema crkvenog govora o medijima, ali potiče

\footnotetext{
${ }^{13}$ Korišten je službeni prijevod na hrvatski jezik: Brzi razvoj (2005), Zagreb, IKA
} 
medije i na neke druge vrednote: „U usklađenom i ispravnom viđenju razvoja ljudskog bića, mediji mogu i moraju promicati pravdu i solidarnost, donoseći događaje na točan i istinit način, cjelovito analizirajući situacije i probleme, dajući mjesta različitim mišljenjima. Vrhovni kriterij istine i pravde, u zrelom korištenju slobode i odgovornosti, predstavljaju obzorje unutar kojega se smješta istinska deontologija u korištenju prednosti suvremenih i moćnih sredstava društvene komunikacije (BR, br. 3).

Kao i mnogo puta ranije, papa ističe pozitivnu vrijednost medija, ali uvjetno, to jest pojašnjavajući još jednom da sve ovisi kako ih se koristi: „Zahvaljujemo Bogu zbog postojanja tih moćnih sredstava koja, ako ih vjernici koriste u duhu vjere i poučljivosti svjetlu Duha Svetoga, mogu pridonijeti lakšem širenju Evanđelja i stvaranju učinkovitijih spona zajedništva među crkvenim zajednicama“ (BR, br. 6). Ivan Pavao II. na taj način još jednom naglašava ono što Crkva govori o medijima, to jest da su „moćna sredstva“ koja je potrebno koristiti na pozitivan način.

Papa niti u ovome dokumentu uime Crkve ne želi nametati etičke norme i zakone, ali jasno naglašava da se oni koji rade u medijima susreću s etičkim dvojbama, te vidi dužnost Crkve da im ponudi pomoć: „Dok sadržaji moraju biti naravno prilagođeni potrebama različitih skupina, njihova bi svrha uvijek morala biti osvješćivanje etičke i moralne dimenzije informacije. Isto je tako važno jamčiti formaciju i pastoralnu skrb zaposlenicima $u$ komunikacijama. Često se ti muškarci i žene nalaze pod osobitim pritiskom i u etičkim dvojbama koje proizlaze iz svakodnevnog posla; mnogi od njih 'iskreno žele znati i živjeti ono što je ispravno na polju etike i morala', te od Crkve očekuju smjernice i potporu“ (BR, br. 9).

Upravo u odnosu na etičku dimenziju, papa smatra potrebnim da se ovo područje i zakonski regulira: „Neophodno je da i društvene komunikacije uđu u okvire cjelovito strukturiranih prava i dužnosti, sa stajališta, kako etičke formacije i odgovornosti, tako i u odnosu na zakone i institucionalne nadležnosti“ (BR, br. 10).

\subsection{Pravo društva na informaciju na temelju istine, slobode, pravde i solidarnosti - Etika u promidžbi (1997)}

O tematici etike u promidžbi već je 1977. godine progovorio papa Pavao VI. u poruci za Svjetski dan sredstava društvenih komunikacija, pod naslovom „Promidžba u društvenim 
komunikacijama“. Točno 20 godina poslije, Papinsko vijeće objavljuje dokument koji također govori o etici u promidžbi, pod naslovom Etika u promidžbi (EP) ${ }^{14}$ (Valković, 2013: 74).

Već u prvoj točki dokument se dotiče nekih važnih postavki medijske etike: „Crkva ističe odgovornost medija da pridonose autentičnom i cjelovitom razvoj osobe i da potiče dobrobit društva. Informacije u medijima moraju biti u službi općeg dobra. Društvo ima pravo na informaciju na temelju istine, slobode, pravde i solidarnosti" (EP, br. 1). U istoj točki, dokument navodi da „ona (Crkva, op.a.) svraća pozornost na moralna načela i norme relevantne u društvenim komunikacijama, kao i drugim područjima ljudskog djelovanja, istovremeno kritizirajući politike i prakse koje djeluju protiv tih standarda“ (EP, br. 1).

Također, u istoj točki, dokument nastavlja: „Želimo skrenuti pozornost na pozitivne doprinose koje oglašavanje može donijeti i koje donosi; istaknuti etičke i moralne probleme koje oglašavanje otvara; ukazati na moralna načela koja se odnose na to područje; i, konačno, predložiti određene korake za razmatranje onima koji profesionalno sudjeluju u oglašavanju“ (EP, br. 1).

Govoreći o različitim vrstama oglašavanja dokument kaže: „Razlikuje se prema publici kojoj je namijenjen, tako npr. reklame usmjerene na djecu postavljaju određena tehnička i moralna pitanja značajno drugačija od onih koja se odnose na oglašavanje usmjereno prema odraslima“" (EP, br. 2).

Nadalje, dokument upozorava: „Ne slažemo se s tvrdnjom da reklama jednostavno odražava stavove i vrijednosti prevladavajuće kulture. Nema sumnje da oglašavanje, kao i sredstva društvene komunikacije općenito, djeluje kao ogledalo. Ali, isto tako kao mediji u cjelini, to je ogledalo koje pomaže oblikovati stvarnost koju odražava, a ponekad predstavlja i iskrivljenu sliku stvarnosti“ (EP, br. 3). U istom broju dokument nastavlja: „Oglašivači su selektivni u svom odabiru vrijednosti i stavova koje njeguju i potiču, promovirajući neke ignoriraju druge. Ova selektivnost daje lažnu sliku ideje da oglašavanje ne može drugo nego odražavati okolnu kulturu“( (EP, br. 3).

U dokumentu se upozorava i na utjecaj oglašavanja na medije: „Oglašavanje ima neizravan, ali snažan utjecaj na društvo kroz svoj utjecaj na medije. Mnoge publikacije i

\footnotetext{
${ }^{14}$ Dokument „Etika u promidžbi“ nije preveden na hrvatski jezik, ta ga za potrebe ovog rada prevodim s poveznice:

ttp://www.vatican.va/roman_curia/pontifical_councils/pccs/documents/rc_pc_pccs_doc_22021997_ethics-inad_en.html
} 
programi ovise od prihoda iz oglašavanja kako bi opstali. To često vrijedi i za vjerske medije, kao i komercijalne. Sa svoje će strane, oglašivači, naravno, nastojati doći do publike; i mediji, u nastojanju da omoguće oglašivačima put do publike, moraju oblikovati svoj sadržaj kako bi privukli željenu publiku. Ova ekonomska ovisnost medija i moći koje daju oglašivačima sa sobom nosi ozbiljne odgovornosti za oboje“(EP, br. 3).

Dokument $\mathrm{u}$ br. 4. donosi neke stavove koji ističu oglašavanje kao isključivo negativnu aktivnost, nakon čega kaže da se s tim ne slaže, te da u oglašavanju može biti i mnogo toga (etički) pozitivnog i vrijednog, doduše samo ,ponekad“, te jasno kaže: „Oglašavanje također ima u sebi značajan potencijal za dobro, a ponekad ga i realizira“ (EP, br. 4). Među brojnim prednostima, dokument navodi i sljedeće: „Oglašavanje može igrati važnu ulogu u procesima u kojima uz pomoć moralnih normi i odgovornosti za opće dobro, pridonosi razvoju društva“ (EP, br. 5). U istom broju navodi se da „oglašavanje može biti koristan alat za održavanje poštene i etički odgovorne konkurentnosti koja pridonosi gospodarskom rastu u službi istinskoga ljudskoga razvoja“ (EP, br. 5).

Jednako tako, dokument uočava još neke etički pozitivne strane oglašavanja: „Oglašavanje to čini, među ostalim načinima, kroz informiranje ljudi o dostupnosti racionalno poželjnih novih proizvoda i usluga i poboljšanja u postojećima, pomažući potrošačima da donesu informirane, razborite odluke, što pridonosi učinkovitosti i snižavanju cijena, i poticanje gospodarskog napretka kroz širenje poslovanja i trgovine. Sve to može doprinijeti otvaranju novih radnih mjesta, viših dohodaka i više pristojnog i humanog način življenja za sve. Ona također pomaže medijima financirati publiciranje, programiranje i produkciju uključujući i crkvene medije - koji donose informacije, zabavu i inspiraciju za ljude širom svijeta“" (EP, br. 5).

Ono što valja istaknuti kao posebnost ovoga dokumenta, činjenica je da su u njemu istaknute - i to vrlo jasno - pozitivne strane raznih vrsta oglašavanja, od političkog, preko gospodarskog i kulturnog, do vjerskog. Tako dokument donosi i etičke prednosti političkog oglašavanja: „Političko oglašavanje može dati doprinos demokraciji analogan doprinosu ekonomskom blagostanju u tržišnom sustavu, vođen moralnim normama. Kao slobodni i odgovorni mediji u demokratskom sustavu pomažu u suprotstavljanju tendenciji monopolizacije moći od strane vladajućih i posebnih interesa, te tako političko oglašavanje može dati svoj doprinos kroz informiranje ljudi o idejama i prijedlozima mjera stranaka i kandidata, uključujući nove kandidate koji nisu ranije bili poznati javnosti“ (EP, br. 6). 
U br. 7. dokumenta piše: „Zbog utjecaja oglašavača na medije koji o njima ovise s obzirom na prihode, oglašivači imaju priliku izvršiti pozitivan utjecaj na odluke o sadržaju medija. To čine podupirući sadržaje izvrsne intelektualne, estetske i moralne kvalitete, predstavljene u pogledu javnog interesa, a posebno potičući ohrabrivanjem i stvaranjem moguće medijske prezentacije koja je usmjerena prema manjinama čije potrebe inače ne bi bile zadovoljene“ (EP, br. 7).

Dokument ističe pozitivne dimenzije oglašavanja, uključujući društvene organizacije koje u svojoj biti prenose pozitivne poruke, a između ostalog im to omogućuje i oglašavanje: „U mnogim slučajevima, također, dobronamjerne društvene institucije, uključujući i one religiozne prirode, koriste oglašavanje za komuniciranje svoje poruke - poruke vjere, domoljublja, tolerancije, suosjećanja i bratske uslužnosti, ljubavi prema potrebitima, poruke iz područja zdravlja i obrazovanja, konstruktivne i korisne poruke koje obrazuju i motiviraju ljude na razne korisne načine“" (EP, br. 8).

Govoreći o etičkoj dimenziji oglašavanja, dokument govori ono što Crkva i inače naučava vezano uz medije: „Ne postoji ništa suštinski dobro ili zlo u oglašavanju. Ono je alat, instrument: može se koristiti dobro, a može se koristiti loše“ (EP, br. 9), te nastavlja da „oglašavanje može izdati svoju ulogu izvora informacija lažnim prikazivanjem i uskratom relevantnih činjenica. Ponekad, također, informacijska funkcija medija može biti kompromitirana od strane oglašivača pritiskom na izdanja ili programe da ne obrađuju pitanja koja bi se mogla za njih pokazati neugodnima ili nezgodnima“ (EP, br. 10). Odmah nakon toga dokument donosi i mogućnosti zloupotrebe. „Češće, međutim, oglašavanje se koristi ne samo za informiranje, već kako bi se uvjerilo ili motiviralo - uvjerilo ljude da se ponašaju na određeni način: kupe određene proizvode ili usluge, preferiraju određene institucije, i slično. Ovo je mjesto gdje možete doći do određene zloporabe“ (EP, br. 10).

Dokument opominje i na neetičnost „,prakse branda“, te naglašava: „'Praksa brand' u oglašavanju može izazvati ozbiljne probleme. Naime, često postoje samo zanemarive razlike između sličnih proizvoda različitih marki, a oglašavanje može pokušati potaknuti ljude da djeluju na temelju iracionalnih motiva ('vjernost brandu', društveni status, moda, 'seksepil', itd.), umjesto da predstave razlike u kvaliteti proizvoda i cijene što bi bila osnova za racionalni izbor"“ $(E P, 10)$.

Ništa manji problem nije ni „fenomen konzumerizma“, pa dokument naglašava da oglašavanje često stvara umjetne potrebe: „Ponekad oglašivači djeluju na način kao da je dio 
njihove zadaće 'stvoriti' potrebe za proizvode i usluge - to jest, zbog njih ljudi osjećaju žudnju i teže za predmetima i uslugama koje zapravo ne trebaju“ (EP, br. 10). Naglašava i da se iz toga onda kod pojedinca mogu stvoriti ,uvjeti koji su objektivno nepravilni i često štetni za njegovo fizičko i duhovno zdravlje.“ (EP, br. 10). Dokument o ovoj temi dalje nastavlja: „To je ozbiljno zlostavljanje, napad na ljudsko dostojanstvo i opće dobro kada se pojavi u bogatim društvima. No, zlostavljanje je još strašnije kad se konzumeristički stavovi i vrijednosti prenose kroz medije i oglašavanje u zemljama u razvoju, gdje se time pogoršavaju socijalnoekonomski problemi na štetu siromašnih“ (EP, br. 10).

Dokument progovara i o činjenici da oglašavanje često donosi i neke stereotipe: „Prečesto, reklama pridonosi stvaranju negativnih stereotipa o pojedinim skupinama što ih stavlja u nepovoljan položaj u odnosu na druge. To često vrijedi i za način na koji oglašavanje tretira žene i za način na koji iskorištava žene, oboje i u oglašavanju i uz pomoć oglašavanja, a to je često i žalosno zlostavljanje“ (EP, br. 12).

„Oglašavanje može biti umjesno i u skladu s visokim moralnim standardima, a povremeno čak i podiže mračno raspoloženje, ali također može biti vulgarno i moralno ponižavajuće“ (EP, br. 13), upozorava se u dokumentu koji se nakon toga poziva na ranije objavljeni dokument o pornografiji i nasilju u medijima koji smo prethodno analizirali.

Govoreći i o problematičnom tretiranju religije dokument navodi: „Komercijalni oglašivači ponekad uključuju vjerske teme ili koriste religijske slike ili osobe za prodaju proizvoda. To je moguće učiniti na ukusan i prihvatljiv način, ali praksa pokazuje da često zna biti neprihvatljivo i uvredljivo kad se iskorištava religiju ili je se tretira lakomisleno“ (EP, br. $10)$.

Iako cijeli dokument progovara o etičkim i moralnim načelima vezanima uz promidžbu, od broja 14 do broja 17 konkretnije i fokusirano na načela i norme obrađuju se teme koje su naslovljene „Neka etička i moralna načela“.

$\mathrm{Na}$ početku ovog poglavlja dokument je dosta odriješit: „Sredstva društvene komunikacije imaju dvije mogućnosti, i samo dvije. Ili će pomoći osobi da sazrijeva u razumijevanju i prakticiranju onoga što je istinito i dobro, ili će je destruktivno tjerati u sukob s općim dobrom. To je cijela istina oglašavanja“ (EP, br. 14). Potom donosi i temeljno etičko načelo: „Možemo ukazati na ovo temeljno načelo za osobe koje se bave oglašavanjem: oglašivači - to jest, oni koji procjenjuju, pripremaju ili šire oglašavanje - moralno su 
odgovorni za ono na što ljude potiču da čine; i to je odgovornost koju također dijele izdavači, glavni urednici i drugi u svijetu komunikacija, kao i oni koji daju komercijalna i politička odobrenja, u mjeri u kojoj su uključeni u proces oglašavanja“ (EP, br. 14).

U istome kontekstu dokument upozorava: „Ako strukture oglašavanja nastoje usmjeriti ljude da izaberu i djeluju na moralno dobar način, koji su istinski korisni i za njih i za ostale, oni rade ono što je moralno ispravno, no ako potiču ljude da čine zla djela koja su destruktivna za te osobe i destruktivna za njihovu zajednicu, onda čine zlo“ (EP, br. 14).

Kao poseban problem dokument ističe prikriveno oglašavanje koje jasno osuđuje tretirajući ga kao „neizravno reklamiranje“: „Moralno je pogrešno koristiti manipulativne, izrabljivačke, pokvarene i potkupljivačke metode uvjeravanja i motivacije. U tom smislu, možemo primijetiti posebne probleme povezane $\mathrm{s}$ tzv. neizravnim reklamiranjem koje pokušava potaknuti ljude da djeluju na određeni način - npr. kupe određeni proizvod - bez da su svjesni kako se na njih utjecalo. Tehnike kojima se služe su prikazivanje nekog proizvoda ili oblika ponašanja u naizgled glamuroznim događajima povezanim s naizgled glamuroznim ljudima; a u ekstremnim slučajevima to može uključivati i korištenje podsvjesne poruke“ (EP, br. 14).

Nakon toga dokument obrađuje tri moralna načela za koja smatra da su posebno važna u oglašavanju: istinoljubivost, dostojanstvo ljudske osobe i društvena odgovornost.

Govoreći o istinoljubivosti, dokument opominje: „Neke reklame su jednostavno i namjerno neistinite. Općenito govoreći, ipak, problem istine u oglašavanju je nešto složeniji: nije da reklama iznosi nešto što je potpuno lažno, ali se može dogoditi da iskrivi istinu implicirajući stvari koje nisu uistinu takve ili uskraćujući relevantne činjenice. Kao što papa Ivan Pavao II. ističe, kako na osobnoj tako i na društvenoj razini, istina i sloboda su nerazdvojni; bez istine kao osnove, polazišta, kriterija rasuđivanja izbora i djelovanja, ne može biti vjerodostojno ostvarena sloboda“ (EP, br. 15). Nadalje, dokument nastavlja: „Oglašavanje, kao i drugi oblici izražavanja, ima svoje konvencije i oblike stilizacije, i to treba uzeti u obzir kada se raspravlja o istinitosti. Ljudi uzimaju zdravo za gotovo neka retorička i simbolička pretjerivanja u oglašavanju; u granicama priznatim i prihvaćenima $u$ praksi, to može biti dopušteno“ (EP, br. 15).

O dostojanstvu ljudske osobe dokument kaže da je „,imperativ da oglašavanje poštuje ljudsku osobu, njezinu dužnost i pravo za odgovornu odluku, njezinu unutarnju slobodu“ (EP, 
br. 16). Nadalje, dokument naglašava da zloupotrebe u oglašavanju nisu samo hipotetska mogućnost, već vrlo često i realnost: „Oglašavanje može prekršiti dostojanstvo ljudske osobe i kroz svoj sadržaj - ono što je reklamirao, način na koji se reklamira - i kroz utjecaj koji nastoji ostvariti kod svoje publike“ (EP, br. 16). Iako to pogađa sve, dokument spominje i posebne skupine: „Ovaj problem je posebno aktualan kada su u pitanju ranjive skupine ili kategorije osoba: djeca i mladi, starije osobe, siromašne i osobe u kulturno nepovoljnom položaju“ (EP, br. 16). Posebno se osvrće upravo na djecu: „Mnogo reklama usmjerenih na djecu očito pokušava iskoristiti njihovu lakovjernost i podložnost sugestijama, u nadi da će vršiti pritisak na svoje roditelje da kupuju proizvode bez stvarne koristi za njih. Ovako oglašavanje vrijeđa dostojanstvo i prava djece i roditelja; ono narušava odnos roditelj-dijete i nastoji manipulirati njihovim vlastitim rezultatima. Također, relativno malo oglašavanja usmjereno je posebno na starije osobe ili osobe u kulturno nepovoljnom položaju, te se ostvaruje na način da se igra s njihovim strahovima kako bi ih se uvjerilo da izdvoje neke od svojih ograničenih resursa na robu ili usluge sumnjive vrijednosti““ (EP, br. 16).

Za društvenu odgovornost dokument kaže da je riječ o širokom pojmu, te obrađuje samo neke vidike u odnosu na oglašavanje. Na prvom mjestu spominje ekološki problem: „Oglašavanje koje potiče rastrošan stil života koji rasipa resurse i eksploatira okoliš stvara ključne ekološke probleme“ (EP, br. 17). Kad daje odgovor na pitanje što je od temeljne važnosti u oglašavanju piše da je to ,autentičan i integralni ljudski razvoj“ (EP, br. 17), te nastavlja: „Oglašavanje koje ljudski napredak reducira na stjecanje materijalnih dobara i ostvarenje raskošnog stila života izražava lažnu i destruktivnu viziju ljudske osobe štetne za pojedinca i društvo podjednako“ (EP, br. 17).

Dio o etičkim pitanjima dokument zaključuje: „Oglašivači, kao i osobe koje se bave drugim oblicima društvene komunikacije, imaju ozbiljnu dužnost da izraze i potaknu autentično viđenje ljudskog razvoja u materijalnoj, kulturnoj i duhovnoj dimenziji. Komunikacija koja zadovoljava ovaj standard je, između ostalog, pravi izraz solidarnosti. Zapravo, te dvije stvari - komunikacija i solidarnost - su nerazdvojni, jer, kako Katekizam Katoličke Crkve ističe, solidarnost je 'posljedica iskrene i prave komunikacije i slobodne izmjene ideja kako bi se ostvarilo dodatno znanje i poštovanje jednih prema drugima"' (EP, br. 17).

U zaključku samog dokumenta donose se „neki koraci“ koje treba poduzeti, kako glasi i sam naslov zaključka. „Neizostavni jamci etički korektnog ponašanja oglašivačke industrije 
su dobro formirana i odgovorna savjest reklamnih stručnjaka samih: savjest osjetljiva na njihove dužnosti koje nisu samo služiti interesima onih od kojih dolazi zarada i financiranje njihovog rada, već i poštovanje i podržavanje prava i interesa njihove publike i služenje općem dobru“ (EP, br. 18), podvlači još jednom dokument, koji potom iznosi i pozitivnu stranu, s vjerom u savjest djelatnika u oglašavanju: „Mnoge žene i muškarci koji se profesionalno bave oglašavanjem imaju osjetljivu savjest, visoke etičke standarde i jak osjećaj odgovornosti“ (EP, br. 18). Ali istodobno govori i o pritiscima kojima su izloženi: „Čak i za njih vanjski pritisci - od klijenata koji plaćaju njihov rad, do konkurenata unutar njihove struke - mogu stvoriti snažne poticaje za neetično ponašanje. To naglašava potrebu za vanjskim strukturama i sustavima za potporu i poticanje odgovorne prakse u oglašavanju, kako bi se obeshrabrilo neodgovorno ponašanje“ (EP, br. 18).

Kao jedan od vanjskih poticaja dokument spominje etičke kodekse: „Dobrovoljni etički kodeksi su jedan izvor takve potpore. Oni već postoje na brojnim mjestima. Dobrodošli, kao što oni jesu, ipak su učinkoviti samo ako postoji spremnost oglašivača da ih se u potpunosti pridržava“ (EP, br. 19). Dokument jasno uočava ono što je jasno, a to je da ti kodeksi, iako su dobri, mogu često ostati samo mrtvo slovo na papiru. Realnost potvrđuje da se vrlo često upravo to i događa.

Dokument naglašava i važnost uključivanja javnosti: „Predstavnici javnosti bi trebali sudjelovati u formuliranju, primjeni i pravovremenom obnavljanju etičkih kodeksa. Ti javni predstavnici trebaju uključivati etičare i ljude Crkve, kao i predstavnike potrošača. Pojedinci bi se trebali organizirati u takve skupine kako bi zaštitili svoje interese u odnosu na komercijalne interese“ (EP, br. 19).

Osim toga, dokument ističe da i tijela javne vlasti također imaju svoju važnu ulogu. S jedne strane, vlada ne bi trebala nastojati kontrolirati i diktirati politiku oglašivačkoj industriji, barem ne više nego drugim sudionicima društvenog priopćivanja. S druge strane, regulacija reklamnog sadržaja i prakse, što već postoji u mnogim državama, može i treba se proširiti i više od zabrane lažnog oglašavanja, usko definiranog. „Po proglašenju zakona i nadziranju njihove primjene, tijela javne vlasti trebaju osigurati da javni moral i društveni napredak ne budu ozbiljno ugroženi kroz zloupotrebe medija“ (EP, br. 20), piše dokument i navodi primjere: „Na primjer, vladini propisi trebaju obratiti pozornost na pitanja poput količine oglašavanja, posebice u elektronskim medijima, kao i sadržaj oglašavanja prema skupinama koje su posebno ranjive, kao što su djeca i starije osobe“ (EP, br. 20), te - kao što smo 
spomenuli - govori i o političkom oglašavanju, pri čemu ovaj puta navodi da je ,političko oglašavanje također nužno regulirati““ (EP, br. 20).

Dokument kaže da bi mediji trebali sebi zadati zadaću da javnost obavijeste o svijetu oglašavanja: „S obzirom na društveni utjecaj oglašavanja, prikladno je da mediji redovito pregledavaju i kritiziraju oglašivače, baš kao što to rade u odnosu na druge skupine čije djelatnosti imaju značajan utjecaj na društvo“ (EP, br. 21). Mogli bismo reći da je to ispravno zamišljeno, ali u praksi nažalost rijetko ostvareno, posebno kad je riječ o oglašivačima koji oglašavaju u mediju koji bi trebao kritički analizirati tog oglašivača. No, iako je na taj način postavljen visok ideal, to ne znači da njemu ne treba težiti i da ga ne treba ostvariti.

U posljednjem poglavlju u prvome se planu ističe pitanje slobode: „Gdje sloboda govora i komunikacije postoji, to je u velikoj mjeri zahvaljujući samim oglašivačima koji su stvorili etički odgovorne osobe u svojoj struci. Osim izbjegavanja zloupotreba, oglašivači trebaju nastojati popraviti štetu koju ponekad stvori oglašavanje, u mjeri u kojoj je to moguće: na primjer, objavljujući demantije, kompenzaciju oštećenima, povećavajući količinu usluga oglašavanja od javnog interesa, i slično“ (EP, br. 23). U istom poglavlju piše: „Mi ne želimo, i svakako ne očekujemo, da se reklama eliminira iz suvremenog svijeta. Oglašavanje je važan element $u$ današnjem društvu, a posebno u funkcioniranju tržišnog gospodarstva, koje postaje sve više i više široko rasprostranjeno. Štoviše, iz razloga i na način na koji je prikazano ovdje, vjerujemo da oglašavanje može igrati, a često i igra, konstruktivnu ulogu u gospodarskom rastu, $u$ razmjeni informacija $\mathrm{i}$ ideja, te $\mathrm{u}$ poticanju solidarnosti među pojedincima $\mathrm{i}$ skupinama“ (EP, br. 23). Na samom kraju dokumenta poziva se „stručnjake za oglašavanje i sve one koji su uključeni u proces oglašavanja, da uklone svoje društveno štetne aspekte i teže visokim etičkim standardima u pogledu istinitosti, ljudskog dostojanstva i društvene odgovornosti. Na taj način, oni će dati poseban i značajan doprinos ljudskom napretku i općem dobru“" (EP, br. 23).

\subsection{Temeljni dokument teološke medijske etike - Etika u obavijesnim sredstvima (2000)}

Premda se u više dokumenata bavi i pitanjem medija i medijske etike, možemo reći da je jedini crkveni dokument koji se u potpunosti i naširoko bavi medijskom etikom objavilo 
Papinsko vijeće za društvena obavijesna sredstva 2000. godine pod nazivom „Etika u obavijesnim sredstvima“" (EOS) ${ }^{15}$.

Na samome početku dokumenta ističe se etička neutralnost medija samih po sebi: „I premda komunikacije često imaju nepredvidive posljedice, ljudi sami odabiru hoće li koristiti društvena sredstva u dobru ili lošu svrhu, na dobar ili loš način. Ovi se izbori, temeljni za etičko pitanje, ne odnose samo na one koji priopćenja primaju - gledatelje, slušatelje, čitatelje - nego i na one koji nadziru društvena obavijesna sredstva i utvrđuju njihovo ustrojstvo, njihove politike i njihov sadržaj. Riječ je o javnim službenicima i urednicima, voditeljima službi u uredništvu, proizvođačima, piscima, dopisnicima i drugima. Za te je osobe osobito važno etičko pitanje: primjenjuju li se društvena obavijesna sredstva za dobro ili za zlo?“ (EOS, br. 1). Važno je primijetiti da se odgovornost ne pripisuje samo pojedinoj skupini, nego svim sudionicima u tom procesu.

Tekst ističe i različitost medijskih sadržaja iz čega se iščitava i njihova etička (ne)vrijednost, jer zasigurno ne želi jednako etički vrednovati npr. s jedne strane molitvu i s druge strane pornografiju: „Sadržaji te široke ljestvice idu od vijesti do čiste zabave, od molitve do pornografije, od kontemplacije do nasilja“" (EOS, br. 2).

Dokument naglašava svoj pozitivan pristup medijima, $i$ to ne samo pristup ovog dokumenta, nego cjelokupnog crkvenog Učiteljstva o ovoj temi: „Pristup Crkve društvenim obavijesnim sredstvima temeljno je pozitivan i ohrabrujući. Ona jednostavno ne sudi i ne osuđuje, štoviše ona smatra ta sredstva ne samo proizvodima ljudskoga genija, nego također velikim Božjim darovima i pravim znacima vremena“ (EOS, br. 4).

U ovome se dokumentu potvrđuje i već naglašena neutralnost medija, no ističe se $\mathrm{i}$ potreba određenih (načelnih) instrumenata kako bi se moglo ispravno djelovati: „Društvena obavijesna sredstva nisu ništa sama po sebi, ona su sredstva, oruđe, upotrijebljeni kako ljudi izaberu da ih upotrijebe. (...) Za ispravan odabir potrebno je dobro poznavati 'pravila moralnog reda' i 'vjerno ih provoditi u djelo'، (EOS, br. 4).

Želeći iskazati koji je doprinos Crkve cjelokupnom etičkom promišljanju medija, dokument navodi: „Crkva donosi različite elemente toj raspravi. Donosi dugu baštinu moralne mudrosti, ukorijenjenu u božansku objavu i u ljudsko razmišljanje. U to spada i cjelina bitnog i trajno rastućeg socijalnog nauka. (...) Crkva pridonosi raspravi i nešto drugo. Njezin osobit

\footnotetext{
${ }^{15}$ Korišten je službeni prijevod na hrvatski jezik: Etika u obavijesnim sredstvima (2000), Zagreb, IKA
} 
doprinos ljudskim pitanjima, uključujući svijet društvenih priopćavanja, upravo je ono viđenje dostojanstva osobe koje se pokazuje u svoj punini u otajstvu utjelovljene Riječi“ (EOS, br. 5).

Pozitivnu dimenziju medija dokument vidi i u njihovom doprinosu tržišnom gospodarstvu: „Tržište nije moralna norma ni izvor moralne vrijednosti i tržišne ga ekonomije mogu zlorabiti. Ipak, tržište može služiti čovjeku i društvena obavijesna sredstva vrše nenadomjestivu zadaću u tržišnom gospodarstvu“ (EOS, br. 7). Također, pomažu i građanima kako bi sudjelovali u političkom događanju: „Društvena obavijesna sredstva koriste društvu olakšavajući svjesno sudjelovanje građana u političkom događanju“ (EOS, br. 8).

Ujedno se uočava i pozitivan doprinos medija u nekim umjetnostima: „Društvena obavijesna sredstva pružaju ljudima pristup književnosti, kazalištu, glazbi i umjetnosti koji bi im inače bili nedostupni, te tako promiču ljudski razvoj s obzirom na znanje, mudrost i ljepotu“ (EOS, br. 9), a ističe se i pozitivan doprinos medija u obrazovanju: „Javna su glasila važna odgojna sredstva u brojnim okolnostima, od škole do radnog mjesta, i u raznim životnim razdobljima“ (EOS, br. 10).

Mediji osim toga pomažu i duhovnom obogaćenju osoba uočava dokument: „Vjerski se život obogaćuje društvenim obavijesnim sredstvima koja donose vijesti i izvješća o vjerskim događanjima, idejama i osobama. Ona su prenosioci evangelizacije i kateheze. Iz dana u dan pružaju nadahnuće, ohrabrenje i mogućnost sudjelovanja u bogoslužju osobama vezanim uz krevet ili ustanove. Ponekad društvena obavijesna sredstva pridonose duhovnom obogaćenju osoba na izuzetan način“(EOS, br. 11).

No istodobno dokument ne skriva niti one negativne dimenzije medija: „Društvena obavijesna sredstva mogu se koristiti za blokiranje zajednice i uništavanja cjelokupnog dobra osoba, odvraćajući ih, potiskujući ih na rub i izolirajući ih ili privlačeći ih u zajednice koje su negativne ili usmjerene na lažne i razorne vrijednosti. Mogu raspaljivati neprijateljstvo i sukob, demonizirati druge i stvarati mentalitet „mi“ - „oni“, predstavljati nisko i ponižavajuće u blistavom svjetlu, ignorirati ili umanjivati ono što uzdiže i oplemenjuje. Mogu širiti dezinformaciju i krivu informaciju. Promicati prostotu i banalnost. Svođenje na ustaljene obrasce, utemeljeno na rasi ili pripadnosti različitim etničkim skupinama i drugim čimbenicima, uključujući religiju, bolno je rašireno u društvenim obavijesnim sredstvima. Često, osim toga, društvene komunikacije potamnjuju ono što je izvorno novo i važno, uključujući radosnu vijest Evanđelja, i usredotočuju se na ono pomodno i nastrano“ (EOS, br. 13), a slična se stajališta vide i tvrdnji da se ,ponekad društvena obavijesna sredstva 
upotrebljavaju za izgradnju i potporu gospodarskih sustava u službi gramzljivosti i pohlepe“ (EOS, br. 14).

U dokumentu se također upozorava i na medijski doprinos etičkom relativizmu: „Društvena obavijesna sredstva često promiču etički relativizam i utilitarizam koji označuju suvremenu kulturu smrti. Oni sudjeluju u suvremenoj 'zavjeri protiv života'‘ (EOS, br. 15).

Dokument se dotiče i vječnog pitanja uzroka, „̌̌utila“ u medijima, tj. jesu li krivi mediji ili korisnici medija: „Kritičari često osuđuju površnost i loš ukus društvenih obavijesnih sredstava koji, premda nisu prisiljeni na siromaštvo i jednoličnost, ne bi smjeli biti ni neukusni ni ponižavajući: tvrditi da društvena obavijesna sredstva odražavaju narodni ukus sigurno nije opravdanje, jer ona vrše veliki utjecaj na te iste ukuse i dužnost im je istančati ih a ne degradirati“ (EOS, br. 16). Smjer u kojem je dokument krenuo u ovom poglavlju, nastavlja se i u idućem: „Umjesto da promiču obrazovanje, društvena obavijesna sredstva mogu ljudima drugamo obraćati pozornost navodeći ih da gube vrijeme. Tako su osobito pogođeni djeca i mladi, ali su i odrasli oštećeni površnim i niskim zabavama. Među uzrocima te zloporabe tuđeg povjerenja od strane djelatnika društvenih obavijesnih sredstava je pohlepa kojoj je stjecanje važnije od osoba. Ponekad se društvena obavijesna sredstva koriste i kao oruđe za nametanje mišljenja, za nadzor nad onim što bi ljudi smjeli znati, sprečavajući im pristup onim vijestima koje vlasti ne žele proširiti. To znači iskrenuti pravi odgoj koji inače teži ljudima proširiti znanje, jačati njihove sposobnosti, pomoći im slijediti vrijedne ciljeve, ne ograničavajući njihova obzorja i ne stavljajući njihove sile u službu ideologije“ (EOS, br. 17).

Dokument progovara i o odnosu medija i vjere, te kušnji s obje strane koje svakako imaju svoju etičku dimenziju: „U odnosima među sredstvima društvenog priopćavanja i vjere postoje kušnje s obje strane. Sa strane društvenih obavijesnih sredstava među tim su kušnjama ignoriranje i potiskivanje religioznih poimanja i iskustava, površan ili čak preziran pristup religiji kao nečemu što ne zaslužuje ozbiljnu pozornost. (...) Od strane religije moguće kušnje uključuju: promatranje obavijesnih sredstava isključivo u negativnom svjetlu; neshvaćanje da razumni kriteriji društvenih obavijesnih sredstava poput objektivnosti i nepristranosti mogu također zaskočiti posebne postupke u korist institucionalnih religioznih interesa; predstavljanje vjerskih poruka na način utemeljen na osjećajnosti i manipulaciji, kao da su proizvod u takmičenju na zasićenom tržištu; korištenje medija kao sredstva za nadzor i prevlast“" (EOS, br. 18). 
Dokument, još jednom ponavlja tezu o neutralnosti medija samih po sebi: „Društvena obavijesna sredstva mogu se koristiti za dobro ili loše, to je pitanje izbora“" (EOS, br. 19), pa potom naglašava da ona etička načela koja Crkva ima na drugim područjima, jednako vrijede i na području medija: „Etička načela i norme koje važe na drugim područjima vrijede i za područje društvenih obavijesnih sredstava. Načela društvene etike, poput solidarnosti, pravednosti, supsidijarnosti, jednakosti i odgovornosti u korištenju javnih izvora i u razvoju zadaća koje se temelje na povjerenju ljudi, trebaju se uvijek držati na pameti. Priopćavanje mora uvijek biti u skladu s istinom, jer istina je bitna za osobnu slobodu i za pravo međusobno zajedništvo. Etika se u društvenim obavijesnim sredstvima ne odnosi samo na ono što se pojavljuje na ekranima i kinematografima ili na televiziji, u radijskim emisijama, ili u tiskovinama i na internetu, nego i u više drugih pogleda. Etički doseg ne odnosi se samo na sadržaj i proces priopćavanja, nego također na temeljna ustrojstvena i sistematska pitanja, koja često uključuju teme koje se odnose na političke distribucije tehnologija i sofističke (op.a. ovdje bi ispravno bilo „sofisticirane“, prevoditelj je pogrešno preveo talijansku riječ „sofisticati“) proizvode (tko će biti bogato informiran, a tko oskudno)? (...) Također ljudima dobre volje nije uvijek sasvim jasno kako primijeniti etička načela i norme u pojedinim slučajevima. Potrebni su razmišljanja, razglabanja, dijalog“ (EOS, br. 20).

Kao što je istaknuto $\mathrm{i} u$ drugim dokumentima o medijima, $\mathrm{i}$ ovdje se ponavlja da je $u$ središtu svakoga etičkog načela zapravo sam čovjek: „Na sva tri područja - poruci, procesu, ustrojstvenim i sistematskim pitanjima - temeljno je etičko načelo: ljudska osoba i ljudska zajednica svrha su i mjerilo upotrebe društvenih obavijesnih sredstava. Priopćavanja bi trebali raditi ljudi u korist cjelokupnog razvoja drugih ljudi““(EOS, br. 21).

Dakako da se u tom kontekstu nužno progovara i o odnosu pojedinca i općeg dobra: „Dobro osobe ne smije se ostvarivati neovisno od općeg dobra zajednica kojima osobe pripadaju. (...) Djelatnici u sredstvima priopćavanja i oni koji određuju njihovu politiku, moraju se staviti u službu i stvarnih potreba i interesa kako pojedinaca tako i skupna na svim razinama. (...) Tko donosi odluke na tom području ima ozbiljnu moralnu dužnost priznati potrebe i interese onih koji su osobito ranjivi, siromaha, starih, koji se tek imaju roditi, djece i mladih, potlačenih, potisnutih na rub društva, žena i manjina, bolesnih i nesposobnih, kao i obitelji i vjerskih skupina“"(EOS, br. 22).

Govori se i o slobodi izražavanja u odnosu na kontrolu države: „Kako bilo da bilo, i dalje vjerujemo da rješenje problema koji nastaju iz te nesređene komercijalizacije i 
privatizacije nije u državnom nadzoru sredstava priopćavanja, nego u obuhvatnijem uređenju koje odgovara normama javne službe kao i u većoj javnoj odgovornosti. (...) Treba se uvijek zauzimati za slobodu izražavanja, jer kad god ljudi, u skladu sa svojom naravi izmjenjuju međusobno informacije i drugima iznose svoje misli služe se svojim pravom a ujedno time iskazuju službu društvu. Ipak, promatrano s etičkog motrišta, ta pretpostavka nije apsolutna, nezastariva norma. Postoje očite razine gdje ne postoji pravo na priopćavanje, primjerice kletve i ogovaranje, poruke koje nastoje promicati mržnju i sukob među pojedincima, skupinama, besramnost i pornografiju, te bolesno opisivanje nasilja. I slobodno izražavanje moralo bi obdržavati norme poput istine, korektnosti i poštovanje privatnog života. Profesionalci u sredstvima priopćavanja morali bi se, u skladu s javnim predstavnicima, djelatno zauzimati za razvijanje i jačanje etičkih stručnih ponašanja“ (EOS, br. 23).

Posebna je pozornost posvećena i važnosti sudjelovanja javnosti: „Drugo, već spomenuto etičko načelo odnosi se na sudjelovanje javnosti u procesu odlučivanja glede politike komunikacija. To bi sudjelovanje na svim razinama trebalo biti organizirano, sustavno i istinski reprezentativno, koje ne skreće u korist posebnih skupina. (...) U interesu sudjelovanja javnosti, izvjestitelji trebaju ,nastojati razgovarati s osobama, a ne im samo govoriti. (...) Odluke o sadržajima i usmjerenjima medija ne bi se smjele prepustiti samo tržištu i ekonomskim čimbenicima, ili stjecanju dobiti, jer se na to posljednje nije moguće osloniti niti za čuvanje javnog interesa kao cjeline, osobito ne zakonitih interesa manjina“ (EOS, br. 24).

Kao što smo već isticali ranije u našem radu, vrlo često se sva odgovornost stavlja na medijske djelatnike. No, Crkva jasno ističe da je to pogrešno, te da i korisnici medija imaju svoju ništa manju odgovornost: „Etičke obveze nemaju samo profesionalni izvjestitelji. I korisnici imaju obveze. (...) Prva je dužnost korisnika društvenih obavijesnih sredstava razlikovanje i odabir. Oni se trebaju informirati o medijima, njihovim ustrojstvima, načinima djelovanja i sadržajima, te načiniti izbor prema zdravim moralnim načelima o tome što čitati ili gledati ili slušati. (...) Po svojim školama i odgojnim programima Crkva bi morala pružati takvu izobrazbu na području medija. (...) Isto tako, roditelji imaju ozbiljnu dužnost pomoći svojoj djeci učeći ih kako procijeniti i koristiti društvena obavijesna sredstva, oblikujući ispravno njihove savjesti i razvijajući njihovu kritičku sposobnost“" (EOS, br. 25).

Dok iznosi i naučava etičke norme u medijskom svijetu, Crkva ne smije zaboraviti primjenjivati ih u „svom dvorištu“, što dokument naglašava ovim riječima: „Nadasve, crkvena 
bi praksa priopćavanja morala biti primjerna, odražavajući najviše uzore istinitosti, vjerodostojnosti, tankoćutnosti za ljudska prava i druga važna načela i norme. Osim toga, obavijesna sredstva kojima Crkva raspolaže morala bi se brinuti za priopćavanje pune istine o značenju ljudskog života i povijesti. (...) Tko predstavlja Crkvu mora biti pošten i otvoren u svojim odnosima s novinarima. Čak i kad su pitanja ,zbunjujuća ili uznemirujuća, osobito kad ne odgovaraju potpuno poruci koju moramo širiti“, treba se sjetiti da „većina naših suvremenika postavlja tako zbunjujuća pitanja“. Svi koji govore uime Crkve moraju dati vjerodostojne i iskrene odgovore na ta i takva naizgled nezgodna pitanja. (...) Crkvi bi bolje služilo kad bi oni koji služe i vrše svoje dužnosti u njezino ime bili bolje izobraženi u sredstvima priopćavanja. To ne važi samo za bogoslove, za redovničke pripravnike i za mlade katoličke laike, nego i za crkveno osoblje općenito“ (EOS, br. 26).

U konačnici, dokumentom se opet naglašava da su mediji zapravo samo sredstvo: „Unatoč njihovoj golemoj moći, društvena obavijesna sredstva jesu i ostat će samo sredstva, ili oruđe koje se može koristiti za dobro ili za zlo. Na nama je da izaberemo. Društvena obavijesna sredstva ne zahtijevaju novu etiku nego primjenu ustaljenih načela u novim okolnostima. I to je zadaća u kojoj svatko ima svoju ulogu. Etika u društvenim obavijesnim sredstvima ne odnosi se samo na stručnjake, pa bili oni i stručnjaci u društvenim obavijesnim sredstvima ili stručnjaci moralne filozofije. Štoviše, mora doći do razmišljanja i dijaloga svih, koje ovaj dokument ohrabruje i podupire“ (EOS, br. 28).

Međutim, postavlja se i pitanje okrupnjavanja vlasništva medija, koje je veoma aktualno i goruće pitanje medija: „Hoće li buduća publika biti sastavljena od mnoštva osoba koje slušaju samo jednu?“ (EOS, br. 29), te dokument istodobno naglašava potrebu zajedničke brige za etičke vrednote u medijima: „Nastojeći promicati i podupirati uzvišene etičke obrasce u društvenim obavijesnim sredstvima, Crkva traži dijalog i suradnju s drugima“ (EOS, br. 30).

U tom zajedničkom nastojanju oko promicanja i podupiranja etičkih načela, važnu ulogu imaju i vjerski mediji: „Kršćanski izvjestitelj ima osobito proročku zadaću, poziv: govoriti protiv lažnih suvremenih bogova i idola, materijalizma, hedonizma, potrošaštva, uskogrudnog nacionalizma itd., podupirući cjelinu ćudoredne istine utemeljene na dostojanstvu i ljudskim pravima, na povlaštenom opredjeljenju za siromahe, na općoj namjeni dobara, na ljubavi prema vlastitim neprijateljima, na bezuvjetnom poštivanju ljudskog života od trenutka začetka do njegove naravne smrti, slijedeći cilj najsavršenijeg ostvarenja 
Kraljevstva u ovome svijetu, ostajući svjesni činjenice da će na svršetku svijeta Isus sve iznova uspostaviti i predati Ocu“" (EOS, br. 31).

Dokument na samom kraju stavlja Isusa Krista kao uzor etičkog ponašanja u medijima: „Isus je uzor i primjer našeg ophođenja. Za one koji rade na području društvenih obavijesnih sredstava, bilo kao oni koji donose odluke bilo kao stručnjaci ili korisnici medija, zaključak je jasan: 'Zato odložite laž i govorite istinu jedan drugomu, jer udovi smo jedni drugima... Nikakva nevaljala riječ neka ne izlazi iz vaših usta, nego samo dobra, da prema potrebi saziđuje' (Ef 4, 25.29)“(EOS, br. 33).

\subsection{Dokumenti o medijskoj etici i internetu}

\subsubsection{Pitanje interneta nadilazi samo tehničke mogućnosti - Crkva i internet ${ }^{16}$ (2002)}

Papinsko vijeće za sredstva društvenog priopćavanja objavilo je dokument Crkva $i$ internet $(\mathrm{CI})^{17}$ 2002. godine. Uz dokument je objavljen i još jedan pod nazivom Etika na internetu. Govoreći o promjenama koje je internet unio u svijet, dokument kaže: „U priloženom dokumentu 'Etika na internetu', promišljamo ta pitanja u njihovoj etičkoj dimenziji“, iz čega je vidljivo da se prvi spomenuti dokument - Crkva i internet - ne dotiče suviše etičkih tema, no ipak obrađuje i njih, pa ćemo prikazati i analizirati promišljanje o etičkoj dimenziji medija u tom tekstu.

$\mathrm{Na}$ početku dokument govoreći o medijima ističe da je Crkva često izražavala svoje uvjerenje da su oni, „kako je ustvrdio Drugi vatikanski koncil, 'zapanjujući izum tehnike' koji već sada mnogo čini u pogledu zadovoljavanja čovjekovih potreba, a može činiti još i više. Zbog toga je Crkva zauzimala temeljno pozitivan pristup društvenim obavijesnim sredstvima. Čak i kada osuđuju njihove ozbiljne zlouporabe, dokumenti Papinskog vijeća za društvena obavijesna sredstva zaokupljeni su pojašnjavanjem da 'čisto restriktivni ili kritički stav Crkve niti je dostatan niti primjeren'” (CI, br. 1). Dakle, dokument ovdje, pozivajući se na prijašnji nauk, jasno s jedne strane ističe ozbiljne zloupotrebe medija, te već samim time Crkva ističe svoj etički stav o tim pojavama, no istovremeno dokument, pozivajući se također na prijašnji nauk, ističe da nije dovoljan restriktivan ili kritički stav Crkve, čime zapravo potvrđuje da nije

\footnotetext{
${ }^{16}$ U službenom prijevodu riječ ,internet“ se (pogrešno) piše velikim početnim slovom. U ovoj disertaciji se ta greška ne preuzima, nego se piše malim početnim slovom, u skladu s hrvatskim pravopisom.

${ }^{17}$ Korišten je službeni prijevod na hrvatski jezik: http://www.ika.hr/index.php?prikaz=vijest\&ID=49521
} 
dovoljno samo ukazati na etički dvojbene situacije, već je nužno pokušati ponuditi rješenja, što se dokumentima o ovim temama niti ne može osporiti.

Pozivajući se na Etiku na internetu, dokument navodi da su odgoj i obrazovanje korisno i potrebno područje i u širem etičkom i moralnom kontekstu: „Danas je svima potreban određen oblik trajnog odgoja za medije, bilo osobnim učenjem ili sudjelovanjem u organiziranom programu ili i jedno i drugo. Više nego samo pouka o tehnikama, odgoj za sredstva priopćavanja pridonosi stvaranju dobrog ukusa kod ljudi i ispravnoga moralnog prosuđivanja. Riječ je, u određenom pogledu, o odgoju savjesti. Po svojim školama i odgojnim programima Crkva bi morala pružati takvu izobrazbu na području medija” (CI, br. 7). Ovdje se u govoru o odgoju za medije jasno naglašava da nije dovoljno podučiti samo o tehničkoj dimenziji medija, već da je potrebno stvaranje ispravnog moralnog etičkog prosuđivanja. Slično dokument ponavlja i nešto kasnije: „Poučavati o internetu i novim tehnologijama znači mnogo više no poučavati tehnikama. Mladi moraju naučiti kako dobro živjeti u virtualnom svijetu, znati zdravim moralnim mjerilima prosuđivati sve ono što $\mathrm{u}$ njemu nalaze i koristiti novu tehnologiju za vlastiti cjeloviti razvoj i na dobrobit drugih“(CI, br. 7). U tom se kontekstu navode i neke etički negativne pojave: „Među osobitim problemima koje predstavlja internet jest prisutnost web stranica koje šire mržnju, kleveću i napadaju vjerske i etničke skupine“ (CI, br. 8).

Jednako se tako potiče da Crkva donese neke etičke smjernice i na nižoj razini (ne samo poput ovih na općoj razini, već i nacionalnoj i mjesnoj), te navodi: „U pogledu materijala specifično naukovne ili katehetske naravi koristio bi sustav dragovoljne provjere na mjesnoj i nacionalnoj razini pod nadzorom učiteljstva. Nije riječ o nametanju cenzure, već o tome da internet korisnicima pruži pouzdan vodič o onomu što je u skladu s istinskim stajalištem Crkve“ (CI, br. 11), što bi moglo izgledati poput nekog oblika cenzure, no uzevši u obzir tekst cijeloga dokumenta ipak nije riječ o tome.

Osim potrebe za odgojem i obrazovanjem, kao i za utvrđivanjem etičkih i moralnih načela, dokument ističe i važnost roditeljske kontrole interneta: „Roditelji su dužni voditi i nadzirati djecu u korištenju Interneta“ (CI, br. 11.), nakon čega tu temu, pozivajući se djelomično na dokument Etika u obavijesnim sredstvima, ali sa značajnim dodacima dodatno produbljuje: „Temeljna je roditeljska dužnost pomoći djeci da postanu odgovorni internet korisnici koji će znati razlikovati njegove sadržaje, a ne ovisnici o internetu koji zanemaruju kontakt sa svojim vršnjacima i samom prirodom. Djeci i mladeži internet su otvorena vrata u 
očaravajući i uzbudljivi svijet koji ima snažan odgojni utjecaj; no nije sve što se krije iza tih vrata zdravo, sigurno i istinito. 'Prema dobi i prilikama, djeca i mladi morali bi biti otvoreni odgoju glede društvenih obavijesnih sredstava, odupirući se jeftinom putu nekritične pasivnosti, pritiscima njihovih drugova i tržišnom iskorištavanju.' Mladi imaju dužnost dobro koristiti internet zbog sebe samih, zbog svojih roditelja i prijatelja, svojih pastira i učitelja i, u konačnici, iz poslušnosti Bogu. Internet mladim ljudima u najranijoj dobi nudi ogromnu mogućnost da sebi i drugima čine dobro i zlo. Može obogatiti njihove živote na način koji prethodni naraštaji nisu mogli ni zamisliti i osposobiti ih također da obogate živote drugih. Može ih također uvući u konzumerizam, potaknuti fantazije koje izviru iz pornografije i nasilja i gurnuti ih u bolesnu izoliranost“" (CI, br. 11).

Na kraju dokument podsjeća i na i neke konkretne kreposti vezane uz područje medija, pozivajući se djelomično na obraćanje Ivana Pavla II. generalnom tajniku Ujedinjenih naroda i Administrativnom uredu za koordinaciju UN-a 7. travnja 2000: „Na kraju, želimo predložiti neke kreposti koje trebaju njegovati svi oni koji se žele dobro koristiti internetom. Njihovo se postupanje mora temeljiti na realnoj procjeni internet sadržaja. Potrebna je mudrost kako bi se jasno uočile implikacije - potencijalno dobro i zlo - toga novog sredstva i stvaralački odgovorilo na njegove izazove i mogućnosti. Neophodna je pravednost, osobito kako bi se uklonio 'digital divide', jaz između informacijama bogatih i informacijama siromašnih u današnjem svijetu. To zahtijeva zauzimanje za međunarodno opće dobro i 'globalizaciju solidarnosti.' Nužni su i jakost i hrabrost. To znači stajati na strani istine nasuprot vjerskom i moralnom relativizmu, na strani altruizma i velikodušnosti nasuprot individualističkom konzumerizmu i na strani pristojnosti nasuprot putenosti i grijehu. Neophodna je umjerenost, disciplinirani pristup tome važnom tehnološkom sredstvu što ga predstavlja internet kako bi ga se koristilo mudro i isključivo za dobro“ (CI, br. 11).

\subsubsection{Nužnost etičkog djelovanja na internetu - Etika na internetu (2002)}

Ovaj dokument $(E I)^{18}$ objavljen 2002. godine na samome početku, a pozivajući se na Aetitatis novae, govori o promjenama: „'Prevrat koji se danas zbiva na području društvenog priopćavanja pretpostavlja nešto više od čisto tehničke revolucije; pretpostavlja, naime, temeljnu preobrazbu elemenata kojima čovjek obuhvaća svijet koji ga okružuje, kojima

\footnotetext{
${ }^{18}$ Korišten je službeni prijevod na hrvatski jezik: http://www.ika.hr/index.php?prikaz=vijest\&ID=49520
} 
provjerava svoje zapažanje te mu nalazi izraz. Neprestana raspoloživost slika i predodžbi i njihovo brzo prenošenje, čak od kontinenta do kontinenta, u isti mah djeluje pozitivno i negativno na duševni, moralni i društveni razvitak osoba, na tkivo i djelovanje društava, na razmjenu i komuniciranje između kultura, na razumijevanje i prenošenje vrednota, na svjetonazore, ideologije i religiozna uvjerenja.' Posljednjih je deset godina istinitost tih riječi postala više no ikad prije očita. Danas nije potrebna neka posebno velika mašta da bi se zemlja mogla zamišljati kao globus isprepleten elektronskim prijenosima, kao bučni planet ugniježđen u posvemašnjoj tišini svemira. No doprinosi li to istinskom razvoju čovjeka i pomaže li pojedincima i narodima da budu u skladu sa svojim transcendentnim određenjem? To je temeljno pitanje koje se ovdje postavlja. Naravno da je iz mnogih razloga odgovor na to pitanje potvrdan. Novi su mediji moćna sredstva odgoja i kulturalnog obogaćivanja, trgovanja i političkog sudjelovanja, dijaloga i razumijevanja među kulturama, i kao što smo istaknuli u dokumentu koji je priložen ovome, mogu također poslužiti i u vjerske svrhe. Ipak, postoji i druga strana medalje. Društvena obavijesna sredstva, koja mogu biti korištena na dobro osoba i zajednica mogu se također upotrijebiti za izrabljivanje, manipuliranje, dominaciju i korupciju“ (EI, br. 1). Ovdje, pozivajući se na već spomenuti dokument, donosi se opis činjeničnog stanja, a ono je da je došlo do promjena na području medija, te da je tih 10 godina (Aetatis novae izdan je 1992, a ovaj dokument 2002.) samo potvrdilo ono što je prije tih 10 godina izrečeno. Nakon toga ide se korak dalje te se postavlja pitanje ima li taj razvoj pozitivan ili negativan predznak. Kao što je uobičajeno u crkvenim dokumentima, ne pokušava se stvarnost prikazati crno-bijelom, nego se donose različiti argumenti u prilog objema stranama, pokazatelji i jedne i druge krajnosti, sugerirajući da se odgovor krije negdje u sredini, tj. da ima i negativnih i pozitivnih promjena.

Dokument još jednom naglašava dvoznačnost interneta, tj. da ima i dobre i loše strane: „Internet ima mnoge pozitivne primjene i dobre strane, a obećava i mnogo više, no njegovim se neprimjerenim korištenjem može počiniti i mnogo štete. Hoće li se koristiti za dobro ili na štetu ovisit će u velikoj mjeri o pristupu. U vezi s tim Crkva nudi dva vrlo važna prinosa: svoju zauzetost za dostojanstvo ljudske osobe i svoju dugu baštinu moralne mudrosti“ (EI, br. 2). Osim govora o dvoznačnosti interneta, dokument postavlja i određena pitanja, predlažući i dva načela koja mogu pridonijeti pronalaženju odgovora: dostojanstvo ljudske osobe i duga baština moralne mudrosti. 
Dokument naglašava kako je u središtu svakog etičkog promišljanja zapravo osoba, bilo kao pojedinac bilo kao zajednica: „Kao i kod ostalih medija, u središtu etičkog vrednovanja interneta su osoba i zajednica osoba. Što se tiče poruke, procesa komuniciranja i ustrojstvenih i sistemskih pitanja u komunikaciji 'temeljno je etičko načelo: ljudska osoba i ljudska zajednica svrha su i mjerilo upotrebe društvenih obavijesnih sredstava. Priopćavanje bi trebali raditi ljudi u korist cjelokupnog razvoja drugih ljudi.' Opće dobro - tj. skup onih uvjeta društvenog života koji grupama i pojedincima omogućuju da potpunije i lakše dođu do vlastitog savršenstva - pruža drugo korisno načelo za etičko vrednovanje obavijesnih sredstava. Ono bi se moglo cjelovito razumjeti kao skup ciljeva za koje se pripadnici neke zajednice zajednički zalažu i radi čijeg ostvarivanja i podupiranja zajednica i postoji. Dobro pojedinaca ovisi o općem dobru njihovih zajednica. Krepost koja u ljudima budi nagnuće zaštite i promicanja općeg dobra je solidarnost. To nije osjećaj 'neke neodređene sućuti ili površnog ganuća' zbog tuđih patnji, već je 'čvrsta i postojana odlučnost zauzeti se za opće dobro, to jest za dobro svih i svakoga, jer svi smo mi uistinu za sve odgovorni.' Posebno danas solidarnost je poprimila jasne i snažne međunarodne razmjere. O međunarodnom općem dobru treba govoriti i nužno se za njega zauzimati““ (EI, br. 3). Osim naglaska na osobi kao temeljnoj vrednoti, dokument pod etičkim vidikom obrađuje i temu odnosa pojedinca, zajednice i općeg dobra, naglašavajući upravo vrijednost općeg dobra koje je nužno i za dobro pojedinca.

$\mathrm{Na}$ sličan način dokument postavlja i neka konkretna etička pitanja o internetu: „Širenje interneta pokreće brojna druga etička pitanja kao što su pravo na tajnost, sigurnost i povjerljivost podataka, pravo na intelektualno vlasništvo i autorska prava, zatim pitanja pornografije, web stranicâ koje potiču mržnju, širenje glasina i kleveta pod krinkom vijesti i mnoga druga. Ukratko ćemo govoriti o nekim od navedenih pitanja koja zahtijevaju stalnu analizu i raspravu svih uključenih subjekata. Ipak, internet nećemo promatrati samo kao izvor problema, već kao izvor dobrobiti za ljudski rod. No te će se dobrobiti u potpunosti ostvariti tek nakon rješenja postojećih problema“ (EI, br. 6). Kao što je vidljivo iz navedenog citata, osim navođenja pitanja dokument još jednom naglašava pozitivan aspekt interneta te da ga se ne smije promatrati kao izvor problema. Međutim, ističe se i potreba rješavanja tih problema i pitanja.

Također se jasno se navode i etički vidici i problemi koji se javljaju u vezi s razvojem tehnologije i samoga interneta: „Tehnološka konfiguracija interneta usko je vezana uz njegove 
etičke vidike: ljudi ga koriste u skladu s načinom na koji je konfiguriran i oblikuju ga kroz prilagodbu toj vrsti primjene. Taj 'novi' sustav datira iz 60-ih godina, odnosno godina hladnog rata, kada se nastojalo spriječiti nuklearni napad stvaranjem decentralizirane mreže računala koja su sadržavala važne podatke. Decentralizacija je bila ključ toga sustava, jer na taj način, bar se tako mislilo, gubitak jednog računala ili čak više računala nije automatski značio i gubitak svih podataka. Idealistička vizija slobodne razmjene informacija i zamisli odigrala je pozitivnu ulogu u razvoju Interneta. Ipak, njegova decentralizirana konfiguracija jednako kao i decentralizirani oblik World Wide Web (WWW) mreže kasnih 80-ih također su se pokazali srodni zamisli koja se protivila svemu što je imalo okus legitimnog uređenja i javne odgovornosti. Tako je za internet postao karakterističan pretjerani individualizam. To je, govorilo se, novo kraljevstvo, čudesni cyberspace, gdje je dopušten svaki oblik izražavanja i gdje je jedini zakon potpuna individualna sloboda da se čini što se hoće. Naravno, to je značilo da bi jedina zajednica, čija se prava i interesi u tome virtualnom svijetu uistinu priznaju, bila zajednica radikalnih libertarijanaca (pristaša načela slobodne volje, op. pr.). I danas je u nekim krugovima ostao utjecajan taj način razmišljanja, poduprt tipičnim libertarijanskim tvrdnjama koje se također iznose u obrani pornografije i općenito nasilja $\mathrm{u}$ medijima. Premda radikalni individualisti i poduzetnici očito predstavljaju dvije različite skupine, postoji neka bliskost interesa između onih koji žele da internet bude mjesto svakovrsnog izražavanja, bez obzira koliko ono bilo izopačeno ili štetno i onih koji žele da internet bude prijenosnik nesmetanog tržišnog djelovanja prema neoliberalnom modelu koji profit i tržišne zakone promatra kao apsolutne parametre na štetu dostojanstva i poštivanja osobe i naroda" (EI, br. 8).

Dokument ističe sposobnost interneta da ujedini ljude, ali nažalost i da stvori podjele: „Internet može ujediniti osobe, ali ih može i podijeliti, bilo kao pojedince bilo kao međusobno nepovjerljive skupine podijeljene ideologijom, politikama, posjedovanjima, rasom, etničkom pripadnošću, generacijskim jazom, čak i religijom. Već je bio korišten na agresivne načine, gotovo kao ratno oružje te se već govori o opasnosti što je predstavlja 'cyber-terorizam'. Bila bi gorka ironija da se to obavijesno sredstvo, s takvim mogućnostima uzajamnog zbližavanja ljudi, okrene svojoj prvobitnoj svrsi iz doba hladnog rata i postane poprište međunarodnog sukoba“ (EI, br. 9).

Uz brojne druge poteškoće, dokument ovdje ističe jednu specifičnu koju naziva „digital divide“, to jest „digitalni jaz“, a riječ je digitalnoj diskriminaciji siromašnih u odnosu 
na bogate, o čemu je među prvima - drugim riječima - pisao Sean McBride 1980. godine, a nakon njega upozoravali i brojni drugi autori: „U svemu što smo do sada govorili kriju se brojne zabrinutosti vezane uz internet. Jednu od najvećih predstavlja ono što se danas naziva 'digital divide', oblik diskriminacije koji dijeli bogate od siromašnih, kako među narodima tako i unutar njih samih, na temelju pristupa odnosno nemogućnosti pristupa toj novoj informatičkoj tehnologiji. U tom smislu riječ je o suvremenoj verziji staroga jaza između 'informacijama bogatih' i 'informacijama siromašnih.' Izraz 'digital divide' ukazuje na činjenicu da pojedinci, skupine i narodi moraju imati pristup toj novoj tehnologiji kako bi mogli imati udjela u blagodatima koje obećavaju globalizacija i razvoj te kako ne bi dalje zaostajali. Neophodno je zajamčiti da jaz koji korisnike novih obavijesnih i informativnih ${ }^{19}$ sredstava odvaja od onih koji nemaju prilike njima se služiti, neće postati još jedan nesavladivi razlog nepravde i diskriminacije” (EI, br. 10). Isto to, ali na nešto drugačiji način, dokument naglašava i kasnije: „Cyberspace bi morao biti izvor informacija i servisa koji će biti dostupni svima besplatno i na čitavom nizu jezika“ (EI, br. 10). No, nalazi i još neke razloge tog jaza: „U vezi s tim nužno je imati na umu da uzroci i posljedice te podjele nisu samo ekonomske već i tehničke, društvene i kulturalne. Tako, primjerice, postoji određena 'podjela' u radu s internetom na štetu žena te se i ta podjela, također, mora ukloniti““ (EI, br. $10)$.

Dijalog među kulturama i doprinos interneta tome dijalogu jedna je od važnih tema ovoga dokumenta, koji naglašava da taj dijalog mora biti dvosmjeran, a ne dominacija zapadne kulture nad drugim manje razvijenim kulturama: „Ipak, taj dijalog mora biti dvosmjeran. Kulture imaju što naučiti jedna od druge, međutim kada jedna kultura drugoj nameće vlastiti pogled na svijet, vrijednosti i čak jezik, to nije dijalog već kulturalni imperijalizam. Posebno je ozbiljan problem kada prevladavajuća kultura prenosi lažne vrijednosti koje proturječe istinskom dobru osoba i skupina. Kako stvari stoje, internet, zajedno s ostalim društvenim obavijesnim sredstvima, prenosi poruke u kojima su sadržane vrijednosti vlastite zapadnoj svjetovnoj kulturi, pojedincima i društvima koja ih u većini slučajeva nisu spremna pravo procijeniti i s njima se uhvatiti u koštac. To dovodi do ozbiljnih problema, primjerice na području braka i obitelji, koji bilježe 'rasprostranjenu i korjenitu krizu' u mnogim dijelovima svijeta. U tim okolnostima imperativ predstavljaju kulturna osjetljivost i poštivanje tuđih vrijednosti i uvjerenja“" (EI, br. 11).

\footnotetext{
${ }^{19}$ U službenom prijevodu je „,izražajnih“, no prikladnije i točnije je prevesti riječju „informativnih“.
} 
Vrlo važna tema koja se tiče upravo medijske etike jest i zauzimanje za slobodu izražavanja na internetu: „Snažno podupiremo slobodu izražavanja i slobodnu razmjenu ideja. Sloboda traženja i spoznaje istine je temeljno ljudsko pravo, a sloboda izražavanja temeljni kamen demokracije“ (EI, br. 12), ističe dokument i jasno proziva i pojedine sustave koji ju ne poštuju: „U svjetlu tih zahtjeva općeg dobra ne odobravamo pokušaje javnih vlasti da sprječavaju pristup informacijama na internetu ili ostalim društvenim obavijesnim sredstvima doživljavajući ih kao opasnost ili prijetnju, da manipuliraju javnim mišljenjem putem propagande i širenja dezinformacija ili da onemogućavaju legitimnu slobodu izražavanja i mišljenja. Autoritarni režimi u tom pogledu čine najteža kršenja, ali problem postoji i u liberalnim demokracijama, gdje pristup društvenim obavijesnim sredstvima u svrhu političkog djelovanja često ovisi o bogatstvu i gdje političari i njihovi savjetnici krše istinitost i poštenje klevećući protivnike i prikazujući probleme beznačajnim“(EI, br. 12).

Prema dokumentu istinsko bi novinarstvo trebalo voditi računa o raznim aspektima, novinama i promjenama kroz koje i samo prolazi: „U tom novom ozračju, kako je često isticano, novinarstvo prolazi kroz duboke promjene. Spoj nove tehnologije i globalizacije 'povećao je moć medija, ali ih je ujedno učinio podložnijim ideološkim i tržišnim pritiscima', a isto vrijedi i za novinarstvo. Internet je vrlo učinkovito sredstvo za brzi prijenos vijesti i informacija ljudima. Ipak, ekonomski duh natjecateljstva i danonoćna prisutnost on-line novinarstva pridonose također senzacionalizmu i širenju glasina, stapanju vijesti, promidžbenih poruka i zabavnih sadržaja, i, bar prividnom, smanjenju ozbiljnih kronika i komentara. Istinsko novinarstvo prijeko je potrebno za opće dobro naroda i međunarodne zajednice, a probleme koji su se očitovali u radu s internet novinarstvom trebaju brzo riješiti sami novinari. Za mnoge je problem silna količina informacija na internetu, od kojih većina nije provjerena te se ne zna jesu li uopće točne. No, zabrinuti smo i zbog činjenice da korisnici interneta koriste tehnološku mogućnost tog medija da stvara vijesti 'po narudžbi' jednostavno kako bi podigli elektronske ograde prema nepoznatim idejama. To bi bilo nezdravo u pluralističkom svijetu u kojem ljudi moraju rasti u uzajamnom razumijevanju. Premda korisnici interneta imaju obvezu biti selektivni i samodisciplinirani, to ih ipak ne smije odvesti u drugu krajnost, naime da se zatvore prema drugima. Pored toga potrebno je stalno proučavati utjecaje medija na psihološki razvoj i zdravlje, uključujući mogućnost da dugotrajnija zadubljenost u virtualni svijet za nekoga bude štetna“" (EI, br. 13). 
Kao što smo već vidjeli, jasno se osuđuje ideja libertarijanizma: „Osim pitanja vezanih uz slobodu izražavanja, potpunost i točnost vijesti, sama razmjena ideja i informacija također pobuđuje drugi niz zabrinutosti koji proistječu iz libertarijanizma. Ideologija radikalnog libertarijanizma ujedno je i pogrešna i štetna, u prvom redu u pogledu slobodnog izražavanja u službi istine. Pogreška se sastoji u tome da se sloboda uzdiže 'te se od nje tvori apsolut koji bi bio izvor vrijednosti. Ali na taj način iščezava neophodan zahtjev istine, u korist kriterija iskrenosti, autentičnosti, sklada sa samim sobom'. U tom načinu razmišljanja nema mjesta istinskom zajedništvu, općem dobru i solidarnosti““(EI, br. 14).

U dokumentu se postavlja još jedno temeljno pitanje - ono o upotrebi medija za dobre ili loše svrhe - o kojemu je već bilo riječi u dokumentu Etika u obavijesnim sredstvima, iz kojeg je to pitanje i citirano: „Kao što smo vidjeli, krepost solidarnosti mjerilo je za određivanje korisnosti služenja interneta općem dobru. Upravo se kroz prizmu općeg dobra promatra etičko pitanje: 'Primjenjuju li se društvena obavijesna sredstva za dobro ili za zlo?' Mnogi pojedinci i skupine snose zajedničku odgovornost na tome području, primjerice multinacionalne korporacije o kojima smo ranije govorili. Svi su korisnici interneta dužni koristiti ga znalački i disciplinirano u moralno ispravne svrhe. Roditelji bi morali voditi i nadzirati na koji način njihova djeca koriste internet. Škole i ostale ustanove i odgojni planovi morali bi poučavati razboritom korištenju interneta kao dio cjelokupnog medijskog obrazovanja, koje ne uključuje samo obrazovanje u tehničkim znanjima - 'internet početnicu' i tome slično - već i osposobljavanje za znalačko i mudro vrednovanje sadržaja. Oni čije odluke i djelovanja pridonose stvaranju internet strukture i njegovih sadržaja imaju dužnost provoditi solidarnost u služenju općem dobru“ (EI, br. 15).

Pozivajući se na Communio et progressio oštro se osuđuje i cenzura, uz napomenu da ipak i na internetu moraju postojati zabranjena djelovanja: „Trebalo bi izbjegavati cenzuru a priori od strane vlada. 'Stoga se cenzura smije primijeniti jedino u krajnjim slučajevima.' Internet je kao i ostala društvena obavijesna sredstva podložan opravdanim zakonima protiv izraza mržnje, klevetanja, obmana, dječje pornografije i pornografije općenito kao i ostalih njihovih povreda. Kriminalno vladanje u ostalim sredinama kriminalno je i u virtualnom svijetu te je dužnost i pravo građanskih vlasti te zakone primjenjivati. Možda će biti neophodno donijeti i nove uredbe protiv posebnih kaznenih djela na internetu poput širenja virusa, krađa osobnih podataka pohranjenih na tvrdom disku i slično“ (EI, br. 16). 
Dokumentom se potiče i izrada etičkih kodeksa: „Industrijski etički kodeksi, ako ih se uzme ozbiljno, mogu odigrati korisnu ulogu. U njihovu formuliranju i njihovu primjenu uključeni su predstavnici javnosti i, osim što pružaju pozitivni poticaj odgovornim komunikatorima, određuju primjerene kazne za kršenje propisa, uključujući javnu cenzuru. Okolnosti ponekad mogu zahtijevati intervenciju države: primjerice osnivanje nadzornih odbora za obavijesna sredstva koji će predstavljati sve sektore javnog mišljenja u društvu“ (EI, br. 16).

Dokument na kraju postavlja i ostala važna pitanja: „Mnoga teška pitanja vezana uz internet zahtijevaju međunarodnu suglasnost: primjerice, kako zajamčiti privatnost pojedinaca i skupina koji se pridržavaju zakona, a da se pritom u radu ne spriječe službene osobe zadužene za provođenje zakona i jamčenje sigurnosti u nadgledanju kriminalaca i terorista? Kako zaštititi autorsko pravo i pravo na intelektualno vlasništvo bez ograničavanja pristupa materijalima koji nisu podložni autorskim pravima i kako uopće definirati sam pojam nepodložnosti autorskom pravu? Kako urediti i čuvati bezbroj informacija pohranjenih na internetu koje su besplatno dostupne svim korisnicima na različitim jezicima? Kako zaštititi prava žena u pogledu pristupa internetu kao i ostalih vidika nove informatičke tehnologije? Posebno pitanje kako ukloniti 'digital divide' između bogatih informacijama i siromašnih informacijama zahtijeva ozbiljnu pozornost prema njegovim tehničkim, odgojnim i kulturalnim vidicima“" (EI, br. 17).

\subsection{Papine poruke za svjetski dan sredstava društvene komunikacije}

„Drugi vatikanski koncil odobrio je godine 1963. dokument 'Inter mirifica' o sredstvima društvene komunikacije. Taj je dokument, uz svoj doktrinarni i pastoralni značaj, donio i tri posebna prijedloga:

1. potrebu utemeljenja komisije Svete Stolice koja bi se bavila pitanjima vezanim uz sva sredstva komunikacije - to je ostvario nekoliko mjeseci kasnije Pavao VI. utemeljujući Papinsku komisiju (kasnije Vijeće) za sredstva društvene komunikacije;

2. pripremu pastoralnih uputa o sredstvima društvene komunikacije - što je ostvareno godine 1971. objavljivanjem dokumenta 'Communio et progressio', te njegove kasnije dopune 'Aetatis novae', dokumenta objavljenog 1992. 
3. utemeljenje Svjetskog dana Sredstava društvene komunikacije, na dan koji bi odredili biskupi diljem svijeta - što je kasnije prihvaćeno da se taj dan slavi na nedjelju koja pada između svetkovine Uznesenja Gospodinova i Pedesetnice. Prva poruka Svetoga Oca za Svjetski dan sredstava društvene komunikacije objavljena je 1967. godine“ (Foley, u: Ivan Pavao II, 2003: 5).

Ove su poruke za javnost postale vrlo važne, te zbog toga zaslužuju sustavni prikaz i analizu jer redovito prate medijski aktualne teme i redovito progovaraju i o pitanjima vezanima uz medijsku etiku. Ova disertacija obradit će 50 poruka - od prve 1967. godine do jubilarne 50. koja je objavljena 2016. godine. Papa Pavao VI, izdao ih je 12, jer je bio papa do 1978. godine. Te godine ga je naslijedio Ivan Pavao I., no s obzirom da je umro samo 33 dana nakon izbora za papu, nije napisao niti jednu poruku. Nakon njega dolazi Ivan Pavao II. koji je prvu poruku objavio 1979. godine, a zadnju 2005. godine, te je papa koji je, zasada, napisao najviše poruka, čak 27. Papa Benedikt XVI. objavio je osam poruka (prvu 2006., a zadnju 2013, godine). Papa Franjo je u razdoblju koje analiziramo (do 2016. godine, tj. do jubilarne 50. poruke) objavio tri poruke.

Naime, ,poruke za Svjetski dan sredstava društvene komunikacije pozivaju sve one koji upravljaju medijima i stvaraju njihov sadržaj da budu odgovorni u korištenju tih važnih sredstava komunikacije i rade na dobrobit društva i poštovanje svake ljudske osobe. Poruke pozivaju i sve korisnike medija na kritičnost i razumnost u služenju tiskom, radijem i televizijom, kinom i internetom, te da ne budu samo pasivni primatelji slika i novinskih izvještaja“ (Foley, u: Ivan Pavao II., 2003: 6).

Za potrebe ovog rada, poruke nisu prikazane kronološki, nego unutar pojedinih tema koje se u porukama pronalaze, tako da su poruke podijeljene unutar sljedećih pet skupina: „Istina i druge vrednote“ (11 poruka), „Odgovornost medijskih korisnika“ (četiri poruke), „Čudesni Božji darovi i moćna sredstva“" (pet poruka), „Obitelj i drugi međuljudski odnosi“ (13 poruka) i „Otvorenost prema drugim (narodima)“ (17 poruka). 


\subsubsection{Sredstva društvene komunikacije u službi istine $(1972)^{20}$}

Ova poruka posvećena je važnoj temi medijske etike koju smo već više puta prethodno spominjali i analizirali, a koja se često obrađuje i u crkvenim dokumentima: to jest odnosu medija i istine: „Svaka činjenica ima svoju istinu, ali čak i jasna i jednostavna činjenica može imati više kutova, tako da nije uvijek lako shvatiti istinu o nekoj činjenici u cijelosti. No, to ne znači da je nemoguće; daleko od toga. S obzirom na kombinaciju marljivosti i iskrenosti osoba koje komuniciraju činjenice i osoba kojima je komuniciramo, postoji veoma velika šansa da će se sigurno prenositi 'istina, cijela istina i ništa osim istine'“ (SD 1972).

Nadalje, papa Pavao VI. nastavlja: „Davanje informacija podrazumijeva mnogo više od promatranja i izvješćivanja o događaju u prolazu. Novinar se odnosi prema događaju u kontekstu u kojem se to događa. On traži uzroke. On istražuje okolnosti i pokušava procijeniti moguće učinke takvog događaja. Novinarova zadaća se možda, na neki način, može usporediti sa znanstvenim istraživanjem, jer on mora pažljivo promatrati činjenice, mora provjeriti njihovu točnost, napraviti kritičku evaluaciju izvora informacija, i konačno, proučiti sve što je pronašao, cijelo vrijeme vodeći računa da se ništa bitno ne propusti ili potisne. Teret odgovornosti koji je na leđima novinara sve je teži kada je, kao što se često događa, on pozvan, ne samo da prenese jednostavne činjenice o događaju, već i da objasni njegove implikacije uz komentar, procjenu i predviđanje razvoja situacije“ (SD 1972).

\subsubsection{Masovni mediji u ulozi afirmacije i promicanja duhovnih vrijednosti $(1973)^{21}$}

Pozivajući se na Communio et progressio poruka naglašava: „Ljudi dobre volje vide kako se sredstva društvene komunikacije često koriste u proturječju ili iskrivljivanju temeljnih vrijednosti ljudskog života i stvaranju nesloge i zla“ (SD 1973). Nakon toga nastavlja: „Zloupotrebe i štete koje se njima uzrokuju su dobro poznati. Širenje lažnih ideologija i

\footnotetext{
${ }^{20}$ Poruka nije prevedena na hrvatski jezik, te ju za potrebe ovog rada prevodim s poveznice: http://w2.vatican.va/content/paul-vi/en/messages/communications/documents/hf_p-vi_mes_19720421_vi-comday.html

${ }^{21}$ Poruka nije prevedena na hrvatski jezik, te ju za potrebe ovog rada prevodim s poveznice: http://w2.vatican.va/content/paul-vi/en/messages/communications/documents/hf_p-vi_mes_19730501_vii-comday.html
} 
pretjerane zaokupljenosti samim materijalnim napretkom često umanjuje brigu za prave mudrosti i trajne vrijednosti“ (SD 1973).

Govoreći o djelatnicima masovnih medija, papa Pavao VI. ističe: „Mi smo ih sve zamolili da obnove svoju odlučnost u preoblikovanju masovnih medija u goruće baklje i moćne svjetionike koji osvjetljavaju put do jedine prave sreće. Svijet treba afirmaciju duhovnih vrijednosti kao što se vidi u njihovom konkretnom izražavanju. Da bi se postigao ovaj cilj oni koji su u mogućnosti koristiti društvene komunikacije u svim svojim nastojanjima dužni su to učiniti. Riječ, slika i tisak, svjetlo, glazba i zvuk moraju pomoći prenijeti poruku dobrote, ljepote i istine. Tisak, radio, televizija, kino, kazalište i oglašavanje moraju biti korišteni u punini u toj misiji prenošenja smislene poruke svijetu“ (SD 1973).

\subsubsection{Društvene komunikacije i odgovorna ljudska sloboda $(1981)^{22}$}

U poruci iz 1981. Ivan Pavao II. naglašava dvije važne teme medijske etike - slobodu i odgovornost, te upozorava na utjecaj medija: „Crkva, uzimajući u obzir velike mogućnosti masovnih medija, uvijek je uz njihove pozitivne elemente naglašavala i potrebu promišljanja koje nadilazi puku oduševljenost medijima. Crkva stoga potiče ljude na razmišljanje i uzima u obzir snagu medijskog utjecaja na čovjeka. Taj utjecaj je prisutan sada, a bit će prisutan i u budućnosti, u različitim oblicima, o kojima se uvijek mora u potpunosti voditi računa. Čovjek, čak i u prisutnosti masovnih medija, pozvan je biti ono što on u svojoj biti jest: slobodan i odgovoran, subjekt, a ne objekt, kritičan, ne pasivan“"(SD 1981, br. 1).

Govoreći pak o ljudskom dostojanstvu u poruci se naglašava: „To dostojanstvo zahtijeva da čovjek donosi odluke informirano i slobodno“ (SD 1981, br. 2), dok se zbog negativnosti upozorava: „Mediji su često instrumenti vlasti koji mogu postati tiranski, posebno tamo gdje ne postoji pluralizam. To se može dogoditi ne samo tamo gdje sloboda ne postoji, kao što je to pod diktaturom bilo koje vrste, već i gdje je sloboda u znatnoj mjeri sačuvana, ali veliki interesi stvaraju konstantan pritisak na medije“ (SD 1981, br. 3).

Stoga se jasno poziva i na odgovornost medija i novinara: „Odgovorna sloboda komunikatora, koji imaju moć odabira onoga što komuniciraju, mora uzeti u obzir i korisnike

\footnotetext{
${ }^{22}$ Poruka nije prevedena na hrvatski jezik, te ju za potrebe ovog rada prevodim s poveznice: http://w2.vatican.va/content/john-paul-ii/en/messages/communications/documents/hf_jp- 
medija, koji su također slobodni i odgovorni“ (SD 1981, br. 3), a papa Ivan Pavao II. pomalo osobno navodi: „Podsjetiti komunikatore da njihov poziv od njih traži ljubav, pravdu, istinu, kao i slobodu - to je dužnost mog pastorala. Istina nikada ne smije biti iskrivljena, pravda zanemarena, ljubav zaboravljena, ako polazimo od etičkih standarda“" (SD 1981, br. 3).

Ivan Pavao II. upozorava i na opasnost od izostanka „odgovorne slobode onih koji koriste sredstva društvenih komunikacija, opasnost koja poprima oblik ozbiljnog korištenja seksa do točke u kojoj zapravo postaje pornografija: u izgovorenoj ili napisanoj riječ, na slikama, pa čak i tzv. 'umjetničkim' plakatima. S vremena na vrijeme na to se pristaje, rezultat čega je i destrukcija i izopačenost. Odbijanje ovog stanja ne znači zagovaranje onoga što se tako često opisuje kao 'nazadni mentalitet' ili cenzuru slobodne volje: odbijanje svoj razlog pronalazi u samom značenju slobode, a sloboda traži i zahtijeva da se ne nameću stavovi, pa tako niti od strane onih koji traže da se transformira seksualnost u samoj sebi“" (SD 1981, br. 4).

\subsubsection{Društvene komunikacije, kršćani i formiranje javnog mijenja $(1986)^{23}$}

Papa Ivan Pavao II. u ovoj poruci naglašava veliku odgovornost onih koji utječu na javno mnijenje te još jednom pojašnjava crkveni nauk o toj temi medijske etike: „To pokazuje veliku odgovornost ljudi koji zbog svog obrazovanja ili prestiža oblikuju javno mnijenje ili utječu na njegovu izgradnju u određenoj mjeri. Ljudi, naime, imaju pravo misliti i osjećati se u skladu s onim što je istinito i dobro, jer od njihovog načina razmišljanja i osjećaja ovisi njihov moralni učinak. To će biti u redu, ako je njihov način razmišljanja odgovara istini““ (SD 1986, br. 2). Ta velika odgovornost jamačno se može najviše primijeniti upravo na medijske djelatnike koji su primarni oblikovatelji javnog mnijenja, te je i njihova odgovornost najveća, pa poruka nastavlja da s tim u vezi „treba naglasiti da javno mnijenje ima veliki utjecaj na način razmišljanja, osjećaje i ponašanje onih koji su, bilo zbog svoje mladosti ili njihovog nedostatka obrazovanja, nesposobni za stvaranje kritične prosudbe. Dakle, postoje mnogi koji misle i djeluju u skladu s onim što se obično misli u zajednici, a da nisu u stanju oduprijeti se pritisku koji im se nameće. Također treba naglasiti da javno mnijenje ima snažan utjecaj na formiranje zakona. Ustvari, nema sumnje da je uvođenje nepravednih zakona u nekim

\footnotetext{
${ }^{23}$ Poruka nije prevedena na hrvatski jezik, te ju za potrebe ovog rada prevodim s poveznice: http://w2.vatican.va/content/john-paul-ii/en/messages/communications/documents/hf_jp- 
zemljama, kao što su na primjer legalizacije pobačaja, rezultat pritiska od strane javnog mnijenja koje je bilo povoljno za taj korak“" (SD, 1986, br. 2).

Podsjećajući na različite vrste medija - tisak, kino, radio, televiziju - Ivan Pavao II. naziva ih glavnim kreatorima javnog mnijenja i ističe da je velika „moralna odgovornost svih onih koji su zaposlenici tih sredstava, te na različitim moćima koje se kriju iza njih. Sredstva društvenih komunikacija treba staviti u službu humanosti, i u službu istine i dobrote koje predstavljaju najvažnije i potrebne vrijednosti čovječanstva. Oni, dakle, koji rade profesionalno u području društvenih komunikacija trebaju se osjećati dužnima formirati i ostvariti široko javno mnijenje koje je u skladu s istinom i dobrotom (SD 1986, br. 5).

\subsubsection{Kršćanska poruka u kompjuterskoj kulturi (1990) ${ }^{24}$}

Ova poruka nije izravno posvećena samo medijskoj etici, ali nakon što govori o velikim promjenama koje su nastale upravo zbog napretka tehnike, nastavlja: „To priznanje brzih promjena i ove otvorenosti prema novim dostignućima pokazale su se pravovremenim $u$ godinama koje su uslijedile, te se tempo promjena i razvoja nastavio ubrzavati, te se danas, na primjer, više ne misli ili govori o društvenim komunikacijama kao pukim instrumentima ili tehnologijama. Umjesto toga ona se sada promatraju kao dio još uvijek razvijajuće kulture čije će se pune posljedice tek dokučiti i čiji potencijali ostaju za sada samo djelomično iskorišteni“ (SD 1990).

\subsubsection{Filmska produkcija: komunikator kulture i vrijednosti $(1995)^{25}$}

Povodom 100. obljetnice filma, „toga posebnog i raširenog sredstva izražavanja, u današnje vrijeme pristupačnog svakome“ (SD 1995), papa Ivan Pavao II. progovara upravo o filmu, te između ostalog i o nekim etičkim dimenzijama tog medija. Odmah na početku

\footnotetext{
${ }^{24}$ Poruka nije prevedena na hrvatski jezik, te ju za potrebe ovog rada prevodim s poveznice: http://w2.vatican.va/content/john-paul-ii/en/messages/communications/documents/hf_jpii_mes_24011990_world-communications-day.html

${ }^{25}$ Korišten je službeni prijevod na hrvatski jezik: Filmska produkcija: komunikator kulture i vrijednosti (1995), u: Ivan Pavao II. (2003), Deset poruka za slavlje Svjetskog dana sredstava društvene komunikacije, Zagreb, IKA
} 
poruke jasno kaže da želi o njemu promišljati kao o „,nositelju kulture i ponudi vrednota“ (SD 1995).

Nadalje, papa progovara o prisutnosti vrednota u ovom mediju: „Ljudske i vjerske vrednote koje zaslužuju pozornost i pohvalu, često su prisutne ne samo u filmovima koji se izravno bave tradicijom kršćanstva, nego i u filmovima različitih kultura i vjera“ (SD 1995).

Papa zatim naglašava i važnost brige oko sadržaja filma, te govori o neetičnim motivima kao što je samo povećanje broja gledatelja: „Proizvoditi filmove koji su osiromašeni sadržajem i koju su namijenjeni isključivo razonodi, ili im je motiv tek povećanje broja gledatelja, nije u skladu s najautentičnijim i dubokim zahtjevima i čovjekovim očekivanjima“"(SD 1995, str. 17).

Pozivajući se na Pija XII. (Miranda prorsus), kao i na svoju poruku za svjetski dan medija 1981., te na samo evanđelje, Ivan Pavao II. ističe: „Kao što se to događa sa svim medijima društvenog priopćavanja, film, pored svojih ogromnih zasluga za doprinos kulturnom i humanom rastu pojedinca također može biti kočnica slobode, posebno onima najslabijima, a naročito kada iskrivljava istinu (usp. Pio XII, Miranda prorsus, 1957), kada se predstavlja kao ogledalo negativnih tipova ponašanja koristeći scene nasilja i seksa koje vrijeđaju ljudsko dostojanstvo i 'podstiču nasilne emocije kako bi stimulirale pažnju gledatelja' (Ivan Pavao II., Poruka povodom Svjetskog dana sredstava javnog priopćavanja 1981). Filmovi koji neodgovorno potiču negativno ponašanje, o čijim štetnim efektima se svakoga dana može čitati u novinama, ne mogu biti definirani 'slobodnim umjetničkim izražajem'. Jer kao što nas Evanđelje podsjeća, samo smo u Istini oslobođeni““ (SD 1995).

Referirajući se između ostalog i na svog prethodnika Pija XII. i njegov „Idealni film“ iz 1955., Ivan Pavao II. poziva na odgovornost i one koji stvaraju program, ali i one koji ga konzumiraju: „Hitnost rješavanja problema nasilničkog ponašanja u našem društvu, za kojeg se prečesto stječe dojam da ga nadahnjuju negativni podražaji koje pruža film, televizija i tisak, potiče me da još jednom uputim poziv svima koji su odgovorni za filmsku industriju, kako bi se posvetili profesionalnom poslu u odgovornosti, ali i gledateljima - kako bi znali kritički reagirati na sve zahtjevnije ponude medija, uključujući i film, te da budu spremni razlučiti ono što nas može oplemeniti od onoga što nam može naškoditi. Kada nas film, u skladu s jednim od svojim temeljnih ciljeva, predstavlja kao ljudska bića, on nam mora omogućiti, na temelju realnosti, vrijedne refleksije o konkretnim uvjetima u kojima živimo. Film, dakle, mora ponuditi građu za refleksiju o pitanjima kao što su društvene odgovornosti, 
osuda nasilja, osude svih oblika isključivanja, rata i nepravde. Ovi društveni problemi kojima se film tijekom svoje stogodišnje povijesti često bavio, ne mogu ostaviti ravnodušnima sve one koji su zabrinuti za sudbinu čovječanstva. To znači prihvaćanje i promicanje tih vrednota koje Crkva nosi na srcu i izravan je doprinos njihovom širenju putem medija koji lako i djelotvorno dolaze do javnosti“(SD 1995).

Papa ističe i važnost postavljanja pravih pitanja: „Danas posebno, a u praskozorje trećeg milenija, od silno velike važnosti je da si postavimo jasna pitanja, da ne zažmirimo na probleme nego da potražimo odgovore i rješenja. U ovom kontekstu, film nedvojbeno ima svoje mjesto i svoju vrijednost za koju je namijenjen. No i pored toga, apelirao bih na odgovorne osobe na svakoj razini da u potpunosti budu svjesne ogromnog utjecaja kojega imaju na ljude i misiju koju trebaju ispuniti u ovo sadašnje vrijeme bremenito potrebama za univerzalnim zahtjevima za mirom i onog dostojanstva koje nam je svakome dao Bog, Tvorac. Oni koji se bave osjetljivim područjem filma moraju kao komunikatori ostati otvoreni dijalogu i stvarnosti koja ih okružuje. Moraju se potruditi da filmovima istaknu najvažnija pozitivna nastojanja koja će navoditi na razmišljanje, svjesni da će ovakav pristup zbližiti ljude različitih kultura i svima donijeti pozitivne rezultate“ (SD 1995).

Pozivajući se djelomično i na Aetatis novae, papa ističe važnost obrazovanja: „Da bi se sa sigurnošću u potpunosti razumjele poruke koje film može pružiti za ljudski i duhovni rast onih kojima je namijenjen, također je potrebno voditi brigu o naobrazbi gledatelja glede rječnika u filmu koji često odudara od izravnog predstavljanja stvarnosti, kako bi se razumjeli sudovi simbola koji nisu uvijek lako shvatljivi. Bilo bi korisno kad bi i u školama nastavnici posvećivali pažnju tom problemu, te studente činili osjetljivijima na slike i postupno razvijali njihov kritički odnos prema obliku izražavanja koji je postao integralni dio naše kulture; jer 'primjena komunikacijske tehnologije može biti i korisna i štetna a njezino korištenje u dobre svrhe zahtijeva zdrave vrijednosti i mudre odluke od strane pojedinaca, od privatnog sektora, vlada i svekolikog društva'“‘ (SD 1995).

\subsubsection{Ohrabreni duhom, priopćavati nadu $(1998)^{26}$}

U svojoj poruci iz 1998. godine papa Ivan Pavao II. govori o temeljnom postulatu svake medijske etike i svakoga novinarskog kodeksa časti - o „snazi istine“ u izvještavanju.

\footnotetext{
${ }^{26}$ Korišten je službeni prijevod na hrvatski jezik: Ohrabreni duhom, priopćavati nadu (1998), u: Ivan Pavao II. (2003), Deset poruka za slavlje Svjetskog dana sredstava društvene komunikacije, Zagreb, IKA
} 
Premda se izravno obraća kršćanskom izvjestitelju koji „uči snagom istine prikazivati poruku nade muževima i ženama našega doba“ (SD, 1998.), ova snažna poruka vrijedi za sve novinare, jer ,nikada ne smije zaboraviti da komunikacija prenošena društvenim obavijesnim sredstvima nije koristoljubiva vježba jednostavno za požurivanje, uvjeravanje ili prodavanje. Još je manje ideološki vodič. Društvena obavijesna sredstva mogu ponekad svesti ljudska bića na potrošačke ili na interesne skupine u uzajamnom natjecanju ili manipulirati gledateljima, čitateljima i slušateljima samo kao brojkama od kojih se očekuju koristi, da ih se veže uz političku potporu ili prodaju proizvoda, a to uništava zajednicu. Priopćivanje ima zadaću ujedinjavati osobe i obogaćivati njihov život, ne odvajati ih i iskorištavati. Obavijesna sredstva, ispravno upotrijebljena, pridonose stvaranju i podržavanju ljudskog zajedništva utemeljenog na pravednosti i djelatnoj ljubavi te, u mjeri u kojoj to čine, postaju znakovi nade“ (SD 1998).

Za kršćanske izvjestitelje, kao i za sve medijske djelatnike, poruka ističe važnost odgoja, između ostalog i u ćudoređu kao i u poznavanju profesionalnih propisa: „Kršćanski izvjestitelji moraju primiti odgoj koji im omogućuje uspješno djelovati na području priopćivanja tog tipa. Takav će odgoj morati uključiti: obrazovanje u tehničkim vještinama, odgoj u ćudoređu, s posebnom pozornošću na vrijednosti i propise važne za profesionalnu djelatnost, obrazovanje u ljudskoj uljudbi, filozofiji, povijesti, društvenim znanostima i estetici. Ipak, prije svega, to mora biti odgoj u nutarnjem životu, životu Duha“" (SD 1998).

\subsubsection{Naviještati Krista u društvenim obavijesnim sredstvima u zoru novog tisućljeća $(2000)^{27}$}

Porukom iz 2000. godine Ivan Pavao II. na određeni način proziva medije i potiče ih na ispit savjesti zbog nepoštivanja etičkih načela: „Potreban je određeni 'ispit savjesti' od strane društvenih obavijesnih sredstava, koji bi doveo do veće kritičke svijesti glede sve manjeg poštovanja za vjerska i moralna uvjerenja“ (SD 1999).

\footnotetext{
${ }^{27}$ Korišten je službeni prijevod na hrvatski jezik: Naviještati Krista u društvenim obavijesnim sredstvima u zoru novog tisućljeća (2000), u: Ivan Pavao II. (2003), Deset poruka za slavlje Svjetskog dana sredstava društvene komunikacije, Zagreb, IKA
} 
U ovoj se poruci iz 2001. Ivan Pavao II. ponovno vraća na ključno načelo medijske i novinarske etike - istinu: „Odnos, dakle, između istine i društvenih obavijesnih sredstava postao je sve zamršeniji, a to rađa dvojakom pojavom. S jedne strane može zasjeniti razliku između istine i obmane, no s druge strane mogu se otvoriti do sada neviđene mogućnosti da se istina proširi do sve većeg broja osoba. Zadaća je Crkve zajamčiti da se ostvaruje ovo posljednje“(SD 2001).

Papa i ovu poruku koristi kako bi govorio o postojanju ili nepostojanju istine $\mathrm{u}$ medijima, posebno u suvremeno postmoderno doba: „Svijet društvenih obavijesnih sredstava može se katkad činiti ravnodušnim ili čak neprijateljski raspoloženim prema kršćanskoj vjeri i moralu. To je djelomično zbog toga što je kultura društvenih obavijesnih sredstava tako duboko prožeta tipično postmodernističkim obilježjem da jedina apsolutna istina jest - da ne postoje apsolutne istine, odnosno da su, ako postoje, nedohvatljive ljudskom razumu i samim time nevažne. S tog gledišta ono što vrijedi nije istina već 'vijest'. Ako je nešto vrijedno objavljivanja ili može poslužiti za zabavu korisnicima, napast da se istinitost toga ne uzme u obzir postaje gotovo neodoljiva. Zbog toga svijet društvenih obavijesnih sredstava katkad izgleda ne manje neprijateljski raspoložen od poganskog u kojem su djelovali apostoli. No, poput prvih svjedoka Radosne vijesti, ni današnji Kristovi sljedbenici ne bi smjeli uzmicati pred nevoljama“" (SD 2001).

Papa porukom upozorava i na dužnosti kršćanskih izvjestitelja, uključujući i naviještanje istine: „Nadasve im je dužnost i povlastica naviještati istinu, slavnu istinu o čovjekovu životu i sudbini objavljenoj u utjelovljenoj Riječi. Neka katolici zauzeti u svijetu društvenih obavijesnih sredstava još radosnije i još hrabrije naviještaju s krovova Isusovu istinu“" (SD 2001).

\footnotetext{
${ }^{28}$ Korišten je službeni prijevod na hrvatski jezik: Propovijedate na krovovima: evanđelje u dobu globalne komunikacije (2001), u: Ivan Pavao II. (2003), Deset poruka za slavlje Svjetskog dana sredstava društvene komunikacije, Zagreb, IKA
} 
2.10.1.10. Sredstva društvene komunikacije: na raskrižju između protagonizma i služenja. Tražiti istinu da bi ju se dijelilo (2008) ${ }^{29}$

Mediji se oduvijek nalaze na raskrižju na kojemu nekada previše žele biti protagonisti, a trebali bi više služiti istini i tražiti istinu kako bi ju podijelili sa svojim publikama. O tome piše Benedikt XVI. u svojoj poruci iz 2008, hvaleći na početku njihov tehnološki razvitak i mnogostruki doprinos: „Zahvaljujući vrtoglavom tehnološkom razvitku, ta su sredstva stekla izvanredne mogućnosti, istodobno postavljajući nova i nečuvena pitanja i probleme. Ne može se zanijekati doprinos što ga mogu dati kolanju novosti, upoznavanju s činjenicama i širenju znanja: na odlučujući su način pridonijela, na primjer, opismenjivanju i socijalizaciji, a također i razvoju demokracije i dijaloga među narodima“ (SD 2008, br. 2). Papa dalje ističe i da bi bez medija bilo teško podupirati i poboljšavati razumijevanje među narodima, pružiti univerzalnu širinu dijalozima o miru, zajamčiti čovjeku prvotno pravo na informaciju osiguravajući istodobno slobodno kolanje misli nadasve što se tiče ideala solidarnosti i društvene pravde. Piše da i da mediji u svojoj cjelini nisu samo sredstva za širenje ideja, već mogu i moraju biti i sredstva u službi pravednijega i solidarnoga svijeta. Papa ističe i drugu stranu kada naglašava da ne nedostaje rizika da se mediji pretvore u sustave usmjerene na podvrgavanje čovjeka logikama što ih diktiraju prevladavajući interesi određenoga trenutka: „To je slučaj kod komunikacije koja se koristi u ideološke svrhe ili za raspoređivanje potrošnih roba pomoću bjesomučne promidžbe. Uz izgovor da se predstavlja zbilju, zapravo se nastoji legitimirati i nametnuti iskrivljene modele osobnoga, obiteljskoga ili društvenoga života. Osim toga, da bi se povećao broj korisnika, tj. publika, ponekad se ne oklijeva pribjegavanju transgresiji, vulgarnosti i nasilju. Na kraju, tu je i mogućnost da se putem medija predlaže i podupire modele razvoja koji povećavaju umjesto da smanjuju tehnološki jaz između bogatih i siromašnih zemalja“ (SD 2008, br. 2).

Dvoznačnost koja obilježava ljudski razvoj nije mimoišla ni medije, upozorava papa, posebno ističući problem nemoralnosti manipulacije stvarnošću: „Čovječanstvo se danas nalazi na raskrižju. I za medije također vrijedi ono što sam u enciklici 'Spe salvi' napisao o dvoznačnosti napretka, koji pruža nečuvene mogućnosti za dobro, ali istodobno otvara neizmjerne mogućnosti zla što prije nisu postojale (usp. br. 22). Zato se potrebno pitati je li mudro prepustiti da sredstva društvene komunikacije budu sluganski podložna

\footnotetext{
${ }^{29}$ Korišten je službeni prijevod na hrvatski jezik: http://www.ika.hr/index.php?prikaz=vijest\&ID=100167
} 
nezaustavljivom protagonizmu ili da završe na milost i nemilost onih koji ih koriste za manipulaciju savjestima. Ne bi li baš bila dužnost učiniti sve da ostanu u službi osobe i zajedničkoga dobra i da pospješuju etičko formiranje čovjeka, u rastu čovjeka iznutra?“ (SD 2008, br. 3). Papa ističe da danas komunikacija ponekad ima pretenziju ne samo predstavljati stvarnost, već je određuje zahvaljujući moći i snazi sugestije što ju posjeduje. Tako se konstatira da se u nekim događajima mediji ne koriste za ispravnu ulogu informiranja, već za „stvaranje“ samih događaja. Papa nastavlja da „baš zbog toga što je riječ o stvarima koje duboko utječu na brojne dimenzije ljudskoga života (moralne, intelektualne, vjerske, relacijske, afektivne, kulturne), dovodeći u pitanje dobro osobe, potrebno je ponovno upozoriti da sve ono što se tehnički može izvesti nije također i etički prihvatljivo. Utjecaj sredstava komunikacije na život suvremenog čovjeka postavlja neizbježna pitanja, koja očekuju odluke i odgovore koji se više ne mogu odgađati“ (SD 2008, br. 3). Papa se u sljedećem broju (br. 4) nadovezuje na ovo. Zagovara i pojam ,info-etike“, te upozorava da „kada komunikacija izgubi etička uporišta i izbjegne društvenoj kontroli onda više ne vodi računa o središnjoj ulozi i nedodirljivom dostojanstvu čovjeka, riskirajući da negativno utječe na njegovu savjest, na njegove odluke, te u konačnici da uvjetuje samu slobodu i život osoba. Evo zašto je nužno da društvene komunikacije ljubomorno brane osobu i da joj potpuno poštuju dostojanstvo. Više je onih koji misle da je danas, na tome području, potrebna 'infoetika' kao što postoji bio-etika na području medicine i znanstvenoga istraživanja povezanoga sa životom“ (SD 2008, br. 4). Ovdje valja osobito istaknuti da Benedikt XVI. zapravo zagovara sustavan pristup medijskoj etici i zauzima se za njezino poštivanje u praksi, što je cilj ne samo svjetovne etike koju smo obradili u prvome poglavlju ovoga rada, nego je očito i tema kojom se bave crkveni dokumenti koje prikazujemo i analiziramo u ovome poglavlju.

Mediji si nikada ne bi smjeli dopustiti da postanu bilo čiji „,megafon“, ni ekonomskoga materijalizma ni etičkoga relativizma, ,pravih rana našega doba“, piše papa i poručuje: „Dapače, oni mogu i moraju pridonijeti upoznavanju istine o čovjeku, braneći je pred onima koji je nastoje zanijekati ili uništiti. Može se zapravo reći da traženje i predstavljanje istine o čovjeku tvore najuzvišeniji poziv društvene komunikacije. Koristiti s tim ciljem sve jezike kojima mediji raspolažu, a koji su sve ljepši i profinjeniji, uzvišena je zadaća u prvome redu povjerena odgovornima i djelatnicima toga sektora. No, ta nas se zadaća na neki način tiče sviju jer smo svi, u doba globalizacije, korisnici i djelatnici društvenih komunikacija. Novi mediji, telefonija i posebno internet preobražavaju sam izgled komunikacije i možda je ovo dragocjena prilika da ga se ponovno ocrta kako bi bolje bile uočljive - kako je to rekao moj 
časni prethodnik Ivan Pavao II. - bitne i nužne crte istine o ljudskoj osobi (usp. apostolsko pismo "Brz razvoj", 10)““(SD 2009, br. 5).

\subsubsection{Istina, navještaj i autentičnost života u digitalnom dobu (2011)}

Istina je u ovoj poruci i dalje u središtu razmišljanja pape Benedikta XVI, ali je kontekst nov - digitalno doba koje mijenja komunikaciju iznutra: „Nove tehnologije ne mijenjaju samo način komuniciranja, već komunikaciju u njoj samoj, zbog čega se može reći da prolazimo kroz razdoblje goleme kulturne preobrazbe. Zahvaljujući tom načinu širenja informacijâ i spoznajâ javlja se novi način shvaćanja i razmišljanja, s do sada nezabilježenim mogućnostima za uspostavu odnosa i izgrađivanje zajedništva“ (SD 2011). Zbog toga se „kao i svaki drugi plod ljudskog uma, nove komunikacijske tehnologije moraju staviti u službu cjelovitog dobra osobe i čitavoga čovječanstva. Ako ih se mudro koristi, one mogu pridonijeti zadovoljavanju želje za smislom, istinom i jedinstvom što je najdublja težnja ljudskog bića“ (SD 2011).

Naime, „nove tehnologije omogućuju ljudima da se susreću onkraj granica prostora i samih kultura, otvarajući tako potpuno novi svijet mogućih prijateljstava. To je velika mogućnost, ali to zahtijeva također veću pozornost i svijest o mogućim opasnostima“, piše Benedikt XVI. i postavlja više ključnih pitanja važnih u digitalno doba: „Tko je moj 'bližnji' u tome novom svijetu? Postoji li opasnost da budemo manje prisutni onima koje susrećemo $u$ našem svakodnevnom životu? Postoji li opasnost da budemo rastreseniji, jer je naša pažnja fragmentarna i zaokupljena svijetom 'različitim' od onoga u kojem živimo? Imamo li vremena da kritički razmišljamo o našim odlukama i njegujemo ljudske odnose koji su doista duboki i trajni? Uvijek je važno podsjećati da virtualni kontakt ne može i ne smije zamijeniti izravni ljudski kontakt s osobama na svim razinama našega života“ (SD 2011).

\footnotetext{
${ }^{30}$ Poruka nije prevedena na hrvatski jezik, te ju za potrebe ovog rada prevodim s poveznice: http://w2.vatican.va/content/benedict-xvi/hr/messages/communications/documents/hf_benxvi_mes_20110124_45th-world-communications-day.html
} 


\subsubsection{Društvene komunikacije i evangelizacija u današnjem svijetu (1974) ${ }^{31}$}

Papa Pavao VI. i u ovoj poruci ističe već ranije spomenutu i poznatu važnost medija, ovaj puta u društvenom kontekstu: „Važnost sredstava društvene komunikacije u strukturi društva danas stalno raste, iz čega se rađa njihov utjecaj na oblikovanje ljudskih odnosa. Svjesni važnosti ovog rasta ponavljamo naše čvrsto uvjerenje da su svi ljudi pozvani ponuditi svoj doprinos u području medija, jer su svi postali uključeni u komunikaciju na ovaj ili onaj način, svatko prema vlastitim posebnim okolnostima. Način tog djelovanja može poprimiti najrazličitije oblike, od izravne intervencije u stvaranju i proizvodnji programa, ili u odgovornom izboru u vezi onoga što neće gledati ili slušati. Također, svatko mora donijeti svoju vlastitu odluku hoće li je prihvatiti u cijelosti ili samo s određenom rezervom, za svaku pojedinu poruku koju prima od sredstava društvenih priopćavanja“ (SD 1974).

Pavao VI. govori i o odgovornosti samih korisnika medija, doduše konkretno za kršćane, ali je njegova poruka primjenjiva za svakoga čovjeka: „Smatramo, također, da su kršćani posebno dužni držati se uvijek pripravnima u odnosu prema medijima, spremni da donesu trenutne procjene događanja u ovom području, kako bi brzo uspostavili kriterije i tako zadržali korak s novim suvremenim zahtjevima“(SD 1974).

\subsubsection{Sredstva društvene komunikacije u službi temeljnih ljudskih prava i dužnosti} $(1976)^{32}$

U ovoj poruci Pavao VI, govoreći o različitim zadaća medijima, ističe ,zadaću za dobavu točne i potpune informacije na koju ljudi imaju pravo“, te nastavlja: „Trebali bismo reći čak i da velikim dijelom o informativno-edukativnom djelovanju sredstava društvenih priopćivanja ovisi hoće li ljudi ili neće imati zdravu svijest o svojim pravima i dužnostima“ (SD 1976).

\footnotetext{
${ }^{31}$ Poruka nije prevedena na hrvatski jezik, te ju za potrebe ovog rada prevodim s poveznice: http://w2.vatican.va/content/paul-vi/en/messages/communications/documents/hf_p-vi_mes_19740516_viii-comday.html

${ }^{32}$ Poruka nije prevedena na hrvatski jezik, te ju za potrebe ovog rada prevodim s poveznice: http://w2.vatican.va/content/paul-vi/en/messages/communications/documents/hf_p-vi_mes_19760411_X-comday.html
} 
Papa ističe da mediji ,trebaju biti službenici i branitelji čovjekovih temeljnih prava i čovjekovih temeljnih dužnosti“ (SD 1976), te navodi što se na području medijske etike ponajprije traži od medijskih djelatnika: „Mi bismo željeli da kod djelatnika masovnih medija bude, kao prvo, iskrenost; istinska dosljednost između onog u što vjeruju i onog što emitiraju u svojim programima i vijestima ili tumačenju vijesti; isto bi tako bez okolišanja trebali izraziti onaj ideal života kojim su inspirirani, odbaciti mogućnost da budu dio plana ili politike koji će tražiti da se 'manipulira' publikom; staviti ljubav i služenje ljudima ispred želje za popularnošću i ispred ekonomske dobiti““(SD 1976).

I dok otvoreno progovara o očekivanjima od medijskih djelatnika, Pavao VI. opet ne zaboravlja govoriti i o zadaćama i odgovornosti same publike: „Od čitatelja, slušatelja i gledatelja koji su zapravo korisnici službe priopćavanja, traži se da odgajaju sami sebe kako bi bili budno kritični prema onome što se piše i govori, jer na taj način će se staviti u poziciju u kojoj mogu poticati i podržavati, i moralno i materijalno, ljude koji pišu ili proizvode one publikacije, emisije i filmove koji brane ljudska prava te ih obrazuju za njihove dužnosti; i oni će omogućiti sami sebi, u isto vrijeme, obranu od agresije koja je u suprotnosti s istinom i ljudskim dostojanstvom. Potičemo ih da dobro procjenjuju stvari koje im mediji predstavljaju i da kvalificirano interveniraju, pojedinačno i kolektivno, kako prigode dopuštaju, kako bi se osiguralo poboljšanje u službama informacija. Čitatelji, gledatelji i slušatelji uvijek će imati odlučujuću riječ o budućnosti medija, jer su oni ti koji odlučuju hoće li prihvatiti ili odbiti ono što im se nudi. To im daje odgovornost koju često ignoriraju“ (SD 1976).

U poruci se ističe i uloga Crkve: „Crkva, sa svoje strane, ne polaže pravo na posebnu privilegiju u području masovnih medija, ali potvrđuje svoje pravo i obvezu da bude prisutna na tom području, obogaćujući ga baštinom svoje duge i univerzalne, povijesne i kulturne tradicije i iznad svega one koja je vjerska i edukativna“"(SD 1976).

\subsubsection{Oglašavanje u masovnim medijima: prednosti, opasnosti i odgovornost (1977) ${ }^{33}$}

I ova poruka - koja govori o oglašavanju u medijima - opet ističe odgovornost publike, želeći dovesti do ,poticanja savjesti osoba koje koriste društvene komunikacije - bez

\footnotetext{
${ }^{33}$ Poruka nije prevedena na hrvatski jezik, te ju za potrebe ovog rada prevodim s poveznice: http://w2.vatican.va/content/paul-vi/en/messages/communications/documents/hf_p-vi_mes_19770512_xi-comday.html
} 
obzira jesu li čitatelji, slušatelji ili gledatelji - na nužnost da budu selektivni u onom što čitaju, gledaju ili slušaju; selektivnost koja često djelotvorno utječe na one koji su odgovorni za medijsku proizvodnju i na njihov odabir što će kao medijski djelatnici ponuditi publici“ (SD 1977).

Pavao VI. odgovara i na pitanje zašto se Crkva uopće dotiče teme oglašavanja: „Možemo se upitati zašto bi oglašavanje i njegov utjecaj na sredstva društvene komunikacije bio od interesa za Crkvu? Odgovor leži u činjenici da je oglašavanje vrlo važan element u zajedničkom životu ljudi, jer ima utjecaja na čovjekov cjeloviti razvoj i, posredno ili neposredno, ima utjecaj na njegov kulturni život. Nitko u sadašnjem trenutku ne može izbjeći utjecaj oglašavanja, a čak i ako ne obraća pozornost na stvarni sadržaj poruka koje se predstavljaju, oglašavanje ipak sugerira određene vizije svijeta, što se neminovno tiče i kršćanina, te to utječe na njegove odluke kao i na njegov način djelovanja. Oglašavanje, štoviše, poprima sve veće značenje, jer u velikoj mjeri financira razvoj medija i koristi ih za svoje potrebe, i ponekad izravno i opasno utječe na njihovo usmjerenje i slobodu“ (SD 1977).

Poruka upozorava i na važnost ispravnoga odnosa oglašavanja prema općem dobru: „Oglašavanje je, zatim, promotivni alat posebnih interesa koji, čak i ako su legitimni, moraju uzeti u obzir opće dobro, imati na umu jednako legitimne interese drugih, a pogotovo gajiti dužno poštovanje za konkretne okolnosti cjelovitog razvoja ljudi kojima su upućeni, kao i sluha za njihove kulturne i gospodarske prilike, te njihovu razinu obrazovanja. Kao što je dobro poznato, oglašavanje je, naravno, osmišljeno da uvjeri ljude, te koristi tehnike na temelju preciznih psiholoških i društvenih znanja, i stalno istražuje načine i sredstva uvjeravanja“ (SD 1977). Govori se i da oglašavanje mora „,bezuvjetno poštivati ljudsku osobu i njezino pravo - dužnost da odgovorno izabire, njezinu unutarnju slobodu“ (SD 1977).

\subsubsection{Korisnik društvenih komunikacija, njegova očekivanja, prava i dužnosti (1978) ${ }^{34}$}

Poruka pape Pavla VI. iz 1978. godine posvećena je korisnicima medija, te govori o potrebi „dvosmjerne razmjene“ između medijskih djelatnika i korisnika medija: „Prostor što ga novine, radijske i televizijske postaje dodjeljuju za dopisivanje sa svojim čitateljima,

\footnotetext{
${ }^{34}$ Poruka nije prevedena na hrvatski jezik, te ju za potrebe ovog rada prevodim s poveznice: http://w2.vatican.va/content/paul-vi/en/messages/communications/documents/hf_p-vi_mes_19770512_xi-comday.html
} 
slušateljima i gledateljima, tek djelomično odgovara na tu legitimnu želju, jer se odnosi samo na izolirane slučajeve, dok svi 'primatelji' osjećaju potrebu da budu u mogućnosti izraziti svoje mišljenje i ponuditi svoje osobne ideje i prijedloge. Sada, kako bi se osigurao takav dijalog, za promicanje dvosmjerne razmjene i da ga se usredotoči na važne probleme, i 'komunikatori' će morati uspostaviti stalan i poticajan kontakt s društvom, a da bi se 'primatelja' dovelo do točke u kojoj je aktivni sudionik““ (SD 1978).

Istina i potreba njezinoga prenošenja još je jednom tema ovakvih poruka: „Jedno od temeljnih ljudskih prava svake osobe je da joj bude priopćena istina, koja je ukorijenjena $\mathrm{u}$ samoj ljudskoj prirodi, a usko je povezana s pravom za pripadanjem i sudjelovanjem, što današnji razvoj teži osigurati svakom članu društva. Ta težnja, taj zahtjev za istinom, ima izravan utjecaj na medije, od kojih primatelji imaju pravo očekivati pravovremene izvještaje, poštenje, objektivnost u istraživanju i prezentaciji, poštivanje ljestvice vrijednosti i, gdje su u pitanju 'pozornica' i ekran, prezentiranje prave slike čovjeka, bilo kao pojedinca ili kao dijela određenog društvenog konteksta“ (SD 1978).

Porukom se također ističe važnost suradnje korisnika medija i medijskih djelatnika: „Odgovorna suradnja se traži od primatelja samoga, koji bi trebali aktivno sudjelovati u procesu oblikovanja komunikacije. Ovo nije zagovaranje grupnog pritiska, što će samo pogoršati napetosti i sukobe u sadašnjem trenutku. Ali, moglo bi se dogoditi da umjesto 'okruglog stola društva' kojem bi svi imali pristup prema pravu i prema pojedinačnoj odgovornosti te važnosti predmeta o kojima se raspravlja, da se korištenje medija ograniči na način da nereprezentativne skupine mogu tako nametnuti gledište povoljno samo vlastitom interesu. Ne smije se dopustiti da se to dogodi, a na 'primatelju' je da se pobrine da se to ne dogodi“ (SD 1978).

Papa se korisnicima obraća i izravno: „Dragi čitatelji, slušatelji, gledatelji, morate naučiti jezik sredstava društvenog priopćavanja, iako to može biti teško, kako bi mogli biti u poziciji djelotvorno intervenirati. Morate znati kako dobro odlučiti, kada odlučujete koje novine ili knjigu kupiti, koji ćete film gledati, koje programe slušati na radiju, ili što gledati na televiziji; cijelo vrijeme svjesni da je izbor koji napravite zapravo glasovanje koje daje ohrabrenje i podršku (čak i stvarnu gospodarsku podršku) objavi ili programu za koji ste se odlučili, a istodobno glasujete i odbijanjem onoga što ne smatrate prikladnim“ (SD 1978).

Poruka korisnike upozorava i na moguće prijevare u medijima: „Potrebno je, nadalje, imati na umu da su moderne komunikacije same po sebi veoma složene i poprilično često se 
dogodi da se istina predstavi kao laž, a dobro da je prikaže kao zlo. Tu zapravo često nema istine, nema svetinje, nema moralnih principa, koji se mogu izravno ili neizravno osporavati u širokom rasponu diskursa tih komunikacija. Morate se, zbog toga vježbati u razlučivanju, vrednovanju onoga što dobivate iz medija uz mjerilo istinskih etičko-religijskih vrijednosti““ (SD 1978).

2.10.3. Čudesni Božji darovi i moćna sredstva

2.10.3.1. Crkva i društvene komunikacije: Prvi Svjetski dan sredstava društvene komunikacije $(1967)^{35}$

„Zahvaljujući tim divnim čudima tehnike, čovjekov društveni život poprima nove dimenzije: on osvaja vrijeme i prostor, postao je građanin svijeta, dijeleći i svjedočeći i najudaljenije događaje i promjene cijelog ljudskog roda“ (SD 1967), piše pozitivno o medijima na početku poruke papa Pavao VI. koji istodobno jasno ističe i etičke opasnosti: „Ne može se ignorirati opasnost i štetu koju ona (sredstva društvenog priopćavanja, op.a.), kolikogod plemenita u sebi, mogu nanijeti pojedincima i društvu kad u njima nisu zaposlene osobe s osjećajem odgovornosti, s iskrenom namjerom, te u skladu s objektivnim moralnim poretkom“ (SD 1967). Poruka također nastavlja u tom duhu te još snažnije ističe odgovornost: „Što je veća, u stvarnosti, snaga i ambivalentna djelotvornost tih sredstava, veća mora biti i briga i odgovornost medijskih djelatnika“" (SD 1967).

Govoreći i dalje o medijskim djelatnicima, poruka navodi da oni ,imaju pravo da ne budu uvjetovani ideološkim, političkim i ekonomskim pritiscima, koji ograničavaju njihovu pravednu i odgovornu slobodu izražavanja, njihov govor $u$ javnosti zahtijeva poštovanje dostojanstva čovjeka i društva. Neka svaki njihov napor bude usmjeren na širenje istine u ljudskome umu, vjernost onome što je dobro u njihovim srcima i dosljednost u svojim akcijama. Tako će doprinijeti unaprjeđenju čovječanstva i igrat će konstruktivnu ulogu u izgradnji novog društva koje će biti slobodnije, budnije, odgovornije, uz više bratstva i plemenitosti“" (SD 1967).

\footnotetext{
${ }^{35}$ Poruka nije preveden na hrvatski jezik, ta je za potrebe ovog rada prevodim s poveznice: http://w2.vatican.va/content/paul-vi/en/messages/communications/documents/hf_p-vi_mes_19670507_i-comday.html
} 
Osim medijskim djelatnicima, ova se poruka obraća i drugim subjektima odgovornosti za medijske sadržaje, to jest korisnicima: „Veoma korisna i pohvalna je, dakle, svaka ozbiljna inicijativa koja ima za cilj formiranje kritičkog razmišljanja čitatelja i gledatelja, navodeći ih da ocijene vijesti, ideje i slike koje su im prikazane, ne samo u estetskom i tehničkom aspektu, nego i s ljudskog, moralnog i vjerskog gledišta, imajući na umu najviše vrijednosti života“ (SD 1967).

\subsubsection{Društvena obavijesna sredstva: instrumenti susreta između vjere i kulture $(1984)^{36}$}

U svojoj poruci iz 1984. Papa još jednom ističe dva oprečna aspekta medija, ali naglasak stavlja na onaj pozitivan: „Određeni razočaravajući aspekti uporabe suvremenih masovnih medija ne smiju nas navesti da zaboravimo da oni svojim sadržajem mogu postati predivni instrumenti za širenje evanđelja, pogodnog za sva vremena, te da mogu doseći najudaljenije kutke zemlje“ (SD 1984, br. 4).

Ivan Pavao II. daje i nekoliko savjeta medijskim djelatnicima: „Nositelji komunikacije, nemojte davati nepotpunu, iskrivljenu sliku čovjeka, zatvorenu za autentične ljudske vrijednosti! Dajte prostora transcendentnom, koje čovjeka čini još više čovjekom! Ne ismijavajte vjerske vrijednosti, nemojte ih ignorirati, nemojte ih tumačiti prema ideološkim shemama! Neka vaše informiranje bude uvijek inspirirano kriterijima istine i pravde; možda ćete osjećati dužnost da ispravite i popravite nešto kad će vam se dogoditi da napravite pogrešku. Ne kvarite društvo, a posebno mlade, odobravanjem i ustrajnim prikazom zla, nasilja, moralne pokvarenosti, ideološkom manipulacijom, sijanja razdora! Svi vi koji radite u medijima, znajte da će vaša poruka doseći masu koja iako jest takva zbog svog broja, ipak je svatko od njih pojedinačni čovjek, konkretna i jedinstvena osoba, koju se mora priznavati i poštivati kao takvu. Jao onome tko donese sablazan, pogotovo malenima (usp. Mt 18, 6). Ukratko, njegujte kulturu koja poštuje čovjekovo dostojanstvo, svjesni da se na taj način olakšava susret s vjerom, čega se nitko ne mora bojati““ (SD 1984, br. 4).

Papa nadalje kritički primjećuje: „Nažalost, kad realno pogledamo vidimo da se danas goleme potencijale u masovnim medijima vrlo često koristi protiv čovjeka““ (SD, 1984, br. 5).

\footnotetext{
${ }^{36}$ Poruka nije prevedena na hrvatski jezik, te ju za potrebe ovog rada prevodim s poveznice: http://w2.vatican.va/content/john-paul-ii/en/messages/communications/documents/hf_jpii_mes_24051984_world-communications-day.html
} 


\subsubsection{Navještaj Kristove poruke u sredstvima društvenog priopćavanja (1992) ${ }^{37}$}

Porukom iz 1992. papa Ivan Pavao II. progovorio je o važnosti vjerodostojnosti u komunikaciji, ali je podsjetio i na važnost obrazovanja za rad u medijima: „Kristalno je jasno da ta 'moćna sredstva' zahtijevaju posebne vještine i sposobnosti kod onih koji ih koriste, kao i komunikacijsku vjerodostojnost $\mathrm{u}$ korištenju tih 'novih jezika', te uz te sklonosti i odgovarajuću obuku“(SD 1992).

\subsubsection{Video i audio kazete u formiranju kulture i savjesti (1993) ${ }^{38}$}

Papa Ivan Pavao II. ističe: „To su doista nevjerojatni Božji darovi u naše doba, koje je moguće očuvati i lako transportirati, tako da ih možemo opetovano slušati i gledati sami ili u društvu, kod kuće ili negdje drugdje, kako god nam se svidi i neograničeni broj puta, kako za pouku i zabavu tako i za potpunije razumijevanje vijesti i informacija ili pak možda samo zbog umjetničkog užitka. Dopustite mi da ponovno kažem da su audio-video kazete Božji darovi, određeni u Njegovoj riznici za sve nas, iz naraštaja u naraštaj. Mora nam biti jasno da nam nisu dani na našu štetu“ (SD 1993).

Prema papinom mišljenju, „medijski profesionalac koji je svjestan prave vrijednosti i utjecaja medijske produkcije koju stvara, osobito će paziti da ju krasi visoka moralna kvaliteta, te da njihov utjecaj na formiranje kulture svoje generacije uvijek bude pozitivan. Bit će vjeran sebi, svom zanimanju i svojoj vjeri, te se mora oduprijeti sveprisutnoj napasti lake zarade i čvrsto odbiti sudjelovati u bilo kojoj proizvodnji koja iskorištava ljudske slabosti, vrijeđa ljudsku savjest ili ljudsko dostojanstvo“ (SD 1993).

U poruci se naglašava da svi imaju odgovornost, a ne samo medijski djelatnici: „Uloga nestručnih, ili 'običnih kršćana/građana', u odnosu na medije kao što su audio ili videokazete, ne smije se gledati kao da je to uloga pukog potrošača. Svaki pojedinac, jednostavno tako što reagira na medijske ponude koje se stavljaju pred njega i daje to do znanja onima koji ih

\footnotetext{
${ }^{37}$ Poruka nije prevedena na hrvatski jezik, te ju za potrebe ovog rada prevodim s poveznice: http://w2.vatican.va/content/john-paul-ii/en/messages/communications/documents/hf_jpii_mes_24011992_world-communications-day.html

${ }^{38}$ Poruka nije prevedena na hrvatski jezik, te ju za potrebe ovog rada prevodim s poveznice: http://w2.vatican.va/content/john-paul-ii/en/messages/communications/documents/hf_jpii_mes_24011993_world-communications-day.html
} 
proizvode, djeluje na način da će to definitivno utjecati na sadržaj i moralni ton budućih proizvoda. Potrošač mora vrlo ozbiljno prihvatiti svoju odgovornost da bi mogao dati aktivni doprinos u zaštiti i poboljšanju medijske sredine u kojoj su on i oni koji proizvode medijski sadržaj“ (SD 1993). I ovdje se jasno naglašava medijska odgovornost publike, koja je često tema teološke medijske etike, te bez te teme bi teološka medijska etika bila nepotpuna.

\subsubsection{Javna glasila: prijateljska prisutnost ukorak s onima koji traže Oca (1999) ${ }^{39}$}

I ova poruka pape Ivana Pavla II. ističe jednu važnu etičku dimenziju medija, jer govori o izvanrednoj odgovornosti ,u svjedočenju istine o životu, o ljudskom dostojanstvu, o izvornom značenju naše slobode i uzajamne međuzavisnosti““(SD 1999).

Govoreći o odnosu Crkve i medija, papa ističe obostranu pomoć: „Crkveno gajenje radosti može kulturu razonode što ju gaje javna glasila spasiti da ne postane bezdušni bijeg od istine i odgovornosti; sredstva društvenog priopćivanja mogu Crkvi pomoći da bolje shvati kako privlačnije i ugodnije saobraćati s osobama“ (SD 1999).

Poruka također upozorava i na određene negativnosti: „Najnovijim razvojem informatičke tehnologije mogućnost saobraćaja među pojedincima i skupinama u svakom dijelu svijeta veća je nego ikada. Ipak, premda proturječno, upravo snage koje vode boljem saobraćaju mogu povećati otuđenje i egocentrizam“ (SD 1998).

\subsubsection{Obitelj i drugi međuljudski odnosi}

\subsubsection{Društvene komunikacije i obitelj $(1969)^{40}$}

Papa Pavao VI. govoreći o odnosu medija i obitelji ističe: „Sredstva društvene komunikacije sada su ušla u samo središte obiteljskog okružja. Utječu na dnevne rasporede ljudi. Promijenila su uspostavljene navike. Predmetom su razgovora i potiču rasprave. Iznad

\footnotetext{
${ }^{39}$ Korišten je službeni prijevod na hrvatski jezik: Javna glasila: prijateljska prisutnost ukorak s onima koji traže Oca (1999), u: Ivan Pavao II. (2003), Deset poruka za slavlje Svjetskog dana sredstava društvene komunikacije, Zagreb, IKA

${ }^{40}$ Poruka nije preveden na hrvatski jezik, ta je za potrebe ovog rada prevodim s poveznice:

http://w2.vatican.va/content/paul-vi/en/messages/communications/documents/hf_p-vi_mes_19690407_iii-comday.html
} 
svega, ta sredstva imaju utjecaj na psihologiju onih koji ih koriste. Taj utjecaj je s vremenom postao veoma snažan, te se ostvaruje preko emocija i intelekta. Prostire se na moralno, kao i na vjersko područje“ (SD 1969).

Kratko nakon toga, Pavao VI. ističe dvostruku dimenziju medija u odnosu na etičku vrijednost: „Nema sumnje da intelektualni razvoj mladih ljudi raste. Njihova kulturna baština je obogaćena. Njihova srca i duhovi su osjetljiviji na velike probleme ljudske zajednice poput mira, pravde i razvoja. Međutim, također je jasno da se uvjerljiva snaga tih novih sredstava može iskoristiti za dobro ili za zlo. Štoviše, zlostavljanje, makar samo količinom programa, može donijeti sa sobom iskrivljenje vrijednosti obiteljskog života; kao rezultat toga može se dogoditi da se ljudi međusobno udaljuju umjesto da se zbližavaju. Potrebno je dakle, da se formira savjest, kako bi se inteligentno koristili ovi izvori kulturnog obogaćivanja. Ovo je nova zadaća dodana tradicionalnim dužnostima odgajatelja. Vrijeme je da obitelj poduzme vlastiti 'aggiornamento' na tom području, tako da uz neizostavnu suradnju škole, obitelj može postupno brinuti za odgoj savjesti kako bi savjest došla do smirene i objektivne prosudbe vodeći je da prihvati ili odbaci razne programe koji joj se nude“(SD 1969).

U tom kontekstu poruka govori i o odgovornosti medijskih djelatnika, to jest komunikatora: „Komunikatori moraju, sa svoje strane, znati poštivati i potrebe obitelji. To pretpostavlja ponekad puno hrabrosti s njihove strane, i uvijek visok osjećaj odgovornosti. U praksi to znači da bi s jedne strane trebali isključiti sve što može štetiti obitelji u njezinom postojanju, stabilnosti, njezinoj biti i njezinoj sreći, jer svaki napad na istinske temeljne vrijednosti obitelji - bilo da je to erotika ili nasilje, potpora razvodu ili antisocijalnim stavovima među mladima - napad je na istinsku ljudsku dobrobit i javno dobro. S druge strane, komunikatori imaju tešku zadaću educiranja javnosti da upozna, cijeni i ljubi vrijednosti koje su često nepoznate ili prezrene, ali koje su snaga i vrijednost određenog društva kao što su predanost cijelog bića za velike ideale, smisao za žrtvu i skriveno junaštvo u običnoj svakodnevici“ (SD 1969). Istovremeno, Pavao VI. ne stavlja svu odgovornost na medijske djelatnike, nego i na same obitelji, tražeći i od njih odgovornost, te ih potiče na suradnju s udrugama koje se bave ovim pitanjima.

Govoreći o potrebi članova obitelji da se i sami upuste u profesionalno bavljenje medijima, papa veoma pozitivno govori o moralnom životu medijskih djelatnika: „Hvala Bogu u svijetu društvenih komunikacija, ne manje nego u drugim područjima, postoje sjajni primjeri moralnog življenja kako profesionalne dimenzije života, tako i one obiteljske. Ima 
onih u svijetu novinarstva, kazališta i na području filmova koji žive svoju vjeru u Boga u mirnom i savjesnom obavljanju svoje profesije“ (SD 1969).

\subsubsection{Društvene komunikacije i mladi $(1970)^{41}$}

Nakon što poruka iznosi pozitivne utjecaje medija na mlade upozorava $i$ na negativnosti: „Svjedočimo da se mlade i djecu koristi kao lako povodljive potrošače od strane industrije koja uništava, koja ih odvlači u ponor erotike i nasilja, i dovodi ih do stanja neizvjesnosti, tjeskoba i bijede. Nije previše tražiti da se svi ljudi dobre volje ujedine kako bi oglasili alarm za uzbunu i stali na kraj poduzetnicima koji zaslužuju da ih se naziva iskvarenima“"(SD 1970).

Govoreći o tome da mladima mediji mogu ponuditi mnogo vrijednoga i pozitivnog, naglašava se da mediji to ne mogu sami od sebe, već trebaju pomoć drugih: „To je ogromna zadaća, doista veličanstveni pothvat, za sve koji pokreću ove iznimno moćne instrumente za službu mladosti. Sve to, međutim, neće nas odvesti daleko, ako se ne uključe roditelji i nastavnici koji imaju svoju zadaću u pomaganju mladim ljudima kako bi mladi mogli izabrati, prosuditi i asimilirati ono što im je predstavljeno, tako da i oni mogu postati cjelovite ljudske osobe i kršćani. Neće se mnogo toga postići ako mladi ljudi sami ostanu pasivni, ako padnu pod začaranost tih moćnih sredstava, nepotrebnih želja i nesposobne samokontrole“ (SD 1970).

\subsubsection{Masovni mediji i pomirenje $(1975)^{42}$}

Na početku poruke Pavao VI. poziva medije na ostvarivanje njihove uloge u svijetu: „Da, tisak, radio, televizija i film trebali bi biti službenici pomirenja među ljudima u svijetu. Oni bi trebali biti nositelji zajedništva, obvezujući sve kršćane zajedno u ostvarenju čvrste i

\footnotetext{
${ }^{41}$ Poruka nije preveden na hrvatski jezik, ta je za potrebe ovog rada prevodim s poveznice: http://w2.vatican.va/content/paul-vi/en/messages/communications/documents/hf_p-vi_mes_19700406_iv-comday.html

${ }^{42}$ Poruka nije prevedena na hrvatski jezik, te ju za potrebe ovog rada prevodim s poveznice: http://w2.vatican.va/content/paul-vi/en/messages/communications/documents/hf_p-vi_mes_19750419_ix-comday.html
} 
vidljive ljubavi, u suglasju s jednim ciljem: čvrstoj usmjerenosti prema dobroti i prema Bogu“ (SD 1975).

Nadalje u poruci ističe njihove pozitivne strane i navodi kako treba spriječiti zloporabe u njima: „Slavimo Boga za ta divna djela nastavka Njegovog stvaranja koji su doveli do takvog savršenstva u našem vremenu. Prepoznajemo snažnu mogućnost za dobro koje se može ostvariti ako se pojedinci i društvo medijima služe savjesno i odgovorno. No, podsjećamo i da su, poput mnogih drugih dobrih stvari u stvaranju, mediji otvoreni za zlouporabu; i još uvijek razmatramo pred Bogom koje se mjere mogu poduzeti kako bi se spriječila njihova zloupotreba. Sredstva društvene komunikacije nesumnjivo imaju sposobnost poticanja i podupiranja svih napora. Oni mogu nevjerojatno pomoći čovjeku dok se bori kako bi osigurao ostvarenje svojih najdubljih nadanja. No, bilo bi besmisleno sakriti da jednako tako, u rukama onih koji ih žele iskoristiti za manje vrijedne svrhe, mogu djelovati samo da bi se zadovoljilo površne potrebe koje se ostvaruju u imperativu trenutne mode ili hira; ili još gore, za promicanje i podršku diskriminacijske prakse u društvu, stvaranje ili naglašavanje podjele među ljudima“(SD 1975).

Papa Pavao VI. se osvrće i na svoju poruku od prije četiri godine, produbljujući je novim sadržajem i naglascima s područja medijske etike - posebno što se tiče objektivnosti, činjeničnosti i vjernosti načelima: „U našoj poruci od 25. ožujka 1971. već smo skrenuli pozornost na činjenicu da masovni mediji mogu pridonijeti postizanju jedinstva čovječanstva. Ove godine smo se usredotočili na jedan bitan uvjet koji mora biti zadovoljen u sredstvima društvenih komunikacija kako bi masovni mediji mogli stvoriti klimu koja je povoljna za pomirenje. Ti uvjeti su objektivnost i poštivanje činjenica, kao i vjernost pravoj i pouzdanoj ljestvici vrijednosti u njihovom ostvarenju. S tim u vezi, osjećamo obvezu izraziti naše poštovanje i divljenje prema svim djelatnicima masovnih medija koji se trude ozbiljno, iskreno i energično da se sazna istina i da joj dadnu istaknuto mjesto koje ona i zaslužuje“ (SD 1975).

O jednoj od ključnih vrednota medijske etike - objektivnosti - Pavao VI. piše: „Objektivnost u odabiru i prezentaciji činjenica koje će doista promicati pomirenje zahtijeva dobro razvijen osjećaj odgovornosti, adekvatnu obuku i istinsku profesionalnu kompetenciju“ (SD 1975).

Istodobno potiče i na ostvarivanje mogućnosti pristupa informacijama i razvoju dijaloga u cijelome svijetu: „Jedna stvar za koju bismo snažno željeli da se ostvari je da se u 
svim zemljama dostupnost informacija iz različitih izvora ostvari kao standard. Umjesto prisiljavanja javnosti da se oslanja na jednu službenu verziju vijesti i interpretacije vijesti, treba se ostvariti otvoreni dijalog“" (SD 1975).

Papa isto tako ne zaboravlja da sloboda medija ima svoje granice: „Sloboda koja se traži za masovne medije ne oslobađa, i nikada ne može osloboditi, od njihove obveze vjernosti moralnim načelima, ali ni od poslušnosti prema građanskim zakonima koji štite te principe; uvijek je uvjetovana, u praksi, činjenicom da drugi ljudi imaju prava koja ne smiju biti povrijeđena, te da život u društvu nameće određene uvjete koje moraju, imperativno, biti ispunjeni. Masovni mediji su, dakle, obvezni poštivati pravo osobe na dobar glas, pridržavati se javne ćudorednosti; jednom riječju poštovati svoju odgovornost za opće dobro“ (SD 1975).

\subsubsection{Društvene komunikacije: zaštita djeteta i promoviranje njegovog najboljeg interesa u obitelji i društvu (1979) ${ }^{43}$}

U ovoj svojoj prvoj poruci za svjetski dan sredstava društvenog priopćavanja papa Ivan Pavao II. progovara upravo o djeci u kontekstu medija: „Želim samo ukratko podsjetiti na ono što djeca imaju pravo očekivati i dobiti od medija. Očarani sredstvima društvene komunikacije i bez obrane od svijeta i odrasle osobe, oni su prirodno spremni prihvatiti sve što im se nudi, bilo dobro ili loše. Vi, komunikacijski stručnjaci, a osobito oni koji rade s audiovizualnim medijima, dobro ste svjesni toga. Oni su privučeni 'malim ekranima' i od strane 'velikog zaslona', oni prate svaku gestu koja im se servira, i oni to vide, brže i bolje nego bilo tko drugi““(SD 1979).

Ivan Pavao II. na suradnju poziva sve - ne samo medije i medijske djelatnike: „Isto tako obraćam se vama, roditelji i nastavnici, i vama vjeroučitelji i dužnosnici raznih crkvenih udruga, te vas molim da date ozbiljan doprinos promišljanju problema korištenja sredstava društvenog priopćivanja od i za djecu, koje je pitanje od presudne važnosti - i to ne samo za njihov intelektualni napredak, nego i za razvijanje kritičkog mišljenja, i učeći ih, kao što bi se moglo reći, samodisciplini u odabiru programa i pomažući im s ljudske strane, nego je važno i za razvoj cijelog društva na tragu poštenja, istine i bratstva“" (SD 1979).

\footnotetext{
${ }^{43}$ Poruka nije prevedena na hrvatski jezik, te ju za potrebe ovog rada prevodim s poveznice: http://w2.vatican.va/content/john-paul-ii/en/messages/communications/documents/hf_jpii_mes_23051979_world-communications-day.html
} 


\subsubsection{Društvene komunikacije i obitelj $(1980)^{44}$}

Poruka pape Ivana Pavla II. iz 1980. godine na medije baca novo svjetlo, jer dok govori o odnosu medija i obitelji, ističe da su postali neizostavni „,̌lan“ gotovo svakoga doma: „Jedna od okolnosti koja danas intimno utječe na sve obitelji je rasprostranjenost sredstava društvene komunikacije: tiska, filma, radija i televizije. Uistinu su rijetki domovi u kojima nije prisutno nešto od tih sredstava. Dok se jednom, ne tako davno, obitelj sastojala od roditelja, djece i možda nekoliko rođaka ili sluge, sada je krug u određenom smislu proširen više ili manje trajno 'društvom' voditelja, novinara, zabavljača, sportskih komentatora i komentatora aktualnih događanja, s njihovim čestim posjetima, kao i posjetom poznatih i utjecajnih ljudi svih nacionalnosti, uvjerenja i struka“(SD 1980).

U nastavku poruke papa piše o opasnostima medija u odnosu na obitelj: „Ako medijski programi često predstavljaju iskrivljenu sliku o tome što je obitelj, ili predstavljaju karikaturu obiteljskog života, ili ako se lažno predstavlja ili umanjuje pedagoška funkcija obitelji; članovi obitelji, prihvaćajući ova iskrivljenja pasivno i nekritički, mogu vrlo lako početi oponašati to krivo ponašanje i usvojiti stavove unatoč njihovih nedostataka i površnosti. (...) Tu je još rizik, - i to je pravi i veliki, - da se obitelj odrekne odgovornosti koja joj s pravom pripada u oblikovanju dječjih stavova prema životu i oblikovanju njihovog osjećaja vrijednosti, a može ga nesvjesno ustupiti medijima“" (SD 1980).

Zbog svih navedenih opasnosti, u poruci se potiče na opreznost: „Mudro je biti oprezan s obzirom na rastući utjecaj koji masovni mediji, a pogotovo televizija, imaju na razvoj svijesti kod mladih, posebno što se tiče njihovog viđenja čovjeka, svijeta i odnosa s drugima; jer vizija koja je prisutna u medijima često se duboko razlikuje od onoga što bi obitelj željela prenijeti na njih. Roditelji, u mnogim slučajevima, ne pokazuju dovoljnu brigu o tome. Općenito, oni pridaju veliku pozornost tome s kime se njihova djeca druže, ali ne pridaju istu pozornost pitanju koje radio, televiziju, glazbu i stripove unose u 'zaštićenu' i 'sigurnu' intimnost njihovih domova. I tako masovni mediji često ulaze u živote najmlađih članova obitelji bez potrebnih objašnjenja ili ispravaka od strane roditelja ili drugih odgajatelja koji bi mogli neutralizirati štetne elemente i koji bi jednako tako mogli upotrijebiti

\footnotetext{
${ }^{44}$ Poruka nije prevedena na hrvatski jezik, te ju za potrebe ovog rada prevodim s poveznice: http://w2.vatican.va/content/john-paul-ii/en/messages/communications/documents/hf_jpii_mes_01051980_world-communications-day.html
} 
mnoge vrijedne mogućnosti koje bi pomogle u procesu u kojem djeca postupno postaju zreli muškarci i žene““(SD 1980).

Međutim, čuvajući ravnotežu u mišljenju i stajalištima, poruka ističe i pozitivnu dimenziju medija: „Istina je, s druge strane, da sredstva društvene komunikacije mogu biti najvrjedniji izvor kulturnog obogaćivanja za obitelj i za svakog člana pojedinačno. Dobro organizirano čitanje, slušanje i gledanje može uvelike pridonijeti poticanju dijaloga i razmjene unutar male zajednice, i može stvoriti širenje interesa, što dovodi i do uključivanja obitelji u aktivnosti cjelokupne ljudske obitelji“ (SD 1980).

Ivan Pavao II. doslovno piše: „Ali kako bi obitelj mogla stvarno izvući koristi od uporabe medija, a u isto vrijeme se zaštititi od štetnih utjecaja, potrebno je da njezini članovi, osobito roditelji, aktivnije koriste svoje kritičke sposobnosti. Moraju uz više pozornosti tražiti sadržaj programa koji im se nudi. Moraju donijeti prosudbu o porukama koje im mediji prenose. Nadalje, obitelj treba donijeti odluku koliko vremena odgovorno mogu ostaviti za medije, uzimajući u obzir razne druge aktivnosti i zadaće koje se moraju obaviti“( SD 1980).

\subsubsection{Društvene komunikacije i problem starijih osoba $(1982)^{45}$}

Ova poruka nema puno elemenata medijske etike, no istaknimo da je posvećivanje pažnje starijim gledateljima također, u određenom smislu, etička obveza. Kada se govori o medijskoj publici, nipošto se ne smije zaboraviti stariju populaciju, budući da je i ona često vezana uz medije - posebno radio i televiziju, a danas sve češće i uz nove medije. Tako se u poruci Ivana Pavla II. iz 1982. ističe da „medijski djelatnici dobro znaju da starije osobe čine velik i stabilan dio njihove javnosti, pogotovo što se tiče korisnika radija i televizije, te će se pobrinut da postoje programi i publikacije pogodni za njih, nudeći im ne samo rekreativne sadržaje, već im pružajući i pomoć u njihovoj kontinuiranoj edukaciji, a koja je potrebna u svakoj životnoj dobi““(SD, 1982, br. 5).

\footnotetext{
${ }^{45}$ Poruka nije prevedena na hrvatski jezik, te ju za potrebe ovog rada prevodim s poveznice: http://w2.vatican.va/content/john-paul-ii/en/messages/communications/documents/hf_jp- 
Poruka iz 1985. usmjerena je ponajprije na odnos medija i mladih, pa tako Ivan Pavao II. naglašava: „Prema pravu na informacije kojeg svaki čovjek ima, komunikacija uvijek mora u svom sadržaju odgovarati istini, i to uz poštovanje prema pravdi i ljubavi koje bi ju trebale upotpuniti. To posebno vrijedi kada je komunikacija upućena mladim ljudima, koji su u poziciji da se otvaraju iskustvima života. Prije svega, u ovom slučaju, informiranje ne može ostati ravnodušno na vrijednosti koje dodiruju ljudsko postojanje do same njegove biti, kao što su poštivanje života od trenutka začeća, moralna i duhovna dimenzija mira i pravde. Informiranje ne može biti neutralno u susretu s problemima i situacijama koje na nacionalnoj i međunarodnoj razini narušavaju zajedničko vezivno tkivo društva, kao što su rat, kršenje ljudskih prava, siromaštvo, nasilje i droge“ (SD 1985, br. 2).

Porukom se govori i o još jednoj važnoj temi medijske etike, kao što je sloboda, jer je ona oduvijek bila i ostala ,veliki izazov s kojim se društvena komunikacija mora suočiti, kako bi se postiglo osvajanje dovoljno prostora za dovoljno autonomije, posebno tamo gdje je to veoma potrebno, gdje je prisutna cenzura totalitarnih režima ili nametanje pritiska od strane moćnih kulturnih i ekonomskih ili političkih skupina“" (SD 1985, br. 3).

Poruka upozorava i na moguće negativne aspekte djelovanja medija: „No, u isto vrijeme pred nama se nalaze velike opasnosti koje masovni mediji stavljaju pred društvo sklonost moći ili samo vlastitom interesu, izobličenju stvarnosti, protiv istine, protiv dostojanstva ljudske osobe i njezine slobode: i, najgore od svega: protiv najslabijih i nezaštićenih“ (SD 1985, br. 4)

\subsubsection{Prava mjera televizije u obitelji $(1994)^{47}$}

U ovoj poruci progovarajući o televiziji Ivan Pavao II. ističe njezine pozitivne i negativne aspekte: „Televizija može obogatiti vjerski život. Ona može zbližiti članove obitelji, ohrabriti njihovu povezanost u odnosu na druge obitelji i cijelo društvo. (...)

\footnotetext{
${ }^{46}$ Poruka nije prevedena na hrvatski jezik, te ju za potrebe ovog rada prevodim s poveznice: http://w2.vatican.va/content/john-paul-ii/en/messages/communications/documents/hf_jpii_mes_15041985_world-communications-day.html

${ }^{47}$ Korišten je službeni prijevod na hrvatski jezik: Prava mjera televizije u obitelji (1994), u: Ivan Pavao II. (2003), Deset poruka za slavlje Svjetskog dana sredstava društvene komunikacije, Zagreb, IKA
} 
Televizija također može ranjavati obiteljski život: promičući vrijednosti i uzorke ponižavajućeg ponašanja, prenoseći pornografske sadržaje i prikazujući zvjerske okrutnosti; ucjepljujući moralni relativizam i religijski skepticizam, šireći izobličene i manipulirane događaje o kojima izvješćuje ili izobličujući tekuće probleme; razglašujući zloupotrebe najnižih nagona, slaveći pogrešna poimanja života koja priječe uzajamno poštovanje, pravednost i mir“"(SD 1994).

U tom se kontekstu izravno navode mogući negativni aspekti čak i kad nije problematičan sam sadržaj: „I onda kada se nema što prigovoriti sadržaju televizijskih programa, televizija može u obitelji utjecati negativno. Ona može pojedine članove obitelji zatvoriti u njihov vlastiti svijet, ugroziti izvorne međusobne odnose; može također podijeliti obitelj tako da roditelji postanu djeci stranci, kao i djeca roditeljima“ (SD 1994).

Papa nastavlja govoriti i o odgovornosti roditelja: „Tako, osim što oni sami trebaju biti sposobni kritički gledati televiziju, roditelji trebaju kod svoje djece djelatno oblikovati naviku takvog služenja televizijom da ih to vodi zdravom čovječnom, moralnom i religijskom razvoju. Roditelji bi se trebali sami unaprijed informirati o sadržaju programa i na temelju toga svjesno birati, za dobro obitelji, što treba a što ne treba gledati. U tome im mogu pomoći kritike i ocjene vjerskih ustanova i ostalih odgovornih skupina kao i odgojni programi u sredstvima javnog priopćivanja“ (SD 1994).

Porukom se ističe i odgovornost ne samo medijskih djelatnika, već i drugih: „U ovoj poruci htio bih posebice istaknuti odgovornost roditelja, muževa i žena $u$ televizijskoj industriji, javnih vlasti i onih koji su odgovorni za pastoral i za odgoj u Crkvi“ (SD 1994). Slično nastavlja i dalje: „Roditelji koji redovito i dugo upotrebljavaju televiziju kao svojevrsnu elektronsku dadilju, odriču se svoje uloge prvih odgojitelja vlastite djece“ (SD 1994).

Treba spomenuti i kako se porukom naglašava i poštivanje etičkog kodeksa: „Moramo svemu tome pristupati odgovorno - ne upadajući u senzacionalizam i s iskrenom skrbi za društveno dobro, također $\mathrm{s}$ brižljivim poštovanjem istine. (...) Ispunjavajući svoju javnu odgovornost, televizijska proizvodnja mora razvijati i poštovati etički kodeks, ćudoredni zakonik koji sadrži služenje potrebama obitelji i promicanje vrijednosti koje podupiru obitelji i život" (SD 1994). 
Uz potrebu poštivanja etičkog kodeksa, porukom se još jednom snažno naglašava odgovornost televizijskih mreža: „Televizijske mreže, bilo javne bilo privatne, javno su odgovorne u službi općeg dobra; one nisu tek sredstva čuvanja trgovačkih interesa ili oruđe moći ili sredstvo promidžbe društvenih, ekonomskih ili političkih elita, one su tu da služe dobrobiti cijeloga društva“" (SD 1994).

Također se naglašava i odgovornost javnih vlasti: „Javne su vlasti pozvane isticati i jačati razumna ćudoredna mjerila za programe, mjerila koja će davati prednost humanim i religioznim vrijednostima na kojima se gradi obiteljski život, odbacujući sve što mu je štetno“ (SD 1994).

Crkva nudi i svoj doprinos u vrednovanju između ostalog i ćudorednih načela: „Budući da su televizijski stručnjaci zauzeti time da širokoj javnosti predstavljaju određeni pogled na život, javnosti koja obuhvaća djecu i mladež, mogu se okoristiti pastoralnim služenjem Crkve koja im može pomoći vrednovati ćudoredna i religijska načela koja daju puni smisao ljudskom i obiteljskom životu“ (SD 1994).

\subsubsection{Sredstva društvene komunikacije areopag za promicanje žene u društvu (1996) ${ }^{48}$}

Poruka iz 1996. godine u svoje središte stavlja razmišljanje o medijima koji bi morali biti areopag - otvoreni javni trg - za promicanje žene u društvu. Već na samom početku poruke Ivan Pavao II. naglašava da ,javna glasila imaju osobitu ulogu ne samo kao pokretači pravde i jednakosti za žene, nego i kao promicatelji osobito ženskih darova, koje sam drugom zgodom označio kao ženski 'genij'“‘ (SD, 1996).

Papa hvali ulogu medijskih djelatnika, te istodobno ukazuje na dva problema: „Djelatnici društvenih sredstava priopćivanja, branitelji onih koje se ne sluša i isključenih, u jedinstvenom su položaju da potiču javnu savjest da svrati pozornost na dva ozbiljna problema koji se odnose na položaj žene u današnjem društvu. Prije svega, kao što sam napisao u svom pismu, majčinstvo je često kažnjavano umjesto da bude nagrađeno, premda čovječanstvo duguje svoj opstanak onim ženama koje su izabrale da budu supruge i majke

\footnotetext{
${ }^{48}$ Korišten je službeni prijevod na hrvatski jezik: Sredstva društvene komunikacije areopag za promicanje žene u društvu (1996), u: Ivan Pavao II. (2003), Deset poruka za slavlje Svjetskog dana sredstava društvene komunikacije, Zagreb, IKA
} 
(...) Jednako sam tako upozorio na žurnu potrebu postizanja djelotvorne jednakosti dostojanstva s muškarcem, na svakom području“ (SD 1996).

I dok govori o utjecaju medija s jedne strane, papa s druge strane upozorava na iskorištavanje žena u medijima koje je isto tako nemoralno, jer ne poštuje ljudsko dostojanstvo kao jedno od načela medijske etike: „Javna glasila (tisak, film, radio, televizija, glazbena proizvodnja, informativne mreže) predstavljaju suvremeni areopag gdje se informacije brzo primaju i prenose općem 'slušateljstvu', gdje se izmjenjuju pojmovi, gdje se uobličuju nova ponašanja i gdje se doista ocrtava nova kultura. Ona su, dakle, određena za vršenje moćnog utjecaja da se ostvari da društvo prizna i cijeni ne samo prava nego i specifične sposobnosti žena. Nažalost, često smo svjedoci iskorištavanja žena u javnim glasilima, umjesto njihova uzdizanja. Koliko puta vidimo kako se s njima postupa ne kao s osobama s nepovredivim dostojanstvom, nego kao s predmetima kojima drugi utažuju žeđ za užitkom i moći. Koliko puta vidimo podcijenjenu i čak izrugivanu ulogu žene kao supruge i majke. Koliko je puta uloga žena u radu ili profesionalnom životu orisana kao karikatura muškarca, što se vidi po odbacivanju specifične sposobnosti ženske intuicije, suosjećanja i razumijevanja, što su bitni doprinosi 'civilizaciji ljubavi'?“ (SD 1996).

\subsubsection{Naviještati Krista koji je put, istina i život $(1997)^{49}$}

Poruka iz 1997. govori o silnom zamahu u razvoju medija, te započinje upravo govorom o odgovornosti glede izbora medijskih sadržaja i medija samih, a posebno roditeljskoj odgovornosti: „Draga braćo i sestre, dok se približava kraj stoljeća i ovog tisućljeća, doživljavamo neviđeno bujanje javnih glasila, umnažanje takvih novih proizvoda i brojnih službi. Kao nikada dosada brojne su osobe zauzete širenjem novih tehnologija izvješćivanja i priopćivanja. No, unatoč tome mnogo je ljudi koji nemaju pristupa javnim glasilima, ni uobičajenim ni novim. Koji imaju prilike koristiti se tim razvojem nalaze se pred sve većim izborom izvora informacija. Što je veći izbor, to će teža biti odgovorna odluka. Zapravo je sve teže čuvati oči i uši od slika i zvukova koji neočekivano i neželjeno naviru iz javnih glasila. Osobito je teško roditeljima zaštićivati djecu od zlih poruka i osiguravati da njihov odgoj u sklopu međuljudskih odnosa i njihova poimanja svijeta bude primjeren

\footnotetext{
${ }^{49}$ Korišten je službeni prijevod na hrvatski jezik: Naviještati Krista koji je put, istina i život ( 1997), u: Ivan Pavao II. (2003), Deset poruka za slavlje Svjetskog dana sredstava društvene komunikacije, Zagreb, IKA
} 
njihovoj dobi i njihovoj osjećajnosti, da idu ukorak s rastom njihove svijesti o dobru i zlu. Javno mnijenje je zbunjeno jer uviđa kako je zlonamjernim ljudima lako zlorabiti najnaprednije obavijesne tehnologije. Uostalom, zar ne primjećujemo stanoviti zamor među onima koji bi se htjeli dobro služiti tim mogućnostima?“"(SD 1997).

Papa Ivan Pavao II. progovara i o nekim drugim aktualnim pitanjima: „Nadajmo se da jaz koji korisnike novih obavijesnih sredstava odvaja od onih koji nemaju prilike njima se služiti, neće postati još jedan nesavladivi razlog nepravde i diskriminacije. U nekim dijelovima svijeta dižu se glasovi protiv onoga što se doživljava kao gospodarenje zapadnjačke kulture u javnim glasilima. Ta obavijesna proizvodnja predstavlja, kako neki misle, vrijednosti koje su vlastite Zapadu i u skladu s time vrijednosti koje se smatraju kršćanskima. A bilo bi mnogo istinitije reći da im je prva i izvorna vrijednost trgovački profit"“(SD 1997).

\subsubsection{Mediji i obitelj: rizik i bogatstvo $(2004)^{50}$}

O odnosu medija i obitelji, to jest medija prema obitelji govori poruka Ivana Pavla II. objavljena 2004. godine. Papa već na početku poruke naglašava da „sva komunikacija ima moralnu dimenziju“ (SD 2004, br. 1), pa potom govori o pozitivnim dimenzijama medija, ali ističe i njihovu drugu stranu: „Ipak, ti isti mediji imaju također snagu nanijeti ozbiljnu štetu obitelji predstavljajući nedostatan ili čak iskrivljen pogled na život, na obitelj, na religiju i na moral“" (SD 2004, br. 2). U istome broju poruke Papa ističe dva važna kriterija ili načela medijske etike - istinu i čovjekovo dostojanstvo: „Komunikacija u bilo kojem obliku mora uvijek biti nadahnuta etičkim kriterijem poštivanja istine i dostojanstva ljudske osobe“ (SD 2004, br. 2).

Poruka također $\mathrm{u}$ tom etičkome kontekstu naglašava da ,savjesno promišljanje o etičkoj dimenziji komunikacije treba koristiti u praktične poticaje usmjerene na otklanjanje rizika za dobrobit obitelji koji se javljaju u medijima i osiguranje da će ova moćna sredstva komunikacije ostati pravi izvori nutarnjeg obogaćenja. Posebna odgovornost u tom pogledu leži na komunikatorima samima, na javnim vlastima, te na roditeljima“" (SD 2004, br. 4).

\footnotetext{
${ }^{50}$ Poruka nije prevedena na hrvatski jezik, te ju za potrebe ovog rada prevodim s poveznice: http://w2.vatican.va/content/john-paul-ii/en/messages/communications/documents/hf_jpii_mes_20040124_world-communications-day.html
} 
Poruku iz 2007. godine Benedikt XVI. posvetio je odnosu medija prema djeci, ističući već u samome naslovu da mediji predstavljaju odgojni izazov, o čemu su već ranije pisali crkveni dokumenti, posebno pastoralna uputa „Communio et progressio“ iz 1971. godine: „Odgoj djece da budu selektivna prilikom korištenja medija odgovornost je roditelja, Crkve i škole. Uloga je roditelja od prvotne važnosti. Oni imaju pravo i obvezu jamčiti razborito korištenje medijima, odgajajući savjest svoje djece kako bi bila u stanju formulirati ispravne i objektivne sudove koji će ih voditi u izboru ili odbacivanju programa koji im se nude (usp. Ivan Pavao II., apostolska pobudnica "Familiaris consortio", 76). U tom poslu roditelji bi trebali naći ohrabrenje i potporu u školi i župi, te imati sigurnost da im u tom teškom, premda zahvalnom, vidu roditeljske uloge pomoć pruža čitava zajednica. Odgoj za medije trebao bi biti pozitivan. Izlažući djecu onome što je estetski i moralno najbolje, pomaže im se da razviju svoje mišljenje, razboritost i sposobnost razlikovanja“ (SD 2007, br. 2).

U nastavku poruke papa ponovno podsjeća na važnost odgovornosti i na sve veće posebno gospodarske - pritiske kojima su izloženi mediji, ali i dalje potiče na odgoj djece: „Želja što je roditelji i učitelji duboko osjećaju, da poučavaju djecu putu ljepote, istine i dobra može biti podržana i od strane medijske industrije samo u onoj mjeri u kojoj ova promiče temeljno dostojanstvo ljudskoga bića, istinske vrijednosti braka i obiteljskog života, pozitivna dostignuća i ciljeve čovječanstva. Odatle, potreba da mediji budu zauzeti u stvarnom odgoju i u poštivanju etike ima posebnu važnost i hitnost, ne samo u očima roditelja, nego i u očima svih onih koji imaju osjećaj građanske odgovornosti. Dok se vidi da mnogi djelatnici u medijima žele činiti ono što je ispravno (usp. Papinsko vijeće za društvene komunikacije, Etika u društvenim komunikacijama, 4), valja primijetiti da se oni koji rade u tom području susreću s 'posebnim psihološkim pritiscima i etičkim dvojbama' (Aetatis Novae, 19), budući da ponekad tržišna konkurencija prisiljava medijske djelatnike na snižavanje standarda. Svaka tendencija proizvodnje programa - uključujući i animirane filmove i video igre - koji u ime zabave uzdižu nasilje, odražavaju antisocijalna ponašanja ili vulgariziraju ljudsku spolnost, predstavlja perverziju, a posebice kad su takvi programi namijenjeni djeci i adolescentima. Kako objasniti tu 'zabavu' bezbrojnim nevinim mladima koji su u stvarnosti žrtve nasilja, izrabljivanja i zloporaba? U tom smislu, svi bi morali promisliti o suprotnosti između Krista, koji ih 'zagrli pa ih blagoslivljaše polažući na njih ruke' (Mk 10, 16), i onoga koji sablažnjava

\footnotetext{
${ }^{51}$ Korišten je službeni prijevod na hrvatski jezik: http://www.ika.hr/index.php?prikaz=vijest\&ID=94330
} 
jednog od ovih malenih, za kojega je korisnije ako je 's mlinskim kamenom strovaljen u more' (Lk 17, 2). Iznova pozivam odgovorne u medijskoj industriji da modeliraju i potiču proizvođače na očuvanje općega dobra, na podržavanje istine, na štićenje osobnog ljudskog dostojanstva te na promicanje poštovanja potreba obitelji“ (SD 2007, br. 3).

\subsubsection{Komunicirati obitelj: povlašteno mjesto susreta u daru ljubavi $(2015)^{52}$}

U poruci iz 2015. papa Franjo piše o obitelji kao mjestu komunikacije, ističući komunikaciju kao prepoznavanje i stvaranje bliskosti: „U obitelji učimo jedni druge prihvaćati i podržavati, razabrati izraze lica i trenutke šutnje, smijati se i plakati zajedno s ljudima koji nisu izabrali jedni druge, a ipak su jedni drugima toliko važni. To nam uvelike pomaže razumjeti značenje komunikacije kao prepoznavanje i stvaranje bliskosti““(SD 2015).

Papa u samoj komunikaciji, dobronamjernoj i iskrenoj, vidi blagoslov te ističe: „U svijetu u kojem se tako često proklinje, govori zlo o drugima, i kojem se sije razdor i ogovaranjem truje sredinu u kojoj živimo, obitelj nas može naučiti razumjeti komunikaciju kao blagoslov. I to također u situacijama u kojima očito prevladavaju mržnja i nasilje, gdje su obitelji razdvojene kamenim zidovima ili ništa manje neprobojnim zidovima predrasuda i ozlojeđenosti, gdje se čini da postoje dobri razlozi da se kaže 'sad je dosta'; zapravo, jedino blagoslovom a ne proklinjanjem, susretanjem a ne odbacivanjem, prihvaćanjem a ne borbom, možemo razbiti spiralu zla, pokazati da je dobrota uvijek moguća i djecu učiti bratstvu“" (SD 2015).

Poruka ističe i mnoge pozitivne strane medija: „Mediji mogu potpomoći komunikaciju kad omogućuju ljudima razgovor i dijeljenje iskustava, ostati u kontaktu s prijateljima koji su daleko, zahvaliti drugima ili tražiti oproštenje, otvoriti vrata za nove susrete. Svakodnevno otkrivajući to živo središte koje je susret s drugima, taj 'novi početak', znat ćemo mudro koristiti tehnologiju, ne dopuštajući da nam ona dominira“ (SD 2015). Istovremeno, ističe i drugu dimenziju: „Veliki izazov koji se danas postavlja pred nas je, dakle, kako ponovno naučiti razgovarati jedni s drugima, a ne samo proizvoditi i konzumirati informacije. To je smjer prema kojem nas vode važni i utjecajni moderni komunikacijski mediji. Informacija je važna, ali to nije dovoljno. Prečesto se stvari pojednostavljuju, suprotstavljaju različiti stavovi

\footnotetext{
${ }^{52}$ Korišten je službeni prijevod na hrvatski jezik: http://www.ika.hr/index.php?prikaz=vijest\&ID=167319
} 
i pogledi pozivajući osobe da se svrstaju na jednu ili drugu stranu, namjesto da im se pomogne steći cjelovit uvid“ (SD 2015).

2.10.5. Otvorenost prema drugim (narodima)

\subsubsection{Društvene komunikacije i razvoj naroda $(1968)^{53}$}

Odmah na početku poruka pape Pavla VI. poziva se na odgovornost: „Želimo vam pomoći da razmislite o značenju promjena koje se događaju u tom području pred našim očima, te da sebi osvijestimo ozbiljnu odgovornost koja se stavlja pred sve nas pojedinačno, ali i zajedno"(SD 1968).

Poruka postavlja i ključno pitanje: „Hoće li novine, filmovi, radio i televizija uistinu pomoći razvoju naroda? To je pitanje koje bih ozbiljno stavio pred sve vas, naše katoličke sinove i kćeri, ali ne manje i pred svako ljudsko biće“ (SD 1968). Otvarajući put za odgovor na to pitanje, a ne dajući ga do kraja, poruka pojašnjava različite vrste razvoja, upozoravajući da se razvoj ne može svesti samo na onaj ekonomski.

Pavao VI. ističe i jednu od opasnosti u zatvaraju prema ostalim narodima: „Opasno je poticati u narodu duh samodostatnosti i uskog nacionalizma“ (SD 1968). Upozorava se i da se mediji ne smiju koristiti za pogrešne svrhe: „U svijetu u kojem tolikim ljudima nedostaje ono što je nužno - kruh, znanje i duhovno svjetlo - ozbiljna je pogreška koristiti sredstva društvene komunikacije za poticanje osobne i kolektivne sebičnosti, za stvaranje novih i nestvarnih potreba među potrošačima koji su već u potpunosti zadovoljni i poticati želju za užitkom množenjem praznog užitaka“ (SD 1968).

\subsubsection{Uloga medija u promicanju jedinstva među ljudima $(1971)^{54}$}

Poruka govori o jedinstvu među ljudima te spominje i mnoge poteškoće koje se mogu javiti na putu k tome cilju, a u tom kontekstu spominje i medije: „Tko može kazati da jedna od njih

\footnotetext{
${ }^{53}$ Poruka nije preveden na hrvatski, ta je za potrebe ovog rada prevodim s poveznice: http://w2.vatican.va/content/paul-vi/en/messages/communications/documents/hf_p-vi_mes_19680326_ii-comday.html

${ }^{54}$ Poruka nije preveden na hrvatski, ta je za potrebe ovog rada prevodim s poveznice: http://w2.vatican.va/content/paul-vi/en/messages/communications/documents/hf_p-vi_mes_19710325_v-comday.html
} 
nije i iskušenje da koriste ta moćna sredstava društvene komunikacije, sa svojim snažnim utjecajem, kako bi se pogoršale napetosti, razdori i podjele, da ih gura do ekstremnih posljedica, da se ide tako daleko da se obeshrabri mnoge ljude dobre volje u njihovim nesavršenim, ali velikodušnim pokušajima da promiču jedinstvo i bratstvo? Moramo snažno spriječiti ovaj rizik i hrabro se suočiti s njim. S druge strane, moramo priznati da su goleme mogućnosti ovih čudesnih sredstava društvene komunikacije još uvijek nedovoljno istražene, te moramo pomoći čitateljima, slušateljima i gledateljima da postanu svjesni stvarnih problema, pomažući ljudima kako bi bolje upoznavali jedni druge i više cijenili jedni druge u njihovim legitimnim različitostima, kako bi prevladati prepreke svih vrsta $u$ duhu razumijevanja i ljubavi, još bolje, da iskuse istinsku solidarnost $u$ duhu unatoč tolikim preprekama, a solidarnost sjedinjuje jedne s drugima i jedne za druge u traženju zajedničkog dobara velike zajednice čovječanstva“" (SD 1971).

Nakon toga Pavao VI. pri kraju poruke kaže: „Djelatnici i korisnici sredstava društvenih komunikacija, ujedinite svoje napore kako bi moglo svugdje u svijetu i na svim razinama biti sudjelovanja i odgovornosti. Odbacite sve što narušava istinski dijalog među ljudima, bez obzira na ono što se skriva pod krinkom ljudskih prava, bez obzira na podupiratelje nesporazuma i mržnje, sve što odvlači od mira i od bratstva, i sve što nas sprječava u traženju istine u slobodi. Konačno, ne slijedi li pitanje postavljeno svakome od nas: Što tražišš Što želiš? Želiš li biti moj brat, da ili ne? Jer, ako komunikacija nije sama po sebi već zajedništvo, onda može biti barem povlašteni put k tome cilju“ (SD 1971).

\subsubsection{Društvene komunikacije i promicanje mira $(1983)^{55}$}

Nema kodeksa novinarske etike koji među svojim načelima ne spominje promicanje mira. I Papina poruka iz 1983. započinje pohvalom medijima u odnosu na promicanje mira, no spominje i oprečnu mogućnost: „Zahvaljujući spektakularnom napretku i brzom širenju masovnih medija, komunikacija i informacija danas predstavljaju snagu koja može vrlo snažno služiti velikom i plemenitom cilju koji se naziva mir, ali može isto tako pogoršati tenzije i skrenuti prema novim oblicima nepravde i kršenja ljudskih prava“ (SD 1983, br. 1).

\footnotetext{
${ }^{55}$ Poruka nije prevedena na hrvatski jezik, te ju za potrebe ovog rada prevodim s poveznice: http://w2.vatican.va/content/john-paul-ii/en/messages/communications/documents/hf_jp- 
Postavljajući pitanje na koji način društvene komunikacije mogu promicati mir, poruka nalazi rješenje: „Prije svega, kroz institucionalnu razinu i određenje komunikacije kao one koje jamče ispravno, pravedno i konstruktivno korištenje informacija, slobodne od ugnjetavanja, zlostavljanja i diskriminacije na temelju političke, gospodarske ili ideološke odrednice. Nije ovdje namjera u prvom govoriti o tehničkim sredstvima, već prvenstveno ponovno promišljati temeljna načela $\mathrm{i}$ ciljeve kojima treba dati prednost $\mathrm{u}$ društvenoj komunikaciji, u svijetu koji je postao poput jedne obitelji i gdje bi legitimni pluralizam trebao biti osiguran na zajedničkom temelju konsenzusa o bitnim vrijednostima ljudskog suživota“ (SD 1983, br. 1). Poruka dalje ističe kako da bi se to postiglo, potrebno je obrazovno sazrijevanje savjesti i kod medijskih djelatnika i kod njihove publike, a potrebni su i prosvijećeni, čestiti i hrabri izbori od strane društva u cjelini. Ivan Pavao II. naglašava i da ispravno ustrojstvo društvene komunikacije i ravnopravno sudjelovanje u svim pogodnostima, s punim poštivanjem prava svih ljudi, stvara okruženje i povoljne uvjete za međusobno obogaćivanje dijaloga između građana, naroda i različitih kultura, dok nepravda i nered u ovom području stvaraju sukobe. Smatra i da ,jednosmjerna komunikacija nametnuta odozgor ili određena samo zakonima tržišta i oglašavanja; monopolistički koncentrirana, uz manipulaciju bilo koje vrste, ne samo da urušava ispravno ustrojstvo komunikacije, već također dovodi do odbacivanja prava na odgovorno informiranje, te dovodi i do ugrožavanja mira“ (SD 1983, br. 2).

Poruka potom ulazi u samu srž novinarskog djelovanja i ističe kako je „također potrebno da se medijski djelatnici izdignu iznad shvaćanja etike kao one koja se odnosi samo na pojedinca, te osim toga ne smiju dopustiti da budu pritisnuti od strane moćnih skupina, bez obzira je li taj pritisak jasan, ili je pak prikriven. Oni bi trebali“, tumači se dalje u poruci „također imati na umu da osim svojih ugovornih obveza prema svojim poslodavcima, i osim pravne odgovornosti, također imaju precizne dužnosti prema istini, prema javnosti u odnosu na opće dobro društva. Ako u obavljanju svoje zadaće, a koja je doista poslanje, društveni komunikatori daju sve od sebe za promicanje mirne i nepristrane informacije, u korist razumijevanja i dijaloga, jačanja razumijevanja i solidarnosti, to će biti veliki doprinos uspostavi mira“" (SD, 1983, br. 4). 
Novoj važnoj temi - odnosu medija prema javnom mnijenju, pravdi i miru - posvećena je i poruka Ivana Pavla II. iz 1987. godine. „Kvalitetna informacija o javnom mnijenju ima izravan utjecaj na promicanje pravde i mira“ (SD 1987), piše u poruci koja se potom izravno obraća i medijskim djelatnicima: „Znam da za vas, djelatnike u području društvenih komunikacija, mase nisu anonimno mnoštvo. Oni za vas predstavljaju kontinuirani izazov kako doći do svakog i to svakog u njegovom određenom kontekstu, na njegovoj razini razumijevanja i senzibiliteta, zahvaljujući sve naprednijoj tehnologiji i sve učinkovitijim sredstvima komunikacije. Ovaj apel odjekuje u vašoj savjesti: ostvariti misiju povjerenja kroz sredstva društvenog priopćavanja, u službi pravde i mira!“ (SD 1987). Mir nije moguć bez dijaloga, kaže Papa i te nastavlja: „Istina je dijalog koji ne može biti uspostavljen bez dobre informiranosti“ (SD 1987), pa poruka pred medije stavlja veliku zadaću: „Potrebno je prevladati barijere nepovjerenja. Može li išta bolje od društvenih komunikacija prevladati sve prepreke rase, klase i kulture koje su nasuprot jedne drugima?“ (SD 1987).

\subsubsection{Društvene komunikacije i promicanje solidarnosti i bratstva među ljudima $i$ narodima $(1988)^{57}$}

Poruku o medijima i njihovoj zadaći promicanja solidarnosti i bratstva među ljudima iz 1988. papa Ivan Pavao II. započinje jednim retoričkim pitanjem: „Ako se jednog dana bude moglo doista kazati da je 'komunicirati' isto što i 'biti braća', da 'komunikacija' označava ljudsku 'solidarnost', neće li to biti najljepši rezultat 'masovnih komunikacija'?“ (SD 1988).

$\mathrm{U}$ istome kontekstu papa ipak ne prešućuje negativnosti: „U ovom razdoblju spektakularnog razvoja masovne komunikacije, veze koje nastaju između naroda i kultura predstavljaju najdragocjeniju i veoma vrijednu podršku koja se može ponuditi čovječanstvu. Istodobno znam da ste vi komunikatori svjesni negativnih posljedica, kao što su prijetnje uništenja i urušavanja tih odnosa između naroda i kultura. Veličanje sebe, omalovažavanje i

\footnotetext{
${ }^{56}$ Poruka nije prevedena na hrvatski jezik, te ju za potrebe ovog rada prevodim s poveznice: http://w2.vatican.va/content/john-paul-ii/en/messages/communications/documents/hf_jpii_mes_24011987_world-communications-day.html

${ }^{57}$ Poruka nije prevedena na hrvatski jezik, te ju za potrebe ovog rada prevodim s poveznice: http://w2.vatican.va/content/john-paul-ii/en/messages/communications/documents/hf_jp- 
odbijanje onih koji su drugačiji, može pogoršati napetosti i podjele. Iz takvih stavova rađa se nasilje, krivi smjerovi, destrukcija istinske komunikacije, jer onemogućuju bratski odnos“ (SD 1988).

Istodobno, papa nudi i rješenja: „Da bi bilo omogućeno i samo postojanje bratstva i ljudske solidarnosti, a još više da se intenzivnije razvije njihova kršćanska dimenzija, mora se krenuti od elementarnih vrijednosti koje predstavljaju njihovu podlogu. Dopustite mi ovdje podsjetiti koje su to: poštovanje drugih, spremnost na dijalog, pravda, zdrava etika u osobnom i zajedničkom života, sloboda, jednakost, mir u jedinstvu, promicanje dostojanstva ljudske osobe, sposobnost da se dijeli s drugima. Bratstvo i solidarnost nadilaze sve klanske i društvene podjele, nacionalizam, rasizam, svaku zloporabu moći, svaki fanatizam, bilo da je kulturni ili religiozni“(SD 1988).

Pozivajući se na savjest medijskih djelatnika, papa im daje i konkretne upute:

- „Neka novinske informativne agencije i svi novinari pokažu svoje poštovanje prema drugima dajući potpunu i uravnoteženu informaciju;

- radijska rasprostranjenost riječi će bolje postići svoju svrhu u mjeri u kojoj se mogućnost recipročne razmjene nudi svima;

- mediji koji su glasnogovornici pojedinih skupina mogu pridonijeti ostvarenju pravde i u davanju glasa onima koji nemaju glasa;

- televizijski programi dotiču gotovo sve aspekte života, a mreže imaju bezbroj mogućih primjena i veza: s obzirom na njihov velik utjecaj moraju se temeljiti na odgovornosti i etičkom imperativu, moraju se ponuditi osobama i zajednicama na način da podupiru uzajamno prožimanje kultura, bez netrpeljivosti i bez nasilja, u službi jedinstva;

- mogućnost osobne komunikacije telefonom, čak i teletekstom, kao i preko satelita, zajedno ukazuju na to da bismo trebali imati brigu za jednakost među ljudima i olakšati pristup tim medijima u većem broju, kako bi se ostvarila istinska dvosmjerna komunikacija;

- informacije se sve više odnose na gospodarske i kulturne aktivnosti, skup podataka raznolikih informacija što je bilo nezamislivo u ranijim vremenima: poznato je da bi se to moglo koristiti na takav način da donese raznoliku pomoć za privatni i zajednički život; i mudro upravljanje tim medijima tako postaje pravi preduvjet mira;

- stvaranje programa koji sadrže različite audiovizualne sadržaje podrazumijeva obvezu poštivanja savjesti bezbrojnih 'gledatelja' u publici; 
- oglašavanje kod javnosti budi ili povećava želje i stvara potrebe: oni koji su oglašavanje naručili ili ga realizirali trebali bi imati na umu nepovoljan položaj onih kojima nisu dostupne stvari koje se reklamiraju“ (SD 1988).

\subsubsection{Religija u medijima $(1989)^{58}$}

Papa Ivan Pavao II. u poruci iz 1989. godine koja je posvećena mjestu religije u medijima, ističe: „Želio bih također kazati svim komunikatorima koji su se i pokazali takvima, s obzirom na njihovo pažljivo poštivanje najviših standarda profesionalne etike i prakse (...)“ (SD 1989, br. 6). Ovaj dio je zanimljiv jer zapravo pravo ostvarenje komunikatora, tj. medijskih djelatnika, papa vidi upravo u njihovom poštivanju profesionalne etike, dakle u ovom slučaju medijske etike.

„Zaključujući ovu poruku“, piše završno Ivan Pavao II, „zasigurno ne smijem propustiti potaknuti sve one kojima je na srcu apostolat komunikacije da se sa žarom i energijom, a uz dužno poštovanje prema svakoj osobi, posvete velikom djelu evangelizacije u kojem je svatko pozvan sudjelovati““ (SD 1989, br. 8). Ovdje je važno primijetiti kako papa poziva na „dužno poštovanje prema svakoj osobi“ koje može poslužiti kao mjerilo djelovanja medijskih djelatnika u svakoj prilici.

\subsubsection{Sredstva društvenog priopćavanja te jedinstvo i napredak ljudske obitelji $(1991)^{59}$}

U poruci iz 1991., a koju je posvetio medijima i jedinstvu i napretku ljudske obitelji, papa Ivan Pavao II. ističe da je ,svrha ovih novih darova isto kao što je i kod više tradicionalnih komunikacijskih medija: da nas približe jedne drugima u bratstvu $\mathrm{i}$ međusobnom razumijevanju, i da nam pomognu da napredujemo u potrazi za našom ljudskom sudbinom Božjih ljubljenih sinovi i kćeri““(SD 1991).

\footnotetext{
${ }^{58}$ Poruka nije prevedena na hrvatski jezik, te ju za potrebe ovog rada prevodim s poveznice: http://w2.vatican.va/content/john-paul-ii/en/messages/communications/documents/hf_jpii_mes_24011989_world-communications-day.html

${ }^{59}$ Poruka nije prevedena na hrvatski jezik, te ju za potrebe ovog rada prevodim s poveznice: http://w2.vatican.va/content/john-paul-ii/en/messages/communications/documents/hf_jp- 
U tom kontekstu potiče i na odgovornost svih uključenih naglašavajući da mediji, kao moćna sredstva, stavljaju uzvišen osjećaj odgovornosti pred čovjeka, bez obzira da li on medijske sadržaje stvara ili je samo njihov korisnik, jer su prema kršćanskom poimanju „komunikacijska sredstva divni instrumenti na čovjekovu raspolaganju“ (SD 1991) i ,ako su oni učinkovito sredstvo zajedništva i istinskog ljudskog napretka, moraju biti sredstvo i izraz istine, pravde i mira, dobre volje i aktivne ljubavi, uzajamne pomoći, poštovanja i zajedništva“ (SD 1991). Ivan Pavao II. nakon toga tvrdi: „Hoće li mediji služiti obogaćenju ili osiromašenju ljudske naravi ovisi o moralnoj viziji i etičkoj odgovornosti onih koji su uključeni u proces komunikacija i o primateljima medijske poruke“" (SD 1991), a nakon toga jasno ističe i da je to odgovornost svih: „Svaki član ljudske obitelji, bio on obični potrošač ili najmoćniji proizvođač medijskih programa, ima individualnu odgovornost $\mathrm{u}$ tom pogledu“ (SD 1991).

\subsubsection{Internet: novi forum za naviještanje evanđelja (2002) ${ }^{60}$}

U poruci iz 2002. godine Ivan Pavao II. bavi se internetom kao novim forumom za naviještanje evanđelja i kaže: „Poput ostalih sredstava komunikacije on je sredstvo, a ne cilj samome sebi. Internet može pružiti veličanstvene mogućnosti za evangelizaciju ako se koristi stručno i s jasnom sviješću o njegovoj moći i njegovim slabostima“ (SD 2002).

Papa postavlja i pitanje koje se čini kao da odaje negativan stav prema internetu, no iz njegovih riječi na kraju jasno je da to nije tako, jer Crkva s optimizmom promatra razvoj interneta. „Na kraju, u ovim nemirnim vremenima, dopustite mi upitati: kako možemo jamčiti da će to divno oruđe, koje je prvotno korišteno u vojne svrhe, sada moći služiti miru? Može li ono promicati kulturu dijaloga, sudjelovanja, solidarnosti i pomirenja bez kojeg se mir ne može razvijati? Crkva vjeruje da ono to može“ (SD 2002).

\footnotetext{
${ }^{60}$ Korišten je službeni prijevod na hrvatski jezik: Internet: novi forum za naviještanje evanđelja (2002), u: Ivan Pavao II. (2003), Deset poruka za slavlje Svjetskog dana sredstava društvene komunikacije, Zagreb, IKA
} 
Još je jedna poruka Ivana Pavla II. - ona iz 2003. - posvećena važnoj temi medijske etike kao što je promicanje istinskoga mira. Ovaj puta papa ju stavlja u kontekst 40. obljetnice od donošenja enciklike „Pacem in terris“ (hrv. Mir na zemlji) pape Ivana XXIII. koja je objavljena 11. travnja 1963. U poruci Ivan Pavao II. naglašava da je „moć javnih glasila da oblikuju ljudske odnose i vrše kako pozitivan tako i negativni utjecaj na politički i društveni život, dostigla goleme razmjere“ (SD 2003).

Osim o miru, poruka govori o još jednom važnom načelu - o istini u medijima: „Temeljni moralni zahtjevi svakog priopćivanja jesu poštivanje istine i služenje istini. Sloboda traženja i govorenja istine temeljna je za međuljudsko priopćivanje, $\mathrm{i}$ to ne samo $\mathrm{u}$ odnosu na činjenice i obavijesti, već također poglavito i zbog onoga što se tiče čovjekove naravi i sudbine, društva i općeg dobra, našeg odnosa s Bogom“ (SD 2003).

Porukom se upozorava i na neke negativnosti poput propagande i dezinformacije, ali se potiče i na djelovanje koje će ih eliminirati: „Doista, javna glasila često hrabro služe istini; no katkad djeluju kao sredstva propagande i dezinformacije, u službi ograničenih interesa, nacionalnih, etničkih i vjerskih predrasuda, pohlepe za materijalnim i raznovrsnih lažnih ideologija. Nužno je stoga da se pritiscima koji se u tom smjeru vrše na javna glasila neizbježno ih navodeći na pogrešku, suprotstave muškarci i žene koji djeluju u javnim glasilima, ali također Crkva i ostale odgovorne skupine“ (SD 2003).

Ivan Pavao II. potom nastavlja s opomenom i pozivom na odgovornost: „Globalna raširenost javnih glasila ima u tom pogledu osobitu odgovornost. Ako je točno da javna glasila često pripadaju određenim, privatnim i javnim, interesnim skupinama, upravo narav njihova utjecaja na život zahtijeva da ona ne potpiruju podjelu među skupinama - primjerice, u ime klasne borbe, pretjeranog nacionalizma, rasne nadmoći, etničkog čišćenja, i tako redom. Huškati jedne protiv drugih u ime religije osobito je teška zabluda protiv istine i pravednosti, kao što je to i diskriminacijski stav prema različitim vjerskim uvjerenjima, budući da ova pripadaju najdubljem području čovjekova dostojanstva i slobode“ (SD 2003).

\footnotetext{
${ }^{61}$ Korišten je službeni prijevod na hrvatski jezik: Mediji u službi istinskog mira u svjetlu „Pacem in terris“ (2003), u: Ivan Pavao II. (2003), Deset poruka za slavlje Svjetskog dana sredstava društvene komunikacije, Zagreb, IKA
} 
Stav je pape Ivana Pavla II. da mediji imaju svoje određene dužnosti i da ih se moraju držati: „Vjerno prenoseći zbivanja, ispravno predstavljajući događaje i nepristrano iznoseći različita gledišta, javna glasila ispunjavaju strogo određenu dužnost promicanja pravednosti i solidarnosti u odnosima, na svim razinama društva. To ne znači umanjivati nepravde $i$ podjele, već otkriti njihove korijene, kako bi ih se moglo shvatiti i zacijeliti““(SD 2003).

Pozornost nakon toga Ivan Pavao II. svraća i na još jednu dužnost medija - da budu u službi slobode, ali i da budu slobodni od raznih pritisaka, posebno vlasti: ,Javna su glasila u službi slobode kada služe istini: ona priječe slobodu kada odstupaju od onoga što je istinito šireći laž ili stvarajući nezdrave emotivne reakcije na događaje. Tek kada osobe imaju slobodni pristup istinitoj i dovoljnoj informaciji mogu težiti općem dobru i smatrati javnu vlast doista odgovornom za to dobro. Kada su javna glasila u službi slobode, ona sama moraju biti slobodna i moraju se tom slobodom ispravno koristiti. Njihov povlašteni 'status' obvezuje javna glasila da se izdignu iznad čisto tržišnih interesa i služe istinskim potrebama i interesima društva. Premda je određena regulacija medija od strane javnosti u interesu općeg dobra primjerena, kontrola nad njima od strane vlasti nije dopuštena. Izvjestitelji i novinari imaju osobito tešku zadaću slijediti ono što im nalaže njihova moralna savjest i oduprijeti se pritiscima koji ih potiču da 'prilagođuju' istinu kako bi udovoljili zahtjevima bogatih ili političke moći“ (SD 2003).

Vodeći računa o ulozi i pravima publike, Papa također ističe: „Na praktičnoj razini treba pronaći način ne samo da se zajamči najslabijim slojevima društva pristup informaciji koju trebaju za svoj individualni i društveni razvoj, već također da se zajamči da oni ne budu isključeni iz djelatne i odgovorne uloge u odlučivanju o sadržajima javnih glasila i određivanju strukturâ i politikâ sredstava društvenog priopćivanja.“ (SD 2003)

Pozivajući se potom i na već spomenutu encikliku Pacem in terris pape Ivana XXIII., poruka ističe: „Sve to predstavlja veliki izazov, no to ne znači da se od muškaraca i žena koji rade u javnim glasilima traži previše. Po svom pozivu kao i po svojoj profesiji oni su pozvani zastupati istinu, pravdu, slobodu i ljubav, pridonoseći svojim tako važnim radom društvenom poretku koji je 'položen na istini, sazdan prema zahtjevima pravde, gajen i ispunjen ljubavlju, a konačno ostvaren u znamenu slobode'““(SD 2003). 
U poruci naslovljenoj „Sredstva društvene komunikacije u službi razumijevanja među narodima“ iz 2005. - što će biti ujedno i posljednja poruka koju je uputio za života - papa Ivan Pavao II. ističe da ono što vrijedi na razini međuljudske komunikacije, vrijedi i u masovnim medijima: „Sveto pismo nas podsjeća da riječi imaju izvanrednu moć te mogu ujedinjavati i dijeliti narode, stvarajući veze prijateljstva ili uzrokujući neprijateljstvo. To ne vrijedi samo za riječi što ih izriče jedna osoba suočena s drugom; isto se može reći za komunikaciju, na bilo kojoj razini se ona odvijala“ (SD 2005, br. 1).

U istom broju Ivan Pavao II. opominje: „Suvremene tehnologije raspolažu mogućnostima bez presedana da čine dobro, da šire istinu o našemu spasenju u Isusu Kristu te da promiču sklad i pomirenje. Pa ipak, njihova loša uporaba može dovesti do ogromne štete, dovodeći do nerazumijevanja, predrasuda, pa čak i sukoba“ (SD 2005, br. 1), a „umjesto izgradnje jedinstva i razumijevanja, mediji mogu demonizirati druge društvene, etničke i religijske skupine, potpirujući strah i mržnju. Odgovorni za način i sadržaj izvješćivanja imaju ozbiljnu dužnost paziti da se to ne dogodi. Upravo suprotno, mediji imaju ogromne mogućnosti za promicanje mira i izgrađivanje mostova dijaloga među narodima, prekidajući, danas tako prisutan, začarani krug nasilja, odmazde i novoga nasilja“ (SD 2005, br. 2).

U poruci se spominje i jedan praktičan primjer medijske pomoći za etički pozitivne ciljeve: „Ako je takav doprinos ostvarenju mira jedan od načina na koji mediji mogu ponijeti narode, drugi je njihov utjecaj na ostvarivanju brzoga mobiliziranja pomoći kao odgovora na prirodne katastrofe. Bilo je utješno gledati kojom je brzinom međunarodna zajednica odgovorila na nedavni tsunami koji je prouzročio nebrojene žrtve. Brzina kojom se danas šire vijesti vidljivo povećava mogućnost pravovremenoga poduzimanja praktičnih mjera kako bi se pružila najveća moguća pomoć. Na taj način mediji mogu polučiti ogromnu količinu dobra“" (SD 2005, br. 3).

Pozivajući se na druge crkvene dokumente, papa ističe: „Temeljno etičko načelo je sljedeće: 'Ljudska osoba i ljudska zajednica svrha su i mjera upotrebe sredstava društvene komunikacije. Komunikaciju bi trebale provoditi osobe na korist integralnoga razvoja drugih osoba' (Etika u društvenim komunikacijama, 21). Prije svega, dakle, sami medijski djelatnici moraju u vlastitome životu oživotvoriti one vrijednosti i stavove kojima su pozvani poučiti

\footnotetext{
${ }^{62}$ Korišten je službeni prijevod na hrvatski jezik: http://www.ika.hr/bilteni/bilten_04-2005.pdf
} 
druge. To posebice od njih iziskuje ulaganje istinskih napora za opće dobro - dobro koje nije zatvoreno u ograničene interese jedne određene skupine ili naroda, nego obuhvaća potrebe i interese svih, dobro cjelokupne obitelji čovječanstva (usp. Pacem in terris, 132). Medijski djelatnici imaju priliku promicati istinsku kulturu života, tako da se oni sami ograde od aktualne urote protiv života (usp. Evangelium vitae, 17) te prenesu istinu o vrijednosti i dostojanstvu svake ljudske osobe“(SD 2005, br. 4).

\subsubsection{Mediji: mreža komunikacije, zajedništva i suradnje $(2006)^{63}$}

Prva poruka pape Benedikta XVI. za Svjetski dan sredstava društvenih komunikacija iz 2006. naslovljena je „Mediji: mreža komunikacije, zajedništva i suradnje“. U njoj papa ističe da je ,tehnološki napredak na području medija nadvladao vrijeme i prostor, omogućavajući trenutnu i izravnu komunikaciju među osobama pa i kada ih dijele ogromne razdaljine. Ovaj razvitak dovodi do ogromnog potencijala u služenju općem dobru te 'predstavlja baštinu koju valja čuvati i promicati' (Brzi razvoj, br. 10). No, kao što nam je dobro poznato, naš je svijet daleko od toga da bi bio savršen. Svakoga dana primjećujemo kako neposrednost komunikacije ne dovodi uvijek do ostvarivanja suradnje i zajedništva unutar društva. Prosvijetliti savjesti pojedinaca, kao i pomoći im da razviju svoje mišljenje, nije nikad neutralan pothvat. Istinska komunikacija iziskuje hrabrost i odlučnost. Iziskuje odlučnost onih koji rade u medijima da ne popuste pod težinom tolikih informacija te se pomire s parcijalnim i provizornim istinama“" (SD 2006, br. 2). U istom broju papa naglašava: „U ovome svijetu mediji mogu konstruktivno pridonijeti širenju svega što je dobro i istinito“ (SD 2006, br. 2).

Nakon govora o tehnološkom napretku na području informacija i komunikacija, Benedikt XVI. upućuje poziv medijima današnjice „da budu odgovorni, da budu protagonisti istine i promicatelji mira koji iz nje proizlazi“, što „podrazumijeva velike izazove. Premda razna sredstva društvenog komuniciranja olakšavaju razmjenu informacija i ideja, pridonoseći međusobnom razumijevanju različitih skupina, istodobno ona mogu biti zaražena dvoznačnošću. Sredstva društvenih komunikacija mogu se usporediti s 'velikim okruglim stolom' dijaloga čovječanstva, no neke tendencije unutar njih mogu proizvesti monokulturu

\footnotetext{
${ }^{63}$ Korišten je službeni prijevod na hrvatski jezik: http://www.ika.hr/index.php?prikaz=vijest\&ID=83775
} 
koja zamagljuje kreativni genij, preoblikuje složenu finoću misli te obezvrjeđuje zanimljivosti običaja vezanih uz kulturu i individualnost religijskoga creda. Do ovih izobličenja dolazi kad medijska industrija postane smislom samoj sebi, okrenuta samo zaradi, te gubi iz vida svijest o odgovornosti u službi općem dobru. Stoga je uvijek potrebno jamčiti točno izvještavanje o događajima, iscrpno tumačenje tema od javnoga značenja, pravilno predstavljanje različitih stajališta" (SD 2006, br. 3).

Konačno, u kontekstu naše teme, valja izdvojiti da poruka ističe da „upravo stoga što suvremeni mediji suoblikuju popularnu kulturu, oni moraju nadvladati svaki pokušaj manipulacije, osobito mladima, nastojeći, nasuprot tome, odgajati i služiti. Na taj će način mediji moći jamčiti ostvarivanje građanskog društva dostojnoga ljudske osobe, a ne njegovo raspadanje. Sudjelovanje u medijima proizlazi iz same njihove naravi, kao dobra namijenjenog svim ljudima“" (SD 2006, br. 4).

\subsubsection{Nove tehnologije, novi odnosi. Promicati kulturu poštivanja, dijaloga i prijateljstva} $(2009)^{64}$

Nove tehnologije koje dovode do novih odnosa koji trebaju pridonijeti promicanju kulture poštivanja, dijaloga i prijateljstva još su jednom u središtu poruke jednoga od poglavara Katoličke Crkve. Tako na početku poruke iz 2009. godine Benedikt XVI. ističe: „U ovogodišnjoj poruci imam posebno pred očima one koji pripadaju takozvanoj digitalnoj generaciji: s njima bih želio podijeliti neka svoja razmišljanja o izvanrednim mogućnostima novih tehnologija, ako ih se koristi za dublje razumijevanje i učvršćivanje solidarnosti među ljudima. Te su tehnologije pravi dar za čovječanstvo: moramo zato učiniti da se prednosti koje one pružaju stave u službu svih ljudi i svih zajednica, prije svega onih koji su u potrebi i ranjivi“ (SD 2009, br. 1).

U nastavku poruke Benedikt XVI. iznosi i poticaj svim ljudima „dobre volje, koji djeluju u novonastalom svijetu digitalne komunikacije, da se založe u promicanju kulture poštivanja, dijaloga i prijateljstva. Zato se oni koji rade na polju proizvodnje i širenja sadržaja koje se prenose putem novih medija moraju zalagati za poštivanje dostojanstva i vrijednosti osobe. Ako nove tehnologije moraju služiti dobru pojedinaca i društva, oni koji se njima

\footnotetext{
${ }^{64}$ Korišten je službeni prijevod na hrvatski jezik: http://www.ika.hr/index.php?prikaz=vijest\&ID=110467
} 
koriste moraju izbjegavati da raspačavaju riječi i slike koje su ponižavajuće za ljudsko biće, te zato isključiti sve ono što potiče mržnju i nesnošljivost, obezvrjeđuje ljepotu i intimnost ljudske spolnosti, zloupotrebljava slabe i nevine“" (SD 2009, br. 3).

Benedikt XVI. govori i o važnosti nove „digitalne pozornice“ i njezinom značenju na globalnom planu i u odnosima među narodima, potičući da se i u kibernetičkom prostoru poštuje dijalog koji se temelji na istini: „Nove tehnologije također su utrle put dijalogu među pripadnicima različitih naroda, kultura i religija. Nova digitalna pozornica, takozvani cyberspace, omogućuje susresti druge ljude i upoznati tuđe vrijednosti i tradicije. Takvi susreti, ipak, da bi urodili plodom, zahtijevaju savjesne i ispravne oblike izražavanja kao i pozorno slušanje i poštovanje sugovornika. Dijalog mora biti ukorijenjen u iskrenom i uzajamnom traženju istine, kako bi se podupirao razvoj u razumijevanju i snošljivosti. Život nije puko izmjenjivanje događaja i iskustava: to je prije traženje istine, dobra i ljepote. Upravo zbog toga donosimo svoje odluke, ostvarujemo svoju slobodu i u tome, to jest u istini, dobru i ljepoti, nalazimo sreću i radost. Ne smijemo se dati obmanuti od onih koji jednostavno traže potrošače na tržištu nediferenciranih mogućnosti, gdje izbor u samom sebi postaje dobro, novost se protura pod ljepotu, a subjektivno iskustvo istiskuje istinu“ (SD 2009, br. 4).

\subsubsection{Svećenik i pastoral u digitalnom svijetu: novi mediji u službi Riječi $(2010)^{65}$}

Ova je poruka iz 2010. upućena na prvome mjestu službenicima Crkve, to jest svećenicima, no papa Benedikt XVI. tu je poruku stavio u kontekst digitalnoga svijeta i novih medija ističući važnu etičku dimenziju koja nije „specifična“ samo za crkvene službenike nego i za sve medijske djelatnike, a to je odgovornost. „Posvećene osobe koje rade u medijima imaju posebnu odgovornost utrti put novim oblicima susreta, trajno jamčiti kvalitetu ljudskog susreta i pokazati brigu za osobe i njihove duhovne potrebe“ (SD 2010), piše papa i zaključuje: „Razvoj novih tehnologija i digitalni svijet u cjelini predstavljaju veliko bogatstvo za čitavo čovječanstvo i za čovjeka pojedinca a može djelovati i kao poticaj na susret i dijalog“(SD 2010).

\footnotetext{
${ }^{65}$ Korišten je službeni prijevod na hrvatski jezik: http://www.ika.hr/index.php?prikaz=vijest\&ID=119674
} 
Premda ova poruka ne progovara posve izravno o temi medijske etike, u njoj nalazimo više s njom povezanih elemenata, posebno vezanih sa samoga čovjeka koji je subjekt i protagonist svakoga svojega čina, bio on etičan ili neetičan, a koji si i sam postavlja mnoštvo pitanja: „U složenom i raznolikom svijetu komunikacije na vidjelo, ipak, izbija činjenica da je mnogo onih koji si postavljaju posljednja pitanja ljudskog života: tko sam? dokle seže moje znanje? što mi je činiti? čemu se mogu nadati?““ (SD 2012). Stoga je važno, piše Benedikt XVI., ,pružiti potporu osobama koje postavljaju ta pitanja i otvoriti mogućnost dubokog dijaloga, kojeg čine riječi, uzajamno razumijevanje, ali također poziv na razmišljanje i šutnju, koja, katkad, može biti rječitija od prenagljenog odgovora i omogućuje onome koji traži odgovore na pitanja koja ga muče da dublje uroni u vlastito biće i otvori se onom putu spoznaje kojeg je Bog upisao u čovjekovo srce“ (SD 2012).

\subsubsection{Društvene mreže: vrata istine i vjere; novi prostori evangelizacije $(2013)^{67}$}

U poruci iz 2013. godine papa Benedikt XVI. govori o vrlo aktualnoj temi - o društvenim mrežama - $\mathrm{i}$ to veoma pozitivno: „Kada se koriste na dobar i uravnotežen način, ti prostori pridonose jačanju oblika dijaloga i rasprave koji, pod uvjetom da se u njima poštuje i uvažava tuđu privatnost te postupa odgovorno i istinoljubivo, mogu učvrstiti sveze zajedništva među osobama i djelotvorno promicati sklad ljudske obitelji. Razmjena informacija može postati prava komunikacija, poveznice mogu prerasti u prijateljstvo, međusobne povezanosti olakšati zajedništvo“ (SD 2013), te nastavlja: „Društveni mediji (social media) trebaju zato zauzetost svih onih koji su svjesni vrijednosti dijaloga, razumske rasprave, logičke argumentacije; osoba koje se trude njegovati oblike razgovora i izražavanja koji apeliraju na najplemenitije težnje onih koji sudjeluju u komunikacijskom procesu. Dijalog i rasprava mogu cvjetati i rasti i kada se razgovara i uzima zaozbiljno one čije se ideje razlikuju od naših“"(SD 2013).

\footnotetext{
${ }^{66}$ Korišten je službeni prijevod na hrvatski jezik: http://www.ika.hr/index.php?prikaz=vijest\&ID=138860

${ }^{67}$ Korišten je službeni prijevod na hrvatski jezik: http://www.ika.hr/index.php?prikaz=vijest\&ID=148376
} 


\subsubsection{Komunikacija u službi istinske kulture susreta $(2014)^{68}$}

Riječ je o prvoj poruci za ovaj dan pape Franje u kojoj, dok govori o medijima, upozorava što se može dogoditi zbog njihova pogrešnoga razumijevanja i korištenja: „Brzina kojom se prenose informacije nadilazi našu sposobnost razmišljanja i prosuđivanja i ne dopušta uravnotežen i ispravan oblik samoizražavanja. Različitost mišljenja može se promatrati kao bogatstvo, ali to također omogućuje ljudima da se zabarikadiraju iza izvorâ informacija koji odgovaraju samo njihovim željama i idejama, ili također određenim političkim i gospodarskim interesima. Svijet komunikacija može nam pomoći kako proširiti svoja znanja tako i, naprotiv, navesti nas na pogrešan put. Želja za digitalnom povezanošću može imati za posljedicu da se izoliramo od naših bližnjih, od onih koji su oko nas. Ne smije se pritom previdjeti činjenicu da su oni koji iz različitih razloga nemaju pristup društvenim medijima izloženi opasnosti da budu isključeni““(SD 2014).

Osvrćući se na jednu biblijsku prispodobu papa piše: „Kadgod je glavna svrha komunikacije potaknuti na potrošnju ili manipulaciju ljudima, tada je riječ o silovitom napadu poput onoga kojem je bio izložen čovjek iz prispodobe kojeg su razbojnici pretukli i ostavili uz cestu“ (SD 2014).

Poruka govori ukratko i o nepristranosti medija, tj. naglašava da je ona danas prividna, a da ne bi bila takva svatko mora uključiti i samoga sebe: „Nepristranost medija je samo prividna: jedino onaj koji u komunikaciju uključuje samoga sebe može predstavljati istinsku referentnu točku za druge“" (SD 2014).

\subsubsection{Komunikacija i milosrđe: plodni susret $(2016)^{69}$}

Poruka iz 2016. sagledava komunikaciju i medije u svoj njihovoj složenosti pozitivnih i negativnih aspekata, a papa Franjo ističe: „Komunikacija ima moć graditi mostove, potpomagati susret i uključivanje, obogaćujući tako društvo. Kako je lijepo kad osobe pažljivo biraju riječi i geste i tako se trude izbjeći nerazumijevanja, ozdraviti ranjeno sjećanje i graditi mir i sklad. Riječi mogu podići mostove među ljudima, obiteljima, društvenim skupinama i narodima. I to kako u fizičkom tako i u digitalnom okruženju. Zato neka naše

\footnotetext{
${ }^{68}$ Korišten je službeni prijevod na hrvatski jezik: http://www.ika.hr/index.php?prikaz=vijest\&ID=160844

${ }^{69}$ Korišten je službeni prijevod na hrvatski jezik: http://www.ika.hr/index.php?prikaz=vijest\&ID=177554
} 
riječi i djela budu takvi da nam pomažu izaći iz začaranih krugova osuđivanja i osvete, koji i dalje zarobljavaju pojedince i narode i koji dovode do toga da se ljudi služe porukama mržnje. Riječ Kristova učenika, naprotiv, trebala bi nastojati pomoći ljudima rasti u zajedništvu i, čak i u slučajevima kad treba odlučno osuditi zlo, nikada ne bi smjela prekidati odnos i komunikaciju“(SD 2016).

Papa potom podsjeća da je slušanje sastavni dio komunikacije: „Komunicirati znači dijeliti, a dijeljenje zahtijeva slušanje, prihvaćanje. Slušati je nešto mnogo više od čuti. Čuti se odnosi na primanje informacije; slušati, međutim, upućuje na područje komunikacije i traži blizinu. Slušanje nam omogućuje zauzeti ispravan stav, a ne samo biti pasivni gledatelji, slušatelji, potrošači. Slušati znači također biti sposobni dijeliti pitanja i sumnje, prijeći neki put rame uz rame s nekim, osloboditi se svake umišljenosti o svemoći i staviti ponizno svoje sposobnosti i svoje darove u službu općeg dobra“ (SD 2016).

No, nije tehnologija ona koja određuje je li komunikacija autentična: „I elektronska pošta, SMS poruke, društvene mreže i interaktivni razgovori više korisnika putem interneta (chat) mogu biti potpuno ljudski oblik komunikacije. Nije tehnologija ta koja određuje je li komunikacija autentična ili ne, već ljudsko srce i njegova sposobnost da koristi dobro sredstva koja mu stoje na raspolaganju. Društvene mreže mogu olakšati uspostavu odnosa s drugima i promicati dobro društva ali mogu također dovesti do daljnje polarizacije i podjele među osobama i skupinama. Digitalni svijet je trg, mjesto susreta gdje možemo jedni druge milovati ili ranjavati, voditi korisnu raspravu ili provoditi moralni linč““(SD 2016). 


\section{USPOREDBA SUVREMENIH MEDIJSKO-ETIČKIH PRAVACA I MEDIJSKE ETIKE U CRKVENIM DOKUMENTIMA}

U ovom ćemo poglavlju usporedno kritički analizirati odabrane i prevladavajuće etičke pravce na području medijske etike s jedne strane i razmišljanja o medijskoj etici u crkvenim dokumentima, to jest doprinos teološke medijske etike s druge strane, tako da ćemo pojedine teme medijske etike sustavno i usredotočeno prezentirati i obraditi s oba stajališta. Ono što će biti u fokusu našega zanimanja bit će moguće točke slaganja i podudaranja kao i mogućih razlika i razilaženja u spomenutim stajalištima.

Činjenica je da suvremeni čovjek kao da vapi za medijskom etikom koja će se snažno zauzimati za prostore njegove slobode usprkos raznim poteškoćama i ograničenjima na koje nailazi. Takva situacija etičkom promišljanju, kao i teološkoj etici i moralu, te suvremenoj medijskoj etici nameće veoma važno pitanje: nalazi li današnji čovjek u teološkoj i suvremenoj medijskoj etici sugovornika? U međusobnom odnosu i medijska bi etika i teološka medijska etika trebale svjesno i odgovorno davati svoj doprinos javnom životu, pokazivati solidarnu otvorenost prema drugima, kao i kritički stav i odnos prema brojnim ponudama u suvremenom svijetu (Valković, 2006: 50-51).

Kriza novinarske etike se pretvorila u krizu cijeloga medijskog sustava, smatra Labaš (2011: 192), dodajući da je nestala granica između novinara i ne-novinara, između diletanata $i$ pravih profesionalaca, pri čemu se sve rjeđe vodi računa o tome tko može biti novinar i koje su to značajke novinarskog subjekta, kao i njegovog ljudskog i profesionalnog identiteta. U toj nezahvalnoj situaciji u kojoj se nalaze mediji, zasigurno je važno analizirati koje moguće smjernice i rješenja, načela i kriterije nudi te koji je mogući doprinos medijske etike i teološke medijske etike iznesene u crkvenim dokumentima.

Pojedini autori medijsku etiku u crkvenim dokumentima smatraju zahtjevnijom. Tako Vilović (2003: 963) pozivajući se na Maxa Webera razlikuje „etiku evanđelja“ i „etiku odgovornosti“, ističući etiku evanđelja kao onu koja je 'apsolutna i bezuvjetna', za razliku od etike odgovornosti koja 'nalaže čovjeku da vodi računa o posljedicama svojih moralnih stavova i čina'. Je li to tako i može li medijska etika kako je predstavljena i obrađena u crkvenim dokumentima dati svoj doprinos suvremenoj medijskoj etici, koja načela medijske etike promiče i zastupa, te po čemu se ta dva smjera razlikuju i/ili nadopunjuju pokušat će se odgovoriti u nastavku ovog poglavlja. 
Teolog i komunikolog Mataušić (2002: 362) ističe da postoji snažna povezanost medijskog i religijskog odnosno crkvenog konteksta, te da danas mediji na određeni način konkuriraju tradicionalnoj ulozi koju je imala religija: oni okupljaju ljude, objašnjavaju im smisao života i obećavaju spasenje. U tom kontekstu navodi da prije svega treba vidjeti pozitivne strane medija te omogućiti da te pozitivne strane dođu što više do izražaja. Crkva si je na tom području u svojim službenim dokumentima zadala vrlo zahtjevan program, ali ga do sada slabo ostvaruje, smatra Mataušić.

Pozivajući se na poruku Ivana Pavla II. iz 1999. godine upućenu katoličkim novinarima, Suzana Vrhovski Peran (2010: 132) primjećuje da se iz crkvenih dokumenata iščitava da Crkva svoju ulogu u odnosu na medije vidi kao ulogu pomoćnice i savjetnice, smatrajući kako kultura crkvene mudrosti može pomoći da kultura informacije društvenih obavijesnih sredstava ne postane puko gomilanje činjenica bez smisla. Ista autorica (Vrhovski Peran, 2010: 132) naglašava: „Kada se govori o odgovornosti novinara i medija u odnosu na kršćanska načela, tada se zahtijeva da oni djeluju za dobro cjelokupnog razvoja ljudi i za opće dobro koje je povezano s dobrom osobe koja toj zajednici pripada“.

Medijska etika i teološka medijska etika o temama etike u medijima promišljaju na sličan način. Analizirajući crkvene dokumente o medijima, uviđa se da teologija kao znanost - a njezin je odraz vidljiv u crkvenim dokumentima koji se na njoj temelje - ide u korak s vremenom, te o medijskim etičkim temama promišlja na sličan način kao i medijska etika, samo što ona svoja promišljanja utemeljuje na Apsolutu - Bogu, dok ostale etike to ne čine i nude svoja znanstvena viđenja i razmišljanja. U tom se kontekstu ipak očituje jedna neprijeporna činjenica, to jest da se medijska etika poput teološke medijske etike zauzima za ista načela: istinu, objektivnost, nepristranost, poštenje i druga načela u medijskom i novinarskom izvještavanju, a što su ujedno i načela koja se najčešće utvrđuju i u novinarskim kodeksima časti po cijelome svijetu.

U ovom usporedbenom prikazu medijske etike i teološke medijske etike će se započeti upravo s temom utemeljenja etičkih normi, budući da je riječ o temeljnom pitanju. Bez obzira na različite pristupe svim je etikama u središtu čovjek, te će stoga nastaviti upravo tom ključnom činjenicom i temom, to jest čovjekom kao središtem i polazištem medijske etike. Nakon toga obradit će se i današnji etički relativizam na koji upozoravaju razni autori, ali ćemo se posvetiti i pitanju općeg dobra, slobode i odgovornosti na kojima počiva svaka etika, 
javnom mnijenju, istini, objektivnosti i ostalim već spomenutim etičkim načelima zastupljenima kod raznih autora koji se bave načelima medijske etike.

\subsection{Utemeljenje normi i svrha medijske etike}

Habermas (1984: 104) razlikuje subjektivno i objektivno ispravno djelovanje komunikatora. Prema njemu, komunikator subjektivno „ispravno“ djeluje u smislu normativne ispravnosti, ako iskreno vjeruje da slijedi postojeću normu djelovanja, a objektivno ,ispravno“ ako normu koja je u pitanju smatraju opravdanom oni na koje se odnosi. Habermas (1984: 162-163) smatra da su podcijenjene one etike koje se temelje na općim načelima, kao i pravne norme (te stvaranja i primjene zakona) koje se pozivaju na magijske svete tradicije, objave i slično.

Apel (1996: 1) pak piše da se javlja filozofska potreba racionalnog utemeljenja univerzalne etike koja se nikad nije činila zahtjevnijom nego u znanstvenom dobu, a to se događa jer je u naše doba pojam intersubjektivne valjanosti unaprijed otuđen od strane znanosti, to jest od znanstvenog pojma normativne neutralnosti i „objektivnosti“ bez vrednota. Apel (1980: 500-501) smatra da izgleda gotovo nemoguće utemeljenje normativne etike, te predočuje najvažnije pretpostavke za utemeljenje te tvrdnje: iz činjenica se ne mogu izvesti nikakve norme; znanost, ako daje sadržajnu spoznaju, ima posla s ,činjenicama“, pa stoga prema njegovom mišljenju nije moguće znanstveno utemeljenje normativne etike. Samo znanost daje objektivno znanje, a objektivitet je identičan s intersubjektivnim važenjem, pa stoga nije moguće intersubjektivno važeće utemeljenje etike. Pozivajući se na Michela Foucaulta, Apel (2001a: 143) ističe da su kršćanstvo i prije svega Kant učinili univerzalno važeće norme morala obvezatnima za sve ljude, što je nespojivo s individualno i kulturalno diferenciranom etikom dobroga života, odnosno etikom „souci de soi“ (brige za sebe).

Jacquette (2007: 374-375) postavlja jako visoke ideale ističući da svatko tko zaista želi pomoći da se svijet promijeni treba ujedno razmisliti o novinarstvu kao o načinu na koji osobe s pravim talentima i obrazovanjem mogu pružiti pozitivan doprinos ovom svijetu. Prema njemu, medijska etika je samo drugo ime za kvalitetno novinarsko izvještavanje.

Day (2014: 13) pak piše da mnogi, kad god se u razgovoru spomene izraz „medijska etika“", kažu da je ta sintagma klasični oksimoron. No, on smatra da nikada nije postojala veća 
potreba da se ponovno naglasi značenje etičkog odgoja i obrazovanja. Day (2014: 28-30) piše da se moralno znanje ne sastoji od pamćenja skupa ili cijeloga niza etičkih principa, to jest načela, već od sposobnosti razlikovanja dobrog i lošeg ponašanja te moralne volje da se to znanje primijeni na stvarne etičke dileme u stvarnim životnim situacijama, te navodi tri moralne vrline koje bi trebale krasiti novinarske djelatnike: kredibilitet, integritet $\mathrm{i}$ civiliziranost. Konačno i Perebinossoff (2008: 47) upozorava da medijski djelatnici imaju slobodu izbora odlučiti da će ignorirati, omalovažiti ili prijeći preko etičkih zahtjeva, ali ne mogu ignorirati njihovo postojanje.

Što se pak teološke etike i medija tiče, valja odmah istaknuti da već ranije spomenuti dokument Drugog vatikanskog koncila Inter mirifica koristi pojam objektivnog moralnog reda, te ističe da Koncil smatra da se svi imaju apsolutno držati primata objektivnog moralnog reda, jer on jedini nadilazi i dovodi u pravilan odnos svaki drugi ljudski red (IM, br. 6). U istom broju dokument također navodi da se i na medije odnose načela koja prema kršćanskom gledanju vrijede za ljudski suživot.

I u pastoralnom naputku Communio et progressio u broju 101. navodi se da Crkva, promatrajući svoju zadaću na području medija, nastoji spojiti katolički nauk s nutarnjim zakonima medija. Dokument Etika u obavijesnim sredstvima u broju 4. ističe da su mediji samo mediji, da su sredstva, to jest alat ili oruđe, pa su zbog toga neutralni po sebi, a da ljudi biraju kako će ih upotrijebiti, a za ispravan odabir potrebno je dobro poznavati ,pravila moralnog reda“ $\mathrm{i}$,vjerno ih provoditi u djelo“. Isti dokument u broju 5. navodi da Crkva u svom naučavanju, posebno na moralnome području glede medija, pruža različite doprinose medijskoj etici, a prije svega nudi ,dugu baštinu moralne mudrosti ukorijenjenu u božansku objavu i u ljudsko razmišljanje“, kao i istaknuto viđenje dostojanstva ljudske osobe. U broju 20. dokument navodi da etička načela i norme koje važe na drugim područjima vrijede i za područje medija, ističući načela kao što su solidarnost, pravednost, supsidijarnost, jednakost, odgovornost i druga.

U dokumentu Etika na internetu u broju 14. kritički se propituje utemeljenje etike isključivo na slobodi, te se navodi da je ideologija radikalnog libertarijanizma pogrešna i štetna, u prvom redu u pogledu slobodnog izražavanja u službi istine, a pogreška se sastoji u tome da se sloboda uzdiže do apsoluta, koji bi bio izvor vrijednosti.

Konačno, možemo reći da crkveni dokumenti u prvi plan stavljaju objektivni moralni red kao nešto na čemu se temelji teološka medijska etika, dok s druge strane u suvremenim 
etičkim pravcima pronalazimo različite stavove i razmišljanja, pa se može govoriti o međusobnoj komplementarnosti. Iznesena razmišljanja različitih autora o medijskoj etici doprinos su i produbljivanju teološkog pristupa medijskoj etici, koji svoje utemeljenje pronalazi u ljudskom dostojanstvu koje proizlazi iz biblijskog učenja da je čovjek stvoren ,na sliku i priliku Božju“, te je zbog toga u središtu svakoga etičkog promišljanja.

\section{2. Čovjek kao središnji subjekt medijske etike}

Medijska etika naglašava da bi u središtu njezinog interesa trebao biti čovjek. Tako Brajnović (2011: 114) piše da se mediji i cijela društvena komunikacija vrednuju prema tome služe li čovjeku i njegovim pravima. Labaš i Uldrijan (2010: 103) u svojim razmišljanjima u središte također stavljaju čovjeka, ističući da za obnovu i očuvanje etičnog novinarstva nije dovoljno napisati novi kodeks, kao što nema svrhe niti samo dijeliti deklarativne ukore onima koji okrenu glavu od temeljnih etičkih vrijednosti, već je zapravo najvažnije, ali i jedino pravo rješenje vratiti se čovjeku i njegovom nepovredivom dostojanstvu, jer je on subjekt novinarstva. Pozaić (1992: 564) piše da je neosporno - ne negirajući niti negativne primjere da mnogi medijski djelatnici imaju svoj osobni visoki etos i trude se djelovati u skladu s njime, te znaju u središte svoje profesije uvijek stavljati čovjeka.

Poput medijske etike i teološka medijska etika koja je iznesena u crkvenim dokumentima u središte stavlja isto tako čovjeka. Tako jedan od najvažnijih crkvenih dokumenata posvećen medijima - apostolska pobudnica Communio et progressio iz 1971. godine - u broju 14. piše da je čovjek sam utvrdio način uporabe medija, pa se i etička načela za tu uporabu trebaju graditi na poštivanju dostojanstva čovjeka. Nadalje, u idućem broju 15. dokument naglašava da tko god želi prosuđivati medijsku etičku vrijednost, nužno mora uzeti u obzir čitavog čovjeka. U istom dokumentu, u broju 72., ističe se da su svi mediji u službi ljudskog roda, te da medijski djelatnici moraju sve svoje sile uložiti u službu čovjeka, a tu službu će pak moći valjano vršiti samo oni koji nastoje shvatiti i istinski ljubiti čovjeka. Isti dokument u broju 102. piše da Crkva želi da se dostojanstvo osobe, bilo komunikatora priopćavatelja bilo recipijenta - primatelja, priznaje u svim njegovim oblicima i da se $\mathrm{s}$ osobom postupa s poštovanjem. I temeljni crkveni dokument o medijskoj etici - Etika $u$ obavijesnim sredstvima - iz 2000. godine u broju 21. stavlja čovjeka u središte, pišući da je temeljno načelo medijske etike ljudska osoba, to jest da su ljudska osoba i ljudska zajednica 
svrha i mjerilo upotrebe društvenih obavijesnih sredstava, to jest medija. $U$ istom broju dokument ističe da bi svaku vrstu informacije trebali pripremati ljudi u korist cjelokupnog razvoja drugih ljudi.

Dokument Etika na internetu iz 2002. godine u broju 3. ističe da su kao i kod ostalih medija u središtu etičkog vrednovanja interneta osoba i zajednica osoba. Prema istome dokumentu poruka, proces komuniciranja, kao i pitanja vezana uz ustrojstvo i sustav u komunikaciji predstavljaju i trebaju predstavljati temeljno etičko načelo, a to je ljudska osoba i ljudska zajednica koji su svrha i mjerilo upotrebe društvenih obavijesnih sredstava.

Međutim, papa Ivan Pavao II. u svojoj poruci za Svjetski dan sredstava društvenog priopćavanja 1985. godine u broju 4. piše da mediji ponekad djeluju protiv dostojanstva ljudske osobe i njezine slobode, te osobito upozorava da djeluju protiv najslabijih i nezaštićenih. U poruci iz 1989. isti papa u broju 8. potiče medijske djelatnike da djeluju uz dužno poštovanje prema svakoj osobi. Ivan Pavao II. u poruci za Svjetski dan sredstava društvenog priopćavanja iz 1998. godine piše da mediji mogu ponekad svesti ljudska bića na potrošače ili na interesne skupine u natjecanju ili manipulirati gledateljima, čitateljima i slušateljima samo kao brojkama od kojih se očekuju koristi, da ih se veže uz političku potporu ili prodaju proizvoda, navodeći da to nije dobro, već da mediji imaju zadaću ujedinjavati osobe i obogaćivati njihov život, a ne odvajati ih i iskorištavati. U svojoj poruci iz 2004. godine u broju 2. Ivan Pavao II. ističe da komunikacija u bilo kojem obliku mora uvijek biti nadahnuta etičkim kriterijem poštovanja dostojanstva ljudske osobe. Isto to u svojoj poruci za Svjetski dan sredstava društvenog priopćavanja 2011. godine ističe papa Benedikt XVI., dodajući da se nove komunikacijske tehnologije moraju staviti u službu cjelovitog dobra osobe i čitavoga čovječanstva, te da njihovo mudro korištenje može pridonijeti zadovoljavanju želje za smislom, istinom i jedinstvom što je najdublja težnja ljudskog bića.

Zaključno bismo mogli reći da i medijska etika i crkveni dokumenti posvećeni medijima i medijskoj etici ističu potrebu stavljanja čovjeka u središte, bez obzira na određene divergencije i razlike u pristupu. Ipak, kao što je vidljivo iz prethodnoga dijela rada, naša analiza je pokazala da odabrani crkveni dokumenti to čine češće. Konačno, možemo reći da oni ovoj temi pristupaju kao i općenito medijska etika s puno pozornosti i otvorenosti za raspravu, smatrajući očito da je odnos prema čovjeku u temelju svake etike, te zato u samo središte stavljaju ljudsko dostojanstvo, čovjekovo nepovredivo pravo i vrijednost ljudske osobe. 


\subsection{Etički relativizam kao problem medijske etike}

Tema etičkog relativizma nije tema koja se tiče i koja zaokuplja samo medijsku etiku, već je aktualno pitanje cjelokupne etike. Dakako, na specifičan način se obrađuje i u užem području medijske etike. O temi etičkog relativizma piše, između ostalih, Hartmann (2003: 29-30) koji etički relativizam smatra pitanjem koje predstavlja samu srž filozofske etike. On polazi od mišljenja koje osvješćuje činjenicu da ako bi etičke zapovijedi bile samo plod ljudskog umovanja, onda bi ih čovjek mogao rušiti jednako kako ih je i postavljao. Također, filozofska misao bi imala moć davati zapovijedi, kao što politička misao ima moć izdavati i objavljivati zakone. No, Hartmann smatra da niti jedna filozofska etika ne bi mogla nositi odgovornost donošenja tih normi, jer ljudska je misao upravo isto tako relativna kao i norme kojih bi relativnost ona trebala prevladati, jer je i povijesno i vremenski uvjetovana i vezana. I Čehok i Koprek (2006: 10) također uočavaju poteškoću etičkog relativizma, napose s obzirom na prisutan pluralizam, pa se prema njihovom razmišljanju stoga javlja shvaćanje da na području moralnosti ništa ne vrijedi apsolutno, bezuvjetno i nužno, nego tek u odnosu prema nečem drugom. Oni smatraju da se problem relativizma u etici očituje i u nemogućnosti racionalne argumentacije na području moralnosti (Čehok i Koprek, 2006: 11). Pri tome se pozivaju na Günthera Patziga koji razlikuje tri vrste relativizma: deskriptivni (koji samo registrira mnoštvo moralnih predstavki bez ikakve prosudbe), principijelni (koji isključuje divergencije konkretnih moralnih ponašanja te kaže da svemu u temelju stoje postavke koje su često međusobno proturječne) i normativni relativizam (koji smatra opravdanim različitost moralnih postavki). Stoga zaključuju da je polazište etičkog relativizma posve pogrešno, jer etički relativizam smatra da ne postoje apsolutna mjerila za biti dobar i biti loš, a time nije izbrisana i bezuvjetna moralna obveza. Ukazuju i na kontradiktornost etičkog relativizma: s jedne strane odbacuje sve norme, a kao da zaboravlja da je i odbacivanje normi svojevrsna norma, pa je i sama relativistička teza zato zapravo neodrživa. Miliša, Tolić i Vertovšek (2009: 129) govore o etičkom relativizmu konkretno u medijima, ističući kao pogrešnu ideju relativističkog pristupa da su moralne vrijednosti ljudski konstrukti, a ne plod transcendentalne istine, te da ih prema poziciji relativista treba odbaciti. Day (2014: 81-82) pak sumira pišući da relativisti vjeruju da ono što je ispravno ili dobro za jednog, ne mora automatski biti ispravno ili dobro za drugog čovjeka, čak i pod istim okolnostima. Relativisti imaju stav da ću ,ja odrediti što je dobro za mene, a ti odredi što je dobro za tebe“. Day u tom kontekstu primjećuje da kada se dovede do svojih krajnjih granica, relativizam može voditi $\mathrm{k}$ 
moralnoj anarhiji u kojoj više nema nikakvih etički važećih normi. Spominje i manje ekstremno polazište, a riječ je o postavkama onih koji prihvaćaju određene principe, ali smatraju da se od njih može relativno lako odstupiti, ovisno o situaciji. Tu je zapravo riječ o „situacijskoj etici“ koja je ublažena verzija moralnog relativizma. No, tom logikom, po kojoj se odlučuje od slučaja do slučaja, dolazi se do ad hoc odlučivanja najgore vrste i teško se može (zapravo ne može) upotrijebiti kao model etičkog odlučivanja. Posebno to ne bi vrijedilo i ne može vrijediti na području medijske etike, budući da je novinarski etički kodeksi jasno propisuju pravila kojih bi se svaki novinar trebao držati želi li poštivati deontološka, to jest etička pravila svoje struke. No, činjenica je da se tih pravila danas ne pridržavaju svi novinari niti svi mediji.

Upravo se zato u temeljnom crkvenom dokumentu o medijskoj etici - Etika $u$ obavijesnim sredstvima - kojega smo već spominjali ranije, upozorava i na tu činjenicu. Tako se u broju 15. ističe da i mediji i novinari pridonose etičkom relativizmu, to jest da mediji često promiču etički relativizam i utilitarizam koji označuju suvremenu kulturu smrti. Govoreći o zadaći medija, dokument Crkva na internetu u broju 11. ističe da mediji trebaju biti jaki i hrabri, tj. stajati na strani istine nasuprot vjerskom i moralnom relativizmu, na strani altruizma i velikodušnosti nasuprot individualističkom konzumerizmu i na strani pristojnosti nasuprot putenosti i grijehu. Dakle, u spomenutome se dokumentu etički relativizam prikazuje i vrednuje kao nešto što bi bilo u suprotnosti s istinom i ispravnim poimanjem same etike.

Među ostalim temama koje mediji mogu relativizirati je i obiteljski život i odgoj djece. Tako u poruci za Svjetski dan sredstava društvenog priopćavanja 1994. godine papa Ivan Pavao II. piše da televizija nažalost može ranjavati obiteljski život: promičući vrijednosti i uzorke ponižavajućeg ponašanja, prenoseći pornografske sadržaje i prikazujući zvjerske okrutnosti; ucjepljujući moralni relativizam i religijski skepticizam, šireći izobličene i manipulirane događaje o kojima izvješćuje ili izobličujući tekuće probleme, itd. I u ovoj se poruci odbacuje etički relativizam kao nešto negativno. Isti je slučaj s porukom prigodom Svjetskog dana sredstava društvenog priopćavanja 2001. godine u kojoj papa Ivan Pavao II. piše da je u medijima ponekad jedina apsolutna istina da nema apsolutne istine, ili ako je ima da je ona ljudskom umu nedohvatljiva. Time se zapravo opet na određeni način prigovara etičkom relativizmu koji ne promiče istinu. I u poruci za isti dan 2009. godine papa Benedikt XVI. u broju 5. ističe da je potrebno izbjeći da mediji postanu megafon ekonomskoga materijalizma i etičkoga relativizma, pravih rana našega doba. Dakle, i taj papa etički 
relativizam smatra „pravom ranom našeg doba“, dodajući da bi poziv sredstava društvene komunikacije trebao biti suprotan relativizmu, tj. trebao bi biti potraga za istinom.

I kod teme etičkog relativizma zaključno možemo reći da se njome bave i autori koji se bave medijskom etikom i crkveni dokumenti, tj. teološka medijska etika. No, iako bismo u crkvenim dokumentima očekivali veoma često upozoravanje na relativizam, jer se u javnosti i u znanstvenim krugovima ponekad stječe dojam kako je crkveni govor posvećen upravo opominjanju na urušavanje moralnih načela, ipak to nije tako često. Pri tome je ipak istaknuto veoma snažno suprotstavljanje toj pojavi. Također treba naglasiti da crkveni dokumenti često i kad ne govore o etičkom relativizmu, nego pišući o drugim temama i naglašavajući univerzalne vrednote, zapravo indirektno odbacuju etički relativizam. To je i razlog zbog čega ga nije potrebno često isticati izrijekom. No, kada se u crkvenim dokumentima o medijima govori o etičkom relativizmu, onda su dokumenti više orijentirani na prisutnost etičkog relativizma u samom medijskom sadržaju i kritizira se prenošenje etičkog relativizma na korisnike medija, a nedovoljno pažnje posvećuju etičkom relativizmu u samom postupanju medija i njihovom odnosu prema etičkim vrednotama $\mathrm{u}$ profesionalnom novinarskom djelovanju.

\subsection{Opće dobro}

Općenito gledano, jasno je da je svakom etičkom promišljanju opće dobro jedna od temeljnih odrednica i vrednota. Isto to vrijedi i za etiku u medijima, jer mediji i jesu osnovani i danas se pokreću da bi služili općem dobru. U tom su kontekstu vrlo važna prava publike pravo na informaciju i s njim ostala povezana prava koja se ističu i u novinarskim deontološkim kodeksima. Malović, Franjo Maletić, Vilović i Kurtić (2014: 235), oslanjajući se na riječi Ricchiardi, navode osnovna načela kojima teže profesionalni komunikatori, zaključuju da se njima služi javnosti, a služenje javnosti je zapravo služenje općem dobru cjelokupne javnosti.

I crkveni dokumenti često koriste pojam općeg dobra u kontekstu medijske etike. Tako dokument Etika u obavijesnim sredstvima u broju 22. ističe da se dobro osobe ne smije ostvarivati neovisno od općeg dobra zajednica kojima osobe pripadaju, te da se medijski djelatnici moraju staviti u službu stvarnih potreba i interesa kako pojedinaca tako i skupina na svim razinama. U poruci za Svjetski dan sredstava društvenog priopćavanja 1994. godine, govoreći o televiziji, papa Ivan Pavao II. piše da su televizijske mreže javno odgovorne u 
službi općeg dobra, te da trebaju služiti dobrobiti cijeloga društva. Isto tako, dokument Etika na internetu u broju 3. piše da opće dobro kao skup uvjeta društvenog života koji grupama i pojedincima omogućuju da potpunije i lakše dođu do vlastitog savršenstva pruža drugo korisno načelo za etičko vrednovanje obavijesnih sredstava, a ono bi se moglo cjelovito razumjeti kao skup ciljeva za koje se pripadnici neke zajednice zajednički zauzimaju i radi čijeg ostvarivanja i podupiranja zajednica i postoji. U poruci za Svjetski dan sredstava društvenog priopćavanja 2005. godine u broju 5. papa ističe da medijski djelatnici moraju u vlastitome životu prije svega oživotvoriti one vrijednosti i stavove kojima su pozvani poučiti druge, a to od njih iziskuje ulaganje istinskih napora za opće dobro.

Zaključno, možemo primijetiti da i općenita medijska etika i teološka medijska etika izuzetno visoko vrednuju pojam općega dobra, a teološka uz njega veže i pojam „zajednice“. Opće dobro očituje se u pravu cjelokupne javnosti na istinito i objektivno, točno $\mathrm{i}$ transparentno informiranje i pristup informacijama, stoga medijska etika i kad ne koristi izričito ovaj pojam, ipak često kroz neke druge termine progovara o temi općeg dobra.

\subsection{Sloboda i odgovornost u medijima}

Pojmovi odgovornosti i slobode često se pojavljuju u medijskoj etici, i to gotovo u međuodnosu - kao da je riječ o dva lica iste medalje - pa ih stoga i obrađujemo na taj način. Kao što navode Čehok i Koprek (2006: 81-83), najpoznatija etika odgovornosti u filozofskoj misli 20. stoljeća izložena je u djelu njemačkog filozofa i teologa Hansa Jonasa Princip odgovornosti. Ona je svojevrstan zaokret u etičkom promišljanju, budući da je počela naglasak stavljati na međudjelovanje ljudi, strogo je antropocentrična, te promatra djelovanje u neposrednome vremenskom i prostornom okruženju u kojem se događa. Promatrajući pojam odgovornosti kao jedan od središnjih pojmova novovjekovne etike, ipak treba naglasiti da ga je tek Weber iskoristio kao naziv za posebno, novo etičko stajalište. Važno je naglasiti i govor o odgovornosti Dietricha Bonhoeffera, Roberta Spaemanna i Apela, kao i da je odgovornost postala jedan od temeljnih pojmova mnogih etičkih kodeksa u medijima, o čemu vrlo iscrpno piše Bertrand (2007).

Spomenuti autori, a među njima i Čehok i Koprek (2006: 100) ističu da se uz odgovornost vezuje i sloboda, no da sloboda nipošto ne znači samovolju, nego upravo odgovornost. Apel (1980: 484) piše o zadatku preuzimanja odgovornosti za djelovanja na 
općoj razini, zbog čega bi trebalo postojati intersubjektivno važenje normi ili barem temeljni principi etike odgovornosti. Apel (1990: 127-128) govori o jednakosti suodgovornosti, te pretpostavlja suodgovornost svih za rješenje problema, a tu je osnovna ideja suodgovornosti, koja je neophodna u vrijeme postkonvencionalne etike.

Jacquette (2007: 15) ističe veliku etičku odgovornost novinara prema njihovim čitateljima, te podsjeća da je ta odgovornost u zavisnom odnosu s pravima (2007: 17): kad novinari koriste svoja profesionalna prava oni zauzvrat imaju profesionalne odgovornosti. Isti autor (Jacquette, 2007: 80) piše da u određenim okolnostima novinar upravo zbog odgovornosti neku priču može ne objaviti, a kada govori o slobodi (Jacquette, 2007: 144) smatra da apsolutne slobode medija nema, kao što je slučaj i u drugim područjima čovjekovog djelovanja. Labaš (2009: 37) ističe da slobodan i odgovoran čovjek ne postaje robom, već sustvarateljem medijskoga prostora, što je osobito važno danas u doba digitalnih medija (Elliott, Spence, 2018).

Day (2007: 183-184) naglašava povezanost slobodnog društva i slobodnog novinarstva, koji ne mogu postojati jedno bez drugog. Day (2014: 48-49) tako posebno spominje slobodu izbora, jer bez slobode niti ne možemo etički vrednovati čovjekove postupke. Isti autor (Day, 2014: 49) piše da etički sustav nije pladanj s kojeg se mogu birati moralne poslastice, već da društvo nameće određene odgovornosti svojim članovima kao uvjet članstva, pa tako i za pripadanje određenim profesionalnim skupinama, među njima i novinarstvu. Govoreći o slobodi i odgovornosti u kontekstu govora mržnje, Day (2014: 240) ističe da pravi protuotrov za govor mržnje nije gušenje govora, već mnogo više govora. Tražeći „mjeru“, Day (2014: 374) kaže da bi etika apsolutne čednosti odbila publiku, a s druge strane da bi apsolutna sloboda vodila kaosu, te da niti jedan (pa tako niti ovaj) ekstrem nije dobar, već treba tražiti srednji put.

Malović, Ricchiardi i Vilović (2007: 37-38) ističu da je sloboda preduvjet bez kojeg se medijska etika teško može ostvariti, to jest da se zapravo ne može ostvariti, te da se bez slobode ne mogu razviti niti ostala načela medijske profesije. Malović (2007: 48) govori o odgovornosti upravo u kontekstu slobode, te ističe da novinar nema neograničenu slobodu, već ima i odgovornost za objavljenu riječ. On smatra da sloboda medija (Malović, 2004: 59) ima visoku cijenu i da mnogi novinari tu slobodu skupo plaćaju. Koliko je odgovornost važan faktor medijske etike pokazuje i tvrdnja Poler Kovačić (1998: 31) koja cijelu medijsku etiku 
smatra etikom (osobne) odgovornosti, te je prema tome temeljno pitanje medijske etike kome ili čemu je medijski djelatnik u svom radu odgovoran.

Brajnović (2011: 117-118) je upozorio i na drugu stranu medalje, tj. da se sloboda medija zna pretvoriti u zloupotrebu slobode. Za novinarsku slobodu Čupić (2010: 14) piše da je preduvjet za ostale novinarske profesionalne standarde. $\mathrm{Za}$ tu istu novinarsku slobodu Gavranović (2009: 26) kaže da je pod ozbiljnim pritiskom iz raznih izvora. Sapunar (2002: 123) za slobodu izražavanja kaže da je proizašla iz osnovnih sloboda, te predstavlja temeljnu civilizacijsku tekovinu i neupitnu vrijednost, dok Letica (2003: 40) smatra da otvoreno, građansko društvo ne može postojati bez slobodnih medija.

Ono što je zanimljivo, s druge strane, činjenica je da prvi crkveni dokument o medijima Mirari vos iz 1832. godine u potpunosti odbacuje bilo kakav oblik slobode u medijima, to jest prvo osuđuje slobodu mišljenja (br. 14), a zatim i slobodu objavljivanja (br. 15). No, suvremeni dokument Drugog vatikanskog koncila Inter mirifica iz 1962. godine kaže da vlast ima obvezu osiguravati istinsku i pravednu slobodu u medijima, što je potpuni zaokret u odnosu na dokument Mirari vos. Ipak, ističe i nužnost zakonske regulative od strane vlasti, kako bi djelovanje medija bilo etično. O istoj temi (odnosu vlasti prema slobodi) govori i dokument Etika u obavijesnim sredstvima iz 2000. god. koji ističe da se treba zauzimati za slobodu izražavanja, ali podsjeća na područja na kojima ipak „ne postoji pravo na priopćavanje, primjerice klevete i ogovaranje, poruke koje nastoje promicati mržnju i sukob među pojedincima, skupinama, besramnost i pornografiju, te bolesno opisivanje nasilja“ (br. 23). I dokument Etika na internetu (2002.) snažno podupire slobodu izražavanja i slobodnu razmjenu ideja na internetu, te se suprotstavlja pokušajima nekih javnih vlasti (autoritarnih režima) da tu slobodu onemoguće (br. 12).

Nešto ranije, i papa Pavao VI. u poruci za Svjetski dan sredstava društvenog priopćavanja iz 1967. godine piše da što je veća snaga medija, mora biti veća i briga i odgovornost medijskih djelatnika. U poruci za isti dan iduće godine (1968.) papa sve poziva na „ozbiljnu odgovornost koje se stavlja pred sve nas pojedinačno, ali i zajedno“. U poruci za 1975. godinu Pavao VI. podsjeća da sloboda koja se traži za masovne medije ne oslobađa obveze vjernosti moralnim načelima. U poruci za 1981. godinu u broju 3, papa Ivan Pavao II. povezuje slobodu i odgovornost, tj. poziva na „odgovornu slobodu komunikatora“ koji imaju moć odabira što će komunicirati, a ističe se da i korisnici medija trebaju imati to dvoje: slobodu i odgovornost. To nastavlja i u broju 4. gdje piše o opasnosti od izostanka odgovorne 
slobode onih koji koriste medije. U poruci za Svjetski dan sredstava društvenog priopćavanja 1986. godine, u brojevima 2. i 5. naglašava se velika odgovornost onih koji utječu na javno mnijenje. U poruci iz 1991. godine ističe se potreba da mediji služe obogaćenju ljudske naravi, kao i da je nužna moralna vizija i etička odgovornost onih koji su uključeni u proces komunikacija. U poruci iz 1995. godine Ivan Pavao II. ponovno poziva na odgovornost i one koji stvaraju program, ali i one koji ga koriste. U poruci za Svjetski dan sredstava društvenog priopćavanja iz 2003. godine isti papa piše da su mediji u službi slobode tek kada su u službi istine.

Zaključno se dakle može reći da i opća medijska etika i teološka medijska etika donose govor o slobodi i odgovornosti, te da ih visoko vrednuju i cijene. I jedna i druga značajno povezuju ta dva pojma u skladan međuodnos koji ukazuje na činjenicu da sloboda ne može bez odgovornosti, niti odgovornost može bez slobode. Iako nema značajnije razlike, stariji su crkveni dokumenti iznosili negativan stav o slobodi, a kasnije se ipak čini da je u tom spoju u crkvenim dokumentima veći naglasak stavljen na odgovornost, dok je $\mathrm{u}$ medijskoj etici veći naglasak na slobodi i njezinoj povezanosti s odgovornošću.

\subsection{Istina kao temelj medijske etike}

Istina je još jedan od temeljnih postulata, normi i načela novinarske i medijske etike. Labaš (2006: 14) smatra da je komuniciranje istine najvažnija dužnost medija, te moraju iznijeti istinu bez služenja vlasnicima medija i ekonomskim interesima. S druge strane, Gianni Vattimo (2008: 201) ističe da se u svijetu masovnih medija ostvaruje jedno Nietzscheovo proročanstvo: istinski je svijet na posljetku postao bajkom, pa se umjesto načela istinitosti u novinarstvu sve češće spominju objektivnost i poštenje, o čemu piše i Malović sa suradnicama (Malović, Ricchiardi, Vilović, 2007: 33).

Zapravo i Lee, novinarska fotografkinja u New York Timesu, kaže da nije moguće doći do čisto objektivnog shvaćanja bilo čega, jer stvarnost je uvijek u očima promatrača. Smatra da više novinara može poći od istog skupa činjenica, a napisati sasvim različite priče (Knowlton, Parsons, 1997: 108). Jacquette (2007: 326) smatra da novinarstvo ne mora imati odgovore na sve zamislive i nezamislive kritike pojma apsolutne istine.

No, istina se doista od samih početka medijske etike smatra njezinim temeljnim postulatom, tako da već 1801. godine Wortmann u djelu Rasprava o politici i slobodi tiska 
kaže da je kobno svako odstupanje od istine, te da nepristranost treba biti postojana odlika tiska (Wortman, 1801, prema Knowlton, Parson, 1995: 64).

Malović, Ricchiardi i Vilović (2007: 33) smatraju da je prva i najčešća žrtva medijskog djelovanja etika, a krajnja žrtva istina. Isti autori (Malović, Ricchiardi, Vilović, 2007: 50) ističu da je poštovanje istine najvažnija profesionalna obveza novinara i ona je neizostavno načelo koje se spominje u preambulama ili pak u člancima etičkih kodeksa. Jacquette (2007: 44) piše da je moralna obveza novinara govoriti istinu u svojim izvještajima, te izbjegavati neistine i predrasude, a ako otkrije pogreške u svom izvještavanju, javno ih ispraviti i otkloniti negativne posljedice svog neistinitog izvještavanja.

Prema Dayu (2004: 106-109) postoje u najmanju ruku tri koncepta koji leže u osnovi pojma istine u izvještavaju. Prvi i najočigledniji koncept kaže da izvještavanje mora biti točno, drugi je da priča mora davati i kontekst iznesenih informacija, a treći kriterij istinitog članka jest taj da on mora biti pošten, objektivan i uravnotežen.

Istinu, kao temelj medijske etike, ističu i gotovo svi kodeksi novinarstva, a među njima i oni Hrvatskog novinarskog društva, Međunarodne federacije novinara, Društva profesionalnih američkih novinara, Britanskog udruženja novinara i drugi.

Labaš (2006: 54) se pita služe li mediji samo svojim prijateljima i vlasnicima, oglašivačima, interesnim krugovima i istomišljenicima, ne mareći za istinu, no dodaje (2006: 55) da mediji zapravo vole istinu, ili se barem takvima vole prikazati. Isti autor (Labaš, 2006: 58) ukazuje na poteškoće i ograničenosti koje nastaju u novinarskom traganju za istinom, kao što su brzina i velika ograničenost vremena, koja može zasjeniti ozbiljnost i temeljitost istraživanja.

Prema teološkoj medijskoj etici, bitna uloga novinara je biti tražitelj istine, što je danas u medijima često zapostavljeno (Vrhovski Peran, 2010: 137). Već Inter mirifica (1962.) u broju 5. piše da novinarsko izvještavanje mora biti uvijek istinito i cjelovito, ali naglašava i da treba biti moralno ispravno i prikladno, tj. poštivati dostojanstvo čovjeka. I Communio et progressio (1971.) u broju 17. navodi da izvještaj mora biti prije svega nepatvoren, pošten i istinit, te da nije dovoljna dobronamjernost i ispravna nakana, već da novinar i medij mora po istini iznositi samu stvarnost.

Papa Pavao VI. u poruci za Svjetski dan sredstava društvenog priopćavanja 1972. godine piše o odnosu medija $\mathrm{i}$ istine, naglašavajući da medijima nije uvijek lako shvatiti istinu 
o nekoj činjenici u cijelosti, ali istovremeno piše da to nije nemoguće. U istoj poruci ističe da dužnost novinara ipak nije samo donijeti istinite podatke, već i kontekst, kao i tražiti uzroke događaja ili fenomena o kojemu piše.

U poruci za Svjetski dan sredstava društvenog priopćavanja 1978. godine Ivan Pavao II. piše da je jedno od temeljnih ljudskih prava svake osobe da joj bude priopćena istina. Smatra da ta potreba za istinom ima izravan utjecaj na medije, budući da od medija ljudi imaju pravo očekivati istinite izvještaje. U poruci za Svjetski dan sredstava društvenog priopćavanja 2001. godine papa Ivan Pavao II. piše da je zadaća Crkve pomoći da se po medijima istina proširi do sve većeg broja osoba. U poruci za isti dan 2003. godine isti papa piše da su temeljni moralni zahtjevi svakog priopćivanja poštivanje istine i služenje istini. U istoj poruci primjećuje i dvojakost medija u odnosu na istinu, tj. često hrabro služe istini, ali katkada djeluju i kao sredstva propagande i dezinformacije, u službi ograničenih interesa, predrasuda i pohlepe za materijalnim.

Konačno, što se istine u medijima kao načela njihovoga djelovanja tiče, i medijska etika, kao i crkveni dokumenti, jako velik naglasak stavljaju upravo na nju, te se može kazati da je i jedni i drugi promatraju kao temelj medijske etike, bez nekih značajnijih razlika.

\subsection{Načela poštenja i objektivnosti u medijskoj etici}

Kao jedno od načela medijske etike Malović (2005: 25-26) ističe poštenje, napose u izboru onoga što će novinar objaviti ili zanemariti. Istovremeno, tvrdi da zahtjev poštenja nije nimalo lagan te da novinari često upadaju u zamke. Jednako tako, podsjeća i na promjenu koja se dogodila kroz posljednjih nekoliko desetljeća, tj. da se prije naglašavalo da izvještavanje mora biti „objektivno“, dok se danas naglašava da mora biti „pošteno“. Premda je riječ o sada već starijem izvoru, vrijedi spomenuti da The Washington Post donosi i taksativnu definiciju novinarskog poštenja koju prenosi Malović (2005: 27-28), a prema njoj izvještaj mora biti cjelovit (donijeti sve važne podatke), relevantan (ne smije donositi nevažne informacije na štetu važnih), iskren prema čitatelju (ne smije navoditi na pogrešan zaključak), ali i jasnoću izraza umjesto fraziranja. Malović (2005: 29) govori i o novinarskoj povezanosti sa strukturama, koja se zatim očituje u pristranosti, favoriziranju, nekritičkom izvještavanju i sličnim moralno i profesionalno neprihvatljivim oblicima pisanja. Također, novinarsko poštenje se narušava i novinarevom povezanošću sa sponzorima koji znaju biti velikodušni u 
svojim „darovima“. Govoreći o nepristranosti, što možemo poistovjetiti s objektivnošću, Malović (2005: 42) ističe da je riječ o važnom i jednom od osnovnih preduvjeta suvremenog novinarstva, tj. da izvještaj mora prikazati upravo onako kako se nešto dogodilo, te da novinar treba isključiti sve svoje osobne sklonosti. Dakako, to se ne odnosi na komentare i kolumne. Ipak, istom autoru je jasno da to nije jednostavno primijeniti u stvarnosti, te se pita jesu li novinari nepristrani i mogu li to uopće biti. Malović (2005: 16-17) navodi i da se objektivnost često doživljava drugačije, ovisno o onome tko gleda. Tako, na primjer, čak i autoritarni sustavi deklarativno potiču novinare na objektivnost, ali samo dok je ta ,objektivnost" $\mathrm{u}$ njihovu korist. A kada novinar objektivno izvještava o onome što ta vlast loše radi, tada može zaboraviti na objektivnost budući da vlast kroz mehanizme kroćenja medija uspostavlja svoju „objektivnost“. A potrebno je naglasiti i da kriterije objektivnosti nije uvijek posve jednostavno definirati, te je zato suvremeno novinarstvo sve više sklono kao načelo izvještavanja prihvatiti pojam poštenja umjesto objektivnosti.

Parafrazirajući Bennet, Malović (2007: 24) kaže da ideja o poštenju izaziva simpatije prema novinarima koji se trude na najbolji mogući način kako bi točno izvještavali u vrlo teškim okolnostima, te da izvješćivanje nije lagan posao, a poštenje više ukazuje na dobre namjere novinara negoli objektivnost, koju je teško, možda čak i nemoguće, postići.

Bauer (1997: 57) primjećuje da objektivnost može postojati samo u idealističkim zamislima iz snova, no istovremeno piše da iako subjektivnost ne može biti totalno potisnuta, ona ne smije postati jeftina isprika za manipulacije. Fink (1995: 32) smatra da je istinsku objektivnost nemoguće postići, budući da je svaki pojedinac „ukorijenjen“ u svoju kulturnu pozadinu i iskustvo koji nužno utječu na to kako vidi stvari i događaje kao novinar.

S teološke i crkvene pak strane, poštenje i objektivnost papa Pavao VI. u poruci za Svjetski dan sredstava društvenog priopćavanja 1975. godine povezuje s odgovornošću, pišući da objektivnost u odabiru i prezentaciji činjenica u medijima zahtijeva dobro razvijen osjećaj odgovornosti, adekvatnu obuku i istinsku profesionalnu kompetenciju. Papa Franjo u poruci za Svjetski dan sredstava društvenog priopćavanja 2014. godine piše da je nepristranost, to jest objektivnost medija samo prividna, te taj fenomen ne promatra kao nešto loše, dodajući da jedino onaj koji u komunikaciju uključuje samoga sebe može predstavljati istinsku referentnu točku objektivnosti i poštenja i za druge.

I općenita razmišljanja o načelima medijske etike i crkveni dokumenti koji iznose teološki etički stav govore o objektivnosti, no čini se kako su oba pojma i načela - i 
objektivnost i poštenje - češća tema opće medijske etike, koja na neki način uvodi i ustrajava na pojmu „poštenja“, zapravo smatra da objektivnost u realnim okolnostima nije moguće postići, te se stoga suvremena medijska etika više usmjerava na pojam poštenja, koje se čini lakše dostižnim. Crkveni dokumenti ne ističu toliko pojam poštenja u kontekstu objektivnosti, no također ističu da je potpunu objektivnost nemoguće postići, a papa Franjo navodi da je za potpunu objektivnost nužna uključenost i samog novinara u cijeli proces, što je zbog brzine posla gotovo nemoguće ostvariti.

\subsection{Medijska etika i javno mnijenje}

Govoreći o odnosu onog što mediji objavljuju (objavljenog mnijenja masovnih medija) i javnog mnijenja, Bauer (1997: 103) ističe da su to najčešće različite stvarnosti, navodeći i konkretne primjerene. Krunoslav Nikodem i Jerko Valković (2012: 812) također pišu da građani medije ne doživljavaju kao svoje sugovornike, ne osjećaju da su mediji tu zbog njih i da nisu dio javnog mnijenja, nego interesnih skupina. Samim time, medije se ne doživljava kao ogledalo društva, kao one koji prikazuju pravo stanje društvenih tijekova i procesa, nego više kao one koji stvaraju novu stvarnost, umjesto da prikazuju stvarnost kakva ona jest. Isti autori (Nikodem i Valković, 2012: 785) donose dvije različite teorije koje zapravo oslikavaju dva različita pogleda na odnos medijski objavljenog mnijenja i javnog mnijenja. Dok pluralističke teorije polaze od hipoteze da medijski sadržaji samo odražavaju društvo i time ne mogu imati veći utjecaj na društvene promjene i procese, marksističke teorije naglašavaju ulogu medija čija zadaća bi trebala biti suprotstaviti se nepravednim odnosima kapitalističkog sustava. Iz toga proizlaze i dva pogleda na ulogu medija: bilo onih koji samo prenose javno mnijenje ili onih koji ga zapravo stvaraju.

S teološkoga pak stajališta, papa Ivan Pavao II. u svojoj poruci u povodu Svjetskog dana sredstava društvenog priopćavanja 1986. godine u broju 2. piše da javno mnijenje ima veliki utjecaj na način razmišljanja, osjećaje i ponašanje onih koji su nedovoljno sposobni za stvaranje kritične prosudbe. Isto tako, ističe i utjecaj javnog mnijenja na formiranje zakona, te u tom kontekstu kao negativan primjer sa stajališta moralnoga nauka Katoličke Crkve navodi legalizaciju pobačaja u nekim zemljama na temelju pritiska javnog mnijenja. Peran i Mataušić (2013: 235) ističu obvezu Crkve, koju si je sama postavila svojim dokumentima, da sudjeluje u stvaranju javnoga mnijenja u društvu, kao i na važnost odgoja vjernika laika kako bi bili u 
stanju zastupati kršćanska načela u društvenom dijalogu. Communio et progressio od br. 24. do br. 32. progovara o javnom mnijenju, pišući da iz činjenice da svatko želi drugome priopćiti svoje poglede, mišljenja i osjećaje, te tako mišljenje i običaji mnogih postaju zajednički, nastaje ,javno mnijenje“ (br. 24). Isti dokument, u br. 25. ističe da „sloboda izražavanja vlastitog mišljenja jest neophodna osobina i sastavni dio u stvaranju javnog mnijenja“. Communio et progressio u br. 31 naglašava se ne smije svako mišljenje, pa i onda kada je veoma rašireno, smatrati javnim mnijenjem, jer općeprihvaćeno mišljenje ne mora samim time nužno biti najbliže istini. Dokument u istom broju piše i da može bit razložno suprotstaviti se takvom mnijenju.

Iako i suvremena medijska etika i teološka medijska etika govore o javnom mnijenju, one ga u određenoj mjeri i različito vrednuju. Naime, suvremena medijska etika javno mnijenje često promatra u odnosu prema objavljenom mnijenju (onom što mediji objave), te kao etički ispravno gleda podudaranje tih dvaju mnijenja, a etički neispravnim smatraju kada to nije slučaj. Teološki govor o toj temi na određeni način to prihvaća, ali i nadograđuje drugačijim pogledom na javno mnijenje koje, prema crkvenim dokumentima, ne mora biti nešto ispravno. Stoga se u crkvenim dokumentima i spominje da postoji i crkveno javno mnijenje, koje se pojmovno razlikuje od javnoga mnijenja, vjerojatno zato što sama Crkva kao ustanova - ima hijerarhijski, a ne demokratski ustroj. Kao primjer može se navesti gore navedeni tekst Ivana Pavla II. o javnom mnijenju u primjeru pobačaja. Dakle, Crkva polazi od toga da postoje određene vrednote, a ako je javno mnijenje suprotno tim vrednotama, tada je i javno mnijenje nešto što se ne može promatrati kao etički vrijedno samo po sebi, nego dapače u tim slučajevima čak i kao nešto moralno neprihvatljivo.

\subsection{Ljubav kao načelo medijske etike}

Premda bi se moglo zaključiti da medijska etika pojam ljubavi ne spominje, što nije iznenađujuće i budući da nije riječ o pojmu koji bi se u jednom takvom području očekivao, pojam i načelo ljubavi prema istini duboko je ukorijenjeno u novinarsko i medijsko djelovanje. A ta ljubav prema istini onda - barem implicite - uključuje i ljubav prema drugome, to jest krajnjim korisnicima medijskih sadržaja, to jest publici. Na kraju krajeva, cilj je svake komunikacije nešto s nekim podijeliti - i to dijeljenje ne staje samo na etimološkom 
objašnjenju samoga pojma komunikacije (comunis facere), nego ide u samu ontološku bit komunikacijskoga procesa koja dovodi do zajedništva (communio).

S teološkoga aspekta upravo se ističe ovakvo tumačenje same komunikacije koja dovodi do zajedništva i napretka (kako je i naslovljen pastoralni naputak iz 1971. Communio et progressio), pa se pojam ljubavi $\mathrm{u}$ dokumentu Inter mirifica Drugog vatikanskog koncila dovodi u vezu s pravom na informaciju, uz naznaku da proces prenošenja informacija mora biti „bez povrede pravde i ljubavi“ (br. 5). I dokument Etika u obavijesnim sredstvima iz 2000. godine u broju 5. ističe da kršćanski izvjestitelj ima zadaću podupirati istinu utemeljenu, između ostalog, „na ljubavi prema vlastitim neprijateljima“ (br. 31), a u dokumentu Etika u promidžbi potiče se na korištenje promidžbe koje ima u sebi „ljubav prema potrebitima“ (br. 8). U poruci za Svjetski dan sredstava društvenog priopćavanja 1971. govori se o golemim mogućnostima medija u prevladavanju prepreka među ljudima „u duhu razumijevanja i ljubavi“. U poruci za isti dan 1975. godine ističe se da bi mediji trebali biti „,nositelji zajedništva, obvezujući sve kršćane zajedno u ostvarenju čvrste i vidljive ljubavi“, dok se iduće godine (1976.) u poruci za Svjetski dan sredstava društvenog priopćavanja piše da bi djelatnici masovnih medija trebali staviti ljubav i služenje ljudima ispred želje za popularnošću i ispred ekonomske dobiti. U poruci iz 1981., u broju 3, papa Ivan Pavao II. podsjeća komunikatore da njihov poziv od njih traži ljubav, naglašavajući da u njihovom izvještavanju ljubav nikad ne smije biti zaboravljena. Isti papa u poruci za Svjetski dan sredstava društvenog priopćavanja 1985. godine ističe da komunikacija uvijek „mora u svom sadržaju odgovarati istini, i uz poštovanje prema pravdi i ljubavi koje bi trebalo to upotpuniti““ (br. 2). U poruci 1991. godine poglavar Katoličke Crkve navodi da mediji moraju biti „,sredstvo i izraz istine, pravde i mira, dobre volje i aktivne ljubavi“, a u onoj iz 1998. godine potiče medijske djelatnike da svojim djelovanjem stvaraju ljudsko zajedništvo utemeljeno na djelatnoj ljubavi. U poruci iz 2003. godine papa Ivan Pavao II. piše da su medijski djelatnici, po svom pozivu pozvani ,zastupati istinu, pravdu, slobodu i ljubav, pridonoseći svojim tako važnim radom društvenom poretku koji je 'položen na istini, sazdan prema zahtjevima pravde, gajen i ispunjen ljubavlju, a konačno ostvaren u znamenu slobode"،

Pojam „ljubav“ kao vrednota koja bi trebala postojati u medijima i koja bi trebala voditi etično djelovanje osoba koje djeluju u medijima, implicitna je i eksplicitna tema kako suvremene medijske etike, tako i one teološke, s time da je zaista često prisutna u crkvenim dokumentima. Riječ je o pojmu i načelu kojeg nije jednostavno definirati kao istinu, 
objektivnost, poštenje i druge, te se stoga logičnim nameće da se u suvremenim pravcima medijske etike ne spominje eksplicitno, što ne znači da je se kao takvu ne vrednuje i ne promiče. No, u crkvenim dokumentima ona dolazi jače i eksplicitno do izražaja, služeći kao svojevrsna nit vodilja kroz druge vrednote koje bi trebale odlikovati medijskog djelatnika koji želi u svom radu postupati etično i raditi na sebi kako bi to svakodnevno iznova postizao jedan od temeljnih ciljeva svake komunikacije, a to je zajedničko dijeljenje informacija shvaćenih kao vrednota.

\subsection{Mir i dijalog kao načelo medijske etike}

Mir je jedna od temeljnih tema suvremene novinarske i medijske etike i u središtu je mnogih istraživanja i promišljanja. Ponekad i ex negativo, kada se o piše o izvještavanju u ratu kao Kunczik i Zipfel (2006: 258-271), ali i Labaš i Marija Barčot (2013: 177-204) kada pišu o etičkim izazovima medijskog izvještavanja o ratu na primjeru Vukovara 1991. godine. O odgovornosti novinara u ratu, na primjeru izvještavanja talijanskog tiska o padu Vukovara piše Labaš (2007: 99-108). O etičkim izazovima rata i medija na kraju XX. stoljeća piše i Branko Klun (2000: 75-87). Svi navedeni tekstovi pišući o odnosu medija i rata ističu obvezu novinara i medija da promiču mir. Poticanje na rat i sukobljavanje zabranjeno je u cijelom nizu novinarskih kodeksa časti. Tako Finsko novinarsko udruženje ističe da profesionalna novinarska etika obuhvaća poštovanje temeljnih ljudskih vrijednosti poput prava čovjeka, demokracije, mira i međunarodnog razumijevanja (prema Malović, Ricchiardi, Vilović, 2007: 227). Bauer (2007: 64) ističe da u medijskoj etici etičke vrijednosti same od sebe provociraju pitanje o njihovu komuniciranju, a kao primjer navodi i mir (kao i slobodu, toleranciju, prihvatljivost, empatiju, itd). Kunczik i Zipfel (2006: 109) donose deset profesionalnih novinarskih načela Martina Lofflera (1961.), a među njima je i mir tj. ,zauzimanje za mir i razumijevanje među narodima“, a na njihovom su tragu i mnoge konkretne odredbe novinarskih kodeksa časti u svijetu, pa tako i Kodeksa časti hrvatskih novinara (2009.).

Teološki pristup pitanju mira istaknuo je među ostalima i papa Pavao VI. u svojoj poruci za Svjetski dan sredstava društvenog priopćavanja 1971. godine, premda je papa Ivan XXIII. prije njega 1963. godine miru na zemlji posvetio cijelu encikliku Pacem in terris. U svojoj poruci Pavao VI. potiče medijske djelatnike, ali i korisnike medija da odbace sve što narušava istinski dijalog među ljudima, bez obzira na ono što se skriva pod krinkom ljudskih prava, bez obzira na podupiratelje nesporazuma i mržnje, te na sve ono što odvlači od mira i 
od bratstva. U poruci za isti dan 1983. godine papa Ivan Pavao II. se pita na koji način sredstva društvene komunikacije, to jest mediji mogu promicati mir, te daje mnogobrojna rješenja, od ispravnog određenja komunikacije do isticanja drugih vrednota, naglašavajući da neetična komunikacija dovodi i do ugrožavanja mira (br. 2). U istoj poruci Ivan Pavao II. ističe i da medijski djelatnici u obavljanju svoje zadaće trebaju dati sve od sebe za promicanje mirne i nepristrane informacije, u korist razumijevanja i dijaloga, jačanja razumijevanja $\mathrm{i}$ solidarnosti, te da je to veliki doprinos uspostavi mira (br. 4). U poruci 1987. godine isti papa obrađuje temu društvenih komunikacija u službi pravde i mira, te piše da ,kvalitetna informacija o javnom mnijenju ima izravan utjecaj na promicanje pravde i mira“, a obraća se medijskim djelatnicima apelirajući na njihovu savjest da rade svoj posao „u službi pravde i mira“, te u istoj poruci ističe i da mir nije moguć bez dijaloga. U poruci iz 1994. godine Ivan Pavao II., govoreći o televiziji piše da ona može ranjavati obiteljski život, te među ostalim načinima kako to može činiti navodi i veličanje pogrešnih poimanja života koja priječe uzajamno poštovanje, pravednost i mir.

U poruci za Svjetski dan sredstava društvenog priopćavanja 2002. godine, Ivan Pavao II. piše o internetu i pita se može li internet, to oruđe koje je prvotno korišteno u vojne svrhe, sada služiti miru i promicati kulturu dijaloga, sudjelovanja, solidarnosti i pomirenja bez kojeg se mir ne može razvijati? Papa odgovara da Crkva vjeruje da internet to može. U poruci za 2005. godinu ističe da „mediji imaju ogromne mogućnosti za promicanje mira i izgrađivanje mostova dijaloga među narodima, prekidajući, danas tako prisutan, začarani krug nasilja, odmazde i novoga nasilja“ (br. 2). U poruci iduće 2006. godine papa poziva medije da budu protagonisti istine i promicatelji mira koji iz nje proizlazi. Papa Franjo u poruci iz 2016. godine potiče medijske djelatnike da se trude u svom radu izbjegavati nerazumijevanja, ozdraviti ranjeno sjećanje te graditi mir i sklad.

Tema mira ne samo da je prisutna i u crkvenim dokumentima i u medijskoj etici, nego ju se promatra kao vrednotu koju mediji trebaju promicati i provoditi u djelo u svom radu. To često isticanje mira može pomoći medijskoj etici - u teoriji i praksi - da dodatno shvati važnost mira, te da se medijske djelatnike i dalje potiče da budu nedvosmisleni i odvažni promicatelji mira koji je suvremenom svijetu itekako potreban kao vrednota na kojoj se temelji suživot različitih ljudi, društava i kultura. Pri tome je važno reći da se u novinarskim kodeksima časti po cijelome svijetu zabranjuje ratna propaganda ili bilo kakav huškački govor u medijima. 


\subsection{Moć medija i medijska etika}

Jacquette (2007: 30-31) pomoću slikovitih primjera pokazuje snažnu moć medija u odnosu na običnog pojedinca, podsjećajući kakav učinak ima ako netko nešto kaže svom prijatelju, a kakav je učinak kad to isto novinar prenese u nekom utjecajnom mediju. Malović (2007: 10) piše da su mediji vrlo često nazvani sedmom silom zbog njihove društvene snage, ističući da ipak ne bi smjeli biti „sila“. Ističe također da mediji ne bi smjeli biti niti sluge vlastodržaca. Podsjeća i da se medije nekada naziva četvrtom vlašću (uz zakonodavnu, izvršnu i sudsku vlast). Labaš i Petra Marinčić (2018: 1) pišu da mediji informiraju, odgajaju, obrazuju i zabavljaju, ali i manipuliraju, oblikuju mišljenja i nameću određene dnevne teme. Isti autori (Labaš, Marinčić: 2018: 3) pišu i da masovni mediji neosporno utječu na pojedinca i njegova razmišljanja, ideje i stavove. Malović (2004: 132) ističe i da mediji i novinari često nisu svjesni moći koju imaju, što je posebno štetno u trenutku kada objave neku poluistinu ili dezinformaciju.

O dezinformacijama, odnosno o „fake news“ piše i papa Franjo u poruci za Svjetski dan sredstava društvenog priopćavanja 2018. godine koja je na hrvatski jezik prevedena pod naslovom „Istina će vas osloboditi (Iv 8, 32). Fake news i novinarstvo mira“, gdje piše da se učinkovitost lažnih vijesti prvenstveno ogleda u njihovoj sposobnosti oponašanja stvarnih vijesti, te da su zavodljive u smislu da su kadre privući pažnju onih kojima su namijenjene, pribjegavajući stereotipima i predrasudama.

Dokument Drugog vatikanskog koncila Inter mirifica u broju 11. ističe snažnu moć medija, jer piše da medijski djelatnici imaju moć svojim djelovanjem povesti ljudski rod na pravi put ili u propast, što pokazuje da ovaj dokument medijima i medijskim djelatnicima pripisuje veliku moć. Navedeni dokument medije naziva moćnim sredstvima, a isto čini i dokument Brzi razvoj u kojem papa Ivan Pavao II. (bio je to zadnji dokument kojega je uopće objavio u svome pontifikatu) zahvaljuje Bogu zbog postojanja ,tih moćnih sredstava koja, ako ih vjernici koriste u duhu vjere i poučljivosti svjetlu Duha Svetoga, mogu pridonijeti lakšem širenju Evanđelja i stvaranju učinkovitijih spona zajedništva među crkvenim zajednicama“ (br. 6). Poruka Ivana Pavla II. za Svjetski dan sredstava društvenog priopćavanja 1983. godine također ističe moć medija koja ima snagu koja se može koristiti i u dobre i u loše svrhe (br. 1). U poruci 1987. godine isti papa pripisuje veliku moć medijima retorički se pitajući što bolje od društvenih komunikacija može prevladati sve prepreke rase, klase i kulture koje su nasuprot jedne drugima. Iduće godine (1988.) u poruci Ivan Pavao II. također postavlja 
pitanje: „Ako se jednog dana bude moglo doista kazati da je 'komunicirati' isto što i 'biti braća', da 'komunikacija' označava ljudsku 'solidarnost', neće li to biti najljepši rezultat 'masovnih komunikacija'?“", što ponovno pokazuje kako poglavar Katoličke Crkve veliku moć zapravo pripisuje medijima. U poruci iz 1991. godine isti papa medije ponovno naziva moćnim sredstvima kada kaže da takva moćna sredstva stavljaju pred čovjeka uzvišen osjećaj odgovornosti. U poruci iz 1992. godine Ivan Pavao II. ponovno ih naziva moćnim sredstvima: „Kristalno je jasno da ta 'moćna sredstva' zahtijevaju posebne vještine...“, a papa Franjo 2018. upozorava još jednom u svojoj poruci da se ta moć može zloupotrijebiti i posebno ističe zavaravanje i manipuliranje čitateljima.

Iz svega napisanoga, posve je očito da i suvremeno medijsko-etičko promišljanje, kao i teološka medijska etika iznesena u crkvenim dokumentima o medijima, snažno ističu veliku moć medija, te pri tome nema neke bitne razlike između crkvenih dokumenata i medijske etike, izuzev toga što crveni dokumenti uz govor o moći medija konstantno podsjećaju na činjenicu da se ta moć može iskoristiti i za dobro i za loše, a sve ovisi o tome koliko će etično ili neetično postupiti oni koji sudjeluju u tom procesu. Jasno je to i iz riječi pape Franje koji u poruci za Svjetski dan medija 2018. - govoreći o dezinformacijama - upozorava: „Tragedija dezinformiranja je u tome da se diskreditira drugoga kojega se predstavlja kao neprijatelja do te mjere da ga se demonizira što može imati za posljedicu raspirivanje sukoba.“.

\subsection{Pitanje savjesti i medijska etika}

Čupić (2010: 37) naglašava da novinar, ako želi dobro obavljati svoj posao, mora biti vođen dvjema moćima koje se nadopunjuju: moći znanja i moći savjesti, imajući na umu da nema te naredbe, zapovijedi ili prijetnje koja može dovesti u pitanje savjest i osobnu odluku. Piše da je novinar koji posjeduje moć znanja, ali ne i moć savjesti, stručnjak bez savjesti, te je opasan jer može učiniti zlo na stručan i inteligentan način. Ističe da je to zlo u profesiji organizirano zlo čije su posljedice nemjerljive. Brajnović (1997: 283) označuje savjest kao smisao za etičko i moralno koji „stvara u nama sklonost i sposobnost, po kojoj razlikujemo dobrotu od zloće, poštenje od nepoštenja“, nastavljajući da „konkretno znanje kojim ljudsko biće sudi svoj određeni čin pripada njegovoj savjesti“. Day (2004: 66) navodi da „savjest govori, često brutalno jasno, da postoji jasna razlika između ispravnog i pogrešnog djelovanja“. 
I dokument Drugog vatikanskog koncila Inter mirifica u broju 5. piše da je potrebno da svi u komunikacijskom procesu u sebi oblikuju ispravnu savjest o upotrebi medija. Communio et progressio u br. 15 ističe dužnost koju po savjesti imaju oni koji se bave medijima, a to je da valjano obavljaju svoja zaduženja. U dokumentu Etika u obavijesnim sredstvima dva puta se spominje pojam savjesti, i to oba u kontekstu odgoja za medije. Tako u br. 25 stoji da je danas svima potreban određen oblik trajnog odgoja za medije, te da više nego samo pouku o tehnikama, odgoj za medije pridonosi stvaranju dobrog ukusa kod ljudi i ispravnog moralnog prosuđivanja, te zaključuje da je zapravo riječ o odgoju savjesti. U istom broju dokument navodi da ,roditelji imaju ozbiljnu dužnost pomoći svojoj djeci učeći ih kako procijeniti i koristiti društvena obavijesna sredstva, oblikujući ispravno njihove savjesti““.

U poruci za Svjetski dan sredstava društvenog priopćavanja 1977. godine papa Pavao VI. piše da je potrebno poticanje savjesti osoba koje koriste društvene komunikacije da budu selektivni u onom što čitaju, gledaju ili slušaju, ističući snagu tog izbora budući da je to selektivnost koja djelotvorno utječe na one koji su odgovorni za medijsku proizvodnju. U poruci za isti dan 1999. godine papa Ivan Pavao II. piše da je potreban određeni ,ispit savjesti“ društvenih obavijesnih sredstava, to jest novinarskih i medijskih djelatnika.

Papa Benedikt XVI. u poruci za Svjetski dan sredstava društvenog priopćavanja 2008. godine u broju 3. se pita je li mudro prepustiti da mediji budu sluganski podložni nezaustavljivom protagonizmu ili da završe na milost i nemilost onih koji ih koriste za manipulaciju savjestima? Jasno, riječ je o retoričkom pitanju. U istoj poruci u broju 4. isti papa piše da kada komunikacija izgubi etička uporišta i izbjegne društvenoj kontroli onda više ne vodi računa o središnjoj ulozi i nedodirljivom dostojanstvu čovjeka, riskirajući da negativno utječe na njegovu savjest. Dokument Communio et progressio u br. 162. primjećuje slično, tj. piše da mediji imaju veliki utjecaj na čovjekov život i poslanje upravo tako što utječu na njegovu savjest.

Zaključno, možemo primijetiti da kako teološka medijska etika, tako i autori $\mathrm{s}$ područja suvremenog razmišljanja o medijskoj etici, a posebno Brajnović i Bertrand, dotiču se pitanja savjesti, premda ona na određeni način može izgledati kao apstraktan pojam ili u najmanju ruku kao pojam koji bi trebao imati religijsko značenje, te ju ne bi bilo moguće znanstveno jasno definirati. No, oba spomenuta autora - kao i mnogi drugi, poput Spaemmana, Kopreka i Devčića - pomalo „kantovski“ definiraju savjest kao onaj unutarnji glas u čovjeku - profesionalcu, koji ga potiče na moralno djelovanje. Posve očekivano, 
medijska etika izložena u dokumentima Katoličke Crkve još se i više poziva na savjest. Takvim rezoniranjem i teološka medijska etika širi obzorje i može u tome doprinijeti suvremenoj medijskoj etici. Naime, kao što je poznato, nije moguće sve definirati kodeksima i pravilima, već je potrebno kod novinara razvijati upravo osjećaj savjesti koji će im pomoći razlikovati ispravno od neispravnog ponašanja u njihovom medijskom djelovanju.

\subsection{Solidarnost kao načelo medijske etike}

Medijska etika pojmu solidarnosti pristupa na svoj način, premda bi se površno moglo zaključiti da ga ne stavlja u prvi plan ili da ga (gotovo) redovito ne spominje. No, u svakom svom izričaju o potrebi suradnje i dijaloga među ljudima, u pozivima na toleranciju i promicanje bratstva, ravnopravnosti i uvažavanja, prihvaćanja drugoga i drugačije, prisutan je i pojam solidarnosti, premda - kao i kod ranije spomenutih nekih pojmova - implicite. Tako npr. Bertrand (2007: 27) ističe da se već iz Mojsijevog dekaloga može iščitati norma biti solidaran s drugim novinarima. Isti autor analizirajući različite novinarske kodekse, kao jednu od niti vodilja izdvaja: promicati solidarnost među ljudima (Bertrand, 2007: 27).

U tom istom kontekstu, i dokument Communio et progressio u broju 94. govori o potrebi solidarnosti $\mathrm{u}$ medijima $\mathrm{u}$ kontekstu pomaganja razvijenijih naroda onim manje razvijenim, no istodobno se naglašava i potreba poštivanja etičkih predaja tih naroda. Dokument Etika na internetu u broju 15. navodi krepost solidarnosti kao mjerilo korisnosti služenja interneta općem dobru naglašavajući da oni čije odluke i djelovanja pridonose stvaranju internetske strukture i njegovih sadržaja imaju dužnost provoditi solidarnost $u$ služenju općem dobru.

U poruci za Svjetski dan sredstava društvenog priopćavanja 1988. godine papa Ivan Pavao II. ističe potrebu promicanja solidarnosti u medijima, naglašavajući da bratstvo i solidarnost nadilaze sve klanske i društvene podjele, nacionalizam, rasizam, svaku zloporabu moći, svaki fanatizam, bilo da je kulturni ili religiozni. Isti papa 2003. godine u poruci za Svjetski dan sredstava društvenog priopćavanja piše da mediji - vjerno prenoseći zbivanja, ispravno predstavljajući događaje i nepristrano iznoseći različita gledišta - ispunjavaju strogo određenu dužnost promicanja pravednosti i solidarnosti u odnosima, na svim razinama društva. Papa Franjo u Evangelii gaudium iz 2013. ističe da solidarnost podrazumijeva „stvaranje novog mentaliteta koji razmišlja u terminima zajedništva i prioriteta života svih 
nad prisvajanjem dobara od strane nekolicine“ (br. 188), što je itekako primjenjivo i na medije.

Na prvi pogled, mogli bismo površno i pogrešno zaključiti da suvremeni medijskoetički pravci ne koriste pojam solidarnosti, dok ga teološka medijska etika relativno često koristi. No, riječ je zapravo o pomalo „skrivenom“ pojmu u kontekstu medijske etike, što potiče na razmišljanje da teološka medijska etika može dati svoj doprinos medijskoj etici upravo uvođenjem ove kategorije $\mathrm{u}$ razne međunarodne i nacionalne novinarske kodekse na jasniji način, premda je taj pojam već u nekima uključen, bilo eksplicitno bilo implicitno, posebno kroz pozivanje na toleranciju i prihvaćanje drugih i drugačijih.

\subsection{Vjerodostojnost medija i etika}

Već se više desetljeća $u$ istraživanjima spominje da su mediji izgubili vjerodostojnost $i$ da im publika sve manje vjeruje. Tako Malović (2004: 134) ističe da su prema istraživanjima masovni mediji na dnu ljestvice povjerenja u institucije. Vilović (2007: 168) piše da vjerodostojnost nije tek teorijsko ili filozofsko pitanje, već je temelj profesionalnog života novinara, te da je problem vjerodostojnosti medijske profesije doveden u pitanje učestalom lošom novinarskom praksom. Jednako tako ista autorica (Vilović, 2007: 178) smatra da je za medijsku etiku vjerodostojnost ključni element na kojem se izgrađuje imidž medija. I Kurtić (2007: 40) piše da ako čitatelj susreće kontradiktorne podatke, na kraju izabire one u kojima prepoznaje više vjerodostojnosti, dok Valković (2006: 36-37) smatra da je vjerodostojnost bitan preduvjet svake komunikacije, a riječ je o povjerenju koje mora odlikovati pošiljatelja (jednostavno, primatelj medijske poruke mora vjerovati mediju). Isti autor zaključuje da je stvaranje vjerodostojnosti jedan od velikih izazova za medije. Josip Baloban, Nikodem i Siniša Zrinščak (2014: 368) su objavili istraživanje o vrednotama u Hrvatskoj i Europi, te iznijeli komparativnu analizu. Između ostalog, ispitivali su i povjerenje u medije, te donijeli usporedbu rezultata 1999. i 2008. godine. Tako je u prvom istraživanju veoma veliko povjerenje u medije imalo samo 1.9\% ispitanika, a taj broj je 2008. pao još niže, tj. na 1.3\%. Veliko povjerenje je u prvom istraživanju imalo $15.6 \%$, a u drugom je to palo na $13.1 \%$. Ne baš veliko povjerenje je u prvom istraživanju imalo 59.3\%, a u drugom 54.6\%. Nikakvo povjerenje je u prvom istraživanju imalo $20.9 \%$, a u drugom $29.3 \%$, Iz navedenih podataka jasno je kako je povjerenje u medije nisko, te kako to povjerenje dodatno opada. 
Zdravko Kedžo (2015: 4) ističe da relativno nisko povjerenje koje građani iskazuju prema djelovanju masovnih medija, u normalnim društvenim uvjetima ukazuje na, između ostalog, i nisku vjerodostojnost medija.

Premda bi se moglo reći da crkveni dokumenti ne govore često izravno o ovoj temi, tj. ne spominju često ovaj pojam, no svakako da kroz druge pojmove dotiču sadržaj koji je ovim pojmom obuhvaćen. Ipak, nekad ga i direktno spominju, te tako Communio et progressio u br. 70. piše o povjerenju u ta suvremena iznašašća, misleći na suvremene medije. Isti dokument $u$ br. 156, govoreći o odnosu Crkve i medija, piše da je potrebno uzajamno povjerenje, dakle i povjerenje Crkve u medije.

Zaključno, možemo kazati da se pojam vjerodostojnosti često pojavljuje u obje etike, te se obrađuje bez značajnijih razlika. Riječ je o važnome pojmu, jer gotovo da nema suvremenog istraživanja medija koje ne pokazuje da je javnost izgubila ili da sve više gubi povjerenje u medije i smatra ih nevjerodostojnima.

\subsection{Etika i pitanje vlasništva medija}

Na vrlo važno etičko pitanje vlasništva nad medijima, među ostalim autorima, upozorava i Bauer (1997: 75) koji, slikovito govoreći upozorava da danas sloboda tiska zapravo postaje sloboda onih stotinu ili više bogataša koji, na razne načine, posjeduju medije i njima upravljaju. Slično razmišljaju i Malović, Ricchiardi i Vilović (2007: 32) navodeći da vlasnička struktura izravno utječe na uređivačku politiku medija, te o vlasnicima ovisi hoće li naglasak staviti na kvalitetu ili profit. Naglašavaju i da se novinari koji rade u medijima koji su pod izravnom kontrolom neke političke stranke ili društvene skupine suočavaju s izrazitim etičkim problemima s kojima se teško nositi. Rješenje je uvijek jedna od dvije opcije: ili se novinar mora pokoriti proklamiranoj uređivačkoj koncepciji ili mora napustiti taj medij. Malović (2007: 53) podsjeća na tezu Bena Bagdikiana, iz (sada već davne) 1983. godine, koji je predvidio da će vlasnici svjetskih medija moći sjesti u jednu sobu i dogovoriti se kako informirati svijet, te smatra da se danas upravo to događa. Malović (2004: 84) podsjeća da se vlasništvo nad medijima nažalost ne razlikuje od vlasništva nad bilo kojom tvrtkom, te da su mediji zapravo postali biznis. Naglašava da vlasnik određuje temeljnu orijentaciju medija, a na glavnom uredniku i novinarima bi trebalo biti da dogovoreno realiziraju primjenjujući novinarske standarde, no praksa nažalost često nije tako idealna. 
I Gavranović (2006: 156-157) smatra da nejasnoće oko vlasničkih odnosa dovode do nezgodnih situacija, kao i da vlasnici samo žele zaštititi svoju financijsku investiciju, zbog čega glavnu ulogu u medijima preuzimaju komercijalizam i senzacionalizam, iz čega se javlja zabrinjavajući pad kvalitete medija i medijskih sadržaja. Sve navedeno Gavranović svodi pod sljedeće: isprazna ekskluzivnost i senzacija po svaku cijenu umjesto pune i objektivne informacije.

Kunczik i Zipfel (2006: 96) pišu da se sve više smanjuje krug osoba koje mogu izdavati novine, te da je sloboda tiska sloboda za dvije stotine bogatih ljudi da šire svoje nazore. Bertrand (2007: 2-3) ističe da se sve veća komercijalizacija u 20. stoljeću i koncentracija vlasništva medija ne slažu baš najbolje s pluralizmom, a niti nezavisnošću medija. Isti autor piše i da novinar treba slobodu s obzirom na državu, ali i s obzirom na vlasnike (Bertrand, 2007: 23).

Temeljni crkveni dokument o medijskoj etici Etika u obavijesnim sredstvima iz 2000. godine postavlja jedno pitanje koje je zapravo možda više prikrivena tvrdnja, nego pitanje: „Hoće li buduća publika biti sastavljena od mnoštva osoba koje slušaju samo jednu?“ Communio et progressio u br. 80. govori o vlasnicima medija, priznajući da mediji ne mogu bez ulaganja kapitala, no potiče one koji ulažu sredstva da pridonose općem dobru, a ne samo ekonomskoj koristi.

Medijska etika i suvremena medijska etika obrađuju pitanje vlasništva medija. Obje etike ukazuju na važno pitanje vlasništva medija, a ono se odnosi na udruživanje medija te dolaska u situaciju da samo nekoliko ljudi upravlja velikim brojem medija, što dovodi do ozbiljnih etičkih pitanja i dilema vezanih uz mogući monopol i manipulaciju informacijama na globalnoj razini. Uz nekad neznatno različite naglaske, obje medijske etike polaze od realne slike suvremenih medija i pokušavaju naći prikladne odgovore na pitanja i izazove pred kojima se suvremeni mediji nalaze.

\subsection{Cenzura kao problem medijske etike}

Jedna od važnih tema i velikih problema za medijsku etiku, pa i teološku medijsku etiku jamačno je cenzura koja se provodi na različite manipulativne načine i različitim oblicima, još od samih početaka novinarstva. Ipak, danas je cenzura poprimila neke nove 
oblike, jer je činjenica, naime, da su se razvili i mnogobrojni drugi načini pritiska na novinare i ostale medijske djelatnike, pa je cenzuru sve teže otkriti kao jednu od glavnih poteškoća s kojom se novinari susreću. Ipak, ovu se važnu temu medijske etike ne može ignorirati niti se ignorira, jer je povezana sa slobodom i odgovornošću medijskih djelatnika.

Malović (2004: 23) uspoređuje prijašnja vremena s onim novijima te kaže da su i danas, kao i prije, novinari i dalje izloženi pritiscima, samo je danas riječ o nekim suptilnijim, ali ipak ne manje opasnim metodama: vrlo često se radi bez pravog ugovora o radu, nema kolektivnog ugovora na razini države, plaće su niske ili se pak službeno objavljuju male plaće, s malim doprinosima, a razlika se isplaćuje u drugim vidovima, što je za svakoga medijskog djelatnika problematično. I tu se onda ne javlja izravna cenzura, ali se javlja nešto još nezgodnije: autocenzura. Ona možda posebno pogađa starije novinare i one srednje dobi, koji si jako teško mogu priuštiti otkaz, posebno jer znaju da će jako teško naći posao (ako ga i nađu). I novinaru, nažalost, kao da ne preostaje ništa drugo nego autocenzura.

I u crkvenim je dokumentima tema cenzure također zastupljena, kao što je zastupljena i u suvremenim razmišljanjima o medijskoj etici. No, valja reći - a to smo već dijelom spomenuli i ranije u radu - Crkva u počecima cenzuru promatra kao nešto prihvatljivo, dapače i potrebno i neophodno, dok s vremenom taj stav evoluira u promatranje cenzure kao negativne pojave. Ipak, u određenim situacijama cenzuru i danas smatra potrebnom, osobito vezano uz neke teme kao što su širenje govora mržnje, nasilja, pornografije i sličnih neprimjerenih medijskih sadržaja, o čemu je posebno riječ u dokumentu Papinskoga vijeća za sredstva društvene komunikacije Pornografija i nasilje u sredstvima društvenog priopćivanja (1989). Još ranije, u dokumentu Mirari vos (br. 14-15) 1832. godine papa Grgur XVI. osuđuje religijski pluralizam smatrajući ga opasnim za duše vjernika, uz što osuđuje i pluralizam mišljenja, kao i slobodu govora i slobodu objavljivanja, a time zapravo i slobodu medija, čime zapravo cenzuru smatra nečim poželjnim. No, u dokumentu Communio et progressio iz 1971. godine Crkva zastupa drugačije stajalište, to jest ističe pravo na informaciju, kako pojedinca tako i društva u cjelini. Ipak, ne smatra to pravo apsolutnim, već postavlja i neke granice poput onih da pravo na informaciju ,ne smije doći u sukob s drugim pravima kao što su pravo na istinu koje štiti dobar glas pojedinca i društva, pravo na privatan život koje štiti intimu obitelji i pojedinih ljudi; pravo na tajnu kad to zahtijeva potreba, profesionalna služba ili samo javno dobro. Kad je u pitanju opće dobro valja veoma razborito i trijezno prenositi vijesti“ (CP, br. 42). Isti dokument u broju 43 ističe da valja postupiti krajnje razborito i obazrivo 
kada se opisuju okrutni i nasilni događaji, tj. i to je potrebno u određenoj mjeri „,cenzurirati“, a u broju 84. govori se o utjecaju građanskih vlasti koje bi na području cenzure trebale donijeti više pozitivne negoli negativne smjernice, jer nije zadaća države kočiti i potiskivati, iako će katkada biti neophodno upotrijebiti i prisilne mjere. Dokument se poziva na govor Drugog vatikanskog koncila o slobodi i na potrebu obrane slobode, te da se stoga cenzura smije koristiti samo u krajnjim slučajevima, odnosno kada to traži opće dobro. Kada ovaj govor usporedimo, na primjer, s onim iz Mirari vos, posve je jasno da je riječ o velikoj (pozitivnoj) promjeni. Naime, dok Mirari vos govori o cenzuri kao nečemu poželjnom i dobrom, jasno je da je ovdje taj govor posve drugačiji.

I u dokumentu Aetatis novae iz 1992. godine, u broju 5, Crkva ponovno govori o negativnim pojavama koje nastaju cenzurom. Smatra da su zakoni koji reguliraju područje medija nužni, ali da mogu postati sredstva tlačenja i isključivanja, što svakako treba izbjegavati. Može se reći da dokument traži srednji put između s jedne strane državne cenzure, te s druge strane posve nereguliranog medijskog djelovanja u kojem je sve moguće i dopušteno. Dokument Etika na internetu u broju 16, pozivajući se na Communio et progressio, osuđuje cenzuru, ali s određenom zadrškom, s obzirom da i na internetu moraju postojati zabranjena djelovanja. Dokument ističe da treba izbjegavati cenzuru od strane vlasti, ali se smije primjenjivati u krajnjim slučajevima, kao što su govor mržnje, klevetanja, obmana, dječja pornografija i pornografija općenito, širenje nasilja i netolerancije i slično.

U poruci za Svjetski dan sredstava društvenog priopćavanja 1985. godine u broju 3. papa Ivan Pavao II. je progovorio o cenzuri totalitarnih režima, zazivajući neophodnu slobodu koja je veliki izazov s kojim se društvena komunikacija mora suočiti, kako bi postigla osvajanje dovoljno prostora za autonomiju, posebno tamo gdje je to veoma potrebno. Osim opasnosti od strane totalitarnih režima, istaknuo je i opasnost pritiska od strane moćnih kulturnih i ekonomskih ili političkih skupina.

Zaključno možemo konstatirati, da i suvremena medijsko-etička razmišljanja i crkveni dokumenti temi cenzure pridaju veliku pozornost, što je itekako opravdano jer se kroz povijest medija javljaju uvijek novi oblici želje za kontrolom novinara i medija, a najčešće preko cenzure i poticanja autocenzure. Zbog toga suvremena etička razmišljanja upozoravaju na mnoge oblike pritiska na novinare koji onda vrlo često dovode do autocenzure. S druge pak strane crkveni dokumenti oblikovani prema teološkoj medijskoj etici češće ističu temu cenzure dok o autocenzuri ne govore izravno. Ono što smo otkrili analizom činjenica je da $u$ 
moralnoj teologiji postoji razvoj misli o cenzuri, i to od samih početaka kada je i Crkva bila veoma naklonjena toj pojavi do današnjih vremena kada je gleda kao negativnu pojavu. Ipak, u odnosu na neke teme i suvremeni medijsko-etički pristupi kao i teološka etika zastupaju potrebu cenzure u određenim situacijama, a posebno kada je riječ o govoru mržnje, dječjoj pornografiji, širenju nasilja ili propagiranju rata.

\subsection{Digitalni jaz kao etički problem}

McBrideov izvještaj dotiče se teme digitalnog jaza fenomena kojim opisujemo razliku između zemalja bogatih informacijama i zemalja siromašnih informacijama (McBride, 1980: 96-111). Naravno, digitalni jaz ne vrijedi samo na svjetskoj razini, nego i na razini svakoga društva pojedinačno. Malović, Maletić, Vilović i Kurtić (2014: 204) definiraju digitalni jaz kao „podjelu na one koji imaju redovit pristup digitalnim tehnologijama i one koji taj pristup nemaju“.

Pojam „digitalnog jaza“ između bogatih i siromašnih, onih koji imaju pristup sredstvima društvene komunikacije i onih koji taj pristup nemaju, javlja se također $\mathrm{u}$ crkvenim dokumentima više puta, kao što je to slučaj i kod medijsko-etičkih razmišljanja starijih i suvremenijih autora. Tako papa Ivan Pavao II. u poruci za Svjetski dan sredstava društvenog priopćavanja 1997. godine ističe nadu da jaz koji korisnike novih informacijskih i komunikacijskih sredstava i tehnologija odvaja od onih koji nemaju prilike njima se služiti, neće postati još jedan nesavladivi razlog nepravde i diskriminacije. Mudro primjećuje da se u nekim manje razvijenim zemljama javlja svojevrsno gospodarenje bogatijih zapadnih zemalja nad njima, i to upravo putem medija koji predstavljaju zapadnjačke vrijednosti. Te vrijednosti se možda predstavljaju kao kršćanske, no možda je zapravo više riječ o „vrijednosti“ koja se zove „profit““. Isti papa u poruci za Svjetski dan sredstava društvenog priopćavanja 2003. godine ističe potrebu da se pronađe ,način ne samo da se zajamči najslabijim slojevima društva pristup informaciji koju trebaju za svoj individualni i društveni razvoj, već također da se zajamči da oni ne budu isključeni iz djelatne i odgovorne uloge u odlučivanju o sadržajima javnih glasila i određivanju strukturâ i politikâ sredstava društvenog priopćivanja“, čime se ponovno upozorava na opasnost digitalnog jaza.

Problematiku digitalnog jaza posebno pak ističe dokument Etika na internetu u broju 10, a definira ga kao digitalnu diskriminaciju siromašnih u odnosu na bogate, kako među 
narodima tako i unutar njih samih, na temelju pristupa odnosno nemogućnosti pristupa toj novoj informatičkoj tehnologiji. U tom smislu riječ je o suvremenoj verziji staroga jaza između „,informacijama bogatih“ i ,informacijama siromašnih“. Prema tom dokumentu pojava digitalnog jaza na neki način opominje da pojedinci, skupine i narodi moraju imati pristup novoj tehnologiji kako bi mogli imati udjela u blagodatima koje obećavaju globalizacija i razvoj te kako ne bi dalje zaostajali. Papa smatra da je nužno na vrijeme se potruditi da taj jaz ne postane još jedan nesavladivi razlog nepravde i diskriminacije $\mathrm{u}$ globalnom i globaliziranom svijetu.

I teološka i suvremena medijska etika uočavaju problem digitalnog jaza koji nije nova pojava, ali koji danas poprima neke nove i drugačije oblike. Obje medijske etike, uočavajući problem, žele svojim promišljanjima doprinijeti da taj jaz bude što manje izražen, to jest da na jednoj strani ne budu društva i slojevi društva bogati informacijama, a s druge strane oni koji su siromašni informacijama i prepušteni sebi samima.

\subsection{Pitanje privatnosti i medijska etika}

Pitanje privatnosti i s njome povezanog prava odavno je prisutno u kontekstu medijske etike, a u suvremeno je doba zbog razvoja novih digitalnih medija, pa i određenoga gubitka osjećaja za privatno još izraženije. Jacquette (2007: 253) pravo na privatnost smatra moralno opravdanim kao temelj i zaštitu individualnih sloboda, kao pretpostavku teze da osobe treba poštovati kao moralno vrijedne ciljeve po sebi, te kao zahtjev koji treba ispuniti da bi pojedinci mogli ostvariti sreću i izbjeći strepnju i nelagodnosti. Isti autor (Jacquette, 2007: 278) smatra da činjenica da se neki događaj događa na javnom mjestu sama po sebi ne znači da je događaj javan i da novinari o njemu mogu slobodno prikupljati informacije.

Day (2014: 157) smatra da je privatnost neodređen koncept koji nije lako definirati. Donosi zapravo dvije naizgled suprotne činjenice: smatra se da pojedinac ima pravo na privatnost u smislu prava pojedinca da bude ostavljen na miru ili pravo da ima kontrolu nad neželjenim publicitetom u svezi s osobnim stvarima; dok je s druge strane uloga medija da ljude ne ostavljaju na miru, jer njihov rad je otkrivanje, a ne prikrivanje. Day smatra da je potrebno pronaći balans između ta dva interesa: interesa pojedinca za privatnošću naspram interesa javnosti za pristupom informacijama. Day (2014: 212) stoga pravi jasnu distinkciju između javnog interesa (kao opravdanog razloga za objavu neke informacije) i čisto privatne 
radoznalosti ili osobnog interesa (kao neopravdanog razloga objave neke informacije). Smatra da su informacije u demokratskom društvu važne, te bi informacije od javnog interesa trebalo objavljivati, a ne prikrivati pod krinkom povjerljivosti. Pitanje privatnosti obrađuje se i u međunarodnim i nacionalnim novinarskim kodeksima. Tako Kodeks časti hrvatskih novinara (2009.) u više članaka izravno govori o pravu na privatnost, posebno o zaštiti prava na privatnost kod djece. Tako u čl. 14 ističe da ,novinar treba štititi čovjekovu intimu od senzacionalističkog i svakog drugog neopravdanog otkrivanja u javnosti. Obvezan je poštovati svačije pravo na privatnost".

Communio et progressio u br. 84 navodi da mediji moraju poštivati ljudsku osobnost. Isti dokument u broju 102. piše: da je potrebno dostojanstvo osobe, bilo priopćavatelja bilo primatelja, „priznati u svim njezinim oblicima i da se s njome postupa sa svim poštovanjem kako bi priopćivanje kojim ljudi jedni drugima postaju bližnji preraslo uistinu u pravo zajedništvo“. (br. 102.). Isti dokument navodi da pravo na informaciju ima svoje određene granice i ,ne smije doći u sukob s drugim pravima kao što su pravo na istinu koje štiti dobar glas pojedinca i društva, pravo na privatan život koje štiti intimnost obitelji i pojedinih ljudi; pravo na tajnu kad to zahtijeva potreba, profesionalna služba ili samo javno dobro“ (CP, br. 42). Dokument Etika na internetu u br. 23 navodi: „I slobodno izražavanje moralo bi obdržavati norme poput istine, korektnosti i poštovanje privatnog života".

I suvremena i teološka medijska etika priznaju čovjekovo pravo na privatnost, naglašavajući da se nju ne smije ugrožavati. Prema našem istraživanju i usporedbi, nema značajnije razlike u pristupu ovim temama između suvremene i teološke medijske etike.

\subsection{Profit i kvaliteta kao problem medijske etike}

Habermas (2013: 157-158) ističe da pritisak dioničara koji žeđaju za većim dobitkom i prodor funkcionalnih imperativa tržišne ekonomije $\mathrm{u}$,unutarnju logiku“ proizvodnje i predstavljanja poruka vode prikrivenoj zamjeni jedne kategorije komunikacije drugom, te da zbog komercijalnog pritiska na prvo mjesto dolaze zabavni sadržaji. I Jacquette (2007: 102) također govori o dvije očigledne činjenice: s jedna strane novinarstvo je plemenita profesija čiji je cilj otkrivanje i prenošenje informacija, ali s druge strane riječ je i o velikom biznisu, te zapravo ono prvo često strada nauštrb ovog drugog. Isti autor (Jacquette, 2007: 105) podsjeća da postoje moralne dileme koje nastaju zbog motiva profita u profesionalnom novinarstvu i, u 
krajnjoj liniji, zato što se od novinara traži da rade dvije stvari koje često ne rukovodi isti skupom vrijednosti: $s$ jedne strane trebaju istinito izvještavati, s druge strane zadaća im je stvarati profit. Zato Jacquette (2007: 116-117) također primjećuje da kada o novinarstvu mislimo i kao o biznisu, medijska etika postaje samo posebna grana poslovne etike. Bauer (1997: 33) smatra da je naklada, a time i profit, često nažalost u obrnutom omjeru s kakvoćom medijskih sadržaja. Popularni medijski proizvod, proizveden na najjeftiniji način, u pogledu brojnosti čitateljstva i gledateljstva - ili općenito korisnika - vrlo lako za sobom ostavlja kvalitetne medije. Citirajući Krügera, Bauer (1997: 76-77) primjećuje da je povećanje dobiti usmjereno k tome da se zadobije i ,posljednjeg čovjeka“, zbog čega je uredništvo prisiljeno spusti se „do najnižeg nivoa“, dok Karen Sanders (2004: 27) ističe da nema ništa loše u zaradi, osim kad utrka za profitom i publikom postane jedino što novinar treba raditi. Bertrand (2007: 92) piše da se kvaliteta isplati, naglašavajući da kvaliteta medija može istodobno služiti dobru čovječanstva i biti profitabilna.

U broju 5. dokumenta Aetatis novae piše da u medijima postoji sklonost da se uspjeh ocjenjuje prema dohotku, te da se nažalost više cijeni popularnost nego kakvoća. Dokument Etika na internetu osuđuje pojave u medijima kada se ,profit i tržišne zakone promatra kao apsolutne parametre na štetu dostojanstva i poštivanja osobe i naroda” (EI, br. 8). U poruci za Svjetski dan sredstava društvenog priopćavanja papa Ivan Pavao II. piše da je medijima nekada nažalost ,prva i izvorna vrijednost trgovački profit“ (SD 1997).

I suvremeni medijsko-etički pravci i razmišljanja, kao i teološka etika govore o odnosu profita i kvalitete sadržaja, te primjećuju negativnu pojavu u kojoj profit ima primat pred kvalitetom. Svjesni su činjenice da mediji žele profit, te da sama težnja za profitom nije problematična ili neetična sama po sebi. Problem nastaje kada profit postane jedini kriterij, a kvaliteta nebitan čimbenik.

\subsection{Publika i njezina odgovornost za medijsku etiku}

O medijskoj se publici kroz povijest istraživanja medija različito razmišljalo: $\mathrm{u}$ početku se mislilo da publika (zbog slabe ili gotovo nepostojeće interaktivnosti samih tradicionalnih medija) ima pasivnu ulogu, dok se publici danas posvećuje puno više pozornosti sa sviješću da je itekako aktivna i suodgovorna za medijske sadržaje. Christians ističe kolektivnu odgovornost publike, a poziva se na Jonasovu „etiku predviđanja“ koja 
polazi od toga da ljudi nisu odgovorni samo za svoje izravne čine, već snose kolektivnu odgovornost za budućnost čovječanstva, što onda Christians primjenjuje na medije, smatrajući da korisnici medija imaju svoj dio odgovornosti za kulturu na području komunikacije (prema Čehok i Koprek, 2006: 184).

Hamelink (1998: 49-50) smatra da se medijska etika ne može ograničiti na onoga tko proizvodi medijski sadržaj, veća treba biti i etika korisnika medija, budući da i korisnici donose morale odluke u pogledu slobode, kvalitete i odgovornost medija. I Fink (1995: 12) smatra da i korisnici medija moraju učiti o medijskoj etici, stavljajući pred njih konkretne zadaće: moraju naučiti izabrati odgovorne, vjerodostojne novine i časopise, kao i kritički prosuditi njihovo prenošenje vijesti, informacija i zabave. Ističe da su vremena u kojima su korisnici medija samo primali ono što mediji serviraju postali prošlost.

O odgovornosti primatelja medijskih sadržaja pišu Labaš i Vizler koji smatraju da se primatelji moraju aktivno i odgovorno koristiti mnogobrojnim mogućnostima medija, te jednako tako i kontrolirati rad novinara. Oni su također „produžena ruka“ etičkih kodeksa, budući da svojim primjedbama, prijedlozima i pohvalama mogu biti putokaz novinarskim djelatnicima (Labaš, Vizler, 2006: 278-279). Isti autori ističu i da mediji sami po sebi nisu loši, te ih takvima može učiniti samo nepravilna uporaba od strane korisnika (Labaš, Vizler, 2006: 280). Labaš i Vizler (2006: 282-283) podsjećaju na komunikologa koji se možda najviše od svih ostalih bavio pitanjem etikom primatelja medijskih sadržaja, a riječ je o već spomenutom Hamelinku, koji smatra da se i korisnici u komunikacijskome procesu moraju ponašati moralno i etično, te najviše koristi pojmove „sloboda“ i „odgovornost“ budući da je to dvoje preduvjet etičkog djelovanja. Isti autori (Labaš, Vizler, 2006: 283-284) napominju da se često zaboravlja na odgovornost cijele društveno-političke zajednice, izdavača ili medijskih sustava, urednika i same publike, koji su pozvani biti akteri komunikacijskog procesa. Podsjećaju i da su dugo primatelji bili na margini medijskih istraživanja, no da je to potrebno mijenjati, što je danas i činjenica. Labaš i Vizler (2006: 287) pišu da se korisnika medija ne smije doživljavati kao žrtvu, jer on može na mnogo načina djelovati aktivno u komunikacijskom procesu. Isti autori (Labaš, Vizler, 2006: 289) ističu i pasivnost samih korisnika medija kojima je najlakše smjestiti se u naslonjač i pratiti medijske sadržaje sporne kvalitete, nego se potruditi nešto na tom planu promijeniti. Isto tako, Labaš i Vizler (2006: 294) pišu o važnosti etike primatelja koja podrazumijeva odgovorno biranje medijskih sadržaja, ali i spremnost na aktivnije uključivanje kroz npr. osnivanje različitih udruga koje bi 
se bavile upravo ovim pitanjima iz rakursa samih primatelja, čime se zapravo zauzimaju za informacijsku i medijsku pismenost kojoj se danas posvećuje puno više pozornosti, pa i u Hrvatskoj. Ciboci (2018: 23-46) ističe važnost medijske pismenosti, koja je temelj za mogućnost odgovornog služenja medijima i samih korisnika. Slično se naglašava i u Ciboci, Kanižaj, Labaš (2014: 53-67).

Dokument Drugog vatikanskog koncila Inter mirifica (br. 4) ističe da ako medije žele ispravno upotrebljavati, svi koji se njima služe moraju poznavati norme moralnoga reda i provoditi ih u djelo. Isti dokument u broju 9. ističe da posebne dužnosti obvezuju čitatelje gledatelje i slušatelje, te da ispravan izbor zahtijeva da daju prednost svemu onome što se odlikuje krepošću, znanošću i umjetnošću.

Dokument Communio et progressio u broju 41. piše da primatelji vijesti, iako ne smiju od novinara očekivati savršenstvo koje nadilazi ljudske sile, ipak imaju pravo i dužnost tražiti da se lažne i zlonamjerne vijesti uklone, zahtijevati da se upotpune pojedinosti koje su izostavljene, te se žaliti svaki put kad mediji iskrivljuju činjenice stavljajući ih izvan njihova konteksta. No, da bi to mogli potreban je odgoj za medije, to jest medijska i digitalna pismenost, kojima dokument posvećuje veliku pozornost. Isti dokument navodi i da su mogućnosti primatelja veoma velike i raznovrsne, pa prema tome i njihova je odgovornost veća nego što se obično misli. (CP, br. 81). I dokument Etika u obavijesnim sredstvima u broju 24. ističe da bi sudjelovanje javnosti u komunikacijskom procesu trebalo biti organizirano, sustavno i istinski reprezentativno, ne usmjereno u korist posebnih skupina, te da $\mathrm{u}$ interesu sudjelovanja javnosti novinari trebaju nastojati razgovarati s osobama, a ne im samo govoriti; konkretno, novinari bi u publici trebali vidjeti sugovornika, a ne samo pasivnoga primatelja. Međutim, upravo u tom kontekstu isti dokument u broju 25. podsjeća i opominje da Crkva jasno ističe da i korisnici medija imaju svoju ništa manju odgovornost nego što je imaju novinari, naglašavajući da je prva dužnost korisnika medija razlikovanje i odabir medijskih sadržaja.

U poruci za Svjetski dan sredstava društvenog priopćavanja iz 1976. godine papa Pavao VI. piše da se od korisnika medija traži da „odgajaju sami sebe kako bi bili budno kritični prema onome što se piše i govori, jer na taj način će se staviti u poziciju u kojoj mogu poticati i podržavati, i moralno i materijalno, ljude koji pišu ili proizvode te publikacije, emisije i filmove“, te ih potiče da dobro procjenjuju stvari koje im mediji predstavljaju i da kvalificirano interveniraju kako bi se osiguralo poboljšanje u službama informacija. Isti papa 
smatra da će korisnici medija uvijek biti oni koji imaju odlučujuću riječ u budućnosti medija, jer su oni ti koji odlučuju hoće li prihvatiti ili odbiti ono što im se nudi. Istovremeno primjećuje da je to odgovornost koju korisnici medija često ignoriraju.

I u poruci za Svjetski dan sredstava društvenog priopćavanja 1978. godine isti papa Pavao VI. naglašava važnost suradnje korisnika medija i medijskih djelatnika, a obraća se i direktno korisnicima medija potičući ih da nauče jezik medija, kako bi mogli biti u poziciji djelotvorno reagirati. Papa Ivan Pavao II. u poruci za Svjetski dan sredstava društvenog priopćavanja 1993. godine piše da se na ulogu korisnika medija ne smije gledati kao na ulogu pukog potrošača (,konzumenta“), te da korisnik medija mora uzeti vrlo ozbiljno svoju odgovornost i dati aktivni doprinos u zaštiti i poboljšanju svoje medijske sredine.

Danas su medijska istraživanja izuzetno posvećena medijskoj publici, te ovu temu u značajnom opsegu pronalazimo i u suvremenoj medijskoj etici, kao i u teološkoj. Kako znamo, danas se čak u nekim slučajevima briše granica između korisnika medija i stvaratelja medijskog sadržaja, te se javlja termin „prosumera“, koji dolazi od „producer“ i „consumer“, jer su medijski korisnici danas upravo to: sustvaratelji medijskih sadržaja, a to znači da svoju slobodu moraju koristiti odgovorno i oni, te da je etika primatelja u digitalno doma itekako važna. O odgovornosti medija pišu obje etike, te nema značajnijih razlika u njihovom pristupu, budući da i suvremena i teološka medijska etika snažno naglašavaju ulogu, a samim time i odgovornost korisnika medija.

\subsection{Reklamiranje i etika u promidžbi}

Tema promidžbe ili propagande, reklamiranja ili oglašavanja itekako je važna za medijsku etiku, jer je reklama, kako ističe Jasna Šego (2010: 164) postala vladajući komunikacijski oblik. Day (2014: 47) problematičnim smatra postupno mijenjanje i miješanje novinarskih vrijednosti, tj. komercijalnih i vrijednosti zabave, te ističe da taj trend brisanja granice između različitih medijskih funkcija izaziva etičke zabrinutosti koje se kreću od umjerene manipulacije publikom do izravnog varanja publike, dakle - od prikrivenoga oglašavanja (koje je zabranjeno zakonom, posebno kada je riječ o djeci) do prijevarnoga oglašavanja u čijim se oglasima proizvodi i usluge prikazuju manipulativno ili lažno. Day (2014: 292-293) ističe i pozitivnu stranu oglašavanja, a to je da ono daje mediju financijsku nezavisnost od vlade i drugih političkih interesa, no kao i većina stvari i ovo ima drugu stranu 
medalje: stvara zavisnost od komercijalnog sektora. Ti pritisci se očituju na tri područja: prvi se očituje na kvaliteti komercijalnog materijala koji određuje količinu prostora ili vremena koji ostaju za ne-reklamni, istinski medijski sadržaj - vijesti, kulturu i zabavu; drugi podsjeća da se osjećaju posljedice smanjivanja uloga oglašivača, što je posebno vidljivo u razdobljima ekonomske recesije ili kada prijeđu od jednog k drugome mediju; a treće je područje ono na kojemu je očit izravan pritisak na medijske menadžere.

Malović, Ricchiardi i Vilović (2007: 10) pišu da su interesi i utjecaj oglašivača sve bliži uredničkoj politici pojedinih medija, te da ima sve više urednika koji postaju svojevrsni ekonomi, a uplitanje kompanija u uređivačku politiku postaje zabrinjavajuće. Malović (2007: 68) donosi i drugi naziv za novine koji glasi „omot za oglase“, uz napomenu da tvrdnja da marketinške kompanije uređuju medije uopće nije daleko od istine. Također, podsjeća da mediji većinu prihoda imaju od oglašivača, pa samim time niti ne smiju izdati onoga od koga žive.

Već spomenuto prikriveno oglašavanje je jedna od velikih boljki suvremenog novinarstva, a Branko Hebrang (2011: 13) ističe da je došlo do brisanja granica između odnosa s javnošću i novinarstva, a što razara vrijednosti iz pretpostavljenoga modela društvene odgovornosti medija. Rezultat toga je da se umjesto javnoga dijaloga o važnim društvenim pitanjima u medijima diskutira o pogrješnim obavijestima, dezinformacijama i pseudodogađajima što vodi u zabludu. Ističe $\mathrm{i}$ da su takve medijske obavijesti zapravo „pseudoporuke“ (Hebrang, 2011: 21). Isti autor (Hebrang, 2011: 16) naglašava da su uvjeravanje i promidžba legalne komunikacijske metode dok su u funkciji općega dobra, pravnog i etičkog okvira, to jest ako masovni mediji tako stvorene poruke istraže i objave u okviru pretpostavljene društvene odgovornosti medija.

Jelena Jurišić i Igor Kanižaj (2007: 117) donose istraživanja primjenom znanstvene metode analize sadržaja dviju najutjecajnijih hrvatskih dnevnih novina, Jutarnjeg lista i Večernjeg lista, u kojima je u prosincu 2006. godine otkriveno čak 327 tekstova s elementima prikrivenoga oglašavanja.

Kunczik i Zipfel (2006: 96) primjećuju da se novinari zbog ovisnosti medija o reklamama često suzdržavaju od kritičkog izvještavanja o važnom oglašivaču, što je i dalje veliki suvremeni problem novinarstva i medija. Na to upozoravaju i Miliša, Tolić i Vertovšek (2009: 16), koji smatraju da su većini medija tržište, prihod, čitanost, gledanost i slušanost glavni kriteriji ne zato da bi dokazali kvalitetu, već da bi time opravdali prodaju oglasnog 
prostora. Govoreći o reklamama Miliša, Tolić i Vertovšek (2010: 75) tvrde da se danas stvari personaliziraju i čovjek depersonalizira, a proizvod daje osjećaj pripadnosti, jer se kupnjom upravo tog proizvoda svrstavamo u određenu skupinu. Isti autori (Miliša, Tolić i Vertovšek, 2010: 76) podsjećaju da istraživači upozoravaju na magičnu snagu tzv. subliminalnih reklama, a riječ je zapravo o tehnici tajnog i neizravnog zavođenja.

Valković (2008: 275) se dotiče teme koja je temelj medijske etike, u kontekstu oglašavanja, a riječ je o istinitosti, te piše da kao što se istinitost i autentičnost komunikacije ne može svesti samo na ispitivanje istinitosti ili podudarnosti poruke sa stvarnošću, tako se i promišljanje o istini u promidžbi ne može zaustaviti samo na istinitosti promidžbene poruke. Smatra da etičko promišljanje o istini u promidžbi usmjerava pozornost na cjelokupni komunikacijski proces, dakako uvažavajući pritom specifičnosti promidžbene komunikacije. Valković (2008: 276) se pita je li dovoljno istinitost neke komunikacije, uključujući i komunikaciju u području reklamiranja, određivati isključivo prema istinitosti (podudarnosti) njezina sadržaja (u svjetlu Tomina adaequatio rei et intellectum)? U tom kontekstu (Valković, 2008: 285) smatra da je promidžba „etički“ prihvatljiva kada je obazriva prema vrednotama i normama, kako onih koji je kreiraju tako i onih kojima je upućena. Valković (2008: 299) ističe da je u promidžbi važna odgovornost u kontekstu osjetljivosti prema onima kojima se promidžba obraća. Na tu su odgovornost pozvani svi koji je oblikuju: ekonomski subjekti koji je naručuju te masovni mediji preko kojih se promidžba najvećim dijelom distribuira.

Kada je riječ o teološkom promišljanju o etici u promidžbi, valja reći da dokument Communio et progressio (br. 60) ističe da ako se reklamiraju štetni proizvodi, ako se o proizvodima iznose lažne tvrdnje, ako se zloupotrebljavaju čovjekovi porivi, tada oni koji su odgovorni za reklamu nanose štetu društvu te gube povjerenje i reputaciju. Na istom mjestu dokument ističe da je potrebno izbjegavati reklamu koja bestidno zloupotrebljava seks za stjecanje novca ili prodire $u$ podsvijest čovjekova duha te u opasnost dovodi i samu slobodu kupaca. Dokument smatra da prilikom proizvodnje reklama treba paziti da ne bi komercijalnost povrijedila ljudsko dostojanstvo i nanijela nepravdu društvu.

Dokument Etika u promidžbi u broju 3. ističe da reklama ne označava nužno stavove i vrijednosti prevladavajuće kulture. Istina je da oglašavanje nekada djeluje kao ogledalo, no istovremeno, kao i u samim medijima, to je ogledalo koje pomaže oblikovati stvarnost koju odražava, a nažalost ponekad predstavlja i iskrivljenu sliku stvarnosti. $U$ istom broju dokument nastavlja da su oglašivači selektivni u odabiru vrijednosti i stavova koje njeguju i 
potiču, a daje lažnu sliku da oglašavanje ne može drugo nego odražavati kulturu. Isti dokument u tome istome broju navodi da oglašavanje ima neizravan, ali snažan utjecaj na društvo kroz svoj utjecaj na medije. Primjećuje da s jedne strane oglašivači nastoje doći do publike, a s druge strane mediji nastojeći omogućiti oglašivačima put do publike, te moraju oblikovati svoj sadržaj kako bi privukli željenu publiku, a ta ekonomska ovisnost medija i moći koje daju oglašivačima sa sobom nosi ozbiljne odgovornosti za oboje. Nadalje, Etika u promidžbi u broju 5. navodi da oglašavanje može igrati važnu ulogu u procesima u kojima uz pomoć moralnih normi i odgovornosti za opće dobro, pridonosi razvoju društva, kao i da može biti koristan alat za održavanje poštene i etički odgovorne konkurentnosti koja pridonosi gospodarskom rastu u službi istinskoga ljudskoga razvoja. Primjećuje da može pomoći potrošačima da donesu informirane, razborite odluke, što pridonosi učinkovitosti i snižavanju cijena, i poticanje gospodarskog napretka kroz širenje poslovanja i trgovine. U broju 6 . dokument smatra da i političko oglašavanje može dati doprinos demokraciji analogan doprinosu ekonomskom blagostanju u tržišnom sustavu, vođen moralnim normama. U broju 7. dokument podsjeća na veliki pozitivan utjecaj koji oglašivači mogu ostvariti na medije, budući da mediji financijski ovise o njima, a to čine podupirući sadržaje izvrsne intelektualne, estetske i moralne kvalitete, predstavljene u pogledu javnog interesa. U konačnici, Etika u promidžbi u broju 9. naglašava da ne postoji ništa bitno dobro ili zlo u oglašavanju, već je ono alat, instrument: može se koristiti dobro, a može se koristiti loše. U broju 10. dokument ističe umjetno stvaranje potreba kod potrošača, što je svakako neetična praksa. Etika u promidžbi u broju 14. naglašava i da postoje samo dvije mogućnosti: ili će pomoći osobi da sazrijeva u razumijevanju i prakticiranju onoga što je istinito i dobro, ili će je destruktivno tjerati u sukob s općim dobrom, a donosi se i temeljno etičko načelo za osobe koje se bave oglašavanjem: „Oglašivači - to jest, oni koji procjenjuju, pripremaju ili šire oglašavanje - moralno su odgovorni za ono na što ljude potiču da čine; i to je odgovornost koju također dijele izdavači, glavni urednici i drugi u svijetu komunikacija, kao i oni koji daju komercijalna i politička odobrenja, u mjeri u kojoj su uključeni u proces oglašavanja“ (EP, br. 14). U istome broju dokument jasno osuđuje ,prikriveno oglašavanje“, to jest kako ga naziva - „neizravno reklamiranje“. Nakon toga dokument obrađuje tri moralna načela za koja smatra da su posebno važna u oglašavanju: istinoljubivost, dostojanstvo ljudske osobe i društvena odgovornost.

U poruci za Svjetski dan sredstava društvenog priopćavanja 1977. godine papa Pavao VI. piše da oglašavanje sugerira određene vizije svijeta, što se neminovno tiče i kršćanina, te 
to utječe na njegove odluke kao i na njegov način djelovanja, ali i na činjenicu da oglašavanje $\mathrm{u}$ velikoj mjeri financira razvoj medija $\mathrm{i}$ koristi ih za svoje potrebe, te ponekad izravno i opasno utječe na usmjerenje i slobodu samih medija i medijskih djelatnika. Papa piše i da oglašavanje ima imperativni uvjet poštivanja ljudske osobe i njezinog prava i dužnosti odgovornog izbora.

I suvremena razmišljanja o medijskoj etici i teološka medijska etika na sličan način progovaraju o reklamiranju ili oglašavanju. Kod oba je viđenja uočljivo da se na promidžbu gleda pozitivno, ako se koristi u svrhu pozitivnog oglašavanja u prilog bolje informiranosti publike, ali se ne izbjegava spomenuti i tematizirati i one negativne aspekte reklama u onim slučajevima kada se reklamiranje koristi neetično, to jest kada je prijevarno i manipulativno, te se odbacuje bilo koji oblik prikrivenoga oglašavanja.

\subsection{Poštivanje žene i medijska etika}

Labaš i Maja Mihovilović (2011: 99-100) primjećuju da dio feminističkih teorija tvrdi da masovni mediji pogoduju održavanju patrijarhalnoga društva, interesima i dominaciji muškaraca te podređivanju žena, a posebno ističu medijsku stereotipizaciju utemeljenu na seksualnoj privlačnosti i ulogama majke, supruge i kućanice. Labaš i Kristina Koščević (2014: 208) pišu da se žene u oglašavanju prikazuju na stereotipan način, kao nježne, mile, dobre, senzibilne, sramežljive, brižne i požrtvovne. Ističu i da prikaz žena u reklamama nameće stvarnim ženama nedostižan ideal ljepote, te da prema njemu žene moraju biti vitke, mladolike, atraktivne i poželjne, kao i da je seksizam, odnosno diskriminacija na temelju spola i roda čest u reklama, jer se žene prikazuju kao seksualni objekti, kao one koje su podčinjene maštarijama dominantnih muškaraca, te kao ukrasni objekti muškarcu (Labaš, Mihovilović, 2014: 209).

S teološkoga stajališta, papa Ivan Pavao II. u poruci za Svjetski dan sredstava društvenog priopćavanja 1996. godine piše da su medijski djelatnici u jedinstvenom položaju da svrate pozornost na dva ozbiljna problema koji se odnose na položaj žene u današnjem društvu: na njezino majčinstvo i na potrebu postizanja djelotvorne jednakosti dostojanstva $s$ muškarcem na svakom području. U istoj poruci papa ističe da mediji predstavljaju suvremeni areopag i da imaju snažan utjecaj po kojemu bi društvo moralo priznati i cijeniti ne samo prava, nego i specifične sposobnosti žena. Primjećuje također da se u medijima javlja 
iskorištavanje žena, te se s njima postupa ne kao s osobama s nepovredivim dostojanstvom, nego kao s predmetima kojima drugi „utažuju žeđ za užitkom i moći“. Primjećuje i da se u medijima izruguje ženina uloga supruge i majke, ili ju se u radnom ili profesionalnom životu prikazuje kao karikaturu muškarca, što se vidi po odbacivanju specifične sposobnosti ženske intuicije, suosjećanja i razumijevanja, što su bitni doprinosi „civilizaciji ljubavi“. Dokument Pornografija $i$ nasilje $u$ sredstvima društvenog priopćivanja (1989.) također ističe pornografija i nasilje iskorištavaju pojedince, posebno žene (PN, br. 10).

Zaključno, možemo primijetiti da i suvremena medijska etika, kao i ona teološka, posvećuju pažnju ulozi žene u medijima. Uočavaju određene stereotipe, ali i iskorištavanje žena koje je prisutno u sredstvima društvenog priopćavanja. U obradi ove teme nema nema značajnijih razlika između teološke i suvremene medijske etike. 


\section{ISTRAŽIVANJE, ANALIZA I RASPRAVA POZNAVANJA MEDIJSKE ETIKE I VLASTITE PERCEPCIJE DJELOVANJA}

\subsection{Metodologija istraživanja}

U ovom poglavlju disertacije donose se rezultati istraživanja koje je provedeno među

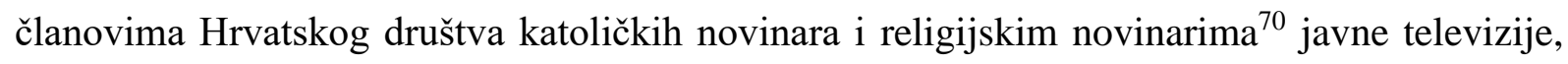
nacionalnih komercijalnih televizija, te nacionalnih dnevnih listova. Putem ankete istraženo je u kojoj su mjeri članovi Hrvatskog društva katoličkih novinara upoznati s kriterijima za novinarsko djelovanje i s teološkim etičkim naukom o medijima. Istraženo je i kakva je njihova percepcija o tome koliko oni kao ispitanici, kao i drugi sudionici medijskog procesa, djeluju (ili ne djeluju) u skladu s temeljnim načelima medijske etike. Kontrolnu skupinu su činili religijski novinari.

Cilj rada je bio istražiti etička načela medijske etike koja su sadržana u suvremenim etičkim pravcima te ih usporediti s načelima iznesenima u dokumentima Katoličke Crkve koji se bave medijima, te analizirati potencijalni međusobni doprinos. Ovo istraživanje, zajedno s prethodnim poglavljima rada, pridonosi ostvarenju toga cilja na način da analizira stavove koje su ispitanici iznijeli, a ispitanici novinari članovi HDKN-a i religijski novinari, su svakako relevantni ispitanici s obzirom na tematiku samog istraživanja, kao i cijele disertacije.

Hipoteze rada su bile:

1. Unatoč razlikama među suvremenim etičkim pravcima na području medijske etike prisutan je značajan broj kriterija koji se podudaraju.

2. U crkvenim dokumentima koji se bave medijima postoje različita, ali temeljno slična etička promišljanja.

3. U crkvenim dokumentima i u svjetovnim etičkim pravcima i međunarodnim kodeksima časti postoji više od polovice zajedničkih kriterija, iako ih se različito tumači.

\footnotetext{
${ }^{70}$ Pojmom „religijski novinari“ označuju se novinari koji se bave religijskim temama, pa ih zato tako zovemo (kao npr. i sportski novinari), te nije riječ o ljudskom nego profesionalnom atributu. Religijski novinari su u ovom istraživanju bili kontrolna skupina.
} 
4. Članovi HDKN-a, prema samoprocjeni, poštuju etičke kodekse i nauk svoje vjerske zajednice o medijima.

5. Nema značajne razlike u samoprocjeni poštivanja kriterija etičkih kodeksa među članovima HDKN-a i djelatnicima svjetovnih medija koji se bave religijskim temama.

Za prve tri hipoteze rezultati ovog istraživanja su važni jer donose percepciju o tim temama samih novinara, a posljednje dvije hipoteze se direktno odnose na samo ovo istraživanje, te će ih se uz pomoć istraživanja potvrditi ili opovrgnuti.

Anketa je provedena putem e-pošte i online obrasca. Anketa je, prema Tkalac Verčič, Sinčić Ćorić i Paloški Vokić (2010: 103) prikupljanje podataka ispitivanjem uz primjenu posebnog formulara - anketnog upitnika, koji je u ovom slučaju bio online. Upitnik predstavlja unaprijed određenu listu pitanja koju se postavlja ispitanicima. Svi ispitanici odgovaraju na ista pitanja, koja su složena određenim redoslijedom. Podaci se obično analiziraju kvantitativno, različitim statističkim postupcima u kojima ključnu ulogu imaju upravo statistički podaci na temelju kojih se izvode znanstveno relevantni zaključci. Kvalitativna metoda kojom se dublje analizira sadržaj prije svega se koristi u drugim vrstama istraživanja, kao što je npr. dubinski intervju. Ipak, u ovom istraživanju služilo se i kvalitativnom metodom, jer u njoj se uzorci biraju namjerno i svrsishodno, budući da su bogati informacijama i omogućavaju dublji uvid i spoznaju problema ili pojave, te se stoga $u$ kontekstu ove disertacije čini korisnim i znanstveno relevantnim provesti anketu i kvalitativnom metodom, s obzirom da su ispitanici birani upravo prema prethodno spomenutom ključu.

Ispitanicima je postavljeno 27 pitanja. Uvodna tri pitanja bila su socio-demografske naravi: spol, dob i (ne)pripadnost nekoj vjerskoj zajednici, nakon čega smo prešli na pitanja vezana uz samu tematiku istraživanja. Tako su pitanja od br. 4 do br. 24. su bila pitanja s određenom tvrdnjom, a ispitanici su Likertovom ljestvicom izražavali svoje slaganje ili neslaganje s njome. Posljednja tri pitanja su bila otvorenog tipka u kojima su ispitanici mogli napisati što smatraju temeljnim postulatima suvremene medijske etike, što smatraju temeljnim postulatima teološke medijske etike, te iznijeti svoje prijedloge kako bi sve navedeno više zaživjelo u praksi. Svih 27 pitanja je bilo označeno kao obvezno, te nije bilo moguće predati anketu ako nije odgovoreno na sva pitanja. 


\subsection{Analiza i rasprava rezultata istraživanja provedenog među članovima Hrvatskog društva katoličkih novinara (HDKN)}

Istraživanje je provedeno anketom koja je preko predsjednice HDKN-a Suzane Peran Vrhovski upućena članovima društva. Anketni upitnik ispunio je 41 član. Načelno govoreći, nije riječ o velikom broju odgovora, no uzevši u obzir da su među članstvom članova HDKNa aktivna 124 člana, tada broj od 41 ispitanika predstavlja trećinu svih članova, što je prihvatljiv uzorak cjeline.

4.2.1. Prikaz i analiza rezultata na zatvorena pitanja

Većinu ispitanika čine muškarci (58,5\%), dok je 41,5\% žena (Grafikon 1).

\section{SPOL}

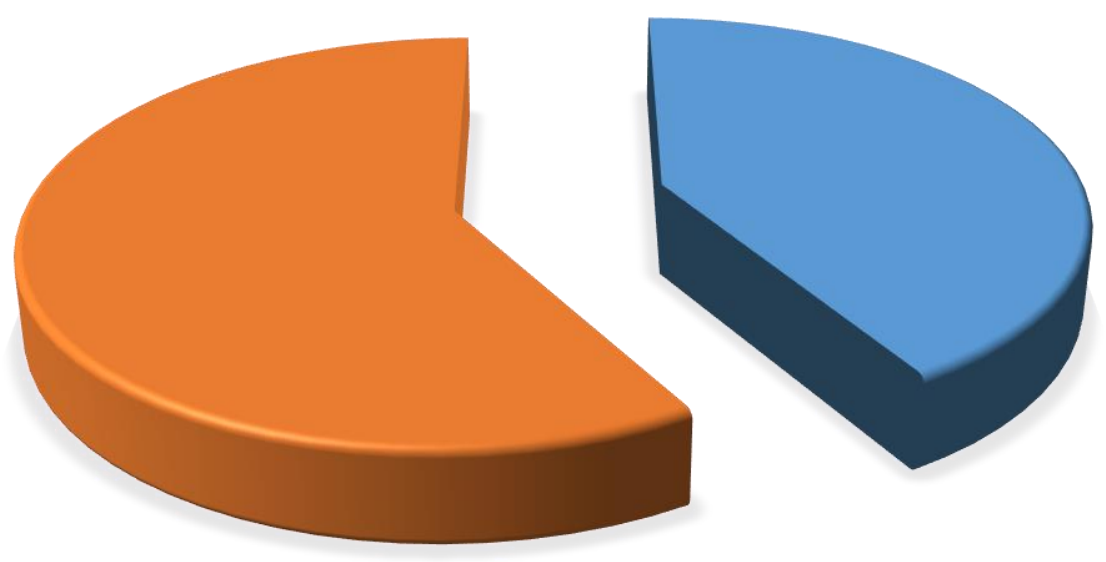

Grafikon 1. Struktura ispitanika po spolu $(\mathrm{N}=41)$ 
U skupini od 20 do 29 godina je 4,9\% ispitanika. U skupini od 30 do 39 godina ih je 12,9\%, dok je u skupini od 40 do 49 njih $31,7 \%$. U rasponu od 50 do 60 godina je $34,1 \%$, a $17,1 \%$ ispitanika ima preko 60 godina (Grafikon 2).

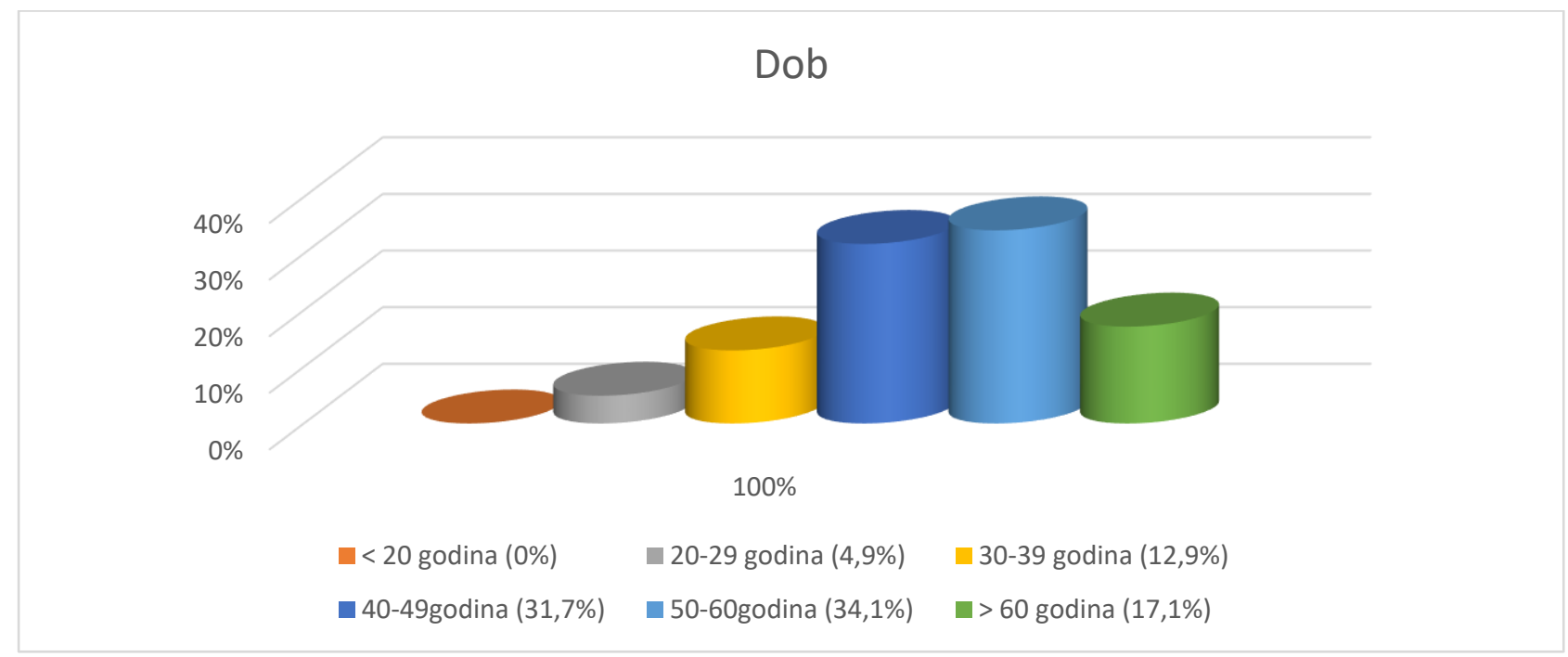

Grafikon 2. Struktura ispitanika po dobi $(\mathrm{N}=41)$

Na pitanje o vjerskom opredjeljenju 90,2\% ispitanih je odgovorilo da se smatraju praktičnim vjernicima katolicima, dok ih je 9,8\% odgovorilo da su nominalni vjernici katolici. Nitko nije odgovorio da je „vjernik nekatolik“ ili ,ateist/agnostik“, što su također bili ponuđeni odgovori (Grafikon 3). S obzirom da je riječ o članovima društva Hrvatskih katoličkih novinara, struktura ispitanika prema vjerskom opredjeljenju je očekivana.

\section{Vjersko opredjeljenje}

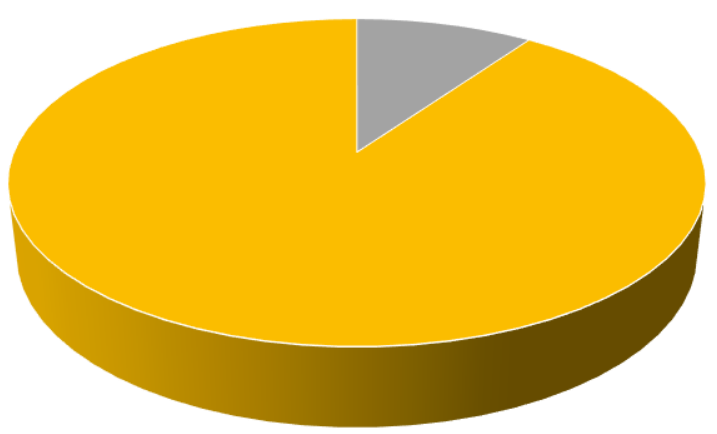

- Ateist/agnostik (0\%) - Vjernik nekatolik (0\%) - Nominalni vjernik katolik $(9,8 \%)$ - Praktičan vjernik katolik $(90,2 \%)$

Grafikon 3. Struktura ispitanika po vjerskom opredjeljenju $(\mathrm{N}=41)$ 
Svi ispitanici (100\%) su se u potpunosti (razina slaganja br. 5) složili s tvrdnjom: „Medijska etika je potrebna u suvremenom novinarstvu“ (Grafikon 4). Ovaj rezultat nimalo ne iznenađuje, štoviše posve je očekivan.

\section{Medijska etika je potrebna suvremenom novinarstvu}

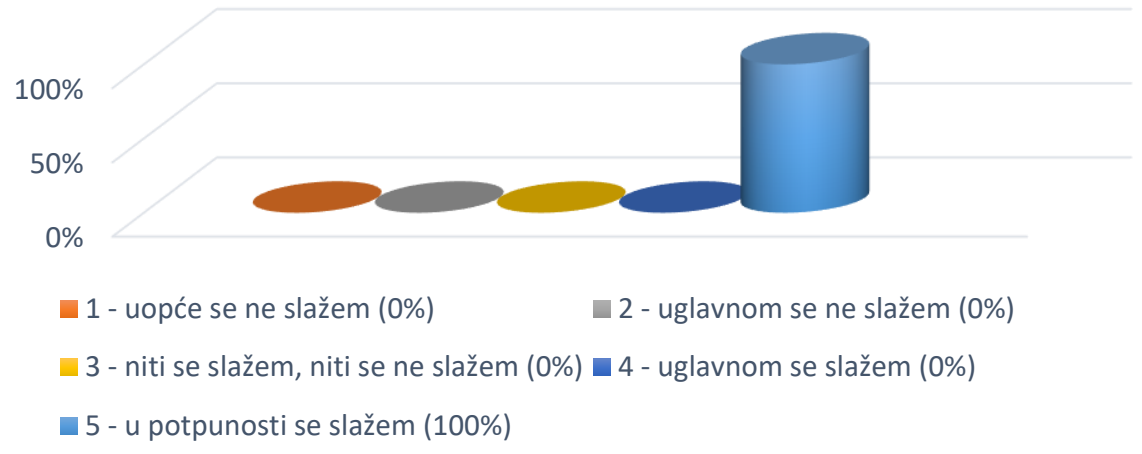

Grafikon 4. Razina slaganja s tvrdnjom o potrebi medijske etike u suvremenom novinarstvu $(\mathrm{N}=41)$

Tvrdnju da „novinari poznaju postulate medijske etike“ u potpunosti odbacuje (razina slaganja br. 1) $7,3 \%$ ispitanika, $34,1 \%$ ima razinu slaganja br. 2, najviše (39\%) ima razinu slaganja br. 3 , njih $17,1 \%$ ima razinu slaganja br. 4 , dok samo $2,4 \%$ u potpunosti smatra da novinari poznaju postulate medijske etike (razina slaganja br. 5) (Grafikon 5). Kod ovoga je pitanja vidljivo da ispitanici imaju relativno nisko mišljenje o svojim kolegama, tj. njihovom poznavanju medijske etike, za razliku od mišljenja koje imaju o svom poznavanju medijske etike, jer će u pitanjima o svom poznavanju medijske etike, što je vidljivo u kasnijim odgovorima, imati znatno pozitivnije mišljenje.

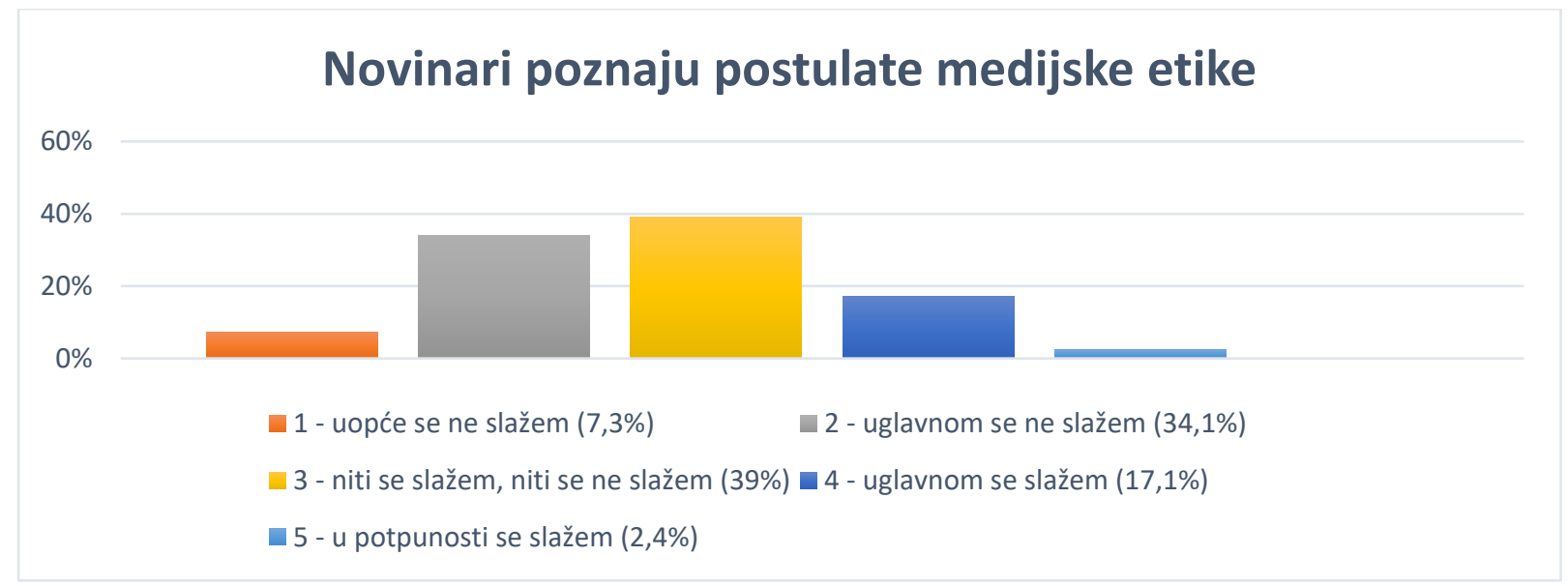

Grafikon 5. Razina poznavanja postulata medijske etike $(\mathrm{N}=41)$ 
Tvrdnju da „novinari poštuju postulate medijske etike“ u potpunosti odbacuje (razina slaganja br. 1) $14,6 \%$ ispitanika, neznatno više od pola, tj. 56,1\% ispitanika ima razinu slaganja br. 2, dok 29,3\% ima razinu slaganja br. 3. Nitko od ispitanika nije iskazao razinu slaganja br. 4 ili br. 5 (Grafikon 6).

\section{Novinari poštuju postulate medijske etike}

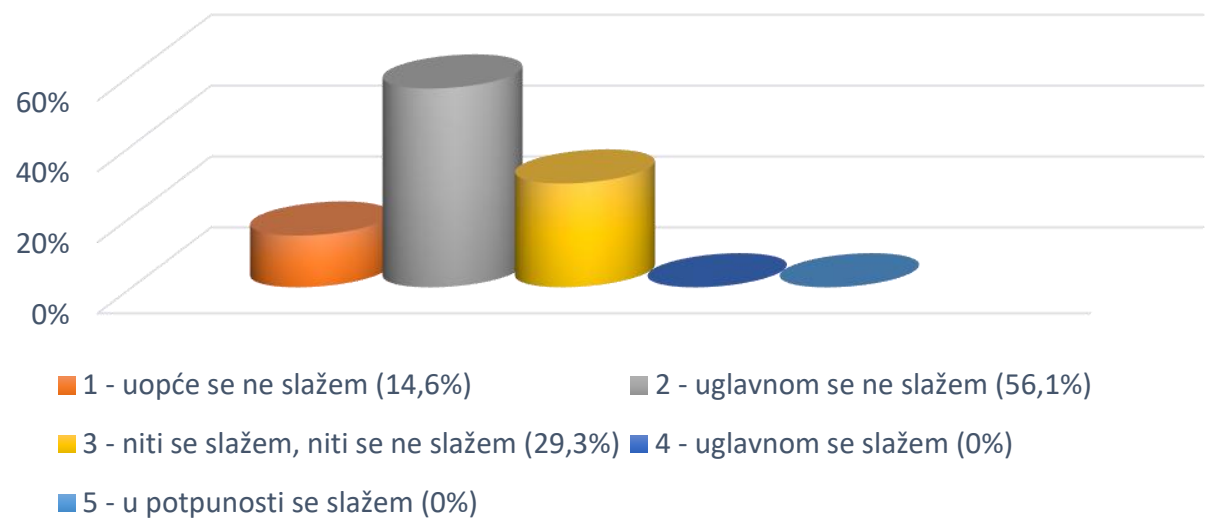

Grafikon 6. Razina poštivanja postulata medijske etike $(\mathrm{N}=41)$

Tvrdnju da „urednici i vlasnici medija poznaju postulate medijske etike“ u potpunosti odbacuje (,uopće se ne slažem“) 14,6\% ispitanika, 19,5\% ima razinu slaganja br. 2, najviše $(36,6 \%)$ ima razinu slaganja br. 3 , njih $26,8 \%$ ima razinu slaganja br. 4, dok 2,4\% ima razinu slaganja br. 5 (Grafikon 7).

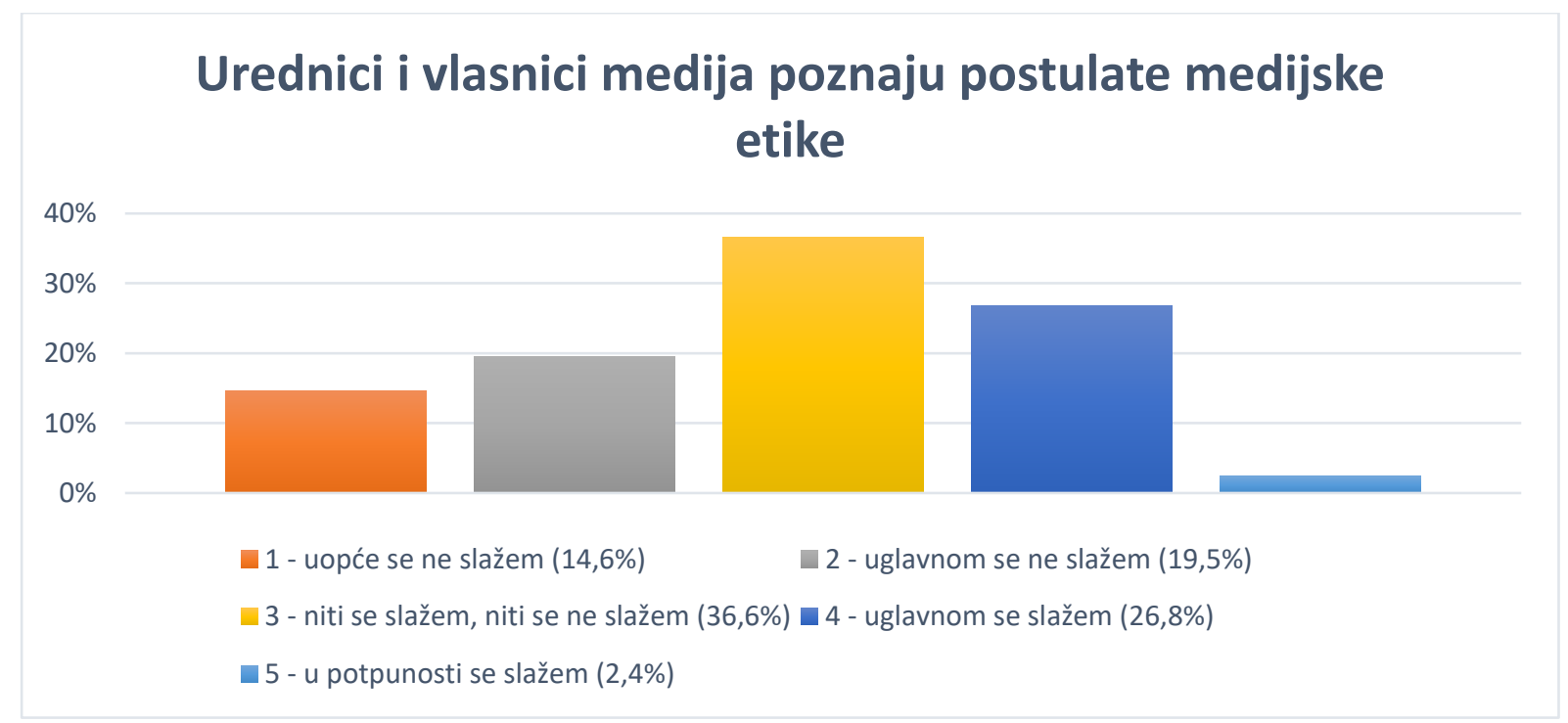

Grafikon 7. Razina poznavanja postulata medijske etike (urednici i vlasnici medija) $(\mathrm{N}=41)$ 
Čak 36,6\% ispitanika za tvrdnju da ,urednici i vlasnici medija poštuju postulate medijske etike“ kaže da se „uopće ne slaže“. Neznatno veći postotak (39\%) ima razinu slaganja br. $2 \mathrm{~s}$ ovom tvrdnjom, $22 \%$ ima razinu slaganja br. 3, dok 2,4\% ima razinu slaganja br. 4. Nitko nije označio da se „u potpunosti slaže“, tj. da ima razinu slaganja br. 5 (Grafikon 8). Kao i za ostale kategorije, i ovdje ispitanici, iako imaju nisko mišljenje o poznavanju medijske etike onih o kojima ih se pita, još niže mišljenje imaju o njihovom postupanju u skladu s postavkama i postulatima medijske etike.

\section{Urednici i vlasnici medija poštuju postulate medijske etike}

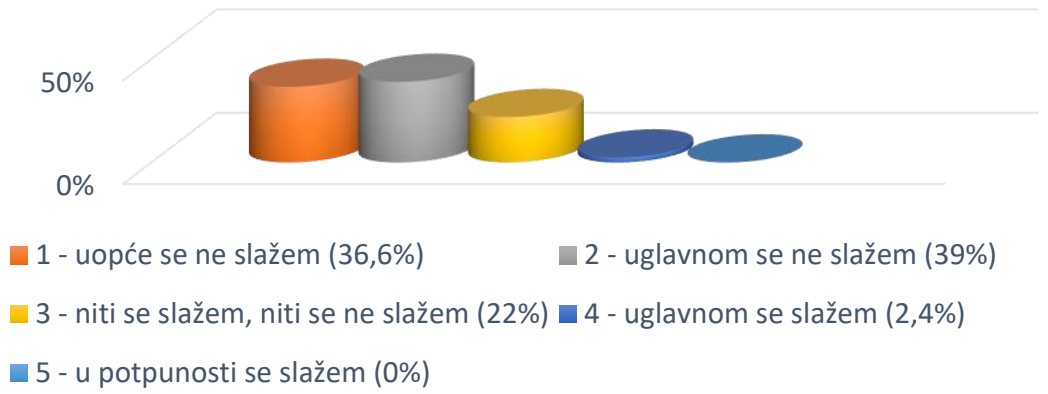

Grafikon 8. Razina poštivanja postulata medijske etike (urednici i vlasnici medija) $(\mathrm{N}=41)$

Odgovorom „uopće se ne slažem“ tvrdnju o tome poznaje li publika postulate medijske etike označilo je 14,6\% ispitanika. Razinu slaganja br. 2 je označilo 34,1\% ispitanika, a br. 3 njih 39\%, dok je razinu slaganja br. 4 odabralo 9,8\%, a br. 5 samo 2,4\% (Grafikon 9).

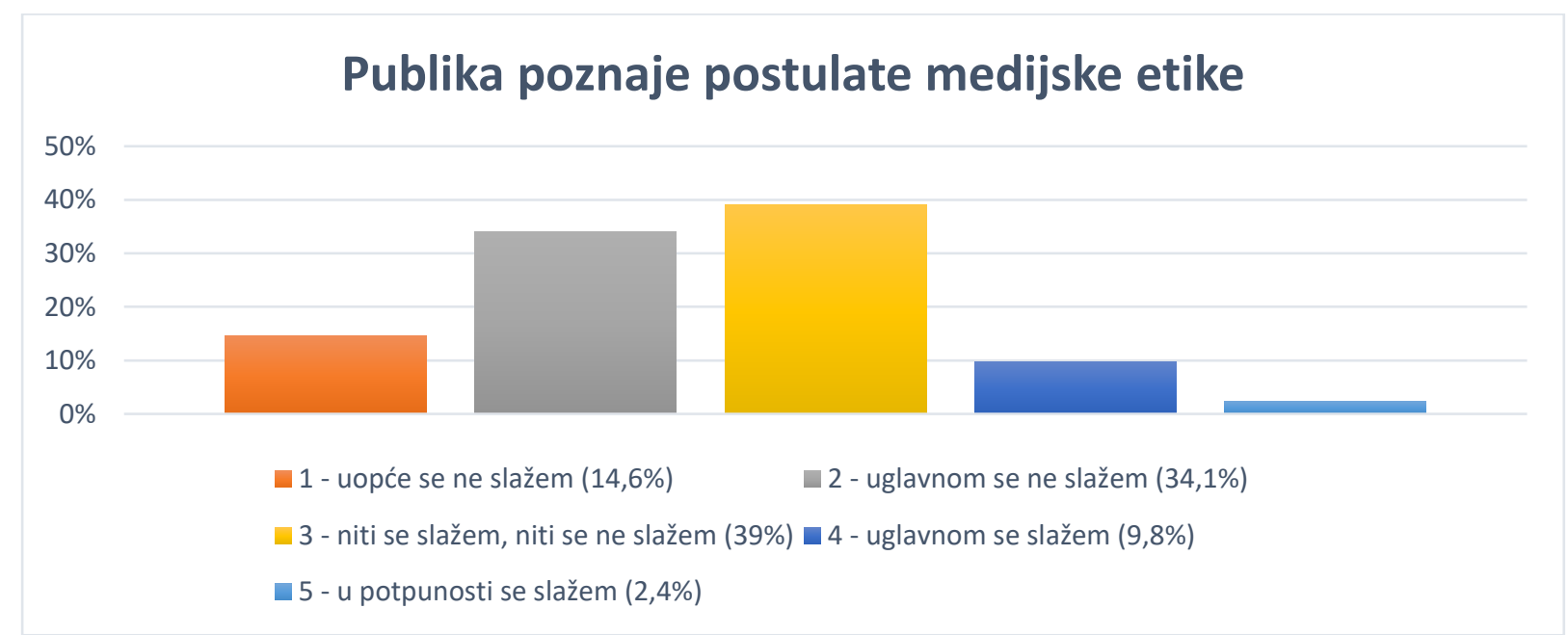

Grafikon 9. Razina poznavanja postulata medijske etike (publika) $(\mathrm{N}=41)$ 
Gotovo polovica, tj. 48,8\% ispitanika se „uopće ne slaže“ s tvrdnjom da publika medijske sadržaje bira u skladu s postulatima medijske etike, $34,1 \%$ ima razinu slaganja br. 2, a $9,8 \%$ je na razini slanja br. 3 . Na razini slaganja br. 4 je 7,3\%, dok nitko od ispitanika nije odgovorio da se „u potpunosti slaže“ s navedenom tvrdnjom (Grafikon 10).

\section{Publika bira medijske sadržaje u skladu s medijskom etikom}

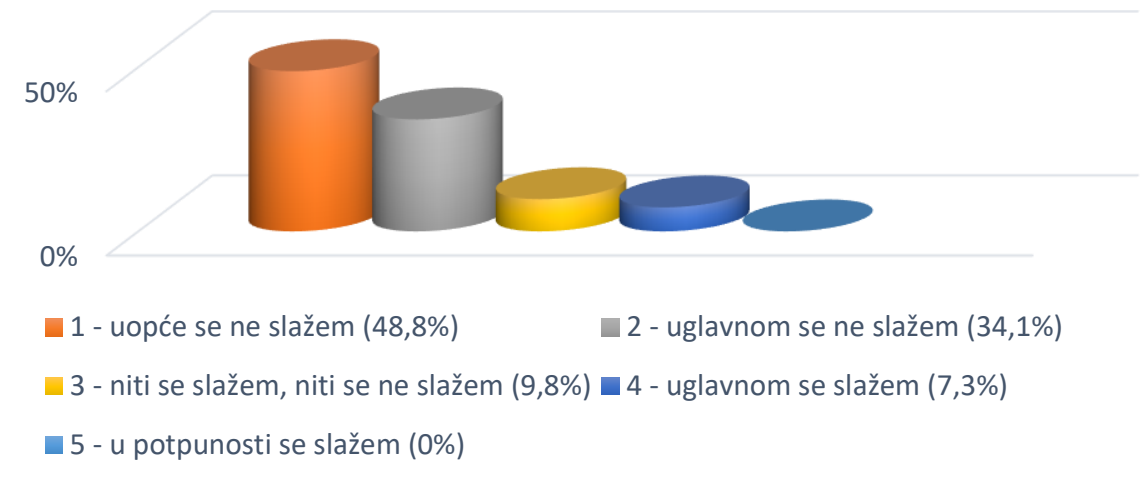

Grafikon 10. Biranje medijskih sadržaja u skladu s postulatima medijske etike $(\mathrm{N}=41)$

Da se „niti slažu, niti ne slažu“ s tvrdnjom o poznavanju postulata medijske etike potvrdilo nam je 7,3\% posto ispitanika (razina slaganja br. 3), 26,8\% na razini slaganja br. 4 , dok se $65,9 \%$ ispitanika „u potpunosti slaže“ s navedenom tvrdnjom. Nitko nije izrazio razinu slaganja br. 1 ili br. 2 (Grafikon 11). Iz ovih je odgovora vidljivo da ispitanici za razliku od ostalih skupina o kojima su pitani, a za koje smatraju da ne poznaju postulate medijske etike, za sebe navode da ih veoma dobro poznaju.

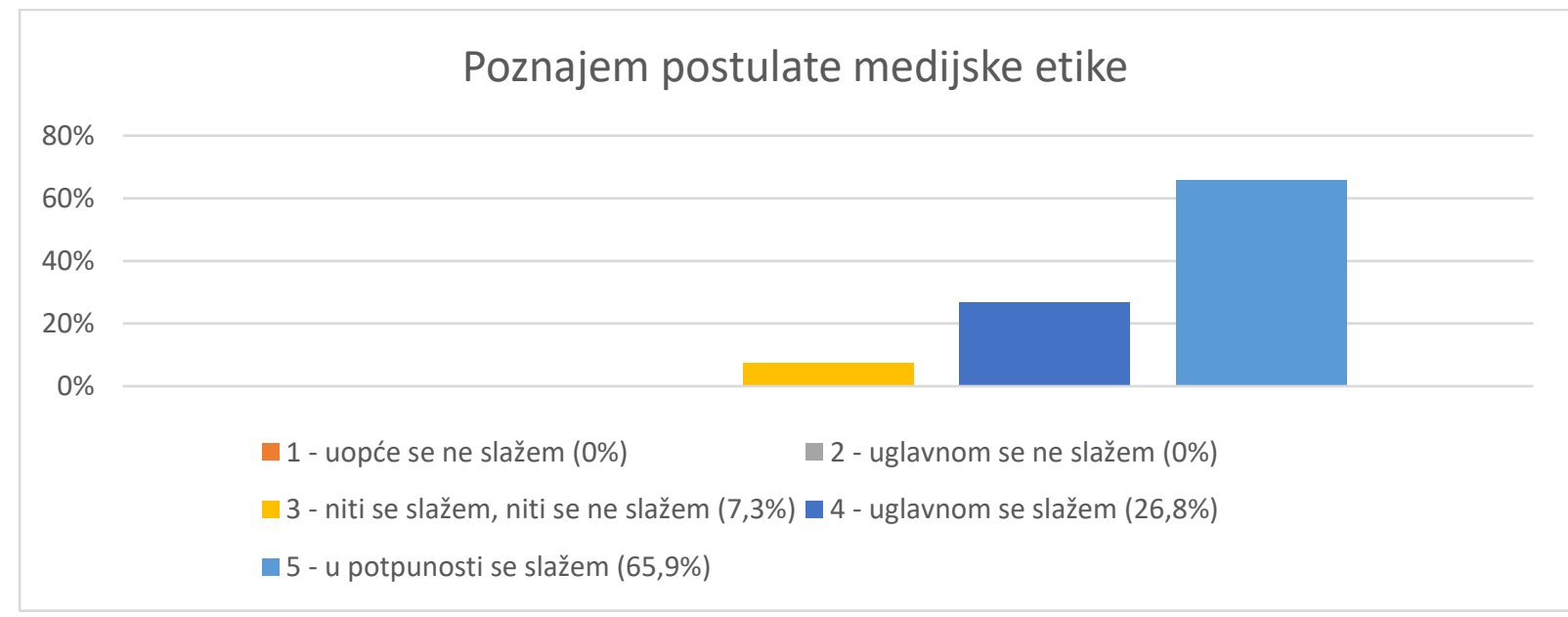

Grafikon 11. Percepcija vlastitog poznavanja postulata medijske etike $(\mathrm{N}=41)$ 
Nitko od ispitanika se nije izjasnio da se „uopće ne slaže“ s tvrdnjom „poštujem postulate medijske etike u svom djelovanju“", 2,4\% se izjasnilo na razini slaganja br. 2, dok se $7,3 \%$ ispitanika izjasnilo na razini br. 3. Na razini slaganja br. 4 izjasnilo se $34,1 \%$ ispitanika, a na razini br. 5 nešto više od pola, tj. 56,1\% (Grafikon 12). I kod odgovora na ovu tvrdnju javlja se sličan zaključak kao u prethodnom pitanju, a vezan je uz samoprocjenu, to jest uz odnos vrednovanja tuđeg i vlastitog poznavanja medijske etike i djelovanja u skladu s tim.

\section{Poštujem postulate medijske etike u svom djelovanju}

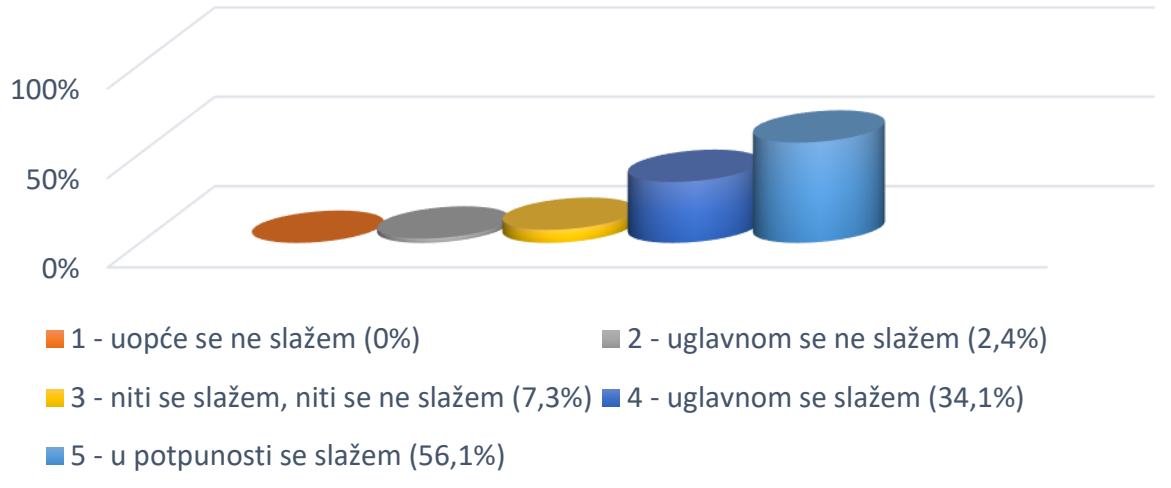

Grafikon 12. Percepcija vlastitog poštivanja postulata medijske etike $(\mathrm{N}=41)$

S tvrdnjom da je „teološka etika potrebna u suvremenom novinarstvu“ nije se složio nitko na razini slaganja br. 1 ili 2, dok se 7,3\% ispitanika složilo na razini br. 3, a na razini br. 4 se izjasnilo $17,1 \%$ ispitanika. Daleko najviše, čak 75,6\% izjasnilo se da se „u potpunosti slaže"s navedenom tvrdnjom (Grafikon 13).

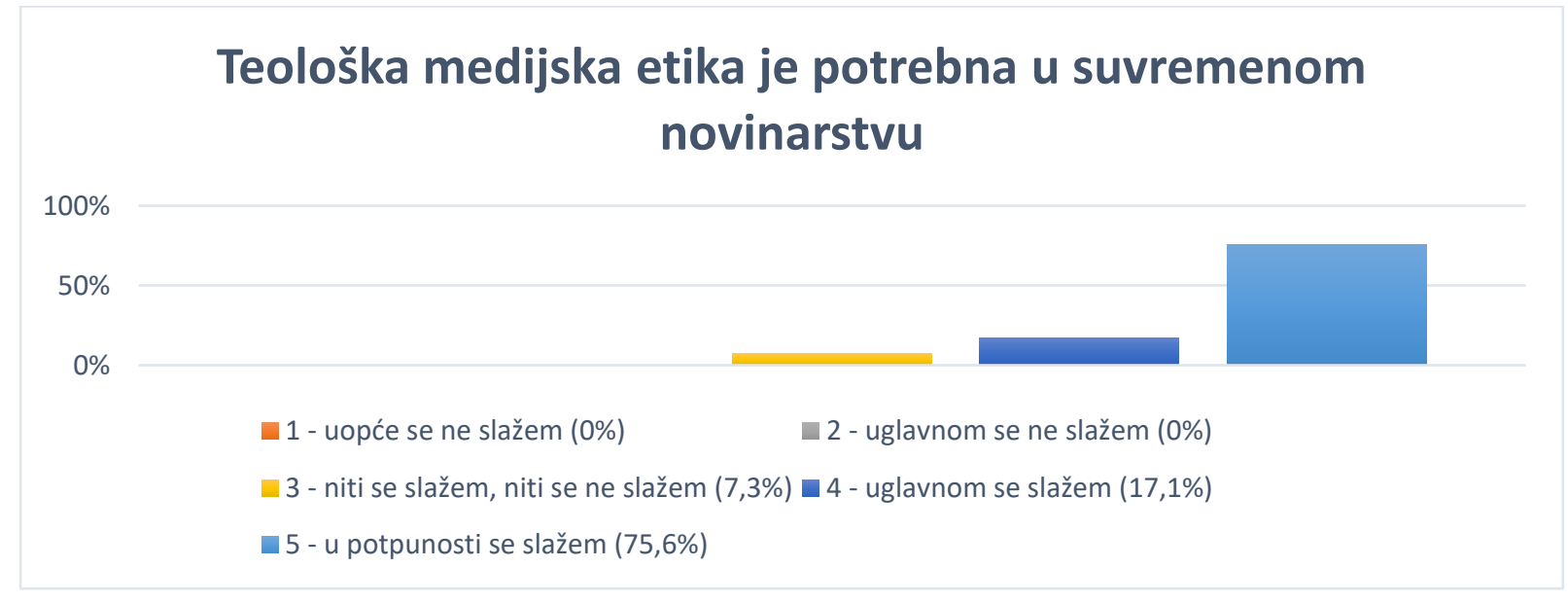

Grafikon 13. Potreba teološke medijske etike $(\mathrm{N}=41)$ 
Čak 26,8\% ispitanika se „uopće ne slaže“ s tvrdnjom da „novinari poznaju postulate teološke medijske etike“, $29,3 \%$ se slaže na razini slaganja br. 2, isti postotak je na razini slaganja br. 3, dok ih $14,6 \%$ na razini slaganja br. 4. Nitko se nije izjasnio da se slaže u potpunosti (Grafikon 14).

\section{Novinari poznaju postulate teološke medijske etike}

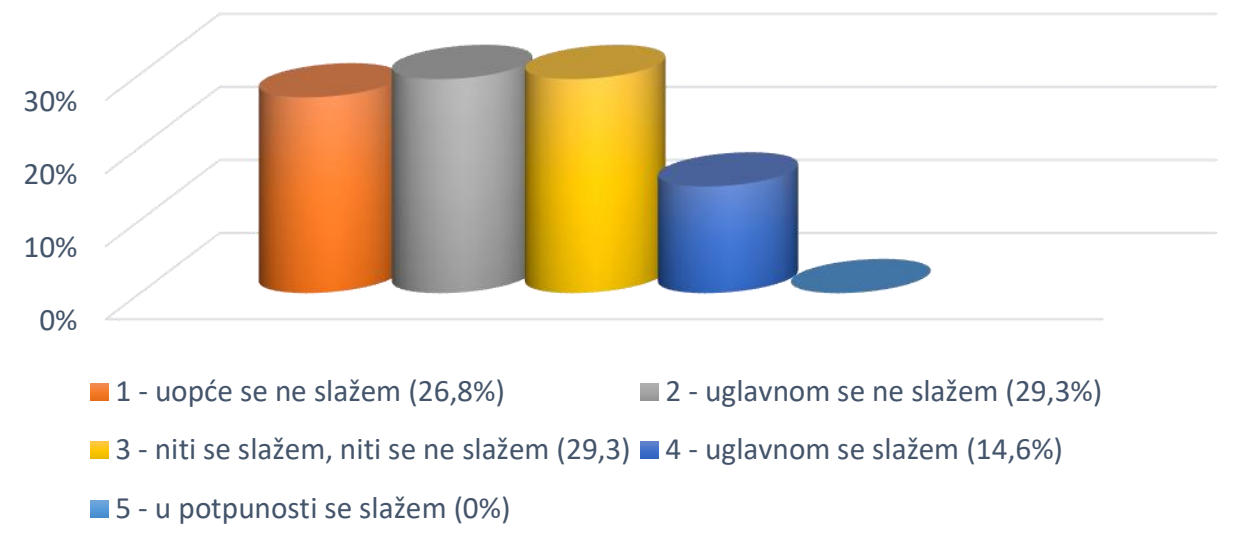

Grafikon 14. Poznavanje postulata teološke medijske etike (novinari) $(\mathrm{N}=41)$

Čak 31,7\% ispitanika se s tvrdnjom da „novinari poštuju postulate teološke medijske etike“" složilo na razini slaganja br. 1, što znači da se uopće ne slažu s njom, dok ih je gotovo polovica, to jest $48,8 \%$ bilo na razini slaganja br. 2 . Na razini slaganja br. 3 je $17,1 \%$, a na razini slaganja br. 4 samo 2,4\%. Nitko među ispitanicima se nije izjasnio da se u potpunosti slaže s navedenom tvrdnjom (razina slaganja br. 5) (Grafikon 15).

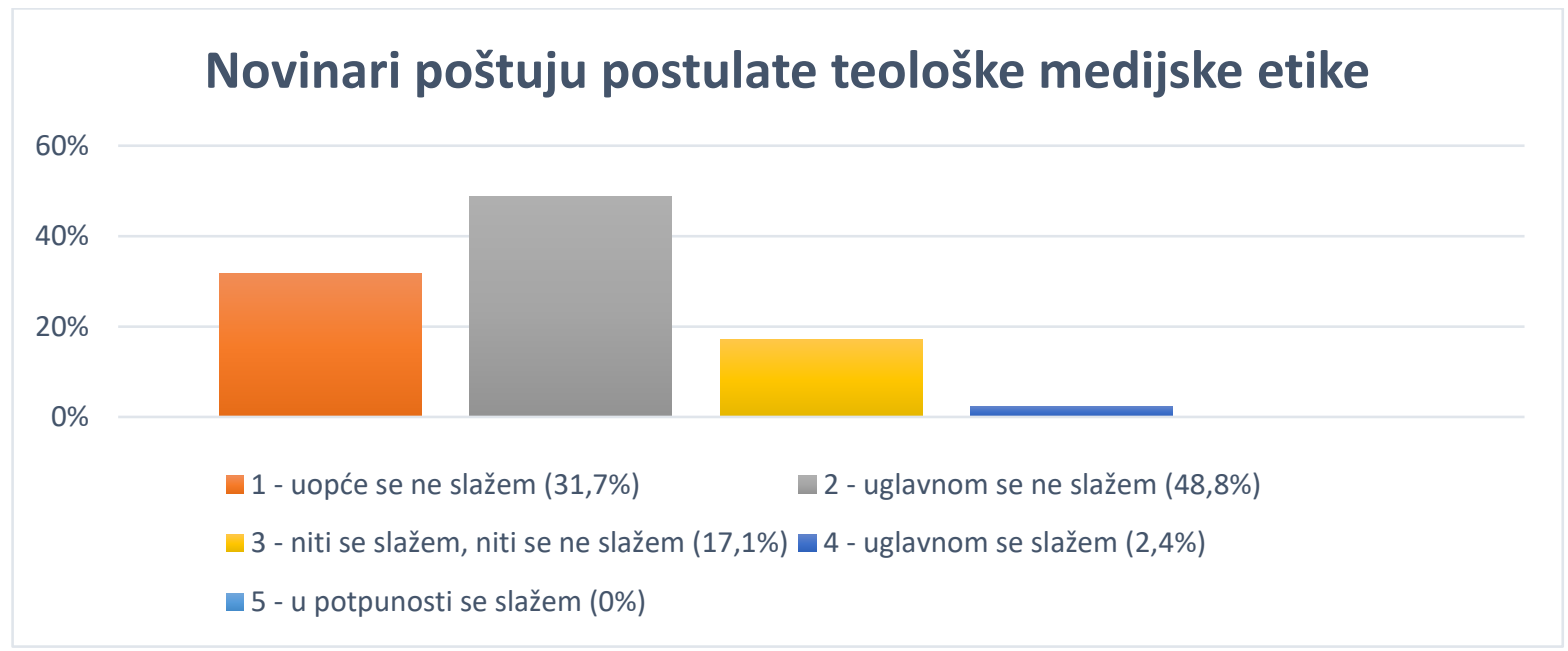

Grafikon 15. Poštivanje postulata teološke medijske etike (novinari) $(\mathrm{N}=41)$ 
Na razini slaganja br. $1 \mathrm{~s}$ tvrdnjom da ,urednici i vlasnici medija poznaju postulate teološke medijske etike" odgovorilo je $22 \%$ ispitanika, na razini slaganja br. 2 njih $36,6 \%$, na razini slaganja br. 3 je 26,8\%, na razini slaganja br. 4 je 16,6\% ispitanika, dok nitko nije dao odgovor na razini slaganja br. 5 (Grafikon 16).

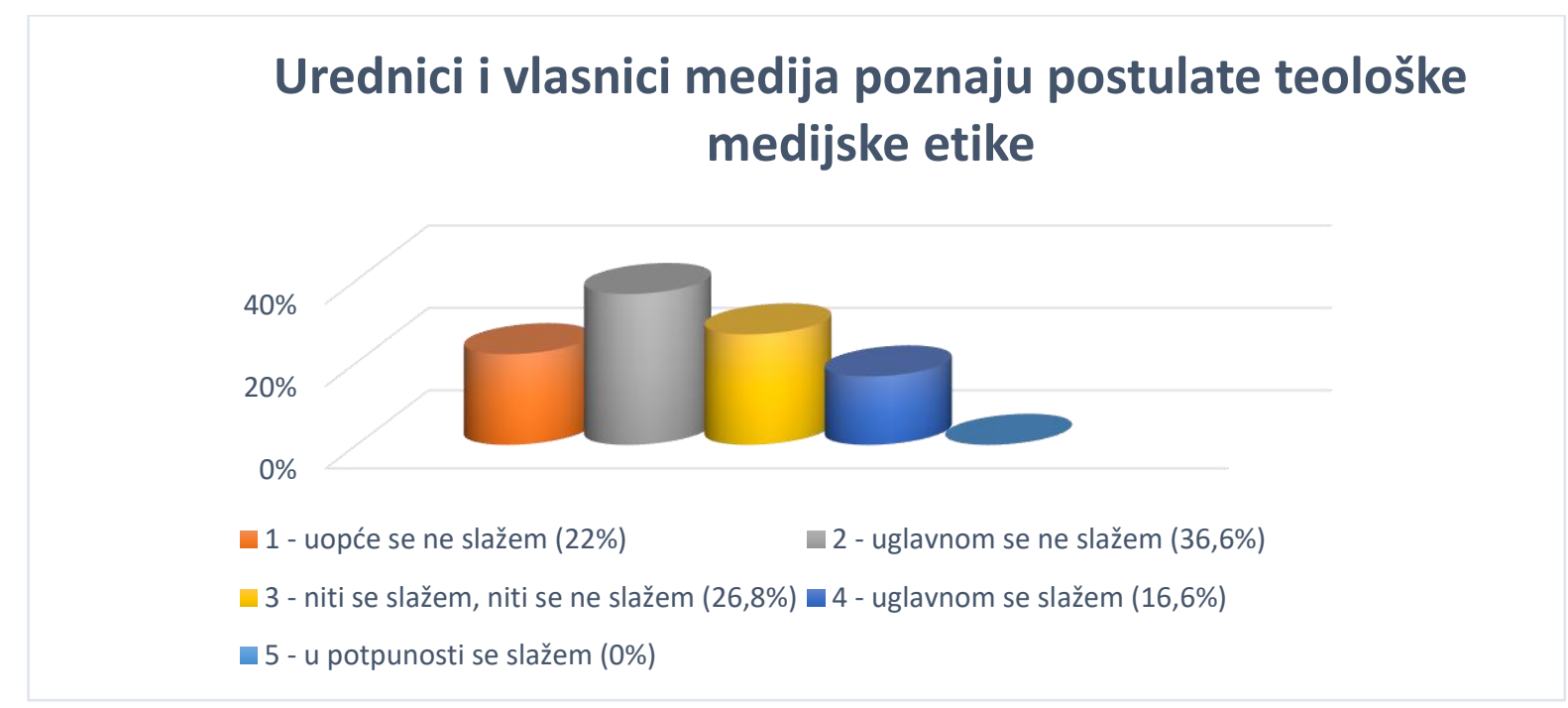

Grafikon 16. Poznavanje postulata teološke medijske etike (urednici i vlasnici medija) $(\mathrm{N}=41)$

Čak 39\% ispitanika je na razini slaganja br. 1 u odnosu na tvrdnju da ,urednici i vlasnici medija poštuju postulate teološke medijske etike“, te su tako jasno istaknuli da se uopće s njom ne slažu, dok ih je nešto manje od pola, to jest 43,9\% dalo odgovor na razini slaganja br. 2 (uglavnom se ne slažem). Na razini slaganja br. 3 bilo je 14,6\% ispitanika, a na razini slaganja br. 4 samo 2,4\%. Nitko među ispitanicima se nije izjasnio da se u potpunosti slaže s navedenom tvrdnjom (Grafikon 17).

\section{Urednici i vlasnici medija poštuju postulate teološke medijske etike}

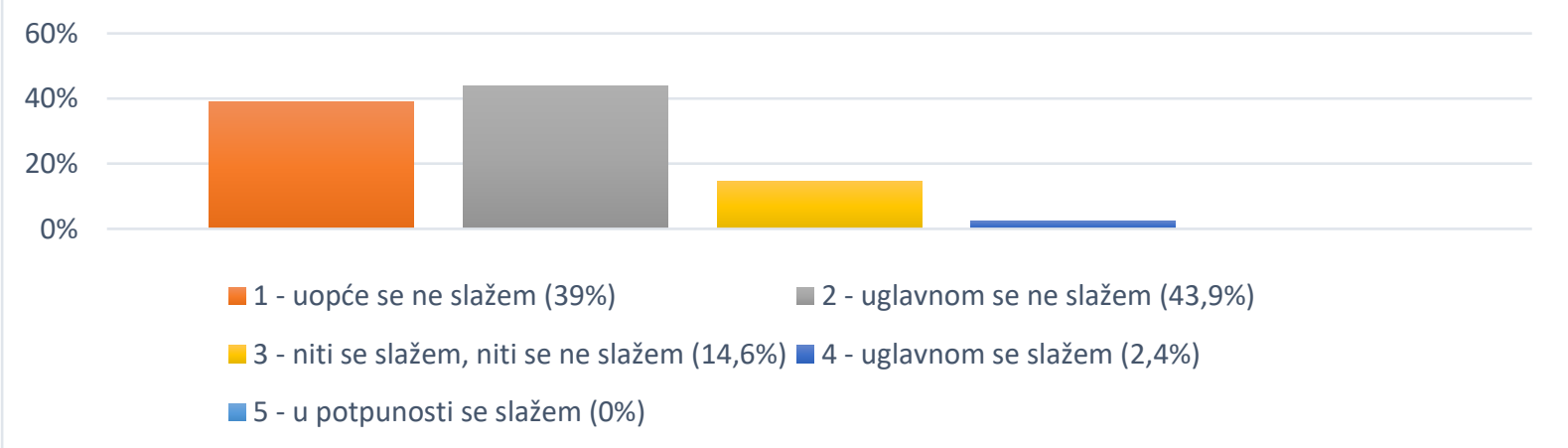

Grafikon 17. Poštivanje postulata teološke medijske etike (urednici i vlasnici medija) $(\mathrm{N}=41)$ 
S tvrdnjom da „publika poznaje postulate teološke medijske etike“ „uopće se ne slaže“ 29,3\% ispitanih. Stupanj slaganja br. 2 je označilo 36,6\% ispitanika, a br. 3 njih 29,3\%, dok je stupanj slaganja br. 4 odabralo 4,9\%. Nitko od ispitanika nije odgovorio da se „u potpunosti slaže“ (razina br. 5) s navedenom tvrdnjom (Grafikon 18).

\section{Publika poznaje postulate teološke medijske etike}

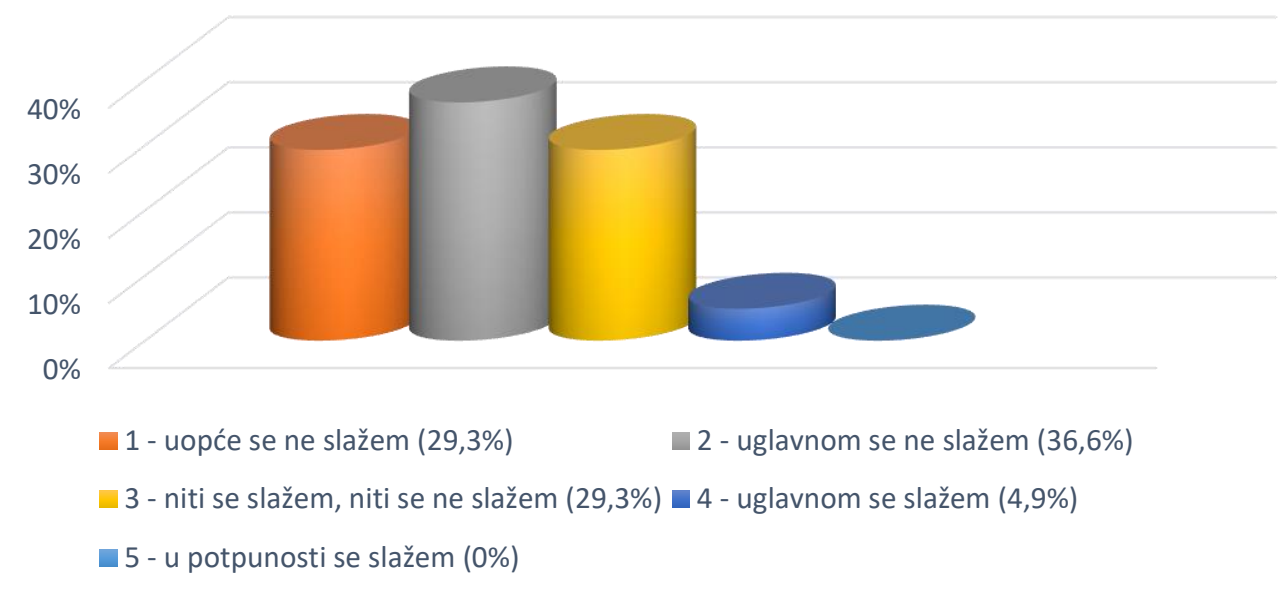

Grafikon 18. Poznavanje postulata teološke medijske etike (publika) $(\mathrm{N}=41)$

Među ispitanicima bilo je 36,6\% koji se „uopće ne slažu“ s tvrdnjom da „publika bira medijske sadržaje u skladu s postulatima teološke medijske etike“, $41,5 \%$ odredilo je razinu slaganja br. 2, a 19,5\% je na razini slanja br. 3. Na razini slaganja br. 4 je 2,4 \%, dok nitko od ispitanika nije odgovorio da se „u potpunosti slaže“s navedenom tvrdnjom (Grafikon 19).

\section{Publika u skladu s postulatima teološke medijske etike bira medijske sadržaje}

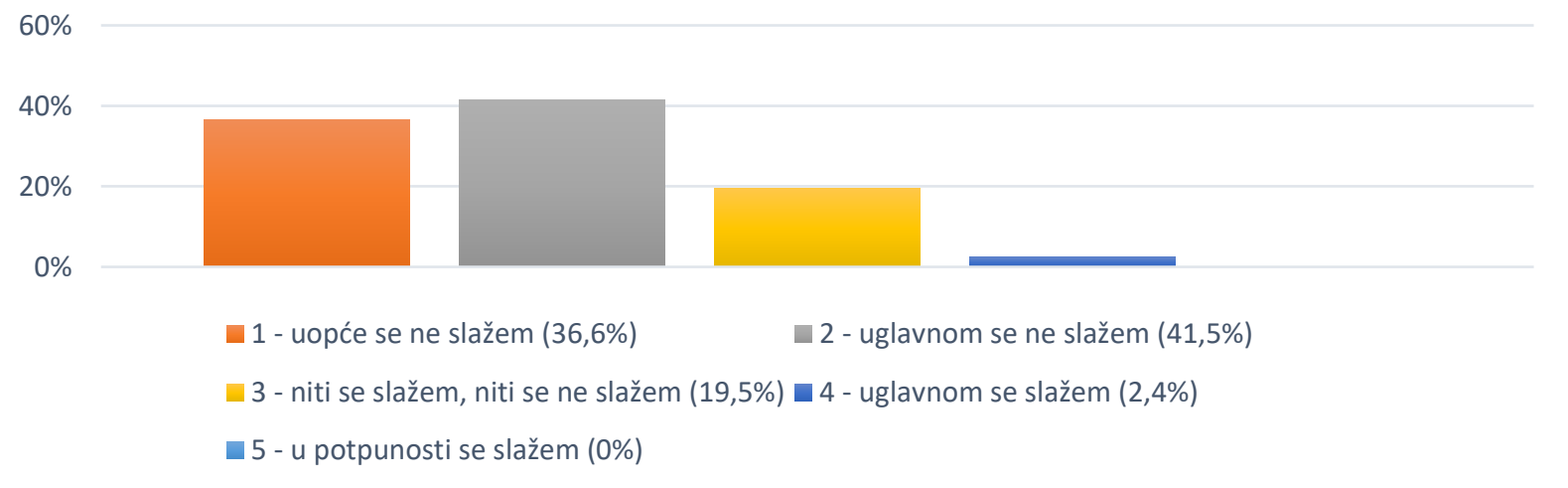

Grafikon 19. Biranje medijskih sadržaja u skladu s postulatima teološke medijske etike $(\mathrm{N}=41)$ 
Nitko se na razini slaganja br. 1 nije složio s tvrdnjom ,poznajem postulate teološke medijske etike“, a na razini slaganja br. 2 glede ove tvrdnje izjasnilo se 2,4\% ispitanika, 9,8\% ispitanika složilo na razini br. 3 , a na razini br. 4 se izjasnilo $26,8 \%$ ispitanika. Daleko najviše, čak 61\% izjasnilo se da se „u potpunosti slaže“s navedenom tvrdnjom (Grafikon 20).

\section{Poznajem postulate teološke medijske etike}

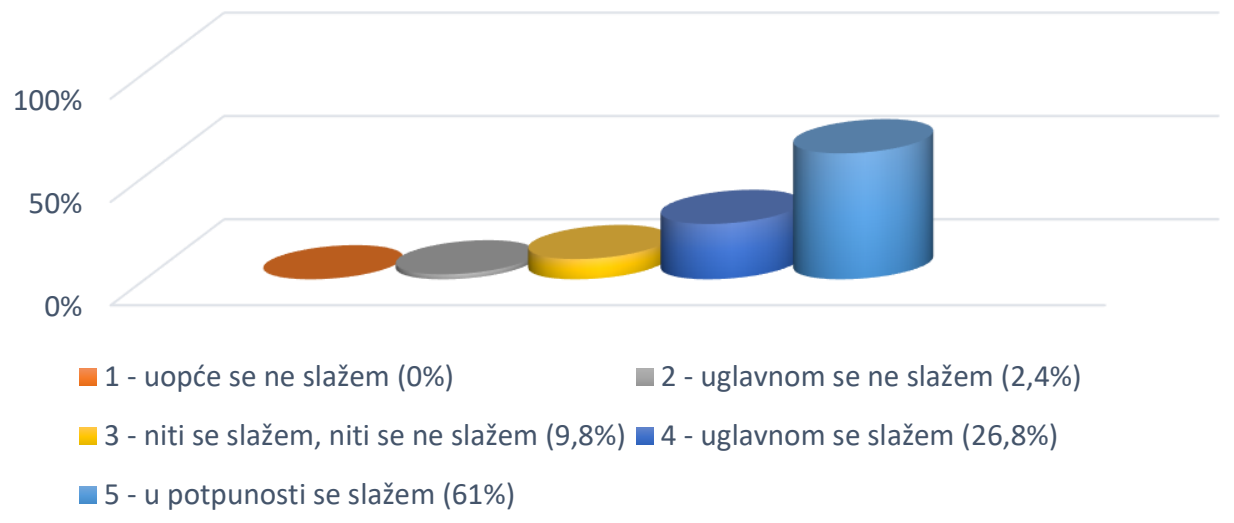

Grafikon 20. Percepcija poznavanja postulata teološke medijske etike $(\mathrm{N}=41)$

Nitko se nije izjasnio da se „uopće ne slaže“ s tvrdnjom „poštujem postulate teološke medijske etike u svom djelovanju“, 4,9\% se izjasnilo na razini slaganja br. 2, dok se 9,8\% ispitanika izjasnilo na razini slaganja br. 3. Na razini slaganja br. 4 izjasnilo se 31,7\% ispitanika, a na razini br. 5 čak više od pola, tj. 53,7\% (Grafikon 21).

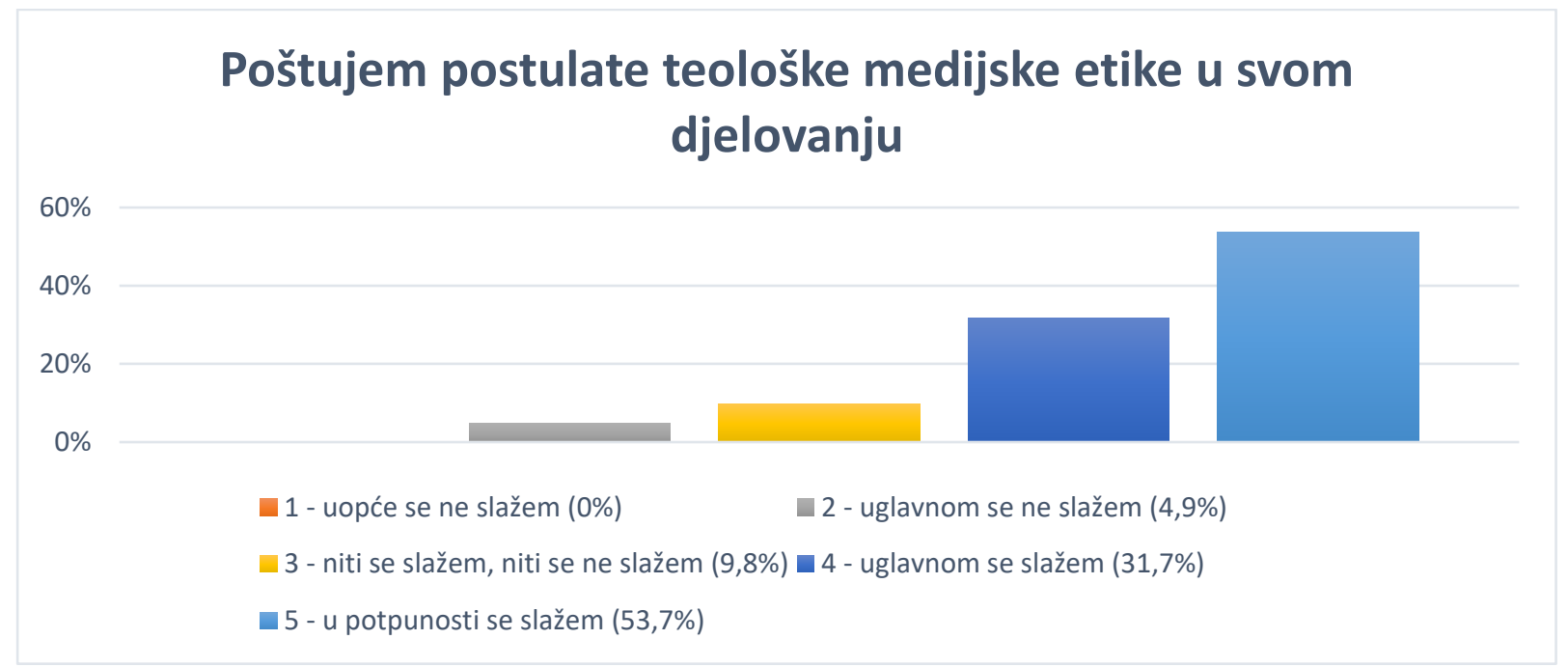

Grafikon 21. Percepcija poštivanja postulata teološke medijske etike $(\mathrm{N}=41)$ 
Nitko se nije izjasnio da se „uopće ne slaže“ s tvrdnjom da „medijska etika može pomoći teološkoj medijskoj etici“, 2,4\% se izjasnilo na razini slaganja br. 2, dok se $22 \%$ ispitanika izjasnilo na razini br. 3. Na razini slaganja br. 4 izjasnilo se $39 \%$ ispitanika, a na razini br. 5 njih 36,6\% (Grafikon 22).

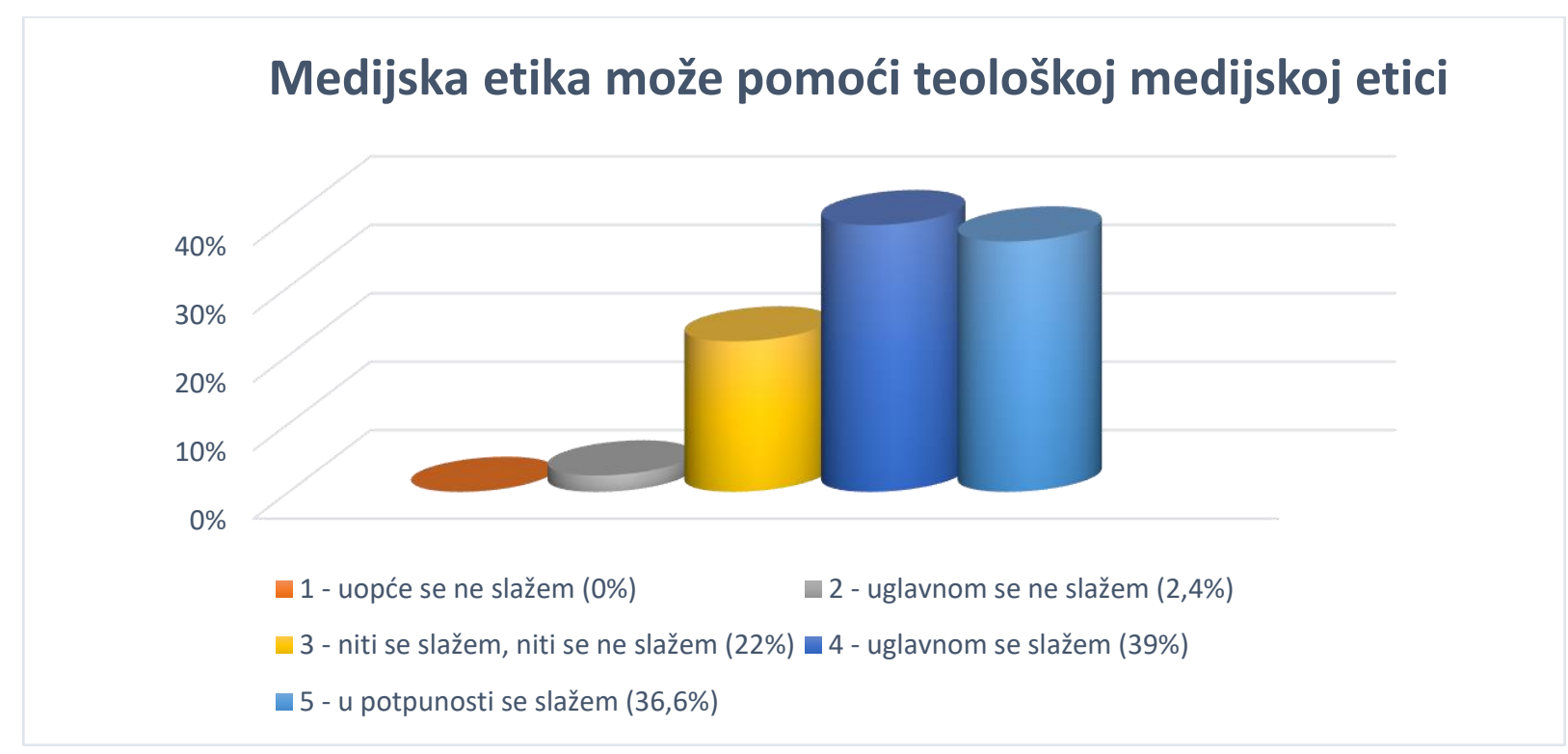

Grafikon 22. Pomoć medijske etike $(\mathrm{N}=41)$

Ispitanici su se u 9,8\% na razini slaganja br. 3 izjasnili o tvrdnji da ,teološka medijska etika može pomoći medijskoj etici“, $26,8 \%$ na razini slaganja br. 4 , dok se $63,4 \%$,u potpunosti slaže“ s navedenom tvrdnjom. Nitko nije izrazio razinu slaganja br. 1 ili br. 2 (Grafikon 23).

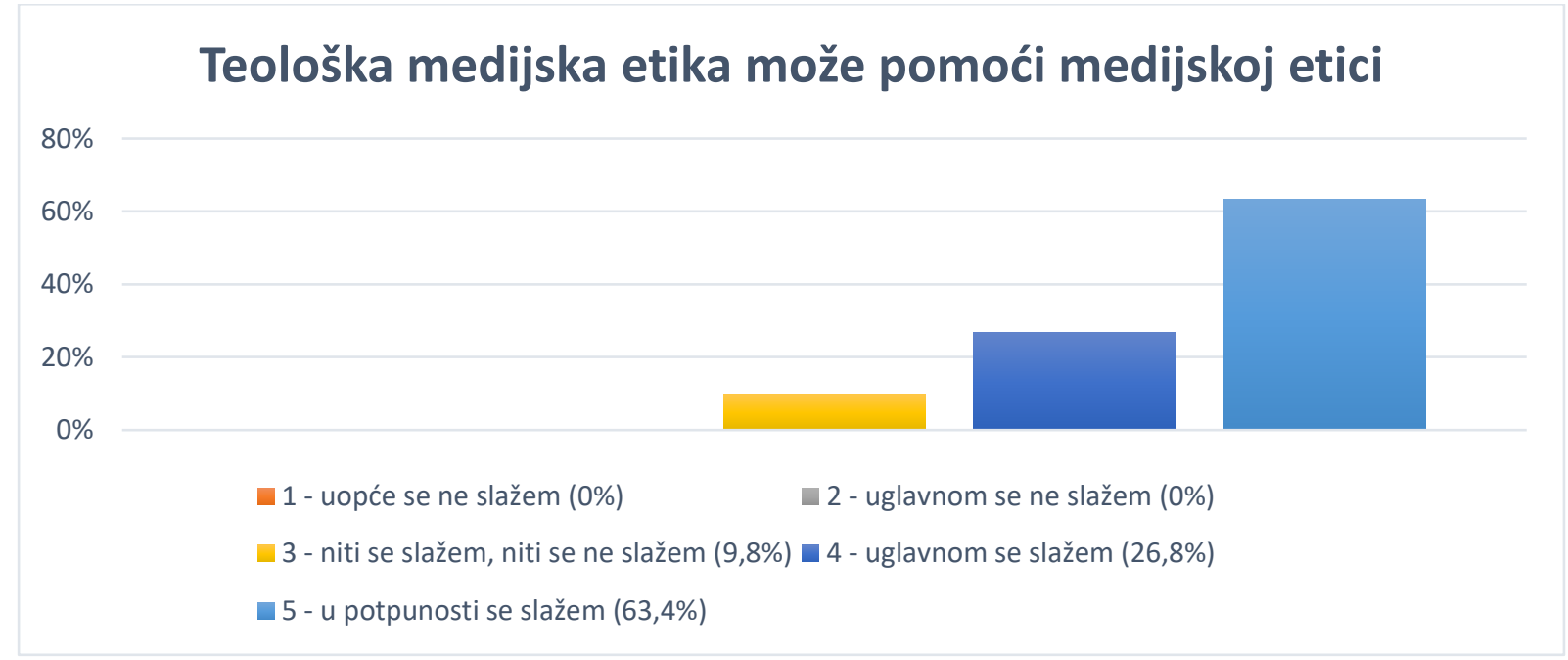

Grafikon 23. Pomoć teološke medijske etike $(\mathrm{N}=41)$ 
Ispitanici - njih 22\% - na tvrdnju ,medijska etika i teološka medijska etika nemaju značajnijih razlika“ odgovorili su s „uopće se ne slažem“ (razina slaganja 1). Stupanj slaganja br. 2 je označilo 14,6\% ispitanika, jednako kao i br. 3, stupanj slaganja br. 4 odabralo je $36,6 \%$, a br. 5 njih $12,2 \%$ (Grafikon 24).

\section{Medijska etika i teološka medijska etika nemaju značajnijih razlika}

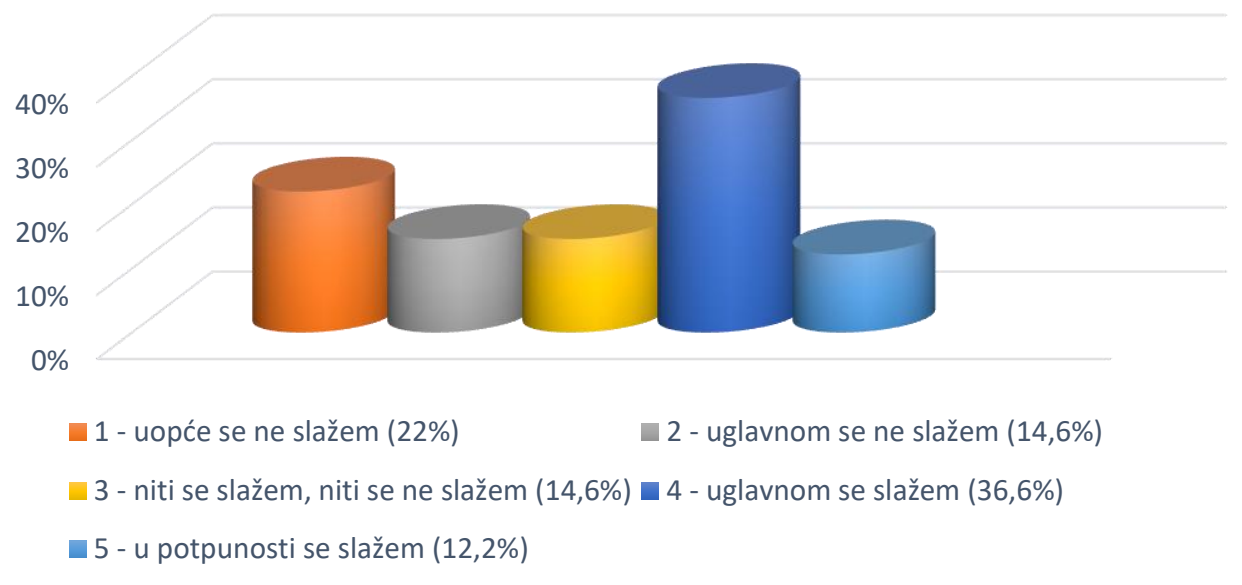

Grafikon 24. Ima li značajnijih razlika između medijske etike i teološke medijske etike? $(\mathrm{N}=41)$

\subsubsection{Prikaz i analiza odgovora na otvorena pitanja}

Na prvo u nizu pitanja otvorenog tipa koje glasi: „Što smatrate temeljnim postulatom medijske etike?" ispitanici su dali sljedeće odgovore: „Istinitost“, „Odgovornost“, „Objektivnost“”, „Istinitost““, „Slijediti načela istinitosti, objektivnosti, slobode i poštenja te odgovornosti“, „Istinoljubivost“, „Istina“, „Istinitost, čuvanje dostojanstva ljudske osobe, svrhovitost novinskih informacija“, „Istina! Pisati i objavljivati istinu“, „Istinitost i objektivnost“, „Objektivnost, istinitost i odgovornost u djelovanju“, „Istina, opće dobro, pozitivna nastojanja“, „Istina“, „Odgovornost i istinitost“”, „Istinitost, objektivnost, odgovornost prema publici i svijest o golemoj moći medija“, „Zdrava nakana i komunikacija, te objektivno pisanje“, „Istina u izvještavanju, poštujući slobodu medija i uz puni osjećaj za odgovornost u djelovanju“, „Iskrenost, istinoljubivost, pravičnost, tolerancija“, „Odgovornost“, „Poštivanje osobe. Istina“, „Objavljivati korektno i istinito“, „Istina“, „Odgovornost za informiranje i javno mnijenje na temelju istinitosti izvještavanja“, „Odgovornost“, „Istina“, „Istinitost“, „Istinitost, objektivnost“, „Istina, pravednost i ljubav - 
slobodni dijalog“, „Govoriti istinu, poštivati dostojanstvo ljudske osobe“, „Odgovornost“", „Zaštita privatnosti i digniteta osobe“, „Objektivnost“, „Uvažavati različita mišljenja“, „Istina radi općeg dobra“, „Istinitost, provjerenost“, „Dostojanstvo ljudske osobe“, „Istina“, „Uvažavanje“, „Istina“, „Poštenje“.

Iz dobivenih je odgovora vidljivo da se daleko najčešće spominje istina kao temeljni postulat medijske etike, a isto smo utvrdili i u teorijskom dijelu rada, kako za medijsku tako i za teološku medijsku etiku. Čak 28 ispitanika (od ukupno 41) navodi istinu kao temeljni, ili jedan od temeljnih postulata medijske etike. Kao važan postulat medijske etike očito doživljavaju i „odgovornost“ koju spominje čak deset ispitanika, kao i „objektivnost“ koju spominju samo jednom manje, tj. devet puta. Može se zaključiti da kao temeljne postulate medijske etike ispitanici doživljavaju istinu, odgovornost i objektivnost. Zasigurno je riječ o veoma važnim i neophodnim postulatima medijske etike, što smo i dokazali u prethodnom dijelu rada, to jest da je riječ o načelima i postulatima koji daju dobre temelje i za ostale postulate koji se na njih mogu nadograditi.

Na sljedeće pitanje: „Što smatrate temeljnim postulatom teološke medijske etike?“ ispitanici su dali sljedeće odgovore: „Istina“, „Istina“, „Istinitost“, „Istinitost“, „Istina“, „Istina“, „Slijediti načela istinitosti, objektivnosti, slobode i poštenja te odgovornosti; svaku osobu o kojoj se izvještava gledati u dostojanstvu djeteta Božjega“, „Odgovornost i edukacija“, „Evangelizacija“, „Istina“, „Poštivanje svih vjeroispovijesti i osobnog odnosa svakog njezinog pripadnika s Transcendentnim“, „Istina! Pisati i objavljivati istinu. Isticati dobro i dobre vijesti. Promicati nadu u dobro i smisao ljubavi“, „Istinitost, objektivnost i evangelizacija“, „Evangelizacija“, „Objektivnost, istinitost i odgovornost usklađeni s temeljnim vjerskim istinama“, „Istina, postojanje Boga ljubavi, milosrđa i providnosti““, „Objektivnost, vjerodostojnost“, „Istina“, „Istinito izvještavanje“, „Ne čini drugomu ono što ne želiš da drugi čini tebi! (tzv. "metoda vlastite kože")“, „Upoznavanje i življenje etičkih i moralnih vrednota, također i teološka naobrazba koja bi dala svoj obol“, „Istina u izvještavanju, poštujući slobodu medija i uz puni osjećaj za odgovornost u djelovanju“, „Poštovanje, otvorenost, ljubav“, „Ljubav prema svakom čovjeku. Istina“, „Objavljivati korektno i istinito“, „Istina“, „Odgovornost za izgradnju javnog mnijenja ali i cjelokupnog društva na temelju istinitosti ali i principu općeg dobra. Stvarati kulturu dobra u društvu“, „Istina na temeljima Kristovog nauka“, „Zdrava ljudskost, zdrava religioznost“, „Objektivnost“, „Slobodni dijalog u istini, pravednosti i ljubavi - poštivanju svake osobe“, 
„Gledati stvari u perspektivi 'Evangelii Gaudium'; gledati osobu kao Božje stvorenje; svojim radom naviještati evanđelje i pomoći ljudima da postignu svoj konačni cilj“, „Istinitost i dostojanstvo drugog čovjeka“, „Zaštita privatnosti i digniteta osobe“, „Istina iz ljubavi prema Bogu, za korist Crkve i dobro naroda“, „Istinitost, upućenost na dobro drugoga“, „Dostojanstvo ljudske osobe“, „Istina“, „Moralnost“, „Poštenje“.

I u ovom se odgovoru daleko najčešće spominje istina, u čak 25 od 41 odgovora. Nadalje se spominju objektivnost šest puta, a odgovornost pet. Ispitanici ističu i neke kategorije koje nisu isticali u prethodnom pitanju, a to su ljubav (tri puta) i evangelizacija (tri puta). Ti pojmovi su svakako imanentni upravo teološkoj medijskoj etici, te je logično da ispitanici to spominju kao odgovor na ovo pitanje, a ne na prethodno. Ipak, unatoč tim razlikama, može se zaključiti da su odgovori načelno slični, te da kao temeljne postavke i medijske etike i teološke medijske etike ispitanici ističu istinu, odgovornost $\mathrm{i}$ objektivnost.

Zaključak iz odgovora na ova pitanja je da ispitanici temeljem medijske etike i teološke medijske etike svakako važnim etičkim načelom smatraju istinu, koja im je ujedno i najvažnija, jer bez nje ostali postulati i načela nemaju svoj smisao, ali je isto tako jasno da vrlo važnima smatraju i odgovornost i objektivnost. Ta se načela nalaze i u kodeksima medijske ili novinarske etike. Analizirajući odgovore ispitanika i uspoređujući ih s onim što suvremena medijska etika, jednako kao i teološka medijska etika, apostrofiraju kao temeljna načela, može se kazati da su ispitanici upoznati s načelima medijske etike i teološke medijske etike. Dakako, medijska etika i teološka medijska etika, kao što je vidljivo i iz samih medijskih i novinarskih kodeksa časti koje smo spominjali, osim ovih postulata i načela koje su naveli ispitanici ističu i mnoge druge, no ovdje su novinari u svojim odgovorima iznosili ono što oni smatraju temeljnim postulatima, iznoseći one koje smatraju najvažnijima, tako da svakako nisu obuhvatili cijelu lepezu onih normi koje obrađuju i kojima se bave medijska etika i teološka medijska etika. Ipak, kad bi se u suvremenom medijskom svijetu istinski i dosljedno primjenjivali „samo“ postulati koje su ispitanici istaknuli kao najvažnije (istinitost, odgovornost i poštenje), mnoge ostale etičke diskusije o medijima postale bi irelevantne, a medijima i medijskim djelatnicima ne bi se prigovaralo da se ne drže temeljnih profesionalnih i etičkih načela svoje struke.

Na pitanje: „Što bi se trebalo učiniti da postulati medijske etike zažive u praksi?“, ispitanici su dali sljedeće odgovore:

- „Poučavati o medijskoj etici; ojačati strukovna prosudbena tijela - Vijeća časti.“ 
- „Neovisnost medija i objektivnost.“

- „Ukloniti privatni interes.“

- „Obrazovati etički osviještene novinare.“

- „Odgajati medijske djelatnike.“

- „Obrazovati kritičko mišljenje od najranije dobi i razvijati vrline.“

- „Odgajati i podučavati buduće novinare na dobro, za istinu, ne ih učiti lažno prikazivati događaje, skandalizirati i izmišljati. Razlučiti egoizam, taštinu, sklonost skandalima i promicanje hedonizma i razvratnosti od pravih vrijednosti života, ljubavi za obitelj, domovinu, opće dobro.“

- „Odgajati ljude.“

- „Informirani, educirani novinari s pravilno oblikovanom savješću.“

- „Raditi na dobronamjernosti, postaviti opće dobro za cilj.“

- „Trebalo bi svojim radom pokazati kršćanstvo.“

- „Svatko mora odgovarati za neistinite tvrdnje u medijima.“

- „Edukacija novinara i urednika medija.“

- „Uporno educirati i odgajati medijske djelatnike i publiku o važnosti medijske etike, uvesti takav predmet od viših razreda osnovne škole.“

- „Svakako obuka mladih novinara na široj razini, osobito inzistirati na značenju etike i etičkih vrednota koje bi bile poticaj na afirmativno pozitivno pisanje.“

- „Educirati buduće medijske djelatnike i publiku, te poraditi na sankcioniranju kršenja medijske etike.“

- „Provjera vlastitih stavova.“

- OO njima upoznavati čitatelje i njih se pridržavati.“

- „Raditi na svjesnosti čitatelja.“

- „Kratki kurs.“

- „Individualizam je uzeo maha. Univerzalna mjerila gube na važnosti. Pojedinac postaje mjerilo sam sebi. Duhovna izgradnja pojedinca i etičnost pojedinca pa tako i novinara, garant je i medijske etike. Ne može se kuća graditi od krova, već od temelja."

- „Utjecati na one koji se odluče za djelovanje u medijima (od malih nogu, Crkva, obitelj, vrtić, škola, do promjene sustava odgoja na fakultetu) te učvrstiti sustav kažnjavanja, snošenja posljedica za neodgovornost, neistine, laži i manipulaciju).“ 
- „Objektivnost.“

- „Stvoriti i provoditi zakone utemeljene na etici kojih bi se novinari i izdavači morali pridržavati.“"

- „Prakticirati ih.“

- „Odbaciti senzacionalizam.“

- „Što mirniji dijalog.““

- „Odgajati osobe koje rade u medijima da budu nekorumpirani.“

- „Imati više obzira prema istini, manje prema senzacionalizmu.“

- „Obrazovati novinare.“

- „Edukacija, javne kritike neetičnog ponašanja medija, licenca u novinarstvu i sankcioniranje neetičnih ponašanja kroz oduzimanje licence i krivičnu odgovornost.“

- „Bolje obrazovani i pošteniji vlasnici, urednici i novinari.“

- ,To je moguće samo Božjom intervencijom.“

- „Više obrazovati i korisnike i djelatnike medija“"

- „Nezavisnost od profita“

- „Kodeks u redakciji“

- „Više educirati i više poticati na poštivanje medijske etike.“

- „Informiranost.“

- „Edukacija medijskih djelatnika.“

- „Sankcionirati prekršaje.“

U ovom pitanju ispitanici su imali mogućnost dati svoje prijedloge, koji doista pokazuju dobru upoznatost sa stanjem novinarske i medijske etike. Oni se kreću od blažih prijedloga koji se temelje samo na poticajima i obrazovanju do prijedloga o potrebi ,javne kritike neetičnog ponašanja medija, licenca u novinarstvu i sankcioniranje neetičnih ponašanja kroz oduzimanje licence i krivičnu odgovornost“‘. Ima i nekih odgovora koji nisu od praktične primjenjivosti, poput onog koji piše: „To je moguće samo Božjom intervencijom“, no načelno odgovori su uglavnom praktični i primjenjivi. Nisu novo otkriće, već su poznati, ali kao podsjetnik su korisni, te je potrebno pokušati ih što više ostvarivati u svom djelovanju. $U$ smislu istraživanja, iako ispitanici ne daju prijedloge koji bi bili posve nepoznati, kao rezultat se vidi da su novinari upoznati s onim što bi moglo i trebalo doprinijeti većoj etičnosti u suvremenom novinarstvu. 


\subsection{Istraživanje i rasprava rezultata dobivenih među religijskim novinarima}

Anketa je poslana religijskim novinarima na nacionalnim televizijama (na HRT-u je to uključivalo i novinare na radiju) i u dnevnim listovima. Na HRT-u rade novinari koji se bave isključivo tim temama, dok je na ostalim televizijama s nacionalnom koncesijom riječ o novinarima koji pokrivaju širi spektar, ali u sklopu toga bave se i religijom. Anketu je popunilo 32 ispitanika. S obzirom da je broj religijskih novinara ograničen, možemo ustvrditi da je riječ o reprezentativnom uzorku.

\subsubsection{Prikaz i analiza rezultata zatvorenih pitanja}

Većinu ispitanika čine muškarci $(81,3 \%)$, dok je $18,8 \%$ žena. Riječ je o pomalo iznenađujućem omjeru, tj. očekivao bi se manji nerazmjer s obzirom da je u novinarstvu ženski spol inače primjereno zastupljen (Grafikon 25).

\section{Spol}

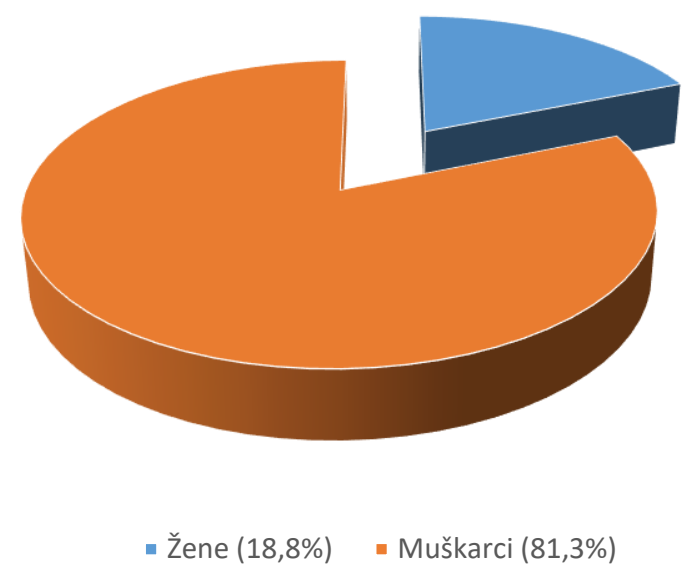

Grafikon 25. Struktura ispitanika po spolu $(\mathrm{N}=32)$ 
U skupini od 30 do 39 godina je 21,9\% ispitanika, dok je u skupini od 40 do 49 njih 18,8\%. U rasponu od 50 do 60 godina je 43,8\%, a 15,6\% ispitanika ih ima preko 60 godina (Grafikon 26).

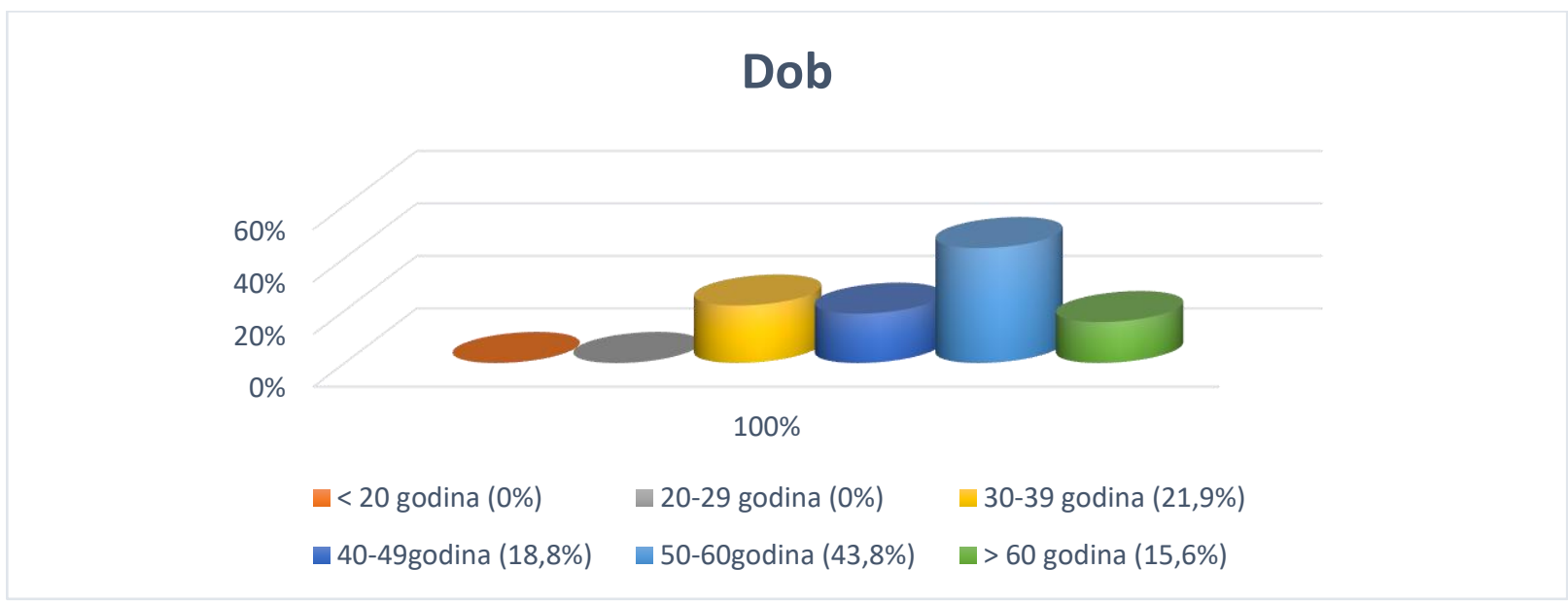

Grafikon 26. Struktura ispitanika po dobi $(\mathrm{N}=32)$

Na pitanje o vjerskom opredjeljenju $87,5 \%$ ispitanika je odgovorilo da se smatraju praktičnim vjernicima katolicima, dok ih je 12,5\% odgovorilo da su ateisti ili agnostici (Grafikon 27). Ostale moguće odgovore nitko nije odabrao. Iz ovih rezultata bi se dalo zaključiti da se religijskim temama bave uglavnom oni koji ili su praktični vjernici, ili pak oni koji uopće nisu vjernici. Dakako, riječ je o uzorku koji se odnosi samo na novinare na nacionalnim medijima u Hrvatskoj, te se ne može donositi neki općenitiji zaključak, no na temelju ovog uzorka čini se da se za praćenje religije odlučuju oni praktični pripadnici religije, dok ateisti ili agnostici osobno pokazuju manje interesa za ove teme, što je u skladu s očekivanim.

\section{Vjersko opredjeljenje}

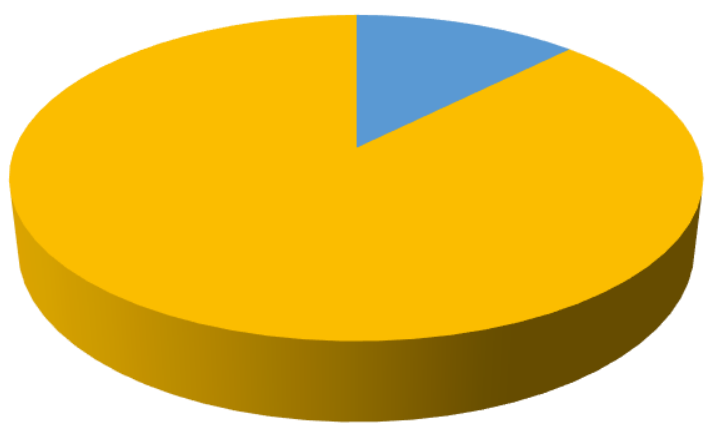

Ateist/agnostik (12,5\%)

- Vjernik nekatolik (0\%)

Nominalni vjernik katolik (0\%)

Praktičan vjernik katolik $(87,5 \%)$

Grafikon 27. Struktura ispitanika po vjerskom opredjeljenju $(\mathrm{N}=32)$ 
Svi ispitanici (100\%) su se u potpunosti (razina slaganja br. 5) složili s tvrdnjom: „Medijska etika je potrebna u suvremenom novinarstvu“ (Grafikon 28). Rezultati su posve očekivani.

\section{Medijska etika je potrebna suvremenom novinarstvu}

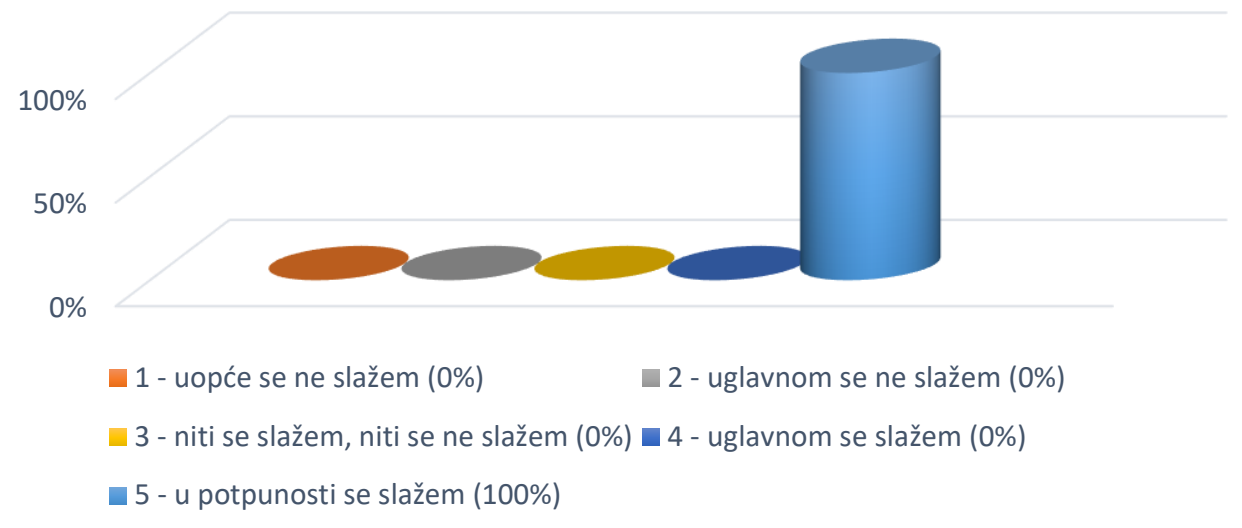

Grafikon 28. Razina slaganja s tvrdnjom o potrebi medijske etike u suvremenom novinarstvu $(\mathrm{N}=32)$

Tvrdnju: „Novinari poznaju postulate medijske etike“ u potpunosti odbacuje (razina slaganja br. 1) $18,8 \%$ ispitanika, $31,3 \%$ ima razinu slaganja br. 2, 28,1\% ima razinu slaganja br. 3 , a $18,8 \%$ ima razinu slaganja br. 4 , dok samo $3,1 \%$ u potpunosti smatra da novinari poznaju postulate medijske etike (Grafikon 29).

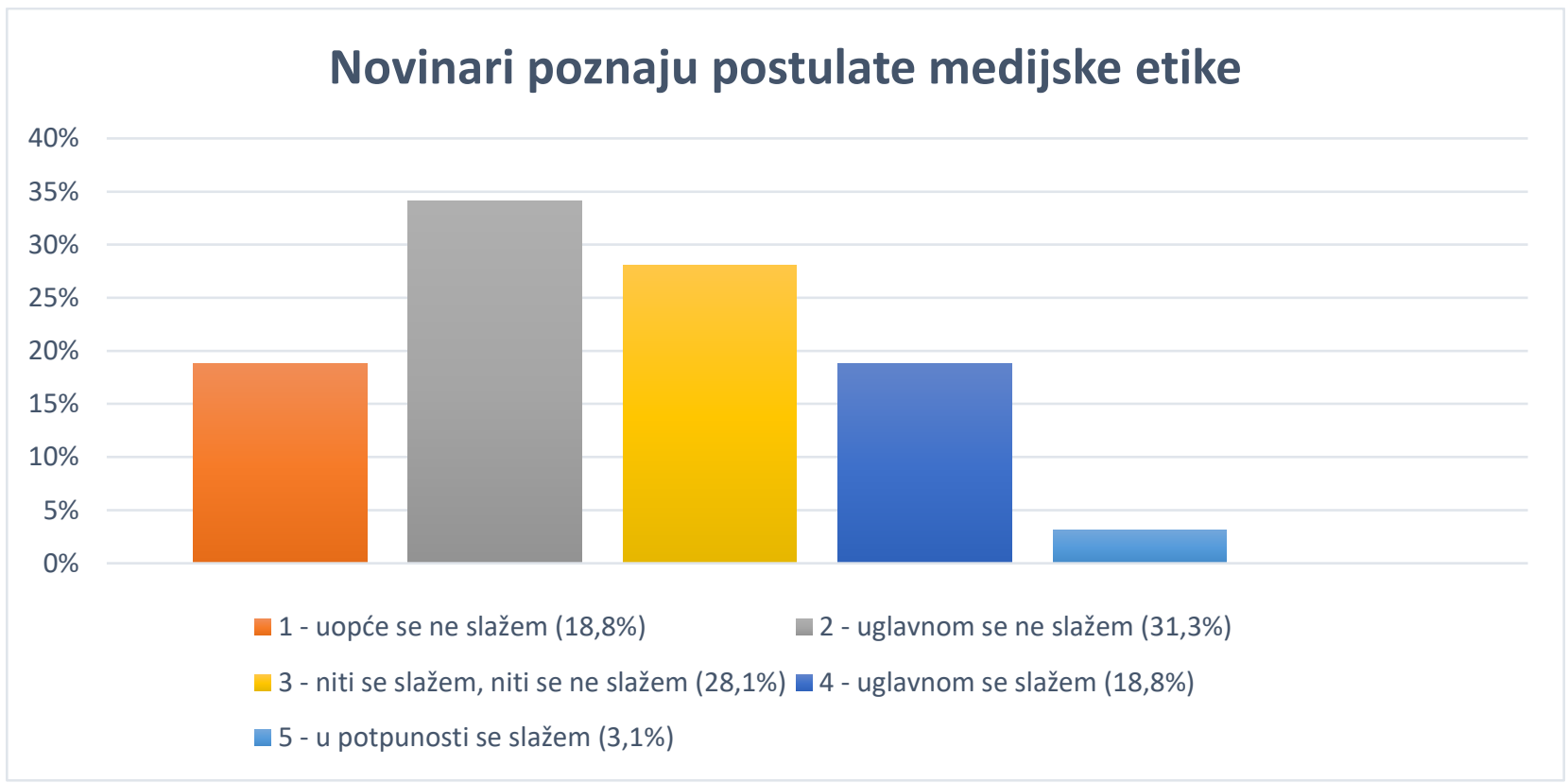

Grafikon 29. Razina poznavanja postulata medijske etike $(\mathrm{N}=32)$ 
$\mathrm{Da}$,novinari poštuju postulate medijske etike“ u potpunosti odbacuje (razina slaganja br. 1) $18,8 \%$ ispitanika, njih točno polovica - to jest $50 \%$ ispitanika - ima razinu slaganja br. 2, dok $31,3 \%$ ima razinu slaganja br. 3. Nitko od ispitanika nije iskazao razinu slaganja br. 4 ili br. 5 (Grafikon 30).

\section{Novinari poštuju postulate medijske etike}

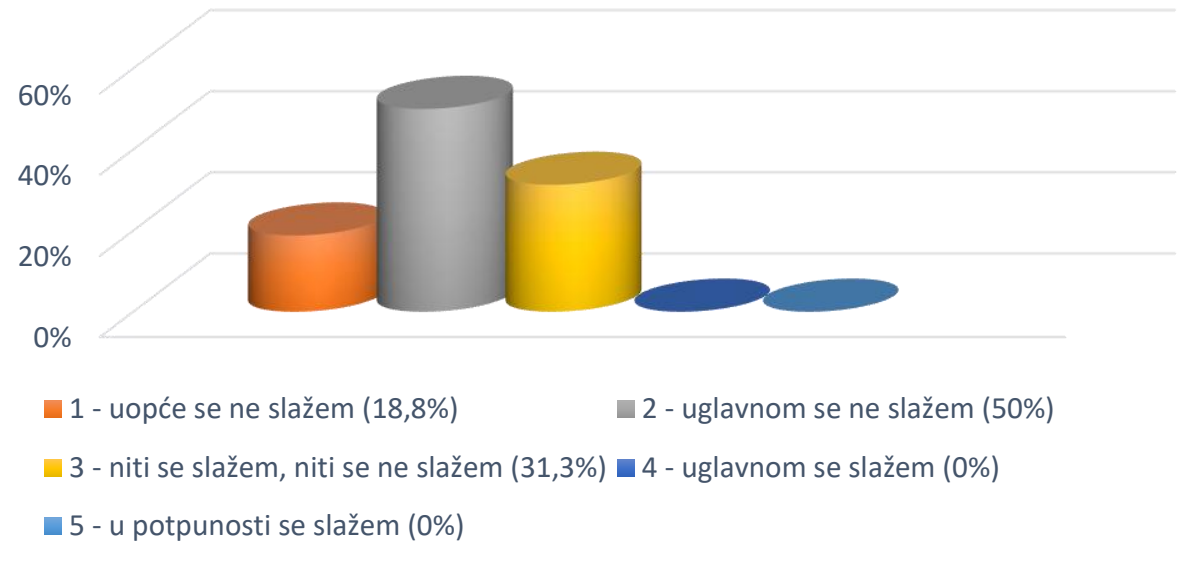

Grafikon 30. Razina poštivanja postulata medijske etike $(\mathrm{N}=32)$

Tvrdnju: „Urednici i vlasnici medija poznaju postulate medijske etike“ u potpunosti odbacuje (,uopće se ne slažem“) 18,8\% ispitanika, 15,6\% ima razinu slaganja br. 2, dok $31,3 \%$ ima razinu slaganja br. 3, najviše $(34,4 \%)$ ima razinu slaganja br. 4 , dok nitko nema razinu slaganja br. 5 (Grafikon 31).

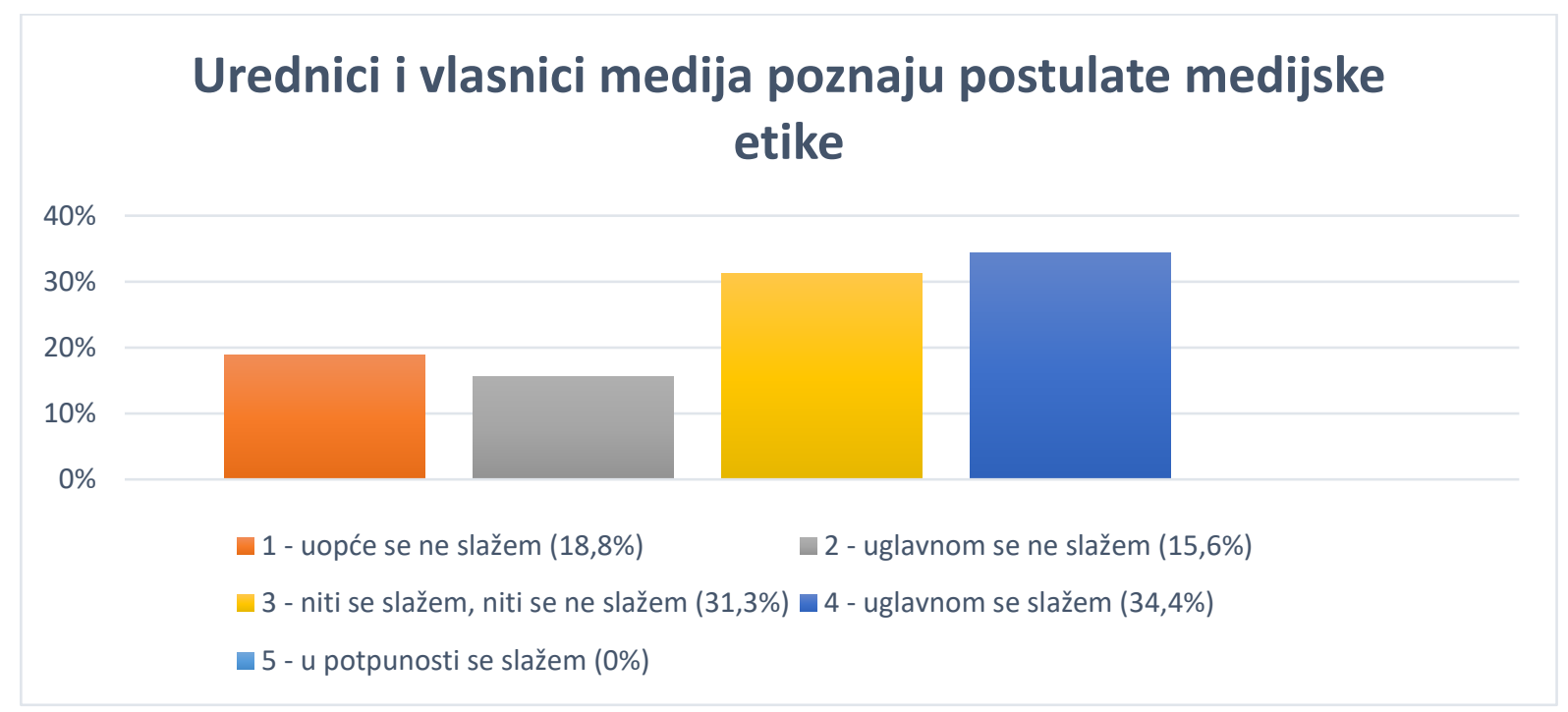

Grafikon 31. Razina poznavanja postulata medijske etike (urednici i vlasnici medija) $(\mathrm{N}=32)$ 
Čak 34,4\% ispitanika za tvrdnju: „Urednici i vlasnici medija poštuju postulate medijske etike“ kaže „uopće se ne slažem“. Neznatno veći postotak (37,5\%) ima razinu slaganja br. $2 \mathrm{~s}$ ovom tvrdnjom, 28,1\% ima razinu slaganja br. 3. Nitko nije označio da se „uglavnom slaže“ ili „u potpunosti slaže“ (Grafikon 32). Iz rezultata zaključujemo da ispitanici očito nemaju povjerenja u urednike i vlasnike medija, tj. u njihovo pridržavanje etičkih načela.

\section{Urednici i vlasnici medija poštuju postulate medijske etike}

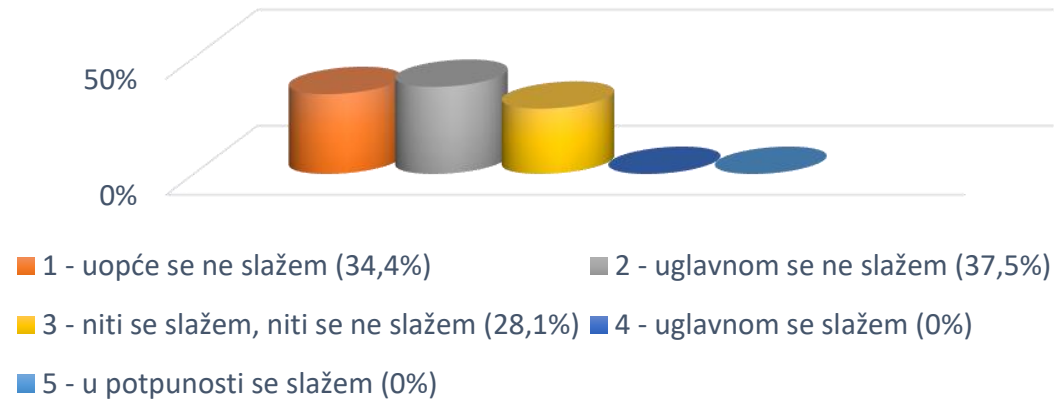

Grafikon 32. Razina poštivanja postulata medijske etike (urednici i vlasnici medija) $(\mathrm{N}=32)$

„Uopće se ne slažem“ je za tvrdnju: „Publika poznaje postulate medijske etike“ označilo 18,8\% ispitanika, a razinu slaganja br. br. 3 je označilo njih 81,3\%. Ostale mogućnosti nitko nije odabrao (Grafikon 33). Na ovom pitanju ispitanici imaju dosta usuglašen stav, odnosno veliki postotak ih se izjašnjava da ,niti se slaže, niti se ne slaže“ s navedenom tvrdnjom da publika poznaje postulate medijske etike.

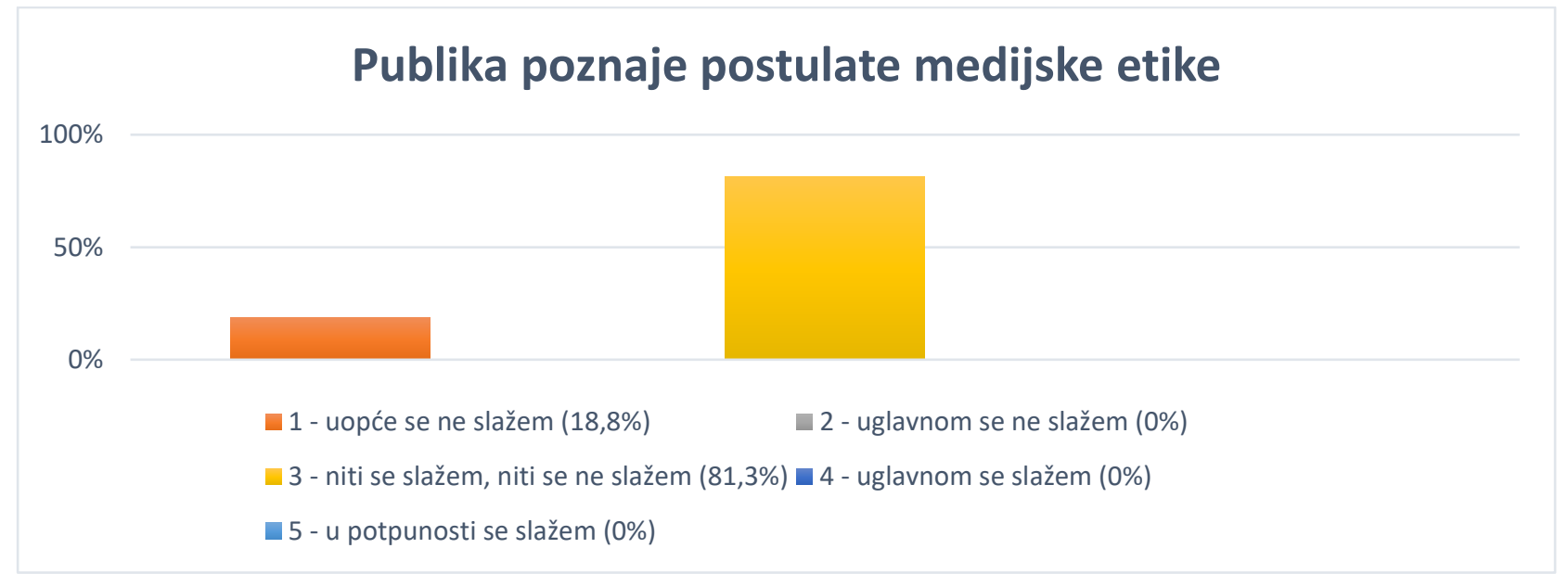

Grafikon 33. Razina poznavanja postulata medijske etike (publika) $(\mathrm{N}=32)$ 
Više od polovice, tj. 53,1\% ispitanika se „uopće ne slaže“ s tvrdnjom: „Publika bira medijske sadržaje u skladu s postulatima medijske etike“, 18,8\% ima razinu slaganja br. 2, a $28,1 \%$ je na razini slaganja br. 3 . Nitko nije označio da se „uglavnom slaže“ ili „u potpunosti slaže“ (Grafikon 34).

\section{Publika u skladu s postulatima medijske etike bira medijske sadržaje}

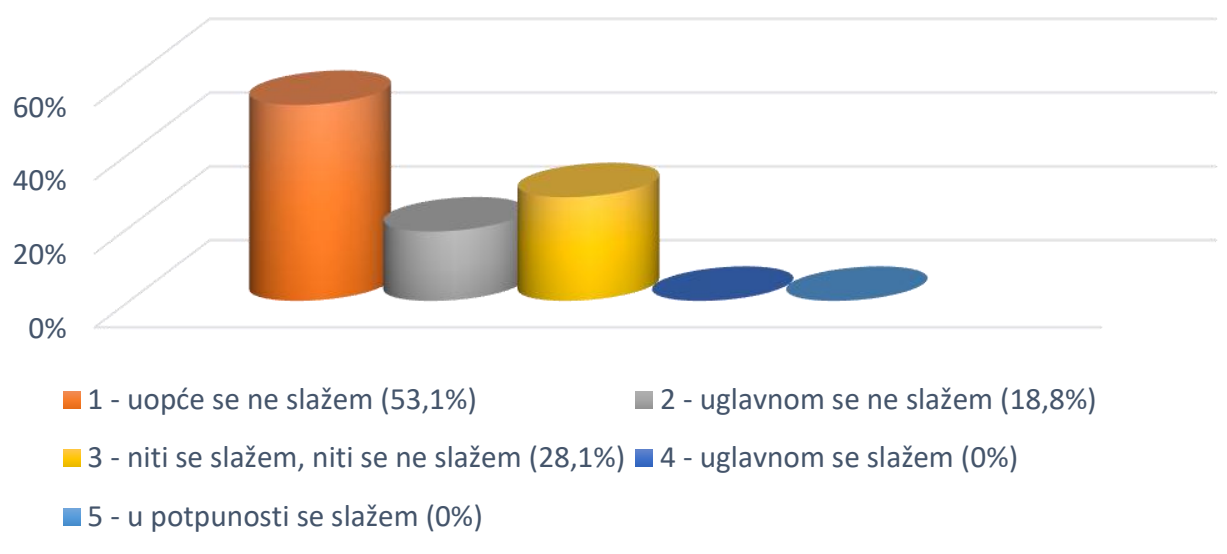

Grafikon 34. Biranje medijskih sadržaja u skladu s postulatima medijske etike $(\mathrm{N}=32)$

Ispitanici se u 3,1\% na razini slaganja br. 4 (,uglavnom se slažem“) izjašnjavaju o svom poznavanju postulata medijske etike, dok se $96,9 \%$ „u potpunosti slaže“ s navedenom tvrdnjom. Nitko nije izrazio razinu slaganja br. 1, br. 2 ili br. 3 (Grafikon 35). Iz ovog se zaključuje da iako za ostale sudionike (uključujući svoje kolege) ispitanici imaju nisko mišljenje o njihovom poznavanju medijske etike, za sebe imaju poprilično drugačije mišljenje.

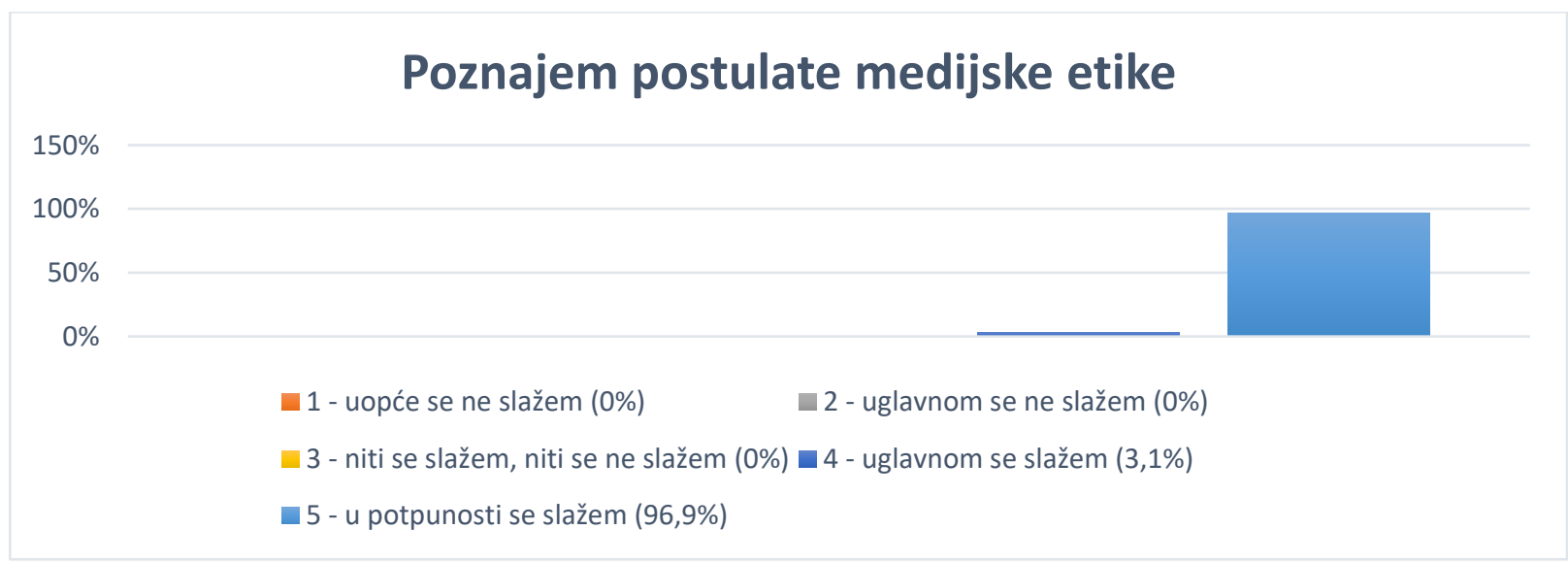

Grafikon 35. Percepcija vlastitog poznavanja postulata medijske etike $(\mathrm{N}=32)$ 
Za tvrdnju „Poštujem postulate medijske etike u svom djelovanju“ na razini slaganja br. 1 izjasnilo se 3,1\% ispitanika, nitko se nije izjasnio na razini br. 2 i br. 3 . Na razini slaganja br. 4 izjasnilo se 9,4\% ispitanika, a na razini br. 5 izuzetno visokih 87,5\% (Grafikon 36).

\section{Poštujem postulate medijske etike u svom djelovanju}

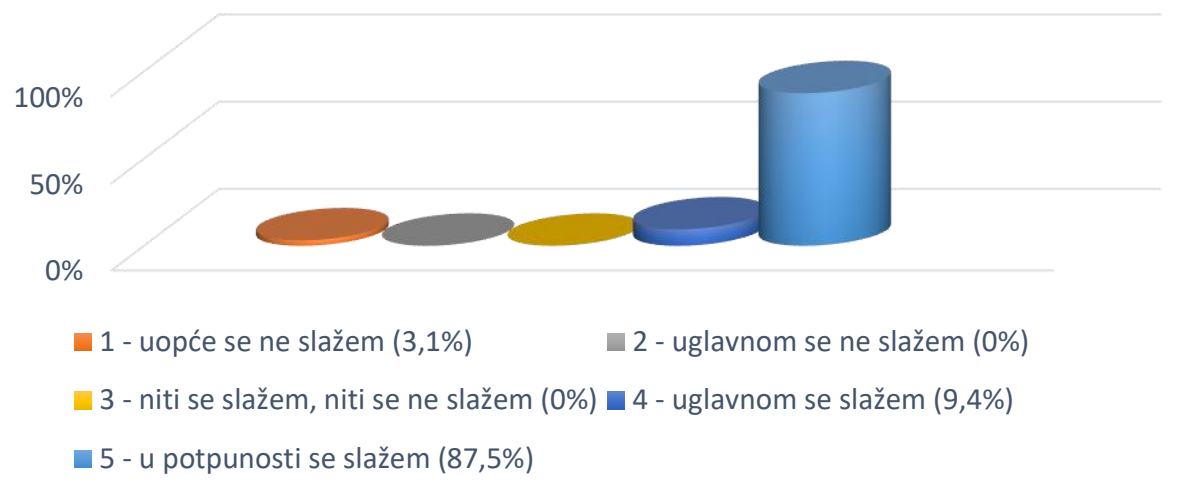

Grafikon 36. Percepcija vlastitog poštivanja postulata medijske etike $(\mathrm{N}=32)$

$\mathrm{Na}$ razini slaganja br. 1 (,uopće se ne slažem“) svi ispitanici zapravo potvrđuju tvrdnju: „Teološka medijska etika je potrebna u suvremenom novinarstvu“, dok se na razini slaganja br. 2 izjasnilo $18,8 \%$ ispitanika, a na razini br. 3 njih 15,6\%. Na razini br. 4 se izjasnilo $3,1 \%$ ispitanika, a više od polovice, to jest $62,5 \%$ se izjasnilo da se ,u potpunosti slaže“" s navedenom tvrdnjom (Grafikon 37). Rezultat pokazuje da ispitanici imaju relativno visoko mišljenje o potrebi teološke medijske etike u suvremenom novinarstvu.

\section{Teološka medijska etika je potrebna u suvremenom novinarstvu}

$100 \%$

$50 \%$

$0 \%$
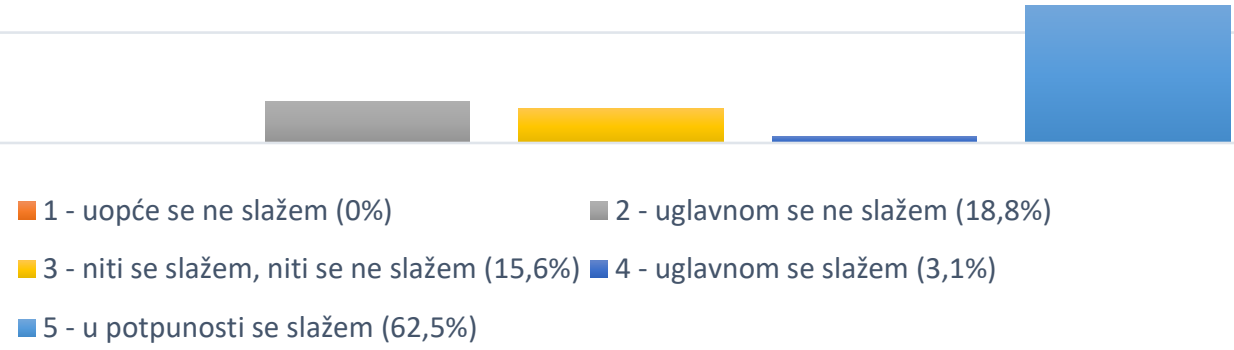

घ 1 - uopće se ne slažem (0\%)

2 - uglavnom se ne slažem $(18,8 \%)$

3 - niti se slažem, niti se ne slažem (15,6\%) 4 - uglavnom se slažem (3,1\%)

5 - u potpunosti se slažem $(62,5 \%)$

Grafikon 37. Potreba teološke medijske etike $(\mathrm{N}=32)$ 
Čak 43,8\% ispitanika se „uopće ne slaže“ s tvrdnjom: „Novinari poznaju postulate teološke medijske etike“, $31,1 \%$ se s njome slaže na razini slaganja br. 2, 21,9\% je na razini slaganja br. 3, dok ih je 3,1\% izrazilo razinu slaganja br. 4. Nitko se nije izjasnio da se u potpunosti slaže (Grafikon 38).

\section{Novinari poznaju postulate teološke medijske etike}

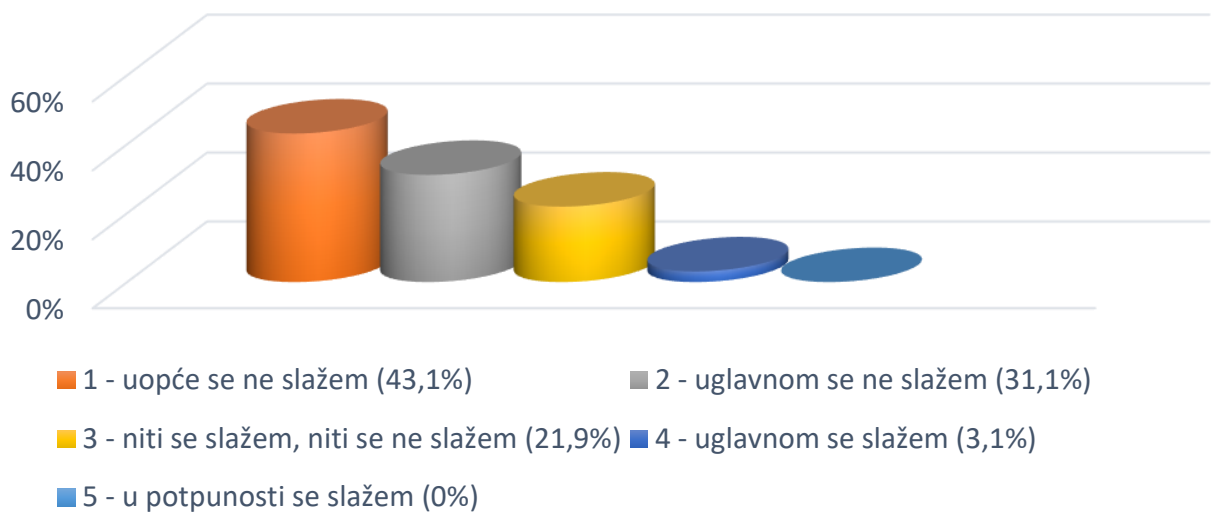

Grafikon 38. Poznavanje postulata teološke medijske etike (novinari) $(\mathrm{N}=32)$

Čak 34,4\% ispitanika je na razini slaganja br. 1, dakle da se „uopće ne slažu“ s tvrdnjom: „Novinari poštuju postulate teološke medijske etike“, dok gotovo polovica tj. 46,9\% ih na razini slaganja br. 2. Na razini slaganja br. 3 je 18,8\%, Nitko među ispitanicima se nije izjasnio da se „uglavnom slaže“ ili da se „u potpunosti slaže“ s navedenom tvrdnjom (Grafikon 39).

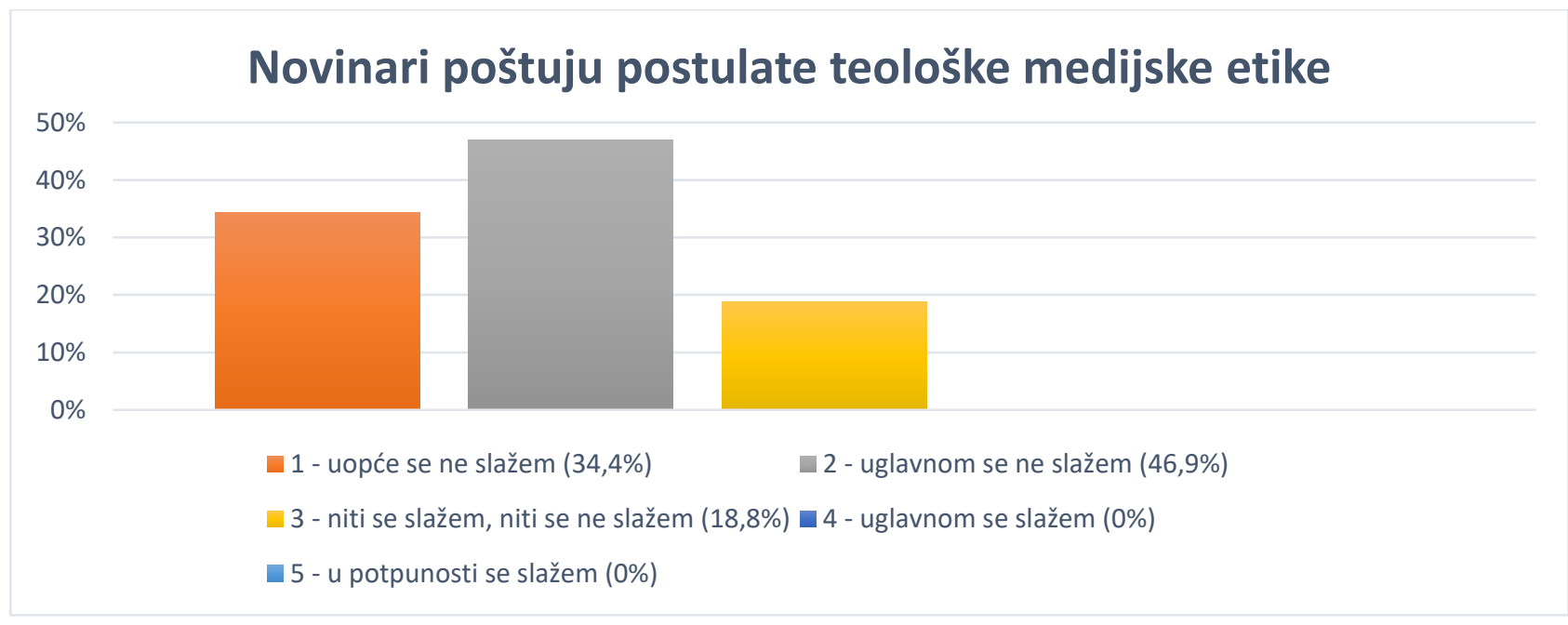

Grafikon 39. Poštivanje postulata teološke medijske etike (novinari) $(\mathrm{N}=41)$ 
Na razini slaganja br. 1 s tvrdnjom „Urednici i vlasnici medija poznaju postulate teološke medijske etike“ je odgovorilo $50 \%$ ispitanika, na razini slaganja br. 2 njih $28,1 \%$, na razini slaganja br. 3 je 21,9\% ispitanika, dok nitko nije na razini br. 4 i br. 5 (Grafikon 40).

\section{Urednici i vlasnici medija poznaju postulate teološke medijske etike}

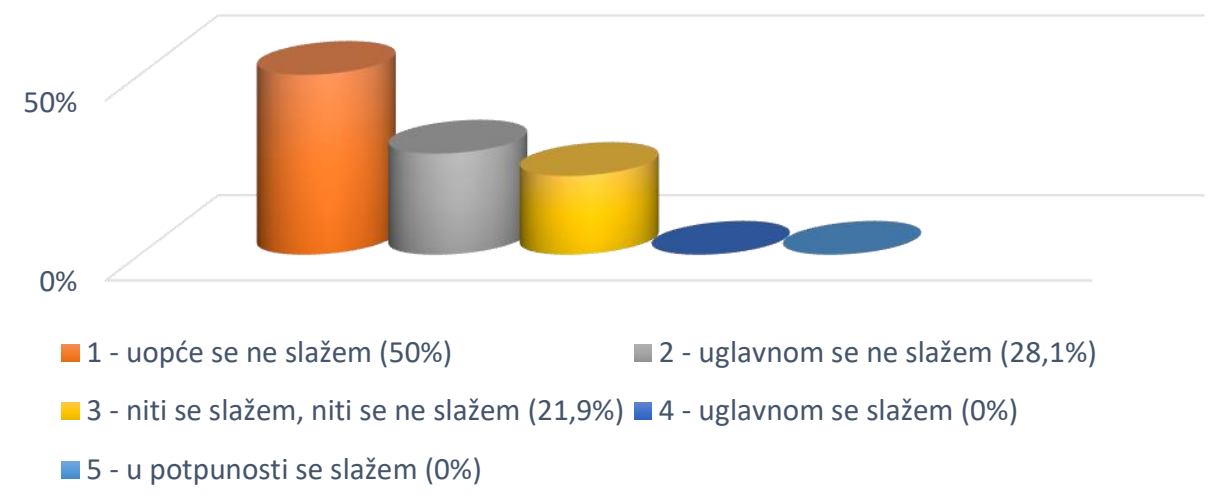

Grafikon 40. Poznavanje postulata teološke medijske etike (urednici i vlasnici medija) $(\mathrm{N}=32)$

Čak 78,1\% ispitanika je na razini slaganja br. $1 \mathrm{~s}$ tvrdnjom: „Urednici i vlasnici medija poštuju postulate teološke medijske etike“, dakle uopće se s njom ne slažu, a 3,1\% ih je na razini slaganja br. 2. Na razini slaganja br. 3 je 18,8\% ispitanika. Nitko među ispitanicima se nije izjasnio da se uglavnom slaže ili u potpunosti slaže s navedenom tvrdnjom (Grafikon 41). Iz rezultata je očito da ispitanici nemaju visoko mišljenje o odnosu urednika i vlasnika medija prema medijskoj etici.

\section{Urednici i vlasnici medija poštuju postulate teološke medijske etike}

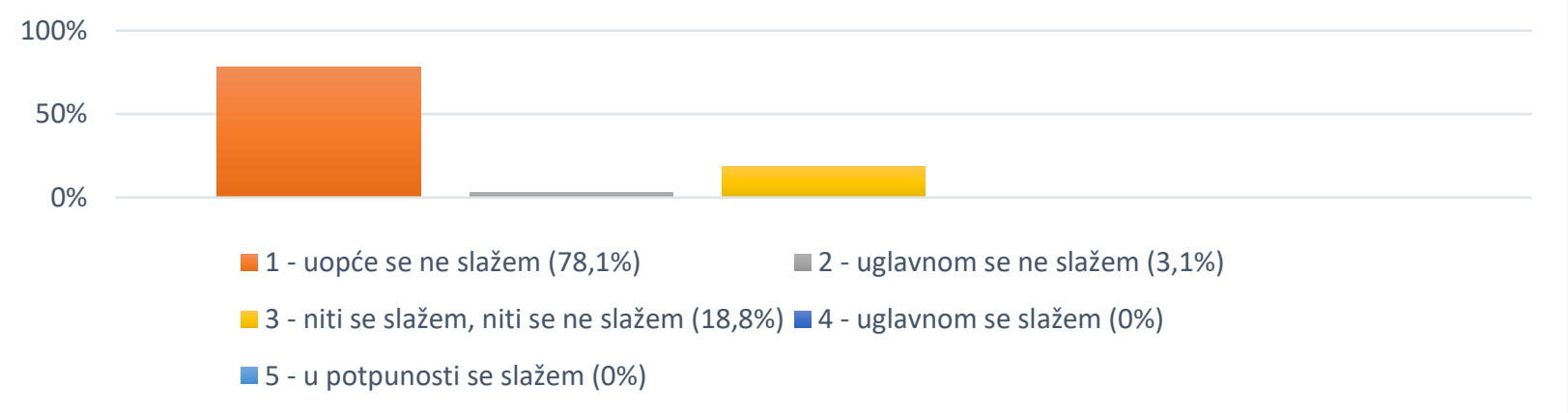

Grafikon 41. Poštivanje postulata teološke medijske etike (urednici i vlasnici medija) $(\mathrm{N}=32)$ 
„Uopće se ne slažem“ za tvrdnju: „Publika poznaje postulate teološke medijske etike“ označilo je 21,9\% ispitanika. Stupanj slaganja br. 2 je označilo njih 59,4\%, br. 3 njih 18,8\%, a nitko od ispitanika nije odgovorio da se „uglavnom slaže“ ili „u potpunosti slaže“ s navedenom tvrdnjom (Grafikon 42).

\section{Publika poznaje postulate teološke medijske etike}

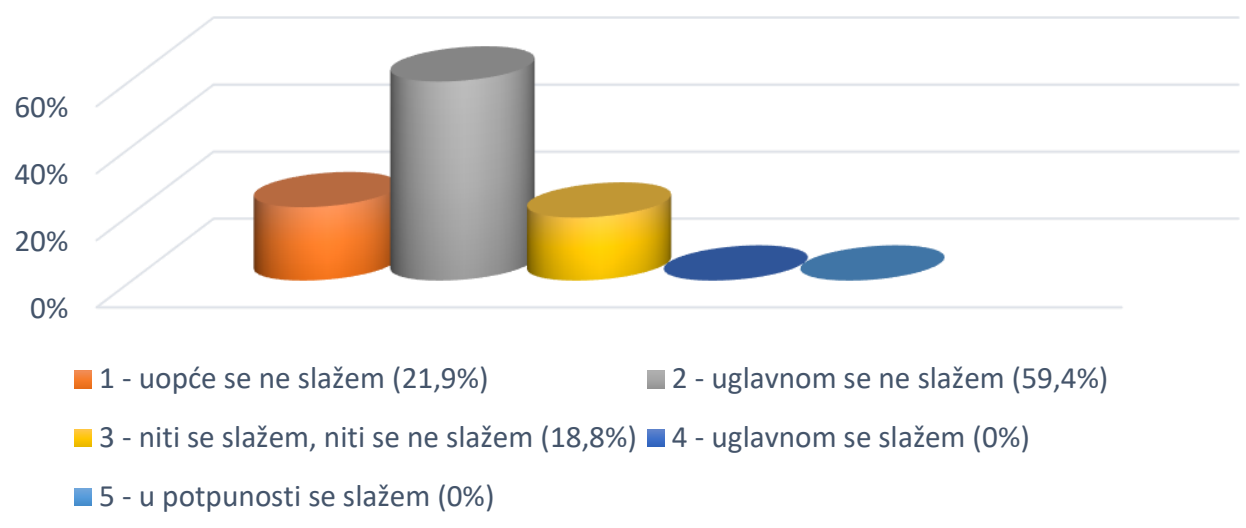

Grafikon 42. Poznavanje postulata teološke medijske etike (publika) $(\mathrm{N}=32)$

Među ispitanicima je 62,5\% onih koji se „,uopće ne slažu“ s tvrdnjom: „Publika bira medijske sadržaje u skladu s postulatima teološke medijske etike“, 37,5\% ima razinu slaganja br. 2, dok se nitko od ispitanika nije izjasnio na razini br. 3, br. 4 ili br. 5 (Grafikon 43) Ispitanici, vidljivo je iz rezultata, smatraju da teološka medijska etika nema nikakvog, odnosno gotovo nikakvog utjecaja kod publike na izbor medijskih sadržaja.

\section{Publika u skladu s postulatima teološke medijske etike bira medijske sadržaje}

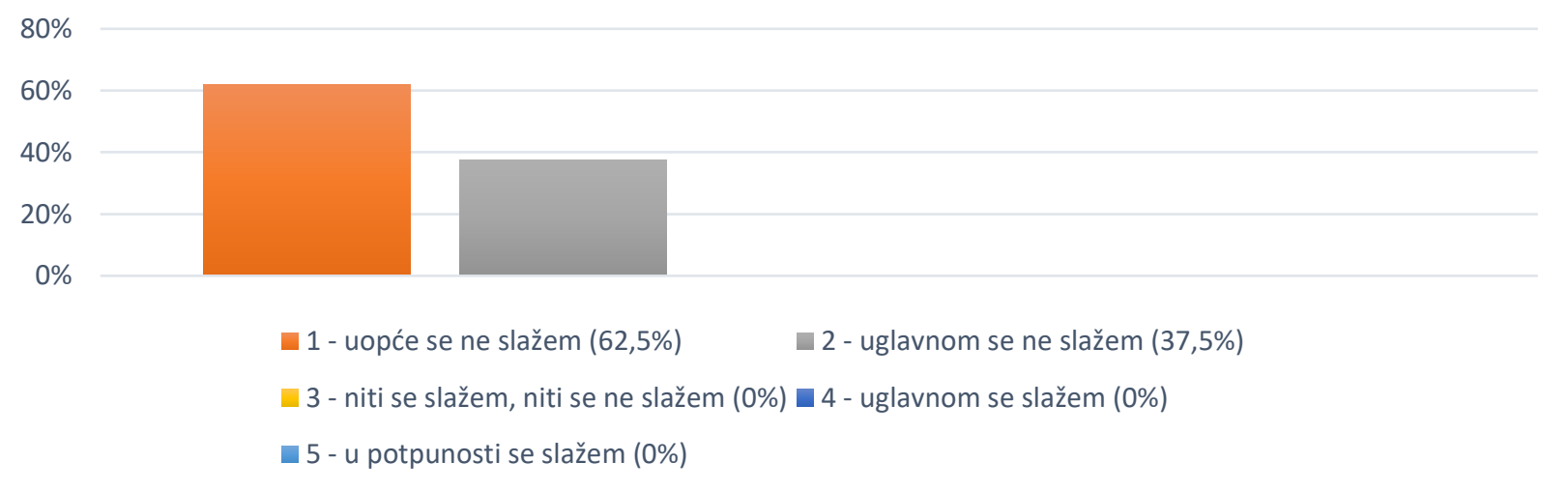

Grafikon 43. Biranje medijskih sadržaja u skladu s postulatima teološke medijske etike $(\mathrm{N}=32)$ 
S tvrdnjom: „Poznajem postulate teološke medijske etike“ se ,uglavnom slaže“ $50 \%$ ispitanika, a jednak postotak se „u potpunosti slaže“. Ostale tri mogućnosti nije nitko odabrao (Grafikon 44), iz čega je jasno da ispitanici imaju jako visoko mišljenje o svom poznavanju teološke medijske etike.

\section{Poznajem postulate teološke medijske etike}

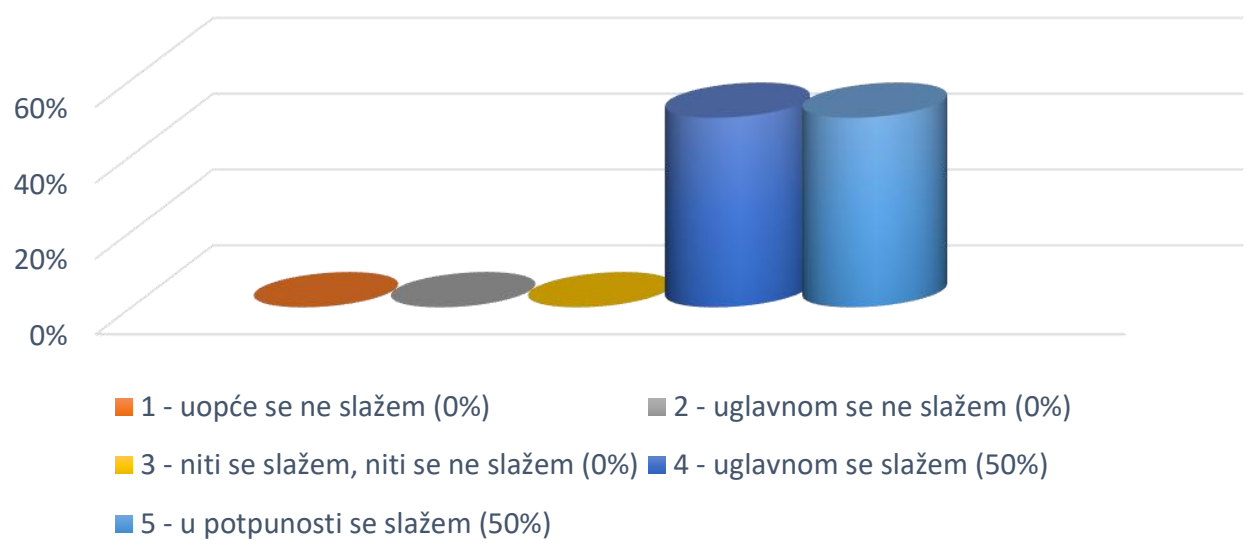

Grafikon 44. Percepcija poznavanja postulata teološke medijske etike $(\mathrm{N}=32)$

Nitko se nije izjasnio da se „uopće ne slaže“ s tvrdnjom „Poštujem postulate medijske etike u svom djelovanju“, $3,1 \%$ se izjasnilo na razini slaganja br. 2, dok se 9,4\% ispitanika izjasnilo na razini slaganja br. 3. Na razini slaganja br. 4 izjasnilo se $18,8 \%$ ispitanika, a na razini br. 5 čak 68,8\% (Grafikon 45). Iako i ovdje imaju visoko mišljenje, ono nije kao na razini pitanja o poznavanju teološke medijske etike. Čini se da ispitanici, iako smatraju da izvrsno poznaju teološku medijsku etiku, ipak smatraju da ne djeluju uvijek u skladu s njom.

\section{Poštujem postulate teološke medijske etike u svom djelovanju}

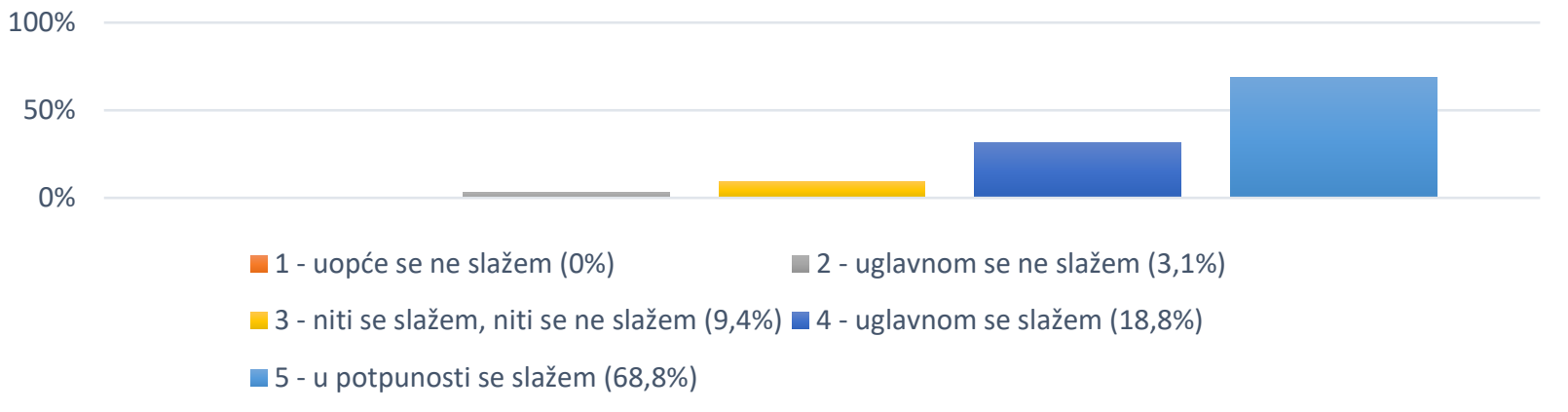

Grafikon 45. Percepcija poštivanja postulata teološke medijske etike $(\mathrm{N}=32)$ 
Uz tvrdnju „Medijska etika može pomoći teološkoj medijskoj etici“ nitko se nije izjasnio da se „uopće ne slaže“ ili da se „uglavnom ne slaže“, dok se 15,6\% ispitanika izjasnilo na razini br. 3. Na razini slaganja br. 4 izjasnilo se $34,4 \%$ ispitanika, a na razini br. 5 njih 50\% (Grafikon 46).

\section{Medijska etika može pomoći teološkoj medijskoj etici}

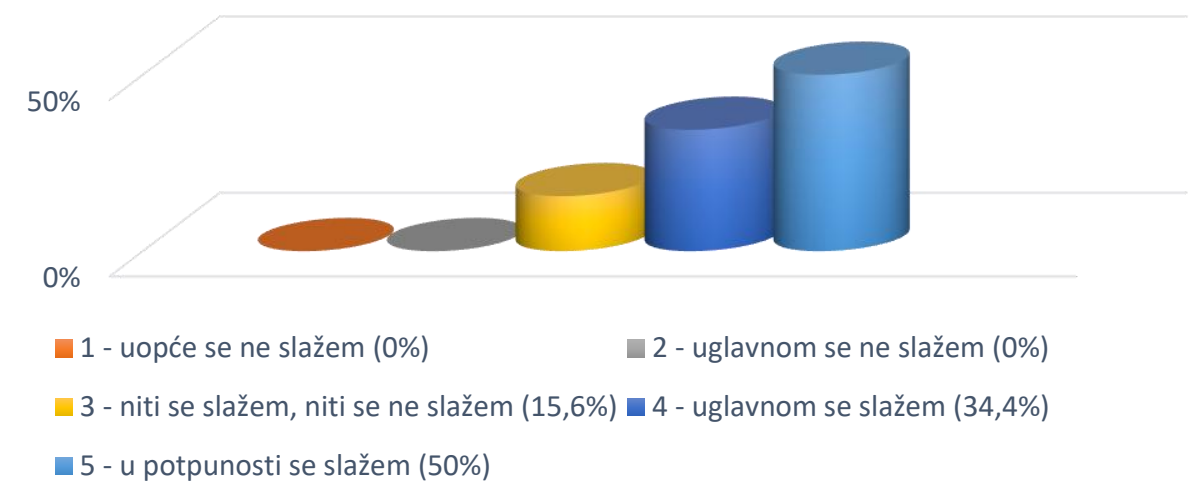

Grafikon 46. Pomoć medijske etike $(\mathrm{N}=32)$

Ispitanici su se u postotku od 3,1\% izjasnili za tvrdnju „Teološka medijska etika može pomoći medijskoj etici“" na razini slaganja br. 2, 12,5\% na razini slaganja br. 3, 37,5\% na razini slaganja br. 4 , dok se $46,9 \%$ ispitanika „u potpunosti slaže“ s navedenom tvrdnjom (Grafikon 47).

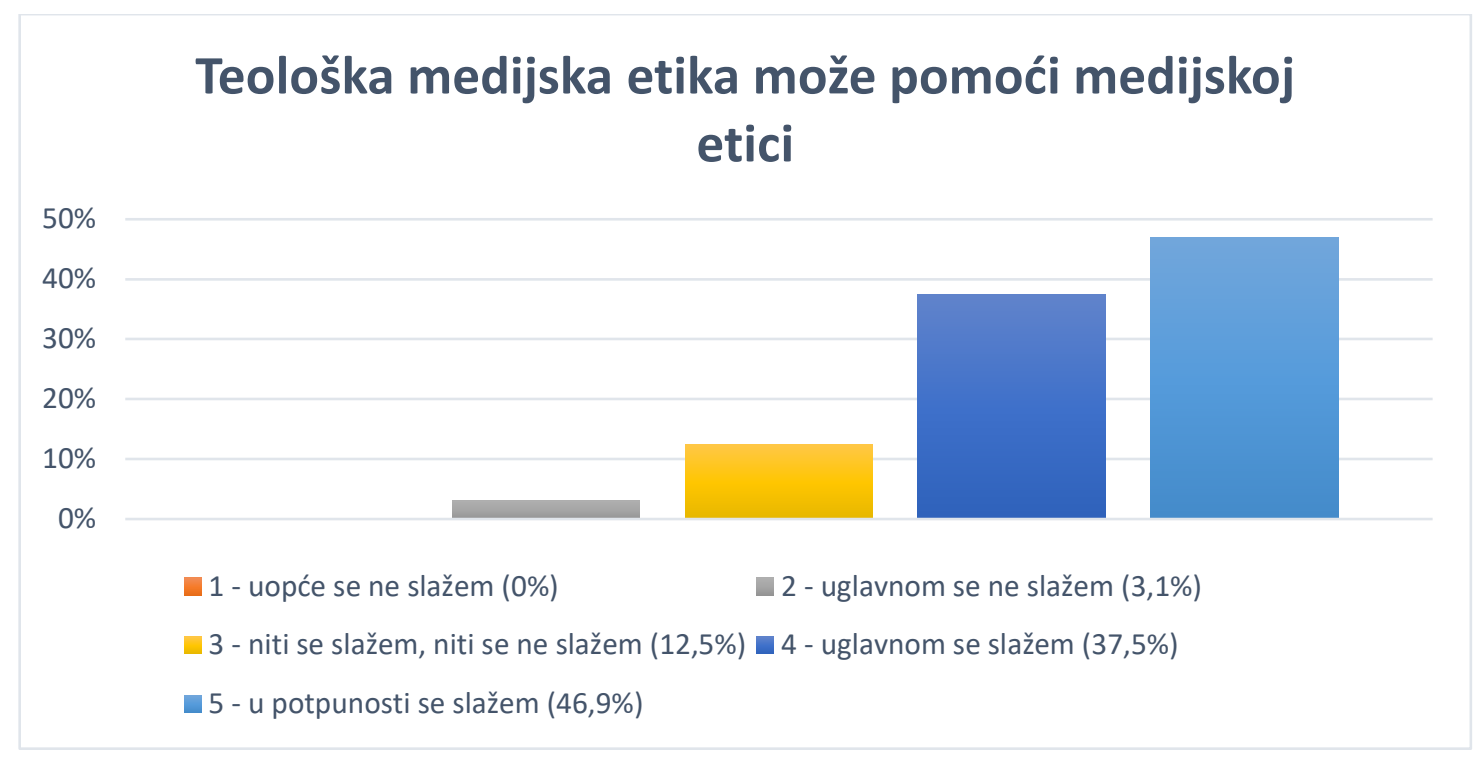

Grafikon 47. Pomoć teološke medijske etike $(\mathrm{N}=32)$ 
„Uopće se ne slažem“ je za tvrdnju „Medijska etika i teološka medijska etika nemaju značajnijih razlika“" označilo $3,1 \%$ ispitanika. Stupanj slaganja br. 2 je označilo 15,6\% ispitanika, br. 3 njih 53,1\%, stupanj slaganja br. 4 odabralo 18,8\%, a br. 5 njih 9,4\% (Grafikon 48).

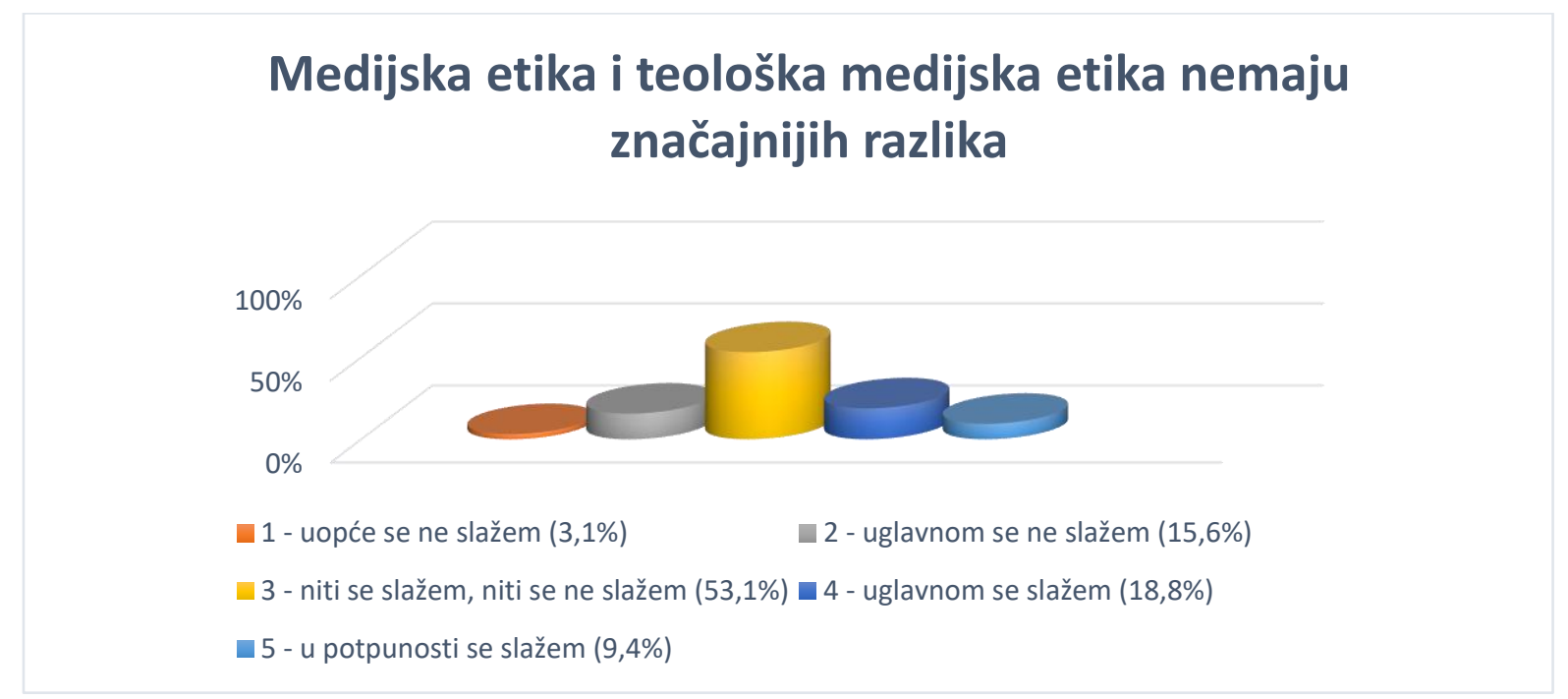

Grafikon 48. Ima li značajnijih razlika između medijske etike i teološke medijske etike? ( $\mathrm{N}=32)$

\subsubsection{Prikaz i analiza rezultata otvorenih pitanja}

Na prvo u nizu pitanja otvorenog tipa: „Što smatrate temeljnim postulatom medijske etike?“, ispitanici su dali sljedeće odgovore: „Istina“, „Istina“, „Objektivnost“”, „Istinitost“, „Istinitost“; „Odgovornost“, „Istina“, „Odgovornost“”, „Poštenje“, „Poštenje“, „Audiatur et altera pars", „Objektivnost i nepristranost“, „Istina“, „Objektivnost", „Istina“", „Vjerodostojnost, istinitost, poštenje“, „Istina“, „Biti objektivan“, Istina“, „Istina“, „Objektivnost, istinitost“, „Istinitost“, „Istina“, „Samo poštenje“, „Istina“, „Objektivnost“, „Istina“, „Istinitost“, „Pošteno izvještavati“, „,Dosljednost“, „Istina“.

Kao što je i očekivano, ispitanici su kao temeljnu postavku medijske etike najviše istaknuli istinu, te su je spomenuli čak 19 puta. Kao jednu od temeljnih postavki ističu i objektivnost (sedam puta), ali i poštenje (četiri puta).

Na pitanje „ک̌́to smatrate temeljnim postulatom teološke medijske etike?" ispitanici su dali sljedeće odgovore: Istina“, „Dosljednost“, „Istina“, „Poštenje“, „Istina“, „Istina“, “Objektivnost“, „Istina“, „Objektivnost“”, „Istinitost", „Odgovornost“, „Odgovornost”, 
„Poštenje“, „Istinoljubivost“”, „Istinoljubivost“, „Istina će vas osloboditi“, „Objektivnost, traženje istine i djelovanje prema moralnim načelima“, „Vjernost objavljenoj istini svoje religije“, „Istina“, „Biti objektivan“, „Istinu“, „Istinitost“, „Ne vidim bitnu razliku između medijske etike i teološke medijske etike osim u pitanjima eutanazije, abortusa“, „Objektivnost“, „Biti istinit“, „Objektivnost“, „Istina“, „Istina“, „Biti pošten i to je to“, „Provoditi načela (vječne istine)“.

I među temeljnim postavkama teološke medijske etike ispitanici najviše ističu istinu, te je spominju čak 18 puta, a osim nje ističe se i objektivnost (osam puta) i poštenje (tri puta). S obzirom na rezultate koji su veoma slični odgovorima na prethodno pitanje, može se zaključiti da ispitanici ne vide (značajnijih) razlika između temeljnih postavki medijske etike i teološke medijske etike.

Zaključno se može reći da su rezultati pokazali kako religijski novinari, to jest novinari koji se bave religijskim temama na temelju medijske etike i teološke medijske etike, jednako kao i članovi HDKN-a, na prvo mjesto stavljaju „istinu“, jer je ona temelj novinarskoga i medijskoga djelovanja. Dok su članovi HDKN-a na drugo i treće mjesto smjestili „odgovornost“" i ,objektivnost“", novinari koji u nacionalnim medijima obrađuju teme religije su istaknuli „objektivnost“ i „poštenje“, pa je jedina razlika u tome što jedni ističu „odgovornost“, a drugi „poštenje“. Analizirajući odgovore ispitanika i uspoređujući s onim što suvremena medijska etika, jednako kao i teološka medijska etika, apostrofiraju kao temeljna načela, može se kazati da se ispitanici slažu i s načelima medijske etike i teološke medijske etike.

Na pitanje „Što bi se trebalo učiniti da postulati medijske etike više zažive u praksi?“, ispitanici su dali sljedeće odgovore:

- „Odgajati novinare.“

- „Veće inzistiranje na njezinoj provedbi od strane glavnih urednika.“

- „Obrazovati novinare, a vlasnike kažnjavati za nepoštivanje.“

- „Dopustiti pravo novinarima na istinito i objektivno informiranje, u skladu sa savjesti.“

- „Edukacija i sve vrste odgoja (od kućnog pa do profesionalnog).“

- „Obrazovati sve dionike i kažnjavati one koji krše.“

- „Više slobodnih i neovisnih medija.“ 
- „Obrazovati novinare.“

- "Više o njoj govoriti.““

- „Sankcionirati prekršaje.“

- „Podučavati buduće novinare o potrebi etičnosti u novinarskom poslu.“

- „Osvijestiti važnost etike.“

- "Poticati na etičnost.“

- „Govoriti o važnosti etike i neprestano to ponavljati dok to ne postane normalni i uobičajeni modus ponašanja i djelovanja.“

- „Obrazovati o etici.“

- „Isticati važnost i potrebu odgovornosti.“

- „Vrijednosti staviti ispred profita.“

- „Isticati poštenje.“

- „Pomoći novinarima da razumiju kako je nužno njihovo poštenje.“

- „Više nagrađivati pozitivne primjere u novinarstvu.“

- „Poticati na istinitost.“

- „Kazniti (financijski) one koji je ne poštuju.“

- ,Više istine.“

- „Poticati novinare na vjernost vlastitim objektivnim načelima.“

- ,Vjernost osobnim načelima.“

- „Obrazovati za etiku.“

- „Poticati istinitost.“

- „Stalno i stalno naglašavati objektivnost kao način djelovanja novinara. Bez objektivnosti nije moguće biti novinar!“

- „Težiti objektivnosti.“

- „Govoriti o objektivnosti.“

- „Kažnjavanje prekršaja.“

- Obrazovati publiku kako bi birala etički ispravne medijske sadržaje.“

Ispitanici u svojim odgovorima nude rješenja koja nisu nepoznata, ali koja treba iznova spominjati, te se truditi provoditi ih u djelo. Njihovi odgovori idu u dva smjera: s jedne strane ističu da je potrebno obrazovati i poticati na etično djelovanje, a s druge strane da je potrebno sankcionirati onda kada se djeluje i one koji djeluju neetično. Kao i za prethodnu skupinu ispitanika, može se zaključiti da rezultati istraživanja pokazuju kako novinari koji se bave 
religijskim temama u nacionalnim medijima iako ne daju prijedloge koji bi bili posve nepoznati, ipak su upoznati s onim što bi moglo i trebalo pridonijeti većoj etičnosti u suvremenom novinarstvu.

\subsection{Usporedbena analiza rezultata ankete po skupinama}

I članovi HDKN-a i religijski novinari apsolutno smatraju da je medijska etika potrebna suvremenom novinarstvu, tj. i kod jednih i drugih prosječna razina slaganja s tom tvrdnjom je 5.00, odnosno svi su se izjasnili da se „u potpunosti“ slažu s tvrdnjom: „Medijska etika je potrebna u suvremenom novinarstvu“. U ovom pitanju, dakle, nemamo niti najmanje razilaženja u stavovima ovih dviju skupina ispitanika.

Članovi HDKN-a kao i religijski novinari imaju dosta nisko mišljenje o poznavanju medijske etike njihovih kolega novinara. Kod članova HDKN-a prosječna razina slaganja oko tvrdnje „Novinari poznaju postulate medijske etike“ je 2.63, dok je kod druge skupine to 2.56, dakle možemo kazati da je razlika neznatna.

Iako imaju loše mišljenje o poznavanju medijske etike svojih kolega, kad je riječ o poštivanju te medijske etike, u obje skupine ispitanika, mišljenje vezano uz tvrdnju „Novinari poštuju postulate medijske etike“ je još niže. Članovi HDKN-a imaju prosječnu razinu slaganja s ovom tvrdnjom samo 2.14 , dok je kod religijskih novinara ta razina čak i niža, tj. iznosi 1.96 .

U pitanju, to jest tvrdnji: „Urednici i vlasnici medija poznaju postulate medijske etike“ razina slaganja je gotovo identična kod obje skupine ispitanika, tj. razlika je samo 0.01. Prosječna razina slaganja s ovom tvrdnjom kod članova HDKN-a je 2.82, a kod religijskih novinara to je 2.81 .

I kod tvrdnje: „Urednici i vlasnici medija poštuju postulate medijske etike“ gotovo da nema razlike između razine slaganja kod ove dvije skupine ispitanika. Dok je kod članova HDKN-a srednja razina slaganja 1.90, kod religijskih novinara to je 1.93. Očito je da obje skupine smatraju da urednici i vlasnici medija nisu skloni djelovanju u skladu s postulatima medijske etike. 
Ispitanici obje skupine kod tvrdnje „Publika poznaje postulate medijske etike“ imaju sličnu srednju razinu slaganja: kod članova HDKN-a to je 2.51, a kod religijskih novinara to je 2.65, no razlika je u tome što su članovi HDKN-a svoje slaganja šarolikije raspodijelili, tj. kroz svih pet razina slaganja, dok je kod druge skupine to raspoređeno pretežno na razinu slaganja br. 3, uz neke koji su se odlučili i za najnižu razinu slaganja. U svakom slučaju, i jedni i drugi svoju razinu slaganja prosječno svrstavaju ispod 3.00, dakle bliži su stavu da publika ne poznaje postulate medijske etike.

U pitanju „Publika bira medijske sadržaje u skladu s postulatima medijske etike“ obje skupine imaju posve identičnu prosječnu razinu slaganja s tom tvrdnjom, te je kod obje skupine ona 1.75. No, očito je da ispitanici obje skupine smatraju kako publici postulati medijske etike ne predstavljaju bitan čimbenik prilikom izbora medijskih sadržaja.

Obje skupine ispitanika imaju dosta visoko mišljenje o svom poznavanju medijske etike, no razlike ipak postoje, a to nam pokazuju odgovori na tvrdnju: „Poznajem postulate medijske etike“. Kod članova HDKN-a prosječna razina slaganja s ovom tvrdnjom je 4.58, dok je kod religijskih novinara ta razina dosta visokih 4.96.

Iako su nešto drugačije raspodijelili razine slaganja oko tvrdnje „Poštujem postulate medijske etike u svom djelovanju“, ipak i kod jedne i kod druge skupine je srednja razina slaganja dosta visoka: kod članova HDKN-a to je 4.43, a kod religijskih novinara to je još viših 4.78 .

Obje skupine za tvrdnju „Teološka medijska etika je potrebna u suvremenom novinarstvu“ smatraju da je teološka medijska etika veoma potrebna suvremenom svijetu, tj. kod članova HDKN-a srednja razina slaganja s ovom tvrdnjom je 4.53, a kod religijskih novinara ta razina slaganja je 4.19, što je nešto niže od prve skupine, ali i dalje jako visoka razina.

S tvrdnjom „Novinari poznaju postulate teološke medijske etike“ se niti prva niti druga skupina ispitanika ne slaže, no kod religijskih novinara je razina slaganja uistinu veoma niska, tj. 1.84. Kod članova HDKN-a ta razina je 2.31 .

Obje skupine ispitanika, vezano uz tvrdnju „Novinari poštuju postulate teološke medijske etike“ smatraju da novinari ne poštuju postulate teološke medijske etike: kod članova HDKN-a razina slaganja s tvrdnjom je 1.90, a religijskih novinara to je 1.84 . 
Ispitanici uz tvrdnju „Urednici i vlasnici medija poznaju postulate teološke medijske etike“" smatraju da urednici i vlasnici medija slabo poznaju postulate teološke medijske etike, no postoji razlika u razini slaganja između ove dvije skupine: kod članova HDKN-a prosječna razina slaganja je 2.34, dok je kod religijskih novinara to 1.74 .

Očekivano, uzevši u obzir odgovor na prethodno pitanje, obje skupine vezano uz tvrdnju: „Urednici i vlasnici medija poštuju postulate teološke medijske etike“ smatraju da urednici i vlasnici medija gotovo uopće ne poštuju postulate teološke medijske etike: kod članova HDKN-a prosječna razina slaganja je 1.80, a kod religijskih novinara to je 1.40.

Odgovarajući na tvrdnju „Publika poznaje postulate teološke medijske etike“, ispitanici smatraju da publika uglavnom ne poznaje postulate teološke medijske etike: članovi HDKN-a prosječno izražavaju razinu slaganja 2.09, dok religijski novinari imaju razinu slaganja 1.96.

Iako ispitanici, dok su odgovarali na tvrdnju „Publika bira medijske sadržaje u skladu s postulatima teološke medijske etike“, imaju nisko mišljenje o poznavanju teološke medijske etike kod publike, još niže mišljenje imaju o tome koliko oni po tome biraju medijske sadržaje. Članovi HDKN-a kao prosječnu razinu slaganja imaju 1.87, a religijski novinari samo 1.37 .

S druge pak strane, ispitanici vezano uz tvrdnju „Poznajem postavke teološke medijske etike“ imaju jako visoko mišljenje o svom poznavanju temeljnih postavki teološke medijske etike, te između ovih dviju skupina ispitanika nema značajne razlike: članovi HDKN-a kao prosječnu razinu slaganja imaju 4.46, a religijski novinari 4.50.

Obje skupine ispitanika smatraju da veoma dobro poštuju postavke teološke medijske etike u svom djelovanju, što su istaknuli odgovarajući na tvrdnju „Poštujem postavke teološke medijske etike u svom djelovanju“: kod članova HDKN-a prosječna razina slaganja je 4.34, a kod religijskih novinara to je 4.53 .

Ispitanici uglavnom smatraju da medijska etika može pomoći teološkoj medijskoj etici: članovi HDKN-a to kod tvrdnje „Medijska etika može pomoći teološkoj medijskoj etici“ smatraju na razini slaganja 4.09, a religijski novinari 4.34.

Da je proces i obrnut, to jest da teološka medijska etika može pomoći medijskoj etici, istaknuli su ispitanici odgovarajući na tvrdnju „Teološka medijska etika može pomoći 
medijskoj etici“: članovi HDKN-a na razini slaganja 4.53, a religijski novinari na razini slaganja 4.28. Ovdje je zanimljivo, uspoređujući ove odgovore s odgovorima iz prethodnog pitanja, primijetiti sljedeće: članovi HDKN-a smatraju da teološka medijska etika može više pomoći medijskoj etici (4.53) nego obrnuto (4.09), dok je kod novinara religijskih novinara situacija drugačija: oni smatraju da medijska etika može više pomoći teološkoj medijskoj etici (4.34) nego obrnuto (4.28).

Obje skupine kod tvrdnje „Medijska etika i teološka medijska etika nemaju značajnijih razlika“ imaju dosta slično mišljenje, odnosno ono se nalazi otprilike u sredini: „niti se slažem, niti se ne slažem“. Kod članova HDKN-a ta razina slaganja je 3.02, a kod druge skupine 3.15 .

Uzevši $\mathrm{u}$ obzir prosječnu razinu slaganja s pojedinim tvrdnjom za obje skupine izračunata je razlika u razini slaganja. Kada se na kraju uzme prosječna razlika u razini slaganja, ona je samo 0.21 , dakle očito je da ove dvije skupine ispitanika, kada se izračunava prosječno odstupanje u njihovim stavovima, imaju vrlo slične stavove, tj. da između njih nema većih razlika, a rezultati su vidljivi iz Tablice 1.

Tablica 1. Prosječno odstupanje u stavovima između dviju skupina ispitanika

\begin{tabular}{|l|l|l|l|}
\hline Tvrdnja & $\begin{array}{l}\text { Članovi } \\
\text { HDKN-a }\end{array}$ & $\begin{array}{l}\text { Religijski } \\
\text { novinari }\end{array}$ & Razlika \\
\hline $\begin{array}{l}\text { Medijska etika je potrebna u } \\
\text { suvremenom novinarstvu. }\end{array}$ & 5.00 & 0.00 \\
\hline $\begin{array}{l}\text { Novinari poznaju postulate medijske } \\
\text { etike. }\end{array}$ & 2.63 & 2.56 & 0.07 \\
\hline $\begin{array}{l}\text { Novinari poštuju postulate medijske } \\
\text { etike. }\end{array}$ & 2.14 & 1.96 & 0.18 \\
\hline $\begin{array}{l}\text { Urednici i vlasnici medija poznaju } \\
\text { postulate svjetovne medijske etike. }\end{array}$ & 2.82 & 2.81 & 0.01 \\
\hline $\begin{array}{l}\text { Urednici i vlasnici medija poštuju } \\
\text { postulate medijske etike. }\end{array}$ & 1.90 & 1.93 & 0.03 \\
\hline \begin{tabular}{l} 
Publika poznaje postulate medijske etike. \\
\hline
\end{tabular} & 2.51 & 2.65 & \\
\hline
\end{tabular}




\begin{tabular}{|c|c|c|c|}
\hline Tvrdnja & $\begin{array}{l}\text { Članovi } \\
\text { HDKN-a }\end{array}$ & $\begin{array}{l}\text { Religijski } \\
\text { novinari }\end{array}$ & Razlika \\
\hline $\begin{array}{l}\text { Publika u skladu s postulatima medijske } \\
\text { etike bira medijske sadržaje. }\end{array}$ & 1.75 & 1.75 & 0.00 \\
\hline Poznajem postulate medijske etike. & 4.58 & 4.96 & 0.38 \\
\hline $\begin{array}{l}\text { Poštujem postulate medijske etike u } \\
\text { svom djelovanju. }\end{array}$ & 4.43 & 4.78 & 0.35 \\
\hline $\begin{array}{l}\text { Teološka medijska etika je potrebna u } \\
\text { suvremenom novinarstvu. }\end{array}$ & 4.53 & 4.19 & 0.34 \\
\hline $\begin{array}{l}\text { Novinari poznaju postulate teološke } \\
\text { medijske etike. }\end{array}$ & 2.31 & 1.84 & 0.47 \\
\hline $\begin{array}{l}\text { Novinari poštuju postulate teološke } \\
\text { medijske etike. }\end{array}$ & 1.90 & 1.84 & 0.06 \\
\hline $\begin{array}{l}\text { Urednici i vlasnici medija poznaju } \\
\text { postulate teološke medijske etike. }\end{array}$ & 2.34 & 1.71 & 0.63 \\
\hline $\begin{array}{l}\text { Urednici i vlasnici medija poštuju } \\
\text { postulate teološke medijske etike. }\end{array}$ & 1.80 & 1.40 & 0.40 \\
\hline $\begin{array}{l}\text { Publika poznaje postulate teološke } \\
\text { medijske etike. }\end{array}$ & 2.09 & 1.96 & 0.13 \\
\hline $\begin{array}{l}\text { Publika u skladu s postulatima teološke } \\
\text { medijske etike bira medijske sadržaje. }\end{array}$ & 1.87 & 1.37 & 0.50 \\
\hline $\begin{array}{l}\text { Poznajem postulate teološke medijske } \\
\text { etike. }\end{array}$ & 4.46 & 4.50 & 0.04 \\
\hline $\begin{array}{l}\text { Poštujem postulate teološke medijske } \\
\text { etike u svom djelovanju. }\end{array}$ & 4.34 & 4.53 & 0.19 \\
\hline $\begin{array}{l}\text { Medijska etika može pomoći teološkoj } \\
\text { medijskoj etici. }\end{array}$ & 4.09 & 4.34 & 0.25 \\
\hline $\begin{array}{l}\text { Teološka medijska etika može pomoći } \\
\text { medijskoj etici. }\end{array}$ & 4.53 & 4.28 & 0.25 \\
\hline $\begin{array}{l}\text { Medijska etika i teološka medijska etika } \\
\text { nemaju značajnijih razlika. }\end{array}$ & 3.02 & 3.15 & 0.13 \\
\hline \multicolumn{3}{|l|}{ Prosječna razlika u slaganju s tvrdnjama } & 0.21 \\
\hline
\end{tabular}




\section{ZAKLJUČAK}

Etička pitanja vezana uz novinarsku i medijsku etiku u suvremenom svijetu novih digitalnih medija postaju sve aktualnija i relevantnija. Ona su temom brojnih znanstvenih djela, simpozija i istraživanja, ali i promišljanja samih medijskih djelatnika koji bi u svojemu radu, sa stajališta svakodnevne prakse, htjeli jasno definirana etička načela prema kojima bi mogli ravnati svoje djelovanje, napisati nove ili osuvremeniti već postojeće kodekse časti vezane u novinarsku profesiju.

U tom širokom kontekstu mnogobrojnih etičkih pitanja koja se povezuju kako s tradicionalnim, tako i s novim medijima, među ostalim čimbenicima svoj doprinos želi pružiti i jedna vjerska organizacija, to jest Katolička Crkva služeći se pri tome svojim teološkim moralnim naučavanjem. Ona u svojim dokumentima često, izravno ili neizravno, dotiče, analizira i procjenjuje pitanja vezana uz korištenje medija, a posebno se posvećuje onima vezanima uz medijsku i novinarsku etiku. Stoga se kao jamačno znanstveno relevantno nametnulo i pitanje analize, povezivanja i istraživanja upravo navedenih područja, to jest samog etičkog sadržaja i etičkih kriterija iznesenih u crkvenim dokumentima kao i suvremenih razmišljanja o medijskoj i novinarskoj etici povezanih s novinarskom strukom i njezinim etičkim kodeksima. Jednako tako, ovim smo radom propitali i njihov međusobni odnos. Da bismo to ostvarili, uvodno smo prikazali, obradili i analizirali suvremenu svjetovnu medijsku etiku, pokušavajući sustavno donijeti presjek sadržaja vezanih uz pitanja etike i morala u području medija i novinarstva. Stoga smo odgovorili na pitanja razumijevanja etike kao filozofske discipline, predočene su podjele etike, iznesene teorije o novinarstvu u odnosu prema medijskoj etici, obrađena istina kao temelj medijske etike, postavljeno je pitanje o tome zašto je medijska etika uopće potrebna, a obrađena je i tema etičkog relativizma. U tu smo se svrhu posebno posvetiti i izlaganju i analizi dva relevantna suvremena autora i njihovih teorija: komunikacijskoj etici Jürgena Habermasa i etici diskursa Karla Otta Apela. Jednako tako, radom smo obuhvatili i analizu medijske etike Dala Jacquettea i njegovog govora o moralnoj odgovornosti u medijima, Louisa Alvina Daya o medijskoj etici te Claude-Jeana Bertranda o deontologiji medija. Obrađeni su i drugi strani i domaći autori, koji su posvećeni različitim pitanjima i temama kao što su: medijska i novinarska etika; društvene i medijske stvarnosti; odnos etike, vlasništva i profita; kriza vrednota u medijima; sloboda izražavanja i temelj novinarskog djelovanja; pitanja manipulacije i (auto)cenzure u medijima; vjerodostojnost, izvori informiranja i medijska pismenost te odgovornost primatelja. Kroz taj 
presjek odabranih promišljanja koja su relevantna za područje medijske i novinarske etike, predočena je slika suvremene medijske i novinarske etike, iznesena i protumačena načela, kriteriji i postulati kako bi ih se potom usporedilo s prijedlogom medijske etike i načelima koje na temelju teološkoga pristupa pružaju dokumenti Katoličke Crkve. Analizom se otkrilo po čemu se razlikuju ova dva pristupa, u čemu su slični i nude li nam oba pristupa zajedničke značajke onoga što se uobičajeno naziva minima moralia za ljudsko djelovanje, ne samo u suvremenom svijetu općenito, nego i na medijskom području.

Ovim su radom po prvi puta u Hrvatskoj sustavno analizirani crkveni dokumenti o medijima pod preciznim vidikom, to jest sa stajališta medijske etike, počevši od dokumenta Mirari vos pape Grgura XVI. iz 1832. godine, do mnogobrojnih dokumenata i poruka suvremenih papa: Ivana Pavla II., Benedikta XVI. i Franje. Valja istaknuti kako nije riječ o prvom doktorskom radu koji se bavi crkvenim dokumentima o medijima, ali je riječ o prvom koji sustavno i obuhvatno obrađuje crkvene dokumente o medijima pod specifičnim vidom medijske etike na hrvatskom području i stavlja ih u kontekst suvremenih znanstvenih razmišljanja o medijskoj etici. Važno je istaknuti da je teološki pristup medijskoj i novinarskoj etici jedan od pristupa među različitim suvremenim etičkim pristupima, kao i da teološki pristup ima svoje osobitosti koje je vrijedno i potrebno istražiti, prezentirati, analizirati i kritički usporediti s drugim etičkim prijedlozima za djelovanje novinara i medija u cijelosti, osobito stoga što postoji cijeli niz vjerskih medija i kod nas i u svijetu, a i zato što se specijalizirani novinari u svjetovnim medijima bave religijskim ili vjerskim pitanjima $\mathrm{i}$ temama.

Dajući svoj znanstveni doprinos na tom području, ovaj rad analitički uspoređuje suvremene etičke pravce te načela medijske etike općenito i one iznesene u crkvenim dokumentima. Rezultati analize su prikazani kroz različite teme u kojima je donesen usporedbeni prikaz, uz donošenje sličnosti i razlika u temama: utemeljenje normi i svrha medijske etike, čovjek kao središnji subjekt medijske etike, etički relativizam kao problem medijske etike, opće dobro, sloboda i odgovornost, istina kao temelj medijske etike, načela poštenja i objektivnosti, javno mnijenje, ljubav kao načelo medijske etike, mir i dijalog, moć medija, pitanje savjesti, solidarnost, vjerodostojnost medija, vlasništvo medija, cenzura i autocenzura, digitalni jaz, pitanje privatnosti, profit i kvaliteta, publika i njezina odgovornost za medijsku etiku, reklamiranje i etika u promidžbi. 
Nakon što je analizirao s jedne strane suvremene filozofske pravce medijske etike, te s druge strane teološku medijsku etiku iznesenu u crkvenim dokumentima, rad zaključuje da teološka medijska etika može dati svoj doprinos medijskoj etici i obratno. Kao konkretne teme kojima može pomoći, rad izdvaja sljedeće teme i naglaske teološke medijske etike koje mogu pridonijeti medijskoj etici: stavljanje čovjeka u središte, inzistiranje na istini, naglašavanje pojmova savjesti, općeg dobra, solidarnosti, mira i ljubavi u etičkom diskursu, kao i snažno inzistiranje na odgovornosti, te promišljanje o utemeljenju normi i svrsi medijske etike. Neosporno je, kao što smo rekli, da i medijska etika daje svoj doprinos teološkoj medijskoj etici, jer su većinom posvećene istim temama i pitanjima, samo iz različitih rakursa. Stoga bismo na temelju teorijske analize koju smo proveli u radu i usporedbe etičkih načela i postulata mogli zaključiti da su komplementarne.

Nadalje, iz istraživanja koje je provedeno anketnim upitnikom među članovima Hrvatskog društva katoličkih novinara i djelatnicima svjetovnih medija koji se bave religijskim temama, a koje je drugi dio rada, zaključili smo kako ispitanici za sebe smatraju da veoma dobro poznaju postulate i medijske etike i teološke medijske etike, te da u skladu s njima i djeluju, dok za druge sudionike medijskog procesa (vlasnike, urednike, kolege novinare, publiku...) imaju mnogo niže mišljenje. Također, imaju veoma visoku razinu slaganja s tvrdnjama da su i medijska etika i teološka medijska etika potrebne suvremenom novinarstvu (s tim da smatraju kako je medijska etika potrebnija nego teološka medijska etika), te možemo zaključiti da su takvi rezultati u skladu s očekivanjima.

Ispitanicima smo postavili i tri pitanja otvorenog tipa iz kojih se može zaključiti da temeljnim postulatima medijske etike smatraju: istinu, odgovornost, objektivnost i poštenje, a ta ista četiri načela smatraju i temeljnim postulatima teološke medijske etike. Analizirajući odgovore ispitanika i uspoređujući ih s onim što suvremena medijska etika, jednako kao i teološka medijska etika, apostrofiraju kao temeljna načela, može se kazati da ispitanici prepoznaju i pozitivno vrednuju postulate suvremene medijske etike i teološke medijske etike. Dobiveni rezultati se mogu primijeniti u edukaciji i konkretnom radu medijskih djelatnika u cilju ostvarivanja pozitivnog pomaka u komunikacijskim obrascima suvremene društvene komunikacije.

U uvodu smo kao cilj rada istaknuli: „Istražiti etička načela medijske etike koja su sadržana $\mathrm{u}$ suvremenim etičkim pravcima te ih usporediti $\mathrm{s}$ načelima iznesenima $\mathrm{u}$ 
dokumentima Katoličke Crkve koji se bave medijima, te analizirati potencijalni međusobni doprinos", što smo radom i ostvarili.

Na početku je postavljeno i pet hipoteza, koje smo potvrdili:

1. Unatoč razlikama među suvremenim etičkim pravcima na području medijske etike prisutan je značajan broj kriterija koji se podudaraju.

Hipoteza je potvrđena. Iz reprezentativnog uzorka prevladavajućih filozofskih pravaca na području medijske etike, zaključili smo da nema značajnijih razlika među njima.

2. U crkvenim dokumentima koji se bave medijima postoje različita, ali temeljno slična etička promišljanja.

Ova hipoteza je potvrđena. Kako je pokazala naša analiza etička su promišljanja „različita, ali temeljno slična“, a ta različitost je gotovo neprimjetna, tj. veći naglasak je na ovom drugom dijelu hipoteze, odnosno potvrđeno je da su to „temeljno slična etička promišljanja.“

3. U crkvenim dokumentima i u svjetovnim etičkim pravcima i međunarodnim kodeksima časti postoji više od polovice zajedničkih kriterija, iako ih se različito tumači.

I ova hipoteza je potvrđena, jer je u velikom dijelu analiziranih dokumenata riječ o zajedničkim kriterijima. Potvrđeno je i da ih se nekada različito tumači (npr. u odnosu „objavljenog mnijenja“ i ,javnog mnijenja“), ali ta različita tumačenja su manja nego se očekivalo.

4. Članovi HDKN-a, prema samoprocjeni, poštuju etičke kodekse i nauk svoje vjerske zajednice o medijima.

Hipoteza je u potpunosti potvrđena.

5. Nema značajne razlike u samoprocjeni poštivanja kriterija etičkih kodeksa među članovima HDKN-a i djelatnicima svjetovnih medija koji se bave religijskim temama. Hipoteza je u potpunosti potvrđena.

Zaključno, nakon provedene analize i istraživanja povezanih sa suvremenim filozofskim razmišljanjima o medijskoj etici i teološkoj medijskoj etici iznesenoj u crkvenim dokumentima, ističemo:

1. Crkveni dokumenti u prvi plan stavljaju objektivni moralni red kao nešto na čemu se temelji teološka medijska etika, a u suvremenim etičkim pravcima pronalazimo različite stavove i razmišljanja, pa se može govoriti o međusobnoj komplementarnosti. 
2. I medijska etika i crkveni dokumenti posvećeni medijima i medijskoj etici ističu potrebu stavljanja čovjeka u središte, bez obzira na određene divergencije i razlike u pristupu. Ipak, prema našoj analizi crkveni dokumenti to čine češće. Konačno, možemo reći da oni ovoj temi pristupaju kao i općenito medijska etika s puno pozornosti i otvorenosti za raspravu, smatrajući očito da je odnos prema čovjeku u temelju svake etike, te zato u samo središte stavljaju ljudsko dostojanstvo, čovjekovo nepovredivo pravo i vrijednost ljudske osobe.

3. I kod teme etičkog relativizma možemo reći da se njome bave i autori koji se bave medijskom etikom i crkveni dokumenti, tj. teološka medijska etika. Treba naglasiti da crkveni dokumenti, ali i suvremena medijska etika, često i kad ne govore o etičkom relativizmu, nego pišući o drugim temama i naglašavajući univerzalne vrednote, zapravo indirektno odbacuju etički relativizam.

4. I općenita medijska etika i teološka medijska etika izuzetno visoko vrednuju pojam općega dobra, a teološka uz njega veže i pojam zajednice. Opće dobro očituje se u pravu cjelokupne javnosti na istinito i objektivno, točno i transparentno informiranje $i$ pristup informacijama, stoga medijska etika i kad ne koristi izričito ovaj pojam, ipak često kroz neke druge termine progovara o temi općeg dobra.

5. Oba etička pristupa donose govor o slobodi i odgovornosti, te ih visoko vrednuju i cijene. I jedan i drugi značajno povezuju ta dva pojma u skladan međuodnos koji ukazuje na činjenicu da sloboda ne može bez odgovornosti, niti odgovornost može bez slobode. Iako nema značajnije razlike, stariji su crkveni dokumenti iznosili negativan stav o slobodi, a kasnije je u crkvenim dokumentima veći naglasak stavljen na odgovornost, no sloboda više nije isključena, dok je u medijskoj etici veći naglasak na slobodi i njezinoj povezanosti s odgovornošću.

6. Što se istine u medijima kao načela njihovoga djelovanja tiče, i medijska etika suvremenih autora koje smo obradili, kao i crkveni dokumenti, jako velik naglasak stavljaju upravo na nju, te se može kazati da je i jedni i drugi promatraju kao temelj medijske etike, bez nekih značajnijih razlika.

7. I općenita razmišljanja o načelima medijske etike i crkveni dokumenti koji iznose teološki etički stav govore o objektivnosti, no čini se kako su oba pojma i načela - i objektivnost i poštenje - češća tema opće medijske etike, koja na neki način uvodi i ustrajava na pojmu ,poštenja“, zapravo smatra da objektivnost u realnim okolnostima nije moguće postići, te se stoga suvremena medijska etika više usmjerava na pojam 
poštenja, koje se čini lakše dostižnim. Crkveni dokumenti ne ističu toliko pojam poštenja u kontekstu objektivnosti, no također ističu da je potpunu objektivnost nemoguće postići.

8. Iako i suvremena medijska etika i teološka medijska etika govore o javnom mnijenju, one ga u određenoj mjeri i različito vrednuju. Što se odnosa medija i medijske etike prema javnom mnijenju tiče, oni se najčešće oslanjaju, premda tu nismo ulazili u dublje analize, na činjenicu da se danas javno mnijenje smatra mišljenjem većine, pa ga tako prikazuju i tako vrednuju. S druge strane, teološki govor je suzdržaniji, a u nekim je slučajevima i suprotan, jer se u crkvenim dokumentima koje smo obradili javnim mnijenjem ne smatra mišljenje većine, nego se i takvo mišljenje propituje, dovodi u sumnju, a kada je riječ o nekim istinama koje zastupaju ti dokumenti, onda $\mathrm{i}$ odbacuje kao neispravno.

9. Pojam „ljubavi“ kao vrednote koja bi trebala postojati u medijima i koja bi trebala voditi etično djelovanje osoba koje djeluju u medijima, implicitna je i eksplicitna tema kako suvremene medijske etike, tako i one teološke, s time da je zaista često prisutna u crkvenim dokumentima. Riječ je o pojmu i načelu kojeg nije jednostavno definirati kao istinu, objektivnost, poštenje $\mathrm{i}$ druge, te se stoga logičnim nameće da se $u$ suvremenim pravcima medijske etike ne spominje eksplicitno, što ne znači da je se kao takvu ne vrednuje i ne promiče.

10. Tema mira ne samo da je prisutna i u crkvenim dokumentima i u medijskoj etici, nego ju se promatra kao vrednotu koju mediji trebaju promicati i provoditi u djelo u svom radu. To često isticanje mira može pomoći medijskoj etici - u teoriji i praksi - da dodatno shvati važnost mira, te da se medijske djelatnike i dalje potiče da budu nedvosmisleni i odvažni promicatelji mira koji je suvremenom svijetu itekako potreban kao vrednota na kojoj se temelji suživot različitih ljudi, društava i kultura. Pri tome je važno reći da se u novinarskim kodeksima časti po cijelome svijetu zabranjuje ratna propaganda ili bilo kakav huškački govor u medijima.

11. I suvremeno medijsko-etičko promišljanje, kao i teološka medijska etika iznesena u crkvenim dokumentima o medijima, snažno ističu veliku moć medija, te pri tome nema neke bitne razlike između crkvenih dokumenata i medijske etike, izuzev toga što crveni dokumenti uz govor o moći medija konstantno podsjećaju na činjenicu da se ta moć može iskoristiti i za dobro i za loše, a sve ovisi o tome koliko će etično ili neetično postupiti oni koji sudjeluju u tom procesu, dok se medijska etika više 
usredotočuje na prikazivanje i analizu te medijske moći u odnosu na politiku ili gospodarstvo, te propituje tko pokušava više utjecati na medije: političari ili ekonomija, to jest zarada i profit.

12. Kako teološka medijska etika, tako i autori s područja suvremenog razmišljanja o medijskoj etici, a posebno Luka Brajnović i Claude-Jean Bertrand, dotiču se pitanja savjesti, premda ona na određeni način može izgledati kao apstraktan pojam ili u najmanju ruku kao pojam koji bi trebao imati religijsko značenje, te ju ne bi bilo moguće znanstveno jasno definirati.

13. Na prvi pogled, mogli bismo površno i pogrešno zaključiti da suvremeni medijskoetički pravci ne koriste pojam solidarnosti, dok ga teološka medijska etika relativno često koristi. No, riječ je zapravo o pomalo „skrivenom“ pojmu u kontekstu medijske etike, što potiče na razmišljanje da teološka medijska etika može dati svoj doprinos medijskoj etici upravo uvođenjem ove kategorije u razne međunarodne i nacionalne novinarske kodekse na jasniji način, premda je taj pojam već u nekima uključen, bilo eksplicitno bilo implicitno, posebno kroz pozivanje na toleranciju i prihvaćanje drugih i drugačijih.

14. Pojam vjerodostojnosti se pojavljuje i obrađuje u obje etike, te se obrađuje bez značajnijih razlika. Riječ je o važnome pojmu, jer gotovo da nema suvremenog istraživanja medija koje ne pokazuje da je javnost izgubila ili da sve više gubi povjerenje u medije i smatra ih nevjerodostojnima.

15. Obje etike ukazuju na važno pitanje vlasništva medija, a ono se odnosi na udruživanje medija i činjenice da samo nekoliko ljudi upravlja velikim brojem medija, što dovodi do ozbiljnih etičkih pitanja i dilema vezanih uz mogući monopol i manipulaciju informacijama na globalnoj razini. Uz nekad neznatno različite naglaske, obje polaze od realne slike suvremenih medija i pokušavaju naći prikladne odgovore na pitanja $\mathrm{i}$ izazove pred kojima se suvremeni mediji nalaze.

16. I suvremena medijsko-etička razmišljanja i crkveni dokumenti temi cenzure pridaju veliku pozornost, što je itekako opravdano jer se kroz povijest medija javljaju uvijek novi oblici želje za kontrolom novinara i medija, a najčešće preko cenzure i poticanja autocenzure. Zbog toga suvremena etička razmišljanja upozoravaju na mnoge oblike pritiska na novinare koji onda vrlo često dovode do autocenzure. S druge pak strane crkveni dokumenti oblikovani prema teološkoj medijskoj etici češće ističu temu cenzure dok o autocenzuri ne govore izravno. Ono što smo otkrili analizom činjenica 
je da u moralnoj teologiji postoji razvoj misli o cenzuri, i to od samih početaka kada je i Crkva bila veoma naklonjena takvom postupanju do današnjih vremena kada je gleda kao negativnu pojavu.

17. I teološka i suvremena medijska etila uočavaju problem digitalnog jaza koji nije nova pojava, ali koji danas poprima neke nove i drugačije oblike. Obje medijske etike, uočavajući problem, žele svojim promišljanjima pridonijeti da taj jaz bude što manje izražen, to jest da na jednoj strani ne budu društva i slojevi društva bogati informacijama, a s druge strane oni koji su siromašni informacijama i prepušteni sebi samima

18. I suvremena i teološka medijska etika priznaju čovjekovo pravo na privatnost, naglašavajući da ju se ne smije ugrožavati. Prema našem istraživanju i usporedbi, nema značajnije razlike $u$ pristupu ovim temama između suvremene i teološke medijske etike.

19. I suvremeni medijsko-etički pravci i razmišljanja, kao i teološka etika govore o odnosu profita i kvalitete sadržaja, te primjećuju negativnu pojavu u kojoj profit ima primat pred kvalitetom. Svjesni su činjenice da mediji žele profit, te da sama težnja za profitom nije problematična ili neetična sama po sebi. Problem nastaje kada profit postane jedini kriterij, informacija roba, a kvaliteta nebitan čimbenik.

20. Danas su medijska istraživanja izuzetno posvećena medijskoj publici, te ovu temu u značajnom opsegu pronalazimo i u suvremenoj medijskoj etici, kao i u teološkoj. Kako znamo, danas se čak u nekim slučajevima briše granica između korisnika medija i stvaratelja medijskog sadržaja, te se javlja termin „prosumera“, koji dolazi od „producer“ i „consumer“, jer su medijski korisnici danas upravo to: sustvaratelji medijskih sadržaja, a to znači da svoju slobodu moraju koristiti odgovorno i oni, te da je etika primatelja u digitalno doba itekako važna.

21. I suvremena razmišljanja o medijskoj etici i teološka medijska etika na sličan način progovaraju o reklamiranju ili oglašavanju. Kod oba je viđenja uočljivo da se na promidžbu gleda pozitivno, ako se koristi u svrhu pozitivnog oglašavanja u prilog bolje informiranosti publike, ali se ne izbjegava spomenuti i tematizirati $\mathrm{i}$ one negativne aspekte reklama u onim slučajevima kada se reklamiranje koristi neetično, to jest kada je prijevarno i manipulativno.

22. Suvremena medijska etika, kao i ona teološka, posvećuju pažnju ulozi žene u medijima. Uočavaju određene stereotipe, ali i iskorištavanje žena koje je prisutno u 
sredstvima društvenog priopćavanja. U obradi ove teme nema značajnijih razlika između teološke i suvremene medijske etike. 
Prilog 1.

\title{
Anketni upitnik
}

\author{
Uvodna pitanja
}

1. Spol

Žena Muškarac

2. Dob

< 20 godina 20-29 godina 30-39 godina 40-49godina 50-60godina > 60 godina

3. Sebe bih okarakterizirao

Ateist/agnostik Vjerniknekatolik Nominalni vjernik katolik Praktičan vjernik katolik

Medijska etika

U pitanjima u ovom odjeljku, kao i onima koji slijede, tj. u pitanjima od br. 4 do br. 24 izričete svoje slaganje ili neslaganje s određenom tvrdnjom na sljedeći način: 1 - uopće se ne slažem, 2 - uglavnom se ne slažem, 3 - niti se slažem, niti se ne slažem, 4 - uglavnom se slažem, 5 - potpuno se slažem.

4. Medijska etika je potrebna u suvremenom novinarstvu.

$\begin{array}{lllllll}\text { Uopće se ne slažem } & 1 & 2 & 3 & 4 & 5 & \text { Potpuno se slažem }\end{array}$

5. Novinari poznaju postulate medijske etike.

$\begin{array}{lllllll}\text { Uopće se ne slažem } & 1 & 2 & 3 & 4 & 5 & \text { Potpuno se slažem }\end{array}$ 
6. Novinari poštuju postulate medijske etike.

$\begin{array}{lllllll}\text { Uopće se ne slažem } & 1 & 2 & 3 & 4 & 5 & \text { Potpuno se slažem }\end{array}$

7. Urednici i vlasnici medija poznaju postulate medijske etike.

$\begin{array}{lllllll}\text { Uopće se ne slažem } & 1 & 2 & 3 & 4 & 5 & \text { Potpuno se slažem }\end{array}$

8. Urednici i vlasnici medija poštuju postulate medijske etike.

$\begin{array}{lllllll}\text { Uopće se ne slažem } & 1 & 2 & 3 & 4 & 5 & \text { Potpuno se slažem }\end{array}$

9. Publika poznaje postulate medijske etike.

$\begin{array}{lllllll}\text { Uopće se ne slažem } & 1 & 2 & 3 & 4 & 5 & \text { Potpuno se slažem }\end{array}$

10. Publika bira medijske sadržaje u skladu s postulatima medijske etike.

$\begin{array}{lllllll}\text { Uopće se ne slažem } & 1 & 2 & 3 & 4 & 5 & \text { Potpuno se slažem }\end{array}$

11. Poznajem postulate medijske etike.

$\begin{array}{lllllll}\text { Uopće se ne slažem } & 1 & 2 & 3 & 4 & 5 & \text { Potpuno se slažem }\end{array}$

12. Poštujem postulate medijske etike u svom djelovanju.

$\begin{array}{lllllll}\text { Uopće se ne slažem } & 1 & 2 & 3 & 4 & 5 & \text { Potpuno se slažem }\end{array}$

Medijska etika u dokumentima Katoličke Crkve

13. Teološka medijska etika je potrebna u suvremenom novinarstvu.

$\begin{array}{lllllll}\text { Uopće se ne slažem } & 1 & 2 & 3 & 4 & 5 & \text { Potpuno se slažem }\end{array}$

14. Novinari poznaju postulate teološke medijske etike.

$\begin{array}{lllllll}\text { Uopće se ne slažem } & 1 & 2 & 3 & 4 & 5 & \text { Potpuno se slažem }\end{array}$ 
15. Novinari poštuju postulate teološke medijske etike.

$\begin{array}{lllllll}\text { Uopće se ne slažem } & 1 & 2 & 3 & 4 & 5 & \text { Potpuno se slažem }\end{array}$

16. Urednici i vlasnici medija poznaju postulate teološke medijske etike.

$\begin{array}{lllllll}\text { Uopće se ne slažem } & 1 & 2 & 3 & 4 & 5 & \text { Potpuno se slažem }\end{array}$

17. Urednici i vlasnici medija poštuju postulate teološke medijske etike.

$\begin{array}{lllllll}\text { Uopće se ne slažem } & 1 & 2 & 3 & 4 & 5 & \text { Potpuno se slažem }\end{array}$

18. Publika poznaje postulate teološke medijske etike.

$\begin{array}{lllllll}\text { Uopće se ne slažem } & 1 & 2 & 3 & 4 & 5 & \text { Potpuno se slažem }\end{array}$

19. Publika bira medijske sadržaje u skladu s postulatima teološke medijske etike.

$\begin{array}{lllllll}\text { Uopće se ne slažem } & 1 & 2 & 3 & 4 & 5 & \text { Potpuno se slažem }\end{array}$

20. Poznajem postulate teološke medijske etike.

$\begin{array}{lllllll}\text { Uopće se ne slažem } & 1 & 2 & 3 & 4 & 5 & \text { Potpuno se slažem }\end{array}$

21. Poštujem postulate teološke medijske etike u svom djelovanju.

$\begin{array}{lllllll}\text { Uopće se ne slažem } & 1 & 2 & 3 & 4 & 5 & \text { Potpuno se slažem }\end{array}$

Odnos medijske etike i teološke medijske etike

22. Medijska etika može pomoći teološkoj medijskoj etici.

$\begin{array}{lllllll}\text { Uopće se ne slažem } & 1 & 2 & 3 & 4 & 5 & \text { Potpuno se slažem }\end{array}$ 
23. Teološka medijska etika može pomoći medijskoj etici.

$\begin{array}{lllllll}\text { Uopće se ne slažem } & 1 & 2 & 3 & 4 & 5 & \text { Potpuno se slažem }\end{array}$

24. Medijska etika i teološka medijska etika nemaju značajnijih razlika.

$\begin{array}{lllllll}\text { Uopće se ne slažem } & 1 & 2 & 3 & 4 & 5 & \text { Potpuno se slažem }\end{array}$

Pitanja otvorenog tipa

25. Sto smatrate temeljim postulatom medijske etike?

26. Što smatrate temeljnim postulatom teološke medijske etike?

27. Što bi se trebalo učiniti da postulati medijske etike više zažive u praksi? 


\section{LITERATURA}

1. Apel, Karl-Otto (1980), Transformacija filozofije, Sarajevo, Veselin Masleša

2. Apel, Karl-Otto (1996), Selected Essays - Vol. 2 - Ethics and the Theory of Rationality, New Jersey, Humanities Press

3. Apel, Karl-Otto (2001), Etnoetika i univerzalistička makroetika: protuslovlje ili komplementarnost?, u: Flego, Gvozden (2001), uredio, Zbilja i kritika, Zagreb, Antibarbarus

4. Apel, Karl-Otto (2001), The response of discourse ethics, Louven, Peeters

5. Baloban, Josip; Nikodem, Krunoslav; Zrinščak, Siniša (2014), Vrednote u Hrvatskoj $i$ Europi. Komparativna analiza, Kršćanska sadašnjost, Katolički bogoslovni fakultet Sveučilišta u Zagrebu, Zagreb

6. Balukčić, Ivo (2012), Masmediji u novoj evangelizaciji, u: Vrhbosnensia, časopis za teološka i međureligijska pitanja, god. 16, br. 1, 2012, 125-141

7. Bauer, Helmut (1997), Sloboda medija i javno mnijenje. Medijska politika u Saveznoj Republici Njemačkoj, Osijek-Split-Zagreb, Pan Liber

8. Bauer, Thomas A. (2007), Mediji za otvoreno društvo. Medijska odgovornost kao temelj demokratske medijske kulture, Zagreb, Sveučilišna knjižara

9. Bertrand, Claude-Jean (2007), Deontologija medija, Zagreb, Sveučilišna knjižara

10. Boss, Judith A., (2004), Ethics for life, New York, McGraw-Hill

11. Brajnović, Luka (1997), Novinarska deontologija. Nauka o dužnostima novinara kao moralnoj obavezi, u: Hrvatska revija, 47 (1997) 2, 272-289.

12. Burger, Hotimir (1988), „Subjektnocentrirana“ filozofija i komunikativna intersubjektivnost, uvod u: Habermas, Jurgen (1988), Filozofski diskurs moderne. Dvanaest predavanja, Globus, Zagreb

13. Ciboci, Lana (2018), Medijska pismenost učenika osmih razreda u Zagrebu, u: Medijske studije, 9 (2018) 17, 23-46. 
14. Ciboci, Lana; Kanižaj, Igor; Labaš, Danijel (2014), Media Education from the Perspective of Parents of Preschool Children: Challenges and Trends in Free Time Media Use, u: Medijska istraživanja, 20 (2014) 2, 53-69.

15. Čehok, Ivan; Koprek, Ivan (1996), Etika. Priručnik jedne discipline, Zagreb, Školska knjiga

16. Čupić, Čedomir (2010), Medijska etika i medijski linč, Beograd, Čigoja štampa

17. Jacquette, Dale (2007), Novinarska etika. Moralna odgovornost u medijima, Beograd, Javno poduzeće Službeni glasnik

18. Jacquette, Dale (2010), Jurnalism ethics as truth-telling in the public interest; u Stuart Allan (2010), ed., The Routledge Companion to News and Journalism, London - New York, Routledge.

19. Day, Louis Alvin (2014), Etika u medijima. Primeri i kontraverze, Beograd, Medija centar

20. Devčić, Ivan (2006), Crkva i svijet medija: put od nepovjerenja do poziva na dijalog, u: Riječki teološki časopis, god. 14, br. 1, 2006, 5-26.

21. Elliott, Deni; Spence, Edward H. (2018), Ethics for a Digital Era, Oxford, Willey Blackwell

22. Fink, Conrad C. (1995), Media ethics, Boston [etc.], Allyn and Bacon

23. Foley, John P. (2003), u: Ivan Pavao II. (2003), Deset poruka za slavlje Svjetskog dana sredstava društvene komunikacije, Zagreb; IKA

24. Fučak, Ivan (1989), Novi dokument o pornografiji, u: Obnovljeni život 44 (1989) 5, 471-481.

25. Gavranovic, Ante (2006), Medijska obratnica, Zagreb, Sveučilišna knjižnica

26. Gavranović, Ante (2009), Mediji, mitovi i stvarnost, Zagreb, Sveučilišna knjižnica

27. Gavranović, Ante (2011), Poslovno novinarstvo između etike i zarade, Zagreb, Pressus studio

28. Habermas, Jürgen (1980), Teorija i praksa, Socijalnofilozofske studije, Beograd 
29. Habermas, Jürgen (1984), Theory of Communicative Action (vol. I), Boston, Beacon Press

30. Habermas, Jürgen (2001), Justification and Application. Remarks on Discourse Ethics, The MIT Press, Cambridge, Massachusetts and London, England

31. Habermas, Jürgen (2013), Politička komunikacija u medijskom društvu: da li demokracija još uživa spoznajnu dimenziju? Utjecaj normativne teorije na empirijska istraživanja, u: Politička misao, god. 50, br. 2, 2013, 145-160

32. Halder, Alois (2002), Filozofijski rječnik, Zagreb, naklada Jurčić

33. Hamelink, Cees J. (1998), Etika za korisnike medija, u: Medijska istraživanja 4 (1998) $1,47-59$

34. Hartmann, Nicolai (2003) Etika, Zagreb, Naklada Ljevak

35. Interview s Karl - Otto Apelom, u: Politička misao, Vol. XXVII (1990), No. 2, 126132

36. Johnson, Oliver A.; Reath, Andrews (2007) Ethics, Selections from Clasical and Contemplorary Writters, Belmont, Thomson Wadsworth

37. Jurišić, Jelena; Kanižaj, Igor (2007), Manipulacija čitateljima - prikriveno oglašavanje u hrvatskim novinama, u: Politička misao, XLIV (2007.) 1, 117-135.

38. Kedžo, Zdravko (2015.), Povjerenje u medije i krizno komuniciranje: lokalni radio u izvanrednoj situaciji. Doktorska disertacija, Sveučilište Josipa Jurja Strossmayera, Osijek

39. Klun, Branko (2000.), Rat i mediji - etički izazov na kraju stoljeća, u: Medijska istraživanja, 6 (1), 75-87.

40. Knowlton, Steven, Parson, Patrik R. (1997), The Journalist: Cases and Comentary, Westport

41. Kodeks časti hrvatskih novinara (2009), dostupno na: http://www.hnd.hr/dokumenti, (gledano 13. lipnja 2019.)

42. Kulrtić, Najil (2007), Konceptualizacija istraživanja. u: Malović, Stjepan (2007), ur., Vjerodostojnost novina, Zagreb, Sveučilišna knjižara 
43. Kunczik, Michael; Zipfel, Astrid (2006), Uvod u znanost o medijima i komunikologiju, Zagreb, Zaklada Friedrich Ebert

44. Kurtić, Najil; Maletić, Franjo; Malović, Stjepan; Vilović, Gordana (2014), Masovno komuniciranje, Zagreb, Sveučilište Sjever

45. Labaš, Danijel (1993), Crkva i društvene komunikacije, u: Obnovljeni život, god. 48, br. 1, 1993, 76-97

46. Labaš, Danijel (1993), Crkva i društvene komunikacije, u: Obnovljeni život, 48 (1993) $1,76-97$

47. Labaš, Danijel (2006), Novinarstvo pred zahtjevom istine, u: Riječki teološki časopis, 14 (2006) 1, 53-68.

48. Labaš, Danijel (2007.), Odgovornost novinara u ratu - izvještavanje talijanskog tiska o padu Vukovara, u: Žebec, Ivana; Živić Dražen, Vukovar - hrvatska baština $i$ perspektive razvoja, Zagreb - Vukovar, Institut društvenih znanosti Ivo Pilar, 99-108.

49. Labaš, Danijel (2009), Međuljudska komunikacija, novi mediji i etika: u: Labaš Danijel, (ur.), Novi mediji, nove tehnologije, novi moral, Zagreb, 13-40.

50. Labaš, Danijel (2010), Luka Brajnović - od vjernosti sebi do vjerodostojnosti profesije, u: Medijske studije, 1 (2010) 1-2, 171-182.

51. Labaš, Danijel; Barčot, Marija (2013), Mediji i rat - etički izazov. Tiskovni mediji u Domovinskom ratu na primjeru Vukovara 1991, u: Živić, Dražen; Špoljar Vržina, Sanja; Lupis, Vinicije B.; Cvikić, Sandra (2013), Vukovar '91. - istina i/ili osporavanje (između znanosti i manipulacije), Zagreb - Vukovar, Institut društvenih znanosti Ivo Pilar - Ogranak Matice hrvatske Vukovar

52. Labaš, Danijel; Koščević, Kristina (2014), Etička manipulacija i etika u oglašavanju, u: Mostariensia, 18 (2014.) 1-2, 201-230.

53. Labaš, Danijel; Marinčić, Petra (2017), The Media on the Subject of Media Literacy in the Croatian Education System, u: Communication Management Review, 2 (2017) 2, 120-137. 
54. Labaš, Danijel; Uldrijan, Ivan (2010), Može li dobro novinarstvo biti nemoralno? Pitanje odnosa kvalitete, etike i medijske pismenosti. u: Labaš, Danijel (ur.), Mediji i društvena odgovornost, Zagreb, Hrvatski studiji, 85-106.

55. Labaš, Danijel; Vizler, Ana (2005), Odgovornost primatelja i medijska etika, u: Nova prisutnost, III/2, 2005, 277-295.

56. Letica, Zvonko (2003) Televizijsko novinarstvo, Zagreb, Disput

57. MacBride, Sean (1980), Many Voices One World, Kogan Page, Unipub, Unesco, London, New York Paris

58. Malović, Stjepan (1995), Novine, Zagreb, Sveučilišna knjižara

59. Malović, Stjepan (1997), Profesionalizam - preduvjet objektivnog i poštenog novinarstva, u: Politička misao, XXXIV (1997) 4, 151-165.

60. Malović, Stjepan (2004), Medijski prijepori, Zagreb, Sveučilište u Dubrovniku

61. Malović, Stjepan (2005), Osnove novinarstva, Zagreb, Golden marketing - Tehnička knjiga

62. Malović, Stjepan (2007), Mediji i kultura društva, Zagreb, Sveučilišna knjižara

63. Malović, Stjepan (2007), Vjerujemo li novinama. Istraživanje o vjerodostojnosti novina u Hrvatskoj, Bosni i Hercegovini i Crnoj Gori, u: Malović, Stjepan (2007) (ur.), Vjerodostojnost novina, Zagreb, Sveučilišna knjižara

64. Malović, Stjepan; Ricchiardi, Sherry; Vilović, Gordana (2007), Etika novinarstva, Zagreb, Sveučilišna knjižara

65. Mataušić, Mirko J. (2002), Mediji u krizi vrednota, u: Bogoslovska smotra 71 (2002) 2-3, 361-379

66. Mihovilović, Maja; Labaš, Danijel (2001), Masovni mediji i semiotika popularne kulture, u: Kroatologija 2 (2011) 1, 95-122.

67. Miliša, Zlatko; Tolić, Mirela; Vertovšek, Nenad (2009.), Mediji i mladi - prevencija ovisnosti o medijskoj manipulaciji, Sveučilišna knjižara, ICEJ, Zagreb

68. Mišić, Ante (2002), Rječnik filozofskih pojmova, Verbum, Split. 
69. Nikodem, Krunoslav; Valković, Jerko (2012), Mediji u hrvatskom društvu. Analiza osnovnih karakteristika medijskog prostora $\mathrm{s}$ obzirom na supsidijarnost, $\mathrm{u}$ : Bogoslovska smotra, 81 (2012) 4, 783-814

70. Paić, Žarko (2009), Novi mediji: od „živih slika“ do „slika života“, u: Riječi 1-3 (2009), 175-213

71. Peran, Suzana; Mataušić, Juraj Mirko (2013), Javno mnijenje i dijalog u Crkvi, u: Bogoslovska smotra, 83 (2013.) 2, 235 -261.

72. Perebinossoff, Philippe (2008), Real-world media ethics, Amsterdam (etc), Focal Press

73. Poler Kovačić, Melita (2001), Kriza novinarstva kao kriza etike: tko je novinarski subjekt?, u: Medijska istraživanja 7 (2001) 1-2, 25-44.

74. Poler, Melita (1998), Što je novinarska etika? u: Medijska istraživanja 4 (1998) 1, 2945.

75. Pozaić, Valentin (1992), Granica morala i nemorala na TV, u: Obnovljeni život, 47 (1992) 6, 557-569

76. Sanders, Karen (2004), Ethics \& Journalism, London, Thousand Oaks; New Delhi : Sage Publications, 2004.

77. Sapunar, Marko (2002), Opća povijest novinarstva, Zagreb, vlastita naklada

78. Sapunar, Marko (2004), Osnove znanosti o novinarstvu, Zagreb, vlastita naklada

79. Šarčević, Abdulah (1980), Pogovor, u: Apel, Karl-Otto, Transformacija filozofije, Sarajevo, Veselin Masleša

80. Tkalac Verčić, Ana, Sinčić Ćorić, Dubravka, Paloški Vokić Nina (2010.), Priručnik za metodologiju istraživačkog rada, Zagreb, M.E.P.

81. Valković, Jerko (2006), Medijska manipulacija - stalni izazov etičkom promišljanju, u: Riječki teološki časopis, 14 (2006) 1, 27-52.

82. Valković, Jerko (2008), Istina u promidžbi. Retorički elementi promidžbene komunikacije i etičke implikacije, u: Obnovljeni život (63) 3 (2008), 275-300. 
83. Valković, Jerko (2012), Duc in altum! Evangelizacija u ,digitalno doba“, u: Diacovensia god. 20, br. 2, 2012, 171-186.

84. Valković, Jerko (2013), Crkva i svijet medija, Zagreb, Glas Koncila

85. Vilović, Gordana (2003), Istraživačko novinarstvo, tabloidizacija i etika, u: Društvena istraživanja, 12 (2003) 6, 957-974

86. Vilović, Gordana (2007), Etički aspekti (ne)vjerodostojnosti novina. Kredibilitet i etičke standarde profesije u Hrvatskoj, Bosni i Hercegovini i Crnoj gori tek treba početi izgrađivati, u: Malović, Stjepan (ur.), Vjerodostojnost novina, Zagreb, Sveučilišna knjižara

87. Zlatko Miliša - Mirela Tolić - Nenad Vertovšek (2010), Mladi - odgoj za medije. Priručnik za stjecanje medijskih kompetencija, MEP, Zagreb

88. Žlof, Ksenija (2007), Važnost izvora za vjerodostojnost medija. Neobjavljivanje izvora informacija najčešći uzrok smanjenje vjerodostojnosti medija., u: Malović, Stjepan (2007) (ur.), Vjerodostojnost novina, Zagreb, Sveučilišna knjižara

\section{Crkveni dokumenti}

89. Brzi razvoj (2005), Zagreb, IKA

90. Communio et Progressio (2002), Zagreb, Kršćanska sadašnjost

91. Crkva i internet, dostupno na: http://www.ika.hr/index.php?prikaz=vijest\&ID=49521, (gledano 7. srpnja 2016.)

92. Etika na internetu, dostupno na http://www.ika.hr/index.php?prikaz=vijest\&ID=49520, (gledano 13. srpnja 2016.)

93. Etika u obavijesnim sredstvima (2000), Zagreb, IKA

94. Etika u promidžbi, dostupno na: http://www.vatican.va/roman_curia/pontifical_councils/pccs/documents/rc_pc_pccs_d oc_22021997_ethics-in-ad_en.html, (gledano 15. srpnja 2016.)

95. Evangelii Nuntiandi (2000), Zagreb, Kršćanska sadašnjost

96. Evangelii Gaudium (2015), Zagreb, Kršćanska sadašnjost 
97. Inter Mirifica, u: Drugi vatikanski sabor. Dokumenti (2008), Zagreb, Kršćanska sadašnjost

98. Mirari Vos, dostupno na http://www.papalencyclicals.net/Greg16/g16mirar.htm, (gledano 27. srpnja 2016.)

99. Nadolaskom novog doba. Aetatis Novae (1998), Zagreb, Kršćanska sadašnjost

100. Pornografija i nasilje u sredstvima društvenih komunikacija, dostupno na: http://www.vatican.va/roman_curia/pontifical_councils/pccs/documents/rc_pc_pccs_d oc_07051989_pornography_en.html, (gledano 2. kolovoza 2016.)

101. Redemptoris Missio (1991), Zagreb, Kršćanska sadašnjost

102. Vigilanti Cura, dostupno na http://w2.vatican.va/content/pius-

xi/en/encyclicals/documents/hf_p-xi_enc_29061936_vigilanti-cura.html, (gledano 12. kolovoza 2016.)

\section{Poruke za Svjetski dan sredstava društvene komunikacije}

103. Crkva i društvene komunikacije: Prvi Svjetski dan sredstava društvene komunikacije (1967), dostupno na: http://w2.vatican.va/content/paul-

vi/en/messages/communications/documents/hf_p-vi_mes_19670507_i-com-day.html, (gledano 15. kolovoza 2016.)

104. Društvene komunikacije i razvoj naroda (1968), dostupno na: http://w2.vatican.va/content/paul-vi/en/messages/communications/documents/hf_pvi_mes_19680326_ii-com-day.html, (gledano 16. kolovoza 2016.)

105. Društvene komunikacije i obitelj (1969), dostupno na http://w2.vatican.va/content/paul-vi/en/messages/communications/documents/hf_pvi_mes_19690407_iii-com-day.html, (gledano 17. kolovoza 2016.)

106. Društvene komunikacije i mladi (1970), dostupno na: http://w2.vatican.va/content/paul-vi/en/messages/communications/documents/hf_pvi_mes_19700406_iv-com-day.html, (gledano 18. kolovoza 2016.)

107. Uloga medija u promicanju jedinstva među ljudima (1971), dostupno na: http://w2.vatican.va/content/paul-vi/en/messages/communications/documents/hf_pvi_mes_19710325_v-com-day.html, (gledano 19. kolovoza 2016.) 
108. Sredstva društvene komunikacije u službi istine (1972), dostupno na: http://w2.vatican.va/content/paul-vi/en/messages/communications/documents/hf_pvi_mes_19720421_vi-com-day.html, (gledano 20. kolovoza 2016.)

109. Masovni mediji u ulozi afirmacije i promicanja duhovnih vrijednosti (1973), dostupno na: http://w2.vatican.va/content/paulvi/en/messages/communications/documents/hf_p-vi_mes_19730501_vii-comday.html, (gledano 21. kolovoza 2016.)

110. Društvene komunikacije i evangelizacija u današnjem svijetu (1974), dostupno na: http://w2.vatican.va/content/paul-vi/en/messages/communications/documents/hf_pvi_mes_19740516_viii-com-day.html, (gledano 22. kolovoza 2016.)

111. Masovni mediji i pomirenje (1975), dostupno na: http://w2.vatican.va/content/paulvi/en/messages/communications/documents/hf_p-vi_mes_19750419_ix-comday.html, (gledano 23. kolovoza 2016.)

112. Sredstva društvene komunikacije u službi temeljnih ljudskih prava i dužnosti (1976), dostupno na: http://w2.vatican.va/content/paulvi/en/messages/communications/documents/hf_p-vi_mes_19760411_x-com-day.html, (gledano 24. kolovoza 2016.)

113. Oglašavanje u masovnim medijima: prednosti, opasnosti i odgovornost (1977), dostupno na: http://w2.vatican.va/content/paulvi/en/messages/communications/documents/hf_p-vi_mes_19770512_xi-comday.html, (gledano 25. kolovoza 2016.)

114. Korisnik društvenih komunikacija, njegova očekivanja, prava i dužnosti (1978), dostupno na: http://w2.vatican.va/content/paulvi/en/messages/communications/documents/hf_p-vi_mes_19770512_xi-comday.html, (gledano 26. kolovoza 2016.)

115. Društvene komunikacije: zaštita djeteta i promoviranje njegovog najboljeg interesa $u$ obitelji i društvu (1979), dostupno na: http://w2.vatican.va/content/john-paulii/en/messages/communications/documents/hf_jp-ii_mes_23051979_worldcommunications-day.html, (gledano 27. kolovoza 2016.)

116. Društvene komunikacije i obitelj (1980), dostupno na: http://w2.vatican.va/content/john-paulii/en/messages/communications/documents/hf_jp-ii_mes_01051980_worldcommunications-day.html, (gledano 28. kolovoza 2016.) 
117. Društvene komunikacije i odgovorna ljudska sloboda (1981), dostupno na: http://w2.vatican.va/content/john-paulii/en/messages/communications/documents/hf_jp-ii_mes_10051981_worldcommunications-day.html, (gledano 29. kolovoza 2016.)

118. Društvene komunikacije i problem starijih osoba (1982.), dostupno na http://w2.vatican.va/content/john-paulii/en/messages/communications/documents/hf_jp-ii_mes_10051982_worldcommunications-day.html, (gledano 30. kolovoza 2016.)

119. Društvene komunikacije i promicanje mira (1983), dostupno na: http://w2.vatican.va/content/john-paulii/en/messages/communications/documents/hf_jp-ii_mes_25031983_worldcommunications-day.html, (gledano 31. kolovoza 2016.)

120. Društvena obavijesna sredstva: instrumenti susreta između vjere i kulture (1984), dostupno na: http://w2.vatican.va/content/john-paulii/en/messages/communications/documents/hf_jp-ii_mes_24051984_worldcommunications-day.html, (gledano 1. rujna 2016.)

121. Društvene komunikacije i kršćansko zauzimanje za mlade (1985), dostupno na: http://w2.vatican.va/content/john-paulii/en/messages/communications/documents/hf_jp-ii_mes_15041985_worldcommunications-day.html, (gledano 2. rujna 2016.)

122. Društvene komunikacije, kršćani i formiranje javnog mijenja (1986), dostupno na: http://w2.vatican.va/content/john-paulii/en/messages/communications/documents/hf_jp-ii_mes_24011986_worldcommunications-day.html, (gledano 3. rujna 2016.)

123. Društvene komunikacije u službi pravde i mira (1987), dostupno na: http://w2.vatican.va/content/john-paulii/en/messages/communications/documents/hf_jp-ii_mes_24011987_worldcommunications-day.html, (gledano 4. rujna 2016.)

124. Društvene komunikacije i promicanje solidarnosti i bratstva među ljudima i narodima (1988), dostupno na: http://w2.vatican.va/content/john-paulii/en/messages/communications/documents/hf_jp-ii_mes_24011988_worldcommunications-day.html, (gledano 5. rujna 2016.) 
125. Religija u medijima (1989), dostupno na: http://w2.vatican.va/content/john-paulii/en/messages/communications/documents/hf_jp-ii_mes_24011989_worldcommunications-day.html, (gledano 6. rujna 2016.)

126. Kršćanska poruka u kompjuterskoj kulturi (1990), dostupno na: http://w2.vatican.va/content/john-paulii/en/messages/communications/documents/hf_jp-ii_mes_24011990_worldcommunications-day.html, (gledano 7. rujna 2016.)

127. Sredstva društvenog priopćavanja te jedinstvo i napredak ljudske obitelji (1991), dostupno na: http://w2.vatican.va/content/john-paulii/en/messages/communications/documents/hf_jp-ii_mes_24011991_worldcommunications-day.html, (gledano 8. rujna 2016.)

128. Navještaj Kristove poruke u sredstvima društvenog priopćavanja (1992), dostupno na: http://w2.vatican.va/content/john-paulii/en/messages/communications/documents/hf_jp-ii_mes_24011992_worldcommunications-day.html, (gledano 9. rujna 2016.)

129. Video i audio kazete u formiranju kulture i savjesti (1993), dostupno na: http://w2.vatican.va/content/john-paulii/en/messages/communications/documents/hf_jp-ii_mes_24011993_worldcommunications-day.html, (gledano 10. rujna 2016.)

130. Prava mjera televizije u obitelji (1994), u: Ivan Pavao II. (2003), Deset poruka za slavlje Svjetskog dana sredstava društvene komunikacije, Zagreb, IKA

131. Filmska produkcija: komunikator kulture i vrijednosti (1995), u: Ivan Pavao II. (2003), Deset poruka za slavlje Svjetskog dana sredstava društvene komunikacije, Zagreb, IKA

132. Sredstva društvene komunikacije areopag za promicanje žene u društvu (1996), u: Ivan Pavao II. (2003), Deset poruka za slavlje Svjetskog dana sredstava društvene komunikacije, Zagreb, IKA

133. Naviještati Krista koji je put, istina i život ( 1997), u: Ivan Pavao II. (2003), Deset poruka za slavlje Svjetskog dana sredstava društvene komunikacije, Zagreb, IKA

134. Ohrabreni duhom, priopćavati nadu (1998), u: Ivan Pavao II. (2003), Deset poruka za slavlje Svjetskog dana sredstava društvene komunikacije, Zagreb, IKA 
135. Javna glasila: prijateljska prisutnost ukorak s onima koji traže Oca (1999), u: Ivan Pavao II. (2003), Deset poruka za slavlje Svjetskog dana sredstava društvene komunikacije, Zagreb, IKA

136. Naviještati Krista $u$ društvenim obavijesnim sredstvima u zoru novog tisućljeća (2000), u: Ivan Pavao II. (2003), Deset poruka za slavlje Svjetskog dana sredstava društvene komunikacije, Zagreb, IKA

137. Propovijedate na krovovima: evanđelje u dobu globalne komunikacije (2001), u: Ivan Pavao II. (2003), Deset poruka za slavlje Svjetskog dana sredstava društvene komunikacije, Zagreb, IKA

138. Internet: novi forum za naviještanje evanđelja (2002), u: Ivan Pavao II. (2003), Deset poruka za slavlje Svjetskog dana sredstava društvene komunikacije, Zagreb, IKA

139. Mediji u službi istinskog mira u svjetlu „Pacem in terris“ (2003), u: Ivan Pavao II. (2003), Deset poruka za slavlje Svjetskog dana sredstava društvene komunikacije, Zagreb, IKA

140. Mediji i obitelj: rizik i bogatstvo (2004), dostupno na: http://w2.vatican.va/content/john-paulii/en/messages/communications/documents/hf_jp-ii_mes_20040124_worldcommunications-day.html, (gledano 21. rujna 2016.)

141. Sredstva društvene komunikacije u službi razumijevanja među narodima (2005), dostupno na: http://www.ika.hr/bilteni/bilten_04-2005.pdf, (gledano 22. rujna 2016.)

142. Mediji: mreža komunikacije, zajedništva i suradnje (2006), dostupno na: http://www.ika.hr/index.php?prikaz=vijest\&ID=83775, (gledano 23. rujna 2016.)

143. Djeca i komunikacijska sredstva: izazov za odgoj (2007), dostupno na: http://www.ika.hr/index.php?prikaz=vijest\&ID=94330, (gledano 24. rujna 2016.)

144. Sredstva društvene komunikacije: na raskrižju između protagonizma i služenja. Tražiti istinu da bi ju se dijelilo (2008), dostupno na: http://www.ika.hr/index.php?prikaz=vijest\&ID=100167, (gledano 25. rujna 2016.)

145. Nove tehnologije, novi odnosi. Promicati kulturu poštivanja, dijaloga i prijateljstva (2009), dostupno na: http://www.ika.hr/index.php?prikaz=vijest\&ID=110467, (gledano 26. rujna 2016.)

146. Svećenik i pastoral u digitalnom svijetu: novi mediji u službi Riječi (2010), dostupno na: http://www.ika.hr/index.php?prikaz=vijest\&ID=119674, (gledano 27. rujna 2016.) 
147. Istina, navještaj i autentičnost života u digitalnom dobu (2011), dostupno na: http://w2.vatican.va/content/benedict-

xvi/hr/messages/communications/documents/hf_ben-xvi_mes_20110124_45th-worldcommunications-day.html, (gledano 28. rujna 2016.)

148. Šutnja i Riječ: put evangelizacije (2012), dostupno na: http://www.ika.hr/index.php?prikaz=vijest\&ID=138860, (gledano 29. rujna 2016.)

149. Društvene mreže: vrata istine i vjere; novi prostori evangelizacije (2013), dostupno na: http://www.ika.hr/index.php?prikaz=vijest\&ID=148376, (gledano 30. rujna 2016.)

150. Komunikacija u službi istinske kulture susreta (2014), dostupno na: http://www.ika.hr/index.php?prikaz=vijest\&ID=160844, (gledano 1. listopada 2016.)

151. Komunicirati obitelj: povlašteno mjesto susreta u daru ljubavi (2015), dostupno na: http://www.ika.hr/index.php?prikaz=vijest $\& I D=167319$, (gledano 2. listopada 2016.)

152. Komunikacija i milosrđe: plodni susret (2016), dostupno na http://www.ika.hr/index.php?prikaz=vijest $\& I D=177554$, (gledano 3. listopada 2016.)

153. "Istina će vas osloboditi" (Iv 8, 32). Fake news i novinarstvo mira (2018), dostupno na: http://www.ktabkbih.net/info.asp?id=74427, (gledano 13. lipnja 2019.) 


\section{ŽIVOTOPIS}

Šime Zupčić je rođen u Dubrovniku 30. rujna 1985. godine od oca Ivice Zupčića i majke Anđele r. Andrić. Završio je Klasičnu gimnaziju Ruđer Bošković (2000.-2004.). Nakon srednje škole u rujnu 2004. godine upisuje Filozofsko-teološki studij na Katoličkom bogoslovnom fakultetu Sveučilišta u Zagrebu kojeg je uspješno završio 2010. godine s odličnom uspjehom te time stekao akademsko zvanje magistra teologije.

Iste godine upisuje Poslijediplomski doktorski studij informacijskih i komunikacijskih znanosti na Filozofskom fakultetu Sveučilišta u Zagrebu. Ovom disertacijom taj studij privodi kraju.

Nakon završenog fakulteta u rujnu 2010. godine započeo je raditi kao profesor vjeronauka u osnovnoj školi „Antun Masle“ u Orašcu (do 2012. godine), nakon toga u Gimnaziji Dubrovnik (2012.-2016.), Osnovnoj školi Gruž (2016.-2018.) i Klasičnoj gimnaziji Ruđera Boškovića (od 2018.)

Od 2012. godine, paralelno s radom u školi, na pola radnog vremena zaposlen je u Dubrovačkoj biskupiji, prvo u Uredu za medije, a kasnije u Katehetskom uredu. U sklopu svog rada u biskupiji bio je i predsjednik Pododbora za medije Organizacijskog odbora Susreta hrvatske katoličke mladeži u Dubrovniku 2014. godine.

Od 2013. godine na Odjelu za komunikologiju Sveučilišta u Dubrovnik, kao vanjski suradnik ima tri kolegija/radionice: „Glasnogovorništvo“, „Javni nastupi““ i „Religijska kultura“. Trenutno predaje samo na dvije (Glasnogovorništvu i Religijskoj kulturi).

Oženjen je i otac dvoje djece.

Objavio je izvorni znanstveni rad „Sadržaji medijske kulture u udžbenicima za katolički vjeronauk u srednjim školama“ u Zborniku sa znanstvenog skupa s međunarodnim sudjelovanjem „Dijete i jezik danas - Dijete i mediji“ u Osijeku 2013 godine. Izlagao je na međunarodnom znanstvenom skupu (Seventeenth International Conference Information Technology and Journalism, Dubrovnik, Hrvatska, 2011) s temom „Security and vulnerability of children on social networks" 